UNIVERSIDADE DE SÃO PAULO

FACULDADE DE FILOSOFIA, LETRAS E CIÊNCIAS HUMANAS

DEPARTAMENTO DE SOCIOLOGIA

PROGRAMA DE PÓS-GRADUAÇÃO EM SOCIOLOGIA

\title{
SINDICALISMO E DESEMPREGADOS \\ NO BRASIL E NA ARGENTINA DE 1990 A 2002: \\ UNIDADE E FRATURA ENTRE O EXÉRCITO DE \\ OPERÁRIOS ATIVO E DE RESERVA
}

Davisson Charles Cangussu de Souza

\begin{abstract}
Tese de doutorado apresentada ao Programa de Pós-Graduação em Sociologia, do Departamento de Sociologia da Faculdade de Filosofia, Letras e Ciências Humanas da Universidade de São Paulo, para obtenção do título de Doutor em Sociologia.
\end{abstract}

Orientadora: Profa. Dra. Heloisa Helena Teixeira de Souza Martins.

São Paulo 
O almejado período de prosperidade reluta em voltar; quando acreditamos divisar os sinais que o anunciam começam êles a desaparecer.

Entrementes, em cada inverno, renova-se a pergunta: "O que fazer com os desempregados?" Enquanto se avoluma, cada ano, o número dêles, não há ninguém para responder a essa pergunta; e quase podemos prever o momento em que os

desempregados perderão a paciência e encarregar-se-ão de decidir seu destino com suas próprias forças.

(Friedrich Engels, Prefácio da Edição Inglesa d'O Capital)

Meus senhores, é mesmo um problema Esse desemprego! Com satisfação acolhemos

Toda a oportunidade De discutir a questão. Quando queiram os senhores! A todo o momento! Pois o desemprego é para o povo Um enfraquecimento.

Para nós é inexplicável

Tanto desemprego.

Algo realmente lamentável Que só traz desassossego. Mas não se deve na verdade Dizer que é inexplicável Pois pode ser fatal, Dificilmente nos pode trazer

A confiança das massas Para nós imprescindível.

É preciso que nos deixem valer Pois seria mais que temível

Permitir ao caos vencer Num tempo tão pouco esclarecido! Algo assim não se pode conceber

Com esse desemprego!

Ou qual a sua opinião? Só nos pode convir Esta opinião: o problema,

Assim como veio, deve sumir. Mas a questão é esta: nosso desemprego

Não será solucionado

Enquanto os senhores não Ficarem desempregados!

(Bertolt Brecht "Esse desemprego!" In: Poemas 1913-1956. São Paulo: Editora 34, 6a. ed. 2001, p. 69-70) 
Para Mariana 


\section{AGRADECIMENTOS}

A Heloisa Martins, pelas valiosas aprendizagens de sete anos de parceria, pela orientação dedicada e enriquecedora, pelo apoio e incentivo em todas as etapas desta pesquisa, pela atitude sempre generosa e compreensível, e pela relação serena, de autonomia e respeito ao meu trabalho.

Ao Programa de Pós-Graduação em Sociologia da Universidade de São Paulo, pelas excelentes condições oferecidas para a realização desta pesquisa.

Ao Conselho Nacional de Pesquisa (CNPq), pela concessão de uma Bolsa de Doutorado de quatro anos que viabilizou a realização deste trabalho.

À Coordenação de Aperfeiçoamento de Pessoal de nível Superior (Capes), pela concessão de uma Bolsa de Estágio no Exterior, que realizei na França. À Cité Internacionale Universitaire de Paris, pelas condições oferecidas para a estadia em Paris. Ao professor Didier Demazière, pela aceitação da supervisão das atividades de pesquisa realizadas na Université de VersaillesSaint-Quentin-en-Yvelines.

À Pró-Reitoria de Pós-Graduação da USP, pela Bolsa de Estágio de Doutorado de cinco meses, que realizei na Universidad de Buenos Aires (UBA) e no Programa de Investigación sobre el Movimiento de la Sociedad Argentina (Pimsa), que foi imprescindível para a realização da pesquisa de campo.

Ao professor Nicolás Iñigo Carrera, pela seriedade e compromisso durante a supervisão do estágio em Buenos Aires, pelos valiosos ensinamentos sobre a Argentina, pelas inumeráveis contribuições para esta pesquisa e pelas inspirações mais estimulantes que tive neste trabalho.

Ao Pimsa, pela receptividade durante o estágio, pelo fornecimento de todas as condições materiais e acadêmicas para a realização do mesmo, pelo acesso à Base de Dados e ao Arquivo de Jornais que me permitiram realizar a pesquisa de campo e pelo honroso convite de me incorporar ao grupo efetivo de pesquisadores.

Aos colegas do Pimsa (Paula Klacho, María Celia Cotarelo, Germán Rosati e Roberto Tarditi), pelo companheirismo, pelas contribuições a este trabalho e pelo rico diálogo durante o estágio e as atividades do programa desde a minha incorporação ao mesmo. Um agradecimento especial a Ricardo Donaire, pelo apoio e aprendizagem durante nossa convivência cotidiana e pelas incontáveis contribuições em diversas etapas desta pesquisa; e a Fabián Fernández, pelas inúmeras sugestões, pelas leituras rigorosas de versões parciais de artigos e capítulos da tese, e pela parceria enriquecedora de nossos trabalhos.

A Álvaro Comin (FFLCH/USP), pela participação na banca de qualificação.

A Andréia Galvão (Unicamp), pelas excelentes sugestões feitas à versão preliminar deste trabalho na banca de qualificação e pelo rico diálogo que tivemos ao longo desta pesquisa.

Às centrais sindicais pesquisadas no Brasil (CUT e FS) e na Argentina (CGT e CTA), pelo apoio dado para a realização da pesquisa de campo. 
Ao Centro de Documentação e Memória Sindical (Cedoc) da CUT, onde realizei a leitura do material referente a esta central.

À Biblioteca do Centro de Documentação da CTA, pelo acesso aos documentos disponíveis em seu arquivo.

Ao Centro de Memória Sindical, onde pude ter acesso aos documentos da Força Sindical

À Universidad Torcuato di Tella, que por meio de seu Archivo del Sindicalismo Argentino Santiago Senén González (Asassg), viabilizou o cumprimento de parte da pesquisa de campo na Argentina.

A todos os militantes e sindicalistas entrevistados, pela gentileza da concessão das entrevistas, pelos diversos tipos de auxílio para o levantamento de dados e pelos relatos que me permitiram acumular um rico material de análise. Um agradecimento especial a Andrés Larisgotia, da CTA, e a Oscar Martínez, do Taller de Estudios Laborales, pela contribuição no estabelecimento de contatos com os entrevistados.

Ao Centro de Estudos Marxistas (Cemarx), pelo rico diálogo estabelecido desde minha incorporação como pesquisador do centro. Um agradecimento especial ao Grupo de Estudos do Neoliberalismo, coordenado por Armando Boito Jr., que tem me proporcionado grandes aprendizagens nos debates e atividades conjuntas que vimos realizando.

Aos amigos (Andriei Gutierrez, Marcelo Chaves, Magrão, Fernando Rodrigues), pelo apoio, incentivo, companheirismo e diálogo durante toda a minha trajetória.

À amiga Selma Venco, pela solicitude e pelo valioso apoio em diversos momentos desta empreitada.

Ao amigo Hector Navarro Carrión, pelo incentivo demonstrado em todas as etapas da minha trajetória, e pela revisão das traduções para o espanhol.

Ao amigo Leandro de Oliveira Galastri, pelas valiosas contribuições sempre presentes em nossos diálogos, pelo apoio e aprendizagens de nosso convívio e pelo companheirismo e camaradagem de momentos muito importantes deste trabalho.

Ao amigo Danilo Enrico Martuscelli, pelos debates sempre tão enriquecedores, por suas leituras atentas e rigorosas de versões preliminares dos capítulos, pelas sugestões e críticas ao texto final e pelo imensurável apoio na reta final, que contribuiu de maneira decisiva para o último impulso necessário para terminar este trabalho.

Aos meus familiares, pelo incentivo em todas as etapas deste percurso. A meus seis sobrinhos (Camila, Fernanda, Vítor, Gabriela, Júlia e Daniel). A meus sete irmãos. A Delma, pelo incentivo que me deu para que seguisse esta empreitada, e a meu cunhado Eduardo, pela contribuição com os contatos para as entrevistas. A Dalmo, pelo apoio e confiança em todos os meus projetos. A Darlene, pela generosidade, pelo estímulo e pela presença em todos os momentos cruciais de minha trajetória. A Dalton, pelo incentivo que sempre me deu para estudar. A Dayse, pelos valiosos diálogos, e pela disposição e companheirismo em todos os 
momentos decisivos, e a meu cunhado Dean, pela solicitude e apoio em vários momentos deste trabalho. Ao grande amigo Denner, pela camaradagem, pela força de sempre e pela lista interminável de todo tipo de suporte (no cotidiano e na distância), sem o qual este trabalho não teria se concretizado. A Débora, pelo incentivo e entusiasmo com os meus projetos, e pela árdua tarefa de de transcrição das entrevistas feitas no Brasil. A meus pais, Lúcio e Izalina, pelo apoio e confiança que sempre tiveram na realização de minhas maiores aspirações.

A Mariana, que esta pesquisa me colocou no caminho, pela paciência e pelo afeto do dia-adia, pela dedicação e companheirismo presente em cada linha aqui escrita, pelo apoio de sua família (especialmente Dona Liliana e Seu Eduardo), pela atenção e desprendimento de cada um de seu gestos, pela atitude curiosa diante de todos os meus projetos, pelas mais diversas contribuições para a concretização deste trabalho (tradução, transcrição, revisão, leituras, releituras, diálogo, escuta, debate, críticas, sugestões, etc.), pela cumplicidade e capacidade de superação de todas as dificuldades, pela presença (na ausência e na distância) em todas as etapas das andanças que envolveram a pesquisa (Buenos Aires, Paris, Buenos Aires, Campinas...) e pela aprendizagem em nosso convívio que tanto me estimula a querer crescer. 


\title{
RESUMO
}

Esta tese trata da relação entre o sindicalismo e os desempregados no Brasil e na Argentina no período de 1990 a 2002. Foram consideradas na análise as duas centrais sindicais mais importantes de cada país: a Central Única dos Trabalhadores (CUT) e a Força Sindical (FS), no caso brasileiro; a Confederación General del Trabajo (CGT) e a Central de los Trabajadores de la Argentina (CTA), no caso argentino. A pesquisa de campo foi realizada com base em documentos de fonte primária e 48 entrevistas com sindicalistas e militantes de organizações de desempregados dos dois países. O marco teórico adotado foi baseado fundamentalmente na teoria da superpopulação relativa criada por Engels e desenvolvida por Marx. Ademais, foram incorporadas as contribuições de autores contemporâneos da sociologia francesa, com a qual se discutiu a noção de construção social do desemprego e os limites da mobilização dos desempregados. Por último, a partir de Gramsci e da História Social britânica foram fundamentados os conceitos de experiências e tradições de luta. $\mathrm{O}$ argumento central da tese é de que a relação entre o sindicalismo e os desempregados deve ser compreendida como parte do processo de construção de unidade e fratura entre o exército de operários ativo e de reserva, presente na formação histórico-cultural da classe trabalhadora. A partir das referências teóricas mencionadas, foram comparadas as ações e representações das centrais pesquisadas nos dois países com relação aos desempregados, relacionando-as à correlação de forças, à estrutura sindical, aos interesses da base e da cúpula, à posição adotada diante do neoliberalismo, e às experiências e tradições de luta da classe trabalhadora.

\begin{abstract}
This thesis deals with the relationship between the trade unionism and the unemployed workers in Brazil and in Argentina in the period between 1990 and 2002. It was considered in the analysis the two most important unions of each country: the Central Única dos Trabalhadores (CUT) and Força Sindical (FS), in the Brazilian case; the Confederación General del Trabajo (CGT) and the Central de los Trabajadores de la Argentina (CTA), in the Argentinean case. The research was based in primary source documents and 48 interviews with trade unionists and militants of unemployed organizations of the two countries. The adopted theoretical mark was based fundamentally in the theory of the relative overpopulation created by Engels and developed by Marx. Besides, contemporary contributions of the French Sociology were incorporated, with which was discussed the notion of social construction of the unemployment and the limits of the unemployed mobilization. Last, the concepts of experiences and fight traditions were based in Gramsci and the British Social History. The central argument of the thesis is that the relationship between the trade unionism and the unemployed workers should be understood as part of the unity construction process and fracture between the active army of labour and the reserve army of labour, present in the historical-cultural making of the working class. From the mentioned theoretical references, this thesis searches to compare the actions and representations of the researched unions in the two countries concerning to the unemployed workers, relating them to the correlation forces, the unionism structure, the cupola and the base interests, the adopted position in relation to the neoliberalism, and the experiences and fight traditions of the working class.
\end{abstract}




\section{LISTA DE SIGLAS:}

AB: Asociación Bancaria

ABI: Associação Brasileira de Imprensa

AC!: Agir ensemble contre le Chômage

ACO: Ação Católica Operária

ADS: Agência de Desenvolvimento Solidário

AFJP: Administradoras de Fondos de Jubilación y Pensión

AIE: Aparelho Ideológico de Estado

ALCA: Área de Livre Comércio das Américas

ANL: Aliança Nacional Libertadora

AOT: Asociación Obrera Textil de la República Argentina

Apeis: Association pour l'Emploi, l'Information et la Solidarité

ART: Administradoras de Riesgos del Trabajo

AS: Articulação Sindical

Asassg: Archivo del Sindicalismo Argentino Santiago Senén González

ASS: Alternativa Sindical Socialista

ATE: Asociación de Trabajadores del Estado

ATEN: Asociación de Trabajadores de la Educación del Neuquén

Bndes: Banco Nacional de Desenvolvimento Econômico e Social

BP: Barrios de Pie

CAME: Coordinadora de Actividades Mercantiles Empresarias

CAT: Central Autônoma dos Trabalhadores

CCC: Corriente Clasista y Combativa

CEA: Consejo Empresario Argentino

CEB: Comunidade Eclesial de Base

Cedoc: Centro de Documentaçao e Memória Sindical da CUT

CGT (Argentina): Confederación General del Trabajo

CGT (Brasil): Central/Confederação/Comando Geral dos Trabalhadores

CGT (França): Confédération Generale du Travail

Ciosl: Confederação Internacional das Organizações Sindicais Livres

CLT: Consolidação das Leis do Trabalho

CMP (Argentina): Central de Movimientos Populares

CMP (Brasil): Central de Movimentos Populares

CMS: Centro de Memória Sindical

CMS: Coordenação dos Movimentos Sociais

CNBB: Confederação Nacional dos Bispos do Brasil

CNM: Confederação Nacional dos Metalúrgicos

CNPq: Conselho Nacional de Pesquisa

CNQ: Confederação Nacional do ramo Químico

CNRS: Centre National de la Recherche Scientifique

Codefat: Conselho Deliberativo do FAT

Conaccovest: Confederação Nacional dos Trabalhadores nas Indústrias do Setor Têxtil,

Vestuário, Couro e Calçados

Conicet: Consejo Nacional de Investigaciones Científicas y Técnicas

Conlutas: Coordenação Nacional de Lutas

Contag: Confederação Nacional dos Trabalhadores na Agricultura 
Conticom: Confederação Nacional dos Trabalhadores nas Indústrias da Construção e da Madeira

Contracs: Confederação Nacional dos Trabalhadores no Comércio e Serviços

Contraf: Confederação Nacional dos Trabalhadores do ramo Financeiro

CSC: Corrente Sindical Classista

CST: Centro de Solidariedade ao Trabalhador

CTA: Central de Trabajadores de la Argentina

CTB: Central dos Trabalhadores e Trabalhadoras do Brasil

Ctera: Confederación de Trabajadores de la Educación de la República Argentina

CTR: Central de Emprego e Renda

CUT: Central Única dos Trabalhadores

Dieese: Departamento Intersindical de Estatística e Estudos Sócio-Econômicos

ESSP: Escola Sindical São Paulo

Faecys: Federación Argentina de Empleados de Comercio y Servicios

Faspygp: Federación Argentina Sindical del Petróleo y Gas Privado

FAT: Fundo de Amparo ao Trabalhador

Fatsa: Federación de Asociaciones de Trabajadores de la Sanidad

FEM/SP: Federação dos Metalúrgicos do Estado de São Paulo

FFLCH: Faculdade de Filosofia, Letras e Ciências Humanas

FGTS: Fundo de Garantia do Tempo de Serviço

Fiesp: Federação das Indústrias do Estado de São Paulo

FMI: Fondo Monetário Internacional

Foetra: Federación de Obreros y Empleados Telefónicos de la República Argentina

FORA: Federación Obrera Regional Argentina

Frenapo: Frente Nacional contra a Pobreza

Frepaso: Frente País Solidario

FS: Força Sindical

FTV: Federación de Tierra, Vivienda y Habitát

IBGE: Instituto Brasileiro de Geografia e Estatística

IDH: Índice de Desenvolvimento Humano

IPI: Imposto sobre Produtos Industrializados

IPTU: Imposto Predial e Territorial Urbano

IVA: Impuesto al Valor Agregado

LAP: Ley de Asociaciones Profesionales

MCD: Movimento Contra o Desemprego

MIJD: Movimiento Independiente de Jubilados y Desocupados

MNCP: Mouvement National des Chômeurs et Précaires

Mocase: Movimento Campesino de Santiago del Estero

MOP: Movimiento Obrero con Propuestas

MST (Argentina): Movimiento Socialista de los Trabajadores

MST (Brasil): Movimento dos trabalhadores rurais Sem-Terra

MTA: Movimiento de los Trabajadores Argentinos

MTD (Argentina): Movimiento de Trabajadores Desocupados

MTD (Brasil): Movimento dos Trabalhadores Desempregados

MTL (Argentina): Movimiento Territorial de Liberación

MTL (Brasil): Movimento Terra, Trabalho e Liberdade

MTST: Movimento dos Trabalhadores Sem-Teto

NCST: Nova Central Sindical de Trabalhadores 
OAB: Ordem dos Advogados do Brasil

OIT: Organização Internacional do Trabalho

OLT: Organização no Local de Trabalho

ONG: Organização Não-Governamental

ORIT: Organización Regional Interamericana de Trabajadores

PAMI: Programa de Atención Médica Integral

PBPQ: Programa Brasileiro de Qualidade e Produtividade

PCB: Partido Comunista do Brasil

PCdoB: Partido Comunista do Brasil

PCR: Partido Comunista Revolucionário

PDT: Partido Democrático Trabalhista

PEA: População Economicamente Ativa

PFL: Partido da Frente Liberal

PIB: Produto Interno Bruto

Pimsa: Programa de Investigación sobre el Movimiento de la Sociedad Argentina

PJ: Partido Justicialista

PMEs: Pequenas e Médias Empresas

PNUD: Programa das Nações Unidas para o Desenvolvimento

PO (Argentina): Polo Obrero

PO (Brasil): Pastoral Operária

PPS: Partido Popular Socialista

Printemps: laboratoire Professions, Institutions, Temporalités

Proger: Programa de Geração de Emprego e Renda

PSDB: Partido da Social-Democracia Brasileira

PSOL: Partido Socialismo e Liberdade

PT: Partido dos Trabalhadores

PTB: Partido Trabalhista Brasileiro

SBSP: Sindicato dos Bancários e Financiários de São Paulo, Osasco e Região

SDS: Social-Democracia Sindical

SEC: Sindicato de Empleados de Comercio de Buenos Aires

Sefor: Secretaria Nacional de Formação Profissional

SINE: Serviço Nacional de Emprego

Sintetel: Sindicato dos Trabalhadores em Empresas de Telecomunicações no Estado de São

Paulo

Sintracon: Sindicato dos Trabalhadores nas Indústrias da Construção Civil de São Paulo

Smata: Sindicato de Mecánicos y Afines del Transporte Automotor

SMCR: Sindicato dos Metalúrgicos de Campinas e Região

SMSP: Sindicato dos Metalúrgicos de São Paulo e Mogi das Cruzes

Somisa: Sociedad Mixta Siderurgia Argentina

SQSP: Sindicato dos Químicos e plásticos de São Paulo e região

SUPE: Sindicato Único Petroleros del Estado

UBA: Universidad de Buenos Aires

UCR: Unión Cívica Radical

UEJN: Unión de Empleados de la Justicia de la Nación

UGT: Unión General de los Trabajadores

UIA: Unión Industrial Argentina

UTAB: União dos Trabalhadores Agrícolas do Brasil

UNE: União Nacional dos Estudantes 
Unicamp: Universidade Estadual de Campinas

Uocra: Unión Obrera de la Construcción de la República Argentina

UOM: Unión Obrera Metalúrgica de la República Argentina

UPCN: Unión Personal Civil de la Nación

USP: Universidade de São Paulo

UTA: Unión Tranviarios Automotor de la República Argentina

UTD: Unión de los Trabajadores Desocupados

UVSQ: Université de Versailles-Saint-Quentin-en-Yvelines

YPF: Yacimientos Petrolíferos Fiscales

62OP: 62 Organizaciones Peronistas 


\section{SUMÁRIO}

CONSIDERACÕES INICIAIS

CAPÍTULO 1 - A ANÁLISE DA RELAÇÃO ENTRE SINDICALISMO E DESEMPREGADOS

1.1 A análise da ação conjunta entre movimento sindical e desempregados ........................... 10

1.2 Limites da organização dos desempregados e construção social do desemprego.............. 22

1.3 Movimento operário e mobilização dos desempregados: o exército de operários de reserva

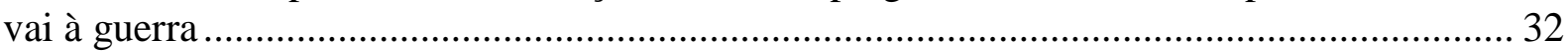

1.4 Correlação de forças, experiências e tradições de luta...................................................... 44

\section{CAPÍTULO 2 - MOVIMENTO OPERÁRIO E SINDICAL NO BRASIL E NA}

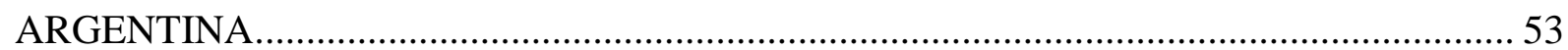

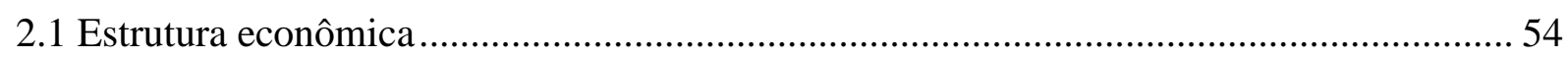

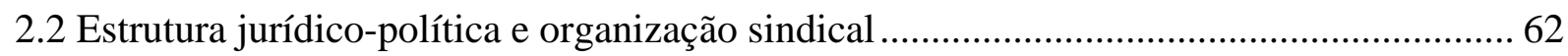

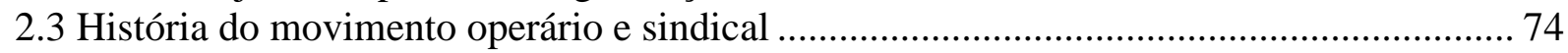

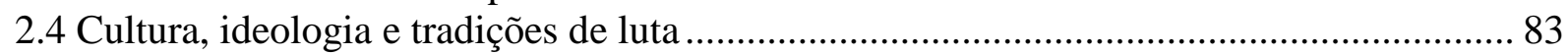

CAPÍTULO 3 - SINDICALISMO E DESEMPREGADOS NO BRASIL: AS AÇÕES E REPRESENTAÇÕES DA CUT E DA FORÇA SINDICAL ................................................ 94

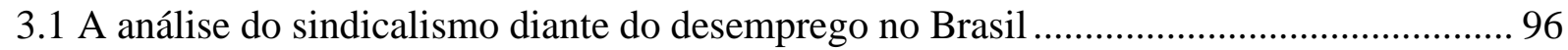

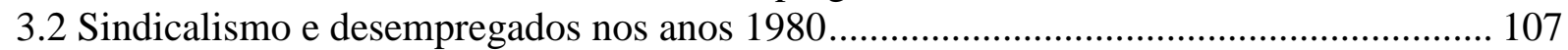

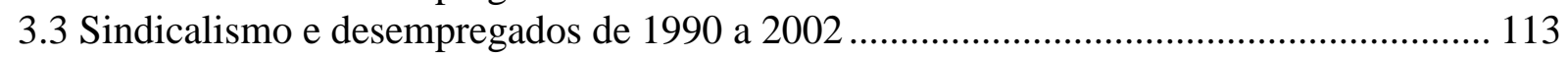

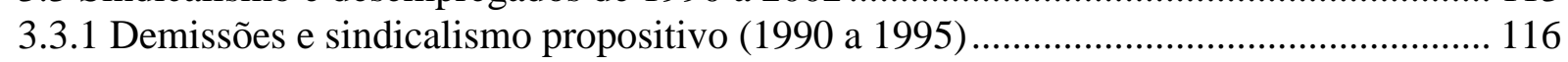

3.3.2 Desemprego e sindicalismo de serviços (1995 a 1998) .............................................. 143

3.3.3 Desempregados e sindicalismo cidadão: requalificação profissional, intermediação do

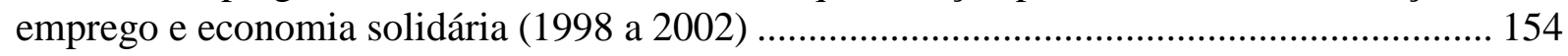

3.4 Representações dos quadros dirigentes sobre a organização dos desempregados ............ 177

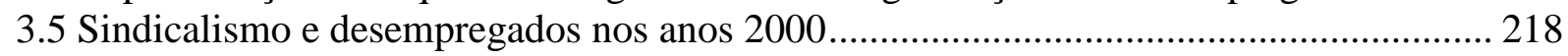

CAPÍTULO 4 - SINDICALISMO E DESEMPREGADOS NA ARGENTINA: AS AÇÕES E

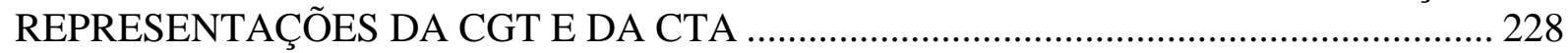

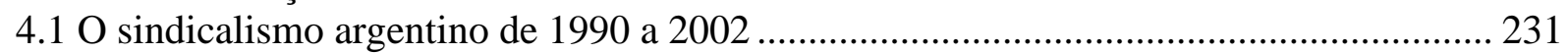

4.2 Sindicalismo e desempregados (1995 a 2002) ................................................................. 242

4.2.1 Pico de desemprego e protestos contra as demissões (janeiro a agosto de 1995) ......... 244

4.2.2 Unidade do movimento operário e mobilização contra o desemprego (setembro de 1995

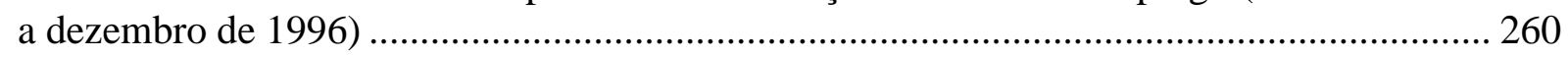

4.2.3 Os bloqueios de rodovias, o "efeito caipirinha" e o surgimento das organizações de

desempregados (janeiro de 1997 a novembro de 1999) ........................................................ 283

4.2.4 Expansão das organizações de desempregados, greves gerais e insurreição espontânea

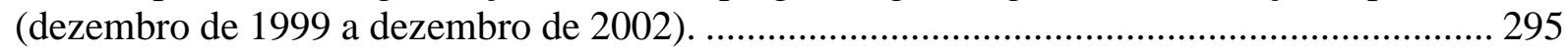

4.3 Representações dos quadros dirigentes sobre a organização dos desempregados ............ 324

4.4 Movimento sindical e de desempregados na Argentina................................................ 361

CAPÍTULO 5 - UNIDADE E FRATURA ENTRE O ATIVO E A RESERVA NO BRASIL E

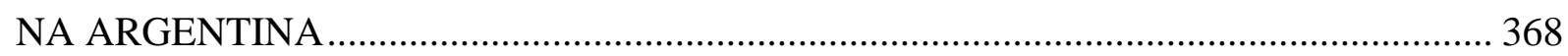

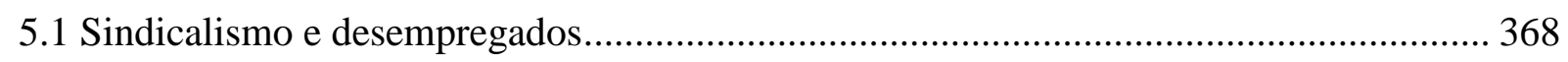




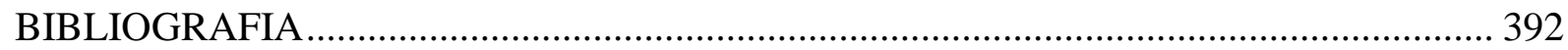

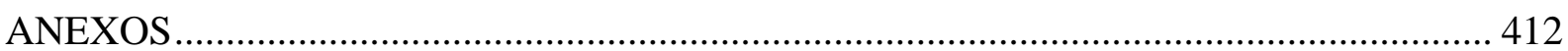

Mapa da Argentina ...................................................................................... 412

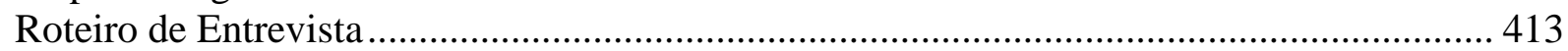

Tabela 1: População total no Brasil e na Argentina (1872-2000) ......................................... 415

Tabela 2: População urbana e rural no Brasil e na Argentina (1895-2001) ........................... 415

Tabela 3: População urbana e rural no Brasil e na Argentina (1991-2000) ............................. 416

Tabela 4: Imigrantes no Brasil e na Argentina (1861-1920)............................................. 416

Tabela 5: População total, de estrangeiros, rural e urbana na Argentina (1869-1914) .......... 417

Tabela 6: População total e estrangeira em São Paulo e Buenos Aires (1886-1936) ............. 417

Tabela 7: PIB do Brasil e da Argentina (1900-1935).............................................................. 418

Tabela 8: PIB do Brasil e da Argentina (1960-2008)............................................................. 418

Tabela 9: PIB per capita no Brasil e na Argentina (1965-1985) .......................................... 418

Tabela 10: Afiliados sindicais na Argentina, segundo a tendência (1936-1940)................... 418

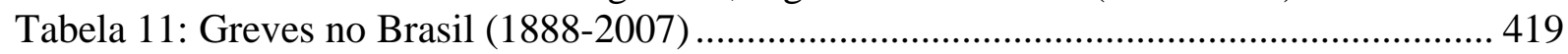

Tabela 12: Greves, grevistas e dias parados na Argentina (1906-1918) .............................. 420

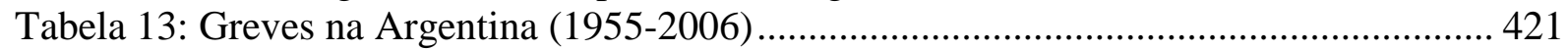

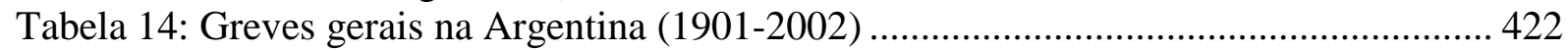

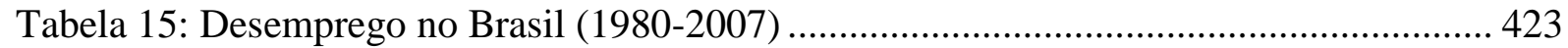

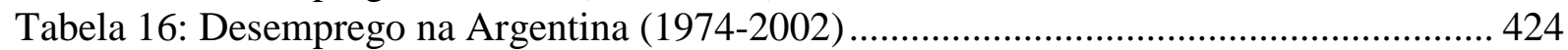

Tabela 17: Protestos de empregados e desempregados na Argentina (1993-2006) ............... 425

Tabela 18: Protestos de assalariados segundo o segmento (1993-2007) .............................. 426

Tabela 19: Protestos de desempregados e demitidos, em conjunto ou não com empregados

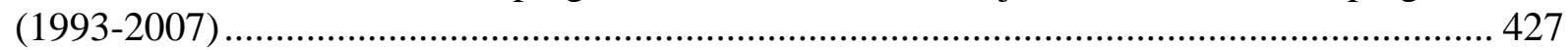

Quadro I: Perfil das organizações de desempregados da Argentina ................................... 428

Quadro II: Fisionomia das greves gerais na Argentina (1989-2002) .................................... 432

Quadro III: Sindicalismo desempregados no Brasil e na Argentina ................................... 436

Quadro IV: A mobilização dos desempregados no Brasil e na Argentina............................. 437 


\section{CONSIDERACÕES INICIAIS}

O objetivo desta tese é analisar a relação do movimento sindical com os desempregados no Brasil e na Argentina durante o período de 1990 a 2002. Na análise desse vínculo, foram enfatizadas as ações e representações feitas pelas duas centrais sindicais mais importantes de cada país: a Central Única dos Trabalhadores (CUT) e a Força Sindical (FS), no caso brasileiro; a Confederación General del Trabajo (CGT) e a Central de los Trabajadores de la Argentina (CTA), no caso argentino.

O recorte temporal se insere em um contexto de intensificação da reestruturação técnica capitalista e de implantação das políticas neoliberais, sob a hegemonia do capital financeiro em escala mundial. Essas mudanças provocaram, nas duas formações sociais estudadas, o crescimento da superpopulação relativa, tanto em sua forma de manifestação aguda como em sua forma crônica. A maior evidência desse processo está no aumento das taxas de desemprego e subemprego.

A escolha da Argentina para a comparação se deve ao fato de que nesse país, no período estudado, os desempregados se organizaram de maneira massiva e nacional, tendo se tornado importantes sujeitos dos protestos sociais. Ademais, algumas das principais organizações desse segmento tiveram o apoio institucional de uma das centrais sindicais, a CTA. Ao contrário, no caso brasileiro as mobilizações de desempregados foram pouco representativas. Além disso, não houve experiências significativas de organização para a luta dos trabalhadores sem emprego levada a cabo pelas entidades sindicais.

A partir dessa constatação inicial, estabeleci as principais questões que nortearam a pesquisa: (i) por que no período considerado não houve no Brasil um movimento de desempregados com peso político no conjunto dos protestos sociais?; (ii) quais foram as condições que possibilitaram o surgimento de organizações desse tipo na Argentina?; (iii) qual foi o papel desempenhado pelo movimento sindical nos dois contextos?; (iv) como se deu, ao longo do período estudado, o processo de construção de unidade e fratura entre o exército de operários ativo organizado sindicalmente e o segmento desempregado do exército de operários de reserva ${ }^{1}$ nessas duas formações sociais?

\footnotetext{
${ }^{1}$ Esses conceitos, criados por Engels e desenvolvidos por Marx, serão explicados no primeiro capítulo. Como forma de simplificação, empregarei doravante ativo e reserva.
} 
A idéia de trabalhar com essa temática surgiu no mestrado, quando estudei as ações do Sindicato dos Metalúrgicos de Campinas e Região (SMCR) diante do desemprego e das demissões no mesmo período (Souza, 2005b). Durante essa investigação, analisei a relação da entidade com o Movimento Contra o Desemprego (MCD) de Campinas, que atuou na cidade entre 1997 e 1998. Esta organização teve alguns ex-metalúrgicos em seu núcleo originário, e recebeu apoio do SMCR para sua criação. No entanto, de acordo com os entrevistados do MCD, o Sindicato não logrou incorporar a luta dos desempregados em seu cotidiano, entre outras razões, pelo acomodamento à estrutura sindical corporativa. Para os dirigentes sindicais, o SMCR não pode ser responsabilizado pela desmobilização dos desempregados, já que havia problemas internos, no próprio MCD, que escapavam de seu controle. Ademais, os entrevistados afirmaram que a organização desse segmento era de responsabilidade do conjunto do movimento sindical, e não apenas de uma entidade. As questões analíticas mais relevantes da dissertação foram tomadas como pontos de partida para esta pesquisa. Primeiramente, foi necessário estabelecer uma diferença entre o processo de negociação/mobilização sindical diante das demissões e as bandeiras de combate ao desemprego. Em segundo lugar, foi importante distinguir as ações de resistência dos demitidos da representação e organização sindical dos desempregados. Em suma, foi a partir da análise dos vínculos entre o SMCR e o MCD de Campinas que resolvi explorar, na tese de doutorado, a relação entre o sindicalismo e os desempregados. Para tanto, ampliei o escopo da análise às centrais sindicais e à comparação da experiência brasileira com a de outro país em que este segmento havia se organizado massivamente, em parte por fora das organizações sindicais, mas também por meio de sua estrutura organizativa.

Partindo, especialmente, do marco analítico marxiano e engelsiano, o fundamento teórico central deste trabalho é de que para refletir sobre a relação do movimento sindical com os desempregados, deve-se recorrer à análise da correlação de forças e das experiências $e$ tradições de luta da classe trabalhadora de cada formação. Além disso, é importante considerar que, no estudo da mobilização dos trabalhadores sem emprego, o sindicalismo pode ser um componente decisivo, por seu caráter orgânico nas lutas sociais diante dos efeitos do regime social capitalista. Sendo assim, o processo organizativo dos trabalhadores desempregados será analisado nesta tese em sua relação com as ações políticas dos trabalhadores empregados organizados sindicalmente, como partes constitutivas do movimento social da classe trabalhadora. Parto do pressuposto de que, nessa dinâmica, os 
protestos sociais de ambos se constroem em torno de interesses de distintas frações de classe (ativa e de reserva), que apresenta traços de continuidade e nexos causais constituídos no processo histórico-cultural de formação da classe e da luta de classes.

Uma referência teórica importante para este trabalho foi a Sociologia do Desemprego produzida principalmente na França. Dialogarei com as principais contribuições dessa área, especialmente as implicações que a noção de "construção social" (normativo-institucional e biográfico-subjetiva) do desemprego tem para a análise dos limites e possibilidades da mobilização dos desempregados, especialmente na formação das condições prévias da constituição identitária e política desses sujeitos.

Além do repertório conceitual clássico de Marx e Engels, e o diálogo com a sociologia francesa, outras contribuições teóricas se tornaram importantes na trajetória da pesquisa, acionadas de acordo com as necessidades de refletir sobre as hipóteses formuladas. Entre as principais, posso citar: o legado de Antonio Gramsci para a análise das relações entre ideologia e cultura; o método analítico proposto por Nicos Poulantzas por meio da noção de correlação de forças, além de sua compreensão das classes sociais como efeito das estruturas sociais (jurídico-política, econômica e ideológica); o conceito de ideologia e Aparelhos Ideológicos de Estado (AIEs), de Louis Althusser; a noção de experiência de Edward Thompson, advinda de sua interpretação acerca da formação das classes sociais como resultado das relações de enfrentamento surgidas no processo histórico de construção social e cultural; e o desenvolvimento da noção gramsciana de tradição, feito especialmente pelo historiador britânico George Rudé em seus estudos sobre a construção da ideologia de protesto popular, no qual o autor se refere ao processo de incorporação dos elementos tradicionais a partir do conceito de ideologia inerente. O intuito de superar o mecanicismo subjetivista e objetivista (principalmente o economicismo) presente nas análises sindicais também me levou a buscar fundamentação teórica na noção de estruturas do sentir de Raymond Willians e no conceito de habitus elaborado por Pierre Bourdieu.

Esta tese parte da análise da estrutura social e da correlação de forças, por um lado, e das experiências e tradições de luta, por outro, para interpretar a relação entre o sindicalismo e os desempregados como parte do processo histórico-cultural de construção de unidade e fratura entre o ativo e a reserva. As distintas perspectivas teóricas consideradas podem parecer inconciliáveis, mas serão acionadas em diferentes momentos da análise com o objetivo teórico de estreitar as fronteiras entre a sociologia e a história. Tal como sustentaram 
Bourdieu e Wacquant (1992), toda sociologia é histórica, e toda história é sociológica. A partir de tal pressuposto, procurei me fundamentar na História Social britânica, no Estruturalismo francês e no Marxismo clássico.

Para realizar este estudo, fiz um levantamento bibliográfico nos dois países acerca dos principais blocos temáticos contemplados (desemprego, sindicalismo, ação sindical diante do desemprego e mobilização dos desempregados). Constatei que são escassas as pesquisas comparativas entre o Brasil e a Argentina, o que dá a este estudo certo caráter pioneiro, pelo menos no campo de análise e no recorte proposto. A pesquisa de campo foi composta: (i) por entrevistas semi-estruturadas com dirigentes sindicais e de organizações de desempregados; (ii) pela coleta de informações e dados estatísticos; (iii) e pela leitura de documentos de fonte primária das centrais analisadas, tais como resoluções de congressos e plenárias, jornais e revistas.

No total, foram realizadas 48 entrevistas, tendo sido 24 no Brasil e 24 na Argentina. Nas entrevistas feitas com sindicalistas priorizei membros da direção nacional das quatro centrais, além de líderes de algumas das categorias mais afetadas pelo desemprego em cada país (metalúrgico, bancário, construção civil, etc.). ${ }^{2}$ Por conta do fato de que organização sindical argentina esteja estruturada em sindicatos nacionais únicos, os entrevistados puderam detalhar sobre a situação do conjunto de seu setor no país. No caso brasileiro, a base de representação mais comum é municipal, e por isso, além de dirigentes de algumas entidades localizadas na região metropolitana de São Paulo com peso na direção das centrais, entrevistei representantes de algumas federações paulistas e confederações nacionais.

A elaboração do roteiro foi fundamentada a partir dos seguintes critérios: (i) compreender a articulação e os conflitos existentes entre o movimento sindical e os desempregados; (ii) indagar sobre as causas e possíveis soluções para o desemprego na visão dos entrevistados; (iii) obter informações sobre as ações diante do desemprego realizadas pela entidade que o representa; (iv) no caso dos dirigentes sindicais, interessou-me saber como estes concebem o papel dos sindicatos diante do desemprego e dos desempregados; (v) no caso dos militantes do movimento de desempregados, procurei mapear como analisam a ação sindical diante do desemprego e dos desempregados. ${ }^{3}$

\footnotetext{
${ }^{2}$ Esse material será analisado nos capítulos 3 e 4, nos quais explicitarei com mais detalhes os procedimentos dessa etapa da pesquisa.

${ }^{3}$ Ver o Roteiro de Entrevista nos Anexos.
} 
Essa etapa da investigação foi cumprida em São Paulo e Buenos Aires, pois aí se encontram as sedes das centrais analisadas. No caso argentino, justificou-se também porque a zona metropolitana da capital federal esteja reunida uma grande variedade de organizações de desempregados, além de ter sido a partir daí que algumas delas adquiriram caráter massivo e nacional.

Inicialmente, essa pesquisa se intitulava Corporativismo sindical e movimentos de desempregados no Brasil e na Argentina. Esse título antecipava uma das hipóteses iniciais do projeto, segundo a qual o corporativismo, presente na estrutura sindical tanto do Brasil como da Argentina, seria o principal fator de inibição de uma ação conjunta entre o movimento sindical e os desempregados. No entanto, no decorrer da pesquisa de campo, outros elementos ganharam espaço na análise. $\mathrm{O}$ fato de que uma das centrais sindicais argentinas (a CTA) se propunha a representar esses trabalhadores organizando-os para a luta me levou a buscar compreender os limites e possibilidades de práticas que superem o corporativismo em cada contexto. Por tal motivo, penso que o título final explicita melhor o objetivo deste estudo, qual seja, o de analisar o processo de construção de unidade e fratura entre o ativo organizado sindicalmente e o segmento da reserva composto pelos desempregados.

Considero importante destacar, como nota introdutória, algumas dificuldades que encontrei para realizar este estudo. $\mathrm{O}$ fato de ser brasileiro e ter vivido e realizado toda minha atividade acadêmica sobre o Brasil me levou a pensar que o resultado final deste estudo traria, inevitavelmente, uma desproporção em termos de densidade analítica entre os dois países. Por isso, tinha claro de antemão que, mais do que algumas visitas rápidas para a coleta de material, seria preciso passar um período prolongado na Argentina com o objetivo de: (i) aprofundar os conhecimentos do idioma espanhol e, assim, ter melhores condições de realizar as entrevistas; (ii) e ter o maior contato possível com os "códigos culturais" do país no cotidiano, a fim de acumular mais elementos para a construção dos referenciais analíticos.

Apesar do esforço de investigação feito nesse sentido, estou ciente das eventuais obviedades que este trabalho pode conter para um leitor argentino. Porém, para o objetivo de realizar a análise comparativa, este procedimento me proporcionou um salto teórico e metodológico suficiente para buscar responder às principais inquietações expostas. Ademais, vale destacar que, desde o início, a postura assumida durante a pesquisa era de ter como objetivo final o aprimoramento da reflexão sobre o movimento operário e sindical brasileiro. Por isso optei por fazer, primeiramente, a pesquisa de campo na Argentina, pois foi a partir da 
análise de caso desse "outro" que aprimorei as perguntas sobre o "meu" país. Assim, mais do que uma análise comparativa entre ambos, a reflexão sobre o caso argentino serviu como um "suporte" para melhor pensar sobre o Brasil. Também devo alertar o leitor, desde já, que várias afirmações presentes neste trabalho somente puderam ser feitas por conta do contexto da comparação, e não devem ser consideradas isoladamente. Voltarei a este ponto ao longo do trabalho.

Para cumprir a etapa inicial da pesquisa de campo na Argentina, realizei um estágio em Buenos Aires, entre abril e agosto de 2007. O mesmo contou com a coordenação do professor Nicolás Iñigo Carrera, do Consejo Nacional de Investigaciones Científicas y Técnicas (Conicet), com assento no Instituto de Historia Argentina y Americana Dr. Emilio Ravignani, da Facultad de Filosofía y Letras da Universidad de Buenos Aires (UBA), e do Programa de Investigación sobre el Movimiento de la Sociedad Argentina (Pimsa), centro de pesquisa no qual o estágio foi efetivamente realizado. ${ }^{4}$ A dinâmica do estágio combinada com o supervisor contribuiu muito para o andamento da pesquisa, pois foi feito por meio de um acompanhamento sistemático das atividades, além de um diálogo intelectual muito rico com os demais pesquisadores do Pimsa. Em 2009, estive no país durante mais dois meses para concluir a pesquisa de campo. Nessa ocasião, fui incorporado como membro efetivo do centro, ao qual sigo pertencendo. A realização de atividades nesse espaço a partir de então foi fundamental para o aprofundamento das questões desenvolvidas neste trabalho.

A referência constante aos autores da sociologia do desemprego, campo desenvolvido especialmente na França, levou-me a solicitar um estágio de doutorado nesse país pelo período de um ano, com o objetivo de realizar um aprofundamento teórico na área. Essa etapa foi realizada no laboratório Professions, Institutions, Temporalités (Printemps), associado ao Centre National de la Recherche Scientifique (CNRS), com sede na Université de VersaillesSaint-Quentin-en-Yvelines (UVSQ) ${ }^{5}$, sob a supervisão do professor Didier Demazière. O contato com pesquisadores franceses e de outras nacionalidades, o levantamento bibliográfico realizado nas bibliotecas de Paris e a participação em diversos eventos científicos possibilitaram uma ampliação do meu repertório analítico e conceitual. Nesse momento, foi

\footnotetext{
${ }^{4}$ O Pimsa foi fundado em 1993 e conta com um grupo de cerca de dez pesquisadores, entre professores secundários e universitários, e estudantes de graduação e doutorado, predominantemente das áreas de História e Ciências Sociais. O laboratório tem como principal objetivo a realização de investigações sobre os protestos e a estrutura social da Argentina e conta com uma publicação anual, os Documentos de Trabalho, que se tornou uma das principais fontes deste estudo. Ver a página oficial do centro: www.pimsa.secyt.gov.ar ${ }^{5}$ www.uvsq.fr.
} 
importante tomar conhecimento acerca das análises das experiências de mobilização dos desempregados levadas a cabo, desde a década de 80, em diversos países da Europa como França, Itália, Irlanda, Bélgica, Alemanha, Espanha, entre outros. O estudo da dinâmica dessas organizações (e suas reivindicações, objetivos, ferramentas de luta, relação com as entidades sindicais, entre outros aspectos) constituiu um contraponto fundamental para formular novas perguntas sobre o Brasil e a Argentina. Entre esses questionamentos, destaco: (i) a análise crítica das metodologias de mensuração do desemprego a partir da abordagem dessa categoria como "construção social"; (ii) os limites e possibilidades de mobilização política dos desempregados; (iii) o papel das instituições que dão suporte a este segmento (pertencentes ou não ao aparelho estatal) na vivência cotidiana do "desemprego" e no autoreconhecimento do sujeito como "desempregado".

A tese foi dividida em cinco capítulos. No primeiro, apresentarei o marco teórico em que o trabalho se insere. O principal objetivo dessa parte será elaborar uma proposta de análise da relação entre sindicalismo e desempregados, tomando como principal referência o repertório conceitual clássico elaborado por Marx e Engels para o estudo do movimento operário e das classes sociais. Nesse sentido, o conceito de superpopulação relativa e a análise das frações, segmentos, camadas e parcelas da classe trabalhadora serão o ponto de partida para a compreensão da construção da unidade e fratura entre o ativo e a reserva. Farei também um diálogo crítico com a sociologia francesa para pensar a "construção social" da categoria de desemprego e os limites organizativos dos desempregados. Além desses referenciais, incorporarei as contribuições de Gramsci, da História Social britânica (Hobsbawn, Thompson e Rudé), do estruturalismo francês (Althusser e Poulantzas) e de outros clássicos do pensamento sociológico, como Willians e Bourdieu, para ressaltar a importância da análise das experiências e tradições de luta para o objeto estudado.

No segundo capítulo buscarei aplicar o método analítico comparativo proposto para a análise da história do movimento operário e sindical do Brasil e da Argentina. Nesse capítulo mencionarei as principais tradições de luta de cada país, destacando o papel da estrutura social (econômica, política e ideológica), da organização do aparelho ideológico sindical, das experiências históricas e da ideologia de protesto popular constituída ao longo do processo de constituição da classe trabalhadora de ambas as formações sociais.

No terceiro capítulo farei uma análise da relação do movimento sindical com os desempregados no Brasil entre 1990 e 2002. Avaliarei as ações e representações da CUT e da 
Força Sindical sobre essa questão, e farei um exercício de periodização e conceituação para interpretar as ações e representações dessas centrais. Procurarei me contrapor ao economicismo presente nos estudos da relação entre a estrutura social e a organização dos trabalhadores, e especialmente aos apriorismos presentes na análise dos vínculos entre sindicalismo e desemprego.

No quarto capítulo farei um exercício analítico semelhante sobre a Argentina. Avaliarei os casos da CGT e da CTA, considerando ainda os setores dissidentes cegetistas atuantes nos diferentes momentos do período estudado. No caso argentino analisarei ainda as organizações de desempregados que, entre o final da década de 90 e a primeira metade dos anos 2000, constituíram-se em um dos principais sujeitos dos protestos sociais no país. A abordagem proposta nessa parte do trabalho se contrapõe às interpretações mais comuns sobre o tema, que consideram não ter havido qualquer vínculo entre a eclosão desse movimento e o sindicalismo.

O quinto e último capítulo possui um caráter conclusivo, pois busca fazer uma análise comparativa da relação entre o movimento sindical e os desempregados no Brasil e na Argentina, retomando os argumentos e o marco teórico trabalhados ao longo do texto. A tese central que defenderei é de que as experiências dos dois países foram construídas historicamente por meio da interação entre a estrutura social, a correlação de forças, e as experiências prévias e tradições de luta da classe trabalhadora que compõem o processo histórico-cultural de construção da ideologia de protesto popular na formação das classes e da luta de classes. Resgatarei a proposta analítica apresentada no primeiro capítulo, e proporei um quadro interpretativo da construção da unidade e fratura entre o ativo e a reserva como parte do processo de constituição do movimento operário, popular e sindical nas duas formações sociais. 


\section{CAPÍTULO 1 - A ANÁLISE DA RELAÇÃO ENTRE SINDICALISMO E DESEMPREGADOS}

Este trabalho se insere em uma perspectiva teórica que pretende resgatar a atualidade do pensamento marxista para a compreensão da relação entre sindicalismo e desempregados, tendo como ponto de partida a utilização dos conceitos elaborados originalmente por Marx e Engels para o estudo do movimento operário e das classes sociais. Nesse sentido, procura apresentar uma proposta alternativa aos apriorismos na análise dos limites da mobilização dos desempregados e de sua ação conjunta com o movimento sindical. Ademais, propõe um diálogo com estudos recentes que buscaram atribuir um estatuto sociológico à categoria de desempregado. Essa linha teórica foi desenvolvida especialmente pela Sociologia do Desemprego francesa, que vem tratando a questão para além da leitura meramente estatística que predomina nas ciências econômicas e sociais.

Para aprofundar o repertório de ferramentas analíticas do movimento operário e sindical, o estudo comparativo entre duas formações sociais foi fundamental. Durante a pesquisa de campo, muitas questões teóricas, metodológicas e empíricas me desafiaram a ressignificar constantemente os conceitos utilizados. Esse exercício foi realizado sob a perspectiva do materialismo dialético, pois busquei analisar o objeto de estudo como uma unidade contraditória (portanto, múltipla e processual).

Este capítulo está dividido em quatro itens. No primeiro, exporei a perspectiva teórica adotada para a análise da ação conjunta entre sindicalismo e desempregados, partindo dos conceitos de superpopulação relativa e exército industrial de reserva, de Marx e Engels. No segundo item, debaterei com a sociologia francesa sobre os principais limites que esta aponta para a organização dos desempregados. Farei uma crítica ao apriorismo e ao essencialismo predominante nessa abordagem. $\mathrm{O}$ terceiro item possui o objetivo de demonstrar a atualidade da análise marxista das classes sociais e do processo histórico de formação e evolução do capitalismo para a compreensão do desemprego e da mobilização dos desempregados. Ademais, farei uma análise dessa questão com base em seu caráter de classe, considerando as diferentes frações, parcelas, camadas e segmentos da classe trabalhadora. Nessa parte da exposição, dialogarei também com a noção de "construção social" da categoria, que traz contribuições indispensáveis para uma análise crítica do tema proposto. No quarto item, farei algumas considerações sobre o método de interpretação das classes sociais empregado, 
destacando os conceitos de correlação de forças, experiências e tradições da classe trabalhadora, os quais serão fundamentais para interpretar a formação da unidade e fratura entre o ativo e a reserva nos países estudados.

\subsection{A análise da ação conjunta entre movimento sindical e desempregados}

A análise da relação entre o sindicalismo e os desempregados exige uma reflexão sobre o significado desses dois sujeitos no capitalismo. ${ }^{6} \mathrm{O}$ movimento operário não se restringe ao sindicalismo, mas este é o movimento orgânico (Gramsci, 1976) de resistência dos trabalhadores contra os efeitos do regime social capitalista. Os desempregados, por sua vez, não são o único segmento da superpopulação relativa (Marx, 1982), já que se incluem também nessa categoria os trabalhadores subempregados, ou empregados parcialmente, abaixo das condições sociais médias. Os protestos de ambos podem se dar por meio de uma relação de unidade ou fratura, o que em última instância se remete a seu pertencimento a frações de classe com interesses relativamente distintos e conflitantes.

A partir da leitura da análise pioneira de Engels n'A situação da classe trabalhadora na Inglaterra (Engels, 1986), aprofundada por Marx n’O Capital (Marx, 1982), é possível concluir que a classe trabalhadora pode cumprir o papel de exército de operários ativo ou de exército industrial de reserva na acumulação capitalista. É ativo quando realiza diretamente a produção social de mais-valia sob as condições médias da relação de dependência. Forma parte da reserva quando se constitui como estoque de força de trabalho desempregado ou empregado de maneira irregular, participando indiretamente da valorização do capital como instrumento de rebaixamento salarial que exerce uma constante pressão sobre os trabalhadores empregados. ${ }^{7}$ Sendo assim, a relação entre o ativo e a reserva está pautada em interesses de classe convergentes que advém de sua condição comum de "expropriado" e "despossuído". Porém, a competição no interior da classe trabalhadora, como antagonismo estrutural próprio do regime social capitalista, divide-a entre uma fração de classe "alojada" e outra "desalojada" do emprego da força de trabalho (Carrera e Podestá, 1989). A ação conjunta

\footnotetext{
${ }^{6}$ Versões preliminares dos itens $1.1,1.2$ e 1.3 foram desenvolvidas em artigos publicados nos anais do $18^{\circ}$ Congresso da AILSF (Souza, 2008c), do 32 ${ }^{\circ}$ Encontro Anual da Anpocs (Souza, 2008a), do $6^{\circ}$ Colóquio Marx/Engels (Souza, 2009b) e na revista Passages de Paris (Souza, 2008b).

${ }^{7}$ No item 1.3 esse repertório conceitual será apresentado mais detalhadamente.
} 
entre ambas foi considerada por Marx como uma importante forma de luta contra os efeitos da lei da oferta e procura de trabalhadores:

Quando os trabalhadores descobrem que, quanto mais trabalham, mais produzem riquezas para os outros, quanto mais cresce a força produtiva de seu trabalho, mais precária se torna sua função de meio de expandir o capital; quando vêem que a intensidade da concorrência entre eles mesmos depende totalmente da pressão da superpopulação relativa; quando, por isso, procuram organizar uma ação conjunta dos empregados e desempregados através dos sindicatos etc., para destruir ou enfraquecer as conseqüências ruinosas daquela lei natural da produção capitalista sobre sua classe, então protestam em altos brados o capital e seu defensor, o economista político, contra a violação da "eterna" e, por assim dizer, “sacrossanta" lei da oferta e da procura. Todo entendimento entre empregados e desempregados perturba o funcionamento puro dessa lei. (Marx, 1982: 743).

A análise da relação entre empregados e desempregados exige um exame profundo das formas e instrumentos de luta utilizados pela classe trabalhadora. Existe uma tendência a se considerar que este vínculo parte de uma questão anacrônica de antemão, já que atualmente as organizações sindicais são entidades corporativas que representam os interesses do trabalhador ativo, representado com base em sua categoria profissional ou ramo de atividade. Veremos, no decorrer do trabalho, em que medida e em que contexto essa formulação procede. Cumpre destacar, inicialmente, que uma análise histórica do tema permite afirmar que a unidade entre o sindicalismo e os desempregados está presente desde as origens do movimento operário, a exemplo dos fundos de solidariedade das primeiras tradeunions na Inglaterra do início do século XIX. Engels (1986) estuda este momento e afirma que, em seu início, os sindicatos sustentavam financeiramente os operários sem trabalho e os orientavam a passar de uma região a outra sendo socorridos pelos companheiros de ofício e informados sobre as oportunidades de trabalho. No mesmo período, surge o movimento ludita, que tinha como objetivo principal lutar contra as demissões em massa provocadas pela mecanização da indústria, utilizando, como instrumento, a destruição das máquinas. ${ }^{8}$

Vale retomar esta análise engelsiana para identificar a presença da construção de unidade entre o ativo e a reserva nas origens do sindicalismo, como uma forma de luta constitutiva dos protestos do movimento operário. Segundo Engels, os interesses antagônicos entre os proletários e a burguesia conformam a gênese de uma rebelião que atravessa

\footnotetext{
${ }^{8}$ Liderados por Ned Ludd, de onde deriva seu nome, os luditas ficaram conhecidos como "quebradores de máquinas". A ação mais conhecida do movimento foi a ocupação da manufatura de William Cartwright, em 1812, que provocou a condenação de 64 manifestantes, dos quais 13 receberam a pena de morte e dois, a deportação para colônias britânicas.
} 
diferentes "etapas", a começar pela mais "individual", o delito. No contexto do desenvolvimento industrial na Inglaterra, a forma de luta que marcou o início dessa oposição de classe, segundo o autor, foi justamente a resistência dos trabalhadores à introdução das máquinas, o que é uma clara demonstração de que Engels interpretava esse tipo de protesto como parte da rebelião operária (Engels, 1986). Cabe ressaltar, no entanto, que o ludismo foi apenas a mais conhecida dessas mobilizações. Protestos com características semelhantes ocorreram em outras partes da Europa, e mesmo no século XVIII já havia ações desse tipo, tal como faz referência Marx n'O Capital (Marx, 1982). ${ }^{9}$ Na realidade, como assinala Hobsbawn (2000, pp. 19-21), a destruição das máquinas (e também de matérias-primas, de produtos acabados e da propriedade privada dos empregadores) era uma "técnica" do sindicalismo, desde as primeiras fases da Revolução Industrial, utilizada principalmente como forma de resistência às reduções salariais.

Historicamente, na maioria dos casos os sindicatos não desenvolvem qualquer política de representação dos desempregados (com o argumento de que as entidades sindicais devem se ocupar dos trabalhadores empregados de sua base). Porém, em outros momentos essa relação se estabelece, por exemplo, a partir da criação de comitês de desempregados (baseados na idéia de que, como parte da classe trabalhadora, estes devem ser incorporados à luta sindical). ${ }^{10}$ Sendo assim, os conflitos, os interesses comuns e os limites da ação conjunta entre ambos não devem ser tratados de forma apriorística. Essa tese busca avançar na teorização desse campo, tão pouco explorado pelos estudiosos das questões sindicais. ${ }^{11}$ Sua delimitação, no entanto, exige algumas observações adicionais.

A unidade e a fratura entre o ativo e a reserva se manifestam de diferentes maneiras. A análise que proponho neste trabalho trata apenas de uma de suas dimensões: a relação do movimento sindical com os desempregados. Para analisar este vínculo, é importante diferenciá-lo das ações de denúncia e apresentação de propostas de combate ao desemprego, bem como das resistências às demissões protagonizadas pelos sindicatos. ${ }^{12}$ É necessário, pois, considerar dois momentos (a demissão e o desemprego) e, conseqüentemente dois sujeitos do protesto: o demitido e o desempregado propriamente dito. O primeiro, no momento de sua

\footnotetext{
${ }^{9}$ Sobre o tema, ver também Thompson (1997).

${ }^{10}$ As experiências são diversas. No próximo item, farei referência a alguns exemplos de mobilização dos desempregados. Vale ressaltar desde já, no entanto, que a unidade com o movimento operário e sindical esteve presente na maioria dos casos.

${ }^{11}$ As referências sobre o tema são escassas. Ver, por exemplo, Faniel (2006) e Pierru (2005).

${ }^{12}$ Em minha dissertação de mestrado (Souza, 2005b) destaquei a necessidade de se diferenciar essas instâncias.
} 
demissão, ainda pode oferecer alguma resistência no local de trabalho. O segundo, por não ter um vínculo empregatício, não possui essa mesma possibilidade, e diante da permanência na situação de desemprego, não necessariamente se organiza a partir de uma categoria ou sindicato específico. ${ }^{13}$ Essa delimitação é indispensável para distinguir as diferentes instâncias de intervenção das entidades sindicais em relação aos sujeitos do desemprego, ou seja, se esta é feita com os demitidos de sua base ou com os desempregados de maneira geral. Desse modo, diferenciarei, por um lado, os "protestos contra as demissões" das "manifestações contra o desemprego" e, por outro, a "representação" dos interesses dos demitidos e dos desempregados de sua "organização" para a luta.

Torna-se importante, ademais, levar em conta a existência de um traço estrutural na análise do desemprego, que consiste na separação entre o problema e o sujeito envolvido. É possível que um sindicato atue diante das demissões sem organizar os demitidos. Também é possível que uma central apresente uma proposta de combate ao desemprego sem organizar os desempregados. Ou seja, o desemprego e as demissões, no plano teórico-discursivo das representações ideológicas sobre suas causas e possíveis soluções, podem ser tratados pelas organizações sindicais sem que estas desenvolvam estratégias e ações de protesto, no plano prático, com os desempregados e os demitidos. Como veremos mais adiante, há de se considerar ainda a possibilidade de eclosão de um "movimento dos desempregados" que não se enquadre na estrutura de representação sindical. Nesse caso, é necessário avaliar a relação de aliança e isolamento entre as organizações. Interessa-me neste trabalho o vínculo entre o ativo (mais especificamente, o movimento operário organizado sindicalmente) e os desempregados (o segmento mais expressivo da reserva), estejam estes mobilizados ou não.

Ao longo da pesquisa, pude identificar os seguintes tipos de políticas desenvolvidas para os desempregados pelas entidades sindicais: (i) o oferecimento de serviços (cursos de qualificação e intermediação do emprego da força de trabalho) e a assistência (caixas de auxílio e fundos de greve); (ii) a organização para a produção e o consumo (cooperativas e recuperação de empresas); (iii) a mobilização para a luta (protestos) e a organização permanente (sindicalização e criação de associações, comitês, fundos de solidariedade, sindicatos de desempregados); (iv) a aliança com organizações de desempregados ou com as organizações cujas bases sociais são compostas predominantemente por desempregados.

\footnotetext{
${ }^{13}$ Como veremos no item 1.2, os desempregados podem se organizar de maneira "autônoma", apesar de ser mais comum que sua mobilização seja parte da estratégia de alguma entidade político-partidária ou sindical.
} 
A construção dessas ferramentas depende da correlação de forças (Poulantzas, 1971), mas também está condicionada por elementos estruturais. Engels (1986) oferece um quadro dos limites do sindicalismo que antecipa muitas das questões que serão tratadas neste trabalho. Para o autor, o caráter fundamental dos sindicatos está na sua defensividade diante dos abusos dos capitalistas, situação provocada (i) pela concorrência no interior da classe trabalhadora, identificada por Engels como "a arma mais afiada da burguesia na sua luta contra o proletariado"; (ii) pelo fato de os trabalhadores estarem sempre expostos à lei da oferta e procura de trabalho, caracterizada pela existência estrutural de um "exército de reserva de operários"; (iii) pela impotência da classe trabalhadora diante da introdução das máquinas no processo produtivo e das flutuações e crises cíclicas da economia capitalista. ${ }^{14}$ Em um artigo intitulado "Os Sindicatos", Engels (1974, p. 44) afirma que "mesmo considerando até ao detalhe as funções assumidas pelos sindicatos (...), [estes] se limitam a regularizar o salário médio e a fornecer aos operários, na sua luta contra o capital, alguns meios de resistência", quando na verdade, segundo o autor, estes deveriam ter como objetivo supremo do seu movimento "a luta pela abolição do sistema salarial na sua totalidade".

A consideração desses limites não significa que o sindicalismo, na tradição marxista, seja uma instituição fadada ao objetivo puramente "sindical" por salário, dentro dos limites da ordem capitalista. De acordo com Marx, sua luta imediata baseada na melhoria do "valor da força de trabalho" não deve ser subestimada pela classe trabalhadora (Marx, 1974b). Como afirma o autor no Preâmbulo aos Estatutos da $1^{a}$ Internacional "[...] a emancipação econômica da classe operária é o grande objetivo ao qual todo movimento político deve estar subordinado como meio" (Marx, 1974c, p. 27). Para Marx, o movimento sindical deve ser visto nesse sentido como um dos principais focos da resistência dos trabalhadores, conforme explicita na Resolução da Associação Internacional dos Trabalhadores sobre os sindicatos: "se os sindicatos são indispensáveis na guerra de escaramuças do trabalho e do capital, eles são ainda mais importantes como força organizada para suprimir e substituir o sistema do trabalho assalariado" (Marx, 1974d, p. 29). ${ }^{15}$

Uma análise reducionista da teoria marxista do sindicalismo pode ser encontrada em Anderson (1973). Analisando os limites históricos da instituição sindical, esse autor argumenta que o sindicalismo é "expressão" do capitalismo, e não uma instituição capaz de

\footnotetext{
${ }^{14}$ Para um estudo da concepção marxista sobre os limites do sindicalismo, ver Alves (2003).

15 A dialética entre luta política e econômica foi amplamente discutida em diversos textos de Lênin sobre o sindicalismo (Lênin, 1979). Dessa coletânea, ver especialmente o artigo "Sobre as greves".
} 
promover a sua "supressão". Afirma também que os sindicatos negociam dentro do sistema e, portanto, não questionam a divisão de classes, o que o impediria de se constituir como uma via ao socialismo. Anderson considera a ação sindical muito limitada, pois está geralmente restrita a aumentos salariais, melhorias nas condições de trabalho e conquista de direitos trabalhistas. Destaca, ademais, que seus meios de ação, como a greve, não são recursos que visam o fim do regime social capitalista. Por último, o autor sustenta que, na luta sindical, o poder e a consciência não são universais ou classistas, mas setoriais e corporativistas (pp. 5861). Aprofundemos sobre essa última questão.

Além dos elementos apontados até aqui para a análise da prática sindical em geral, a ação conjunta com os desempregados pode ser interpretada a partir da dificuldade das entidades de conciliar a representação dos interesses do grupo sócio-profissional com as do grupo social fundamental. Gramsci chama a atenção para o trecho da Miséria da Filosofia, em que Marx se refere à fase do "desenvolvimento de um grupo social" na qual "os membros de um sindicato não lutam só pelos seus interesses econômicos, mas na defesa e pelo desenvolvimento da própria organização" (Gramsci, 1976, p. 34). Nesse sentido, pode-se compreender as entidades sindicais como "aparelhos privados de hegemonia", segundo a expressão gramsciana, por reproduzirem as relações capitalistas no nível ideológico. Nessa mesma linha, Althusser (1999) cunhou o conceito de Aparelho Ideológico de Estado (AIE). Segundo este autor, em última instância, o sindicalismo é um sistema de instituições que reproduz a lógica de dominação burguesa, pois realiza a "ideologia de Estado", criando as condições para sua reprodução. ${ }^{16}$ No entanto, vale ressaltar que o autor considera que nem todo movimento sindical se constitui como AIE:

\footnotetext{
${ }^{16}$ Vale mencionar que da noção althusseriana de AIE decorre minha acepção de seu conceito de ideologia. Para Althusser (1999) esta não é formada por uma mistificação ou manipulação "de um reduzido número de homens cínicos que consolidam sua dominação e exploração do 'povo' sobre uma representação falseada do mundo" (p. 204). Também não advém da noção de que "os homens formam uma representação alienada (= imaginária) de suas condições de existência porque essas condições de existência são em si mesmas alienantes" (idem). Para o autor, essas interpretações se baseiam na idéia de que a ideologia é um reflexo do "mundo real", tal como na interpretação luckacsiana de "falsa consciência da realidade". Ao contrário, Althusser define as ideologias como "representações", não das condições de existência reais, mas da "relação" com essas condições de existência reais. Ou seja, a ideologia é uma "representação" imaginária da relação imaginária dos indivíduos com suas condições reais de existência. Não correspondem à realidade (não é uma simples "ilusão"), embora faça "alusão" ao mundo real. Afirma o autor: “(...) a representação das condições de existência reais dos indivíduos que ocupam postos de agentes da produção da exploração, da repressão, da ideologização e da prática científica, depende, em última instância, das relações de produção e da relação delas derivadas (...) toda ideologia representa não as relações de produção existentes (...), mas antes de tudo a relação (imaginária) dos indivíduos com as relações de produção e com as relações que dela derivam" (p. 205).
} 
(...) não se trata de toda a luta de classes, nem tampouco do terreno em que está enraizada a luta. Trata-se de um campo em que a luta de classes reveste suas formas legais (...). Sob as formas legais da existência dessas organizações, a burguesia sabe que o que está em questão supera infinitamente essas formas (...) (pp. 129-130).

A institucionalização do sindicalismo pode ser entendida a partir da teoria do corporativismo. Uma definição clássica desse conceito está em Philippe Schmitter, segundo o qual:

[o corporativismo é] um sistema de representação de interesses no qual as unidades constituintes são organizadas num número limitado de categorias singulares, compulsórias, não-competitivas, hierarquicamente ordenadas e funcionalmente diferenciadas, reconhecidas ou permitidas (se não criadas) pelo Estado, às quais se outorga o monopólio de representação deliberada no interior das respectivas categorias em troca de observância de certos controles na seleção de seus líderes e na articulação de suas demandas e apoios (Schmitter apud L. Rodrigues, 1990b, p. 54). ${ }^{17}$

Antes de incorporar essas definições à análise, retomemos os argumentos centrais desenvolvidos até aqui. Esta tese parte da premissa de que empregados e desempregados, ao formarem parte, respectivamente, do ativo e da reserva, constituem frações da classe trabalhadora com interesses imediatos antagônicos entre si. Esse antagonismo advém da função que cumprem no processo de acumulação do capital, ainda que em última instância, sua condição comum de expropriados é a que determina seu pertencimento a um mesmo grupo social. Sendo assim, a relação entre ambos é dada pelo processo histórico de construção social e cultural da luta de classes, na qual sempre está aberta a possibilidade de uma ação conjunta no enfrentamento com a classe capitalista.

Porém, esta análise se restringe à estrutura sindical oficial corporativa, ou seja, à forma legal de manifestação histórica do sindicalismo, como Aparelho Ideológico de Estado. Mas, qual Estado? O Estado burguês, entendido aqui, no sentido empregado por Saes (1998, pp. 30-31), como o tipo específico de aparelho estatal que "cria as condições ideológicas necessárias à reprodução das relações de produção capitalista”, a partir do exercício de uma dupla função. A primeira delas é a "individualização dos agentes da produção", o que produz o efeito de representação da unidade Povo-Nação, mas que individualiza o produtor direto, na medida em que o coloca "no mercado de trabalho, como sujeito individual, dotado de vontade e de direitos". A segunda visa "neutralizar, no produtor direto, a tendência à ação coletiva", o

\footnotetext{
${ }^{17} \mathrm{O}$ autor diferencia dois modelos de corporativismo: o corporativismo societal, que não depende diretamente da tutela do Estado, e o corporativismo estatal, no qual o aparelho sindical é incorporado à administração do Estado. Ver Schmitter (1974).
} 
que advém do caráter socializado do processo de trabalho, que produz um efeito de isolamento, "decorrente do caráter privado assumido pelos trabalhos nesse processo", inibindo os trabalhadores "a se unirem num coletivo antagônico ao proprietário dos meios de produção".

A partir do que foi exposto, podemos indagar: quem são os desempregados para a estrutura sindical corporativa, esta entendida aqui como AIE burguês? Uma anomalia jurídica. O legalismo no meio sindical restringe o sindicalismo à representação dos interesses de um segmento da classe trabalhadora (organizado por categoria profissional ou por ramo) que realiza a venda de sua força de trabalho sob um "contrato" formal. Os demais trabalhadores não inseridos nesse vínculo empregatício não são "sindicalizáveis". Nesse sentido, o AIE sindical, ademais de legitimar a divisão da base empregada formalmente, dá expressão jurídica ao fracionamento no interior da classe trabalhadora entre o ativo e a reserva, levando ao paroxismo a individualização dos agentes diretos da produção e a neutralização de sua tendência à constituição como classe.

A forma mais acabada de manifestação da ideologia jurídica no discurso sobre a representação dos desempregados está na justificativa comum da impossibilidade de seu enquadramento por conta dos critérios de sindicalização previstos na legislação. Trata-se de uma forma de reprodução do burocratismo burguês no meio sindical (Saes, 1998, p. 45). Ora, o interesse particular da burocracia sindical é a própria conservação do AIE sindical. Particularmente ao tema estudado, seu efeito mais direto está nos critérios de filiação e representação, que pressupõe a separação entre o ativo e a reserva. $O$ efeito prático da reprodução dessa ideologia jurídica, de natureza corporativa e burguesa, é o desinteresse dos sindicatos pelos desempregados, já que estes, em última instância, não votam nem contribuem financeiramente com as entidades sindicais. É nesse terreno que a ideologia do Estado burguês é reproduzida no aparelho sindical, pois provoca, no plano ideológico, o efeito de ocultação da "lei geral da acumulação capitalista", ao legitimar, juridicamente, a existência de uma população sobrante para as necessidades do capital. Esse mecanismo garante ao capitalista a pressão da reserva sobre o ativo como instrumento disciplinador dos protestos e de rebaixamento do salário e das condições de trabalho, que amortece a luta de classes, já que pressupõe que empregados e desempregados não fazem parte da mesma coletividade: a classe trabalhadora. 
O corporativismo reproduz, ainda, a ideologia da igualdade jurídica, principal pressuposto da existência do Estado burguês (Saes, 1998). Ora, os desempregados não são impedidos, por lei, de se sindicalizarem, na medida em que são "livres" para vender sua força de trabalho sob um contrato formal e, assim, afiliarem-se à entidade que lhe corresponde. Nesse sentido, o sindicalismo de Estado atua como limitador da luta de classes (Boito Jr., 1991a). O princípio fundante desse efeito desmobilizador está na separação entre empregados e desempregados, e de maneira mais abrangente, na fratura entre o ativo e a reserva. A aparência de igualdade no vínculo empregatício, como "ato de vontade realizada por iguais" na "troca desigual entre o uso da força de trabalho e o salário" (Saes, 1998, p. 30), oculta ainda o caráter social desse "contrato", a partir do qual o conjunto da classe capitalista se apodera da força de trabalho do conjunto da classe trabalhadora. Como se depreende da leitura de Marx, a exploração capitalista não se realiza apenas diretamente (na relação de trabalho), mas indiretamente (por meio da apropriação do estoque de força de trabalho à disposição para ser utilizado conforme as necessidades imediatas de expansão do capital). O modelo de representação do AIE sindical restringe a relação capital e trabalho ao assalariamento formal entre "empregadores" e "empregados", e não a considera como uma relação entre burguesia e proletariado, ou ainda, entre classe trabalhadora e classe capitalista.

No entanto, essa problemática provoca um efeito ainda mais perverso. A divisão entre empregados e desempregados não pressupõe uma separação entre os problemas do emprego e do desemprego nas entidades sindicais. Isso é o que torna possível que a luta contra o desemprego seja desvinculada da ação com os desempregados. Não é casual que as práticas sindicais para os desempregados, nos marcos legais do aparelho sindical, restrinjam-se à reivindicação por emprego ou a políticas assistencialistas para estes trabalhadores, ainda que sem se propor a atuar com estes por meio de sua mobilização e inserção cotidiana na atividade dos sindicatos. Em suas bandeiras e propostas de combate ao desemprego, o sindicalismo atua com a aparência de legítimo defensor da classe trabalhadora, ocultando o efeito de isolamento que o aparelho sindical provoca em relação aos desempregados. Ora, no plano discursivo, nenhum dirigente é a favor do desemprego, ainda que o desempregado possa aparecer nas entidades como mero um número das estatísticas. Pode-se dizer inclusive que, discursivamente, nenhuma classe ou ideologia defende abertamente o desemprego, o que 
ofusca os interesses de classe em torno da questão. ${ }^{18}$ Nem o Estado burguês e os capitalistas assumem a defesa do desemprego, mesmo se beneficiando de sua existência para exercer sua exploração e dominação de classe.

A quem se atribui a culpa pela falta de emprego? Governo e empresários se culpam entre si, ou ao assumir a posição liberal, identificam os próprios trabalhadores como os responsáveis de sua situação. O movimento sindical tem o privilégio de poder acusar a todos, mesmo que não o faça em conjunto com os desempregados. ${ }^{19} \mathrm{E}$ a quem o sindicalismo destina a tarefa de resolver o problema do desemprego? Geralmente ao Estado burguês, que aparece como uma instituição que defende o direito de todos. Nesse sentido, o AIE sindical é portador, no nível das propostas de políticas de emprego, da ideologia do fetiche do Estado protetor da vontade geral. Para os sindicalistas, por meio de sua intervenção na economia, o aparelho estatal tem o papel de conter os efeitos da acumulação capitalista. Por tal motivo, em nome da defesa do emprego, o AIE sindical não oferece organização para os desempregados. Defende seus interesses e sabe o que é melhor para eles, mas se relaciona com estes trabalhadores, de maneira geral, somente por intermédio do setor de homologação. Nesse terreno, cumpre suas atribuições burocráticas como funcionários da administração do Estado (H. Martins, 1978). Um argumento muito recorrente entre os sindicalistas é de que a representação dos desempregados é uma forma de aceitação da situação de desemprego. Ademais, segundo essa acepção, seria contraditório organizar um grupo com o objetivo final de extingui-lo.

Ao não investir na ação conjunta entre empregados e desempregados como forma de pressionar os capitalistas, o sindicalismo legitima a pressão que os desempregados exercem sobre os empregados. O AIE sindical pressupõe o isolamento entre o ativo e a reserva. Dessa maneira, é possível afirmar que a representação dos desempregados pelos sindicatos requer, necessariamente, uma prática anti-burocrática. Como explica Saes (1998),

\footnotetext{
${ }^{18}$ Mesmo o neoliberalismo, ou a leitura liberal de Schumpeter, que assume a "necessidade" do desemprego para o crescimento e para a eficácia do mercado de trabalho, o faz por meio da noção de que a "mão invisível" do mercado realoca naturalmente esses trabalhadores por meio de mecanismos de criação e destruição de empregos. Com base nessa perspectiva, Cahuc e Zylberberg (2005) partem de uma leitura dos dados empíricos segundo a qual a cada dia, na França, 10.000 postos de trabalho são destruídos e outros 10.000 são criados. Apesar de se fundamentar na teoria shumpeteriana, a proposta analítica desses autores possui um efeito ideológico funcional ao neoliberalismo, pois se pauta no pressuposto de que o "livre" mercado possui mecanismos de auto-regulação.

${ }^{19}$ Para o sindicalismo revolucionário, essa ação conjunta tem o objetivo de ir à raiz da relação entre capital e trabalho para defender a abolição do regime assalariado do qual a própria instituição sindical corporativa depende para subsistir.
} 
(...) o desenvolvimento da luta de classes pode determinar a organização, no seio do Estado burguês, de alguma forma propriamente política - não burocrática - de representação popular. Isso significa que, nessa formação social, os efeitos ideológicos produzidos pelo burocratismo são insuficientes para desorganizar uma ou mais classes populares (...) (pp. 47-48).

No caso da superação desse elemento, a classe dominante, segundo o autor, "deve constituir novos mecanismos ideológicos de desorganização das classes populares" (p. 48). A concretização da representatividade popular anti-burocrática, no entanto, necessita de um trabalho político de militância e mobilização que, de acordo com a correlação de forças, consiga se contrapor aos efeitos neutralizadores advindos do AIE sindical. Caso contrário, a acomodação à estrutura significa a reprodução de práticas invariantes que podem assumir diferentes feições apenas em seus efeitos secundários. $\mathrm{O}$ reconhecimento oficial pelo Estado (investidura sindical), o monopólio de representação (unicidade sindical) e a contribuição compulsória (imposto sindical) tornam a organização dos trabalhadores independente da base (Boito Jr., 1991a), além de burocratizar as entidades sindicais dentro dos marcos institucionais. Nesse sentido, o grau de oposição a este modelo é determinado pela capacidade de atuar por fora da legalidade.

Como se torna possível uma ação conjunta entre o movimento operário organizado sindicalmente e os desempregados? A chave para a compreensão desse vínculo está na construção, por parte das entidades, de uma unidade que aponte para a superação da competição estrutural no interior da classe trabalhadora, cuja forma jurídica é assumida pelo AIE sindical, que reproduz a ideologia burguesa por meio do burocratismo corporativista. Como partes constitutivas, respectivamente, do ativo e da reserva, empregados e desempregados representam frações de classe com interesses conflitantes, que em última instância se remetem à luta pela permanência no emprego, de um lado, e ao desejo de obtenção de um meio de subsistência, do outro. O vínculo entre ambos revela a maneira como a classe trabalhadora resiste ou negocia com a classe capitalista as condições em que se realiza a produção social de mais-valia (Podestá, 1999), que ademais do valor pago e da intensidade do emprego da força de trabalho, também se remete à quantidade de trabalhadores submetidos a essa relação. Esta problemática está presente nas origens do sindicalismo e, em linhas gerais, é a base da bandeira histórica de redução da jornada de trabalho.

A ação conjunta entre empregados e desempregados foi identificada por Marx como um importante instrumento de pressão dos trabalhadores diante das leis que regem o funcionamento da economia capitalista. No âmbito da forma legal da prática sindical, trata-se 
ademais, de um modo de superação do corporativismo, este último caracterizado pela tendência de representação dos interesses da organização e da categoria sócio-profissional em detrimento do conjunto da classe trabalhadora como grupo social.

O argumento central desta tese é de que para compreender a relação de unidade e fratura entre o ativo e a reserva, e mais especificamente, do sindicalismo com os desempregados, deve-se ter em conta a estrutura e a correlação de forças de uma determinada formação social, mas também é necessário destacar as experiências e tradições da classe trabalhadora. A partir desse referencial, pode-se compreender que os vínculos entre esses sujeitos não se manifestam somente na representação e organização direta dos sindicatos. A análise de suas imbricações deve ser interpretada mais amplamente, no contexto cultural e social de formação da classe social, marcada pelas alianças e conflitos entre as organizações.

Vale dizer ainda que se estatuto do desemprego se define pelo seu oposto (o emprego), a mobilização dos desempregados possui um vínculo estreito com a rebelião dos empregados, seja em relação de unidade, seja de fratura. Além disso, é importante sublinhar que as experiências e tradições do movimento operário, sindical e popular são constitutivas do movimento cíclico da rebelião, e os trabalhadores sem emprego não estão imunes a este processo por conta de supostas características estruturais que impossibilitam sua mobilização. $\mathrm{Na}$ análise da construção da unidade e fratura entre o ativo e a reserva é necessário ter em conta esses elementos. Por um lado, os protestos da reserva - tal como o dos desempregados possuem um traço de continuidade com o movimento operário organizado sindicalmente e politicamente, em especial quando se trata de trabalhadores repelidos pelo processo de substituição de trabalho vivo por trabalho morto. Por outro lado, em formações sociais caracterizadas pela existência de uma superpopulação relativa crônica (no campo e/ou na cidade) é necessário levar em conta as formas de luta do movimento popular que se constroem em torno de reivindicações pela satisfação das condições materiais de sobrevivência. As tradições de organização e luta conformam um patrimônio da classe que "circula" na memória coletiva dos trabalhadores. São, portanto, constitutivas da "ideologia de protesto" e, a depender das circunstâncias dadas pela correlação de forças, são acionadas e adaptadas às novas experiências. No processo histórico de construção social e cultural das classes sociais e da luta de classes, a análise da unidade e fratura entre o ativo e a reserva - do qual fazem parte o movimento sindical e os desempregados - é fundamental, já que esta relação é fruto de relações sociais orgânicas do capitalismo. 
Antes de passar ao próximo item, insistirei em um argumento já enunciado ao longo da exposição. A análise da relação entre o movimento sindical e os desempregados é não só pertinente, mas central para compreender a rebelião da classe trabalhadora, já que explicita como os sindicatos se apresentam diante das condições gerais em que a classe capitalista compra a força de trabalho do conjunto da classe operária. Nesse processo, a burguesia procura manter, à sua disposição, e sem custos adicionais, um estoque de trabalhadores dispostos a ocupar um posto a qualquer momento. Essa premissa já seria suficiente para se contrapor ao discurso bastante comum de que o tema deste trabalho trata de uma questão anacrônica de antemão, pelo fato de que o sindicalismo no capitalismo contemporâneo representa exclusivamente os empregados. Porém, se em alguns momentos históricos os protestos dos trabalhadores sem emprego apareceram em uma relação de fratura com os sindicatos, e até mesmo em conflito com estes, em outros é possível verificar iniciativas de representação, seja por meio de políticas assistencialistas, seja através de sua organização para a luta. A unidade ou fratura entre suas diferentes frações fazem parte, pois, do repertório de formas e instrumentos de luta dos trabalhadores. Essas referências são fundamentais para a construção deste campo analítico tão pouco explorado pelo marxismo, apesar das ferramentas teóricas deixadas por Marx e Engels.

\subsection{Limites da organização dos desempregados e construção social do desemprego}

As questões trabalhadas no item anterior possuem uma estreita relação com os argumentos levantados pelos próprios sindicalistas para explicar os limites da representação dos demitidos e dos desempregados pelo movimento sindical. Durante a pesquisa de campo, os elementos mais citados pelos entrevistados, especialmente os brasileiros, foram: (i) a competição no interior da classe trabalhadora, que dificulta uma ação conjunta entre os trabalhadores (ii) a legislação, que impede os desempregados de se sindicalizarem; (iii) a ausência de ações sindicais que busquem representar e organizar os trabalhadores não sindicalizáveis; (iv) a ideologia e a prática corporativa dos direção sindical, que prioriza a representação dos que permanecem em sua base; (v) a falta de interesse político nesse segmento, que não cotiza nem vota nas eleições sindicais; (vi) a frágil organização no local de trabalho para enfrentar as demissões, que poderia conformar em experiências prévias de luta para serem utilizadas na situação de desemprego; (vii) o baixo custo e a ausência de 
mecanismos institucionais inibitórios às demissões; (viii) a relação de forças desfavorável com as empresas quando essas decidem demitir e a intransigência do patronato em sua relação com os sindicatos no tratamento dessas questões; (ix) e a frágil tradição de negociação coletiva, que favorece as relações diretas entre empregadores e empregados.

O desemprego é considerado pelos dirigentes como um dos principais inibidores da ação sindical. Além de provocar a diminuição da base e das finanças das entidades, enfraquece seu poder de mobilização e reduz a capacidade de resistência por conta do medo da demissão que se instaura entre os trabalhadores que permanecem empregados. Entre os fatores que dificultam a organização dos desempregados, os sindicalistas citam ainda as características "próprias" desse segmento, sendo as mais comuns: a dispersão, a fragmentação, o isolamento, a transitoriedade, o individualismo na busca de alternativas para a sobrevivência, a heterogeneidade, a falta de recursos materiais e a baixa auto-estima. Esses elementos foram trabalhados teoricamente por algumas análises sociológicas produzidas na França, com as quais passo a dialogar.

A Sociologia do Desemprego francesa vem debatendo desde o início dos anos 1980 os limites da mobilização política dos desempregados. As diferentes interpretações vão de encontro com o posicionamento adotado diante das principais correntes da Sociologia dos Movimentos Sociais. Sendo assim, encontraremos na bibliografia tanto aqueles que se aproximam das abordagens clássicas da disciplina (ação racional/ mobilização de recursos/ novos movimentos sociais/ estrutura das oportunidades políticas), quanto das abordagens mais atuais que primam pelo estatuto da construção identitária e simbólica da categoria. ${ }^{20}$

A análise dessa questão se desenvolveu em um contexto de eclosão de diversos protestos sociais levados a cabo pelos desempregados na França. Em 1983, surgiu no país o Sindicato de Desempregados, que protagonizou algumas ações pontuais com relativa repercussão, mas que diminuiu seu peso político ao longo da década até desaparecer, em 1989. Nos anos 90, as lutas contra o desemprego crescente se intensificaram a partir do surgimento de quatro associações: a AC!, o MNCP, a Apeis e os comitês de desempregados da $\mathrm{CGT}^{21}$, uma das principais centrais sindicais do país. No entanto, na ausência de eventos

\footnotetext{
${ }^{20}$ Para uma análise das teorias dos movimentos sociais, ver Neveu (1996).

${ }^{21}$ AC! (Agir ensemble contre le Chômage, "Agir juntos contra o Desemprego"); MNCP (Mouvement National des Chômeurs et Précaires, "Movimento Nacional de Desempregados e Precários"); Apeis (Association pour l'Emploi, l'Information et la Solidarité, “Associação pelo Emprego, pela Informação e pela Solidariedade”); CGT (Confédération Generale du Travail, "Confederação Geral do Trabalho"). Para mais detalhes sobre esses
} 
de grande repercussão até o chamado "inverno de 97-98",22, as análises francesas versavam exclusivamente sobre a caracterização da "impossibilidade estrutural" (Castel, 1995; Rosanvallon, 1995) ou dos "limites" (Demazière, 1996; Fillieule, 1993; Galland e Louis, 1981; Pignoni, 1994) da constituição de mobilizações de desempregados com peso no conjunto da rebelião. Após as ações de dezembro de 1997 e janeiro de 1998, entretanto, houve uma inversão na prioridade das análises, que também passaram a contemplar questões de diversas ordens, tais como os fatores que possibilitam a emergência das "ações coletivas", as dificuldades cotidianas das organizações e o processo de "engajamento" individual (Cohen, 2003; Demazière, Pignoni, 2003; Maurer, 2003; Pierru, 2005).

A análise dos limites da mobilização política dos desempregados parte de quatro tipos de argumentos: (i) morfológico-sociais; (ii) psicológicos e identitários; (iii) políticoideológicos; (iv) e normativo-institucionais. ${ }^{23} \mathrm{O}$ limite morfológico e social se explica pelo caráter essencialmente heterogêneo do grupo, por agregar diferentes "estatutos sociais" (gênero, etnia, idade, nível de escolaridade, região de procedência, entre outros). Como conseqüência desse aspecto, o desemprego é vivenciado de diferentes maneiras, o que provoca o isolamento social dos indivíduos, que recorrem a estratégias individuais e dispersas para escapar do problema. ${ }^{24}$

Os fatores psicológicos e identitários se referem à dificuldade de aceitação da condição de desemprego, tratado desde os precursores da análise sociológica do tema como uma "condição humilhante" (Lazarsfeld, Yahoda, Zeizel, 1981; Ledrut, 1966). Por conta desse fator, o desemprego é vivenciado como uma "provação", pois seu estatuto é essencialmente

movimentos, consultar, respectivamente, Aguiton (1998), Bourneau e Martin (1993), Hoareau (1998) e Pagat (1987).

${ }^{22}$ Período de maior concentração da mobilização dos desempregados na França, cujo evento de maior peso político foi a série de ocupações dos escritórios da Assedic (Association pour l'Emploi Dans l'Industrie et le Commerce, Associação para o Emprego na Indústria e no Comércio), orgão que entre outros fins, administra o pagamento do seguro-desemprego em parceria com a ANPE (Agence Nationale pour l'Emploi, Agência Nacional para o Emprego).

${ }^{23}$ As duas primeiras teses são apresentadas pela maioria dos autores citados. Entretanto, é em Demazière (1996) que se encontra de maneira mais desenvolvida as duas últimas.

${ }^{24}$ Para Galland e Louis (1981), por exemplo, o principal fator da desmobilização dos desempregados é a atomização e a heterogeneidade no interior de sua população, o que dificulta a "construção de uma visão unitária", a "identificação do problema e do inimigo" e a "homogeneidade nas reivindicações", consideradas como principais pressupostos da mobilização. Para esses autores, além da construção de uma identidade coletiva, a homogeneidade do grupo e a solidariedade são condições prévias indispensáveis da "ação coletiva". No caso dos desempregados, consideram difícil a construção de uma luta em comum por conta do individualismo predominante na vivência cotidiana do desemprego. 
negativo por conta do desejo do sujeito de sair de sua situação (Schnapper, 1994), o que provoca a dessocialização e dificulta a construção de uma identidade coletiva.

O elemento político-ideológico pode ser sintetizado através da tese da despolitização do desemprego, ou seja, na maneira como a questão é apresentada na mídia e nos discursos oficiais dos governos. Por exemplo, no contexto atual é muito comum a atribuição de responsabilidade individual aos desempregados, vistos ora como "preguiçosos" ou "vagabundos", ora como "não empregáveis" ou "inadaptados" às exigências do mercado de trabalho, ou ainda, como "acomodados" ou "aproveitadores" do sistema de segurodesemprego, por uma suposta falta de esforço na busca de trabalho. Desse modo, a "revolta" e a "indignação" dão lugar ao "fracasso pessoal" e à "auto-culpa", o que contribui para dificultar ainda mais a construção de um "laço coletivo" e o "sentimento de injustiça social" necessários para a mobilização.

$\mathrm{O}$ aspecto normativo-institucional está presente especialmente na maneira como se processa a categorização social e a construção jurídica do desemprego. Principal responsável por este processo, as instituições que administram o sistema de seguridade tendem a criar estatutos intermediários entre o emprego e o desemprego ${ }^{25}$, o que dificulta a apreensão do problema pelos indivíduos, separando-os em grupos isolados que dificilmente constroem uma luta comum. Apresentarei a seguir uma série de críticas a essas teses.

Os argumentos morfológicos e sociais fazem "tábula rasa" das possibilidades de mobilização política dos desempregados, pois partem de um "modelo único" de organização que advém de uma idéia romântica e idealizadora do movimento operário, tal como argumenta Hyman (1994) quando este critica a noção de crise do sindicalismo. Ora, a heterogeneidade não é uma característica restrita aos desempregados, mas é comum a todo grupo social, e inclusive aos empregados. Ademais, nem todo coletivo, à primeira vista "homogêneo", constrói uma mobilização. Também vale ressaltar que o caráter heterogêneo é sempre relativo, e está exposto a fatores de diversas ordens, não podendo ser considerado um fator desmobilizador em si. Os pares de opostos apresentados por Galland e Louis (1981) (identidade positiva e coletiva/ identidade negativa e individual; homogeneidade/heterogeneidade; solidariedade/individualismo) não são particulares dos desempregados, mas uma questão histórica presente no conjunto da classe trabalhadora e já abordada por diversos estudos sobre o movimento operário e sindical.

\footnotetext{
${ }^{25}$ Como se observa na França, por meio da diferenciação entre "demandante" e "não demandante" de emprego.
} 
A respeito dos fatores psico-identitários, Maurer (2003) argumenta que em determinados contextos de "desemprego em massa", a identidade construída em torno do desemprego pode deixar de ser negativa para ser interpretada individualmente e pelo "senso comum" como um problema econômico, social e político, o que possibilita a construção de um terreno propício para a indignação e o engajamento.

Galland e Louis (1981) partem de uma crítica ao apriorismo e ao dualismo do modelo olsoniano de análise dos movimentos sociais para explicar a ausência de organização coletiva dos desempregados. ${ }^{26}$ Nesse sentido, por um lado, referem-se à falta de "sub-produtos" e de "coerção" nas interpretações dessa corrente; e por outro, à dualidade entre os comportamentos “interessado" e "altruísta” para explicar a mobilização. Em seguida, propõem outro modelo no qual as identidades são interpretadas como "meios sociais de reconhecimento". Ao valorizarem os interesses e o poder como parte do quadro de relações sociais que orientam as ações individuais e coletivas, os autores buscam não perder de vista a questão do prestígio e da dominação. No entanto, adotam o mesmo procedimento apriorístico da teoria da ação racional ao considerarem a dificuldade de construção da identidade dos desempregados como condição prévia necessária para sua organização (ou, nas palavras dos autores, como "trampolim indispensável para seu desencadeamento"), opondo de forma dicotômica "portadores" e "não portadores" desse reconhecimento. Nesse sentido, cometem um erro semelhante à aplicação mecanicista do conceito de "consciência de classe". Ora, "interessados" e "altruístas", “conscientes" e "inconscientes", "portadores" e "nãoportadores" de reconhecimento são categorias que possuem uma mesma matriz dicotômica, que analisa as possibilidades de eclosão dos protestos sociais a partir de pares de opostos estanques, apreensíveis a partir de uma lógica de classificação previsível, na qual não há espaço para a contradição. ${ }^{27}$

A partir desse fundamento, segundo o qual a construção identitária é uma condição prévia da "ação coletiva", pode-se argumentar que a mobilização dos desempregados não é possível sem a formação de uma identidade coletiva de desempregados. No entanto, os desempregados não se mobilizam sempre como desempregados. Especialmente se o desemprego vem acompanhado de um processo de pauperização familiar, a reivindicação por

\footnotetext{
${ }^{26}$ Ver Olson (1966).

${ }^{27}$ Ademais, uma inconsistência metodológica decisiva na análise desses autores é a de ampliar as conclusões sobre os jovens desempregados que estudam ao conjunto desses últimos, tomando-o, portanto, como um bloco homogêneo.
} 
emprego (ou por um seguro-desemprego) dá lugar a "outras" bandeiras, que podem ser levantadas por outras camadas pobres de trabalhadores, tais como políticas emergenciais na forma de alimentos ou renda, isenção de tarifas públicas, melhores condições de vida nos bairros, acesso à terra ou à moradia, etc. É por isso que a busca de algum (ou um melhor) meio de vida se torna uma questão central, já que a pobreza (esta entendida, no marco teórico marxista, como a insuficiência dos meios de reprodução da vida em condições consideradas socialmente "normais") e a pauperização aparecem não só nas reivindicações de desempregados, mas em outros tipos de protestos, como o movimento dos precários, dos chamados "sem" (sem documentos, sem-teto, sem terra) ${ }^{28}$, entre outros, incluindo aí as revoltas de fome. ${ }^{29}$ Em uma palavra, trata-se de "movimentos de pobres" (Fox Piven, Cloward, 1979) ${ }^{30}$, desempregados ou não. É o momento, por excelência, em que a "o exército industrial de reserva vai à guerra", que se constrói em uma relação de enfrentamento contra os efeitos mais perversos de sua condição de supérfluo para as necessidades imediatas da produção capitalista. Uma guerra onde não é possível a utilização da "arma" clássica do movimento sindical de interromper a produção das mercadorias nas indústrias, ainda que se possa bloquear sua circulação.

Também levamos em consideração que nem toda mobilização de desempregados é composta apenas por desempregados. É necessário diferenciar um "movimento de desempregados" de um "movimento contra o desemprego", já que este último pode aglutinar diversos grupos sociais de "descontentes" com o problema, tais como militantes partidários, sindicalistas, estudantes e intelectuais. De maneira resumida, é possível observar: (i) a existência de diversas identidades em um único movimento; (ii) a construção de uma identidade neutra assumida em torno do desemprego; (iii) a organização de um movimento apesar da ausência de uma definição clara e única de sua identidade coletiva.

$\mathrm{Na}$ própria França, por exemplo, encontramos a AC!, que não congrega apenas desempregados, mas também intelectuais, estudantes, entre outros, que assumem a bandeira

\footnotetext{
${ }^{28}$ A categoria de movimento dos "sem" (sans) vem sendo trabalhado por diversos estudiosos franceses. Ver, por exemplo, o trabalho de Mouchard (2002).

${ }^{29}$ Hobsbawn (2000, p. 158), em artigo sobre a relação entre as flutuações econômicas e a eclosão dos movimentos sociais, referindo-se aos "meios de vida" e "condições de trabalho" da classe operária, afirma: "os índices mais utilizados pelos estatísticos, os dos salários, custo de vida e desemprego, são extremamente defeituosos; primeiro, devido a nossa ignorância abismal da maneira pela qual várias classes da população ganham sua vida e como as flutuações econômicas as afetaram; segundo, devido aos obstáculos técnicos dos próprios índices que, de qualquer maneira, raramente foram elaborados para o nosso propósito”.

${ }^{30}$ Mouriaux (2002) denomina as organizações atuais que se mobilizam em torno de questões ligadas diretamente à sobrevivência como "movimentos de urgência".
} 
da luta "contra o desemprego". Da mesma forma, a Apeis se define como um movimento "pelo emprego", mas sem restringir sua base social aos desempregados. O MNCP aglutina desempregados e precários, portanto, não constrói sua identidade apenas em torno do desemprego, mas também da precariedade dos trabalhadores empregados. ${ }^{31}$ Por último, temos o caso dos comitês da CGT, cuja organização e estrutura vêm do movimento sindical.

Valem ainda algumas palavras adicionais sobre o terceiro e quatro blocos de argumentos apresentados por Demazière (1996), definidos como "político-ideológicos" e "normativo-institucionais". Ora, se a maneira como o desemprego aparece política e ideologicamente nos discursos oficiais e midiáticos é um fator condicionante da desmobilização dos desempregados, pode-se argumentar que a militância pode desconstruir seus pressupostos e promover a mobilização desse segmento. O trabalho de Fillieule (1993) traz uma contribuição significativa nesse terreno, pois ao separar os determinantes individuais e coletivos da mobilização, o autor deixa espaço para os fatores subjetivos e para a análise de conjuntura na compreensão do fenômeno. Procurando se diferenciar das análises "psicossociológicas" e "estruturais", o autor propõe um modelo que se fixa na determinação dos fatores de participação a partir das "percepções" do "potencial mobilizável" e do "trabalho de manipulação simbólica" em função dos contextos sócio-políticos nos quais os movimentos estão inseridos, o qual identifica como a "estrutura das oportunidades políticas". A partir de um estudo de caso sobre a tentativa de consolidação do Sindicato dos Desempregados, na década de 1980, ao invés de analisar os obstáculos para a mobilização, o autor se preocupa com a "ativação dos fatores de participação". Assim, tomando a análise dos "aspectos cognitivos da perda do emprego", o autor mostra como a aquisição e a manipulação de "recursos simbólicos" puderam modificar a interpretação dos trabalhadores sem-emprego sobre sua situação.

Valem ainda algumas considerações sobre os fatores normativo-institucionais. Ora, se o estatuto de desempregado depende do "reconhecimento social" por parte das instituições, como as que regulam o seguro-desemprego, nos países onde o papel desse mecanismo é pouco presente e a sua constituição é deficitária, esse argumento tem pouca força explicativa. Desse modo, não pode ser considerado como um fator de desmobilização, pois nesses contextos aqueles que não têm emprego são suscetíveis à inserção ocupacional como trabalhador "precário" ou "informal". Esse paradoxo leva às seguintes indagações: (i) a

\footnotetext{
${ }^{31}$ Sobre o tema, ver Perrin (2004).
} 
mobilização política dos desempregados, como tais, é menos provável onde seu estatuto é mais fluído?; (ii) nesses casos, existem outros tipos de luta construídas em torno das zonas de intersecção entre o "emprego", o "desemprego" e a "inatividade"?; (iii) ou se trata de considerar os outros problemas sociais a partir dos quais o movimento popular se constitui, tais como demonstram a eclosão de organizações de precários, sem-terra, sem-teto, etc., cuja base social é composta predominantemente por desempregados?; (iv) se no interior das próprias organizações a construção identitária em torno da categoria do "desemprego" não se apresenta sempre clara e bem delimitada, como definir um movimento de desempregados?

Vimos até aqui que a análise dos fatores prévios da mobilização dos desempregados é feita de forma apriorística por uma série de autores. Porém, a história dessa forma de luta atesta que seus limites não podem ser vistos como barreiras intransponíveis. Antes de passar à análise de seu caráter de classe, vejamos como a questão de sua "construção social" do desemprego é trabalhada pela Sociologia do Desemprego francesa. Essa abordagem toma como ponto de partida os trabalhos de Salais, Bavarez e Reynaud (1999) e Topalov (1987, 1994). Segundo estes autores, o desemprego é fruto de uma "construção social" datada histórico e socialmente entre o fim do século XIX e início do XX, no contexto de constituição do trabalho assalariado. Essa "invenção", promovida pelas instituições administrativas encarregadas do controle social dos trabalhadores "sem-emprego" teria sido efetuada numa época em que estes eram confundidos com os "pobres", "marginais", "indigentes" ou "vagabundos". 32

Essa premissa se tornou uma espécie de "pecado original" entre os estudiosos, pois se trata de uma categoria que limita a reflexão de diversos aspectos da problemática. A noção de "construção social" levada a cabo por estes autores repousa, exaustivamente, em uma questão meramente terminológica, por exemplo, quando comparam a definição mais "moderna" do verbo francês chômer em relação àquela utilizada anteriormente, que se referia simplesmente a "um dia sem trabalho" (por folga, greve ou falta de emprego). Nesse sentido, a noção de "construção social" da categoria desemprego oculta o "processo histórico" de seu aparecimento como problema social concreto da classe trabalhadora resultante da dinâmica social capitalista. Ao enfatizarem os aspectos normativos e institucionais dessa construção, deixa-se de ressaltar a objetividade das relações de produção, presentes desde as origens do

\footnotetext{
${ }^{32}$ No Brasil, um dos primeiros trabalhos a incorporar essas referências foi o de Pereira (1993). No entanto, foi a partir de Guimarães $(2002,2004)$ que a Sociologia do Desemprego ganhou impulso no Brasil.
} 
capitalismo, que provocam a subutilização do emprego da força de trabalho. Afinal, não é possível a construção da categoria desemprego sem a existência de desempregados.

As consequiências teóricas e metodológicas de tal abordagem são diversas. Cohen (2003), por exemplo, constata que antes da "invenção do desemprego" não se pode falar em "ação coletiva dos desempregados". Essa autora desconsidera a história dos protestos desse segmento ao longo de todo o século XIX. Nesse tipo de marco interpretativo, o pertencimento de classe do desempregado é omitido e suas possibilidades de mobilização política são limitadas pela construção social da categoria, vista como um fator apriorístico de sua eclosão.

Porém, os pressupostos teóricos da Sociologia do Desemprego são úteis para a contraposição às análises economicistas, que de maneira geral identificam o problema como um "dado objetivo", cuja mensuração depende apenas de uma "metodologia correta". Os autores que partem dessa perspectiva consideram que o desemprego possui um caráter polissêmico, por ser suscetível a um constante processo de categorização, cuja maior evidência está na falta de consenso acerca dos critérios metodológicos para mensurá-lo. Ademais, essa abordagem oferece importantes argumentos analíticos e conceituais para problematizar os fundamentos da forma de aparição estatística do desemprego e para historicizar a aplicação desse conceito feita pelos institutos de pesquisa populacional, pelos organismos governamentais que gerenciam o seguro-desemprego e pelos discursos políticos e midiáticos sobre o tema. ${ }^{33}$ Ora, se o desemprego, como estatuto jurídico e categoria estatística, está sujeito a um processo de "construção social”, é porque a categoria é resultado de mecanismos normativos e institucionais circunscritos no tempo e no espaço.

Por conta desses fatores, os índices de desemprego só podem ser considerados na análise como uma ferramenta que permite fazer uma primeira "aproximação" da população sobrante para as necessidades imediatas da acumulação do capital em uma dada formação social. No entanto, vale um esclarecimento. A análise da superpopulação relativa não poderia ser feita a partir de critérios meramente estatísticos. Sua descrição não se restringe à análise da fisionomia do mercado de trabalho. Ora, o exército industrial de reserva dos países europeus centrais é composto pelos desempregados e subempregados desses países, mas também pelos trabalhadores do norte da África, da península balcânica e do leste europeu que exercem pressão sobre seu ativo. $\mathrm{O}$ alcance desse fenômeno na atualidade levou Chesnais (2007) a cunhar a categoria de "mundialização do exército industrial de reserva". Da mesma

\footnotetext{
${ }^{33}$ Para uma discussão sobre essas questões, ver Demazière (2006a, 2006c), Freyssinet (1984) e Maruani (2002).
} 
forma, no Brasil, a reserva em São Paulo é composta também por nordestinos e por trabalhadores provenientes de outras regiões que se encontram disponíveis para a migração. Não se trata, pois, de uma técnica de mensuração de um elemento morfológico do mercado de trabalho, mas de uma relação social, construída sócio-culturalmente e experimentada no cotidiano. Suas formas de manifestação mais evidentes são as filas de emprego e a sujeição do ativo a piores salários e condições de trabalho por conta da pressão exercida pela disponibilidade social do excedente relativo de população.

No entanto, a perspectiva sociológica do desemprego coloca ainda outro problema analítico. Se a "construção social" do desemprego está relacionada ao processo de constituição da "sociedade salarial" (Castel, 1995) ${ }^{34}$, o reconhecimento de seu estatuto se deve a sua identificação como "o outro do emprego", este último visto como um contrato formal por tempo indeterminado e exercido em jornada integral. No entanto, o "aparecimento" de uma zona fluída, ou fronteiriça, entre o desemprego, a inatividade e a ocupação na Europa, levou alguns autores a se referirem à "desconstrução" da categoria (Gautié, 2000). Há também inúmeras pesquisas que partem de um variado repertório conceitual para caracterizar as "novas formas de desemprego", tais como o desemprego de longa duração e o desemprego recorrente. ${ }^{35}$

Da mesma forma, pode-se dizer que os países capitalistas periféricos nem sequer passaram por um processo de "assalariamento" e a constituição de estatutos intermediários entre o emprego formal e o desemprego friccional é a regra. ${ }^{36}$ Nesses casos a aplicação da noção de "construção social" do desemprego deve ser contextualizada. Como os desempregados se auto-identificam nesses países? A construção desse estatuto é fundamental para analisar a formação da identidade política do desempregado e seu reconhecimento como tal para o processo de mobilização e organização como desempregado, tal como veremos durante este trabalho.

A abordagem normativo-institucional e biográfico-subjetiva do desemprego oculta uma dimensão fundamental para a análise: a dinâmica social que o engendra. $\mathrm{O}$ estudo de sua

\footnotetext{
${ }^{34}$ Para este autor, o assalariamento é um processo de constituição da formalização jurídica do contrato de trabalho. Não pode ser confundida, portanto, à utilização marxista do conceito de "assalariado", que se refere àqueles que, por não possuir os meios materiais da reprodução de sua existência, necessita vender a sua força de trabalho em troca de um salário.

${ }^{35}$ Para uma síntese desse debate, ver Demazière (2006c). Para uma discussão sobre o desemprego de longa duração, ver Demazière (1995a).

${ }^{36}$ Ver por exemplo o trabalho de Loison (2006) sobre o caso de Portugal.
} 
categorização permite compreendê-lo como parte do processo histórico, social e cultural de formação de determinadas experiências e tradições de luta. A existência do desemprego não garante a formação da identidade coletiva de desempregado em contextos onde sua construção social é frágil. Isso não quer dizer que não existam mobilizações desse segmento, mas ao contrário, que suas formas de manifestação se dão em torno de outras identidades políticas constituídas pelo movimento popular e de pobres.

O repertório marxista para a compreensão do desemprego, por meio dos conceitos de superpopulação relativa e exército industrial de reserva preservam sua atualidade porque apreende o problema do ponto de vista da análise da estrutura e das relações de classe. As contribuições da sociologia francesa para o tema são relevantes para problematizar as definições aplicadas para sua mensuração. No entanto, o procedimento analítico de enfatizar o processo de construção social da categoria, adotado consensualmente por essa corrente, oculta a compreensão do processo social intrínseco ao capitalismo que cria a "população sobrante". Se na discussão estatística o desemprego é um "dado objetivo" de uma metodologia pretensamente "correta", a abordagem sociológica o apresenta como um "termo polissêmico" relativo a critérios normativo-institucionais e biográfico-subjetivos, mas sem um lastro na dinâmica de funcionamento do capitalismo. Levaremos em conta essa perspectiva, porém, para analisar historicamente o processo de formação da ideologia de protesto em sua relação com as formas aguda e crônica de manifestação da superpopulação relativa. Antes de refletir, teoricamente, sobre esta última questão, farei algumas considerações a respeito do caráter de classe da mobilização dos desempregados.

\subsection{Movimento operário e mobilização dos desempregados: o exército de operários de reserva vai à guerra}

N'A situação da classe trabalhadora na Inglaterra, Engels (1986) se refere aos trabalhadores sem emprego como o "exército de reserva de operários desempregados", conceito que foi empregado pela primeira vez nessa obra clássica. $\mathrm{O}$ repertório analítico que dele deriva foi amplamente desenvolvido por Marx no capítulo 23 d'O Capital. De acordo com Marx, o movimento de oferta e demanda de força de trabalho no capitalismo é a expressão máxima do despotismo do capital, já que a disponibilidade de "trabalho" e de "trabalhadores" se tornam independentes. Forma-se então uma superpopulação relativa, 
resultado do processo de acumulação de capital, que cumpre o papel de reserva para as necessidades imediatas do capitalismo. Assim, o processo de valorização não se restringe à relação de compra e venda da força de trabalho de cada "operário individual". Trata-se da realização da exploração capitalista do "operário social", ou seja, do conjunto da classe trabalhadora, esteja em atividade ou disponível. É com base na existência dessa população sobrante, resultante do processo simultâneo de superexploração e sobreutilização da força de trabalho, que a burguesia concretiza seu objetivo de acumulação explorando não apenas cada trabalhador, mas o conjunto do proletariado. A pressão que a reserva exerce sobre o ativo é o principal instrumento de disciplinamento operário, pois permite um maior grau de arbitrariedade patronal por baratear o preço pago pela força de trabalho, submeter o trabalhador a piores condições de trabalho e amortecer os protestos sociais da classe trabalhadora. Sendo assim, é uma condição indispensável para a própria existência do capitalismo, um elemento estrutural que significa esse regime social e explicita o caráter de expropriado do proletariado. Seu papel no processo de acumulação capitalista foi assim identificado por Marx:

[...] se uma população trabalhadora excedente é produto necessário da acumulação ou do desenvolvimento da riqueza no sistema capitalista, ela se torna por sua vez a alavanca da acumulação capitalista, e mesmo condição de existência do modo de produção capitalista. Ela constitui um exército industrial de reserva disponível, que pertence ao capital de maneira tão absoluta como se fosse criado e mantido por ele. Ela proporciona o material humano a serviço das necessidades variáveis de expansão do capital e sempre pronto para ser explorado, independentemente dos limites do verdadeiro incremento da população (Marx, 1982: 733-734). ${ }^{37}$

Como se depreende da leitura dessa passagem, a formação de uma população ao mesmo tempo "excedente" e "disponível" é estrutural no capitalismo, já que cumpre o papel de "produto" e "alavanca" da acumulação do capital (Marx, 1982, pp. 733-734). ${ }^{38}$ Desse modo, a classe trabalhadora é composta por duas frações ${ }^{39}$ : o exército de operários ativo e o exército industrial de reserva. ${ }^{40}$ Desse último grupo fazem parte os desempregados, que constituem

\footnotetext{
${ }^{37}$ Lênin identifica a teoria do exército industrial de reserva como a "lei capitalista da população", na qual a "superpopulação, complemento necessário da superprodução, constitui um elemento necessário da economia capitalista, sem o qual esta não poderia existir nem se desenvolver" (Lenin, 1958, p. 170).

38 Não foi casual que Marx e Engels tenham utilizado uma analogia militar para desenvolver esse conceito. No Certificado de Dispensa de Incorporação do Ministério do Exército brasileiro, lê-se: "Em caso de convocação deve apresentar-se imediatamente".

${ }^{39}$ Empregamos o conceito de fração de classe no sentido de Poulantzas (1971) como um subgrupo de uma determinada classe que possui interesses de classe relativamente divergentes.

${ }^{40}$ Nesse capítulo Marx amplia o uso de metáforas militares. Refere-se aos trabalhadores de fábrica como os "soldados industriais" e à camada condenada ao pauperismo como o "asilo dos inválidos" da classe trabalhadora.
} 
apenas sua "parte mais visível" (Carrera, 2007b), por se tratar de trabalhadores que nem mesmo podem concretizar a relação de assalariamento da qual dependem para reproduzir sua existência. Na condição de pobreza, estando ou não em relação de dependência, a classe trabalhadora sobrevive abaixo das condições sociais médias. Como veremos mais adiante, muitos teóricos interpretam os pobres e desempregados com base na categoria de "excluídos". A partir da "lei da população" marxista, deve-se interpretá-los como "incluídos", já que se encontram no centro da acumulação de capital, como fator indispensável para sua reprodução. $^{41}$

As categorias criadas pela economia burguesa para compreender o "mercado de trabalho" encobrem as relações de classe resultantes da apropriação capitalista da força de trabalho proletária, no plano individual e social. Os cortes mais usuais utilizados por economistas, estatísticos e sociólogos (empregado/desempregado; ativo/inativo; trabalho formal/trabalho informal; assalariado/empregador/autônomo), apesar de descreverem aspectos importantes da fisionomia da "estrutura ocupacional", fetichizam as relações entre capital e trabalho, e ocultam a condição comum de expropriado do conjunto do proletariado. Mesmo as análises feitas pelas correntes mais críticas, que consideram o "desemprego oculto" e o "salário encoberto" (presente no chamado trabalho por "conta própria"), ainda encobrem o significado dessa dinâmica. A análise da compra e venda da força de trabalho sob uma perspectiva de classe somente pode ser feita a partir da divisão proposta por Marx entre possuidores e despossuídos das condições de produção de sua existência e, no interior destes últimos, as frações que cumprem o papel de ativo e de reserva.

Esta ferramenta de análise vem sendo omitida por sociólogos e economistas que interpretam o desemprego. ${ }^{42}$ Sua atualidade, no entanto, não pode ser reduzida à interpretação simplista de que o exército industrial de reserva seja sinônimo de desempregados. Como ressalta Marx, faz parte da superpopulação relativa todo trabalhador “durante o tempo em que

\footnotetext{
Em outra passagem, o autor analisa a população nômade de origem rural que se desloca geralmente para trabalhar na construção civil como a "infantaria ligeira do capital".

${ }^{41}$ Uma crítica ao conceito de "exclusão" está presente em J. Martins (2007, p. 14).

42 Algumas exceções são os trabalhos de Barreto (2005), Chesnais (2007), Iturbe (2001) e Souza (2005a). Aplicando este repertório conceitual Melenau Neto (1996) sustenta que o aumento do desemprego verificado nas últimas décadas não foi apenas conseqüência, mas condição da implantação do neoliberalismo. Com argumentos semelhantes, Podestá (1999) afirma que a chamada "crise" do desemprego é, na realidade, um dos aspectos da saída da crise de acumulação de capital vivida especialmente nos países centrais e nos países de capitalismo dependente industrializados. Posição semelhante é assumida por Duménil e Lévy (2003), que caracterizam o aumento do desemprego como condição necessária para a nova fase do capitalismo sob a hegemonia do capital financeiro.
} 
está desempregado ou parcialmente empregado" (Marx, 1982, p. 743). ${ }^{43}$ Segundo Marx, essa fração da classe trabalhadora se manifesta de diferentes formas, entre as quais se encontram as parcelas latente, estagnada e flutuante, além do lumpemproletariado e de uma camada condenada ao pauperismo que, segundo a metáfora militar que adota, constitui-se o "asilo dos inválidos" da classe trabalhadora e o "peso morto" da reserva.

A parcela flutuante é fruto da atração e repulsão cíclica dos trabalhadores na indústria, seja pelo aumento, estagnação ou decréscimo da produção, mediante o incremento de capital constante em detrimento do variável. A parcela latente se forma pelo apoderamento e penetração da produção capitalista na agricultura, mediante a "repulsão dos trabalhadores que não é contrabalançada por maior atração, como ocorre na indústria não-agrícola" (p. 745). ${ }^{44} \mathrm{~A}$ terceira categoria analisada por Marx é a forma estagnada, constituída por “(...) parte do exército de trabalhadores em ação, mas com ocupação totalmente irregular" ${ }^{45}$ Segundo o autor, essa parcela da população sobrante “(...) proporciona ao capital reservatório inesgotável de força de trabalho disponível". Ademais, para Marx, "sua condição de vida se situa abaixo do nível médio normal da classe trabalhadora (...). Duração máxima de jornada e mínimo de salário caracterizam sua existência”. O autor chega a afirmar, inclusive, que este é “(...) o componente da classe trabalhadora que tem, no crescimento global dela uma participação relativamente maior que a dos demais" (p. 746).

Finalmente, Marx analisa o sedimento da superpopulação relativa que, segundo ele, "vegeta no inferno da indigência". Segundo o autor, excluindo os vagabundos, os criminosos,

\footnotetext{
${ }^{43}$ Lenin (1960) chamou a atenção para este aspecto ao destacar que "seria um erro imaginar o exército de desocupados de reserva como formado exclusivamente por operários sem trabalho". O autor faz referência aos pequenos proprietários camponeses que possuem uma quantidade de terra tão ínfima que os impede de sobreviver exclusivamente da mesma, o que o obriga a procurar outros meios de vida com o trabalho assalariado. O autor denomina a essa camada oculta da superpopulação de "pseudoproprietários".

${ }^{44}$ Nas palavras de Marx “(...) parte da população rural encontra-se sempre na iminência de transferir-se para as fileiras do proletariado urbano ou da manufatura e na espreita de circunstâncias favoráveis a essa transferência (manufatura aqui significa todas as indústrias não agrícolas). Está fluindo sempre esse manancial da superpopulação relativa. Mas, seu fluxo constante para as cidades pressupõe no próprio campo uma população supérflua sempre latente, cuja dimensão só se torna visível quando, em situações excepcionais, se abrem todas as comportas dos canais de drenagem. Por isso, o trabalhador rural é rebaixado ao nível mínimo de salário e está sempre com um pé no pântano do pauperismo" (pp. 745-746).

${ }^{45}$ A forma estagnada da superpopulação relativa demonstra que Marx já chamava a atenção para o que hoje se denomina "trabalho precário". Por tal motivo, a metodologia marxista de análise da estrutura social deve considerar, além do "desemprego aberto", as diferentes formas de "desemprego encoberto" pelo subemprego, para fazer uma estimativa das diversas categorias que constituem a reserva. Para uma discussão atual sobre o conceito de precariedade, ver Cingolani (2005) e Demazière (2006b).
} 
as prostitutas, "o rebotalho do proletariado"46 (p. 746) esta parcela da superpopulação relativa é constituída por três categorias: (i) os aptos para o trabalho; (ii) os órfãos e filhos de indigentes; (iii) e os degradados, desmoralizados, incapazes de trabalhar. ${ }^{47}$ Essa categoria, denominada pauperismo, constitui para Marx o "asilo dos inválidos do exército ativo dos trabalhadores e o peso morto do exército industrial de reserva". Desse modo, "sua produção e sua necessidade se compreendem na produção e na necessidade da superpopulação relativa, e ambos constituem condição de existência da produção capitalista e do desenvolvimento da riqueza" (p. 747).

Para Marx, quanto maior a riqueza social, e conseqüentemente a magnitude absoluta do proletariado, tanto maior o exército industrial de reserva, pois "a força de trabalho disponível é ampliada pelas mesmas causas que aumentam a força expansiva do capital” (p. 747). Por fim, o autor conclui que:

(...) a magnitude relativa do exército industrial de reserva cresce portanto com as potências da riqueza, mas, quanto maior esse exército de reserva com relação ao exército ativo, tanto maior a massa da superpopulação consolidada, cuja miséria está na razão inversa do suplício de seu trabalho. E, ainda, quanto maiores essa camada de lázaros da classe trabalhadora e o exército industrial de reserva, tanto maior, usando a terminologia oficial, o pauperismo. Esta é a lei geral, absoluta, da acumulação capitalista (p. 747).

Como resposta aos economistas que, tal como Malthus, argumentavam que os trabalhadores deveriam adaptar seu número às necessidades de expansão do capital, Marx responde que, ao contrário, são as necessidades de expansão do capital que se adaptam ao número de trabalhadores disponíveis:

O mecanismo da produção capitalista e da acumulação adapta continuamente esse número a essas necessidades. $\mathrm{O}$ começo desse ajustamento é a criação de uma superpopulação relativa ou de um exército industrial de reserva, e o fim a miséria de camadas cada vez maiores do exército ativo e o peso-morto do pauperismo (p. 748).

Sendo assim, a lei geral da acumulação capitalista é explicitada por Marx pela necessidade de manter uma superpopulação relativa, que por sua vez provoca o crescimento da miséria da classe trabalhadora:

\footnotetext{
${ }^{46}$ Em Luta de classes em França, Marx chama essa categoria de lumpemproletariado, composta por ladrões, criminosos, "viventes dos dejetos da sociedade", indivíduos sem ocupação precisa, etc. (Marx, 1994, pp. 30-31).

${ }^{47} \mathrm{O}$ autor afirma ainda que estes “(...) são notadamente os indivíduos que sucumbem em virtude de sua incapacidade de adaptação, decorrente da divisão do trabalho; os que ultrapassam a idade normal de um trabalhador, e as vítimas da indústria, os mutilados, enfermos, viúvas etc., cujo número aumenta com as máquinas perigosas, as minas, as fábricas de produtos químicos etc.” (p. 746).
} 
A lei que mantém a superpopulação relativa ou o exército industrial de reserva no nível adequado ao incremento e à energia da acumulação acorrenta o trabalhador ao capital mais firmemente do que os grilhões de Vulcano acorrentavam Prometeu ao Cáucaso. Determina uma acumulação de miséria correspondente à acumulação de capital. Acumulação de riqueza num pólo é ao mesmo tempo acumulação de miséria, de trabalho atormentante, de escravatura, ignorância, brutalização e degradação moral, no pólo oposto, constituído pela classe cujo produto vira capital (p. 749).

A partir do que foi exposto, cabe fazer alguns esclarecimentos sobre como empregarei os diferentes recortes da classe trabalhadora a partir de minha interpretação da teoria marxiana. Cada subdivisão da reserva que possua características próprias em sua forma de manifestação é chamada de "parcela". De acordo com as condições de reprodução da sobrevivência, são definidas pelo menos duas "camadas": a camada média (que logra obter os meios necessários) e o "pauperismo" (que vive abaixo das condições "normais"). Por último, é importante destacar que esse conjunto é composto por uma população desempregada e por uma população parcialmente empregada. Chamo cada uma desses estratos de "segmento".48 Como já foi dito, o ativo e a reserva serão considerados frações da classe trabalhadora por possuírem interesses antagônicos, ainda que possuam interesses de classe comuns, opostos aos da classe capitalista.

Essa categorização oferece um contraponto importante tanto às teorias clássicas do desemprego como às noções de "exclusão" 49 e "marginalidade" campo marxista. As interpretações mais correntes sobre o desemprego, de matriz keynesiana, schumpeteriana ou liberal, tendem a desconsiderar esse referencial analítico. Nesse sentido, contribuem para a "naturalização" das chamadas "leis do mercado", onde o desemprego aparece apenas como um dado objetivo resultante de desajustes conjunturais da política macroeconômica, de desequilíbrios momentâneos da estrutura produtiva ou da inadequação dos indivíduos aos critérios de "empregabilidade". 51

\footnotetext{
${ }^{48}$ Essa delimitação é importante para avaliar o perfil do desempregado (e, de maneira mais geral, da reserva) considerado pelas entidades sindicais na sua política de organização e representação, que pode ir desde segmentos desempregados da pequena-burguesia "assalariada" aos subempregados da camada pauperizada da classe trabalhadora. Os desempregados não são uma categoria homogênea, assim como também não o é a classe operária. Este estudo busca estabelecer uma relação entre esses dois sujeitos mais amplos ("o sindicalismo" e "os desempregados"), mas prioriza as ações e representações sindicais (e não o movimento dos desempregados), o que me abstém de buscar especificar a composição social dos trabalhadores sem emprego, ainda que referências a esse aspecto estejam presentes em algumas passagens.

${ }^{49}$ Para uma crítica à utilização da categoria de "excluído" com uma argumentação sobre a atualidade do conceito de reserva para interpretar a estrutura social capitalista, ver Carrera (2009).

${ }^{50}$ Ver, por exemplo, Paugam (2005) e Whul (1992).

${ }^{51}$ No Brasil, consultar Mattoso (1999), Pochmann (1999a) e Singer (2003).
} 
No campo marxista, a desconsideração desse repertório também é notável, tal como se pode observar na utilização recorrente do conceito de "desemprego estrutural" (Antunes, 2005), que se remete, por sua vez, à noção de “crise estrutural do capital” (Meszáros, 2006). O termo é duplamente impreciso. Primeiramente, pelo caráter redundante: ora, o desemprego é sempre estrutural no capitalismo, pois se trata de uma "condição de existência" desse modo de produção (Marx, 1982, p. 733). Em segundo lugar, trata-se de um conceito utilizado originalmente pela teoria econômica burguesa, que opõe o "desemprego estrutural" (fruto de alterações da estrutura econômica, advindas especialmente das inovações tecnológicas) ao "desemprego conjuntural" (resultado das variações sazonais do ciclo econômico), sem analisar o fenômeno como próprio da dinâmica capitalista. Para Marx, a superpopulação relativa pode se manifestar de "forma aguda", "nas crises", ou de "forma crônica", "nos períodos de paralisação" (idem, p. 743). É com base nesse repertório que analisarei as variações na composição da classe trabalhadora entre suas frações ativa e de reserva.

Além dessas imprecisões teóricas, é necessário destacar que os autores que partem da perspectiva mencionada discutem o desemprego do ponto de vista da estrutura ocupacional, e não a partir das relações de classe próprias do processo de acumulação de capital. Pautam-se, assim, em uma oposição entre "incluídos" e "excluídos" do mercado de trabalho, estes últimos compostos por aqueles que, supostamente, não têm mais qualquer chance de conseguir um emprego formal. Com base na noção de "crise estrutural do capital" tratam o desemprego a partir de um pressuposto mecanicista e fatalista: "a novidade da nossa época é que o sistema do capital já não está em posição de conceder seja o que for ao trabalho, em contraste com as conquistas reformistas do passado" (Mészáros, 2005, p. 41). Ou ainda, "Sob as condições da crise estrutural do capital essa é a natureza objetivamente inevitável da ordem socioeconômica" (p. 42).

No final dos anos 1960, Nun (2001) desenvolveu a noção segundo a qual o exército industrial de reserva é mais apropriado para a compreensão do capitalismo competitivo, como na Inglaterra anterior a 1875 sobre a qual escreveu Marx, já que cumpria nesse contexto um papel sempre funcional para a dinâmica capitalista. Para o autor, este conceito é insuficiente para compreender contextos como o do capitalismo monopolista dependente na América Latina. ${ }^{52}$ Como alternativa, o autor cria o conceito de massa marginal a partir do qual considera que determinados excedentes populacionais possuem um caráter afuncional

\footnotetext{
${ }^{52}$ Outras formulações sobre a questão da "marginalidade" se encontram em Kowarick (1975) e Quijano (1970).
} 
para o capital, já que por não possuírem nenhuma expectativa de inserção nas relações assalariadas, não exerce qualquer pressão sobre o exército operário ativo. No entanto, este conceito não é o mais apropriado para o tratamento da questão. Primeiramente, porque foi cunhado em termos de sua "funcionalidade", o que remete à possibilidade de existência de um sistema harmônico integrador, que comporta funções e disfunções. Segundo, por se referir ao mercado de trabalho em detrimento do processo de acumulação de capital. Por último, por conta da terminologia empregada, que se sustenta a partir da noção de marginalidade, como se a população tratada estivesse à margem das relações capitalistas de produção.

Ao contrário das duas abordagens, considero que a superpopulação relativa é uma fração da classe trabalhadora sobrante para as necessidades imediatas do capital, sempre disponível "nos movimentos da oferta e da procura de trabalho" e que pressiona os trabalhadores em ação, ainda que jamais entre em relação de dependência direta (Marx, 1982, p. 742). O mérito de Nun está em destacar a particularidade das formas de manifestação da reserva em contextos de capitalismo dependente. Porém, para me referir a esta camada descartável, empregarei a noção de "superpopulação relativa consolidada" (idem, p. 747).

Valem ainda algumas considerações sobre a definição que emprego de proletários como grupo social fundamental, tal como se depreende da leitura de Gramsci. ${ }^{53}$ O proletariado (e o semiproletariado) é composto por aqueles que, por não possuírem as condições materiais necessárias para a reprodução de sua existência, "vivem principalmente ou medianamente da venda de sua força de trabalho" (Carrera e Podestá, 1989), estejam ou não concretizando essa relação. É a parte mais expressiva da classe trabalhadora, que inclui ainda setores da pequenaburguesia, como os pequenos patrões supostamente "independentes", na expressão de Lênin, os "pseudoproprietários" (Lênin, 1960), que não realizam acumulação de capital, e os trabalhadores intelectuais, cuja posição pressupõe uma capacidade de acúmulo anterior, ainda que em muitos casos cumpram uma função auxiliar à burguesia. Esses setores se encontram sob a constante ameaça de proletarização e pauperização. Ademais, além de "expropriados" e "despossuídos", também podem se encontrar "desalojados" (Carrera e Podestá, 1989) da posição de vendedor da força de trabalho, ou seja, desempregado. Tal como já foi mencionado, do ponto de vista do processo de acumulação capitalista, é ativo quando realiza diretamente o processo de valorização ou socialização da mais valia. Conforma a reserva

\footnotetext{
${ }^{53}$ Voltarei a este ponto mais adiante.
} 
quando se constitui como estoque de força de trabalho que atua como "produto e alavanca" dessa dinâmica.

A utilização do repertório marxiano e engelsiano também preserva sua atualidade para a interpretação dos protestos sociais no capitalismo. Para o que me interessa neste trabalho - a mobilização dos desempregados - sua aplicação permite identificar a natureza de classe de tal movimento e inseri-lo em uma discussão mais ampla sobre as formas e instrumentos de luta dos trabalhadores. Por isso, definir quem compõe o grupo social fundamental, de acordo com a "função" e a "posição" que exercem nas relações de produção e propriedade significa dimensionar o caráter dos protestos sociais e da luta de classes. Ora, se os desempregados fazem parte da superpopulação relativa, que compõe por sua vez a classe trabalhadora, as mobilizações de desempregados são constitutivas do movimento operário. A expressão mais evidente desse vínculo se encontra na relação entre os sindicatos e os desempregados, existente desde o início do capitalismo industrial, nas origens do sindicalismo. Na leitura aqui proposta o movimento operário pode ser definido como a rebelião da classe trabalhadora contra os efeitos ou a superação do modo de produção capitalista, tal como foi explorado de maneira precursora por Engels (1986). Sendo assim, os protestos de desempregados possuem um traço de continuidade com as lutas dos trabalhadores empregados, já que ambos surgem da oposição entre capital e trabalho (Cross, Lenguita, Wilkis, 2002). Assim, se os desempregados conformam um segmento da população que atua como reserva na acumulação capitalista, sua organização é expressão das contradições engendradas nesse processo e deve ser vista como uma forma de luta orgânica engendrada pelas relações antagônicas de classe.

No movimento de resistência do proletariado, o ativo se mobiliza por melhores condições de trabalho e salário através de diversas formas e instrumentos de luta, sendo a greve sua manifestação estrutural. Já a reserva, na sua forma de aparição política, por meio de seus diversos segmentos (o desempregado, seu congênere precursor - o demitido - e o subempregado), aparece como sujeito da rebelião organizada com formas e instrumentos de luta específicos. Em uma ação unificada ou fraturada com partidos ou sindicatos, seus objetivos econômico-corporativos (Gramsci, 1976) geralmente estão pautados na reversão da demissão e na reincorporação, na reivindicação por emprego ou por subsídios que possibilitem sua sobrevivência. Entre essas bandeiras, destacam-se o seguro-desemprego e os auxílios imediatos do Estado (frentes de trabalho, bolsas do governo, cestas de alimentos, etc.), que amenizem o processo de pauperização. Sem a possibilidade de parar a produção, os 
desempregados utilizam geralmente manifestações de rua (marchas, atos, bloqueios de avenidas e rodovias, etc.), com o objetivo de interromper a circulação de pessoas e mercadorias, tal como se pode observar em diversos momentos históricos. Em suma, quando o "exército de reserva de operários desempregados" vai à guerra ${ }^{54}$ contra os efeitos das relações sociais capitalistas, por não ter condições de realizar uma greve, protesta contra sua condição de supérfluos para as necessidades imediatas da produção capitalista. Quando é recrutado pela legião do "exército de operários ativo" é possível a construção de uma unidade na ação na qual as duas frações possuem estratégia e inimigo comum.

Pode-se afirmar que o ativo e a reserva, como frações da classe trabalhadora, são os protagonistas da rebelião dos expropriados e despossuídos contra os efeitos do modo de produção capitalista. Este movimento pode ser posto em marcha a partir de reivindicações pautadas no valor do salário pago pela força de trabalho, nas condições de exercício do trabalho ou, diante da ausência do emprego, na quantidade de trabalhadores submetidos a esta relação. Esses pressupostos colocam este estudo frontalmente contrário às interpretações mais correntes sobre a mobilização dos desempregados, que discutem seus limites sem fazer referência ao caráter de classe e aos elementos que em diversos momentos históricos possibilitaram seu aparecimento.

Argumentei até aqui que se os desempregados fazem parte da população sobrante, que por sua vez representa uma fração da classe trabalhadora, seus protestos compõem o movimento operário. A rebelião do ativo e da reserva se constitui em relações de unidade ou fratura, já que a depender da conjuntura podem expressar conflitos ou convergência de interesses. A ênfase no caráter de classe do desemprego se opõe à abordagem que costuma identificar as "ações coletivas" dos desempregados como expressão dos "novos movimentos sociais", ou como eventos "espontâneos" e isolados de "excluídos" que não possuem qualquer relação com o movimento operário. Ao contrário do que apregoam os autores que partem dessa perspectiva, este tipo de protesto nasce a partir das condições prévias dos protestos dos trabalhadores, e portanto, advém de uma dada correlação de forças. Ao observar a história desse tipo de mobilização, é constante a direção consciente (Gramsci, 1977) de militantes de origem político-partidária ou sindical. Portanto, sua análise deve partir de uma reflexão sobre os interesses expressos em sua relação de unidade ou fratura com o conjunto do movimento operário organizado político e sindicalmente.

\footnotetext{
${ }^{54}$ No sentido de "guerra social", tal como foi empregado por Engels (1986).
} 
Os protestos de desempregados fazem parte do movimento operário e como tal, estão expostos a problemas organizativos semelhantes, tais como a heterogeneidade do grupo, o isolamento social dos indivíduos por conta de sua "situação humilhante", o individualismo na vivência cotidiana do desemprego, a despolitização do problema nos meios políticos e institucionais e a dificuldade de construção de uma identidade coletiva a partir de um estatuto negativo. Essa premissa me afasta das interpretações apriorísticas sobre o tema, que vêem os limites e possibilidades de sua mobilização de maneira determinista e mecânica. Ao contrário, considero que toda ação política é parte de um processo social e histórico que, por ser datado e circunscrito no espaço, constrói-se na luta. Por isso é fundamental que o exame dos protestos de desempregados não seja feito de maneira isolada das diversas formas e instrumentos de luta da classe trabalhadora, como o fazem as análises espontaneístas. A análise do ciclo de lutas sociais e das experiências de luta prévias da classe trabalhadora são fatores explicativos chaves para a compreensão do desencadeamento do movimento de desempregados. Esses são elementos que a bibliografia francesa mencionada no item anterior não dão a devida atenção, o que se explica parcialmente pelo relativo abandono da análise das relações de classe.

Vale mencionar ainda que, de maneira geral, os protestos de desempregados aparecem de maneira esporádica, e está condicionado a períodos de crise marcados por demissões em massa, em que a superpopulação relativa se manifesta não só em sua "forma aguda", mas também de "forma crônica" (Marx, 1982, p. 743). Esse tipo de mobilização também está relacionado ao aumento do tempo de permanência médio na situação de desemprego, e a contextos de predominância do emprego das relações assalariadas formais. Uma primeira aproximação ao tema me levou a buscar fundamentação na teoria da "frustração relativa" de Gurr (1970), categoria definida pelo autor como um "saldo negativo" entre os "valores" (renda, prestígio, reconhecimento, etc.) que os indivíduos possuem em uma dada situação e aqueles que consideram ter direito de obtenção. ${ }^{55}$ Ademais, se o estatuto social do desemprego depende daquele que possui seu oposto (o emprego), a análise do movimento de desempregados deve ser considerada a partir da sua relação com o movimento de trabalhadores empregados, mobilizados nos sindicatos, partidos e organizações populares, que

\footnotetext{
${ }^{55}$ No entanto, como destaca Neveu (1996, pp. 40-43), a teoria de Gurr é mais complexa e abre espaço para as mediações simbólicas e cognitivas, já que fazia parte de suas preocupações indagar a respeito das questões culturais e da memória coletiva, como a "tradição de mobilização", a "cultura de conflito" e a "memória de episódios mitificados" em um determinado grupo ou país. Essas questões serão incorporadas à análise ao longo do trabalho.
} 
são os portadores das experiências e tradições de luta prévias da classe trabalhadora. Assim, é no ciclo de lutas do movimento operário como um todo que se deve buscar os elementos que confluem na eclosão de protestos de desempregados.

Uma das primeiras referências de movimento de desempregados é a ação dos destruidores de máquinas, nas origens do capitalismo industrial. A partir de então, mobilizações de trabalhadores sem emprego acompanharam as lutas operárias em diversos momentos, especialmente nas grandes crises econômicas. Em alguns casos, essa forma de luta assumiu uma considerável repercussão política, tal como se verificou nas marchas contra a fome e o desemprego que ocorreram na Europa durante o século XIX, tendo sido significativas na França dos anos 1880 (Lécerf, 1992); na Rússia pré-revolucionária (Preobrazhenksii, 2005); na Europa, nos EUA (Fox Piven, Cloward, 1979; Ziegler, 1980) e na Argentina (Carrera e Fernández, 2007) durante os anos 1930. Nos últimos trinta anos, podemos identificar movimentos de desempregados na Alemanha (Chômeurs Heureux, 1996), Bélgica (Faniel, 2006), França (Demazière e Pignoni, 2003), Itália (Pignoni, 2006) e Irlanda (Royall, 2005), além de manifestações localizadas na Espanha (Béroud, 2007). No início dos anos 80, os desempregados convocaram marchas e revoltas de fome em São Paulo (Stroh, 1989). Podemos encontrar também as experiências de "uniões transitórias" e organizações de desempregados no Canadá (Girard, 1989). Vale destacar ainda a Argentina, onde, entre o fim da década de 1990 e o início dos anos 2000, os chamados piqueteros se constituíram em um dos sujeitos de maior peso no conjunto das lutas sociais do país (Klachko, 2007). Em todas essas experiências de luta, a presença de partidos ou do movimento sindical esteve presente na constituição dessas organizações. ${ }^{56}$

As reflexões feitas neste item tiveram o objetivo teórico de situar a mobilização política dos desempregados como parte constitutiva do conjunto do movimento operário. Opondo-me principalmente à sociologia dos limites da "ação coletiva" desse segmento da classe trabalhadora, e ressaltando o potencial explicativo da abordagem marxista sobre o tema, procurei demonstrar a natureza de classe desse tipo de protesto. A análise da composição dos grupos sociais fundamentais é necessária para caracterizar os protestos sociais no capitalismo. A partir desse referencial, é possível concluir que, se os desempregados fazem parte do proletariado como um segmento reserva para as necessidades do processo de acumulação de

\footnotetext{
${ }^{56}$ No capítulo quatro, ao refletir sobre o caso argentino, ressaltarei a importância das experiências prévias de militância sindical entre os organizadores e o papel da tradição de luta sindical em sua constituição.
} 
capital, sua organização é expressão dessa contradição principal e, portanto, deve ser vista como uma forma de luta da classe trabalhadora. Manifestações de desempregados existem desde o início do capitalismo industrial e estiveram presentes nas origens do movimento sindical. Por tal motivo, para o estudo da relação entre o ativo e a reserva, a unidade e a fratura entre as entidades sindicais e os desempregados possuem um sentido heurístico, já que revela os traços de continuidade entre o movimento orgânico dos trabalhadores no capitalismo e a parte mais visível de sua superpopulação sobrante. Ademais, se o estatuto de trabalhador desempregado está intimamente ligado ao do seu oposto (o empregado), a construção de sua identidade política e de sua mobilização dialoga com as experiências e tradições de luta do conjunto do movimento operário.

\subsection{Correlação de forças, experiências e tradições de luta}

Feita essa explanação a respeito dos referenciais analíticos que este estudo toma como ponto de partida, bem como seus principais interlocutores, valem algumas palavras sobre como procurei fundamentar, teoricamente, o método empregado para a análise comparativa a que me proponho. O vínculo entre sindicalismo e desempregados é parte do processo de construção de unidade e fratura da classe trabalhadora. Este processo é constitutivo da formação histórico-social das classes sociais (Thompson, 1997) e resulta das relações de enfrentamento, como efeito das estruturas sociais (Poulantzas, 1971). Cumpre um papel fundamental no estudo da questão, portanto, a análise da correlação de forças, a partir da qual é possível historicizar as particularidades das experiências e tradições de cada formação social específica. No capítulo seguinte, tentarei aplicar esse método para interpretar, comparativamente, a história do movimento operário e sindical do Brasil e da Argentina.

É muito comum a crítica ao "estruturalismo", escola representada por autores como Nicos Poulantzas e Louis Althusser, de que suas teorizações se pautam em estruturas estáticas e mecânicas. No entanto, uma leitura atenta de seus textos atesta a preocupação constante que ambos tiveram de compreender o processo histórico como um movimento de estruturação (estruturado e estruturante) das relações sociais. Vejamos como se processa esse procedimento na análise poulantziana, a partir da qual me inspirei para construir o modelo de interpretação que será tomado neste trabalho. Poulantzas (1971) considera que as classes sociais se constituem na luta como efeito das estruturas sociais a partir de uma determinada 
correlação de forças. Essa formulação se inspira nas proposições de Gramsci (1976) em sua análise da situação e das relações de forças. Porém, utilizarei o repertório conceitual poulantziano porque o estudo sistemático desse autor a respeito do Estado burguês e das relações de classe retoma e aprofunda as categorias fundamentais dos textos históricos e políticos de Marx, Engels, Lênin e do próprio Gramsci, o que permite ampliar o escopo da análise por meio de categorias como bloco no poder, classe aliada/classe apoio e, especialmente, frações de classe, que será utilizada neste trabalho.

A maneira como as estruturas sociais e uma dada correlação de forças dialogam com as experiências históricas concretas, sedimentando-se na cultura dos grupos, classes ou formações sociais se encontra bem fundamentada também em Gramsci, tendo sido posteriormente desenvolvida por autores como Thompson (1997), Hobsbawn (2000) e Rudé (1982). Antes de expor como foram incorporadas essas contribuições, destacarei como essas correntes interpretam o processo de formação das classes. O que há de comum entre o pensamento gramsciano, a Historia Social britânica e o chamado Estruturalismo francês é a crítica à explicação dos fenômenos sociais como meros reflexos de fatores econômicos e à análise das classes como um dado objetivo das relações de produção. Esse pressuposto é outra evidência do anti-mecanicismo na obra de Poulantzas, e está presente na sua interpretação de que a classe se constitui nas relações de enfrentamento, e não está dada de maneira apriorística. ${ }^{57}$ Essa questão foi trabalhada classicamente por Gramsci (1976), em sua distinção entre o grupo social fundamental e a classe social. O autor define o grupo social de acordo com sua função e posição nas relações sociais de produção capitalista, e a classe como efeito do processo de construção em oposição a outra classe, portadora de interesses antagônicos. Essa é uma questão primordial da concepção thompsoniana de formação $^{58}$ da classe trabalhadora: “(...) não podemos entender a classe a menos que a vejamos como uma formação social e cultural, surgindo de processos que só podem ser estudados quando eles mesmos operam durante um considerável período histórico" (Thompson, 1997, p.12). Nesse sentido, afirma o autor:

A classe acontece quando alguns homens, como resultado de experiências comuns (herdadas ou partilhadas), sentem e articulam a identidades de seus interesses entre si, e contra outros homens cujos interesses diferem (e geralmente se opõem) dos seus. A experiência de classe é determinada, em grande

\footnotetext{
${ }^{57}$ Esta formulação está presente na tradição clássica marxista desde o trabalho pioneiro de Engels (1986), para o qual o principal instrumento de luta do sindicalismo - a greve - é a "escola de guerra" que prepara os operários para a "grande luta".

${ }_{58}^{5}$ No sentido de "fazer-se" da classe, como o tradutor da versão utilizada assinala (Thompson, 1997, p. 9).
} 
medida, pelas relações de produção em que os homens nasceram - ou entraram involuntariamente. A consciência de classe é a forma como essas experiências são tratadas em termos culturais: encarnadas em tradições, sistemas de valores, idéias e formas institucionais. Se a experiência aparece como determinada, o mesmo não ocorre com a consciência de classe (Thompson, 1997, p.10).

A análise que me proponho leva em conta a estrutura e a correlação de forças, em diálogo com as formas e instrumentos de luta adotados pela classe trabalhadora nas experiências históricas concretas de sua formação, tal como se depreende da leitura de Thompson. Essas experiências, e em especial as experiências de organização e luta, por sua vez, produzem efeitos mais ou menos duradouros sobre as práticas dos grupos e das classes. Esses elementos, "encarnados" por meio da memória e do patrimônio histórico coletivo que se reproduz e se atualiza constantemente (amortecendo ou potencializando as experiências de luta presentes), podem ser definidos como tradições. ${ }^{59}$ Às tradições que se conformam a partir das experiências de luta denominaremos tradições de luta. Na obra de Marx essa temática já aparecia como um problema teórico pertinente. No Dezoito Brumário de Luís Bonaparte diz o autor:

Os homens fazem sua própria história, mas não a fazem como querem; não a fazem sob circunstâncias de sua escolha e sim sob aquelas com que se defrontam diretamente, ligadas e transmitidas pelo passado. A

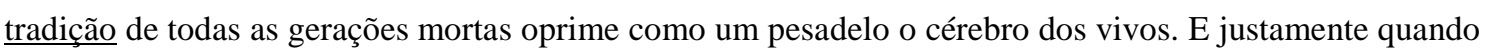
parecem empenhados em revolucionarem-se a si e às coisas, em criar algo que jamais existiu, precisamente nesses períodos de crise revolucionária, os homens conjuram ansiosamente em seu auxilio os espíritos do passado, tomando-lhes emprestado os nomes, os gritos de guerra e as roupagens, a fim de apresentar a nova cena da história do mundo nesse disfarce tradicional e nessa linguagem emprestada (Marx, 1984, grifos meus).

Nos Cadernos do Cárcere Gramsci atentou para a importância de se analisar historicamente a ideologia, que dividia em orgânica, por expressar diretamente os interesses dos grupos sociais fundamentais, e "não-orgânica", composta pelas atitudes e representações feitas pelo "povo comum" e pelas classes tradicionais. Em sua análise sobre a ação das massas, ao delimitar o uso do conceito de espontaneidade, o autor sublinha:

[a espontaneidade não se origina de] uma atividade educadora sistemática por parte de um grupo dirigente já consciente, mas [é] formada através da experiência iluminada pelo sentido comum, ou seja, pela concepção tradicional popular do mundo, coisa que muito pedestramente se chama "instinto", e é nada mais que uma aquisição histórica, mas primitiva e elementar (Gramsci, 1977, p. 329, grifos meus).

\footnotetext{
${ }^{59}$ Ao contrário de Thompson, não considero que este seja um elemento formador da "consciência", mas um fator constitutivo das ideologias. Esse ponto ficará claro mais adiante.
} 
Em Americanismo e fordismo, Gramsci (1976) aplica em estado prático essas formulações. Nesse texto, o autor argumenta que o americanismo e o fordismo surgiram da "necessidade imanente de organizar uma economia programática", condição preliminar presente nos Estados Unidos que se opunha ao "velho individualismo" europeu (p. 375). Para Gramsci, a implantação desse modelo expunha uma tarefa de conciliar o irreconciliável na Europa: "a velha e anacrônica estrutura social demográfica" e a "forma moderníssima de produção e de modo de produzir", tal como concebida por Henry Ford (p. 377). Daí viria a "reação européia ao americanismo", da qual Paris foi o maior exemplo. ${ }^{60}$ Gramsci antepõe ao caso europeu a "composição demográfica racional” pré-existente nos EUA, explicada pelo fato de que nessa formação "não existem classes numerosas sem uma função essencial no mundo da produção, isto é, classes totalmente parasitárias". ${ }^{61}$ Ao contrário, na Europa existiria um elemento tradicional decisivo, assim explicitado por Gramsci:

A 'tradição', a 'civilidade' européia, ao contrário, caracteriza-se pela existência de tais classes, criadas pela 'riqueza' e a 'complexidade' da história passada, que deixou um punhado de sedimentações passivas através dos fenômenos de saturação e fossilização do pessoal estatal e dos intelectuais, do clero e da propriedade agrícola, do comércio de rapina e do exército inicialmente profissional (...) (p. 377, grifo meu).

Gramsci afirma que nos EUA, ao contrário, esses grupos não possuem "grandes tradições históricas e culturais", e que portanto essa formação não estaria envolvida por esta "camada de chumbo". Explica ainda que este foi um dos motivos de sua "formidável acumulação de capitais”. Diz o autor: “A não-existência dessas sedimentações parasitárias, deixadas pelos períodos históricos passados, permitiu uma base sadia para a indústria, e especialmente para o comércio (...)" (p. 381). E acrescenta:

A existência dessas condições preliminares, racionalizadas pelo desenvolvimento histórico, tornou fácil racionalizar a produção e o trabalho, combinando habilmente a força (destruição do sindicalismo operário

\footnotetext{
${ }^{60}$ Diz o autor: "Em Paris, onde existe uma estrutura histórica e artística, onde os testemunhos de uma civilização autóctene estão presentes, o americanismo destoa como a maquilagem na face velha de uma mundana" (p. 411). Ou ainda: “(...) em Paris o americanismo parece uma maquilagem, uma moda estrangeira superficial” (p. 413).

${ }^{61}$ Em relação a esta temática destaco a seguinte passagem de Gramsci para uma posterior reflexão sobre o Brasil: "Pode-se inclusive dizer que quanto mais vestuda é a história de um país, tanto mais numerosas e gravosas são estas sedimentações de massas de mandriões e inúteis, que vivem do 'patrimônio' dos 'avós', destes pensionistas da história econômica" (Gramsci, 1976, p. 377). Nos trechos destacados, interessa-me como o autor emprega as noções de "sedimentação" e "estrutura histórica".
} 
de base territorial ${ }^{[62]}$ ) com a persuasão (altos salários, benefícios sociais diversos, propaganda ideológica e política habilíssima) para, finalmente, basear toda a vida do país na produção. ${ }^{63}$

Inspirado no pensamento gramsciano, o historiador britânico George Rudé buscou aprofundar a análise da relação entre as esferas cultural e ideológica. Rudé (1982) destacou a insistência de Gramsci sobre a necessidade de chamar a atenção para as ideologias das classes "tradicionais" - os camponeses e artesãos, assim como "as idéias mais simples e menos estruturadas das pessoas comuns, composta por uma mistura de folclore, mito e experiência popular cotidiana" (p. 9). Sustentou ainda que Gramsci destacava a importância de se "analisar 'historicamente' a ideologia", tal como na delimitação das categorias de "ideologia orgânica" e "ideologia não-orgânica". Em sua análise da formação da ideologia popular, Rudé desenvolveu os conceitos de ideologia derivada e ideologia inerente. Para o autor, o elemento "derivado" é formado por idéias "tomadas de empréstimo de outro que, com freqüência, adquire a forma de um sistema mais estruturado". Aqui se enquadra, por exemplo, as ideologias políticas e religiosas. O fator "inerente", ou tradicional, por sua vez, está baseado na "experiência direta, na tradição oral, na memória folclórica, e não aprendido escutando um sermão, discursos ou lendo livros". (Rudé, 1982, p. 25). Vale a pena esclarecer ainda que o autor não explica a constituição da ideologia popular como o resultado simples de uma somatória de fatores internos e externos em uma equação do tipo "A + B". Afirma que é importante considerar um terceiro elemento, "as circunstâncias e a experiência", que para ele é o que determina "a natureza da combinação final" (p. 33). Adotarei esse repertório conceitual para explicar como determinados elementos tradicionais da luta e da organização da classe trabalhadora se constituem como ideologias inerentes na conformação dos protestos.

Em estudo comparativo sobre o movimento operário de Inglaterra e França, Hobsbawn (2000, p. 429) parte de uma pergunta similar à que fiz ao longo desta pesquisa: "Que parte o costume, a tradição e a experiência histórica específica de um país desempenham em seus movimentos políticos?". Ao buscar refletir sobre esta questão nas formações sociais estudadas, o autor afirma:

Evidentemente elas [as tradições do movimento "trabalhista" inglês e francês] diferiam, porque as histórias dos seus respectivos países haviam diferido. A acumulação da experiência passada, na qual se

\footnotetext{
${ }^{62}$ Mais adiante, Gramsci (1976) faz referência à "semiliquidação dos sindicatos livres e a sua substituição por um sistema de organização sindical" (p. 387).

${ }^{63}$ A leitura desse caderno suscita diversas questões de ordem metodológica para as pesquisas comparativas. No capítulo seguinte, procurarei analisar a estrutura social do Brasil e da Argentina inspirado nas formulações de Gramsci a fim de apontar alguns elementos tradicionais decisivos para a ideologia de protesto nas duas formações.
} 
inspiraram quando aprenderam como se organizar, para que se organizar, onde recolher o seu quadro de líderes e a ideologia que esses líderes personificavam, eram, pelo menos em parte, elementos específicos franceses e ingleses [...] (p. 430).

Para Hobsbawn, o peso que o elemento tradicional possui, de fato, para a organização é sempre uma incógnita, ainda que sua consideração na leitura que se faz de um determinado movimento seja relevante para contextualizar historicamente as experiências de luta dos trabalhadores. Afirma o autor: "Os homens vivem cercados por uma vasta acumulação de mecanismos passados, e é natural recolher os mais adequados destes e adaptá-los para os próprios fins (ou novos) deles”. (p. 429). No entanto, Hobsbawn não considera essas tradições de forma estática, de maneira determinista, como características "a serem modeladas para se adaptarem à forma do estado de espírito e situação prática dos seus movimentos” (p. 436). Sobre esse elemento, sustenta o autor:

As idéias, na verdade, são mais elásticas do que os fatos. No entanto, uma tradição política ou ideológica, especialmente se resume padrões genuínos de atividade prática no passado, ou é incorporada em instituições estáveis, tem vida e força independente, e deve influir no comportamento dos movimentos políticos. (p. 436).

Por fim, Hobsbawn conclui: "Até que ponto essas diferenças de tradição são importantes na prática, deve permanecer uma questão de especulação. Evidentemente elas não são decisivas. Elas afetam mais o estilo das atividades de um movimento do que a natureza delas ou dele" (p. 442). É essa orientação analítica que busquei dar a este trabalho, ainda que na apresentação dos resultados possa aparentar certa superestimação desses elementos.

Outra referência teórica importante utilizada para pensar essas questões foi Raymond Willians. Esse autor define três aspectos para compreender os processos culturais: as tradições, as instituições e as formações. Willians (1997) sustenta que a hegemonia na formação de uma cultura se trata de um "processo ativo" e não apenas um "complexo de traços e elementos dominantes". Sobre o fator que mais me interessa neste trabalho (a tradição), o autor critica sua utilização como "sobrevivência do passado":

(...) na prática a tradição é a expressão mais evidente das pressões e limites dominantes e hegemônicos. Sempre é algo mais do que um segmento histórico inerte; é na realidade o meio de incorporação prático mais poderoso. O que devemos compreender não é precisamente 'uma tradição', mas uma tradição seletiva: uma versão intencionalmente seletiva de um passado configurativo e de um presente préconfigurado, que resulta então poderosamente operativo dentro do processo de definição e identificação cultural e social (p. 137). ${ }^{64}$

\footnotetext{
${ }^{64}$ Todas as traduções de textos e entrevistas cujas referências se encontram em francês e espanhol são minhas.
} 
Willians destaca ainda que a tradição "é uma versão do passado que se pretende conectar com o presente e ratificar. Na prática, o que oferece a tradição é um sentido de predisposta continuidade" (p. 138). No entanto, o autor afirma que a cultura não deve ser estudada somente em seus "processos variáveis" ou em suas "definições sociais". Sustenta que é necessário observar suas "interrelações dinâmicas", "em cada ponto do processo que apresentam certos elementos variáveis e historicamente variados" (p. 143). Para interpretar essa questão, o autor argumenta que os processos culturais se desenvolvem a partir de uma estrutura formada pelos fatores dominante, residual e emergente. Chamo a atenção para o elemento residual, o qual o autor difere do "arcaico": "o residual, por definição, foi formado efetivamente no passado, mas ainda se encontra em atividade dentro do processo cultural; não só (...) como um elemento do passado, mas como um efetivo elemento do presente". Para compreender o mecanismo de funcionamento dessas instâncias, ou seja, os "significados e valores tal como são vividos e sentidos ativamente", o autor propõe o conceito de estruturas do sentir. Essas estruturas são definidas como experiências sociais "em processo" (p. 155), que se desenvolve em "pensamento como é sentido e sentimento tal como é pensado". Portanto, é "uma consciência prática de tipo presente, dentro de uma continuidade vivente e interrelacionada", como experiências sociais "em solução" (p. 156).

A proposição sociológica de Bourdieu baseada nos conceitos de campo e habitus também foi levada em conta como uma importante fonte de instrumental analítico. Em sua teoria da prática, esse autor busca construir uma ciência experimental baseada na dialética entre interioridade e exterioridade, ou seja, como um processo de interiorização da exterioridade e exteriorização da interioridade. Para desenvolver esse método, Bourdieu propõe o conceito de habitus, que o define como:

(...) um sistema de disposições duráveis, estruturas estruturadas, predispostas a funcionar como estruturas estruturantes, ou seja, como princípio de geração e de estruturação de práticas e de representações que podem ser objetivamente 'regulamentadas' e 'reguladas' sem serem de nenhuma forma o produto da obediência às regras, objetivamente adaptadas a seu fim sem supor a visão consciente de fins e o domínio expresso de operações necessárias para atendê-las e, sendo assim, coletivamente orquestradas sem ser o produto da ação organizadora de um maestro (Bourdieu, 2000, p. 256). [...] A prática é por um lado necessária e relativamente autônoma em relação à situação considerada em sua imediatidade pontual porque ela é o produto da relação dialética entre uma situação e um habitus, entendido como um sistema de disposições duráveis e transponíveis que, integrando todas as experiências passadas, funciona a cada momento como uma matriz de percepções e de ações, e torna possível o cumprimento de tarefas infinitamente diferenciadas, graças às transferências analógicas de esquemas que permitem resolver 
problemas da mesma forma e graças às correções incessantes dos resultados obtidos, dialeticamente produzidos por seus resultados (idem, pp. 261-262).

Como ressalta o autor em produção posterior, seu objetivo teórico era se opor ao mecanicismo e ao finalismo da teoria da ação racional, vistos como duas formas de determinismo (a primeira, por meio de um objeto mecânico externo, e a segunda pela inteligência e o uso da razão):

Contra ambas as teorias, convém ressaltar que os agentes sociais são dotados de habitus, inscritos nos corpos pelas experiências passadas: tais sistemas de esquemas de percepção, apreciação e ação permitem tanto operar atos de conhecimento prático, fundados no mapeamento e no reconhecimento de estímulos condicionais a que os agentes estão dispostos a reagir, como também engendrar, sem posição explícita de finalidades nem cálculo racional de meios, estratégias adaptadas e incessantemente renovadas, situadas porém nos limites das constrições estruturais de que são o produto e que as definem (Bourdieu, 2001, p. 169).

A partir dessa definição, Bourdieu explicita que o agente nunca é inteiramente o sujeito de suas práticas: "por meio das disposições e da crença que estão na raiz do envolvimento no jogo, quaisquer pressupostos constitutivos da axiomática prática do campo (a doxa epistêmica, por exemplo) se introduzem até nas intenções aparentemente mais lúcidas" (p. 169). O autor afirma ainda que "aprendemos pelo corpo" e que "as injunções sociais mais sérias se dirigem ao corpo e não ao intelecto, o primeiro tratado como um "rascunho" (p. 172).

A aplicação do conceito de habitus, de Bourdieu, no estudo das classes sociais (habitus de classe) poderia ser incorporada de maneira mais efetiva na interpretação que farei baseada nas categorias de ideologia inerente, experiências e tradições de luta. No entanto, considero que estas últimas são mais adequadas para a compreensão do objeto proposto, na medida em que se referem diretamente aos problemas analíticos que enfrentei ao longo deste trabalho, com a vantagem de terem sido cunhadas originalmente para o estudo da ideologia do protesto popular com base em sua natureza de classe. Ademais, o esquema interpretativo bourdieusiano prioriza a dimensão da dominação em detrimento da exploração como eixo central das relações sociais capitalistas. Por tal motivo, considero que seu método não resulta o mais adequado para abordar o movimento operário e sindical. Por último, vale dizer que embora a utilização da categoria de habitus permita apreender a dinâmica dos processos culturais na formação das tradições de maneira muito próxima à que empregarei neste trabalho, penso que a opção teórica pela História Social britânica e pelos autores marxistas clássicos dá conta das questões ressaltadas por Bourdieu. 
Vejamos, em síntese, como pretendo incorporar as contribuições dos autores citados ao repertório analítico e conceitual construído para este trabalho. De acordo com a perspectiva teórica que adoto, a formação das tradições de luta do movimento operário e sindical se dá pelo efeito da estrutura e da correlação de forças, considerando esta última não apenas a partir de sua dimensão "derivada", mas também de seu fator "inerente". Este último resulta do "senso comum" ou da "concepção tradicional popular do mundo", que advém da "experiência direta", da "tradição oral" e da "memória folclórica" em um processo de "aquisição histórica", no qual os "espíritos do passado" auxiliam as gerações atuais por meio de uma "linguagem emprestada", constantemente atualizada pelas "circunstâncias" e pela "experiência", funcionando como um "sistema de disposições duráveis", com "predisposta continuidade", "mais elástica do que os fatos", mas que, como elemento "residual", "oprime o cérebro dos vivos".

As ações e representações do movimento operário e sindical são explicadas por muitos autores a partir de seus fatores normativo-institucionais, pela base material, pelas relações políticas e pelas ideologias que orientam suas reivindicações, estratégias e planos de luta, considerando-as apenas em sua instância "derivada", através de um "mapeamento" das diferentes correntes atuantes no movimento. Porém, poucos estudos sociológicos buscam combinar a análise desses fatores com as ideologias inerentes, ou seja, com os elementos tradicionais que se formam a partir das experiências diretas e históricas da classe, em um processo de acúmulo de forças que constituem ciclos de lutas e relações sociais mais ou menos duráveis. As tradições de luta são o resultado de uma "síntese de múltiplas determinações" que, como "unidade da diversidade", constitui-se para o pensamento como o ponto de chegada e de partida da "observação imediata e da representação" (Marx, 1974a, p. 229). Como base nesses pressupostos, para iniciar a reflexão sobre o objeto de estudo específico, tratarei a seguir dos elementos da estrutura social e da correlação de forças que condicionaram a formação da classe e da luta de classes nos países analisados, buscando destacar suas principais experiências e tradições de luta. 


\section{CAPÍTULO 2 - MOVIMENTO OPERÁRIO E SINDICAL NO BRASIL E NA ARGENTINA}

O objetivo deste capítulo é buscar apontar quais são os elementos mais importantes para a construção de uma análise comparativa do movimento operário e sindical no Brasil e na Argentina. Para construir esse quadro, levarei em conta alguns indicadores da estrutura e da correlação de forças das duas formações sociais. O argumento central desta parte é de que, ao longo de sua trajetória, ambas as formações desenvolveram diferentes tradições de luta, constituídas por meio das experiências de organização e luta de sua classe trabalhadora. Essas tradições não se explicam somente pela composição das diferentes correntes ideológicas, mas é parte constitutiva do processo histórico de construção social e cultural de formação da classe e da luta de classes (Thompson, 1997).

O capítulo está dividido em quatro itens. No primeiro, tratarei da estrutura econômica do Brasil e da Argentina e sua relação com o processo de formação da classe operária e do movimento sindical ao longo do século XX. Destacarei alguns elementos que considero essenciais para a análise do desenvolvimento do capitalismo nos dois países, tais como a herança colonial, o fluxo imigratório, a estrutura demográfica e populacional, a produção industrial, a estrutura do mercado de trabalho e a composição dos grupos sociais fundamentais.

Em seguida, tratarei da estrutura jurídico-política e da organização sindical das duas formações. Para estudar essa questão será fundamental refletir sobre o papel do Estado e os fundamentos dos diferentes regimes políticos implantados, bem como sua relação com o bloco no poder hegemônico de cada fase histórica. Darei especial atenção para o papel do peronismo na Argentina e do varguismo no Brasil, pois se trata, nos dois casos, do momento de edificação e consolidação da estrutura sindical oficial. Revisitarei as formulações de Miguel Murmis e Juan Carlos Portantiero, segundo os quais esse processo se consolidou no Brasil "de cima para baixo", sem experiências de luta prévias, e na Argentina "de baixo para cima", a partir de um considerável acúmulo de organização da classe trabalhadora. A essa análise contraporei a tese do "mito da outorga" de Evaristo de Moraes Filho para, ao final, verificar se é possível considerar essas interpretações no contexto comparativo. Com base nesse diálogo histórico, analisarei as especificidades do Aparelho Ideológico de Estado 
sindical e sua relação com a ideologia estatal e os modelos de corporativismo vigentes em ambas as formações.

No terceiro item, tratarei das experiências de luta do movimento operário e sindical no Brasil e na Argentina. Farei referência ainda aos principais marcos da organização dos trabalhadores nos dois países, considerando sua fisionomia, formas e instrumentos de luta, posicionamentos e representações ideológicas, assim como sua relação com os elementos centrais da estrutura sindical. O principal argumento dessa parte é de que o protagonismo exercido pelo movimento operário argentino, relacionado a seu desenvolvimento industrial "precoce" no contexto latino-americano, marcou profundamente o peso da classe trabalhadora no país. Ao contrário, no Brasil, a consolidação "tardia" do movimento sindical de massas é a expressão de uma trajetória marcada pela descontinuidade e pela convivência constante com lutas no campo, dado o peso de sua população rural. Também terá destaque na análise o papel das ditaduras militares para o desenvolvimento do capitalismo brasileiro e argentino. Atentarei para a constituição da hegemonia do capital financeiro na Argentina a partir de 1976 e o projeto estatal de desenvolvimento capitalista no Brasil a partir dos anos 60. Esse processo foi marcado, do ponto de vista econômico e da mobilização operária, por dois momentos distintos. Enquanto o Brasil se encontra com seu "milagre econômico", a Argentina conhece um período prolongado de estagnação. Durante esse período, a repressão no Brasil retardou a consolidação de um movimento operário, popular e sindical de massa. Na Argentina, o genocídio levado a cabo pelos militares reprimiu um movimento que naquele momento se encontrava em seu auge. A partir dos elementos trabalhados ao longo do capítulo, procurarei elaborar uma proposta analítica acerca das principais tradições de luta do movimento operário e sindical em ambas as formações. Esse é o objeto do quarto item.

\subsection{Estrutura econômica}

Do ponto de vista de sua inserção no processo de constituição do capitalismo mundial, Brasil e Argentina possuem o mesmo sentido histórico (Prado Jr., 2000), pois ambos cumpriram a função de fornecedores de produtos primários para a acumulação primitiva do capital. Esse elemento estruturou os laços fundamentais de sua subordinação aos interesses dos países capitalistas centrais, o que os caracteriza como formações pré-capitalistas de tipo dependente (Cardoso e Faletto, 1970, Fernandes, 1975; Furtado, 2000). Em linhas gerais, pode-se afirmar que o passado colonial de mais de três séculos trouxe, tanto para o Brasil 
quanto para a Argentina, o problema crônico da dependência externa, especialmente na questão da modernização tecnológica. No século XX, ambos passaram por uma industrialização "tardia" (em relação ao centro da economia capitalista) baseada no modelo de substituição de importações, ainda que esse processo tenha se dado em etapas diferentes nos dois países. No entanto, apesar dessas similitudes mais gerais, é nas diferenças que me apoiarei para construir os elementos centrais da análise.

O desenvolvimento do capitalismo e a formação da classe operária no Brasil e na Argentina possuem trajetórias bem distintas. Para refletir sobre o tema, é necessário fazer uma aproximação dos elementos que compõem sua estrutura econômica. Parto da análise da fisionomia e da evolução demográfica. Atualmente, o território brasileiro é de $8.514 .876 .599 \mathrm{~km}^{2}$ e o argentino, de $2.780 .400 \mathrm{~km}^{2}$, o que significa que o Brasil é aproximadamente três vezes maior que a Argentina.

Antes do início da imigração européia pela qual passaram os dois países, o número de habitantes do Brasil era aproximadamente 5.5 vezes maior que o da Argentina. Essa diferença pode ser atribuída, entre outros fatores, à intensidade do comércio de negros oriundos da África para trabalhar como escravos no território brasileiro após o genocídio das sociedades pré-coloniais (Maestri, 1993, 1994). A atividade econômica argentina durante o período colonial não dependeu da importação massiva de força de trabalho escrava como no caso brasileiro.

De 1890 às primeiras décadas do século XX, a diferença populacional entre os países diminuiu e passou a oscilar entre 3 a 3.5 vezes. O período coincidiu com o início do fluxo de imigrantes europeus para a América, processo que foi mais intenso na Argentina do que no Brasil, em números absolutos e relativos. Essa proporção foi mantida até a década de 1960, quando se acelerou o processo de urbanização e industrialização brasileira, e sua população em relação à argentina se estabilizou em mais de quatro vezes superior para atingir, segundo as estimativas do censo populacional de 2008, a cifra de quase 4.8 vezes maior. Em resumo, para comparar os dois países deve-se ter conta, primeiramente, essa diferença primordial: o Brasil possui um território três vezes maior e uma população historicamente de três a cinco vezes superior à da Argentina (ver Tabela 1). ${ }^{65}$

Considerando a distribuição geográfica da população entre o campo e a cidade, também são notórias as diferenças. Desde o final do século XIX, mais da metade dos habitantes da

\footnotetext{
${ }^{65}$ Todas as tabelas, quadros e mapas citados ao longo do texto se encontram nos Anexos.
} 
Argentina era composta por proletários e semiproletários. Nessa época o país já contava com um significativo desenvolvimento industrial e nas primeiras décadas do século XX sua população passou a ser majoritariamente urbana. Por tais motivos, pode-se afirmar que o capitalismo argentino teve um desenvolvimento "precoce" em relação aos outros países da América Latina (Carrera, 2006, p. 71). No mesmo período, o Brasil também iniciou sua urbanização e industrialização, mas com um menor peso absoluto e relativo em relação ao vizinho. Até a primeira metade do século XX a população do país seguiu sendo predominantemente rural e sua economia, essencialmente agrária, com exceção de algumas regiões, como Rio de Janeiro e São Paulo, que concentravam a maior parte dos poucos estabelecimentos industriais do país.

Ao comparar mais detalhadamente a evolução da população urbana e rural das duas formações sociais, as diferenças ficam ainda mais evidentes. Historicamente, a população rural brasileira é mais significativa, em números absolutos e relativos. Na Argentina, em 1895 a população urbana somava um terço do total. No Brasil, essa proporção seria atingida apenas em 1950. Na Argentina, desde o censo de 1914 a população urbana já era maior que a rural. No Brasil, os habitantes da cidade passaram a ser a maioria apenas no censo de 1970 . Na Argentina, a população camponesa era de mais de um terço em 1947, cerca de um quarto em 1960 e menos de um quinto em 1980. No Brasil, essas cifras seriam semelhantes, respectivamente, nos censos de 1980, 1991 e 2000. Apesar de que essa diferença seja cada vez menor, permanece bastante acentuada até os dias de hoje, já que a população no campo contabilizada no último censo é de $10.5 \%$ na Argentina e $18.77 \%$ no Brasil (ver Tabela 2). Em números absolutos, essa dessemelhança é ainda mais notável. Até o censo de 1991 a população brasileira no campo era maior do que o total de habitantes da Argentina. Em 2001, mesmo que tenha diminuído a população rural do Brasil, seu número absoluto segue sendo oito vezes maior que seu equivalente argentino (ver Tabela 3$).{ }^{66}$

Com base nesses dados, pode-se afirmar que enquanto a Argentina é um país urbano desde o início do século XX, o Brasil passou de uma situação tradicionalmente agrária nas primeiras décadas desse século para a convivência com uma dupla identidade entre o campo e a cidade ao longo desse período. Essas características demográficas possuem significados econômicos, políticos, ideológicos e culturais marcantes nos dois países. Um dos argumentos

\footnotetext{
${ }^{66}$ É necessário esclarecer que os critérios para definir população rural e urbana no Brasil e na Argentina possuem algumas diferenças. Porém, não entrarei na polêmica acerca dessas definições, já que os dados apresentados são utilizados apenas como um indicativo geral.
} 
deste trabalho é de que este é um dos principais elementos explicativos do maior peso que o movimento operário e a organização sindical adquiriram na Argentina em relação ao Brasil. Aprofundarei essa formulação mais adiante.

Ainda sobre as características populacionais, vale a pena destacar com mais detalhes o significado do processo imigratório em ambas as formações sociais. Como já ressaltei, a imigração européia foi mais significativa na Argentina do que no Brasil. Segundo dados citados por Rapoport (2003, p. 43) entre 1861 e 1920, enquanto o Brasil recebeu cerca de 3.4 milhões de imigrantes, a Argentina recebeu 4.8 milhões (ver Tabela 4). Pensando nas diferenças demográficas já destacadas, pode-se observar que se trata de processos bem distintos em números relativos. De acordo com Devoto e Fausto (2004, p. 178), o censo de 1920 mostrou que pouco mais de $5 \%$ da população total brasileira era representada por estrangeiros. Ainda segundo os autores, estes representavam $18 \%$ da população do Estado de São Paulo, 35\% da capital paulista e 15\% do Rio de Janeiro, a capital da República na época. Na Argentina, de acordo com Rapoport (2003, p. 45) a população de imigrantes havia passado de $12.1 \%$, em 1869, a cerca de um quarto, em 1895, atingindo quase 30\%, em 1914 (ver Tabela 5). No caso brasileiro a chegada de imigrantes, especialmente europeus, teve grande repercussão apenas em São Paulo. No entanto, se comparamos o total de sua população com a de Buenos Aires entre 1886 e 1936, verifica-se que a proporção de estrangeiros da capital argentina era bem maior do que a da capital paulista. Quando a população estrangeira em São Paulo ultrapassou os 200 mil, em 1920, esta significava pouco mais de um terço de seus quase 580 mil habitantes. Em 1914, a população imigrante de Buenos Aires era de praticamente a metade do total da cidade, que na época contava mais de 1.5 milhões de habitantes (ver Tabela 6).

Além do menor peso da população urbana e estrangeira, outra característica demográfica importante do Brasil é a maior dispersão territorial de sua população e a maior quantidade de centros urbanos de importância regional. Desde o período colonial a ocupação do território argentino foi marcada pelo protagonismo da zona portuária em que se formou Buenos Aires, que concentrou desde então o papel de centro político e econômico. Posteriormente, esta também foi a principal região receptora de imigração européia e promotora do processo de industrialização do país a partir do final do século XIX.

Nos primeiros séculos de colonização, o Brasil se caracterizou pelo povoamento ao longo do litoral, formando diferentes centros econômicos ao longo de sua história. Durante 
esse período, Recife e Salvador, esta última a capital da colônia, desempenharam esse papel durante o ciclo econômico da cana de açúcar. A partir do crescimento da exploração aurífera no século XVIII, em Minas Gerais, cresceu a importância do centro sul. No início do século seguinte, o Rio de Janeiro se tornou a capital do país. No entanto, desde que assumiu a liderança da produção de café na segunda metade do século XX, São Paulo passou a ter um papel importante, o que se aprofundou ao se tornar o principal núcleo impulsor da industrialização brasileira a partir das primeiras décadas do século XX. No auge desse processo, na década de 60, a capital se mudou para Brasília, uma cidade planejada para ser o símbolo da modernização do país. Além dos municípios citados, o Brasil se caracterizou pela existência de grandes centros urbanos regionais que tiveram um crescimento acelerado durante a segunda metade do século XX (Porto Alegre, Curitiba, Belo Horizonte, Belém, Manaus, Fortaleza, entre outras).

De acordo com o censo de 2001, a Argentina conta com apenas duas cidades com mais de um milhão de habitantes, seis com mais de 500 mil e nove com mais de 300 mil. Segundo as estimativas do Instituto Brasileiro de Geografia e Estatística (IBGE) para o ano de 2007 o Brasil possui, respectivamente, 14, 37 e 81 municípios com essas características. No caso argentino, deve-se levar em conta ainda que a província de Buenos Aires possui aproximadamente metade da população do país e a região metropolitana da capital federal conta historicamente com um terço do total de seus habitantes.

Apesar da diferença populacional histórica entre os dois países, o Produto Interno Bruto $(\mathrm{PIB})^{67}$ argentino foi superior ao brasileiro até 1950, quando o Brasil ultrapassou a Argentina pela primeira vez, estabilizando-se a um nível de no mínimo duas vezes maior a partir da década de 1970, e de pelo menos três vezes superior a partir da década de 1980, quando atingiu seu patamar máximo de quatro vezes (ver Tabelas 7 e 8). Como observa Rapoport (2003, pp. 1068-1069) a partir desse período apenas a economia do Estado de São Paulo, com uma população semelhante, passou a corresponder ao dobro da argentina. Atualmente, o PIB brasileiro é o nono maior do mundo, (US\$1.981 trilhões, segundo a estimativa do IBGE para o ano de 2008). O argentino ocupa a vigésima terceira posição mundial (US\$523.7 bilhões, segundo estimativa do Indec ${ }^{68}$ de 2007), sendo cerca de 3.5 vezes menor que o do Brasil.

\footnotetext{
${ }^{67}$ Apesar de sua insuficiência para demonstrar o grau de desenvolvimento e expansão das relações capitalistas, tomo os dados do PIB como um indicador aproximativo do volume de capital em circulação.

${ }^{68}$ Instituto Nacional de Estadísticas y Censos.
} 
Esse processo possui uma relação direta com o crescimento acelerado da produção industrial pelo qual passou o Brasil entre as décadas de 1960 e 1970 em comparação com a industrialização na Argentina, que foi mais gradual. Esse elemento pode ser atestado pela média de crescimento do PIB nas duas formações sociais. De acordo com dados citados por Rapoport (2003, p. 737), enquanto o Brasil cresceu 7.3\% por ano entre 1959 e 1973, a Argentina teve um crescimento médio de 3.8\% no mesmo período. Em seguida, de 1973 a 1983, enquanto o PIB argentino apresentou uma média de crescimento de apenas $0.6 \%$, o do Brasil aumentou com uma taxa anual de $4.5 \%$. Os fatores políticos explicativos dessas diferenças serão explorados mais adiante. Destaco preliminarmente o papel da ditadura militar brasileira (1964-1985), que impulsionou o desenvolvimento interno da indústria capitalista, com endividamento externo e investimento estatal nos setores estratégicos, criando as condições necessárias para a expansão da acumulação de capital no país. Sua similar argentina (1976-1983) apresentou como principal característica a política econômica favorável à constituição da hegemonia do capital financeiro imperialista, o que se evidenciou em sua adesão precoce às políticas neoliberais.

Esses dados levam a uma conclusão importante sobre as diferenças presentes na evolução do capitalismo nos dois países. A Argentina teve um desenvolvimento precoce no início do século XX, tendo esgotado sua capacidade de expansão nos anos 70. O Brasil teve um desenvolvimento posterior, porém acelerado, e este processo ainda não está completamente acabado, já que o país ainda possui espaço para o desenvolvimento das relações capitalistas. Ambos possuem a condição comum de país capitalista dependente, o que limita sua possibilidade de buscar recursos externos explorando outros países. No entanto, no que diz respeito ao alinhamento específico nas relações de forças internacionais, pode-se dizer que o Brasil vem desempenhando nas últimas décadas a função de principal aliado estratégico das necessidades de ampliação do capital imperialista no cone-sul. Essa posição permite à grande burguesia interna (Poulantzas, 1971) de se expandir regionalmente, assumindo um crescente papel subimperialista (Marini, 1977). As relações econômicas entre o Brasil e os países sul-americanos, especialmente os do Mercosul, demonstram esse processo.

O Brasil supera a Argentina em todos os dados econômicos consultados, o que demonstra seu maior grau de desenvolvimento e capacidade de expansão das relações capitalistas. A maior evidência desse fator é o maior peso, absoluto e relativo, de indústrias de setores de capital mais concentrado e de alta tecnologia (automobilístico, de aviação, naval, 
etc.). Ademais, o país possui um influente setor bancário nacional (privado e estatal) e seu mercado acionário é bem superior ao argentino. Também é considerável o maior peso da grande burguesia interna, o que permitiu a alguns empresários do país, principalmente na década de 90, a compra de algumas empresas privatizadas (no setor bancário e industrial) e investimentos, aquisições e fusões no exterior. ${ }^{69}$ Apesar do processo de privatizações que se levou a cabo no Brasil, ainda é considerável o peso exercido pelo capital estatal no país. A Petrobrás é a maior empresa da América Latina em lucro e patrimônio líquidos e é a única do subcontinente que figura entre as cem maiores corporações do mundo. Segundo dados divulgados pela revista chilena América Economia, no ano de 2007, entre as 25 maiores empresas latino-americanas em volume de vendas, 11 eram brasileiras, 10 eram mexicanas, duas eram chilenas e apenas uma era argentina, além de uma venezuelana. Entre as 50 maiores, constam 24 brasileiras, 15 mexicanas, cinco chilenas e apenas quatro argentinas, além de uma venezuelana e uma colombiana. ${ }^{70}$

A diferença populacional entre os dois países explica parcialmente o potencial de crescimento de cada um. Nesse sentido, se o desenvolvimento do capitalismo no Brasil se desse sob as mesmas condições da Argentina, sua economia seria cinco vezes maior. Mas não é, justamente porque o que permite a posição subimperialista do Brasil é, por um lado, a formação de um grande capital interno, e por outro, a existência de uma fonte quase inesgotável de população sobrante, que inclui uma camada que vive na condição de miséria absoluta. Isso é o que permite a superexploração existente no país. O alto índice de superpopulação relativa consolidada é uma condição indispensável para o acúmulo de capital em larga escala da grande burguesia brasileira, pois é o que possibilita o rebaixamento do preço da força de trabalho no país. Ao analisar sua estrutura social, verifica-se que é expressivo o contingente que não participa diretamente da atividade econômica e consegue sua sobrevivência apenas através do "pauperismo oficial" (Marx, 1982) promovido pelo Estado (como no atual Programa Bolsa Família) ou se apropriando de recursos alheios, produzidos por outrem (por meio da "caridade", da "esmola", do "lixo urbano" e do "roubo"). Essa análise não leva em conta a parcela que compõe o lúmpem, ou seja, as pessoas que

\footnotetext{
${ }^{69}$ A Yacimientos Petrolíferos Fiscales (YPF), empresa petrolífera argentina que teve parte de suas ações compradas pela Petrobrás, a cervejaria Quilmes foi comprada pela empresa brasileira Ambev, e o Banco de Buen Ayre foi adquirido pelo Banco Itaú, a principal instituição financeira privada do Brasil.

${ }^{70}$ Ver www.americaeconomia.com.br/Multimedios/Otros/3206.pdf. Acesso em 30/10/2009.
} 
sobrevivem das chamadas atividades ilícitas e do crime organizado, o que nos daria uma idéia ainda mais acabada da dimensão da superpopulação relativa no país. ${ }^{71}$

Um dado revelador para explicar essas questões é de que apesar de sua superioridade absoluta, o PIB per capita brasileiro jamais foi superior ao argentino (ver Tabela 9). ${ }^{72}$ Apesar do processo de pauperização pelo qual passou a Argentina a partir de fins da década de 70, a situação sócio-econômica média dos habitantes desse país ainda segue melhor do que a do Brasil. Atualmente, o PIB per capita brasileiro (US\$10.326, segundo a estimativa do IBGE de 2008), que ocupa a $77^{\circ}$ posição no mundo, é menor que o argentino (US\$13.308, segundo estimativa do Indec para o ano de 2007), 57 colocada nesse quesito. Esse dado indica que a desigualdade econômica é outra característica marcante das duas formações sociais, embora a mesma seja historicamente mais acentuada no Brasil. Os indicadores sociais que compõem o Índice de Desenvolvimento Humano (IDH) avaliado pelo Programa das Nações Unidas para o Desenvolvimento (PNUD), podem nos dar uma aproximação do nível de vida médio no Brasil e na Argentina, apesar das limitações dos critérios utilizados em tal medição. No ano de 2007, o IDH da Argentina (0.866), ocupava a $49^{\circ}$ posição mundial. A esperança de vida média era de 75.3 anos $\left(59^{\circ}\right)$, a mortalidade infantil de 13.4/mil (98 mais baixo), e o índice de alfabetização era de $97.2 \%\left(55^{\circ}\right)$. O IDH do Brasil nesse mesmo ano era de 0.807 e ocupava a $70^{\circ}$ colocação. A esperança de vida média era de 72.4 anos $\left(92^{\circ}\right)$, a mortalidade infantil de 23.6/mil (133\% mais baixo) e índice de alfabetização de $90 \%\left(90^{\circ}\right){ }^{73}$

Os dados citados e a bibliografia consultada permitem fazer algumas considerações. Em síntese, as diferenças na estrutura econômica do Brasil e da Argentina são marcadas especialmente: (i) pelo maior peso da população urbana no processo de formação do capitalismo argentino, que alcançou patamares significativos desde o início do século XX, enquanto no Brasil a população rural foi majoritária até os anos 60; (ii) pelo maior peso da população imigrante na Argentina, sendo que no caso brasileiro esse conjunto jamais significou mais de 5\% da população total, tendo sido considerável apenas em São Paulo; (iii) pelo processo de industrialização, que no caso argentino foi mais acentuado que o brasileiro na primeira metade do século XX, o que fica evidente nas cifras do PIB desse período; (iv)

\footnotetext{
${ }_{71}^{71}$ Essa análise foi inspirada nas formulações de Carrera (2008).

${ }^{72}$ Apesar da limitação do conceito de PIB per capita para indicar a distribuição da riqueza, tomo este dado numa perspectiva comparada, e em conjunto com o valor absoluto do PIB, como uma primeira aproximação do nível de concentração de capital e de desigualdade econômica das formações estudadas.

${ }^{73}$ Ainda que durante a década de 2000 várias medições apontem uma redução da pobreza e da desigualdade sócio-econômica no Brasil, as diferenças com a Argentina seguem sendo acentuadas.
} 
pelo papel da grande burguesia brasileira, que passou a desempenhar cada vez mais claramente o papel de líder da economia capitalista na América Latina e principal aliada estratégica dos países imperialistas, desfrutando de algumas brechas deixadas por estes; (v) e pelo maior peso histórico da superpopulação relativa no Brasil. Os índices de informalidade nas relações de trabalho, pobreza e desigualdade econômica, no campo e na cidade, mais acentuados no caso brasileiro do que no argentino, evidenciam o caráter latente da herança do tripé da economia colonial brasileira (escravidão, monocultura exportadora e latifúndio), tal como foi identificado por Prado Jr. (2000). Apesar dessas diferenças, a condição comum de países capitalistas periféricos de economia industrializada coloca tanto o Brasil como a Argentina diante de amarras estruturais que tornam o seu desenvolvimento econômico um “mito" (Furtado, 1974). Esse é o ponto de partida para analisar essas formações sociais.

\subsection{Estrutura jurídico-política e organização sindical}

O sindicalismo no Brasil e na Argentina possui a característica comum de serem legitimados juridicamente, até os dias de hoje, pela estrutura sindical erguida na década de 1940. No caso brasileiro, a regulação dos sindicatos está baseada na Consolidação das Leis do Trabalho (CLT), criada em 1943 durante o governo de Getúlio Vargas (1930-1945). Este dispositivo legal reúne os principais decretos promulgados desde a Lei de Sindicalização, de 1931, e segue sendo o pilar do sindicalismo oficial no país. De forma semelhante, no caso argentino, a legislação destinada a regular os sindicatos é a Ley de Asociaciones Profesionales (LAP), de 1945, promulgada por Perón quando este exercia o cargo de Ministro do Trabalho. Apesar das modificações que sofreram ao longo dos anos, como as alterações na CLT com a Constituição de 1988 e as anulações e reedições da LAP em diversos contextos ${ }^{74}$, ambas permanecem intactas em seus principais aspectos.

Comparando o contexto da implantação do sindicalismo oficial nos dois países, Miguel Murmis e Juan Carlos Portantiero, em seu clássico Estudios sobre los orígenes del peronismo, afirmam que na Argentina a estrutura sindical foi criada em um momento no qual o país já contava com um considerável nível de industrialização e o movimento operário já havia adquirido um alto grau de representatividade. Ao contrário, no Brasil a organização sindical

\footnotetext{
${ }^{74}$ Para detalhes históricos sobre as mudanças na organização sindical argentina ver Abós (1986).
} 
teria sido imposta pelo Estado, sem um acúmulo significativo de lutas prévias do proletariado urbano e industrial (Murmis e Portantiero, 2004).

Essa formulação foi tomada como um dos argumentos centrais deste trabalho. O que não significa que minimizo a história das lutas operárias brasileiras, especialmente antes do golpe de Estado de 1930. Evaristo de Moraes Filho, um dos pioneiros da análise da estrutura do sindicalismo oficial brasileiro, em sua obra $O$ problema do sindicato único no Brasil, de 1952, já alertava para esta questão. Ao discorrer sobre a gênese do movimento sindical no país, Moraes Filho se contrapõe ao que chama de "mito da outorga" da legislação trabalhista promulgada durante o governo de Vargas. O autor argumenta que a organização sindical não foi um "presente de Estado" oferecido aos trabalhadores, mas uma concessão do governo varguista em conformidade com seu projeto populista, que incluía cooptar e disciplinar as mobilizações operárias daquele momento (Moraes Filho, 1978).

Ainda que a análise comparativa com a Argentina mostre o baixo peso relativo do movimento operário brasileiro nessa época, deve-se ter em conta que as primeiras décadas do século XX foram marcadas por importantes ações sindicais protagonizadas por grupos socialistas e anarquistas de origem italiana e espanhola que impulsionavam a organização da classe trabalhadora do país. O auge desse período foi a greve de 1917, originada na tecelagem Matarazzo, em São Paulo, que envolveu 6.000 operários. ${ }^{75}$ Houve repressão e após a morte de um grevista, a paralisação atingiu 70.000 trabalhadores por mais de um mês em todo o Estado, servindo de exemplo para o surgimento de movimentos grevistas em outras partes do país. Durante o conflito na capital paulista, houve levantamento de barricadas e tiroteios no bairro do Brás. A expansão do movimento operário organizado política e sindicalmente a partir de então foi um dos elementos que motivaram os golpes de Estado de 1930 e de 1937 liderados por Getúlio Vargas.

Para o estudo da história do sindicalismo no Brasil, é necessário levar em consideração essas referências. No entanto, a tese da legislação sindical brasileira ter sido "imposta de cima e sem lutas prévias" em relação à argentina, "imposta de baixo com lutas prévias" (Murmis e Portantiero, 2004), ou ainda, de um movimento sindical "de minorias e paraestatal" em relação a outro "de massas e autônomo" (Di Tella, 1997), se tomada em um contexto comparativo, pode ser um indicativo do grau de organização e do peso do movimento

\footnotetext{
${ }^{75}$ Esse evento remonta às paralisações generalizadas de 1906 e 1912, que também tiveram o setor têxtil como principal convocadora, e é o marco do ciclo grevista de 1917-1920, que contou ainda com uma greve geral em 1919. Ver Leite (1992).
} 
operário nas duas formações sociais na primeira metade do século XX. No item seguinte, fundamentarei este enunciado com alguns dados, especialmente de greves. Para o objetivo deste momento da exposição, considero importante destacar que a formulação de Murmis e Portantiero ressalta de maneira acertada o caráter autoritário da legislação sindical erguida pelo varguismo, o que marca sua diferença fundamental com o peronismo quanto ao modelo de relação da classe trabalhadora com o Estado e a classe capitalista. Voltarei a esse ponto mais adiante. Passemos à análise da estrutura sindical nos dois países.

Apesar da presença comum dos aspectos centrais do corporativismo estatal (reconhecimento jurídico pelo Estado, unicidade e monopólio da arrecadação financeira), há diferenças institucionais marcantes entre o sindicalismo do Brasil e da Argentina, a começar pela maneira como é efetuada a legalização dos sindicatos. No caso brasileiro, a carta de reconhecimento é dada apenas a uma entidade, não podendo haver concorrência em uma mesma base. No caso argentino, a personería gremial também é concedida a apenas um sindicato. No entanto, a legislação reconhece outras organizações por meio da inscripción gremial. ${ }^{76} \mathrm{Na}$ prática, a unicidade e o monopólio de arrecadação apresentam características semelhantes nos dois casos, pois na Argentina apenas os sindicatos com personería podem participar das negociações coletivas nacionais e gerir os recursos oficiais. Vale aclarar também que o imposto sindical brasileiro, correspondente a um dia de trabalho anual, é compulsório e universal, sendo descontado de todos os trabalhadores com registro formal em carteira. Na Argentina, a cuota sindical (a contribuição mais próxima ao imposto sindical), ao contrário, é aplicada apenas aos afiliados.

Podemos afirmar que os dois modelos não se enquadram nos critérios de "autonomia e liberdade sindical" definidos pela Convenção 87 da Organização Internacional do Trabalho (OIT). Porém, comparativamente ao Brasil, na Argentina existe maior possibilidade de concorrência sindical e são mais amplos os mecanismos de garantia da Organização no Local de Trabalho (OLT). Além da figura do sindicato "inscrito" e da cobrança restritiva do imposto, o sindicalismo argentino possui incorporado à estrutura organizativa a garantia de um corpo de delegados com estabilidade no emprego, pois a comissão interna é um direito assegurado por lei. Uma empresa de até 50 funcionários pode eleger um delegado; entre 51 e 100, dois delegados; e a partir de 101, um delegado mais para cada 100 trabalhadores. É

\footnotetext{
${ }^{76}$ A personería gremial é similar à carta de reconhecimento; a inscripción gremial é um simples registro no Ministério do Trabalho e não dá à entidade o direito de negociação coletiva, de eleição de delegados e de recolhimento da contribuição sindical estabelecida em lei.
} 
importante esclarecer que os dirigentes não são eleitos livremente, pois para pleitear o cargo o dirigente deve estar filiado à entidade com personería. No Brasil a inexistência de mecanismos semelhantes dificulta a organização da base. Somente a partir de 1988 a OLT passou a ser permitida, embora não tenha sido legalizada, pois não está incluída na estrutura sindical e não garante por lei a estabilidade de seus representantes.

A formação de centrais sindicais no Brasil esteve proibida desde a promulgação da CLT até a Constituição de 1988, tendo sido legalizada e incorporada à estrutura sindical apenas em 2008, no governo de Lula (2002-2005/2006-atual). Na Argentina essa garantia é concedida à central com personería desde a primeira LAP. Outra particularidade do Brasil é que, apesar do monopólio de representação dos sindicatos de base, é permitida a criação de várias centrais sindicais. Na Argentina, assim como nos sindicatos de base, apenas uma central possui a personería, apesar da possibilidade de criação de entidades concorrentes simplesmente inscritas.

A central mais antiga do Brasil em atividade é a CUT, fundada em 1983. Na Argentina é a Confederación General del Trabajo (CGT), criada em 1930 pela fusão de duas centrais que remontam à Federación Obrera Regional Argentina (FORA), de 1901, e à Unión General de los Trabajadores (UGT), de 1904. O Brasil possui diversas experiências anteriores de organização em centrais e entidades intersindicais, mas nenhuma foi tão duradoura quanto à de seu par argentino. Por tal motivo, pode-se dizer que o peso histórico da CGT não encontra semelhantes no caso brasileiro. Ademais, esta central possui uma forte ligação com as origens do peronismo, fenômeno político que vem marcando de maneira persistente as relações entre o Estado e a classe trabalhadora no país por mais de seis décadas.

Durante a presidência de Juan Domingo Perón (1946-1955), o sindicalismo foi um de seus principais aliados e a cúpula sindical cegetista participou da direção do governo, não apenas com a pasta do Ministério do Trabalho, mas também com a do Ministério do Interior, o mais importante da época. O debate sobre o significado da ideologia peronista e seus efeitos sobre a política argentina é um tema complexo e este trabalho não pretende aprofundá-lo. No entanto, é importante destacar algumas de suas características fundamentais. Não se pode entender o peronismo apenas como uma política populista marcada pelo assistencialismo aos pobres e práticas de cooptação da classe trabalhadora, ainda que esses elementos estejam presentes. O elemento crucial no peronismo é que o Estado é identificado não apenas como a instituição responsável por proporcionar a universalização dos direitos sociais e trabalhistas, 
mas também como o mediador de uma aliança entre a burguesia nacional e os trabalhadores, que vêem o capital industrial como o principal instrumento para a construção de uma força social nacionalista. ${ }^{77}$ Nessa relação, os sindicatos são considerados legítimos interlocutores e a ideologia justicialista é reconhecida como a "doutrina essencialmente nacional" que deve substituir as orientações anteriores baseadas em "sistemas alheios a seu meio, estranhas a sua tradição e a seu ambiente" ${ }^{\text {78 }}$, tal como aparece no próprio estatuto da CGT, aprovado em 1950. No Preâmbulo deste documento, vigente até os dias de hoje, lê-se:

Que a Doutrina Peronista, magistralmente exposta por seu criador, o General Juan Perón, define e sintetiza as aspirações fundamentais dos trabalhadores argentinos e lhes assinala a verdadeira doutrina, com raiz e sentido nacional, cuja ampla e leal aplicação haverá de forjar uma Pátria Justa, Livre e Soberana (CGT, 1950).

Mais adiante, no mesmo documento, a central declara "sua indeclinável decisão de constituir-se em zelosa depositária e fiel executora dos altos postulados que alentam a Doutrina Peronista". Vale a pena também destacar a "função social do capital" definida pela CGT: “A organização da riqueza e sua exploração tende por fim ao bem-estar do povo, dentro de uma ordem econômica conforme os princípios de Justiça Social” (CGT, 1950). Esses elementos explicam uma diferença histórica crucial entre Perón e Vargas. Ao contrário do peronismo, o trabalhismo de origem varguista não se constituiu com base em um vínculo tão estreito com o movimento sindical, embora esse fator não tenha estado ausente.

É muito comum entre os sindicalistas da CGT a idéia de que Perón dignificou a classe trabalhadora e de que a estrutura sindical do país é uma herança da organização sindical impulsionada pelo general. Na CUT, muitos identificam Vargas como um ditador autoritário representante da burguesia, e a legislação sindical brasileira como um resquício do fascismo italiano que desmobilizou a classe trabalhadora do país, dada sua influência da Carta del Lavoro de Mussolini. No entanto, asssim como entre os dirigentes peronistas na Argentina, setores expressivos do sindicalismo no Brasil, inclusive cutistas, defendem a idéia de que a estrutura sindical oficial seja um mecanismo de democratização das relações entre capital e trabalho. Isso demonstra que a ideologia populista do trabalhismo possui um importante peso no movimento sindical brasileiro.

\footnotetext{
${ }^{77}$ Uma das referências que melhor caracteriza a formação do peronismo como doutrina nacionalista no meio operário é a Acta de la Independencia Económica, assinada por Perón em 9 de julho de 1947, onde o presidente expôs os princípios que o país deveria seguir para se emancipar economicamente do capitalismo internacional.

${ }^{78}$ Trata-se a uma referência ao socialismo e ao anarquismo.
} 
Por conta dos fatores expostos até aqui, é possível afirmar que existem diferentes prioridades temáticas nos estudos sindicais dos dois países. Enquanto no Brasil, durante décadas, muitos autores se dedicaram à análise da ingerência estatal exercida pela estrutura sindical (J. Rodrigues, 1968, Boito Jr., 1991a, L. Rodrigues, 1966, 1990b, H. Martins, 1978, Moraes Filho, 1978, Simão, 1981, Vianna, 1976), na Argentina a atenção dos estudos clássicos foi dada para a origem e a persistência do vínculo entre os sindicatos e o peronismo (Abós, 1986, Murmis e Portantiero, 2004, Del Campo, 2005, Di Tella, 1997, Doyon, 2006, Levitsky, 2003, Torre, 2006, Zorrilla, 1988). Ainda que a relação entre sindicalismo, partido e Estado apareça na bibliografia brasileira e a estrutura sindical esteja presente nas análises argentinas, a linha condutora das pesquisas é relativamente distinta.

Partindo do repertório conceitual clássico empregado por Philippe Schmitter, Alfred Stepan diferencia o corporativismo estatal em dois tipos: o "inclusivo", que busca representar os interesses dos trabalhadores a partir de sua participação na administração do Estado, e o "exclusivo", que investe na desmobilização das representações sindicais por meio de medidas coercitivas. Como exemplo do primeiro tipo, o autor cita o caso argentino, e como exemplo do segundo, o brasileiro (Stepan, 1980). Utilizarei este modelo interpretativo como ponto de partida para a análise comparativa entre o peronismo e o varguismo.

A aliança de classes levada a cabo por Perón teve como estratégia política a incorporação dos trabalhadores no processo de construção da cidadania, o reconhecimento da instituição sindical como legítima interlocutora e a participação dos sindicalistas na direção do Estado. Ao contrário, em linhas gerais, o governo de Vargas de 1930 a 1945 adotou a prática de coerção da classe trabalhadora e de tutela do movimento sindical, além de não ter incorporado seus dirigentes ao aparelho estatal. No governo eleito de Vargas (1951-1954), principalmente durante o período em que João Goulart comandou o Ministério do Trabalho, houve uma maior liberalização para a prática sindical e certa proximidade com o sindicalismo, tendo sido comuns tanto negociações como concessões aos trabalhadores, a exemplo da implantação, na prática, do fim do atestado de ideologia (D’Araújo e Gomes, 1989, pp. 62-65). Durante seu mandato como presidente, Goulart (1961-1964) aprofundou sua aproximação com o sindicalismo. Porém, o corporativismo inclusivo buscado por Jango não se consolidou na cena política brasileira com o mesmo peso que na Argentina, já que foi interrompida pelo golpe de Estado de 1964. 
A partir dos argumentos apresentados até aqui, é possível fazer algumas considerações acerca dos diferentes efeitos ideológicos das experiências históricas do populismo no Brasil e na Argentina. No populismo trabalhista brasileiro o sindicalismo não teve uma experiência tão profunda de participação no poder político. O que não significa que o governo não tenha ampliado os direitos dos trabalhadores e o movimento sindical não tenha logrado exercer influência política. A aliança de classe almejada pelo varguismo se constituiu pela necessidade histórica de conciliar os interesses das oligarquias rurais regionais dominantes no aparelho de Estado com o capital industrial e outros setores urbanos em crescimento, conservando a velha fórmula da política brasileira de "pacto de elites". Também não se tornou hegemônica naquele momento, nem por parte do Estado nem por parte da classe trabalhadora, a aspiração de um "pacto social" tripartite como elemento estrutural que orientasse a atividade sindical. Esse elemento esteve presente, relativamente, no período de 1951 a 1964, especialmente no populismo janguista, mas ganharia importância somente com o sindicalismo propositivo defendido a partir da década de 90 pela Força Sindical (FS) e pela ala majoritária da CUT, especialmente pela Articulação Sindical (AS).

No caso argentino, o poder de mobilização e a presença de mecanismos institucionais de negociação entre os trabalhadores e os empresários no nível nacional são elementos historicamente mais marcantes. O vínculo histórico da CGT com o Partido Justicialista (PJ), fundado por Perón, proporcionou uma experiência muito profunda de participação sindical no governo do Estado. No caso brasileiro, esse papel foi relativamente exercido pelo Partido Trabalhista Brasileiro (PTB), especialmente na figura de João Goulart em sua passagem no Ministério do Trabalho e depois como presidente. ${ }^{79}$ Mais recentemente, vale destacar o vínculo entre a CUT e o Partido dos Trabalhadores (PT), no governo Lula, o qual, além de ter nomeado ministros e secretários de origem sindical, promoveu um maior canal de diálogo direto com o sindicalismo de base governista.

Considerando as experiências de organização na Argentina, verifica-se que foi fundamental o papel exercido pelas centrais sindicais como convocadoras de greves gerais ${ }^{80}$, uma ferramenta de luta menos presente na tradição de organização do movimento operário e

\footnotetext{
${ }^{79}$ Vale destacar ainda a importância da participação política do Partido Comunista do Brasil (PCB), que se destacou no período estudado por sua representatividade no Parlamento nos poucos momentos de legalidade de que gozou.

${ }^{80}$ As greves gerais possuem um estatuto privilegiado na análise proposta porque se trata do momento em que o conjunto da classe trabalhadora se enfrenta com a classe capitalista, o que exige um acúmulo prévio de lutas regionais e setoriais. É, portanto, a depender das circunstâncias e das condições em que são deflagradas, o principal termômetro do grau de organização e capacidade de mobilização do movimento operário e sindical.
} 
sindical brasileiro, embora tenha sido importante nas primeiras décadas do século XX e no período compreendido entre 1951 e 1964 . Sobre esse aspecto, de certa forma CUT demarcou uma linha divisória na história do sindicalismo no Brasil. Atuante em todo o país, a central levou a cabo algumas mobilizações importantes, cujo auge foi a convocação de três greves gerais nos anos 1980. Além disso, o fato de representar algumas das principais entidades do setor industrial e bancário paulista lhe permitiu por várias vezes paralisar e pressionar o centro da estrutura produtiva e financeira do país. ${ }^{81}$

Por conta da presença histórica contínua de uma central sindical única, de sindicatos nacionais e da organização no local de trabalho, na Argentina as greves gerais possibilitaram, em diversos momentos, interromper o conjunto das atividades estratégicas do país (concentradas na Grande Buenos Aires, Córdoba e Rosário), além de afetar alguns centros regionais. ${ }^{82}$ Ao contrário, comparativamente à Argentina, o Brasil tem poucas experiências de greves gerais anteriores às da década de 80 que tenham adquirido um caráter nacional, ou ao menos logrado articular o eixo Rio-São Paulo. ${ }^{83} \mathrm{O}$ sindicalismo no Brasil possui um caráter mais fragmentado. O alcance das negociações e das mobilizações no país é mais limitado, e dificilmente se constitui em paralisações do conjunto das atividades econômicas do país. Além da menor presença de greves gerais (e principalmente as nacionais), verifica-se no caso brasileiro uma frágil consolidação de uma cultura de interlocução direta dos dirigentes sindicais com o governo federal, tendo aparecido com força nos mandatos de João Goulart como Ministro do Trabalho e Presidente da República e, mais recentemente, no Governo de Lula. $^{84}$ No caso argentino, é comum que os presidentes, mesmo os opositores ao PJ, dialoguem com os representantes das centrais sindicais e dos principais sindicatos nacionais.

\footnotetext{
${ }^{81}$ Algumas ponderações devem ser feitas em relação ao tema. Primeiramente, é necessário diferenciar as greves gerais nacionais das locais, e as setoriais das intersetoriais. Nesse sentido, a grande particularidade argentina é a maior presença da convocação de greves gerais intersetoriais nacionais, presentes desde o início do século XX, e recorrentes e massivas a partir dos anos 1930, ainda que com diferente peso, conforme a conjuntura. Em segundo lugar, vale notar que greves gerais setoriais e locais (e em alguns momentos, setoriais nacionais) não estiveram completamente ausentes no Brasil, como mostrarei mais adiante. Por último, é importante destacar que até os anos 1950, tanto no Brasil como na Argentina, as greves ficavam praticamente restritas aos centros urbanos com considerável nível de atividade industrial. Isso significa que a adesão de uma greve "local" em Buenos Aires, ou no Rio de Janeiro e em São Paulo, possuía um certo caráter "nacional”. Para simplificar a exposição, utilizarei o conceito de "greve geral" na comparação para me referir às paralisações desse tipo com repercussão sobre as principais atividades da economia de uma formação social capitalista.

${ }^{82}$ Isso não significa que todas as greves gerais no país tenham logrado esse feito, especialmente no início do século, quando, tal como já me referi na nota anterior, as paralisações "nacionais" se restringiam a Buenos Aires. ${ }^{83}$ Alguns exemplos de protestos com essa abrangência foram as greves gerais dos bancários de 1961, 1962 e 1963, e a greve dos trabalhadores dos transportes aéreos de 1963. Ver Matos (2009, p. 94).

${ }^{84}$ Também esteve relativamente presente durante a presidêcia de Itamar Franco, quando Walter Barelli exerceu o cargo de Ministro do Trabalho.
} 
O sindicalismo brasileiro é mais fragmentado também por conta do enquadramento sindical vigente no país durante décadas (baseado na representatividade territorial por município). Esse modelo, que era imposto até a Constituição de 88, atualmente é reproduzido pelas organizações sindicais, o que tem tido um efeito pulverizador sobre a ação sindical, já que dificulta a construção de entidades com representação regional e nacional, ainda que este papel seja cumprido parcialmente pelas federações e confederações. A observação de dados sobre a quantidade de sindicatos, de afiliados e da taxa de sindicalização permite avançar no exame dessa questão. Na ausência de uma série histórica, citarei os números mais recentes.

A Pesquisa Sindical realizada pelo Instituto Brasileiro de Geografia e Estatística (IBGE) no ano de 2001 registrou 11.354 sindicatos no Brasil. O levantamento revelou ainda um total de 19.528.311 de associados em entidades sindicais, sobre uma base de 54.064.315 de trabalhadores, o que significa uma média de aproximadamente 1.720 associados sobre uma base de 4.762 trabalhadores por sindicato. Partindo de uma População Economicamente Ativa (PEA) de 83.243.000 e de um total de 75.458.000 de "ocupados", chegamos a uma taxa de sindicalização de $23 \%$ da PEA, 26\% dos empregados e 36\% da base (IBGE, 2001). Os índices não estão muito abaixo da média argentina e dos principais países industrializados, mas expressam a realidade do sindicalismo brasileiro somente a partir dos anos 80 .

$\mathrm{Na}$ Argentina, segundo o Ministério do Trabalho, Emprego e Seguridade Social (MTEySS) relativos ao ano de 2007, a taxa de sindicalização no país era de $37.6 \%$ em fevereiro, de acordo com a Encuesta de Trabajadores en Empresas (ETE), e de $34.5 \%$ em novembro, segundo a Encuesta de Indicadores Laborales (EIL) (MTEySS, 2007a, 2007b). A Central de Trabajadores de la Argentina (CTA) afirma que existem atualmente cerca de 2.800 sindicatos registrados no Ministério do Trabalho, sendo 1.700 com personería e 1.100 com inscrição. De acordo com o último Censo Populacional, realizado em 2001, o país conta com cerca de 13 milhões de trabalhadores com registro formal. A partir desses dados, podemos deduzir que os sindicatos argentinos possuem 4.485.000 de afiliados, o que significa uma média aproximada de 1.600 associados sobre uma base de 4.643 trabalhadores sindicalizáveis por sindicato. Os dados da Argentina e do Brasil são muito parecidos. No entanto, essa semelhança não invalida o argumento anunciado anteriormente, já que o fator fundamental para a formação de uma tradição organizativa é a presença histórica contínua do papel da central sindical e dos sindicatos nacionais nos setores mais expressivos. Afinal, o índice de sindicalização na Argentina é de mais de $20 \%$ pelo menos desde a década de 1940 
(Marshall, 2006). No Brasil, no ano de 1960, no auge do processo de formação de um sindicalismo de massa no país, essa cifra é de $6.11 \%$ da PEA e $14.45 \%$ da PEA ligada a atividades urbanas (Matos, 2009, p. 91).

Outro dado importante para a análise é a representação no local de trabalho. No Brasil, o IBGE registrou um total de apenas 5.294 integrantes em comitês sindicais de empresa, sendo 3.265 com estabilidade e 2.029 sem estabilidade. Desse total, apenas 98 estavam no campo, sendo 50 com estabilidade e 48 sem estabilidade (IBGE, 2001). A CGT afirma possuir 30.000 delegados e a CTA, 8.000, todos com estabilidade. ${ }^{85}$ De acordo com os números da EIL citados pela CTA (2008, p. 25), somente $12.4 \%$ das empresas argentinas possuem delegados no local de trabalho. No entanto, quando se analisa esse dado segundo o tamanho do estabelecimento, essa cifra diminui para 7.5\% entre as empresas com menos de 50 trabalhadores, mas aumenta para $27.7 \%$ nas que possuem entre 51 e 200 trabalhadores e 52.5\% entre as que têm mais de 200 trabalhadores. Ou seja, o sindicalismo argentino conta com representação no local de trabalho em pelo menos metade das maiores empresas.

É necessário ressaltar ainda que no caso brasileiro, do total de sindicatos existentes em 2001, apenas 4.304 (38\%) eram afiliados a alguma central. Dividindo sua área de atuação entre o campo e a cidade, verifica-se que existe no país uma forte tradição de sindicalismo rural, que representa $36 \%$ do número de entidades e $46 \%$ do número de associados. Considerando o conjunto dos sindicatos por central sindical, em 2001 a CUT representava $66 \%$ dos sindicatos brasileiros, contra $19 \%$ da FS e 15\% das outras cinco centrais juntas. Ademais, na CUT predominavam os sindicatos de grande porte (com mais de 1.000 afiliados), enquanto nas outras centrais a maioria era composta por sindicatos de médio porte (entre 101 a 1.000 afiliados).

Sendo assim, pode-se afirmar que entre os 19.328.511 trabalhadores brasileiros afiliados a um sindicato, apenas 10.211.185 pertencem a uma central. Desse total, a CUT representa 5.293.080 com registro (2.841.719 na zona urbana; 2.451 .361 na zona rural) e 1.958.503 sem registro (1.019.242 na cidade; 939.261 no campo), em um total de 7.251.583 de trabalhadores afiliados, 3.860.961 na cidade e 3.390.622 no campo. Não foi possível ter acesso a dados do sindicalismo no campo na Argentina. No entanto, levando em conta que esse país apresenta uma população rural significativamente menor, em números absolutos e relativos, é possível afirmar que o movimento sindical rural brasileiro representa uma base muito mais ampla.

\footnotetext{
${ }^{85}$ Ver www.cgtra.org.ar e www.cta.org.ar.
} 
Na Argentina, a CGT declara possuir 2.500.000 afiliados, e a CTA, 850.000. Assim, enquanto a representatividade dos afiliados da CUT é de $9.6 \%$ da população ocupada, os afiliados da CGT representam 19.2\% desse mesmo conjunto. Pensando no total de afiliados, se a CUT representa $37.5 \%$ dos trabalhadores afiliados a sindicatos no Brasil, a CGT representa $55.7 \%$ desse total. Ademais, enquanto a CUT representa $66 \%$ dos sindicatos brasileiros e cerca de $70 \%$ dos trabalhadores afiliados a centrais, a CGT representa cerca de $75 \%$ deste último conjunto na Argentina. Se levarmos em conta ainda que o total de trabalhadores rurais associados a sindicatos da CUT é bastante significativo (46.7\%) e a pulverização municipal das entidades, é possível afirmar que o poder de convocação de uma única central no sindicalismo brasileiro é menor que no argentino.

Vale lembrar também que o número de afiliados da CUT cresceu significativamente a partir de 1988, com a permissão de organização sindical aos funcionários públicos, e no início dos anos 90, com a incorporação dos sindicatos rurais representados pela Confederação Nacional dos Trabalhadores na Agricultura (Contag) e das entidades ligadas ao Partido Comunista do Brasil (PCdoB) que migraram da CGT para a central. Esses dados nos dão idéia do quanto o peso das centrais é relativamente recente na história do sindicalismo brasileiro. Ainda que tenha estado presente em outros momentos, as entidades sindicais nacionais no Brasil tiveram quase sempre uma existência muito breve.

A seguir, farei alguns comentários sobre os fatores que incidem sobre as taxas de sindicalização na Argentina, que são consideradas altas, historicamente. Um dos fatores que a bibliografia atribui a essa questão é a representação no local de trabalho. Como já foi destacado, no caso brasileiro esse instrumento organizativo é muito menos presente. Ademais, se por um lado existe o fator legislativo, tal como foi demonstrado no item anterior, as experiências de luta concretas dos sindicatos no Brasil não evidenciam um esforço de mudança de seu caráter cupulista. Apesar desse elemento também estar presente na Argentina, existe nesse país uma estrutura organizativa baseada em comissões internas compostas por delegados sindicais com estabilidade, e forte poder de mobilização e convocação no interior da classe trabalhadora. Como resultado desses fatores, existe uma tradição de participação na atividade sindical muito mais intensa que no caso brasileiro.

Marshall (2006) aponta alguns aspectos da regulação trabalhista que produzem efeitos sobre a filiação sindical. Os fatores levantados pela autora para comparar as experiências da Argentina, do Chile e do México são um ponto de partida razoável para a comparação com o 
Brasil. Entre as normas mais influentes, Marshall cita as que se referem à negociação coletiva, as que regulam a representação sindical em geral e no local de trabalho, as que definem o enquadramento sindical a partir de um emprego ao sindicato correspondente, as que definem o grau de centralização da estrutura sindical e as que estabelecem sobre quem (Estado ou sindicatos) recai a prestação de benefícios sociais tais como o serviço de saúde e a previdência social.

Considerando o último aspecto, um dos fatores enfatizados pela autora é a gestão das obras sociales. ${ }^{86}$ Segundo a autora, estas se constituíram, pelo menos até 1970 , em um estímulo adicional para a sindicalização, já que o serviço tendia a se restringir aos afiliados. A partir de então, as obras sociales constituíram um "sistema inseparável" e uma fonte de recursos para as entidades sindicais, sendo vistas pelos trabalhadores como um compromisso de seus sindicatos. No entanto, Marshall afirma que a diferença fundamental entre os modelos de organização sindical dos países estudados está na presença de representação sindical no local de trabalho reconhecida por lei. Sobre o tema, a autora assim explicita:

[...] na Argentina, desde pelo menos 1958, com a lei de associações profissionais que ao garantir a estabilidade dos delegados sindicais nos estabelecimentos, reconhecia legalmente, pelo menos de forma implícita, a representação sindical no local de trabalho, criam-se os cimentos para o papel crucial que a representação sindical teria a longo prazo em relação à filiação sindical (Marshall, 2006, p. 15).

Com referência aos aspectos históricos que contribuíram para a formação desses mecanismos de representação, Marshall ressalta que mesmo antes das políticas pró-sindicais do governo de Perón, já havia 400 mil trabalhadores afiliados a sindicatos, o que representava um índice de cerca de $20 \%$ da força de trabalho urbana. No entanto, a autora argumenta que foi depois de 1946 que cresceu a filiação sindical substancialmente, devido ao esforço dos dirigentes, mas especialmente por conta do apoio estatal às campanhas para organizar os trabalhadores. Por último, Marshall destaca que nesse período Perón impulsionou a institucionalização da provisão sindical do sistema de saúde que se transformaria mais tarde na base de recrutamento de membros, além de benefícios como lazer, esporte e turismo.

Neste item busquei avançar na análise da organização e da estrutura sindical do Brasil e da Argentina, assim como dos principais pilares que contribuíram para construção do modelo de relação da classe trabalhadora com o Estado e o poder político e econômico nos dois países. A seguir, explorarei mais detalhadamente a história do movimento operário e sindical

\footnotetext{
${ }^{86}$ As obras sociales constituem a principal referência do sistema de saúde da Argentina. São administradas pelos sindicatos e fornecem atendimento médico à família de todo trabalhador formal.
} 
brasileiro e argentino, que será um importante fundamento para as formulações posteriores sobre a formação de suas principais tradições de luta.

\subsection{História do movimento operário e sindical}

Desde o início do século XX o movimento operário e sindical é o principal protagonista dos protestos sociais na Argentina. ${ }^{87}$ Essa mesma afirmação não pode ser feita para o Brasil, onde o sindicalismo divide esse papel com o movimento camponês, e as manifestações de massa dos trabalhadores adquiriram peso em alguns momentos no início desse século e entre a década de 50 e o golpe militar, para se consolidar no cenário nacional a partir do final dos anos 70. A trajetória do sindicalismo argentino apresenta uma relativa continuidade, constatável em suas taxas de sindicalização, historicamente altas, na presença constante de centrais sindicais e de sindicatos únicos nacionais com forte poder de negociação e mobilização, e na intensa atividade grevista ao longo de sua história. Um dos principais elementos que evidenciam o nível de organização e o peso do sindicalismo argentino é a presença constante da greve geral como instrumento de luta, que em vários momentos paralisou o conjunto da classe trabalhadora do país.

Desde as experiências precursoras da FORA e da UGT no início do século XX, a organização nacional é um traço característico do movimento sindical argentino. A partir de 1930 a CGT passou a desempenhar esse papel. No entanto, apesar do crescimento que teve após o vínculo histórico com a ascensão do peronismo, o movimento sindical já era importante no país, o que se explica parcialmente por seu nível de industrialização na primeira metade do século XX. O número de operários industriais argentinos era de 396.303, em 1935, 733.968 em 1941 e 889.032, em 1946 (Meléndez e Monteagudo, 1971, p. 77). ${ }^{88}$ Nesse período, o número de afiliados passou de aproximadamente 370.000 em 1935 a mais de 470.000 em 1940, dos quais cerca de 310.000 pertenciam à CGT (ver Tabela 10). Como já foi mencionado, em meados da década de 1940 a taxa de filiação no país correspondia a $20 \%$ de sua força de trabalho urbana. Como se pode explicar as diferenças existentes do peso do movimento operário e sindical brasileiro e argentino ao longo da história? Os fatores são

\footnotetext{
${ }^{87}$ As informações coletadas sobre a história do movimento operário argentino para a construção deste capítulo foram extraídas dos diversos textos que serão citados no decorrer do item, além da leitura de Bilsky e Coggiola (1999), Carrera (2004), Carrera, Grau e Martí (2006) e Del Campo (2005).

${ }^{88}$ Segundo dados citados por Matos (2009, p. 38), havia em São Paulo e no Rio de Janeiro 59.036 operários industriais no ano de 1907, 140.515 em 1920 e 241.901 em 1929.
} 
múltiplos. Buscarei apontar alguns desses elementos que considero centrais, mas sem pretender dar uma resposta completa para a questão, que não é o foco desta tese.

A primeira pista para compreender o baixo peso do sindicalismo brasileiro em relação ao argentino na primeira metade do século XX deve ser buscada nos indicadores da estrutura econômica apresentados no primeiro item deste trabalho. O sindicalismo é um fenômeno da sociedade capitalista que adquire caráter massivo em economias industrializadas (Hyman, 1975). Até a década de 50 o Brasil era um país essencialmente agrário, com população predominantemente rural e baixo nível de industrialização. A Argentina já contava com a maioria de sua população na zona urbana e com um parque industrial mais significativo, o que pode ser atestado pela superioridade de seu PIB em relação ao brasileiro até então. Outro fator explicativo do nível de organização do movimento sindical argentino é a presença massiva de imigrantes europeus na formação de sua classe operária. Os estrangeiros que chegaram ao país nas primeiras décadas do século XX, especialmente espanhóis e italianos, difundiram a ideologia anarquista e socialista em voga em seus países de origem. Esse argumento é praticamente consensual entre os estudiosos do tema e se encontra bem argumentado no trabalho de Del Campo (2005). No Brasil, a presença de imigrantes europeus jamais teve um peso relativo tão significativo quanto na Argentina. Além disso, por conta de seu baixo nível de industrialização, parte considerável dos estrangeiros que desembarcaram no país se dirigia ao campo para trabalhar sob o regime de colonato.

Em São Paulo, que concentrava as indústrias do país a partir da década de 1910 e era o centro receptor do fluxo de imigrantes, o movimento operário e sindical ganhou um considerável impulso. Em linhas gerais, até a década de 60 o sindicalismo brasileiro praticamente se restringia à capital paulista e ao Rio de Janeiro, ainda que estivesse presente em outras regiões. Mas a atividade grevista e a intensidade das mobilizações operárias nas duas principais cidades brasileiras não atingiam o nível da capital argentina, mesmo porque havia uma diferença populacional e de nível de industrialização consideráveis. Essa explicação deve ser complementada pelos fatores políticos (incluindo aí as questões institucionais e jurídicas). Antes de mencioná-los, porém, apresentarei alguns dados que fundamentam as formulações feitas até aqui.

Observando o número de greves ao longo da história dos dois países as diferenças são notórias. Entre 1888 e 1944, foram registradas 364 greves em São Paulo e de 1890 a 1930, 
346 no Rio de Janeiro, totalizando 710 paralisações em todo o período. ${ }^{89}$ De 1945 a 1977 , foram 912 eventos no Brasil, tendo sido registradas ao longo desse esse período (1888-1977) 1.622 greves (ver Tabela 11). Na Argentina, apenas entre 1906 e 1918 ocorreram 1.794 greves (López, 1971. Ver Tabela 12), número superior a mais de 90 anos de história desse tipo de protesto no Brasil. Não disponho de dados do período de 1919 a 1955 na Argentina. No entanto, de acordo com os números citados por Carrera (2007a), entre 1955 e 1980 registra-se um total de 2.670 greves no país (Ver Tabela 13). Desse total, somente no ano de 1975 foram convocadas 1.266 paralisações. Vale destacar também que durante todo esse período não ocorreram greves gerais nacionais e intersetoriais no Brasil convocadas por uma central, instrumento de luta utilizado pela primeira vez no país em 1986, mas com repercussão parcial somente em alguns centros urbanos. ${ }^{90}$ Não disponho de dados sistematizados de greves gerais locais e setoriais no país, mas como veremos mais adiante, essas foram importantes em vários momentos da história do movimento operário brasileiro. Na Argentina, a greve geral tem sido uma constante na história do movimento operário e sindical do país. Entre 1901 e 1927, registra-se 19 protestos desse tipo, sendo 15 locais e quatro nacionais. Entre 1930 e 1943, foram 104, e entre 1955 e 1976, 41, tendo sido 13 locais e 28 nacionais, totalizando 164 greves gerais ao longo de 75 anos (Santella, 2008. Ver Tabela 14). No Brasil foram realizadas sete greves gerais nacionais por vários setores; entre 1986 e 1996, sendo que apenas uma (a de 1996) foi convocada pelo conjunto das centrais sindicais. ${ }^{91} \mathrm{Na}$ Argentina, entre 1979 e 2002 foram convocadas 39 protestos desse tipo pelo conjunto das centrais sindicais (Carrera, 2007a, Ver Tabela 14). A partir de 1978, cresce o número de greves no Brasil. Desse ano até o fim da ditadura militar no país foram convocadas 1.813 greves. Em seguida, foram registradas 13.218 greves entre 1985 e 1990, 1.956 de 1991 a 1992, 5.556 entre 1992 e 1997, e 3.850 de 1998 a 2007. Ou seja, um total de 26.393 greves em pouco menos de 30 anos de movimento sindical (Elias Jr., Gebrim, Noronha, 1998, p. 7. Ver Tabela 11). Na Argentina, registra-se 5.950 greves no mesmo período (Carrera, 2007a).

O estudo da história do movimento operário brasileiro em comparação com o argentino leva a uma reflexão sobre os fatores políticos que dificultaram a construção de centrais sindicais no Brasil, tendo em vista seu caráter descontínuo. Na história do sindicalismo no

\footnotetext{
${ }^{89}$ Apesar da ausência de um registro completo e de abrangência nacional, esses dados constituem um bom indicativo da recorrência desse tipo de protesto no Brasil, pois se tratam dos dois Estados que impulsionaram o desenvolvimento das relações capitalistas no país.

${ }^{90}$ Como já ressaltei, as greves gerais anteriores se restringiram aos Estados do Rio de Janeiro e de São Paulo.

${ }^{91}$ Levantamento próprio a partir da documentação sindical consultada para esta pesquisa.
} 
país, encontramos a experiência pioneira da Confederação Operária Brasileira (COB), fundada em 1906 a partir de um congresso de setores anarquistas e socialistas. Essa central realizou dois encontros (em 1913 e 1920), este último tentando reativar a entidade, que já demonstrava sinais de enfraquecimento em um contexto de intensa repressão. ${ }^{92}$

Em 1922, apareceu o Partido Comunista do Brasil (PCB), que teve uma forte atuação no movimento sindical a partir de então. Em 1929, sob sua influência, foi fundada a Federação Regional do Rio de Janeiro e se realizou o Congresso Sindical Nacional, a partir do qual se criou a Central Geral dos Trabalhadores (CGT). Nesse período as tentativas de organização nacional do sindicalismo brasileiro foram interrompidas pela repressão ao movimento operário característica dos governos autoritários da Primeira República, tendência que foi mantida após o golpe de 1930 que levou Getúlio Vargas ao poder. Em uma sociedade que havia saído há poucas décadas da escravidão, permanecia a cultura de tratamento da questão social como um "caso de polícia" pela política vigente.

Em março de 1934, já durante o governo de Vargas, surgiu a Aliança Nacional Libertadora (ANL). Dirigida pelo militante comunista Luis Carlos Prestes com a finalidade de construir uma frente popular democrática, essa organização chegou a congregar mais de 400.000 membros. No mesmo ano, foi fundada a Confederação Sindical Unitária (CSU), dissolvida logo em seguida e refundada no ano seguinte durante a Convenção Nacional de Unidade dos Trabalhadores, que reuniu cerca de 300 delegados representantes de aproximadamente 500.000 operários.

Um dos elementos que contribuem para explicar a desmobilização do movimento sindical brasileiro no período varguista foi a promulgação da Lei de Segurança Nacional (LSN), em 1934. O decreto proibiu o direito de greve, além de ter criado o estado de sítio e a Comissão de Repressão ao Comunismo. A ANL foi posta na ilegalidade e Prestes organizou um levante armado dissolvido em seguida pelo governo. Em 1939, o decreto-lei 1402 criou o imposto sindical e o enquadramento sindical, o mecanismo responsável por aprovar (ou não) a criação dos sindicatos. Esse estatuto, vigente até 1988, entre outros fatores inibitórios à prática sindical, exigia um atestado de ideologia das entidades.

\footnotetext{
${ }^{92}$ As informações presentes nos próximos parágrafos foram extraídas da leitura dos diversos textos citados. Para uma análise do movimento sindical brasileiro anterior a 1930, ver Simão (1981) e Moraes Filho (1978). Para o período entre 1930 e 1964, ver L. Rodrigues (1981). O período específico de 1945 a 1950 é tratado por Maranhão (1979). Para uma síntese da história do sindicalismo brasileiro, ver Matos (2009).
} 
Logo após o fim da ditadura de Vargas, em 1945, um movimento popular impulsionado pelo PCB conquistou a anistia política. No mesmo ano, foi criado o Movimento Unificador dos Trabalhadores (MUT), entidade opositora ao sindicalismo oficial. Em 1946, o II Congresso Sindical dos Trabalhadores do Brasil, realizado no Rio de Janeiro com a presença de 2.400 delegados, sob o comando dos comunistas, criou a Confederação Geral dos Trabalhadores (CGT). Em poucos meses o PCB se tornou o maior partido comunista da América Latina, com 200.000 membros, conseguindo $10 \%$ dos votos nas eleições presidenciais e elegendo 14 deputados, além de Prestes como o senador mais votado. Porém, no ano seguinte, o presidente Eurico Gaspar Dutra (1946-1951) dissolveu o MUT, colocou o PCB na ilegalidade e suspendeu as eleições nos sindicatos, o que novamente dificultou a ascensão do sindicalismo brasileiro.

Nos anos 1950, no governo eleito de Getúlio Vargas (1951-1954), o movimento sindical começou a atingir proporções de massa. Nesse momento o país já contava com 1.5 milhões de trabalhadores industriais e as greves voltavam a aparecer na cena política. O evento de maior importância desse período foi a greve dos 300 mil de São Paulo, em 1953, que reuniu vários setores (metalúrgicos, têxteis, gráficos, etc.) e se estendeu a outras cidades do interior como Santos e Sorocaba. ${ }^{93}$ Também em 1953 foi criado o Pacto de Unidade Intersindical, que se transformou em seguida no Pacto de Unidade e Ação (PUA). Criou-se também o Pacto Intersindical (PIS), no ABC paulista, que seria o germe do forte movimento que se verificou a partir de então na região, composto especialmente por comunistas e setores ligados à Igreja Católica. Vale ressaltar que no interior desses grupos havia um forte conteúdo anticorporativista, evidente pela constante reivindicação por liberdade sindical.

Durante os governos de Juscelino Kubistchek (1955-1960) e Jânio Quadros (1961), as lutas sindicais seguiram em crescimento, tenho atingido seu auge durante o mandato de João Goulart (1961-1964). Em 1957, as mesmas categorias que haviam paralisado em 1953 realizaram uma greve de dez dias em São Paulo que envolveu 400 mil trabalhadores. Em 1960, realizou-se o III Congresso Sindical Nacional, base para a formação do Comando Geral dos Trabalhadores (CGT), em 1962. Esse grupo se opunha à Confederação Nacional dos Trabalhadores na Indústria (CNTI), comandado por Ari Campista. Nesse período destaca-se o esforço de Goulart de aproximar o PTB ao sindicalismo, como presidente do partido e, em seguida, como Ministro do Trabalho. Essa central não foi reconhecida pelo Ministério do

\footnotetext{
${ }^{93}$ Sobre este evento, ver Costa (1995).
} 
Trabalho e dois anos depois foi desarticulada pelo golpe militar. Nesse contexto, o evento de maior envergadura do movimento operário foi a reedição das greves anteriores no ano de 1963, quando novamente as mesmas categorias levaram 700 mil trabalhadores a paralisar a produção em São Paulo. ${ }^{94}$ Pelo que foi exposto até aqui, pode-se afirmar que as três fundações da CGT, como Central, Confederação e Comando, nos anos 20, 40 e 60 sintetizam a história das tentativas de organização de centrais sindicais no país, marcadas pela constante perseguição aos comunistas do $\operatorname{PCB}^{95}$ (Santana, 2001).

A partir dos anos 50, os protestos sociais no campo também adquiriram um peso significativo no Brasil. Em 1954, já havia sido criada a União dos Trabalhadores Agrícolas do Brasil (UTAB) e a $1^{\text {a }}$ Liga Camponesa, no Engenho Galiléa, na cidade de Vitória de Santo Antão, em Pernambuco. Sob o comando de Francisco Julião, essa experiência remonta às Ligas Camponesas da década de 1930 fundadas pelo PCB. Também nesse período surgiram sindicatos de trabalhadores rurais dirigidos por esse partido e em 1963 foi criada a Contag.

Em 1964, um comício pelas reformas de base na Central do Brasil, no Rio de Janeiro, atraiu 200.000 pessoas. Em 31 de março de 1964, a ditadura militar instaurou um longo período de mais de vinte anos de perseguição, proibição e repressão aos movimentos operário, popular e camponês. O que não impediu que em 1967 surgisse o Movimento Intersindical anti-Arrocho (MIA) e, em 1968, fossem convocadas as primeiras greves do período militar, na Cobrasma de Osasco-SP e Contagem-MG. Depois de dez anos sem registros de atividades grevistas no país ${ }^{96}$, essas voltaram com peso a partir de 1978, com a greve da Scania. Resultado da organização interna dos trabalhadores, sob a liderança de Gilson Menezes, diretor sindical de base, no dia seguinte ao início da paralisação o Sindicato dos Metalúrgicos de São Bernardo do Campo e Diadema, cujo presidente nesse momento era Luis Inácio Lula da Silva, foi avisado e assumiu o controle do movimento.

Com base nas questões apresentadas nessa breve síntese, é necessário fazer algumas considerações. Por conta das características populacionais e econômicas brasileiras, a convivência de movimentos significativos no campo e na cidade constitui um elemento imprescindível para interpretar o caráter dos protestos sociais no país. Essa tendência permanece atualmente, já que há quase trinta anos a rebelião vem sendo protagonizada, de um

\footnotetext{
${ }^{94}$ Para mais detalhes sobre as greves de 1953, 1957 e 1963, ver L. Rodrigues (1981).

${ }^{95} \mathrm{Em}$ 1962, em decorrência de divergências diante do conflito sino-soviético, ocorreu uma divisão nesse partido. O bloco pró-China criou o Partido Comunista do Brasil $(\mathrm{PCdoB})$ e o grupo favorável à União Soviética fundou o Partido Comunista Brasileiro (PCB).

${ }^{96}$ Vale lembrar que a edição do Ato Institucional 5 (AI-5), em 1968, proibiu o direito de greve.
} 
lado, por sindicatos e organizações sociais urbanas, e do outro, pelo sindicalismo rural e organizações camponesas. Após décadas de projetos abortados por governos autoritários, em 1983 foi fundado o PT, em 1984 foi criada a CUT, e em 1985 surgiu o Movimento dos Trabalhadores Rurais Sem-Terra (MST). Ainda que tenha havido rupturas nesse processo, pode-se dizer que a formação desse trio sintetizou um longo processo de construção de uma força popular partidária, operária e camponesa no campo da esquerda, que vinha se desenhando ao longo do século pelas tentativas de consolidação das CGTs, do PCB e das Ligas Camponesas.

É importante para a análise citar alguns indicadores que atestam a importância dos protestos sociais camponeses no Brasil na atualidade. Os índices de sindicalização na zona rural são proporcionalmente maiores que na zona urbana e representa uma fatia importante do sindicalismo brasileiro. Além disso, o MST, que representa trabalhadores camponeses semterra e assentados, é a maior organização social do país e uma das maiores do mundo, com mais de um milhão de associados atuantes em todas as unidades federativas. A Contag, maior entidade sindical rural da atualidade, tem 27 federações e cerca de quatro mil sindicatos afiliados em uma base de 20 milhões de trabalhadores. ${ }^{97}$ Se contamos ainda a ação de outras organizações camponesas e a Pastoral da Terra, têm-se um quadro completo da relevância desse tipo de luta no Brasil.

Ao contrário, no caso argentino os conflitos de trabalhadores no campo são historicamente menos representativos. Nesse país, o traço mais característico da rebelião é o seu caráter callejero $^{98}$, ou seja, sua tradição de manifestação de rua, por meio de diversas formas de luta como marchas, passeatas, bloqueio de ruas, piquetes, escrachos, motins, etc. Essa forma de luta também está presente na história do Brasil, mas o que torna particular a experiência da Argentina é a maior recorrência de eventos de grande repercussão, protagonizados principalmente pelo movimento operário e sindical com ampla mobilização de massa que assumem um caráter insurrecional (Semana Roja de 1909, Semana Trágica de 1919, Greve Geral de 1936, Movimento de 17 de outubro de 1945, Rosariazo e Cordobazo ${ }^{99}$

\footnotetext{
${ }^{97}$ www.contag.org.br. Acesso em 26/06/2009.

${ }^{98}$ O termo em espanhol poderia ser traduzido como "rueiro", mas é aplicado em um sentido inexistente no português brasileiro, para ressaltar a presença massiva da população nas ruas. No Brasil, o termo "rueiro" é um adjetivo aplicado apenas ao primeiro sentido da palavra callejero ou callejeador, como aquele que gosta de andar na rua, ou ainda no sentido de "arruador" ou "arruaceiro", que significa vadio, vagabundo, ou aquele que faz bagunça e depreda a cidade.

${ }^{99} \mathrm{Na}$ Argentina, é comum designar um evento utilizando o superlativo "azo" a fim de destacar a magnitude de sua repercussão.
} 
de 1969, movimento grevista de 1975, insurreição espontânea de 2001, entre outros). Mesmo na Patagônia Rebelde, em um conflito de trabalhadores camponeses na província de Santa Cruz realizado em 1920, o sindicalismo se destacou como o principal organizador do movimento.

As ditaduras militares implantadas na América Latina no pós-guerra tiveram um claro objetivo de conter a expansão do movimento operário e popular, de caráter nacionalista ou socialista, em um contexto de acirramento da luta de classes a nível mundial. Tanto na Argentina como no Brasil esses regimes produziram um significativo efeito desarticulador sobre a classe trabalhadora. No caso brasileiro, a ditadura iniciada em 1964 estancou a ascensão do movimento sindical, que desde a década de 1950 vinha crescendo paralelamente à industrialização e urbanização do país, embora esse mesmo sindicalismo de massas não tenha construído uma força suficiente para resistir à implantação do regime (Toledo, 2004). Para se ter uma idéia, se no período de 1945-1964 houve uma média anual de 43 greves, entre 1965 e 1968 esse número caiu para 13, e entre 1969 e 1977 não foi registrada uma só paralisação no país, já que uma das primeiras medidas do governo ditatorial foi a proibição do direito de greve. O Projeto Brasil Nunca Mais destaca que os sindicalistas estavam entre os setores sociais mais atingidos pelo sistema repressivo (Arquidiocese, 1985). A Comissão de Familiares dos Mortos e Desaparecidos registrou um total de 383 mortos e desaparecidos no país. ${ }^{100}$

A partir de 1968, com a edição do AI-5, o Brasil viveu os "anos de chumbo" da ditadura militar, que intensificou a escalada de violência e repressão ao movimento camponês, operário e popular. Os sindicatos brasileiros, relativamente sob controle, passavam por um intenso processo de deposição de diretorias eleitas e intervenções. Não foi casual que as lideranças comunistas tenham sido as principais vítimas de desaparecimentos no país, dada sua íntima relação com o movimento sindical do período. Ademais, o governo aplicava os dispositivos mais autoritários previstos na CLT, tais como o enquadramento sindical prévio, exigências acerca da utilização dos recursos, o atestado negativo de ideologia, e o controle ministerial e ingerência dos mais variados aspectos organizativos das entidades (eleições, estatuto, composição da diretoria, etc.).

Essa situação foi predominante até o final dos anos 1970, quando os militantes sindicais contrários às diretorias interventoras começaram a organizar um movimento de oposição

\footnotetext{
${ }^{100}$ www.desaparecidospoliticos.org.br.
} 
sindical em várias regiões do país. $\mathrm{O}$ auge desse processo foi o desencadeamento das greves no ABC a partir de 1978, que marcou o início do "período áureo" do sindicalismo brasileiro. Entre 1978 e 1984 foi registrada uma média de 259 greves anuais no país, e logo após o fim da ditadura, essa cifra atingiu o recorde de 2.203 eventos, entre 1985 e 1990 (Elias Jr., Gebrim, Noronha, 1998, p. 7. Ver Tabela 11). Em 1988, o processo constituinte anulou vários aspectos do "modelo de gestão e controle governamental", que abandonou seu caráter "ditatorial" para assumir feições mais "democráticas" (Boito Jr., 1991b), no momento em que a recém criada CUT se consolidava como uma central de massa por protagonizar a cena sindical no país.

A repressão pela qual passou a Argentina em um período muito mais curto (1976-1983) assumiu a cifra de um genocídio calculado em 30.000 desaparecidos políticos. Segundo o relatório Nunca Más, da Comisión Nacional sobre la Desaparición de Personas (Conadep) do total de cerca de 8.960 presos desaparecidos registrados, mais da metade era composta por trabalhadores, que foram detidos principalmente por exercerem atividade político-sindical (Conadep, 1985). ${ }^{101} \mathrm{O}$ número de greves gerais, que nos 21 anos anteriores (1955-1976) havia totalizado 41 eventos (Santella, 2008), caiu para cinco durante a ditadura militar (Carrera, $2007 \mathrm{a}^{102}$, ver Tabela 14).

Entre o fim da década de 1960 e a primeira metade da década de 1970, a Argentina viveu um de seus períodos de maior atividade sindical, com intensas mobilizações de massa e movimentos grevistas nas principais cidades do país. O marco desse ciclo foi o Cordobazzo, a histórica insurreição de maio de 1969 que, contando com uma aliança entre os estudantes e o movimento operário, foi um dos motivos do debilitamento da ditadura de Juan Carlos Onganía (1966-1970). Esse movimento (que se estendeu para outras regiões do país, a exemplo de Rosario), é explicado por diversos autores pela forte organização no local de trabalho existente no país naquele momento. O ponto culminante desse ciclo, no entanto, foi o Devotazo, um movimento armado da guerrilha que culminou com a liberação dos presos políticos em 25 de maio de $1973 .{ }^{103}$

\footnotetext{
${ }^{101}$ Além de 21\% de estudantes, o relatório especifica 30.2\% de "operários", $17.9 \%$ de "empregados", 10.7 de "profissionais" liberais, 5.5\% de docentes, o que totalizaria 58.8\% de trabalhadores (p. 480). Se consideramos outros membros da classe trabalhadora e as vítimas familiares desse segmento, essa cifra é ainda maior.

${ }^{102}$ Para o período de 1979 a 2002, utilizarei os dados de greves gerais de Carrera (2007a), por se tratar de um balanço mais completo, já que Santella (2008) não cita todos os eventos desse tipo ocorridos durante o período militar.

${ }^{103}$ Para uma análise desse período, ver Marín (2003).
} 
Em resumo, pode-se dizer que enquanto a ditadura militar na Argentina teve a finalidade de golpear um movimento operário que já possuía um alto grau de organização para que este não crescesse ainda mais, no Brasil o regime ditatorial cumpriu o objetivo de retardar a explosão das lutas operárias que começavam a tomar proporções de massa. Com o fim das ditaduras militares, o sindicalismo no Brasil e na Argentina ressurge com grande capacidade de organização e mobilização.

Na década de 1980, a CUT monopolizou as lutas sindicais no Brasil como única central de peso. A outra central em atividade era a Confederação Geral dos Trabalhadores (CGT), criada em 1986 por sindicalistas que não concordavam com a fundação daquela entidade. $\mathrm{Na}$ Argentina, após o fim da ditadura militar o movimento sindical viveu um período de intensas atividades grevistas. O governo de Raúl Alfonsín (1983-1989), da Unión Cívica Radical (UCR) se caracterizava pela hiperinflação. A oposição da CGT à política desse governo levou a central a convocar 13 greves gerais em cerca de cinco anos e meio. Ademais, entre 1984 e 1989, foram realizadas 2.741 greves. A partir do que foi exposto até aqui, veremos a seguir como os elementos destacados influenciaram a formação das principais tradições de luta dos países analisados.

\subsection{Cultura, ideologia e tradições de luta}

Desde o início do século XX, os protestos sociais na Argentina se concentram na zona urbana, o que não excluiu a eclosão esporádica de algumas lutas no meio rural. No Brasil, a convivência de mobilizações no campo e na cidade tem sido uma constante em sua história. De modo geral, apareceram isoladas, mas também se pode verificar, em alguns períodos, a constituição de alianças entre operários e camponeses tanto nas práticas como nas estratégicas de luta do movimento operário organizado politicamente. Essas são as características centrais da rebelião de cada formação.

Uma leitura que interpretasse os principais traços dos protestos sociais nessas formações como resultado apenas da estrutura econômica poderia ocultar questões relevantes sobre o tema estudado. Por isso destaquei alguns elementos políticos e ideológicos que, em sua íntima relação com a base material, contribuem para a explicação do fenômeno. Em relação ao tema tratado, destaquei a estrutura sindical e a relação entre os sindicatos, o Estado e o poder político e econômico. Também fiz uma breve descrição da fisionomia do movimento operário e sindical brasileiro e argentino. Este item trata dos efeitos duradouros desses elementos para 
a formação das tradições de luta da classe operária de ambos os países. Ao longo do texto, fiz referência a alguns desses fatores. ${ }^{104}$ É importante ter em conta que uma análise mais ampla sobre essas questões exige um exame histórico mais detalhado em relação ao que apresentei. No entanto, para o objetivo proposto (fazer apontamentos de algumas tendências gerais), é possível elaborar algumas formulações.

Os princípios norteadores da história do Brasil e da Argentina são muito distintos. Um primeiro fator a ser destacado é a frágil presença, no caso brasileiro, de mobilizações populares em seus processos políticos chaves. No caso argentino, esse elemento esteve comparativamente mais presente e forma parte da tradição de luta do país. A emancipação política do Brasil foi declarada pela metrópole. O grito de "Independência ou morte" dado por dom Pedro I, a despeito do mito que o cerca, não foi acompanhado de uma reação armada de Portugal contra o filho "rebelde". Ao contrário, a família real se encarregou de manter a dinastia no poder, dando continuidade ao regime monárquico, desde então batizado de "Império do Brasil". A independência argentina, declarada em 1816, instaurou a República, aboliu a escravidão e foi seguida de uma guerra violenta com a Espanha. O Brasil, apesar de independente desde 1822, seguiu com o sistema escravocrata até 1888 e proclamou a República apenas em 1889, cerca de três quartos de século mais tarde. A concessão de liberdade aos escravos, com a chamada "Lei Áurea", foi apresentada como uma dádiva de uma princesa bondosa, mas a população negra não foi incorporada ao trabalho assalariado em expansão. A instauração do regime republicano ocorreu após um desfile na praça "enquanto o povo assistia bestializado". ${ }^{105}$

Em 1930, o golpe que levou Getúlio Vargas ao poder foi feito sob o lema "Faça a Revolução antes que o povo a faça". ${ }^{106}$ Quinze anos depois, o presidente abandonou o Governo por meio de um acordo e logo após assumiu o general Eurico Gaspar Dutra. Em 1951, Vargas foi eleito pelo voto popular. Três anos depois, o presidente cometeu o suicídio, deixando uma carta testamento em que revelou as pressões políticas que sofria naquele

\footnotetext{
${ }^{104}$ No livro organizado por Grimson (2007) se encontra uma série de estudos comparativos entre o Brasil e a Argentina que têm como objetivo refletir sobre as matrizes da "cultura política" de ambos. Apesar de chegar a resultados semelhantes, o ponto de partida dos autores dessa coletânea é a política institucional. Sobre o tema, ver, principalmente, o texto de Pousadela (2007). Ao contrário, minha proposta baseada na categoria de "tradições de luta" se fundamenta no estudo de sua relação com a estrutura social no processo de formação da ideologia de protesto popular, como parte do movimento de constituição da classe e da luta de classes.

${ }^{105}$ A frase exata, escrita pelo jornalista e político abolicionista Aristides da Silveira Lobo no Diário Popular de 18 de novembro de 1889, foi: "O povo assistiu àquilo bestializado, atônito, surpreso, sem conhecer o que significava. Muitos acreditaram seriamente estar vendo uma parada [militar]".

${ }^{106}$ Ainda que esse elemento esteja presente na história argentina, é possível afirmar, no contexto comparativo, que essa noção possui um caráter mais estrutural no caso brasileiro.
} 
momento. Juan Domingo Perón subiu ao poder após uma intensa mobilização operária, sindical e popular por sua liberdade na Praça de Maio, no dia 17 de outubro de 1945. Essa data foi consagrada como o "Dia da Lealdade" e é considerada o dia da fundação do peronismo. Ao ascender no poder no ano seguinte, o general governou a Argentina por cerca nove anos, sendo deposto por um golpe com bombardeio na Praça de Maio e sua imediata fuga do país. Após dezoito anos no exílio, voltou à Argentina para se tornar presidente, em 1973, mas morreu naturalmente menos de um ano depois. Durante sua ausência do país, o PJ foi proscrito, mas a CGT e membros do partido organizaram a resistência sob a bandeira da volta do ex-presidente, que incluiu movimentos armados e diversas mortes.

Nessa época, o Brasil já vivia a ditadura militar (1964-1985), que levava a cabo, no plano econômico, um projeto nacional de industrialização e desenvolvimento do capitalismo, com investimentos estatais de infra-estrutura que facilitaram a instalação de empresas estrangeiras no país. O chamado "milagre econômico" estendeu o emprego assalariado formal, aumentou a dependência e dívida externa, além de ter aprofundado as desigualdades internas. Esse processo se deu de maneira desigual e combinada, já que foi liderado pelo eixo Rio-São Paulo em detrimento das outras regiões que, como o Nordeste, cumpriram a função de disponibilizar sua superpopulação relativa para as necessidades de expansão capitalista daquele momento. A saída do regime foi anunciada como um "processo lento e gradual", com uma diferença de quase dez anos entre a anistia, o processo constituinte e as eleições presidenciais.

De 1966 a 1970 a Argentina viveu a ditadura de Onganía, que subiu ao poder após um golpe de estado que, entre outros motivos, buscava conter determinadas medidas de seu antecessor, Arturo Umberto Illia, como a revogação da proscrição do peronismo. Durante seu mandato, Onganía buscou promover o propositivismo, na época defendido por sindicalistas como Augusto Vandor. Também suspendeu as greves e as convenções coletivas, cujos efeitos podem ser atestados pelos dados citados por Carrera (2007a), que corresponde ao período de menor atividade grevista entre os registrados pelo autor (ver Tabela 13). A ditadura militar de 1976 a 1983 foi caracterizada pelo início da implantação da plataforma neoliberal e da hegemonia do capital financeiro no país. Nesse período, a Argentina perdeu um conflito internacional para a Inglaterra (Guerra das Malvinas) e levou adiante uma política de extermínio de militantes do movimento operário e popular. Com o fim do regime, foram 
convocadas eleições gerais e assumiu Raúl Alfonsin, que no período em que governou conviveu com uma intensa atividade grevista e a convocação de 13 greves gerais.

Essa descrição não tem o objetivo de afirmar, de maneira dicotômica, que o povo brasileiro sempre esteve ausente nos processos políticos, em oposição ao argentino, sempre presente. Procurarei demonstrar, com essas considerações, apenas algumas referências que fazem esses países serem tão distintos em suas tradições de luta. Porém, pode-se afirmar que em termos comparativos, o elemento "insurrecional" é uma tendência mais marcante na Argentina do que no Brasil. Esse aspecto se traduz no caráter constante da sublevação popular em seus eventos políticos chaves. Vejamos como esses elementos aparecem na formação da classe trabalhadora brasileira e argentina.

Um aspecto que merece ser destacado, por ser constitutivo da formação da ideologia de protesto, é o grau de organização dos trabalhadores. O movimento operário argentino logrou se estabelecer "precocemente" com instituições duradouras e com forte poder de convocação e negociação no nível nacional, elementos menos estruturados historicamente no caso brasileiro. A formação da classe operária brasileira, além de mais tardia, foi marcada pela persistência do caráter autoritário na relação dos trabalhadores com o Estado e a classe capitalista, com um breve intervalo de governos populistas com uma feição mais democrática. Esse autoritarismo foi legitimado por governos que faziam uso de inúmeras medidas coercitivas à prática sindical, como o atestado de ideologia, a proibição do direito de greve, as intervenções nos sindicatos e a dissolução de centrais e entidades intersindicais. Em menor ou maior escala, esses elementos estiveram presentes no governo de Vargas (1930-1945), Dutra (1946-1951) e durante a ditadura militar (1964-1985), no caso dessa última, não casualmente instaurada no período de maior intensidade da industrialização do país.

Também se deve destacar o processo de constituição da cidadania vivido em cada país. Uma evidência desse aspecto pode ser encontrada nos indicadores sociais argentinos, historicamente superiores aos brasileiros. Até a década de 1970 a Argentina foi o país latinoamericano que mais se aproximou do modelo europeu de "Estado de Bem-Estar Social", por conta de seu nível de vida, acesso a direitos sociais e trabalhistas, e incorporação da ampla maioria dos trabalhadores ao mercado formal. Essa condição a tornou conhecida como a "Europa da América do Sul”. A partir da ditadura iniciada em 1976, e especialmente durante os anos 1990, o país passou por um processo acelerado de pauperização, cuja maior evidência foi o crescimento acelerado de sua superpopulação relativa. Isso explica o sentimento de 
“fracasso da nação" instalado desde então no país. No Brasil, que não passou por um processo semelhante, prevalece a lógica da "cidadania regulada" (Santos, 1979), dual e restrita, em que parte significativa da população se enquadra na categoria de "pré-cidadãos", inseridos em um sistema legislativo que reproduz e "sacramenta as desigualdades" (Telles, 1994). A "pobreza latente" herdada da escravidão evidencia as históricas taxas de população sobrante existente no país e segue sendo a característica que melhor define sua estrutura social e econômica. ${ }^{107}$

Em suma, o Brasil não chegou a concretizar um projeto nacional integrador que garantisse um amplo acesso à "cidadania", tal como se deu na Argentina especialmente durante o governo de Perón, entre 1946 e 1955. Não é casual que o peronismo seja reconhecido até os dias de hoje pelo sindicalismo argentino como uma experiência histórica de "dignificação" da classe trabalhadora. Como expressa a Unión Obrera Metalúrgica (UOM) em seu Congresso Nacional de Delegados de 1995, “O Presidente Perón logrou para o povo argentino a maravilhosa experiência de viver uma democracia com sentido social, e esta dignificação está incorporada definitivamente ao patrimônio social dos trabalhadores argentinos". 108

No entanto, vale a pena destacar o contexto em que o peronismo foi implantado em comparação com o varguismo. Seguindo Murmis e Portantiero (2004), a legislação trabalhista brasileira foi outorgada em um momento em que o movimento operário não possuía uma capacidade de pressão significativa como o sindicalismo argentino, estabelecendo-se a partir de um caráter essencialmente antidemocrático e cooptativo. Sua promulgação conservou os pilares da política brasileira, constituídos a partir das noções de "pacto de elites" e "revolução para evitar a revolução", empregadas aqui no sentido do conceito de "revolução passiva" de Gramsci (1976).

Valem ainda algumas palavras sobre as diferenças relacionadas à integração nacional nos dois países. Como foi explicitado neste capítulo, o Brasil possui uma dispersão demográfica muito mais acentuada que a Argentina, marcada pelo maior número, absoluto e relativo, de grandes regiões metropolitanas. Além disso, a história brasileira é caracterizada pela diversidade de protagonismo de suas cidades. Enquanto na Argentina, Buenos Aires é o

\footnotetext{
107 Os últimos aspectos destacados (grau de organização do movimento operário e sindical, processo de construção da cidadania, índice de superpopulação relativa e nível de pobreza latente) explicam consideravelmente porque o preço pago pela força de trabalho no Brasil é historicamente mais baixo do que na Argentina. Voltarei a este ponto durante a análise.

108 "Declaración de principios del Congreso Nacional de Delegados de la UOMRA". Congreso Nacional de la UOM. Solicitada de la UOM. Clarín, 18/12/1995, p. 48.
} 
maior e mais importante município do país, além de ter sido seu centro político, desde o fim da era colonial, em 1776, quando foi nomeada capital do Vice-Reino do Rio de La Plata, o Brasil teve diferentes centros políticos e econômicos ao longo dos anos. Esses elementos trouxeram diversas conseqüências simbólicas, que condicionaram a dinâmica de formação da ideologia dos protestos sociais. No Brasil, São Paulo é a cidade mais importante economicamente, mas a capital está a cerca de mil quilômetros, em Brasília, cuja construção foi concluída em 1960, no auge da industrialização do país. A capital anterior era o Rio de Janeiro, onde a família real se instalou logo após fugir da invasão napoleônica, no início do século XIX. Durante a colonização, Salvador foi o centro político durante quase três séculos. No entanto, a Conjuração Baiana foi deflagrada em um momento em que o centro econômico já havia se deslocado para o sudeste, e a Inconfidência Mineira se constituiu no mais importante movimento independentista do país. Tiradentes, o líder da revolução fracassada, foi decapitado em praça pública no centro de Vila Rica (atual Ouro Preto), localizada a quase 1.500 quilômetros da capital da colônia. Ao longo da história, as principais "lutas do povo brasileiro" (Chiavenato, 1988) se concentraram no campo, o que ainda está presente no país, dada a persistência de uma grande população rural que tem a posse da terra como principal referência de mobilização. A formação do movimento operário e sindical brasileiro se deu em São Paulo e no Rio de Janeiro, por terem sido as propulsoras da industrialização do país.

Os processos políticos chaves para a compreensão da história argentina se desenvolveram quase exclusivamente em Buenos Aires, e muitos momentos estão condensados em um único lugar: a Praça de Maio. Aí estava o Cabildo durante a colônia, e aí está até hoje a Casa Rosada. Nessa praça se viveu da proclamação da independência ao movimento de 17 de outubro de 1945, dos atos das principais greves gerais do país aos protestos das Madres de Plaza de Mayo. Nesse sentido, seu centro histórico é o palco onde se concentra a memória de séculos de luta. No Brasil, não existe uma praça com tamanha simbologia, que sintetize os principais momentos históricos do país. ${ }^{109}$

Feitas essas considerações sobre a política e a cultura brasileira e argentina, procurarei sintetizar a seguir as principais características das tradições de luta do movimento operário e sindical das duas formações. A prática sindical no Brasil possui uma maior tendência à fragmentação; e na Argentina, à centralização. No caso argentino, o enquadramento sindical se caracteriza pela constituição de sindicatos nacionais por ramo de atividade. Ademais,

\footnotetext{
${ }^{109}$ Em São Paulo, a Praça da Sé possui um forte significado para as lutas populares e operárias por ter sido o local por excelência de concentração das principais manifestações políticas e sindicais durante décadas.
} 
verifica-se nesse país a existência duradoura de uma única central sindical, a CGT, fundada em 1930. Essa central é legalizada e incorporada à estrutura sindical oficial, sendo constituída por sindicatos nacionais nos setores estratégicos. As entidades sindicais são reconhecidas como interlocutoras legítimas nas paritarias nacionales (as negociações coletivas centralizadas) e possuem um canal de diálogo freqüente com o Governo Federal. Esses elementos estão praticamente ausentes na história do sindicalismo brasileiro. $\mathrm{O}$ enquadramento sindical no país era previamente estabelecido por lei até a Constituição de 1988, e definido pela categoria sócio-profissional com base municipal. As centrais sindicais, proibidas pela CLT, tiveram experiências curtas e descontínuas até a formação da CUT, em 1984, passando a formar parte do aparelho jurídico-sindical apenas em 2008. A convenção coletiva nacional é uma prática pouco institucionalizada e não é comum que sindicalistas sejam recebidos pelo Ministro do Trabalho ou pelo Presidente, o que esteve presente em poucos momentos, como na atuação de João Goulart e, atualmente, no governo de Lula. Na Argentina, as organizações sindicais são historicamente reconhecidas como interlocutoras legítimas pelos empresários, que convivem com instituições como as negociações paritárias e as comissões internas de base. No Brasil, em relação a este último elemento, prevalece a individualização nas relações entre os trabalhadores e as empresas, e a cultura do arbítrio patronal e do autoritarismo nas relações trabalhistas, pois a organização no local de trabalho é vista como um "abuso" do poder sindical.

Em resumo, trata-se de dois diferentes modelos de relação da classe trabalhadora com o Estado e o poder político e econômico, que não advém apenas da estrutura social, da formação política e do conceito de unidade nacional de cada país. Encontra-se também entre os fatores explicativos dessa questão a herança do tipo de corporativismo estatal ("inclusivo" no caso argentino, "exclusivo" no caso brasileiro), de acordo com a proposta analítica de Stepan (1980). Ademais, vale ressaltar o peso histórico da população sobrante, mais acentuada na sociedade brasileira do que na argentina, que pode ser considerada a maior herança de quase quatro séculos de uso intensivo da força de trabalho escrava.

O sindicalismo brasileiro é, tradicionalmente, mais vertical e de minorias em relação ao argentino, mais horizontal e de massas. $\mathrm{O}$ aspecto mais visível dessa comparação está nas taxas de sindicalização, na ocorrência de greves gerais e no nível de organização no local de trabalho nos dois países. Na Argentina, o ativismo sindical de base é facilitado pelo reconhecimento legal dos delegados, que uma vez eleitos possuem estabilidade no emprego. É 
importante destacar também que essa é uma conquista das aspirações do próprio movimento operário a partir de sua tradição de luta no local de trabalho desde o início do século XX. Esse mecanismo constitui um dos principais incentivos à sindicalização e é um fator explicativo da alta adesão aos protestos sindicais no país. No Brasil, prevalecem ao longo da História os "sindicatos de carimbo" e os "sindicatos de porta-de-fábrica", sendo mais raro que os militantes sindicais possuam estabilidade para atuar no interior das empresas. Essa tendência possui alguns momentos de descontinuidade, como a partir dos anos 1980 com a formação da CUT, embora a própria central reconheça que passou por uma expressiva acomodação de seus sindicatos à estrutura sindical oficial, que se evidencia, entre outros fatores, pela reprodução de uma prática cupulista e distanciada da base.

Também é possível afirmar que os sindicatos no Brasil convivem historicamente com diversas correntes ideológicas, enquanto o argentino possui há mais de meio século uma ideologia que unifica a maior parte do movimento sindical. No campo político-partidário, o anarquismo e o socialismo foram os protagonistas do sindicalismo brasileiro até os anos 30 . No entanto, ao longo do século se constituíram correntes próximas ao liberalismo, ao trabalhismo nacional-populista, à social-democracia e a diversas correntes da esquerda marxista, entre as quais podemos destacar o social-cristianismo, o comunismo e o trotskysmo. A aliança entre partidos e centrais no Brasil é marcada pela descontinuidade, pois não se conformou nenhum laço histórico duradouro entre uma sigla partidária e uma entidade sindical nacional até a formação do PT e da CUT nos anos 1980, já que os vínculos entre os comunistas e as CGTs foram interrompidos em suas tentativas de constituição. Vale ressaltar ainda que a doutrina social da Igreja Católica é uma das bases ideológicas fundamentais do sindicalismo brasileiro desde os anos 1950, por meio da Ação Católica Operária (ACO), e da Pastoral Operária (PO), a partir dos anos 1970. Esse grupo se formou a partir da Teologia da Libertação, setor progressista da Igreja Católica que esteve vinculado ao surgimento das oposições sindicais e dos movimentos populares nesse período. ${ }^{110}$

\footnotetext{
${ }^{110}$ Entre os efeitos duradouros dessa corrente no meio sindical poderia-se destacar o recorrente apelo moral ao "patrão bom e justo", que não pensa apenas no lucro, mas também nos trabalhadores. Tal como explicita Löwy (2007, p. 429), a militância católica na esquerda, fundamentada na Teologia da Libertação, ao se apropriar do repertório conceitual do marxismo e conservar elementos do cristianismo, acaba por conformar um "anticapitalismo intransigente, com forte carga moral". Mas a origem desse elemento pode estar relacionada, de maneira mais ampla, à influência cristã na "concepção popular de mundo" predominante no Brasil. Ademais, cumpre notar que no interior da militância católica se destacaram também correntes revolucionárias, que ao longo da ditadura militar participaram inclusive do movimento guerrilheiro.
} 
$\mathrm{Na}$ Argentina, o sindicalismo também se fundou nas correntes socialista e anarquista, mas estas conviveram com um setor "sindicalista" que antes do advento do peronismo já apresentava um projeto político de conciliação de classes. ${ }^{111}$ Esse foi o principal aliado sindical de Perón, tendo conformado a base do vínculo perdurável da CGT com o PJ. A partir de então, os estilos de negociação e mobilização se desenvolveram no país em torno de diferentes estratégias que, pelo menos a partir da década de 60 , pode ser resumida aos setores "classista e combativo", "confrontacionista", "participacionista" e "propositivo"112 (Fernández, 2002), estruturais no mapa sindical do país a partir de então. No entanto, a diferença mais marcante em relação ao Brasil é que, mesmo existindo diferentes correntes internas no movimento sindical, o peronismo exerce uma função político-sindical integradora de projeto de sociedade que no caso brasileiro não encontra semelhante. Ainda que sua reivindicação seja feita a partir de diferentes matrizes, existe uma orientação ideológica amplamente majoritária no sindicalismo argentino que aponta para um projeto de desenvolvimento baseado na aliança entre capital e trabalho com mediação do Estado. Essa fórmula consagrou no setor majoritário do movimento sindical no país a figura do "empresário bem sucedido", com visão nacionalista, que difere do "patrão". Como explicitou um dirigente da UOM: "Há diferença entre o que é um empresário e o que é um patrão..." (E36). ${ }^{113} \mathrm{Na}$ visão de vários sindicalistas argentinos entrevistados, o "patrão" é um tipo "aventureiro", que visa o lucro rápido e fácil, enquanto o "empresário" é o tipo empreendedor que investe a longo prazo e obtém lucros para, a partir daí, ter condições de conceder benefícios e aumentos salariais aos trabalhadores nas negociações. ${ }^{114}$ É muito comum entre os dirigentes cegetistas a visão de que os industriais brasileiros possuem o perfil. Como expressou um diretor da central ao criticar a atitude empresária argentina nos anos 1990: "gostaria de ser dirigente operário de empresários como os brasileiros". 115

\footnotetext{
${ }^{111}$ Embora com menor peso, essa corrente também esteve presente no Brasil do período pré-1930.

${ }^{112}$ O termo originalmente empregado por Fernández (2002) é "negociador" (ou vandorista, em referência ao tipo de sindicalismo defendido de Augusto Vandor). Porém, considero-o inapropriado, pois a negociação, assim como a mobilização, não pode ser considerada uma matriz da ideologia político-sindical, mas um elemento constitutivo da prática sindical. As categorias que empregarei buscam estabelecer uma correspondência com os diferentes estilos e prioridades dadas à negociação/mobilização pelos setores sindicais analisados.

${ }^{113}$ Referindo-se ao período menemista, o entrevistado acrescentou: "nosso patrões na Argentina foram cúmplices do desastre gerado pela abertura da importação, porque não era tanto que nos metiam produtos de fora, mas que esses patrões iam buscar" (E36).

${ }_{114}$ É comum no meio operário e sindical argentino a frase "si al patrón le va bien, a mi me va bién" ("se o patrão vai bem, eu também vou"). Escutei esse jargão várias vezes nas conversas e entrevistas com os dirigentes.

${ }^{115}$ Clarín, 19/06/1995, p. 4.
} 
A diferença histórica entre os dois países é marcada ainda por experiências muito particulares de populismo e personalismo carismático. No caso brasileiro, a continuidade do culto à figura de Getúlio foi mais frouxa, o que não pode ocultar a herança deixada pelo varguismo, sintetizada nas amarras criadas pelo sindicalismo de Estado, como estrutura jurídico-política e ideologia populista cristalizada no campo sindical (Boito Jr., 1991a). Criada a partir de um corporativismo de tipo exclusivo, o sindicalismo oficial brasileiro funciona como amortecedor da luta de classes e reprodutor de relações autoritárias entre o movimento operário e o poder político e econômico no país. Esse mecanismo institucional está longe de se constituir apenas como uma relação entre Estado-vitimário e Sindicatosvítimas. O corporativismo edificado pelo varguismo possui efeitos duradouros e se reproduz ideologicamente em amplos setores sindicais. Não é casual que parte expressiva do sindicalismo brasileiro defenda a investidura, a unicidade e o imposto sindical, acomodandose aos privilégios que esse sistema baseado no monopólio lhes concede, sem a necessidade de buscar afiliados e representar os trabalhadores no local de trabalho. Como veremos no terceiro capítulo, a maioria das centrais brasileiras e o conjunto das entidades patronais defendem abertamente o sindicato corporativo oficial. A CUT, que nasceu sob a bandeira de combate à estrutura, mas decidiu "atuar por dentro", reconhece a acomodação em seus documentos congressuais, apesar de ter aprovado a legalização das centrais sindicais em 2008, a partir da qual as entidades nacionais passaram a se beneficiar de uma fatia importante da tão criticada arrecadação compulsória.

$\mathrm{Na}$ Argentina, o sindicalismo vem sendo o principal protagonista da rebelião desde o início do século XX. No Brasil, esse papel é historicamente dividido com o movimento camponês. A Argentina convive com uma forte presença de greves gerais com relativa continuidade há mais de cem anos. O Brasil apresenta um histórico de mobilizações sindicais mais dispersas e descontínuas, que assumiu proporções de massa durante a década de 1950 e início dos anos 1960, e a partir do final dos anos 1970. Com a fundação da CUT, essa tendência se alterou relativamente. No entanto, com a adaptação cutista ao sindicalismo de Estado e a recente fragmentação das centrais ${ }^{116}$, o movimento sindical brasileiro acentuou sua tradição de luta pulverizada e com baixo poder de convocação nacional, marcada ainda pela acomodação dos dirigentes, que reproduzem uma prática cupulista e distanciada da base.

\footnotetext{
${ }^{116}$ Explicarei melhor esse evento no terceiro capítulo.
} 
A partir das considerações feitas nesse capítulo, é possível destacar ainda outro ponto fundamental. Ao analisar a evolução do capitalismo nos dois países, observa-se que a Argentina teve um desenvolvimento "precoce" em relação ao brasileiro, que foi mais "tardio". No entanto, enquanto a Argentina esgotou sua capacidade de expansão capitalista em profundidade e extensão, o Brasil ainda possui uma reserva de frentes de acumulação do capital, ainda que limitadas por sua condição periférica. Ademais, é notório seu maior nível de desenvolvimento capitalista a partir dos anos 1970. Essas diferenças, em termos comparativos, expõem um paradoxo que será retomado ao longo do trabalho: o Brasil desenvolveu o capitalismo mais intensamente, embora de modo desigual e combinado, e com um movimento operário tradicionalmente mais débil; a Argentina não alcançou o mesmo patamar de desenvolvimento, ainda que possua um melhor nível médio de vida no interior da classe trabalhadora, e um movimento sindical historicamente mais organizado, e com maior poder de convocação e mobilização. 


\section{CAPÍTULO 3 - SINDICALISMO E DESEMPREGADOS NO BRASIL: AS AÇÕES E REPRESENTAÇÕES DA CUT E DA FORÇA SINDICAL}

O objetivo deste capítulo é refletir sobre a relação entre o movimento operário organizado sindicalmente e os trabalhadores desempregados no Brasil. Será considerado o período de 1990 a 2002, mas retrocederei brevemente à década de 80 e avançarei nos anos 2000 para observar as continuidades e descontinuidades desse vínculo. Esse procedimento será fundamental para buscar refletir sobre uma das principais questões colocadas por este trabalho: por que não houve no período estudado um movimento de desempregados no país com peso político, massivo e nacional? Serão consideradas na análise as duas principais centrais brasileiras: a Central Única dos Trabalhadores (CUT) e a Força Sindical (FS). Tomarei como eixos fundamentais da análise as ações diante dos desempregados e as representações sobre a mobilização desse segmento. O quadro explicativo também levará em conta o posicionamento a respeito das causas do desemprego; as estratégias das entidades de base diante das demissões; e as propostas para a geração de empregos e de políticas de assistência aos desempregados.

O material de pesquisa utilizado foi composto por documentos de fonte primária (resoluções de congresso e plenárias, boletins, jornais e revistas) e entrevistas semiestruturadas individuais, o que possibilitou analisar as contradições entre o discurso e a prática das organizações partindo do próprio universo de suas ações e representações. No caso da CUT, analisei as resoluções do $3^{\circ}$ ao $7^{\circ}$ Congresso Nacional (realizados, respectivamente, em 1988, 1991, 1994, 1997 e 2000) e da $3^{\text {a à }} 10^{a}$ Plenária Nacional (ocorridas em 1989, 1990, 1992, 1993, 1995, 1996, 1999 e 2002). A leitura desses documentos permitiu uma primeira aproximação à política cutista sobre o tema. Ademais, foi consultado o principal periódico da central, o Informacut, única publicação nacional regular do período estudado. A partir de sua leitura aprofundei a análise cronológica necessária para a descrição dos eventos. As resoluções de congressos e plenárias foram obtidas em versão digital no sítio da central. ${ }^{117}$ Os demais documentos foram consultados no acervo do Centro de Documentação e Memória Sindical (Cedoc), na sede nacional da CUT, em São Paulo, que conta com um amplo acervo das principais publicações da entidade desde a sua fundação.

${ }^{117}$ http://www.cut.org.br. 
No caso da Força Sindical, o acesso aos documentos foi mais difícil. A central não disponibiliza em seu sítio as resoluções de congressos. Em sua página, encontram-se somente os números mais atuais da Revista da Força Sindical e do Jornal da Força publicados a partir de 2002. ${ }^{118}$ Ademais, o departamento de imprensa, localizado na sede da central, em São Paulo, não possui um acervo sistematizado de seus documentos e periódicos, ainda que a consulta ao mesmo tenha possibilitado o acesso a alguns exemplares das publicações supracitadas. Completei a pesquisa no Centro de Memória Sindical (CMS) ${ }^{119}$, entidade criada na década de 1980 que funciona atualmente no Sindicato dos Têxteis de São Paulo ${ }^{120}$, filiado à FS. Aí pude consultar as resoluções de alguns congressos e alguns números das revistas, jornais e boletins publicados pela central. Visitei também a base do Arquivo Edgard Leunroth, da Universidade Estadual de Campinas (AEL/Unicamp), mas não foram localizados novos documentos.

Em seguida, realizei entrevistas semi-estruturadas com 24 dirigentes sindicais, tendo sido 17 da CUT e sete da FS. Entrevistei membros da executiva nacional atuantes desde a década de 90 em ambas centrais, bem como de sindicatos da grande São Paulo, federações paulistas e confederações nacionais de alguns dos setores mais afetados pelo desemprego no período estudado (metalúrgico, bancário, construção civil, comerciário, têxtil e químico). O roteiro foi construído com base nas questões do quadro explicativo apresentado no início deste capítulo. A duração média dos depoimentos foi de uma hora e após a transcrição, foi feita a análise qualitativa das respostas a partir das temáticas assinaladas. As entrevistas foram realizadas em 2009, em um contexto no qual ainda se sentia os efeitos das demissões provocadas pela crise capitalista desencadeada no final do ano anterior, o que fez com que muitos entrevistados se referissem também a essa conjuntura. Entre os entrevistados da CUT, contemplei dois diretores atuais e dois ex-membros da Executiva Nacional, um dirigente da Confederação Nacional dos Trabalhadores no Comércio e Serviços (Contracs), um da Confederação Nacional dos Trabalhadores do Ramo Financeiro (Contraf), dois da Confederação Nacional dos Metalúrgicos (CNM), dois da Federação Estadual dos Metalúrgicos de São Paulo (FEM/SP), um da Confederação Nacional dos Trabalhadores nas Indústrias da Construção e da Madeira (Conticom) e dois do Sindicato dos Químicos e

\footnotetext{
${ }^{118} \mathrm{http}: / /$ www.fsindical.org.br.

${ }^{119}$ As referências incompletas de artigos consultados neste arquivo serão citados nas notas de rodapé com a sigla CMS, s/r (sem referência).

${ }^{120}$ Sindicato dos Trabalhadores na Indústria de Fiação e Tecelagem de São Paulo, Itapevi, Cotia, Caieiras e Franco da Rocha (Sintratextil).
} 
Plásticos de São Paulo e Região (SQSP), sendo um deles também da Confederação Nacional do ramo Químico (CNQ), dois do Sindicato dos Metalúrgicos do ABC, um do Sindicato dos Bancários e Financiários de São Paulo, Osasco e Região (SBSP) e um assessor da Escola Sindical São Paulo (ESSP). Entre os entrevistados da Força Sindical, todos participam da Direção Nacional, sendo suas entidades de base as seguintes: um do Sindicato dos Metalúrgicos de Osasco e Região, uma do Sindicato das Costureiras de São Paulo e Osasco, e da Confederação Nacional dos Trabalhadores nas Indústrias do Setor Têxtil, Vestuário, Couro e Calçados (Conaccovest), três do Sindicato dos Metalúrgicos de São Paulo e Mogi das Cruzes (SMSP), um do Sindicato dos Trabalhadores nas Indústrias da Construção Civil de São Paulo (Sintracon) e um do Sindicato dos Trabalhadores em Empresas de Telecomunicações no Estado de São Paulo (Sintetel).

Didivi o capítulo em cinco itens. 3.1) No primeiro, farei um breve balanço crítico da bibliografia sobre sindicalismo no Brasil, procurando traçar as principais discussões teóricas pertinentes ao tema analisado. 3.2) No segundo, farei algumas referências sobre a relação entre o movimento sindical e os desempregados nos anos 1980. 3.3) O terceiro item se dedicará à apresentação da descrição e da análise. Nessa parte será feito um exercício de conceituação e periodização sobre as relações das centrais sindicais com os desempregados. 3.4) No quarto item apresentarei uma análise das principais representações feitas pelos quadros de dirigentes de ambas as centrais. 3.5) No quinto, farei uma breve referência à relação do sindicalismo brasileiro com os desempregados nos anos 2000. Por último, realizarei um balanço das questões levantadas ao longo do capítulo e elaborarei uma proposta de análise da construção da unidade e fratura entre o ativo e a reserva no Brasil, tomando como referência as relações entre o movimento sindical e os desempregados.

\subsection{A análise do sindicalismo diante do desemprego no Brasil}

A bibliografia que trata da relação entre o movimento sindical e os desempregados no Brasil é escassa. O levantamento bibliográfico realizado para esta pesquisa me possibilitou ter contato com análises afins que exploram esse vínculo de maneira tangencial. Há vários estudos sobre a reação de sindicatos específicos diante das demissões (Barreto, 2004; A. C. Cardoso, 1998; Souza, 2005b) ou de políticas específicas para enfrentá-las, tal como se evidenciou no debate a respeito das Câmaras Setoriais no início dos anos 90 (Arbix, 1996, 
Galvão, 1996; Arbix, Rodrigues, 1996). Também encontrei alguns trabalhos sobre as propostas sindicais diante do desemprego e os impactos da eliminação de postos de trabalho para o sindicalismo (I. Rodrigues, 1998, Pochmann, 1999b). Alguns enquadram a problemática no contexto mais amplo da reestruturação produtiva (Antunes, 1995), outros a relacionam com a implantação do neoliberalismo (Boito Jr., 1999). A partir da década de 2000 surgem diversos estudos sociológicos sobre os desempregados, refletindo sobre a vivência cotidiana do desemprego, a trajetória de trabalho dos indivíduos e sua organização para a luta (Jardim, 2004; Guimarães, 2004; Mangueira, 2007; M. Silva, 2009). No entanto, a relação entre esse segmento da superpopulação relativa e o movimento sindical ainda não foi suficientemente explorada pelos estudiosos brasileiros. Este capítulo busca contribuir para o preenchimento dessa lacuna. Comecemos pela inserção do tema no debate sindical.

O primeiro procedimento que adotei para estudar os vínculos entre o movimento sindical e os desempregados foi relacionar os protestos sindicais com as taxas de desemprego e subemprego (ver Tabela 11). Utilizei como referência a evolução das atividades grevistas, mesmo ciente de sua insuficiência para mensurar a capacidade de mobilização sindical (ver Tabela 1). A leitura dos dados permite concluir que existe uma relativa correspondência entre o aumento do desemprego e a diminuição das taxas de greve, ainda que esta não seja a única explicação para tal redução. O índice de inflação, a partir da implantação do Plano Real, em 1994, por exemplo, apesar de não ter tido um efeito mecânico sobre o potencial de mobilização sindical no país, estancou a depreciação salarial mensal e pode ser considerado outro fator determinante.

Outros dados econômicos como o custo de vida também devem ser levados em conta. ${ }^{121}$ No entanto, o que me parece fundamental ressaltar, inicialmente, é que este conjunto de fatores devem ser relacionados aos elementos políticos e ideológicos presentes na construção da luta. Por isso analisei as ações e representações sindicais em relação aos desempregados feitas ao longo do período estudado em diálogo com as transformações mais gerais vividas pelas centrais. Um indicador crucial a ser considerarado em relação a esta questão é que, para além dos constrangimentos políticos e econômicos, o processo de redução da atividade grevista coincide com o fortalecimento do sindicalismo propositivo no país, na primeira

\footnotetext{
${ }^{121}$ Alguns estudos clássicos chamam a atenção para essa problemática. Ver Hobsbawn (2000), especialmente o artigo "Flutuações econômicas e alguns movimentos sociais desde 1800".
} 
metade da década de 90. Ademais, no decorrer dessas mudanças, a resposta para os desempregados não priorizou a mobilização desse segmento para a luta.

É necessário, pois, analisar as posições das entidades a respeito das transformações mais gerais do capitalismo brasileiro expressas nas discussões em torno da reestruturação produtiva e das políticas neoliberais, no contexto de constituição do grande capital financeiro como fração de classe hegemônica no país (Boito Jr., 2002b). Esses elementos são identificados por parte significativa da bibliografia como os principais responsáveis pelo crescimento do desemprego. Alguns autores identificam também que essas mudanças teriam provocado a crise (Alves, 2000; Antunes, 2002; A. M. Cardoso, 2003; Mattoso, 1995; Pochmann, 1999; Ramalho, Rodrigues, 1998; Ramalho, Santana, 2003; Ramalho, 1999; I. Rodrigues, 2003), ou até mesmo declínio histórico (Blass, 1998; Laranjeira, 1998; L. Rodrigues, 1999) do sindicalismo. ${ }^{122}$ Essas interpretações devem ser problematizadas. É necessário analisá-las como parte do processo de formação da estrutura ideológica, que tem como pano de fundo o recuo da luta socialista a nível mundial. Foi nesse terreno que o capitalismo neoliberal difundiu a ideologia da "globalização" e a noção de "inevitabilidade" dos processos econômicos em escala mundial e da necessidade de respostas sindicais mais pragmáticas.

O discurso de "crise" do sindicalismo brasileiro é construído com base nos "impactos" de elementos econômicos e políticos "exógenos" ao movimento sindical. Porém, ainda que o cenário seja de importância fundamental para contextualizar a atuação sindical, é necessário levar em conta a ideologia político-sindical, na sua forma de manifestação teórica e prática (Althusser 1986), presente na resistência dos trabalhadores, tanto em suas ações como em suas representações.

Outro aspecto freqüentemente menosprezado pelos autores é a estrutura sindical brasileira. ${ }^{123} \mathrm{O}$ estudo do sindicalismo de Estado (Boito Jr., 1991a) e do posicionamento dos dirigentes sindicais diante de seus pilares é o ponto de partida para a compreensão do corporativismo no país. Para analisar as relações entre sindicatos e desempregados, por exemplo, é muito comum o argumento segundo o qual se a sindicalização exige o vínculo empregatício formal, a relação entre as entidades sindicais com os desempregados no Brasil seria obsoleta de antemão. Essa formulação pressupõe uma correspondência mecânica e

\footnotetext{
${ }^{122}$ Para uma análise crítica dessas posições, ver Boito Jr. (2003), Béroud, Mouriaux, Vakaloulis (1998) e Carrera (2004).

${ }^{123}$ Entendo a estrutura sindical como um elemento da estrutura jurídico-política, mas também da estrutura ideológica, já que que sua existência na "forma legal", como Aparelho Ideológico de Estado, pressupõe a reprodução da ideologia estatal (Althusser, 1999).
} 
inexorável entre a legislação e as ações concretas das organizações e, portanto, deve ser problematizada como uma forma de reprodução da ideologia jurídica e do legalismo pelas entidades sindicais. Feitas essas considerações metodológicas, vejamos a seguir quais foram as principais transformações ideológicas do sindicalismo brasileiro nos anos 90, procurando relacioná-las à correlação de forças do período analisado.

A CUT conformou, juntamente com o PT, desde seu surgimento até o início do governo de Lula, em 2003, o núcleo da oposição partidária e sindical no país. Na presidência de José Sarney (1985-1989), a central impulsionou três greves gerais e diversas mobilizações contra a política econômica desse Governo. Durante a década de 80, foi a principal protagonista do período de maior atividade grevista da história do movimento sindical brasileiro, cuja característica mais marcante foi a luta por reposição salarial em um contexto hiperinflacionário (Noronha, 1991). A central entidade sob o discurso de defesa do socialismo, feito através da estratégia de combinar os objetivos históricos e imediatos da classe trabalhadora, tal como se lê nas resoluções de seus primeiros congressos. Caracterizouse também pelas greves de massa e pela posição crítica à estrutura sindical, que decidiu combater "por dentro" (L. Rodrigues, 1990a, 1991; Gianotti e Lopes Neto, 1991) ${ }^{124}$, ainda que ao longo de sua trajetória tenha se verificado um processo de acomodação ao corporativismo estatal (M. Oliveira, 1994), fato reconhecido pela própria central. ${ }^{125} \mathrm{~A}$ ausência de organização da base no local de trabalho e a não incorporação de segmentos nãosindicalizáveis à mobilização, evidenciam a relativa incompatibilidade entre a prática cutista e a auto-definição da central como "classista". ${ }^{126}$ Durante a década de 90, de maneira geral a CUT combateu o neoliberalismo, promovendo mobilizações contra as privatizações, a política econômica e as reformas trabalhistas. No entanto, ao longo desse período observam-se mudanças no discurso e prática da ala majoritária da central rumo a um sindicalismo "propositivo" (Boito Jr., 1999; Galvão, 2002) e de caráter “cidadão” (Zarpelon, 2002). Entre os críticos da central, há aqueles que identificam este processo como a evidência do abandono

\footnotetext{
${ }^{124}$ A bibliografia sobre a história da CUT é ampla e diversificada. Muitas reflexões e informações contidas neste capítulo foram extraídas dos trabalhos de L. Rodrigues (1990a), I. Rodrigues (1997) e Veras (2002), assim como dos demais textos que serão citados.

${ }^{125}$ Nas Resoluções da $5^{\text {a }}$ Plenária Nacional, lê-se: "A ruptura com a estrutura sindical oficial, iniciada no final dos anos 1970 e que chegou a seu momento mais alto com a fundação da CUT em 1983, teve grande dificuldade para continuar no nível dos sindicatos de base. A manutenção do 'monopólio de representação' e de grande parte do arcabouço da CLT, mesmo com as modificações na Constituição de 1988, facilitou uma 'acomodação', que na fase atual representa um risco para o sindicalismo cutista" (CUT, 1992, pp. 28-29).

${ }^{126}$ Entendo o classismo como um tipo de prática sindical combativa que prioriza a mobilização com base no antagonismo de classe.
} 
da bandeira socialista e do sindicalismo confrontacionista, que deu lugar à defesa de reformas no capitalismo e a uma política de conciliação de classes (Tumolo, 2002). Entre os entusiastas, alguns afirmam que a estratégia cutista nesse período expressa um "realismo defensivo" na central, que se viu obrigada a se adaptar às tendências objetivas, com uma ação sindical "mais pragmática, menos ideologizada e mais negociadora" (I. Rodrigues, 1999). Vejamos a seguir como a FS apareceu no cenário sindical brasileiro.

A FS surgiu em 1991 aliada ao governo Collor, defendendo a plataforma neoliberal, especialmente as privatizações e a flexibilização trabalhista (Trópia, 2002, 2009). No campo político-partidário, não possui uma relação orgânica com nenhum partido, embora alguns de seus principais dirigentes já tenham se candidatado a cargos executivos e legislativos pelo Partido Democrático Trabalhista $(\mathrm{PDT})^{127}$. Em seu núcleo fundador estiveram presentes dirigentes vinculados ao Partido Comunista do Brasil (PCdoB), ao Partido da Frente Liberal (PFL), ao Partido dos Trabalhadores (PT) e ao Partido da Social-Democracia Brasileira (PSDB) (Cardoso e Rodrigues, $1993^{128}$ ). A central se define como pluralista sob o argumento da necessidade de se combater o modelo de sindicato como "correia de transmissão" do partido, tal como acusam na prática cutista. Para alguns autores, esse discurso é uma forma de ocultar sua origem no sindicalismo de direita, herdeiro do peleguismo vigente durante a ditadura militar, bem como seu conteúdo político de "central neoliberal” (Gianotti, 2002).

No campo ideológico, a FS defende o "sindicalismo de resultados". Nesse modelo de prática sindical a prioridade é dada à negociação, à apresentação de propostas e ao saldo material que esse tipo de postura traria para os trabalhadores. As greves são vistas como último recurso, e não como estratégia, o que não quer dizer que não a usem freqüentemente para pressionar os patrões a negociações que visem obter vantagens econômicas para os associados. ${ }^{129}$ Ao contrário da CUT, que possui em sua base sindicatos rurais e urbanos do setor público e privado, a FS se caracteriza por representar, majoritariamente, sindicatos do setor privado, a maior parte de pequeno porte, ainda que estejam incluídas algumas entidades expressivas como os comerciários e os metalúrgicos de São Paulo (Trópia, 2009, IBGE,

\footnotetext{
${ }^{127}$ No entanto, o trabalhismo defendido pela FS se diferencia da política nacional-populista levada a cabo por Getúlio Vargas e João Goulart. A central prega o fim da herança varguista no país, por meio de sua crítica à rigidez da CLT no campo trabalhista.

${ }^{128}$ Nesse trabalho os autores defendem a tese do caráter pluralista da FS, fundamentada a partir de questionários aplicados aos delegados presentes no congresso de fundação da central.

${ }^{129} \mathrm{O}$ caráter reivindicativo da central e de seu principal sindicato de sua base, os metalúrgicos de São Paulo, por meio da atividade grevista, foi explicitado por Trópia (2009).
} 
2001). Durante o governo de Fernando Henrique Cardoso (1995-1998; 1999-2002), o qual defendeu abertamente, a FS teve um crescimento significativo e se consolidou como a segunda maior central do país, com um número de sindicatos cada vez mais próximo de sua rival, a CUT.

Ao longo dos anos 1990 e 2000, é possível verificar uma retração do movimento grevista no Brasil em relação aos patamares da década de 19980. O movimento descendente, iniciado em 1992, apesar de conter oscilações consideráveis nos dez anos seguintes, estabilizou-se a partir de 2003 nos níveis mais baixos dos últimos trinta anos (Ganz Lúcio, 2008). No entanto, a explicação do ciclo de protestos sindicais exige um exame mais profundo sobre sua fisionomia, que não se restringe a um mero reflexo da ideologia defendida pelos sindicatos, mas também não deve ser explicada apenas pelas transformações na estrutura econômica, no nível de emprego e no perfil das empresas. Deve-se considerar estes fatores numa relação dialética, e acrescentar à análise a posição dos trabalhadores, o momento atual da luta de classes, marcado pela defensiva do movimento socialista e pela ofensiva do neoliberalismo, além de diversos outros elementos jurídico-políticos, institucionais, econômicos, ideológicos e culturais. De acordo com o levantamento apresentado por Elias Jr., Gebrim e Noronha (1998, p. 7), a média de greves anuais foi de 2.203 no período de 1985 a 1990, 978 entre 1991 e 1992, e 926 de 1992 a 1997, sendo que o auge desse último período se deu nos dois anos posteriores à redução da inflação. Segundo levantamento do Departamento Intersindical de Estatística e Estudos Sócio-Econômicos (Dieese) citado por Ganz Lúcio (2008), de 1988 a 1997 a média brasileira foi de 1.084 greves anuais, caindo para 385 entre 1998 e 2007. Se isolamos o período correspondente ao governo Lula (2003-2007) foram convocadas uma média de 300 greves, mas no ano de 2008 conhecemos o auge da atividade grevista de sua Presidência, com 411 eventos. ${ }^{130}$

Ainda que a ideologia política e sindical das centrais tenham mudado e o ciclo grevista tenha entrado em uma nova fase, um elemento persistiu no cenário sindical brasileiro: a estrutura sindical. Após algumas reformulações na legislação sindical, realizadas pelo Ministro do Trabalho Pazzianoto, em 1985, reafirmadas e acrescidas a outras que se incorporaram à Constituição de 1988, alguns analistas do sindicalismo no Brasil passaram a afirmar que a estrutura sindical brasileira já não era mais a mesma e que, com as reformas institucionais, o caráter corporativo teria sido abolido (Almeida, 1998; Pochmann, 1996).

\footnotetext{
${ }^{130}$ http://www.dieese.org.br. Acesso em 30/10/2009.
} 
Almeida (1998, p. 5), por exemplo, afirma que essas reformas teriam abolido os mecanismos de controle estatal das atividades sindicais e que, a partir de então, os sindicatos "tornaram-se autônomos em relação aos governos”. Também está presente entre muitos estudiosos a idéia segundo a qual a diminuição da base de representação dos sindicatos, causada pelo crescimento do desemprego e pela redução dos setores considerados tradicionais, especialmente aqueles ligados à indústria, iria provocar um desmonte dos últimos resquícios do corporativismo. No entanto, verifica-se que as bases do sindicalismo de Estado edificado nos primeiros meses da ditadura Vargas, em 1931, mais uma vez conseguiram permanecer intactas, salvo algumas alterações secundárias. De acordo com Boito Jr. (1991b), as mudanças ocorridas entre 1985 e 1988 se referem ao "modelo de gestão e controle governamental” sobre os sindicatos oficiais, que teria deixado de ser "ditatorial" para assumir uma feição mais "democrática". Este capítulo parte da seguinte hipótese: o crescimento do desemprego não resultou na crise da estrutura sindical brasileira, mas essa estrutura foi um dos principais entraves para a construção de uma luta unificada entre sindicatos e desempregados.

A FS, desde sua origem, defende o modelo sindical oficial. No caso da CUT, apesar do discurso de combate ao corporativismo, setores internos expressivos como a Corrente Sindical Classista (CSC) e a Contag, atualmente fora da central, também defendem essa estrutura. Entre as correntes minoritárias de esquerda, houve um aprofundamento de sua adesão tácita à estrutura sindical, fato reconhecido pelas próprias entidades. ${ }^{131}$ A maior evidência desse processo se deu em 2006, quando a entidade apoiou a reforma sindical que legalizou as centrais, em que estas passaram a ser financiadas com verbas do imposto sindical. Com ampla adesão dos sindicatos dos trabalhadores e defesa incondicional dos sindicatos patronais, o sindicalismo de Estado no Brasil se mantém como a instituição mais estável da estrutura jurídico-política do país, com seus mais de três quartos de século de existência. Galvão (2007) demonstra que durante os anos 90, apesar dos interesses dos governos neoliberais pelas reformas das leis trabalhistas, o mesmo não passou com as reformas sindicais, já que a estrutura sindical brasileira se mostrou eficiente para a implantação do neoliberalismo.

A estratégia da CUT diante do desemprego no período estudado não só acompanhou as alterações mais gerais vividas pela central, mas foi um de seus principais motores. Assim, a passagem do sindicalismo combativo para o sindicalismo propositivo, e deste para o

\footnotetext{
${ }^{131}$ Para uma análise dos metalúrgicos de Campinas, entidade majoritariamente composta por militantes da Alternativa Sindical Socialista (ASS), atualmente na Intersindical, ver Souza (2005b).
} 
sindicalismo cidadão pela ala majoritária da central, teve essa política como carro-chefe. No caso da FS, os elementos centrais de sua ideologia político-sindical também se fundamentam na leitura que a entidade faz sobre o desemprego. Sua proposta de política para os desempregados atestam seu apoio à política neoliberal e afirmam a tradição governista e assistencialista de seus principais sindicatos (Trópia, 2009).

Diante da crescente eliminação de postos de trabalho a partir do início dos anos 1990, a atuação da CUT foi, no plano teórico, de denúncia do desemprego em sua análise de conjuntura, inclusão da questão na sua pauta de reivindicações e elaboração de propostas para solucionar o problema. No plano prático, a ação da central e de seus sindicatos foi predominantemente defensiva, com freqüentes demonstrações de imobilismo e fragilidade, o que não exclui alguns momentos de resistência, mobilizações e greves, presentes com mais intensidade nesta entidade, mas que não estiveram ausentes na FS.

Em consonância com a concepção de sindicalismo propositivo que passaram a defender, no início dos anos 1990 a FS e a ala majoritária da CUT aderiram à tese neoliberal da "inevitabilidade" da "globalização". Esse discurso foi funcional ao colaboracionismo com as empresas, consideradas como vítimas da crescente demanda por aumento da produtividade decorrente da competitividade global. A partir dessa concepção, os sindicatos de ambos os setores passaram a negociar com o objetivo de amenizar as perdas dos trabalhadores "em defesa do emprego"; participar dos fóruns tripartites e das câmaras setoriais ${ }^{132}$; e, por fim, propor uma política de formação e requalificação profissional sustentada pelo discurso neoliberal de "empregabilidade". ${ }^{133}$ Assim, de defensora de direitos sociais e políticas públicas, a CUT passou a exercer também o papel de gestora de políticas de "geração de emprego e renda", sob o discurso de promoção da cidadania. Se por um lado jamais apoiou o tripé da plataforma neoliberal, por outro aceitou parcialmente a política de assistência focalista, apresentada sob o argumento de solidariedade com a "sociedade civil". A partir do final da década de 90, a CUT aderiu ao conceito de "economia solidária" e passou a investir no cooperativismo, consolidando sua estratégia de sindicalismo "cidadão". No caso da FS,

\footnotetext{
${ }^{132}$ Entre os entusiastas do sindicalismo propositivo estão Arbix e Rodrigues (1996), Blass (1998) e Bresciani (1994), que têm em comum a análise positiva das câmaras setoriais do ABC no início dos anos 90. Segundo esses autores, esta teria sido uma experiência de "reestruturação negociada" que trouxe muitas "conquistas" para os trabalhadores. Para uma análise crítica dessas posições, ver Galvão (1996) e Boito Jr. (1999).

${ }^{133}$ A tese da empregabilidade é a leitura neoliberal do desemprego por excelência. Baseia-se na idéia segundo a qual o desemprego é um problema de responsabilidade individual, restando ao trabalhador acompanhar as exigências do "mercado de trabalho" e "reciclar-se" para disputar vagas em uma conjuntura de alta competitividade.
} 
esta política foi condizente com a ideologia neoliberal defendida pela central desde sua origem (e até mesmo antes, por seus principais sindicatos). Vejamos com mais detalhes as principais características desse modelo de atuação sindical.

No decorrer do período estudado, os sindicatos controlados pela ala majoritária da CUT e pela FS negociaram a flexibilização de direitos trabalhistas. Os exemplos mais notórios nesse sentido foram os acordos que resultaram na criação do Banco de Horas e na redução da jornada com rebaixamento salarial, ambos defendidos sob o pretexto da manutenção do emprego. Além desse tipo de negociação, fazendo uso das prerrogativas de poder público que lhe são concedidas pela legislação, as duas centrais usufruíram de recursos advindos do Fundo de Amparo ao Trabalhador (FAT) ${ }^{134}$, promovendo cursos de "requalificação profissional" e uma política de "intermediação de mão-de-obra", ambos pautados na noção de "empregabilidade" (nem sempre de modo explícito, no discurso, mas efetivamente, na prática). Por intermédio dessas ações, as entidades sindicais assumiram o papel de agências de emprego responsáveis pela "recolocação" do trabalhador no "mercado de trabalho". A consolidação desse modelo de prática sindical voltada para os desempregados se deu com a criação do Centro de Solidariedade ao Trabalhador (CST), pela Força Sindical, em 1998, e da Central de Trabalho e Renda (CTR), pela CUT, em 1999. ${ }^{135}$

Em minha dissertação de mestrado (Souza, 2005b), refleti sobre os limites da ação sindical diante do desemprego no Brasil, enfatizando fatores de ordem econômica, política e ideológica, assim como os entraves institucionais impostos pelo sindicalismo de Estado. Entre esses aspectos, naquele momento destaquei o corporativismo, que, alicerçado nas entidades, dificulta a construção de uma luta para além da categoria. Mesmo nos sindicatos onde a crítica a esse modelo foi mais radical, como foi o caso dos metalúrgicos campineiros, não houve uma política consistente de "luta com os desempregados". A entidade se restringiu a levantar bandeiras gerais de "luta contra o desemprego", tais como a redução da jornada de

\footnotetext{
${ }^{134}$ O FAT foi criado em 1990, durante o governo de Collor, com o objetivo de financiar o seguro-desemprego e o abono salarial, e qualificar "mão-de-obra", tendo como principal fonte de recursos o Programa de Integração Social e o Programa de Formação do Patrimônio do Servidor Público (PIS-Pasep). Segundo reportagem publicada no jornal Estado de São Paulo, a maior parte dessas verbas vai para o seguro-desemprego e o abono salarial, e a soma dos itens "qualificação profissional" e "intermediação do emprego" não chega a 0,5\%. ("FAT tem $0.5 \%$ para qualificar desempregados". Estado de São Paulo. Disponível em: http://www.estado.com.br/editorias. Acesso em 01/05/2007.

${ }^{135}$ Entre as funções desses organismos estavam a habilitação dos trabalhadores para o recebimento do segurodesemprego, o oferecimento de cursos de "capacitação" e a intermediação da contratação de trabalhadores a partir de um balcão de anúncios de vagas oferecidas por empresas cadastradas.
} 
trabalho, o fim das horas extras, a reforma agrária e uma política macroeconômica voltada para o setor produtivo interno.

Sendo assim, pode-se dizer que, apesar de haver setores importantes que não seguiram o modelo da ala hegemônica do sindicalismo brasileiro, as correntes minoritárias, herdeiras do sindicalismo “combativo" dos anos 1980, não tiveram força política suficiente para fazer prevalecer suas reivindicações e, acomodada à estrutura sindical, também não logrou incorporar o trabalhador desempregado a sua ação cotidiana. De modo geral, o movimento sindical no Brasil, atrelado aos mecanismos institucionais com os quais não conseguiu romper, mesmo quando se manteve "combativo" no terreno político, atuou de maneira conservadora no terreno sindical, e não logrou superar os efeitos desmobilizadores da estrutura sindical, ainda que tenha buscado romper parcialmente com alguns de seus aspectos. Com o monopólio da representação e o financiamento garantidos por lei, o desempregado seguiu sendo uma espécie de "anomalia" jurídico-institucional para as entidades sindicais. Ao não contribuírem financeiramente nem votarem nas eleições do sindicato, tem acesso aos sindicatos, na maioria dos casos, apenas para se dirigir ao setor de homologação.

É necessário levar em conta que nem todo movimento operário e sindical assume a “forma legal” de Aparelho Ideológico de Estado (Althusser, 1999). O surgimento da CUT é uma manifestação de que a atuação por fora da estrutura sindical pode ser construída na luta, ainda que não dependa apenas da atitude dos dirigentes. O corporativismo não é, pois, uma ação institucionalista ou voluntarista. Sendo assim, deve ser visto como uma imposição do Estado, mas também como um traço cultural da ideologia política fortemente arraigado, defendido abertamente de maneira quase consensual pelos dirigentes sindicais brasileiros, ainda que esse elemento apareça, amiúde, menos no discurso do que na prática.

O modelo interpretativo que adoto se pauta no estudo das mudanças do sindicalismo brasileiro em sua relação dialética com as transformações mais gerais da estrutura e da correlação de forças, levando em conta o processo histórico de construção cultural das experiências e tradições de luta do movimento operário, popular e sindical de uma dada formação. É nesse quadro que se constitui a práxis de resistência dos trabalhadores, que está submetida a fatores históricos "circunstanciais" que exigem dos agentes escolhas e tomadas de decisão, individuais e coletivas, condicionadas (mas não determinadas) pela estrutura social e pela correlação de forças. O resgate da relação entre estrutura e prática é o que permite a superação da tradição analítica do sindicalismo predominante no Brasil, marcado 
pelo determinismo (objetivista ou subjetivista) em suas vertentes politicista, institucionalista e voluntarista, mas especialmente em sua abordagem economicista.

O estudo do sindicalismo deve considerar que as ações das entidades são elaboradas em um dado contexto histórico. Sendo assim, deve levar em conta os fatores externos que as condicionam, mas também as representações ideológicas que sustentam as escolhas políticas. Esse é o pressuposto fundamental do materialismo histórico, que o afasta de qualquer determinismo, pois evita o voluntarismo, que condena as práticas sindicais como se essas não sofressem qualquer constrangimento externo, e o mecanicismo econômico, que naturaliza as práticas sindicais como se essas fossem "inevitáveis".

A análise da correlação de forças em que o movimento sindical atuou nos anos 90 deve partir dessas premissas. A estratégia do sindicalismo propositivo e "cidadão" não se deu isolada de um contexto, nem estiveram ausentes disputas internas entre projetos políticos no interior das centrais. Este modelo de ação sindical foi vencedor entre os demais apresentados diante dos dilemas presentes na conjuntura. A partir desse panorama, buscarei ao longo deste capítulo analisar teoricamente as ações e representações da CUT e da FS diante dos desempregados contrapondo a prática e o discurso dessas centrais a respeito do tema.

Como vimos no primeiro capítulo, nos estudos sobre a mobilização dos desempregados são comuns as referências a seus limites organizativos, ou ainda, a sua incapacidade "quase estrutural" de ações políticas. Esses argumentos também são usados freqüentemente pelos sindicalistas para justificar a ausência de lutas conjuntas de suas entidades com os desempregados. Alguns inclusive afirmam que apesar de sua "vontade", estes não atendem à convocação sindical, e por isso o sindicalismo representa seus interesses sem organizá-los para a luta. Do lado dos desempregados, é muito freqüente o argumento de que o sindicato é uma entidade corporativa e, portanto, está estruturalmente determinado pelos interesses da categoria profissional que representa, como se sua própria organização dependesse única e exclusivamente das entidades sindicais. Esses argumentos fazem tábula rasa do potencial de mobilização dos desempregados e das possibilidades de ação combinada com os sindicatos. Ora, a unidade entre ambos é resultado do processo histórico de construção social e cultural da luta de classes, condicionada pelas escolhas ideológicas, pela estrutura social, pela correlação de forças, pelas experiências prévias e pelas tradições de luta das formações. Vejamos a seguir como essa questão esteve presente nos anos 1980. 


\subsection{Sindicalismo e desempregados nos anos 1980}

O início dos anos 1980 foi um momento de ascensão do movimento popular e sindical. Em um contexto de hiperinflação e de crescimento das demissões, apareceu o Movimento Contra o Desemprego (MCD) de São Paulo, que em 1983 realizou diversos atos no município, caracterizados especialmente pela utilização dos "saques" como instrumento de luta. De acordo com Stroh (1989), essa organização se constituiu em um "momento de fusão" de várias "lutas populares" do período, resultante de "práticas políticas" de "confronto com o Estado". ${ }^{136}$ Ainda segundo esta autora, o MCD teve os pilares de sua eclosão nas experiências prévias de organização sindical de base dos trabalhadores metalúrgicos da Zona Sul do município e do trabalho anterior das Comunidades Eclesiais de Base (CEBs). Alguns entrevistados fizeram referência a essa mobilização. Segundo um dirigente químico cutista, esse movimento teve uma forte ligação com a militância no bairro presente naquele momento, o que explica inclusive sua ausência na atualidade. Esse sindicalista afirma que as organizações populares vêm perdendo seu poder de convocação e os sindicatos, mesmo possuindo sub-sedes, não investem nesse tipo de representação, apesar de terem levado a cabo essa proposta de maneira mais efetiva naquele período:

(...) quando eu comecei a militância tinha os movimentos de carestia, década de 80, e era feito no bairro porque o desempregado está no bairro (...) esses movimentos de desempregados acabaram até pela questão também da fragilidade dos movimentos sociais (...). O sindicato tinha uma vinculação anterior com os movimentos sociais, também trabalhava este tema, a questão do desemprego, dos desempregados, sendo solidário nos bairros. Como os movimentos também se fragilizaram, as relações ficam muito mais difíceis para manter uma política (...) é uma coisa pontual porque os movimentos sociais também (...) são pontuais (E8).

Um dirigente metalúrgico de São Paulo destaca nesse momento o papel da Igreja Católica que, através da Pastoral Operária (PO), fazia um trabalho de organização popular nos bairros. Essa função era cumprida especialmente pelas CEBs, que por sua vez foi um dos principais espaços de formação das oposições sindicais desde o final dos anos 1970. Essa ação territorial, segundo este sindicalista, era o que possibilitava a construção de unidade entre empregados e desempregados:

(...) naquela época (...) a presença da Igreja Católica era muito forte nas comunidades (...). Então, aí a comunidade se encontrava (...) não havia o empregado e o desempregado. (...) talvez falte [atualmente] a presença de uma ação sindical (...) na comunidade em relação aos desempregados, onde ele está

\footnotetext{
${ }^{136}$ A autora se refere às organizações populares estudadas por Sader (1988), como o movimento contra a carestia, a militância católica, entre outros.
} 
vivenciando a sua situação com outras pessoas (...). Seria mais fácil a organização dos bairros, eu acho que nós perdemos muito isso, perdemos a organização da PO, perdemos (...) as associações de bairros, da defesa das condições de bairro. Eu acho que isto se diminuiu muito como ação de organização (E19). ${ }^{137}$

Este último sindicalista afirma que naquele período houve tentativas de representação dos desempregados nos sindicatos de base, mas que não tiveram continuidade:

(...) o sindicato não tinha esta organização para os desempregados. Nós chegamos a ter na Zona Sul a partir desses anos de 83, 84, associações dos desempregados (...). Não permaneceu, foram ações e organizações que eram de momento, (...) de mobilização, mas não conseguiu se efetivar (E19).

Outro entrevistado do Sindicato dos Químicos de São Paulo destacou que foi desenvolvida uma experiência desse tipo em sua entidade entre o final da década de 80 e início dos anos 90. A associação, a princípio, buscava se solidarizar com os demitidos da categoria, mas também organizou ações de protestos por reivindicações específicas para os desempregados:

(...) no começo o objetivo era de certa forma dar um apoio aos desempregados que participavam da luta, faziam a greve (...) a empresa demitia e a gente acabava dando um apoio para ele até ele se recolocar (...) depois nós acumulamos junto com um movimento como um todo, nós tentamos organizar os trabalhadores para fazer reivindicações junto ao Estado, vale transporte gratuito, uma série de reivindicações (...). Isso acabou não dando certo [porque] você começa a organizar um pessoal, onde ele começa a ter um mínimo de consciência dos direitos deles, [e] ele vai trabalhar ou vai fazer um bico e a gente fica tendo que começar tudo de novo e o movimento não pega, não tem consistência (E10).

Quando perguntado sobre experiências de ações conjuntas entre o sindicato e os desempregados, este entrevistado afirma que foram organizadas mobilizações com o movimento de moradia que tinha sua base social composta predominantemente por desempregados:

(...) em vários momentos que nós fomos fazer uma ação na frente de uma empresa, o pessoal do movimento de moradia esteve junto com a gente. Ali tinha muita gente desempregada, então a gente teve uma integração (...) com os movimentos sociais, e não com os desempregados organizados, porque isso ninguém conseguiu fazer (...) um movimento que teve força foi o movimento de moradia. Por quê? O interesse de ter uma casa é a mesma coisa que o interesse de ter um emprego e de ter uma vida melhor (E10).

Um dirigente metalúrgico paulistano explicita que naquele momento as mobilizações se deram em um contexto de inexistência do seguro-desemprego e que sua instituição, em 1988,

\footnotetext{
${ }^{137}$ Esse dirigente também faz referência ao contexto de lutas que a Zona Sul da cidade presenciou no período, marcado pela organização sindical e popular, mas também político-partidária: "O que nós tínhamos ali na zona Sul era uma efervescência, você tinha as POs, ligadas à Igreja Católica, você tinha os movimentos de oposição sindical muito fortes na época aonde tinha pessoas ligadas ao PT, companheiros ligados ao PCdoB" (E19).
} 
ofereceu uma assistência aos desempregados: “(...) naquele momento nós não tínhamos o seguro-desemprego. Quando havia demissões cada empresa negociava com o sindicato um salário a mais, dois salários a mais (...). Quando você começa já ter isso na lei, eu sinto que diminuiu um pouco (...) o enfrentamento”. (...) (E19). Outro dirigente metalúrgico, do ABC e da CNM também ressaltou a importância dessas organizações de bairro para a criação do benefício: "este movimento da década de 80 faz todo um movimento social para ter segurodesemprego". (E6). Até aqui duas conclusões podem ser tiradas a partir dos depoimentos citados. Primeiro, que a organização dos desempregados no início dos anos 80 foi possibilitada pelas experiências prévias de militância popular nos bairros. Houve participação do movimento sindical, mas não propriamente das entidades, por dentro da estrutura. Ademais, a reivindicação por um seguro-desemprego funcionou como um motor do movimento, ainda que atualmente não se trate de um benefício de acesso amplo. Essas referências serão fundamentais para analisar a ausência de mobilização dos desempregados nos anos 90. Antes de passar à análise desse período, insistirei um pouco mais nos relatos dos dirigentes.

Um sindicalista metalúrgico conta que entre as principais ações realizadas pelo movimento foi uma marcha ocorrida em 1983 da Zona Sul da cidade até o Palácio dos Bandeirantes:

(...) o que aconteceu lá em Santo Amaro? Todo mundo procurando emprego, aquela dificuldade, greves também para evitar as demissões, (...) e a Zona sul era (...) uma concentração muito forte de grandes empresas e trabalhadores metalúrgicos, também químicos... e na segunda-feira acumulou mais de 5000 pessoas numa empresa, (...) era o chiclete Adams, se não me engano (...). Quando o pessoal chegou lá não tinha emprego. Foi uma farsa, digamos assim... Aí o pessoal se revoltou porque se apresentaram para procurar emprego e a empresa disse que não tinha emprego. Eu não sei se a empresa se assustou com o número de trabalhadores que lá estavam (...). Aí o pessoal saiu da empresa e vieram em passeata para o Largo 13. Aí começou certo quebra-quebra no Largo 13, a direção do movimento acabou controlando, saíram em passeata e vieram até o Palácio dos Bandeirantes. Chegaram no Palácio dos Bandeirantes, queriam uma audiência com o governador, chegaram até a derrubar (...) as cercas do palácio, quer dizer, foi um movimento importante no sentido de demonstrar a insatisfação dos desempregados (E19).

Em seguida, esse entrevistado destacou a dificuldade de recrutar os desempregados e qual é a política sindical para este segmento:

(...) individualizados, os desempregados não se mobilizam porque cada um está para baixo, o cara está fora da produção, não se sente bem por estar desempregado e você não tinha nenhum local assim que 
pudesse chamá-lo à reunião porque (...) o sindicato está mais preocupado com aqueles que podem pagar a mensalidade (...) (E19).

Mais adiante, o dirigente revelou que a tática utilizada naquele momento para reunir os desempregados, em realidade, foi panfletar sobre uma suposta contratação:

(...) uma das táticas que foi usada foi de panfletar a região indicando que haveria emprego na empresa de fabricação de doces, de balas Adams, do chiclete Adams. Então, com isso (isso foi feito no final de semana) (...), na segunda-feira tinha lá por volta de cinco, seis mil pessoas procurando emprego, acreditando no panfleto que havia sido feito. Quando chegam lá (...), não havia emprego, não era aquilo que estava se esperando. Então, o pessoal se sentiu ludibriado, pedia satisfação (eu estava desempregado também) (E19).

Essa breve referência à mobilização dos desempregados e a algumas tentativas de organização desse segmento para a luta pelos sindicatos nos anos 80 afasta qualquer apriorismo no trato da questão no Brasil. Vale mencionar, portanto, como esses entrevistados explicam a relativa ausência desse tipo de organização nos anos 90. A não continuidade da estratégia de organização de associações de desempregados foi explicada por um sindicalista como parte de uma "mudança de comportamento" da sociedade de maneira geral, mas especialmente do setor de formação sindical. Esse entrevistado destacou em sua resposta o papel da "acomodação à estrutura sindical":

Naquela época, para você ter uma idéia, a gente fazia assembléia que você colocava 50.000. Hoje para você colocar cinco, você tem que usar de alguns recursos (...) hoje tem as facilidades, hoje eu posso pegar este telefone agora e ligar para algum operário dentro da fábrica, ele pega o celular dele, e está trabalhando e me atende. Naquela época não tinha isso, você tinha que ir na porta da fábrica e esperava ele sair na hora do almoço ou na saída ou ele vir no Sindicato (...) (E24).

Este mesmo entrevistado se refere ao papel exercido pela "inflação" como motor da mobilização sindical de maneira geral, além do contexto de luta pela democratização do país:

(...) naquela época o movimento sindical usava mão da inflação para ir pra rua também. "Pô, $100 \%$ de inflação, vamos lutar e queremos aumento". Aí o patrão: "olha, está aqui: 100\% de aumento". Mas não era aumento, ele estava apenas repondo a inflação e no outro dia não valia mais nada. Então, existia uma ilusão, existia um discurso contra a ditadura (...) (E24).

Quando perguntado se é possível uma ação conjunta entre empregados e desempregados através dos sindicatos, este entrevistado respondeu:

Ah, é possível, nós já fizemos isso quando nós tivemos aquela crise da década de 80 . Era uma crise brava (...) naquela época e a gente fez ações (...) até tinha (...) associação de desempregados aqui em São Paulo que a gente ajudava e tal. (...) Eu acho que é um combustível a mais, principalmente na solidariedade de quem está empregado sentir o efeito de quem está desempregado e vice-versa. Então, é possível e eu 
oriento as centrais sindicais, a Força Sindical, a fazer este tipo de movimento e eu acho que isso é muito importante (E24).

Os entrevistados metalúrgicos de São Paulo, atualmente membros da Executiva Nacional da FS, destacaram também que as políticas proporcionadas aos desempregados pelas centrais sindicais, por meio dos cursos de qualificação e da intermediação do emprego da força de trabalho, teriam servido para preencher o espaço deixado pelo "movimento social" na década de 90:

Não quero dizer aqui que quanto pior, [melhor], porque nós tivemos uma conquista que foi o segurodesemprego e depois com a instalação de cursos de qualificação e com o Centro de Solidariedade, eu creio que nós fomos cobrindo uma lacuna que havia no movimento social (E19).

Nessa mesma linha se encontra a argumentação de outro entrevistado metalúrgico da FS, que contrapõe esse tipo de serviço oferecido para os desempregados ao instrumento de mobilização utilizado nos anos 80: "Hoje é diferente, o Centro de Solidariedade é uma forma de você ter o desempregado ali tentando se recolocar no mercado de trabalho, e naquela época a gente usava a rua, usava a manifestação com os desempregados” (E24). Em seguida, o dirigente acrescentou:

Naquela época, por exemplo, não tinha o Centro de Solidariedade, aonde o trabalhador vem aqui, ele já vem aqui, ele já tem uma assistência mais concreta (...), "olha tem esta vaga aqui na empresa tal, tal e tal" e naquela época não tinha nada disso (...) não tinha a qualificação, nós não falávamos nisso (...). Então, por isso que a gente usava o instrumento da mobilização. Eu acho que jamais o movimento sindical pode abandonar (...) essa bandeira da mobilização de rua porque na minha avaliação é a palavra mais forte, é quando você se mobiliza na rua (...) é aonde você é mais ouvido. (E24)

Ainda antes de passar à análise dos anos 1990, vale fazer algumas referências sobre a atuação da CUT nos anos 1980 diante do desemprego e dos desempregados. A CUT surgiu em 1983 como resultado de um processo de militância de base que levou a uma explosão da atividade grevista a partir de 1978. Ao longo dessa década, a central se caracterizou, no campo político, pela luta contra a ditadura militar e pela redemocratização do país, e no campo econômico, pela mobilização contra os planos do governo e pela reposição de perdas salariais em um contexto de hiperinflação. O principal instrumento de luta da central nesse momento era a paralisação, como ficou demonstrado na convocação de três greves gerais (em dezembro de 1986, agosto de 1987 e março de 1989). Uma das principais bandeiras da central nesse período foi o não pagamento da dívida externa. No campo sindical, destacava-se pela luta por liberdade e autonomia na organização, a livre negociação e o contrato coletivo de trabalho. Essas reivindicações faziam parte das estratégias da CUT de "construção de uma 
sociedade democrática rumo ao socialismo" (CUT, 1991, p. 02). Para a central, sua postura nos anos 80 foi o que "impediu que os prejuízos fossem maiores" (CUT, 1991, p. 03).

O $3^{\circ}$ Congresso Nacional da CUT (Concut), ocorrido em 1988, foi um dos eventos mais polêmicos de sua história. Alguns estudiosos o consideram como um símbolo do sindicalismo combativo e de massas no Brasil, pelas posições adotadas pela central e pelo elevado número de participantes. Outros afirmam que este evento foi a última expressão de seu horizonte socialista, e que já se observa aí os primeiros indícios do sindicalismo propositivo que viria a se tornar predominante na ala majoritária da central.

No plano discursivo, a concepção geral de sindicalismo cutista nesse momento remonta ao projeto inicial da central marcado pela "necessidade" dos trabalhadores de "unificar as suas lutas, no campo e na cidade". A entidade se auto caracterizava como "classista e comprometida em articular nas lutas os objetivos imediatos e históricos da classe trabalhadora". Nesse contexto, a CUT também se comprometia a combater o "sindicalismo reformista e conciliador de interesses antagônicos". (CUT, 1988, p. 38).

Durante a presidência de Sarney, o sindicalismo praticado pela central foi marcado pela "denúncia e resistência" contra os planos do Governo e mobilizações de massa (como a greve geral de dezembro de 1986, convocada contra a "política econômica antipopular", e avaliada pela central como a maior da história do país). Naquele contexto o Governo chamou a central para participar do "pacto social", sobre o qual a central assim se expressou: "A CUT entende que não pode haver pacto entre desiguais e que nesse tipo de pacto os trabalhadores só tem a perder" (CUT, 1988, p. 31).

As propostas cutistas para combater o desemprego nos anos 80 podem ser consultadas em suas reivindicações durante o processo constituinte. Na avaliação da central, "Foi a partir dos abaixo-assinados pelas emendas populares, da pressão exercida através das passeatas, dos protestos, das greves e das caravanas ao Congresso Constituinte, que alguns direitos sociais dos trabalhadores foram aprovados na nova Constituição". A central se refere à conquista da redução da jornada de trabalho (de 48 para 44 horas) ${ }^{138}$ e à aprovação de "verbas vinculadas ao seguro-desemprego" (CUT, 1988, pp. 26-27).

\footnotetext{
${ }^{138}$ A redução da jornada de trabalho era vista nesse momento pela CUT como uma bandeira histórica da classe trabalhadora no enfrentamento com o capital: "A luta pela redução da jornada de trabalho para compartir o emprego, pelo uso alternativo do tempo livre para cultura, educação e lazer, é uma tarefa decisiva para o sindicalismo internacional" (CUT, 1988, p. 50).
} 
A luta pela estabilidade no emprego também era contemplada pela CUT e foi uma reivindicação constante nas greves de seus sindicatos (CUT, 1988, p. 34). Nesse momento, o desemprego era considerado pela central como um elemento orgânico da dinâmica capitalista: “O desemprego, estrutural no capitalismo, está aumentando ao longo dos anos em função das inovações tecnológicas (...)"(CUT, 1988, p. 50). A pauta de reivindicações cutistas presentes na $3^{\text {a }}$ Plenária Nacional, realizada em 1989, ressalta as principais propostas da central para combater o desemprego: "estabilidade no emprego"; "redução da jornada de trabalho para 40 horas" (CUT, 1989, p. 9) e "reforma agrária sob o controle dos trabalhadores" (CUT, 1989, p. $10)$.

A CUT surgiu em um contexto de desemprego massivo. Nesse momento, a explosão do movimento popular nos bairros, reivindicando melhores condições de vida e moradia, constituiu como uma experiência prévia de mobilização que os desempregados empregaram especialmente em São Paulo. Os principais aglutinadores desse movimento foram as CEBs, os partidos políticos de esquerda e os movimentos de oposição sindical. Além do surgimento do MCD, alguns sindicatos buscaram construir associações de desempregados com fundos de greve que estimulavam os protestos de massa. Com o crescimento do desemprego nos anos 90, por que essas experiências não tiveram continuidade? E por que o sindicalismo brasileiro não investiu na organização desse segmento para a luta? Quais foram as ações e representações das centrais diante dos desempregados? Essas questões serão tratadas no item que se segue.

\subsection{Sindicalismo e desempregados de 1990 a 2002}

O período de 1990 a 2002 é apresentado, por estudiosos e sindicalistas, como um panorama desfavorável para a atuação sindical. Para muitos, a reação do sindicalismo foi inevitavelmente "defensiva", já que os trabalhadores não tinham o que fazer diante de uma realidade considerada inexorável. Este pragmatismo analítico tem sua expressão máxima nas noções de "crise" e de "declínio histórico do sindicalismo". ${ }^{139}$ Para essas abordagens, os dilemas sindicais são analisados como efeitos mecânicos de elementos exógenos, como se os

\footnotetext{
139 Entendo a "defensividade" como um traço estrutural do sindicalismo, decorrente de sua forma de manifestação orgânica como reação aos efeitos do capitalismo, embora suas ações e representações não sejam um mero reflexo da dinâmica desse regime social.
} 
sindicalistas fossem uma platéia passiva diante do cenário que se lhes apresenta. Para muitos dirigentes, em maior ou menor grau, esse discurso serviu como justificativa para afirmar que não foi possível resistir aos fatores (agora "globais") que se impunham ao sindicalismo. No Brasil, a ofensiva da burguesia imperialista para a recomposição das taxas de lucro sob a hegemonia do capital financeiro ganhou força a partir do governo Fernando Collor de Melo e se estendeu até o final do segundo mandato de Fernando Henrique Cardoso, em 2002. ${ }^{140}$

Durante esse período, as empresas, inspiradas na ideologia neoliberal, defendiam a idéia de que era preciso se modernizar para competir no mercado global, e assim manter o emprego dos trabalhadores, o que acentuava a arbitrariedade patronal no local de trabalho. Nesse contexto, o discurso de inevitabilidade da globalização e da reestruturação produtiva, por um lado, e de empregabilidade, por outro, operaram como elementos funcionais ao acirramento da concorrência no interior da classe trabalhadora.

A tese central que apresentarei neste capítulo é de que as mudanças mais gerais de concepção e prática do sindicalismo a partir dos anos 90 tiveram uma estreita ligação com as reivindicações e propostas das entidades de combate ao desemprego. No caso da CUT, veremos que a leitura dessa problemática como um elemento estrutural do capitalismo deu lugar a uma interpretação mais conjuntural, pautada em aspectos da política econômica e na maneira como os empresários conduziram o processo de reestruturação de suas empresas. A redução da jornada de trabalho seguiu sendo defendida pela central, ainda que tenha sido superposta por outras bandeiras. A FS nasceu defendendo a modernização das relações de trabalho e os pilares da plataforma neoliberal. No campo sindical, as duas centrais passaram a se orientar crescentemente na concepção de sindicalismo "propositivo" e "cidadão".

Este capítulo pretende refletir sobre as ações e representações dessas centrais em relação ao desemprego (este último considerado a partir de seus dois momentos, a demissão e o desemprego propriamente dito), mas fundamentalmente busca avançar na análise das respostas das entidades aos desempregados. Como já mencionei, a representação sindical dos desempregados pode ser feita por meio da organização para a luta (mobilização), da organização para a satisfação das necessidades materiais através da produção e do consumo (cooperativas), de políticas de assistência (caixas de auxílio mútuo e fundos de greve) ou da

\footnotetext{
${ }^{140}$ A hegemonia do capital financeiro também é uma característica do governo Lula, ainda que este procure atender os interesses subimperialistas da burguesia interna associando-se a esta. Sobre o tema ver Boito Jr. (2006).
} 
preparação para a incorporação ao mercado de trabalho (cursos de qualificação e intermediação do emprego), entre outras medidas.

As questões que orientaram este capítulo foram as seguintes: de que maneira as centrais sindicais lutaram contra o desemprego? E seus sindicatos de base, organizaram ações contra as demissões? Houve protestos conjuntos entre empregados e desempregados? As entidades sindicais representaram os interesses dos desempregados? Quais foram os limites para concretizar a representação e a organização para a luta conjunta com os despedidos e os desempregados?

Ao refletir sobre a evolução do tipo de ações e representações feitas pelas centrais diante dessas questões, estabeleci a seguinte periodização: (i) o período de 1990 a 1992 se caracterizou pela resistência às demissões por parte de alguns sindicatos e pela afirmação das principais bandeiras da CUT para enfrentar o desemprego, mas também pela gestação do propositivismo no movimento sindical brasileiro, por meio da ala majoritária da central e da criação da FS; (ii) de 1992 a 1995, especialmente a partir da experiência das Câmaras Setoriais automotivas, consolidaram-se as políticas propositivas levadas a cabo pelas centrais, ainda que sem o abandono das mobilizações reivindicativas ${ }^{141}$; (iii) de 1995 a 1998, com o crescimento do desemprego, as centrais passaram a investir no oferecimento de serviços aos desempregados, através da política de requalificação profissional e de intermediação do emprego da força de trabalho, baseada na ideologia de sindicalismo "cidadão"; (iv) de 1998 a 2002 se consolidou o sindicalismo de serviços em ambas as centrais, embora a CUT tenha sido maior protagonista da política de economia solidária, por meio da qual a central passou a organizar os desempregados para a atividade econômica. ${ }^{142}$

É necessário esclarecer desde já que essa periodização corresponde a tendências que, ao se consolidarem, foram se acumulando com as práticas anteriores. Isso significa dizer que não foi seguida pelo conjunto do sindicalismo, dada a heterogeneidade de correntes no interior das centrais. ${ }^{143}$ Por isso, é necessário levar em conta que o conteúdo dos documentos analisados

\footnotetext{
${ }^{141} \mathrm{Na}$ exposição que será feita a seguir, esses dois períodos serão considerados em conjunto, pela prioridade que terá na análise os outros dois subseqüentes.

${ }^{142}$ Essa periodização se fundamentou em observações de campo e foi inspirada na proposta analítica de Galvão (2002) para a CUT. Essa autora considera quatro fases na trajetória cutista diante dos governos neoliberais: (i) de 1990 a 1992, ocorreu a "gestação do sindicalismo propositivo"; (ii) de 1992 a 1995, o "fortalecimento do sindicalismo propositivo"; (iii) de 1995 a 1999, a passagem "do sindicalismo propositivo ao sindicalismo cidadão" e; (iv) de 1999 a 2002, o surgimento de um dilema na central entre "resistir ou recuar".

${ }^{143}$ Galvão (2002) define a CUT como uma central "frouxamente articulada". Como atesta a própria entidade em um documentos congressuais, existe uma relativa autonomia das bases em relação à direção nacional: "Desde 
representa as idéias das correntes majoritárias. As representações dos setores opositores ora não aparecem, ora estão presentes de maneira secundária e contraditória ao projeto geral.

O período a ser estudado corresponde, na CUT, ao final da segunda e a totalidade da terceira gestão de Jair Meneghelli (1988-1991; 1991-1994), dos dois mandatos de Vicente Paulo da Silva (1994-1997; 1997-2000) e aos dois primeiros anos da presidência de João Antônio Felício (2000-2003). Nesse período a CUT atingiu o maior número de afiliados, chegando ao final da década, segundo sua própria estimativa, a representar mais de 20 milhões de trabalhadores. Na Força Sindical, corresponde à gestão de Luiz Antonio de Medeiros (1991-1999), primeiro presidente da entidade, e aos três primeiros anos do mandato de Paulo Pereira da Silva (1999-atual), que ainda se encontra no comando dessa central.

\subsubsection{Demissões e sindicalismo propositivo (1990 a 1995)}

Os primeiros anos da década de 1990 corresponderam ao governo de Collor (19901992) e foi marcado por um intenso processo de demissões em massa, especialmente no setor industrial. A ação da CUT nesse período se pautou por uma relativa continuidade com o modelo sindical praticado na década anterior. A luta por reposição salarial ainda era o principal motor dos protestos e das greves, o que pode ser atribuído parcialmente ao contexto ainda marcado por altos índices de inflação e ao arrocho acentuado pelas medidas econômicas do Governo, especialmente por meio da desindexação dos salários, em 1990. A central se mobilizou constantemente, tendo sido a principal protagonista do pico máximo da atividade grevista do sindicalismo brasileiro (ver Tabela 11). No entanto, nos anos seguintes começou a tomar forma na central o discurso de sindicalismo propositivo, fundamentado especialmente pela busca de soluções tripartites para as demissões. O mapa sindical no país também se alterou com a criação da FS, em 1991, que surgiu sob o discurso de sindicalismo "de resultados", que para o tema tratado neste trabalho se traduz no melhor saldo possível de empregos que as entidades supostamente conseguem garantir.

O período seguinte corresponde ao Governo de Itamar Franco (1992-1994) e ao primeiro ano da presidência de Fernando Henrique Cardoso (1995). Caracteriza-se pela

1986 estamos investindo na estruturação da CUT, discutindo instâncias, secretarias, departamentos, organismos de apoio à Central e deixando a organização interna dos sindicatos por conta da autonomia e tradição de luta de cada categoria". (CUT, 1994, p. 53). Ou ainda: "A CUT, às vezes, parece agir como uma intersindical ou como uma federação de sindicatos, devido à falta de organicidade nas relações entre os sindicatos com as CUTs Estaduais e, destas, com a Nacional". (CUT, 1997, pp. 33-34). 
consolidação do sindicalismo propositivo no cenário sindical brasileiro. Além da presença crescente da FS no cenário político sindical, pode-se afirmar que a ala majoritária da CUT aderiu definitivamente a esta perspectiva. A partir de 1994 o Plano Real iniciou um novo capítulo na história econômica brasileira. O relativo controle da inflação foi um dos motivos, nos anos seguintes, da redução das atividades grevistas por reposição salarial, ainda que essa tendência não tenha sido fruto de um efeito mecânico e os protestos não tenham desaparecido. A partir desse período, as verbas do FAT começaram a ser contempladas pelas duas centrais. O desempregado seguiu sem espaço no movimento sindical tanto na representação direta de seus interesses quanto na sua organização para a luta. Com base nesses referenciais, farei a seguir uma breve descrição das principais ações e representações da CUT e da FS em relação ao tema.

\section{A CUT}

As propostas cutistas para o desemprego no início de 1990 se caracterizaram pela continuidade das principais reivindicações da central defendidas ao longo da década de 1980, tal como pode ser explicitado pela Plataforma de Ação daquele ano, que manteve na pauta a "estabilidade no emprego" e a "redução da jornada de trabalho para 40 horas semanais" como aspectos centrais. Com o crescimento das demissões, o tema passou a ocupar um lugar de destaque nos protestos da central, a exemplo da Jornada Nacional de Luta "em defesa do salário, do emprego e contra a inflação", ocorrida de 5 a 9 de fevereiro daquele ano. ${ }^{144}$ Após a posse de Collor, a CUT denunciou sistematicamente a política de privatizações do governo. Em uma resolução da Executiva Nacional, aprovada em 18 de março, a central se posicionou em "defesa dos direitos sociais dos trabalhadores", em "defesa do patrimônio público estatal" e "contra a privatização das funções do Estado". ${ }^{145}$ A leitura que a CUT fazia de seu plano de governo (o Plano Collor) era de que o mesmo provocaria mais perdas salariais, recessão e desemprego. ${ }^{146}$ Diversas notas publicadas pela entidade denunciaram a eliminação de postos de trabalho em vários setores e regiões do país. A orientação oficial dada aos sindicatos de base era de que estes deveriam resistir às demissões com os mais variados instrumentos de luta, como greves e ocupações, buscando, inclusive, mobilizar os trabalhadores demitidos:

\footnotetext{
${ }^{144}$ Plataforma de Ação para 1990, Informacut n. 87, 17-25 jan. 1990, p. 3.

${ }_{145}$ Mais um pacote, mais perdas para os trabalhadores, Informacut n. 94, 15-22 mar. 1990, p. 2

${ }^{146}$ Considerações da CUT sobre o Plano Collor, Informacut n. 96, 29 mar. - 04 abr. 1990, p. 1
} 
Na luta pela garantia e estabilidade no emprego, desde já a CUT organizará a resistência às demissões, utilizando todas as formas de luta possíveis (atos, assembléias permanentes, greves, ocupações, etc.). Ao mesmo tempo, os sindicatos, CUTs estaduais e regionais devem realizar reuniões e plenárias com os demitidos visando sua organização e mobilização. ${ }^{147}$

$\mathrm{Na}$ avaliação da central, as dificuldades provocadas por este contexto de crescimento das demissões condicionaram uma mudança das estratégias dos sindicatos, que se viram obrigados a substituir parcialmente a luta por salários pela defesa dos postos de trabalho: “A recessão traz desemprego (ou, pelo menos, a ameaça dele), o que faz com que as lutas do movimento sindical por melhores salários e condições de trabalho dêem lugar à questão da garantia do emprego". ${ }^{148}$ A reivindicação salarial seguiu sendo a maior causa das greves do período. Porém, os documentos consultados também noticiaram diversas mobilizações levadas a cabo por entidades afiliadas à central, algumas consideradas "exitosas" por terem diminuído o impacto das demissões:

Em Belo Horizonte, MG, (...) os funcionários da Mannesmann também realizaram um ato de protesto às demissões em curso (...) os metalúrgicos da Companhia Siderúrgica Nacional [CSN] organizaram-se e promoveram a ocupação pacífica da empresa para negociar as 2.500 demissões anunciadas pela direção (no dia 15 de maio, o Sindicato conseguiu reverter o número das demissões para pouco mais de 1.200). ${ }^{[149]}$ Em Jundiaí, SP, os trabalhadores da Metalúrgica Continental ocuparam a fábrica abandonada pelo seu dono. Hoje, os metalúrgicos produzem e distribuem na íntegra os lucros obtidos. ${ }^{150}$

No entanto, este tipo de protesto nem sempre trazia resultados positivos. Vejamos por exemplo o caso da resistência na Ford, que mesmo após uma ocupação de vários dias, não conseguiu evitar a eliminação de postos de trabalho anunciada pela empresa:

Os funcionários da Ford em São Bernardo ficaram acampados na fábrica no dia 22 [de junho de 1990]. A ocupação foi uma forma de pressão contra cem demissões realizadas pela empresa. Os trabalhadores reivindicam $166.89 \%$ de reposição salarial mas aceitam um índice de $84,32 \%$ como forma de recompor as perdas de abril. ${ }^{151}$

\footnotetext{
${ }^{147}$ Contra a recessão, em defesa do salário, do emprego, da democracia e do patrimônio público. Informacut $\mathrm{n}$. 97, 04-11 abr. 1990, p. 1. Em outro documento, a central acrescentou à lista de instrumentos, "ocupações de fábricas e repartições" e "manifestações públicas" (Combater a recessão. Informacut n. 100, 26 abr. - 03 mai. 1990, p. 1). A proposta de ocupações de fábricas se fez presente também em uma reunião de representantes do setor metalúrgico com o ministro Rogério Magri, em que estes declararam que "orientarão os trabalhadores a ocuparem pacificamente as fábricas para impedir o crescimento das demissões e a imposição de reduções de jornada e salários" (Sindicatos querem ocupar fábricas. Informacut n. 103, 17-24 mai. 1990, p. 4).

${ }_{148}$ O movimento sindical na recessão, Informacut n. 102, 10-17 mai. 1990, Encarte Resenha-Desep.

${ }^{149}$ Em agosto de 1990, a CSN entraria em greve por melhores salários, pela defesa do patrimônio nacional e pela "readmissão e reintegração de demitidos" (A greve na Companhia Siderúrgica Nacional. Informacut n. 112, 0209 ago. 1990, p. 5).

${ }^{150}$ Cresce a mobilização dos trabalhadores. Informacut n. 103, 17-24 mai. 1990, p. 1.

${ }^{151}$ Metalúrgicos ocupam a Ford. Informacut n. 106, 21-28 jun. 1990, p. 4. Segundo uma matéria posterior, "A greve dos 900 golas vermelhas da Ford (os ferramenteiros e pessoal de manutenção) - ao contrário do que a
} 
Como parte da mobilização contra o Governo Collor, a CUT convocou, juntamente com a CGT, uma greve geral para o dia 12 de junho de 1990 "em defesa do salário, do emprego, da economia nacional e da democracia". ${ }^{152} \mathrm{O}$ protesto foi organizado em um contexto de ataque ao funcionalismo público, que segundo o presidente expressava a ineficiência da máquina estatal. O anúncio de que seriam realizadas 360 mil demissões até junho de 1990 foi sistematicamente denunciado pela central. ${ }^{153} \mathrm{Em}$ seguida, a adoção da Medida Provisória (MP) 193, que provocou a desindexação dos salários, restringindo a recomposição a partir de cada data-base, foi também alvo de críticas da entidade. ${ }^{154}$

O programa neoliberal de Collor também previa a abertura do mercado interno. $\mathrm{O}$ anúncio de um novo rebaixamento das alíquotas das importações foi denunciado pela central como mais uma forma de aumentar o desemprego. ${ }^{155}$ Por conta dessa e outras medidas, a CUT avaliava que o governo era responsável pela maior redução na atividade industrial já vivida no país, superando até mesmo a crise de $1981 .^{156}$

A $4^{\text {a }}$ Plenária Nacional, realizada nos dias 17, 18 e 19 de agosto de 1990, foi o primeiro encontro nacional ocorrido durante o governo Collor. Entre as reivindicações para a geração de emprego aprovadas em suas resoluções, a central apresentou a proposta de "readmissão dos demitidos e disponíveis em decorrência do Plano Collor". ${ }^{157} \mathrm{O}$ documento começa com um "Manifesto à classe trabalhadora e à população”, no qual a central “(...) convoca o

\footnotetext{
Autolatina (holding que controla a Ford e a Volkswagen no Brasil) tentou 'plantar' na imprensa - foi um movimento planejado com inteligência e o tempo todo sob o controle das suas lideranças. Se não fosse a truculência da direção da Ford, que demitiu cem grevistas, afastou seis membros da Comissão de Fábrica, três cipeiros e um diretor do Sindicato, a greve, iniciada no dia 11 de junho, deveria se encerrar no dia 29 do mesmo mês, na assembléia geral da categoria que pôs fim a outras paralisações em São Bernardo e Diadema" (A greve inteligente dos golas vermelhas. Informacut n. 112, $02-09$ ago. 1990, p. 7).

${ }^{152}$ Preparar a greve geral: paralisação nacional a partir de 12 de junho. Informacut n. 105, 31 mai. - 07 jun. 1990, p. 1.

${ }^{153}$ Salários, demissões e negociações. Informacut n. 106, 21-28 jun. 1990, p. 3.

${ }^{154}$ A CUT se opôs veemente a tal decreto, acusando-o de inconstitucional através de ação cautelar apresentada ao Supremo Tribunal Federal (STF) por desconsiderar os acordos e convenções coletivas de trabalho ("Pela rejeição da MP 193 e aprovação de uma política salarial". Informacut n. 107, 28 jun. - 05 jul. 1990, pp. 1-2; Decisão sobre MP 193 só em agosto. Informacut n. 108, 05-12 jul. 1990, p. 2). Essas e outras medidas provisórias de Collor também foram sistematicamente denunciadas pela CUT como formas de aumentar o arrocho salarial.

${ }^{155}$ A política externa do governo Collor e as transformações. Informacut n. 110, 19-26 jul. 1990, Encarte Resenha-Desep

${ }^{156}$ A central cita os dados divulgados pela Fiesp de que a indústria paulista teria cortado 170.290 trabalhadores no primeiro semestre de 1990 (Desemprego atinge 170 mil. Informacut n. 109, $12-19$ jul. 1990, p. 4). A política industrial de Collor voltaria a ser criticada com o anúncio do Programa Brasileiro de Qualidade e Produtividade (PBQP), que segundo a central provocaria mais demissões nas indústrias (O novo programa da política industrial do governo Collor. Informacut n. 125, 15-22 nov. 1990, p. 5).

157 O documento acrescenta ainda a "não-privatização das estatais", "reforma agrária sob controle dos trabalhadores" e "assentamento imediato dos acampados e política agrícola" (CUT, 1990, p. 04).
} 
movimento sindical e conclama os movimentos populares e o povo em geral para uma campanha nacional de luta contra as medidas econômicas recessivas e de arrocho salarial autoritariamente impostas pelo governo Collor" (CUT, 1990, p. 01). ${ }^{158}$

Nessa plenária, a CUT define um "Plano de Lutas envolvendo o conjunto dos trabalhadores" que correspondesse ao "novo período da luta de classes no país, combinando a resistência à política neoliberal com a construção de alternativas a esse projeto que sejam hegemônicas no campo popular" para enfrentar o governo, avaliado pela central como "antipopular, antinacional e antidemocrático" (CUT, 1990, p. 2-3). Essa preocupação poderia ser interpretada, à primeira vista, como o início de uma política de organização dos trabalhadores desempregados, já que na proposta da entidade "os interesses de outros setores populares e dos trabalhadores não organizados, também atingidos pelo projeto Collor, serão defendidos pelo movimento sindical" (CUT, 1990, p. 2). ${ }^{159}$ No entanto, em nenhum momento a CUT explicitou essa proposta. Como o próprio documento expressa, a central propunha representar os interesses dos trabalhadores "não organizados" ou atuar conjuntamente com o movimento popular, o que não significa que iria investir em sua organização para a luta.

No segundo semestre o governo convocou trabalhadores e empresários para um "entendimento nacional". A partir de setembro, os dirigentes cutistas entraram em conflito sobre sua participação nessa mesa de diálogo. ${ }^{160}$ Porém, a direção da central decidiu ir à negociação, sob o seguinte argumento: “(...) a CUT não vai a um pacto social, e sim, os trabalhadores vão negociar suas reivindicações". ${ }^{161}$ Este evento seria um dos marcos do propositivismo do setor majoritário cutista na década de 90, ainda que, em meio a esta decisão, alguns membros da diretoria tenham redigido um manifesto intitulado "Que a CUT saia do pacto já!". ${ }^{162}$

Nesse período a denúncia das demissões foi uma constante nos documentos consultados. No entanto, a CUT defendia a idéia de que o desemprego tinha um caráter

\footnotetext{
${ }^{158} \mathrm{Na}$ avaliação da central, "sob o pretexto de zerar a inflação" o governo adotou um pacote econômico que "arrochou os salários" e "aumentou o desemprego". Ademais, para a entidade, a política de Collor estava pautada em um "modelo econômico ortodoxo, de inspiração neoliberal, baseado no receituário do FMI [Fundo Monetário Internacional]" (CUT, 1990, p. 01).

${ }^{159}$ Em outra passagem, a CUT avaliava também a necessidade de unificar a luta "numa experiência de 'campanha salarial' da classe trabalhadora, impulsionando a solidariedade de classe e uma cultura de ações unitárias e intersindicais" "articulada com todos os setores populares e democráticos organizados da sociedade civil" (CUT, 1990, p. 03).

${ }^{160} \mathrm{O}$ entendimento em debate. Informacut $\mathrm{n} .117,13-20$ set. 1990, p. 1-3.

${ }^{161}$ CUT decide: vai à negociação. Informacut n. 118, 20-27 set. 1990, p. 1

${ }^{162}$ A negociação e mobilização continuam. Informacut $n$. 126, 22-29 nov. 1990, p. 1
} 
passageiro, semelhante à conjuntura de 1981 a 1984. A central argumentava sobre seu caráter sazonal no Brasil, que no segundo semestre sempre apresentava sinais de "aquecimento" devido ao consumo de fim de ano. ${ }^{163}$

Na avaliação da CUT a crise que vivia o país poderia ter sido pior se não fosse a atuação da central: "Foram as mobilizações ao lado das negociações que impediram maiores descalabros e têm segurado uma deterioração ainda maior das condições de vida dos trabalhadores e, portanto, da economia nacional". ${ }^{164}$ A central ressaltou ainda seu papel no Fórum de Negociação Nacional e suas mobilizações em defesa do salário e do emprego. ${ }^{165}$ No final do ano, convocou, para 19 de dezembro, o "Dia Nacional de Mobilização Contra a Recessão e o Desemprego". ${ }^{166}$

Em 1991, o primeiro protesto cutista que envolveu a temática do desemprego foi o ato do "Dia Nacional de Mobilização em defesa do emprego e do salário, contra a recessão e a privatização do setor público". ${ }^{167}$ Em seguida, juntamente com outras representações sindicais e líderes partidários, de organizações da "sociedade civil" e do movimento popular, a CUT participou da criação do Fórum Nacional Contra a Recessão e a Fome. ${ }^{168}$

Em fevereiro, os petroleiros entraram em greve por "reposição salarial, fim da privatização da empresa [a Petrobrás], reintegração de 800 demitidos, comissão de saúde com estabilidade e um plano de cargos e salários". ${ }^{169}$ No mês seguinte, ocorreu uma das manifestações mais expressivas dos sindicatos cutistas contra a redução dos postos de trabalho: a greve nacional dos metalúrgicos realizada para o dia 15 de março, no aniversário de um ano do governo Collor, em protesto contra as 300 mil demissões ocorridas no setor ao longo de 1990. ${ }^{170}$ Para o mesmo dia, a CUT anunciou o "Dia Nacional de Protesto e Luta

\footnotetext{
${ }^{163}$ Emprego e salários no governo Collor. Informacut n. 124, 08-15 nov. 1990, p. 1. Quando o Dieese/Seade divulga uma redução das taxas de desemprego na Grande São Paulo, a central declara: "isso já era esperado devido à sazonalidade da economia”. (A conjuntura econômica. Informacut n. 127, 29 nov. - 06 dez. 1990, p. 1). ${ }^{164}$ Desemprego: a bomba relógio explode no Natal. Informacut n. 128, 12-19 dez. 1990, p. 1

${ }^{165}$ Não à recessão: em defesa do salário e do emprego. A conjuntura econômica. Informacut n. 129, $20-27$ dez. 1990, p. 1

${ }^{166} \mathrm{O}$ periódico que noticiou esta mobilização também fez referência à demissão de 1.100 trabalhadores na Brastemp que motivou o Sindicato dos Metalúrgicos de São Bernardo a convocar uma assembléia com os demitidos (Brastemp demite 1100. Informacut n. 129, 20-27 dez. 1990, p. 6).

${ }^{167}$ Em defesa do emprego e do salário, contra a recessão e a privatização do setor público. Informacut $\mathrm{n}$. 132, 17 24 jan. 1991, p. 1

${ }^{168}$ Por outro caminho já, sem recessão, inflação e miséria. Informacut n. 134, 31 jan. - 07 fev. 1991, p. 1

${ }^{169}$ Greve dos petroleiros. Informacut n. 135, 07-14 fev. 1991, p. 6

${ }^{170}$ Metalúrgicos farão greve nacional em março. Informacut n. 137, 21-28 fev. 1991, p. 1.
} 
contra o governo Collor por salário, emprego e pão". ${ }^{171} \mathrm{O}$ evento mais marcante que levou à convocação dessa mobilização foi a greve dos trabalhadores da Autolatina em protesto pelo corte de 8.110 funcionários da empresa em São Paulo, São Bernardo, Osasco e Taubaté. ${ }^{172}$

Nos meses seguintes ainda seriam convocadas as Jornadas de Abril, uma série de mobilizações que antecederam o ato do Dia do Trabalhador, e a greve geral de 22 e 23 de maio "contra a política do governo Collor". Neste evento, de acordo com a CUT, 19.5 milhões de trabalhadores paralisaram suas atividades nos dois dias do protesto. ${ }^{173}$

No segundo semestre de 1991 o tema do desemprego desapareceu parcialmente dos documentos consultados. Porém, a central argumentava que, apesar do clima de "calmaria" que o governo tentava criar, aquela seria "a maior recessão da história do país". ${ }^{174}$ As ações da CUT foram marcadas nesse período pela luta por uma política salarial de reajuste baseada na reposição de perdas e aumento real do salário mínimo, como atestou o lançamento da campanha "SOS Salário", aprovada pela Executiva Nacional. ${ }^{175}$ Também foram importantes nesse contexto os protestos da central contra as privatizações, especialmente após a publicação do edital do leilão da Usiminas, em 29 de junho de $1991 .{ }^{176}$ Concomitante a esse processo, a entidade se voltou também para a crise política do governo e as denúncias de corrupção. ${ }^{177}$

A leitura da conjuntura feita pela CUT naquele momento era de que o desemprego foi provocado pela política recessiva do governo Collor nos primeiros meses de seu governo, sob a estratégia do "choque". Segundo a central os empresários também foram vitimizados após o confisco da poupança, que os "obrigaram" a negociar a redução da jornada com os trabalhadores, "dada a escassez de recursos para o pagamento de salários". ${ }^{178}$

\footnotetext{
${ }^{171}$ Mobilização Nacional para combater a recessão, o desemprego e o arrocho. Informacut n. 138, 28 fev. - 07 mar. 1991, Encarte Especial

${ }^{172}$ Protestos contra demissões na Autolatina. Informacut n. 137, 21-28 fev. 1991, p. 1. Ritmo de demissões cai nas indústrias. Informacut n. 142, 28 mar. - 04 abr. 1991, p. 4. Na primeira semana a temática da jornada foi a "defesa da previdência, aposentadoria por tempo de serviço e saúde pública e gratuita". Na segunda, foi a "defesa do patrimônio e serviços públicos" ( $1^{\circ}$ de maio unificado - rumo à greve geral. Informacut n. 144, 11-18 abr. 1991, p. 1). No mesmo mês do protesto, a CUT informava sobre a redução das demissões nas indústrias: "O resultado reflete a retomada das atividades industriais que estaria sendo sustentada pelo congelamento de preços e os abonos salariais determinados pelo plano Collor 2" (Jornada de Abril rumo à greve geral. Informacut n. 143, 21-28 fev. 04-11 abr. 1991, p. 1).

${ }^{173}$ Os números da greve. Informacut n. 149, 30 mai. - 06 jun. 1991, p. 2.

${ }^{174}$ A recessão continua. Informacut n. 155, 11-18 jul. 1991, p. 1.

${ }^{175}$ SOS Salário: política salarial urgente. Informacut n. 157, 01-08 ago. 1991, p. 1.

${ }^{176}$ Violações ao patrimônio público. Informacut n. 163, 26 set. - 02 out. 1991, p. 1.

177 A crise de governo e os trabalhadores. Informacut n. 164, 03-10 out. 1991, p. 1.

${ }^{178}$ Empregos e salários no governo Collor - Resenha Desep. Informacut n. 160, 15-22 ago. 1991, p. 5.
} 
A gestação do sindicalismo propositivo na central ganho novo impulso no $4^{\circ}$ Concut, ocorrido em setembro de 1991. Nas resoluções desse congresso, a CUT afirmou que, em contexto de perdas salariais, inflação e aumento do desemprego, era necessário que a central tivesse um papel negociador, no sentido de propor alternativas. Referindo-se aos primeiros anos do governo Collor a central declarou:

(...) não bastavam apenas lutas isoladas por categoria. Era necessária uma ação conjunta em que a CUT centralizasse um processo de mobilização/negociação, cumprindo seu papel de central sindical. Não bastava só reivindicar, era necessário discutir também as grandes questões nacionais (CUT, 1991, pp. 5$6)$.

Esse evento demonstrou novamente que houve descontentamento no interior da central em relação a esses encaminhamentos por parte dos setores minoritários, que acusavam a Direção Nacional de substituir a mobilização pela negociação. Esta, por sua vez, ressaltava o caráter anti-democrático e "eleitoreiro" dos setores de esquerda. Também se depreende da leitura desse documento que a avaliação da ala majoritária da central diante da busca de um "entendimento nacional", através das negociações tripartites convocadas pelo governo, foi positiva: “A participação da CUT no fórum foi um obstáculo decisivo para os objetivos do governo, que se manteve intransigente em cima de seu projeto antipopular. A CUT contribuiu, assim, para o isolamento do governo Collor e o desmascaramento de sua política econômica" (CUT, 1991, pp. 7-8). Esta leitura indica que a central acreditava na possibilidade de participação na decisão dos rumos nacionais através do diálogo nas comissões. ${ }^{179}$ Como veremos, este modelo de ação sindical, hegemônico na central, influenciou profundamente sua política de negociação do emprego, assim como esta foi um dos principais motores das mudanças nas diretrizes gerais das práticas da central. No entanto, as grandes transformações nesse terreno ainda estariam por vir.

Diante das demissões, a entidade considerava que deu uma "resposta à ofensiva patronal, não aceitando redução salarial, mobilizando os trabalhadores e exercendo o seu papel de representação nas negociações com os empresários" (CUT, 1991, p. 05). No caso específico do funcionalismo público na avaliação da CUT houve uma constante mobilização

\footnotetext{
${ }^{179}$ Esse discurso vai de encontro ao democratismo presente na central desde a sua fundação, que pode ser evidenciado em sua constante defesa do papel do Estado como gestor de políticas sociais e articulador do desenvolvimento econômico. Porém, no plano discursivo, a CUT reafirmou nesse congresso seus principais princípios políticos organizativos: "A CUT é uma central sindical classista, democrática, autônoma, unitária, de massas e pela base". A entidade também afirmou seu "objetivo de superação do capitalismo e pelo socialismo" (CUT, 1991, pp. 12-13).
} 
desse setor contra a eliminação de postos de trabalho. ${ }^{180}$ Nas negociações, a central exigiu a readmissão dos trabalhadores, o que fez com que o Governo se retirasse da mesa de diálogo "alegando intransigência da Central" (CUT, 1991, p. 06). O documento não faz referência a esta estratégia para o setor privado, adotada apenas no caso de "reversão de demissão de grevistas" (CUT, 1991, p. 07). ${ }^{181}$

Neste congresso apareceu novamente a avaliação por parte da CUT de que era preciso adotar "uma prática voltada para o conjunto da classe trabalhadora" que contemplasse os interesses dos "setores desorganizados ou excluídos do mercado formal" (CUT, 1991, p. 13). Um dos eixos estratégicos definidos pela central foi “(...) destacar a importância da mobilização e defesa dos direitos dos 30 milhões de assalariados sem carteira assinada, dos sem-terra, sem-teto, das crianças de rua etc.” (CUT, 1991, p. 14). Ou ainda:

[A central buscará] dinamizar a união dos mais amplos setores de trabalhadores e populares em geral, colocando no centro das lutas as necessidades vitais do povo. Para isso a CUT deve reunir, além do seu projeto estratégico, propostas de solução contra a fome, a carestia e o desemprego. Nesse sentido, devemos incorporar na dinâmica da Central os setores da economia informal e dos inativos, visando sua organização (CUT, 1991, p. 37).

Como se depreende da leitura dessas resoluções, a CUT apresentou propostas para o desemprego, mas os desempregados não foram contemplados em seu plano de ação, ainda que a representação dos interesses de parcelas da reserva, mais especificamente, da superpopulação relativa latente (sem-terra), estagnada (setores da economia informal) e do pauperismo oficial (sem-teto, crianças moradoras de rua e "inativos") tenha sido considerada. A parcela flutuante, cujo núcleo duro possui uma representação sindical prévia, foi levada em conta como sujeito da mobilização no momento da demissão, mas sua organização para a luta, como desempregado, não foi proposta abertamente pela central.

Ademais, em relação à política sindical de defesa do emprego, a estratégia propositiva da CUT ganhou força a partir da proposta de negociar a reestruturação nas empresas, o que acentuou a dissociação entre o desemprego e os desempregados por parte da central. Para a entidade, era necessário "enfrentar os novos desafios colocados para o movimento sindical priorizando as lutas pelo controle da introdução de novas tecnologias", sobre a qual "a CUT

\footnotetext{
${ }^{180}$ Galvão (2002) argumenta que durante a década de 1990 o sindicalismo cutista no setor público teve uma maior resistência às políticas neoliberais, especialmente às privatizações e às reformas administrativas.

${ }^{181}$ Como mostrei em minha dissertação de mestrado, essa prática se evidencia nas chamadas demissões ilegais, em que o departamento jurídico das entidades é acionado para coibir as arbitrariedades patronais. Essa tendência expressa a adesão da central à ideologia jurídica, e revela o legalismo em suas ações contra a eliminação de postos de trabalho.
} 
deve elaborar propostas referentes às reformas nas áreas de política industrial, social e em todas aquelas que afetarem os níveis de emprego, salário, renda e vida do trabalhador" (CUT, 1991, p. 38). ${ }^{182}$

No período analisado, houve importantes movimentos de resistência à eliminação de postos de trabalho, mas em determinadas declarações a central revelou sua impotência no trato da questão: "Diante das demissões ocorridas nas estatais, principalmente [Banco do Brasil] BB (...) e [Caixa Econômica Federal] CEF, a Executiva orienta aos sindicatos que enviem telegramas às diretorias destes bancos exigindo a imediata readmissão dos companheiros". 183

Em outubro de 1991, a Brastemp decidiu manter as mais de 1.500 demissões que havia anunciado. Tal decisão provocou a mobilização dos trabalhadores e um ato de protesto individual do presidente do Sindicato dos Metalúrgicos de São Bernardo do Campo, Vicente Paulo da Silva, que realizou uma greve de fome de quatro dias contra aquela decisão. Na avaliação da central, “o empresariado não está disposto a ceder em um só níquel, neste momento de crise". ${ }^{184}$ Em seguida, este Sindicato e a diretoria da empresa chegaram a um "acordo" de "demissão voluntária de 1.557 trabalhadores" em troca da não-demissão e o afastamento sem remuneração por quinze dias de três dirigentes e sete integrantes da Cipa, bem como a retirada na Justiça das "queixas-crimes relativas às invasões e aos conflitos" por parte de ambos. ${ }^{185}$

No final de 1991, a Direção Nacional aprovou a realização da campanha nacional "Por uma vida melhor - contra o arrocho, a recessão e a fome". ${ }^{186}$ Ações contra as demissões e atos seguiam sendo convocados pela central. Porém, na própria avaliação da entidade, houve perda da capacidade de resistência, como atesta o decréscimo no número de greves convocadas por seus sindicatos. ${ }^{187}$

\footnotetext{
${ }^{182}$ As iniciativas da CUT para o combate à crise. Informacut n. 174, 07-13 fev. 1992, pp. 1-2. Nesse contexto a CUT passou a participar de diversas instâncias de discussão, tais como os Conselhos Federais, as Câmaras Setoriais Federais, o Fórum do Mercosul, o Movimento Opção Brasil, o Fórum Nacional Capital e Trabalho da USP e as Câmaras Setoriais de São Paulo.

${ }^{183}$ Sem título. Informacut n. 166, 17-31 ago. 1991, p. 2.

${ }^{184}$ Chega de pagar o pato. Informacut n. 166, 17-31 out. 1991, p. 1

${ }^{185}$ Metalúrgicos e Brastemp fecham acordo. Informacut n. 167, 01-17 nov. 1991, p. 7.

${ }^{186}$ Por uma vida melhor - contra o arrocho, a recessão e a fome. Informacut n. 170, 05-26 dez. 1991 , p. 1.

${ }^{187}$ Número das greves em 1991 - resenha Desep. Informacut n. 176, 21-29 fev. 1992, p. 3. O documento afirma ainda que "Predominaram as greves no setor público, diminuiu o tempo médio das paralisações e a participação das greves por empresa ou local de trabalho foi maior do que as greves por categoria".
} 
Durante o ano de 1992, a oposição da CUT à política do governo se expressou em várias mobilizações, como no "Dia Nacional do Protesto", marcado para 13 de março. Entre as principais críticas ao governo estava a responsabilização de sua política econômica pela "crise do desemprego". Entre as prioridades da central previstas no calendário de mobilizações do ano, estavam: a "Campanha SOS salário-mínimo", que visava apresentar um "Projeto de Lei de Iniciativa Popular" sobre "a política de reajuste e de recuperação gradual do valor do salário mínimo" com o recolhimento de um milhão de assinaturas; a "Iniciativa popular contra as privatizações"; o "10 de maio unificado"188; e a participação nas Câmaras Setoriais, com o objetivo de "discutir alternativas para a crise em vários setores da economia". 189

$\mathrm{Na} 5^{\mathrm{a}}$ Plenária Nacional a CUT oficializou sua filiação à Confederação Internacional das Organizações Sindicais Livres (Ciosl) ${ }^{190}$, vista pela entidade como “(...) a única central mundial suficientemente pluralista e representativa capaz de aglutinar as diversas concepções e distintas culturas sindicais existentes no mundo" (CUT, 1992, p. 17). Galvão (2002) considera que esta decisão se inseriu no contexto de adesão da central ao sindicalismo propositivo, já que aquela organização expressava este tipo de concepção no nível internacional. ${ }^{191}$ Essa Plenária foi realizada em meio às denúncias de corrupção que envolveram o presidente Collor. A central se posicionou a favor da investigação e da constituição de uma Comissão Parlamentar de Inquérito (CPI) para apurar o caso. Mais adiante voltarei ao tema.

Nas resoluções da $5^{a}$ Plenária aparecem alguns dos argumentos freqüentes da ala majoritária para justificar o caráter propositivo que se estava gestando na central. As Câmaras Setoriais eram avaliadas como espaços adequados para travar uma "disputa" ideológica e uma oportunidade para conter o avanço das propostas empresariais:

\footnotetext{
${ }^{188}$ Este evento teve como bandeiras " $147 \%$ já, SOS salário mínimo, reposição mensal da inflação, reforma agrária, não à dívida externa e ao FMI, basta de corrupção, em defesa dos servidores públicos e das estatais".

${ }^{189}$ Mobilizar e negociar - os trabalhadores ocupando os espaços. Informacut n. 182, 16-23 abr. 1992, p. 2

${ }^{190} \mathrm{Na}$ avaliação da central, sua filiação à Ciosl se justificava por conta da necessidadde de buscar respostas "globais" para os problemas dos trabalhadores diante do atual processo de "globalização": "Soluções duradouras para os problemas atuais devem abranger espaços de atuação para além dos marcos nacionais. A defesa do emprego, do salário e dos direitos dos trabalhadores pressupõe a superação da lógica corporativa, que estimula no movimento sindical uma postura defensiva" (CUT, 1994, p. 62).

${ }^{191}$ Referindo-se ao tema, um entrevistado de uma corrente minoritária cutista e membro da Direção Nacional da central declarou "(...) hoje o processo de associação do sindicato aos capitalistas não se dá tanto no Estado Nacional, se dá no plano internacional, com a idéia da governança democrática da globalização, atrair as organizações sindicais internacionais, em particular. Mas a CUT é filiada as organizações internacionais, portanto, a CUT vai a reboque para fazer parte de uma parceria capital, trabalho e governos a nível mundial" (E16).
} 
A CUT reafirma a orientação pela participação nas câmaras setoriais como espaço onde se disputa com o projeto neoliberal de reestruturação produtiva e modernização conservadora e onde os sindicatos, representando os trabalhadores e alicerçados na sua mobilização, buscam deter a implantação desse projeto e acumular forças no sentido de um projeto alternativo, através de novas conquistas trabalhistas e sociais (CUT, 1992, p. 05).

O propositivismo da CUT diante da reestruturação produtiva se inseria na perspectiva de que esta estava sendo levada a cabo por um projeto de "modernização conservadora", ao qual a central contrapõe outro, "alternativo". A partir dessa leitura, a central passou a investir na formação e capacitação dos dirigentes para uma compreensão dos fenômenos do "mundo do trabalho", crescentemente desvinculada de uma interpretação estrutural pautada no antagonismo entre capital e trabalho. Ademais, em sua análise da conjuntura, a entidade aderiu parcialmente à tese da fragmentação da classe trabalhadora, que reduz a explicação das mudanças na subjetividade dos trabalhadores e em seus laços de solidariedade às transformações na estrutura produtiva, sem levar em conta, entre outros fatores, o papel que a a própria organização sindical, especialmente no local de trabalho, poderia cumprir para diminuir esse efeito:

A utilização crescente da automação, articulada às novas formas de organização da produção, está levando à fragmentação e à dispersão da mão-de-obra e à flexibilização das relações de trabalho. Isso tem abalado os laços de solidariedade e de sociabilidade entre os trabalhadores e alterado significativamente o perfil da classe trabalhadora (...) (CUT, 1992, p. 11).

A CUT também aderiu ao discurso de "internacionalização econômica e financeira" e de inevitabilidade da "globalização". Em sua avaliação, este processo estaria "obrigando os Estados nacionais a adotar políticas cada vez mais interdependentes" (CUT, 1992, p. 11). Nesse contexto, "algumas formas tradicionais da cooperação sindical (...) restritas muitas vezes ao campo ideológico e das concepções sindicais, têm mostrado poucos efeitos práticos" (CUT, 1992, p. 13).

A proposta de sindicalismo propositivo decorre desse tipo de leitura que passou a vigorar na central. Ora, se os processos econômicos eram "inexoráveis" e os impactos sobre a classe trabalhadora, "inevitáveis", as respostas sindicais foram naturalizadas como "realistas", pois diante de fenômenos tão incontroláveis só restava ao movimento sindical "amenizar" seus efeitos sobre os trabalhadores. As negociações diante das demissões levadas a cabo pelos principais sindicatos da central a partir desse período se constituíram no grande laboratório desse tipo de prática sindical. Porém, é nesta mesma $5^{\text {a }}$ Plenária que, pela primeira vez, a 
necessidade de organização dos desempregados foi destacada por um documento oficial da central:

A CUT deve também desenvolver seus esforços políticos, materiais e organizativos para organizar os desempregados e trabalhadores da economia informal, colocando a Central a serviço do setor da sociedade que mais tem necessidade de se organizar e lutar contra esse sistema de exploração e miséria (CUT, 1992, p. 05).

No entanto, os desempregados desapareceram do Planejamento Estratégico da central nesse mesmo documento, já que o "Projeto 8" contemplou apenas a "Organização dos trabalhadores da economia informal". Constituído em junho de 1992 sob a responsabilidade de Durval de Carvalho, membro da Executiva Nacional, este projeto começou a ser executado após a Plenária (CUT, 1992, p. 51). Um artigo publicado alguns meses depois atestou que houve um relativo avanço na organização desse segmento por parte da entidade, como se pode comprovar pelas experiências de Associação dos Ambulantes de São Paulo, Rio de Janeiro, Campinas e Guarulhos. Porém, a CUT não defende a economia informal como uma estratégia definitiva para os trabalhadores, idéia que sustenta a partir do argumento de que se deve buscar "institucionalizar o desemprego estrutural". ${ }^{192}$ Como veremos, essa foi uma das justificativas mais recorrentes dos sindicalistas entrevistados para explicar a ausência de organização de parcelas não sindicalizáveis.

A partir de maio de 1992, diante das descobertas de irregularidades envolvendo Paulo César Farias (batizado de "Esquema PC"), a CUT se mobilizou sob a bandeira do impeachment, alegando "crime de responsabilidade". ${ }^{193}$ Participou do Movimento pela Ética na Política e nos meses seguintes, foi uma das principais protagonistas das manifestações convocadas sob a bandeira de "Fora Collor". ${ }^{194}$ A crise no governo foi a questão mais tratada dos documentos consultados desse período, e o tema do desemprego não apareceu com freqüência. Antes da votação do impeachment, saiu apenas uma notícia sobre a demissão de 2.000 funcionários da Companhia Siderúrgica de Tubarão, em Vitória-ES. ${ }^{195}$

Finalmente, em outubro de 1992, após uma mobilização popular o Congresso Nacional aprovou o impeachment de Collor. O fato foi considerado pela CUT como uma "vitória histórica da democracia e da moralidade, da sociedade civil e do povo brasileiro", "graças ao maior movimento de massas desde as Diretas Já, à mobilização de milhões de trabalhadores,

\footnotetext{
${ }^{192}$ CUT debate organização do setor informal. Informacut n. 200, 22-29 out. 1992, p. 9

${ }^{193}$ Basta de corrupção. CPI pra valer. Impeachment para Collor. Informacut n. 187, 04-11 mai. 1992, p. 1.

${ }^{194}$ Pela ética na política. Informacut n. 190, 02-09 jul. 1992, p. 1.

195 Modernização de Collor: desemprego. Informacut n. 197, 17-24 set. 1992, p. 8.
} 
estudantes, profissionais liberais, empresários”. Na avaliação cutista, esta luta, travada especialmente contra a corrupção, "capitalizou a insatisfação geral com a estratégia collorida de recessão, degradação salarial, desemprego e marginalização em massa". ${ }^{196}$

As propostas cutistas de combate ao desemprego entre 1992 e 1995 foram muito semelhantes às do período anterior, além do aparecimento de algumas bandeiras. Quando a central entregou seu conjunto de reivindicações ao governo Itamar, afirmou que era necessário "crescimento econômico com ênfase na geração de postos de trabalho". ${ }^{197}$ Esse argumento marcou uma mudança discursiva no interior da central, já que ao longo de sua história promovia um discurso crítico ao chamado "milagre econômico" brasileiro. No plano teórico, efetivou a consolidação de uma leitura predominantemente keynesiana do desemprego no interior da central que, como vimos, nos anos 80 se baseava com mais freqüência nos referenciais marxianos de explicação do fenômeno. ${ }^{198}$

A partir do final de 1992 se iniciou uma preocupação na CUT pela participação na elaboração de propostas de políticas de emprego, como atestou a decisão da Direção Nacional de "oficializar a constituição de uma comissão para discutir e elaborar a questão da formação profissional". ${ }^{199}$ A entidade passou a considerar a possibilidade de utilização de recursos do FAT, avaliando que estes vinham sendo mal geridos, inclusive pelo Bndes ${ }^{200}$, que financiava empresas sem a exigência de manutenção do nível de emprego. ${ }^{201}$ A CUT decidiu participar do Conselho Deliberativo do Fundo de Amparo ao Trabalhador (Codefat) e logo em seguida este Fundo deliberou uma verba 1 bilhão de dólares para a realização de empréstimos para empresas comprometidas com a geração de postos de trabalho. ${ }^{202}$ A partir de maio de 1993, o Conselho começou a discutir a liberação de recursos para o programa do Serviço Nacional de Emprego (SINE) e para a "operacionalização do seguro-desemprego", a "intermediação dos desempregados" e sua "reciclagem profissional". ${ }^{203}$

\footnotetext{
${ }^{196}$ Impeachment: a vitória é nossa. Informacut n. 199, 8-22 out. 1992, p. 1

${ }^{197}$ CUT entrega a Itamar reivindicações dos trabalhadores. Informacut n. 200, 22-29 out. 1992, p. 2

${ }^{198}$ O diagnóstico que a CUT apresentou sobre o desemprego durante o $6^{\circ}$ Concut é de que este era causado pelo "progressivo declínio das taxas de crescimento econômico, aliado ao desenvolvimento tecnológico com aplicação condicionada pelas relações de produção características de tal sistema" (CUT, 1997, p. 10). Ou ainda: "Para incorporar, anualmente, todos aqueles que ingressam no mercado de trabalho e reduzir as taxas atuais de desemprego seria necessário que o país voltasse a crescer cerca de 7\% ao ano" (CUT, 1997, p. 43).

199 A formação profissional em debate. Informacut n. 205, 17 dez. 1992-07 jan. 1993, p. 10

${ }^{200}$ Banco Nacional de Desenvolvimento Econômico e Social.

${ }^{201}$ Atuação dos sindicatos pode ser via FAT. Informacut n. 205, 17 dez. 1992-07 jan. 1993, p. 10

${ }^{202}$ FAT financia programa de geração de empregos. Informacut n. 214, 19-29 abr. 1993, p. 3

${ }^{203}$ Codefat debate políticas de emprego. Informacut n. 218, 27 mai. - 03 jun. 1993, p. 5
} 
A posição da central nesse período também foi marcada pela continuidade da crítica às políticas do governo e às estratégias patronais. Os planos de demissão voluntária nas empresas estatais privatizadas foram denunciados sistematicamente pela entidade. Um exemplo se deu na Companhia Vale do Rio Doce, que em menos de dois meses após a privatização havia demitido aproximadamente 1.200 empregados, sem cumprir a promessa de “indenização imediata, nova recolocação no mercado de trabalho através da terceirização ou da constituição de empresas especializadas na reciclagem e recontratação de funcionários". 204

Em seu Plano de Ação para o ano de 1993 a CUT definiu como uma de suas metas prioritárias o combate à "política privatista neoliberal". ${ }^{205}$ Após a expectativa acerca das primeiras medidas que seriam adotadas por Itamar Franco, a central passou a criticar de maneira mais contundente sua política econômica, especialmente a "manutenção de juros reais elevados". ${ }^{206}$ Em suma, na avaliação da entidade o governo apenas havia introduzido "mudanças no ritmo e nos mecanismos das reformas". ${ }^{207}$ Porém, ao avaliar a "insuficiência" das transformações e a "frustração dos trabalhadores e da população", a central afirmou que "apesar da origem comum, o governo Itamar se diferencia do governo anterior pelo fato que há um refluxo nos atos imperiais do governo Collor, que procurava impor a pauta liberalconservadora à sociedade". ${ }^{208}$ No entanto, com o anúncio do Plano Itamar, que entre outras medidas, buscava "ampliar e acelerar" as privatizações, "estendendo-as às áreas de energia e transportes", a CUT reforçou a leitura de que o novo governo era "muito parecido com seu antecessor". 209

Durante o mandato de Itamar, o desemprego praticamente desapareceu das discussões da central. Nesse momento, a posição oficial do governo, expressa pelo Ministro do Trabalho Walter Barelli, era de que a diminuição dos encargos incidentes sobre a folha salarial no Brasil provocaria crescimento do emprego formal e do salário real. A CUT argumentava que essa medida apenas serviria para "ampliar os ganhos das empresas sem que essas necessitem

\footnotetext{
${ }^{204}$ Demitidos da Vale alertam contra a "modernidade” das privatizações. Informacut n. 205, 17 dez. $1992-07$ jan. 1993, p. 19

${ }^{205}$ Informacut n. 205, 17 dez. 1992-07 jan. 1993, p. 3. Também nesse ano a central afirmava que iria investir em uma "nova cultura sindical" que combatesse as "heranças do sindicalismo oficial", priorizando a inserção da perspectiva de Organização no Local de Trabalho (OLT) nas campanhas salariais nacionais articuladas (Plano de ação organizativa da CUT. Informacut n. 04-11 mar. 1993, p. 3).

${ }^{206}$ Itamar vai empurrar a crise com a barriga. Informacut n. 209, 11-18 fev. 1993, p. 5

${ }^{207}$ O governo Itamar e a agenda política até 94 . Informacut n. 211, 11-18 mar. 1993, p. 5

${ }^{208}$ A CUT e o governo Itamar. Informacut n. 212, 25 mar. - 01 abr. 1993, p. 1

${ }^{209}$ A CUT e o Plano Itamar. Informacut n. 215, 29 abr. - 06 mai. 1993, p. 1. No mesmo mês a CUT participou da CPI das privatizações, com o intuito de "auxiliar a apuração das denúncias de falcatruas nos processos de privatizações realizadas" (CPI das privatizações. Informacut n. 27 mai. - 03 jun. 1993, p. 2).
} 
realizar novos investimentos produtivos e tecnológicos nem buscar estratégias competitivas de mercado". 210

Um dos eventos mais importantes da resistência cutista às demissões foi a criação da Coordenação Nacional dos Demitidos das Estatais. O objetivo do movimento era a "reintegração imediata dos demitidos dos serviços públicos" de empresas privatizadas durante a "reforma administrativa do governo Collor". ${ }^{211}$ Como fruto da mobilização dessa comissão o governo Itamar instaurou um processo de avaliação dos pedidos de reintegração através de um projeto de lei de anistia aos trabalhadores dispensados. ${ }^{212}$

Novamente a política cutista para os demitidos foi justificada a partir de argumentos legais, o que revela a aceitação da central da ideologia jurídica na resolução dos conflitos. Mas a luta da CUT contra a demissão no terreno do Direito ganharia um contorno ainda mais nítido. A central buscava aprimorar o serviço de homologação oferecido pelos sindicatos, o que atesta a institucionalização da ação sindical diante do desemprego como expressão de sua acomodação à estrutura oficial. Essa função burocrática de extensão administrativa do Ministério do Trabalho e do departamento de recursos humanos das empresas é pouco questionada pelos dirigentes. Ao contrário, a própria entidade reconhece a importância de seu papel legal de fiscalizadora do cumprimento da lei durante o processo de demissão:

Um grupo de advogados, assessores da CUT, preparou um parecer para auxiliar os sindicatos na hora das homologações. (...) Agora, ao invés do "carimbo genérico", os sindicatos deverão ressalvar os valores, discriminando item por item e identificando os motivos da ressalva, como por exemplo: reajuste insuficiente, horas extras a reclamar etc. ${ }^{213}$

Como se pode observar, as demissões no Brasil são legitimadas através de um grande acordo tripartite, no qual os empresários possuem o livre arbítrio para demitir, o governo garante ao trabalhador uma indenização com a instituição do Fundo de Garantia do Tempo de Serviço (FGTS), e os sindicatos fazem a homologação, conferindo que ambos cumpriram seu papel dentro da lei. É a partir do exercício dessa função que as entidades sindicais distinguem a figura do demitido legal e ilegal, sobre as quais o departamento jurídico das entidades se

\footnotetext{
${ }^{210}$ Os encargos sociais no Brasil - resenha Desep. Informacut n. 219, 03-10 jun. 1993, p. 5

${ }^{211}$ Demitidos criam coordenação nacional. Informacut n. 212, 25 mar. - 01 abr. 1993, p. 17

${ }^{212}$ Executiva acompanhará Comissão dos Demitidos. Informacut n. 229, 27/10/ 1993, p. 4. No final de julho de 1994 foi concedida a reincoporação desses trabalhadores a partir da lei de anistia 8878/94, "reparando, assim, um ato arbitrário, ilegal e inconstitucional" (Demitidos pedem auxílio para fazer encontro. Informacut n. 243, 21/07/1994, p. 16).

${ }^{213}$ CUT orienta sindicatos na hora da rescisão. Informacut n. 236, fev. 1993, p. 7
} 
pauta para levar a cabo processos de reintegração. ${ }^{214}$ Apesar dessa presença constante dos demitidos/desempregados nas entidades, não foi desenvolvida uma política de organização desse segmento por meio de associações, tal como estiveram presentes na década de 80 .

Durante a $6^{\text {a }}$ Plenária Nacional, ganha forçou na CUT a idéia de reestruturação produtiva "negociada". ${ }^{215}$ A central passou a se preocupar em conhecer as transformações no processo produtivo e ressaltou a participação nas câmaras e fóruns institucionais tripartites, vistos como instância onde os sindicatos deveriam intervir no debate e "contrapor suas propostas às políticas neoliberais do governo" (CUT, 1993, p. 03). A organização dos desempregados e dos trabalhadores "informais" não apareceu no documento analisado. Uma das poucas declarações sobre o desemprego foi apresentada na reivindicação pela reforma agrária, vista pela CUT como um "fator de geração de empregos" e como um "instrumento econômico e político e não só como um instrumento de política social” (CUT, 1993, p. 10).

O ano de 1994 marcou um ponto de inflexão no cenário nacional. O anúncio da criação da Unidade Real do Valor (URV), o índice de medida diária da inflação sem correspondência direta com o dólar, gerou desconfiança no interior da CUT. ${ }^{216}$ A principal preocupação da central era a possibilidade de perdas salariais. ${ }^{217}$ A avaliação da CUT sobre o plano a levou a convocar uma greve geral para o dia 23 de março. ${ }^{218}$ A partir de então aumentaria o descontentamento da entidade com relação ao governo de Itamar, que segundo a central, por meio de seu ministro da Fazenda, FHC, promovia a continuidade da plataforma neoliberal iniciada por Fernando Collor. Nas resoluções do $5^{\circ}$ Concut, a central diagnosticou que o Plano Real era parte do processo de "dolarização da economia brasileira", e argumentou que a redução dos índices de inflação seria mantida através de um "câmbio artificialmente fixo durante alguns meses" (CUT, 1994, p. 14). ${ }^{219}$

Nesse congresso a CUT argumentou que as causas do desemprego eram, por um lado, as políticas neoliberais, e por outro a reestruturação produtiva no campo e na cidade, com a

\footnotetext{
${ }^{214}$ Em minha dissertação de mestrado, avaliei como essa questão se manifestou no Sindicato dos Metalúrgicos de Campinas e Região (Souza, 2005b).

${ }^{215}$ Como bem afirma Boito Jr. (1999) a CUT discute a reestruturação produtiva do ponto de vista das empresas.

${ }^{216}$ Plano FHC pode aumentar arrocho. Informacut $n$. 232, 13/ 12/1993, p. 1. Para uma análise mais detalhada da posição da CUT sobre o plano econômico do governo, ver "Desastre econômico à vista: novo plano econômico no Brasil". Informacut n. 232, 13/ 12/1993, pp. 4-5.

${ }^{217}$ O Plano FHC2 e os salários. Informacut n. 235, 10/02/1994, p. 4-5

${ }^{218}$ Direção decide deflagrar greve contra o Plano FHC. Informacut n. 235, 10/02/1994, p. 4-5

${ }^{219}$ Segundo a central, as causadoras da inflação eram a dívida externa e a dívida pública interna, fruto de uma política de "subordinação ao grande capital internacional, aos governos dos países avançados e ao FMI" (CUT, 1994, p. 39).
} 
implementação de tecnologias e novos métodos de gestão. Com base em tal leitura, a central aprimorou a formulação de propostas de combate ao desemprego, especialmente a partir de março de 1994 durante a campanha pelo emprego que a central realizou. Além das propostas já citadas ao longo deste capítulo, a central defendeu o "fim da dispensa imotivada", o "investimento público orientado para setores que absorvem grandes contingentes de mão-deobra", a "formação profissional adequada às novas exigências do mercado de trabalho e com participação da representação sindical", a "política econômica orientada para a retomada do crescimento com distribuição de renda", um "programa específico de geração de renda" que focalizasse "pequenos produtores, artesãos, trabalhadores autônomos" e "formas associativas" (cooperativas, mutirões etc.) (CUT, 1994, pp. 17-18). ${ }^{220}$ No entanto, o desempregado seguiu sem aparecer como sujeito da mobilização e a entidade se restringiu a orientar seus sindicatos a criar um banco de dados para o oferecimento de serviços: "cada sindicato deve abrir um cadastro de desempregados da categoria, tanto para sistematizar a denúncia concreta sobre a situação em cada setor, quanto para inserir esses trabalhadores em projetos que venham a ser desenvolvidos para a geração de emprego e renda". 221

Como já mencionei, a CUT se referia à renovação técnica do capitalismo como um processo de "reestruturação excludente" (CUT, 1994, p. 09) ao qual contrapunha uma "reestruturação produtiva com desenvolvimento econômico e social". A entidade defendeu um projeto includente e gerador de empregos, ainda que, de maneira ambígua, ressaltase o caráter conflituoso das relações entre capitalistas e trabalhadores:

A busca de um novo modelo de desenvolvimento deve ter como objetivo central a incorporação plena dos trabalhadores e dos marginalizados à vida econômica e social. (...) Devemos disputar as idéias de "qualidade e produtividade" partindo de uma perspectiva da qualidade de vida e trabalho para as maiorias e da distribuição dos frutos do aumento da eficiência do trabalho para o conjunto dos assalariados e da massa de excluídos. Nesse processo se afirma o caráter conflitivo das relações capital-trabalho, negando a ideologia empresarial de parceria (CUT, 1994, p. 29). ${ }^{222}$

O $5^{\circ}$ Concut representou um salto qualitativo na decisão estratégica da CUT de investir na participação institucional em instâncias deliberativas que discutissem a gestão pública. Nesse contexto, a central defendeu políticas industriais, que conciliassem o aumento do

\footnotetext{
${ }^{220}$ Em seguida o documento inclui a proposta de "Expansão do programa de seguro-desemprego com base na gestão democrática dos fundos sociais (FGTS, FAT e FDS)" (CUT, 1994, p. 40).

${ }_{221}$ A CUT na campanha pelo emprego. Informacut n. 237, 21/03/1994, p. 5.

${ }^{222}$ Mais adiante a CUT argumentou que as negociações diante da reestruturação produtiva possuem um respaldo legal, já que se trata de um "direito constitucional dos trabalhadores (Artigo $7^{\circ}, \mathrm{XXVII)}$ desconhecido por muitas de nossas lideranças" (Reestruturação produtiva. Informacut n. 259, dez. 1995, p. 29).
} 
investimento, da tecnologia e da produtividade com o incremento da formação profissional e da qualidade de vida do trabalhador (CUT, 1994, p. 30).

Nesse congresso a CUT sistematizou sua Política Nacional de Formação e de Formação Profissional, para as quais foi dedicado todo um item das resoluções. Nessa época, a central já contava com uma rede de escolas sindicais. ${ }^{223}$ A concepção cutista de formação profissional se baseava em uma proposta de metodologia alternativa ao "adestramento" do sistema "S". A entidade fundamentava seus cursos com base na pedagogia de Paulo Freire, a partir da qual desenvolveu seu projeto "global e emancipador" como uma forma de disputar as idéias dos trabalhadores apresentando-lhes uma contraposição à visão empresarial por meio do "exercício de uma concepção radical de cidadania". Também se inseriu na perspectiva geral de educação pública proposta pela central, na qual os trabalhadores devem ter capacidade de ser gestores diretos (CUT, 1994, p. 103).

No item "Formação profissional", a CUT definiu como uma de suas ações de curto prazo a "vinculação das iniciativas de formação ou requalificação profissional à garantia do emprego e à ampliação de sua oferta, através da elevação do nível cultural, científico e tecnológico dos trabalhadores" (CUT, 1994, p. 106). Com base nesse tipo de leitura, amadureceu na CUT, a partir de então, a proposta política de oferecer serviços aos desempregados, o que contribuiu definitivamente para o afastamento, no interior da central, da idéia de organizar este segmento para a luta, tal como havia considerado, ainda que de maneira pouco elaborada, no começo da década de 90. A entidade seguiu denunciando as demissões ${ }^{224}$, embora nesse momento a questão salarial era o principal motivo das paralisações, como ocorreu na greve dos petroleiros. ${ }^{225}$

O ano de 1995 se iniciou com uma forte oposição da CUT ao governo de $\mathrm{FHC}^{226}$ A central reconhecia a queda nos índices de inflação, apesar de ressaltar a continuidade do

\footnotetext{
${ }^{223}$ Estas eram divididas em conveniadas (Escola Quilombo dos Palmares, em Pernambuco, Escola Sindical 7 de Outubro, em Minas Gerais, Instituto Cajamar, em São Paulo) e orgânicas (Escola Sindical Sul, em Santa Catarina, Escola Sindical do Norte, no Pará, Escola Sindical São Paulo e Escola Sindical Centro-Oeste, no Distrito Federal (CUT, 1994, p. 85).

${ }^{224}$ Ver, por exemplo, o artigo: Desemprego, o principal drama dos trabalhadores brasileiros. Informacut n. 246, 01/10/1994, p. 5

${ }^{225}$ Governo cede e negocia com petroleiros. Informacut n. 247, nov. 1994, p. 4-5. Sobre este evento, a CUT denunciou a "truculência" contra os trabalhadores na ação do Exército para reprimir o movimento (Ausência de políticas sociais e truculência contra os trabalhadores. Informacut n. 255, 1ª quinzena ago. 1995, p. 10-13).

${ }^{226}$ A CUT e o governo FHC. Informacut n. 249, jan. 1995, p. 20-24.
} 
desemprego e do arrocho salarial. ${ }^{227}$ Seguia defendendo uma estratégia propositiva, o que pode ser atestado por sua disposição de participar dos fóruns tripartites, como na proposta de criação de uma Câmara de Relações de Trabalho. ${ }^{228}$

Nesse momento, o propositivismo na CUT se evidenciava na posição que a central assumia diante da reestruturação produtiva: "As exigências de modernização do parque produtivo brasileiro, para competir no mercado atual e suprir necessidades e demandas da população, requerem investimentos em novas tecnologias e melhoria da qualidade e produtividade". ${ }^{229}$ Com base nessa leitura, a entidade reforçou o conceito de "reestruturação negociada", tal como se observa na $7^{\text {a }}$ Plenária Nacional, sob o argumento de que "o conjunto de métodos e técnicas de organização e gestão do processo produtivo vêm demarcados pela lógica da exclusão" (CUT, 1995, p. 24). A CUT também aprofundou a elaboração de propostas de política de educação e formação profissional que, se no plano discursivo se mostrava contrária à tese da empregabilidade, na prática se apresentava com argumentos semelhantes:

Denunciando a falácia ideológica, veiculada no discurso de setores governamentais e empresariais, de resolver o problema do desemprego através da educação e do ensino profissional, reafirmamos nossa posição quanto à sua importância na formação dos trabalhadores aptos a enfrentarem técnica e politicamente a reconversão produtiva (CUT, 1995, p. 28). ${ }^{230}$

A CUT também defendeu a criação de Centros Públicos de Ensino Profissional (CPEP) que teriam o objetivo de "atender às demandas específicas e permanentes de qualificação de milhares de jovens e adultos, empregados e desempregados". A central argumentou que "O processo seletivo existente no Senai exclui os trabalhadores desempregados do acesso aos cursos de reciclagem profissional" e que "Os Centros Públicos consistem em uma opção democrática para profissionalização e re-qualificação" (CUT, 1995, p. 32). Nesse contexto, a entidade apresentou suas "Propostas Relativas à Organização dos Cursos de Formação e Reciclagem Profissional (Convênios com o SINE, utilizando recursos do FAT)”, inserida na bandeira de "melhorar o atendimento aos desempregados - para além da ampliação dos

\footnotetext{
${ }^{227}$ Editorial - Este ano promete. Informacut n. 249, jan. 1995, p. 1. O ano de 1995 também foi marcado pelo início do Mercosul. Após debates com as centrais dos quatro países integrantes, a CUT assinou um documento dirigido aos governos, intitulado "Por um Mercosul com desenvolvimento social e democracia" (Dirigentes sindicais pedem democratização do Mercosul. Informacut n. 249, jan. 1995, p. 4-7).

${ }^{228}$ Sistema Democrático de Relações de Trabalho e Contrato Coletivo. Informacut n. 254, jul. 1995, p. 16.

${ }^{229}$ Sistema Democrático de Relações de Trabalho. Informacut n. 250, jan. 1995, p. 34.

${ }^{230}$ Mais adiante a central afirmou que: "A requalificação profissional é um serviço de fundamental importância no quadro atual, em particular para os atingidos por desemprego decorrente de alguma modernização tecnológica (CUT, 1995, pp. 34-35).
} 
investimentos produtivos, base da geração de novos empregos". A central sustentou, ademais, que este projeto “(...) obrigatoriamente deve incluir a requalificação profissional e a intermediação de empregos, permitindo ao trabalhador desempregado voltar a trabalhar de forma digna. (CUT, 1995, p. 33). Na 7ª Plenária Nacional a central se propôs ao "desafio de transformar os sindicatos filiados em sindicatos orgânicos" (CUT, 1995, p. 07), que segundo a entidade poderia ser o começo de uma política de representação dos desempregados. No entanto, a proposta não foi levada a cabo pela central, que passou a investir crescentemente no oferecimento de serviços a este segmento. Ainda nessa plenária apareceu pela primeira vez nas fontes consultadas a bandeira de cooperativas e empresas auto-geridas". 231

Segundo a CUT, a "reestruturação industrial" provocava "sobre o mundo do trabalho" o "desemprego estrutural e crônico". Entre os "impactos" desse processo sobre o "poder sindical", a central destacou seu "poderoso instrumento de pressão empresarial para forçar a informalização e redução dos direitos", além de "pressionar os trabalhadores para isolar (...) seus diversos níveis de organização das negociações relativas ao engajamento dos trabalhadores nos programas das empresas" e reduzir "a base de representação dos sindicatos". 232

Não se pode deixar de mencionar que, durante o período analisado neste item, o horizonte socialista não foi totalmente abandonado pela central, inclusive nas considerações que esta fazia sobre a reestruturação produtiva: "Só será possível que os avanços tecnológicos se tornem benefícios aos trabalhadores se o capitalismo for destruído". ${ }^{233}$ Apesar desse discurso, a central adotou crescentemente a estratégia de conciliação entre políticas industriais e sociais: "a elevação contínua da produtividade industrial deve resultar da elevação da produtividade social e não da demissão em massa de trabalhadores e da crescente precarização e informalização do mercado de trabalho (...)". ${ }^{234}$

\footnotetext{
${ }^{231}$ O Plano Real e o desempregado. Informacut n. 258, out. 1995, pp. 13-14

${ }^{232}$ Reestruturação produtiva. Informacut n. 259 , dez. 1995, pp. 26-27. Na avaliação da central, a participação das entidades sindicais nos fóruns tripartites foi positiva, ainda que reconheça seus limites: “(...) nestes espaços institucionais, a participação da CUT em vários momentos conseguiu inibir posturas empresariais e governamentais mais truculentas. (...) [Porém,] não temos conseguido, ainda, fazer que essa participação se combinasse com a conquista de instrumentos para exercer uma influência legal (ou mesmo, uma influência contratual) sobre a reestruturação produtiva. Em síntese, o saldo de nossa atuação visando o objetivo anunciado, qual seja a 'influência' sindical sobre o processo de reestruturação, especialmente através de negociações e acordos coletivos, é limitado" (idem, p. 29).

${ }^{233} \mathrm{Idem}, \mathrm{p} .31$.

${ }^{234}$ Idem, p. 32.
} 
Na primeira metade da década de 90, a CUT reconheceu que, diante do desemprego, teve uma "atuação essencialmente defensiva, com raras exceções". A central apresentou propostas de combate à eliminação de postos de trabalho, mas sem organizar os desempregados para a luta. Em consonância com suas mudanças mais gerais de concepção sindical, passou a defender políticas passivas de assistência e oferecimento de serviços para "atender" esse segmento, através da "ampliação do seguro-desemprego", da "intermediação da mão de obra" e da "melhoria da reciclagem profissional”, “(...) articulando-se um Sistema Público de Emprego com a direta participação dos trabalhadores nas suas instâncias de deliberação". ${ }^{235}$ Veremos no próximo item como a CUT concretizou essas políticas.

\section{A Força Sindical}

A Força Sindical (FS) foi fundada em 8 de março de 1991, com uma proposta de central

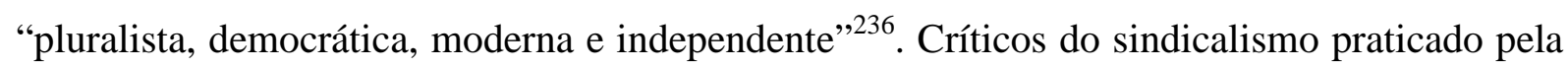
CUT e pela CGT, os dirigentes fundadores da entidade afirmavam estar "cansados do radicalismo estéril ou do conformismo de outras centrais"237 A FS se definia como uma central "apartidária" e afirmava não almejar ser "correia de transmissão de um partido político", tal como verificava na relação entre a CUT e o PT, tendo sido criada para apresentar uma "proposta alternativa de mobilização". Em seu congresso de fundação estiveram presentes 1.793 delegados, representantes de 783 sindicatos e federações. ${ }^{238}$

O sindicalismo propositivo da FS está pautado no discurso de colaboração de classes, no qual o empresário é visto como parceiro que deve ceder parte de seus lucros em prol de um benefício social comum. Como afirmou o fundador e primeiro presidente da central, Luiz Antonio de Medeiros: "É preciso lutar contra as empresas que só querem o lucro fácil, e a qualquer custo. O lucro é justo, mas só é aceitável quando há justiça social, quando há distribuição de renda". ${ }^{239}$ O caráter aliancista da central pode ser expresso na seguinte passagem:

\footnotetext{
${ }^{235}$ Reestruturação produtiva. Informacut n. 259, dez. 1995, p. 34.

236 "Editorial". Revista da Força Sindical, Ano 1, n. 1, junho de 1991, p. 3.

237 "A bandeira que vai mudar este país". Revista da Força Sindical, Ano 1, n. 1, junho de 1991, p. 5.

${ }^{238}$ Idem, p. 10. A pesquisa de Cardoso e Rodrigues (1993) revela que, do conjunto dos delegados prensetes no congresso de fundação, no primeiro turno das eleições presidenciais de 89, Lula recebeu 27.4\%, Covas, $17.9 \%$, Brizola, $17.6 \%$, Collor, $14.7 \%$ e Roberto Freire, 5.3\%. Em vários documentos consultados, a central se apóia nesses dados para argumentar sobre seu suposto pluralismo.

239 “Força para mudar”. Revista da Força Sindical, Ano 1, n. 1, jun. 1991, p. 12.
} 
Trabalhadores e empresários (...) não são e não devem ser inimigos. Diferenças à parte, podem e devem ter, eventualmente, objetivos comuns. Ainda que nós, trabalhadores, sempre tenhamos cedido, historicamente, nos momentos de crise (nem sempre por vontade própria...), ainda é possível ceder desde, é claro, que os empresários abram mão do egoísmo, do lucro fácil e do paternalismo oficial, aquele no qual muitas vezes mamaram. ${ }^{240}$

Para levar a cabo esta estratégia, a entidade defende a idéia de que os trabalhadores devem participar das discussões sobre as grandes questões nacionais: "Nós, os trabalhadores, devemos influir em todas as decisões que dizem respeito a esta nação que queremos ver construída grande, livre, moderna e forte”. Logo após sua fundação, uma das primeiras manifestações da FS foi realizada em frente ao prédio da Federação das Indústrias do Estado de São Paulo (Fiesp), na Avenida Paulista, em São Paulo, na qual reivindicava, entre outras questões: “(...) o fim das demissões, a reposição das perdas salariais, o cumprimento dos acordos coletivos de trabalho e o reaquecimento das atividades produtivas". ${ }^{241}$

Como se pode observar, a estratégia negociadora da FS não descarta a mobilização, tal como veremos em diversos protestos levados a cabo pela central. Porém, muitas dessas ações foram realizadas com o objetivo de abrir o diálogo para as negociações, pois eram consideradas como o "último recurso" (embora jamais dispensável) após a utilização de todos os meios para se chegar a um acordo. ${ }^{242}$ Como sintetiza a própria entidade, sua proposta era promover um "sindicalismo moderno, que luta e mobiliza os trabalhadores, e ao mesmo tempo, que negocia e procura alternativas viáveis". ${ }^{243}$ Além do propositivismo, entre os elementos centrais da ideologia sindical praticada pela FS se destaca o participacionismo ${ }^{244}$ : “(...) admite-se, recomenda-se ou até se exige que os trabalhadores participem da gestão de órgãos públicos, principalmente nas áreas sociais". A central também recusa a bandeira socialista. Seu projeto político de sociedade tem como objetivo o desenvolvimento do capitalismo brasileiro baseado na geração de emprego e melhoria da renda, com ampliação dos direitos e das condições de vida dos trabalhadores, o que pressupõe o fortalecimento dos empresários nacionais, que devem ser competitivos, mas também justos. Essa perspectiva colaboracionista, baseada na aliança entre capital e trabalho, pode ser definida como

\footnotetext{
240 "Um projeto para o Brasil". Cadernos da Força, Ano 1, n. 1, mar. 1992, p. 10-11.

241 “Força para mudar". Revista da Força Sindical, Ano 1, n. 1, jun. 1991, p. 16.

${ }^{242} \mathrm{O}$ caráter reivindicativo da central foi demonstrado por Trópia (2009).

243 “O Brasil ganhou uma Nova Força”. CMS, s/r, Cx. 87, 29/10/1991.

244 Defino o participacionismo de forma muito próxima ao governismo. Este último pressupõe a prática concertacionista e o apoio ou aliança aos governos, independentemente de sua vertente política. O uso do conceito de participacionismo se justifica pela ênfase na lógica da busca da participação direta na gestão do aparelho estatal, por meio de cargos executivos ou administrativos, por parte dos dirigentes.
} 
trabalhista no campo sindical, populista no campo político e desenvolvimentista no campo econômico. De maneira geral, a fórmula que traduz esse aspecto da ideologia da central é a luta "pela transição do capitalismo selvagem para uma sociedade moderna, avançada e competitiva". ${ }^{245}$ Nesse sentido, a entidade defende que a política econômica "deve assegurar um processo de desenvolvimento do mercado interno, elevando o poder de compra dos salários e assegurando, em conseqüência, o desenvolvimento social integral”. ${ }^{246}$

A FS surgiu no cenário político brasileiro como representante do setor sindical que apoiava o neoliberalismo. Desde o início a entidade defendeu as privatizações, ainda que tenha sustentado a "defesa das empresas públicas estratégicas" para o "desenvolvimento sócio-econômico do País". No entanto, assumiu o ataque ao funcionalismo público promovido pelo governo Collor, "Reconhecemos a necessidade de se rever a atuação do Estado em setores que só acarretam prejuízos para o povo, assim como estatais que só servem como "cabide de emprego",. 247

Em seu Programa de Lutas a central defendeu, como proposta para a melhoria das condições de vida do trabalhador, o seguro-desemprego para os "trabalhadores desempregados". Também se mostrou favorável à Participação nos Lucros e Resultados (PLR), que seria uma forma de garantir "uma real distribuição dos resultados". ${ }^{248}$ Essa postura se inseria no objetivo mais geral da FS de articular os benefícios ou perdas dos trabalhadores ao desempenho das empresas. ${ }^{249}$

Desde sua criação, a FS aderiu ao discurso neoliberal de empregabilidade, apresentando de maneira pioneira no cenário sindical a proposta de requalificação do trabalhador que "não

\footnotetext{
245 "Os princípios da Força”. Revista da Força Sindical, Ano 1, n. 1, jun. 1991, p. 39. Em outra passagem, a central assim definiu seus princípios políticos: “a) sindicalismo independente, pluralista, democrático e não partidarizado, que luta pelo fim da estrutura sindical corporativa e busca uma efetiva e real liberdade e autonomia sindicais; b) justiça social, através da redistribuição de renda, com participação dos trabalhadores nos lucros e nas decisões das empresas, defendendo o direito irrestrito de greve e a garantia de extensão de todos os direitos conquistados (...); c) busca permanente de um entendimento nacional, através de uma postura crítica e construtiva (...)" (idem, p. 39).

246 "Os princípios da Força”. Revista da Força Sindical, Ano 1, n. 1, jun. 1991, p. 47.

247 "Os princípios da Força”. Revista da Força Sindical, Ano 1, n. 1, jun. 1991, p. 47. Esta visão na central se justifica a partir da perspectiva de eficiência da máquina estatal no cumprimento dos serviços considerados essenciais, tal como pregava o discurso neoliberal de "Estado mínimo": "O Estado deve se tornar mais leve e mais ágil para poder cumprir, com eficiência, seu verdadeiro papel: garantir ao cidadão o acesso à educação, à saúde, à habitação, ao transporte, à cultura, bem como zelar por sua segurança e por todos os seus direitos de cidadania" ("Um projeto para o Brasil". Cadernos da Força. Ano 1, n. 1, mar. 1992, p. 13).

248 "Os princípios da Força". Revista da Força Sindical, Ano 1, n. 1, jun. 1991, p. 42.

${ }^{249}$ Como veremos ao longo do capítulo, foi com base nesse argumento que a central justificou as propostas de concessão aos empresários levadas a cabo ao longo dos anos 90 para evitar as demissões em momentos de dificuldade financeira, redução da produtividade e dos lucros e aumento da competitividade.
} 
atende as necessidades do mercado". Segundo a central, "A implantação de novas tecnologias deverá ser acompanhada por um processo em larga escala de reciclagem de mão-de-obra, como forma de evitar a falta de capacitação profissional e o conseqüente desemprego". Segundo a entidade, esta seria uma forma “(...) para deixarmos de ser um país de mão-de-obra barata e desqualificada". ${ }^{250}$ Entretanto, este discurso da central não descartava a bandeira de garantia no emprego como forma de conter os abusos patronais e impedir a "recontratação com salário mais baixo": "Defendemos a admissão daquele trabalhador demitido e a penalização dos que demitem sem real justificativa econômica". Ademais, a entidade defendia as "cooperativas de produção, tanto na cidade como no campo, assim como outras formas associadas dos trabalhadores que visem enfrentar e se apropriar da solução de seus próprios problemas". 251

Durante o período analisado neste item, a FS se caracterizou pelo apoio explícito ao governo Collor, e por isso não participou das mobilizações pelo impeachment do presidente. Em artigo publicado no jornal $O$ Globo em 26 de janeiro de 1992, Luiz Antonio de Medeiros argumentou: "Vamos nos despir de preconceitos e olhar a realidade: bem ou mal, ele [Collor] tem um projeto modernizador, desgraçadamente defendido por um homem solitário (...) justiça seja feita, é o presidente, hoje, a principal referência modernizadora em nosso País". ${ }^{252}$

Desde a sua fundação, a Força Sindical se filiou à Ciosl/ORIT ${ }^{253}$, mesma entidade à qual a CUT também aderiu. No período tratado nesse item a central se posicionou a favor das privatizações e argumentou sobre a necessidade de se "modernizar as relações entre trabalho e capital no Brasil" ${ }^{, 54}$, proposta que sustentou tanto a defesa da inovação tecnológica para que as empresas conseguissem enfrentar a competitividade global, quanto a bandeira de flexibilização da CLT.

\footnotetext{
250 “Os princípios da Força”. Revista da Força Sindical, Ano 1, n. 1, jun. 1991, p. 43.

${ }^{251}$ Idem, p. 44.

252 "Um projeto para o Brasil". Cadernos da Força, Ano 1, n. 1, mar. 1992, p. 8.

${ }^{253}$ Organización Regional Interamericana de Trabajadores (ORIT).

254 "Força cresce em todo o Brasil". Jornal da Força, n. 3, abril de 1993, p. 3. As propostas políticas da FS são apresentadas no documento Um projeto para o Brasil. (Força Sindical, 1993), elaborado por 42 especialistas e aprovado durante o II Congresso da central. A supervisão técnica foi do economista Antonio Kandir, que foi Ministro de Planejamento de FHC. Segundo avaliação da própria central, "Muitas das propostas do 'Projeto Brasil' foram incorporadas por programas de diversos partidos, principalmente pelos que apoiaram a campanha presidencial de Fernando Henrique Cardoso que, no governo, tentou aprovar grande parte das idéias sugeridas pela central” (" 3 o Congresso Nacional da Força Sindical. Prioridades para o programa de ação e organização da Força Sindical". CMS, s/r, Cx. 87, 13/08/1997, p. 1).
} 
O ano de 1990 foi marcado por diversas mobilizações da CUT, com greves por reposição salarial e o combate às principais políticas implementadas pelo governo Collor, como as privatizações. Os sindicatos cutistas também organizaram importantes protestos de resistência às demissões, como no caso dos petroleiros, da Ford de São Bernardo e da CSN, em Volta Redonda. Esses protestos estão inseridos no maior pico da atividade grevista da história do sindicalismo brasileiro.

Além disso, durante o governo Collor foram convocadas duas greves gerais pela CUT (em 90 e 91, a primeira em conjunto com a CGT), além de uma greve geral do setor metalúrgico, em 1990. Cabe destacar ainda a organização de pelo menos quatro campanhas nacionais que envolveram a temática do desemprego (uma em 90, duas em 91 e uma em 92), além da participação nos protestos pelo impeachment de Collor.

Porém, o período analisado também correspondeu à gestação do sindicalismo propositivo na central. Em 1991 foram criados diversos fóruns tripartites, sob a bandeira do "entendimento nacional", que buscavam promover um ambiente de "trégua" entre capital e trabalho. A discussão sobre a participação ou não da central gerou uma polêmica interna que polarizou as posições no interior da entidade. De um lado, estavam os setores minoritários que pediam a saída da CUT desses órgãos, sob o argumento de que a central estaria substituindo a estratégia da mobilização pela de negociação. Do outro, estava a ala majoritária encabeçada pela Articulação Sindical, que justificava esta postura sob o argumento de que essas instâncias eram adequadas para a "disputa ideológica" com o governo e os empresários.

Em relação aos anos 80, a questão do desemprego deixou de aparecer nos documentos da central como um elemento orgânico do capitalismo. Nas análises feitas pela entidade, ficou evidente que o foco da questão se deslocou para aspectos conjunturais, como as políticas neoliberais do governo Collor e a reestruturação produtiva. Ademais, na avaliação da central a crise do desemprego seria passageira, pois estava ligada às oscilações sazonais da economia brasileira.

A partir de 1992, observa-se um esforço da CUT para organizar os trabalhadores da chamada economia informal, o que se evidenciou na criação de associações de ambulantes em diversas cidades do país. Porém, a entidade considerava que esta não se tratava de uma "estratégia definitiva", já que tal política significava "institucionalizar o desemprego estrutural”. Essa foi uma das principais justificativas da ausência de política de organização para a luta, que consistiu em dissociar o desemprego dos desempregados. 
A FS já nasceu com um projeto sindical propositivo e de colaboração de classes. A atuação da central se caracterizou, no plano discursivo, pela defesa do emprego e de políticas passivas para o desempregado, como o seguro-desemprego. A entidade também apoiou as privatizações e a abertura comercial. No campo das políticas de emprego, aderiu ao discurso de empregabilidade com a proposta de "requalificação profissional" para os trabalhadores não adequados às exigências do mercado. Apesar de não descartar a mobilização, priorizou a negociação com as empresas por melhorias de condições de trabalho e salário para o trabalhador. Essa estratégia se justificava pela idéia de que era preciso desenvolver o capitalismo aumentando a competitividade do empresariado, com justiça social e trabalhista. Com base nesses argumentos, defendeu, por exemplo, a política de PLR. Não realizou marchas ou greves nacionais em defesa do emprego durante o governo Collor nem participou das mobilizações pelo impeachment. Na documentação consultada, não há registros de tentativas de representar os interesses ou organizar os desempregados para a luta.

Entre 1992 e 1995, o sindicalismo brasileiro foi marcado pela consolidação da prática propositiva. A ampliação de mecanismos institucionais de participação através de fóruns tripartites pode ser interpretada como um dos motivos do recuo das mobilizações, ainda que estas não tenham desaparecido do horizonte sindical. Entre as instâncias deliberativas das quais as centrais participaram, destacou-se o Codefat, pois foi a partir desse conselho que as entidades amadureceram a proposta de formação e qualificação profissional, e de políticas passivas para os desempregados.

Uma bandeira presente na CUT nesse período foi a de "reestruturação negociada", que a central contrastou à de "reestruturação excludente". A entidade propôs a conciliação entre os avanços na qualidade, a produtividade das empresas e as conquistas sociais para os trabalhadores, de maneira muito semelhante ao colaboracionismo preconizado pela FS. Durante o período analisado neste item, a CUT fez uma oposição sistemática aos governos de Itamar e FHC. Ao contrário, a FS apoiou não só a política econômica, mas as privatizações e a abertura às importações. Sua proposta para o desemprego esteve pautada na bandeira de "modernização das relações entre trabalho e capital" e na flexibilização trabalhista. Explorarei essas questões mais detidamente no próximo item. 


\subsubsection{Desemprego e sindicalismo de serviços (1995 a 1998)}

O período que será analisado a seguir se caracterizou, primeiramente, pelo aumento do desemprego. Para enfrentar o problema, as centrais sindicais passaram a investir no oferecimento de serviços aos desempregados, tornando-se gestoras diretas de recursos disponibilizados pelo FAT, especialmente para a requalificação profissional. No entanto, foi esse o período de maior aliança do sindicalismo com o movimento popular e de maior resistência ao neoliberalismo, cujo ápice se deu com a eclosão da primeira greve geral em que a CUT e a FS participaram conjuntamente.

\section{A CUT}

No período analisado neste item, segundo a leitura da CUT, a inovação tecnológica se caracterizava como excludente, pois se trata de uma reestruturação produtiva "não negociada com os sindicatos". A central avaliava que era "papel do governo promover e estimular a negociação da modernização das empresas; apoiar a redução da jornada e realizar uma política de formação profissional ampla". ${ }^{255}$ Além da continuidade das bandeiras defendidas no período anterior, apareceu a proposta de criação de um Serviço Social para Desempregados, que seria desenvolvido por intermédio de uma negociação com as diversas instâncias do poder executivo para contemplar as necessidades imediatas desse segmento, tais como:

(...) negociar junto às Prefeituras, Governos Estaduais e Governo Federal a seguinte lista de auxílio aos desempregados, cujo último salário não seja superior a 10 salários mínimos: a) concessão de transporte gratuito; b) suspensão das contas de água e luz; c) moratória de IPTU [Imposto Predial e Territorial Urbano]; d) suspensão do pagamento da prestação da casa própria; e) material escolar subsidiado. ${ }^{256}$

A central passou a defender crescentemente a proibição da dispensa imotivada, baseada na Convenção 158 da Organização Internacional do Trabalho (OIT). Reivindicou ainda a ampliação do período de pagamento do seguro-desemprego para 12 meses, associada a um "programa público de treinamento e requalificação profissional". ${ }^{257}$. Também defendeu a proposta de "redução de impostos para as pequenas e microempresas" e a "abertura de linha de financiamento no Bndes (...) para a expansão da produção e do emprego (...)" nas empresas desse tipo comprometidas com "metas de expansão do nível de emprego". Por último, a

\footnotetext{
${ }^{255}$ Para gerar empregos. Informacut n. 260, mai. 1996, p. 14.

${ }^{256}$ Idem, p. 15.

${ }^{257}$ Idem, p. 16.
} 
entidade destacou a importância da retomada das Câmaras Setoriais, "tendo em vista sua experiência relevante no papel de geração de investimentos, elevação da produção e do emprego, ganhos salariais e aumento da arrecadação", que deveria ser levado a cabo com a constituição de um "Fundo de Manutenção do Emprego". ${ }^{258}$

Ao longo do ano de 1996, o descontentamento da CUT com o governo aumentou. Nas manifestações do Primeiro de Maio desse ano a central convocou uma greve geral sob o lema "Por emprego, salário, reforma agrária e fim da impunidade", marcada para 21 de junho em conjunto com a CGT e a FS, e com participação de estudantes, partidos políticos e organizações populares. Segundo Martins e Rodrigues (1999, p. 161), “a paralisação não teve o sucesso esperado" e "os próprios sindicalistas reconheceram que não houve adesão total". Nas resoluções da $8^{\text {a }}$ Plenária a central avaliou positivamente o protesto, ressaltando a importância da política de unidade e aliança levada a cabo, assim como sua forte adesão:

A Greve Geral de 21 de junho, um protesto que paralisou mais de 12 milhões de trabalhadores em todo país, foi a principal resposta organizada dos trabalhadores. A unidade entre as três principais centrais sindicais permitiu demonstrar a grande insatisfação dos trabalhadores com a política econômica e cobrar do governo o não cumprimento das suas promessas de campanha: emprego, salário, aposentadoria digna, reforma agrária e a manutenção dos direitos dos trabalhadores. Esse movimento provou o potencial de uma ampla aliança dos trabalhadores com os estudantes, movimentos populares e partidos progressistas que, através do Fórum de Oposições, apoiaram a greve (CUT, 1996, p. 09). ${ }^{259}$

Nesse momento, a CUT afirmava que "a luta em defesa do emprego e dos direitos dos trabalhadores" deve estar associada à luta por "uma sociedade socialista": "É a própria incapacidade do capitalismo de resolver os problemas básicos da humanidade que realça esta necessidade, que deve estar refletida nas atividades de nossa Central" (CUT, 1996, pp. 3233).Como principais fatores que provocavam o desemprego no país, a entidade citou a "sobrevalorização do real", a "abertura indiscriminada às importações", a "política monetária restritiva" e o "uso abusivo das horas extras por parte das empresas". Não apareceram novas propostas da central para a geração de empregos nesse documento (CUT, 1996, pp. 34-36).

\footnotetext{
${ }^{258}$ Idem, p. 17.

${ }^{259}$ Mais adiante a central afirmou que a greve “(...) significou a condenação popular à política econômica do governo, no que tange ao arrocho salarial e ao aumento da exclusão social, com aumento do desemprego, concentração de riquezas, da miséria e da violência, especialmente no campo" (CUT, 1996, pp. 15-16). Em avaliação posterior, a central ressaltou: "O agravamento do desemprego possibilitou que a CUT, junto com as demais centrais sindicais, realizasse um dia de Greve Geral, em 21 de junho, contra o desemprego e a precarização do trabalho e em defesa da reforma agrária e direitos dos trabalhadores. A unidade com as outras centrais foi inédita, a adesão, razoável e grande, o apoio popular. Junto com as ocupações e mobilizações dos trabalhadores rurais, a Greve Geral foi o maior protesto realizado no país após o Plano Real" (CUT, 1997, p. 29).
} 
O ano de 1996 foi marcado pela construção de uma aliança entre a CUT e o movimento popular. Além da greve geral de 21 de junho, a central participou do movimento "Reage, Brasil!", que em conjunto com as demais centrais sindicais, a União Nacional dos Estudantes (UNE), o MST, a Confederação Nacional dos Bispos do Brasil (CNBB), a Central de Movimentos Populares (CMP), a Ordem dos Advogados do Brasil (OAB), a Associação Brasileira de Imprensa (ABI), partidos políticos e várias organizações populares, pretendia construir uma frente operária e popular "contra as políticas neoliberais de FHC" (CUT, 1996, p. 16). No dia 7 de setembro, a central participou do “'Grito dos Excluídos por Justiça e Paz' pelo fim da exclusão social, contra o desemprego, pela reforma agrária, pela independência para todos, pela cidadania", convocado pela CNBB. Como forma de mobilizar os desempregados, a central se propôs a "Organizar em conjunto com as entidades do movimento popular e as centrais sindicais caravanas a Brasília/DF montando acampamentos de desempregados (...)". Esteve contemplada ainda a organização de "um grande showmício" no dia 13 de outubro, "Pela Dignidade e Cidadania e contra o desemprego causado pelas políticas de FHC". Nesse ato, a central apresentaou a proposta de "estimular os participantes a levarem gêneros alimentícios (...) para posterior distribuição aos desempregados”. Também nesse ano a central se comprometeu a "fazer, até dezembro de 1996, o cadastro dos desempregados junto aos sindicatos da CUT no sentido de lançar um movimento pela moratória de tarifas públicas, como água, luz, IPTU etc. junto aos governos". ${ }^{260}$ Foram mencionadas ainda uma mobilização, cujo objetivo era "articular com o Fórum das Oposições e outras entidades da sociedade civil uma campanha de recolhimento de no mínimo 1 milhão de assinaturas para um 'Projeto de Emenda Popular pela Redução da Jornada de Trabalho sem Prejuízo dos Salários"” e uma "Campanha de resistência às demissões, com ocupações aos locais de trabalho, quando houver demissões em massa", sob o lema “Demitiu, ocupou!". Este foi o momento de maior unidade entre as centrais sindicais e da CUT com o movimento popular. Nesse contexto, a central passou a apresentar de maneira enfática a intenção de representar os desempregados:

(...) é evidente que o movimento sindical deve repensar, no curto prazo, a sua base de representação, incorporando as demandas dos segmentos de trabalhadores da economia informal, dos aposentados e dos

\footnotetext{
260 A proposta de se implementar um cadastro de desempregados foi assim definida pela central nesse documento: "A Executiva considera importante que as entidades sindicais filiadas organizem o debate, implementem estudos que identifiquem o impacto das demissões no interior de suas bases, dialoguem com os desempregados, cadastrando e envolvendo-os na ação sindical, e implementar, assim, a campanha por mais e melhores empregos" (Mais e melhores empregos. Informacut n. 263, nov. 1996, p. 07).
} 
desempregados. O papel da CUT na luta contra o desemprego deve ir além da reivindicação por mais emprego. Portanto, é preciso atuar na organização da população desempregada e sub-empregada em conjunto com outros setores do movimento social. ${ }^{261}$

A proposta cutista de organização dos desempregados para a luta se desenvolveu concomitante à defesa de "políticas sociais" para esse segmento. Na avaliação da central, "a execução de políticas sociais consistentes é o único caminho para se reverter o quadro de exclusão e miséria social". ${ }^{262}$ Em 1996, a central investiu na aliança com organizações do movimento popular que representavam trabalhadores desempregados na sua base. No entanto, no decorrer do período é na política de oferecimento de serviços a esse segmento que a entidade passou a concentrar seus esforços.

No contexto da privatização da Companhia Vale do Rio Doce e da emenda de reeleição de $\mathrm{FHC}^{263}$, a CUT realizou a campanha "Reage Brasil” "contra as políticas neoliberais, em defesa da terra, do emprego, do salário e da cidadania, contra a reeleição de FHC"264, o que terminou com um ato, no dia 17 de abril, em Brasília, com a presença de mais de 50 mil trabalhadores:

(...) atendendo à convocação da CUT, dos partidos de esquerda e entidades democráticas da sociedade civil para exigir terra, salário, emprego, previdência e cidadania, unindo forças aos trabalhadores rurais sem terra que, naquele dia, finalizavam uma caminhada que durava dois meses; os milhares de trabalhadores que protestaram em diversas partes do país, com destaque à manifestação, no dia 29 de abril, no centro do Rio de Janeiro, onde, mesmo sob a força bruta do Pelotão de Choque da Polícia Militar, permaneceram firmes e fortes protestando contra a entrega da Cia. Vale do Rio Doce à iniciativa privada; e a participação decisiva de milhares de trabalhadores pelas principais regiões do país, em comemoração ao Dia do Trabalhador, no $1^{\circ}$ Maio, deram provas suficientes de que a população brasileira ainda tem muito fôlego, está decidida a lutar pela sua cidadania e a dobrar as políticas neoliberais de FHC. $^{265}$

\footnotetext{
${ }^{261}$ As políticas sociais na CUT. Informacut n. 263, nov. 1996, p. 20.

${ }^{262}$ Idem.

${ }^{263}$ A privatização da Vale e a reeleição. Informacut n. 264, jan. 1997, p. 11-13.

${ }^{264}$ Como se pode observar, ao longo desse item o conceito de cidadania passou a estar cada vez mais presente na concepção geral da central, como demonstra a seguinte notícia: "A CUT e mais 34 entidades da sociedade civil organizada realizaram, nos dias 2 a 4 de abril, em Brasília, a Conferência Nacional em Defesa da Terra, do Trabalho e da Cidadania" (Em defesa da terra, do trabalho e da cidadania. Informacut n. 266, jun. 1997, p. 17).

${ }^{265}$ Editorial. Os 27 dias que chacoalharam o país. Informacut n. 266, jun. 1997, p. 04. Mais adiante a central considerou que "A conclusão de que a única saída para os trabalhadores é o socialismo não significa que a resistência ao neoliberalismo deva ser abandonada", pois é parte da construção das "condições subjetivas necessárias para a batalha maior, visando a ruptura revolucionária do sistema capitalista e a conquista do socialismo" (CUT, 1997, p. 22).
} 
Entre a aliança com as organizações populares e a denúncia sistemática do neoliberalismo, a CUT voltou a propor, no $6^{\circ}$ Concut, a representação dos desempregados, e outros segmentos não "sindicalizáveis":

A organização dos desempregados, dos trabalhadores informais, das mulheres, que ingressam no mercado de trabalho em condições ainda mais precárias do que os homens, e de contingentes cada vez mais amplos de excluídos, representa um desafio crucial para o futuro do sindicalismo (CUT, 1997, p. 10). A luta contra o desemprego deve envolver os trabalhadores, que vivem sob constante ameaça de desemprego, os jovens impedidos de ter acesso ao primeiro emprego, além dos ambulantes e trabalhadores na chamada economia informal, que têm seus direitos sociais e previdenciários sistematicamente negados (CUT, 1997, p. 42). ${ }^{266}$

Nesse congresso a CUT assim definiu seu modelo de atuação sindical: "Antes, a palavra de ordem era apenas a resistência, e a luta sindical era antes de tudo uma luta democrática. Agora, é preciso prosseguir na resistência, mas apresentando claramente as nossas propostas de classe, e contrapondo-as às propostas das elites brasileiras" (CUT, 1997, p. 38). Desse modo, começou a ganhar espaço na central a proposta de sindicalismo "cidadão":

É fundamental que o $6^{\circ}$ Concut aponte como objetivo aglutinar, no campo cutista, e em associação com o movimento popular e a sociedade civil, experiências que visem formar Cooperativas Habitacionais, Cooperativas de Seguros Civis e Cooperativas de fundos de pensão complementares. Tais recursos e investimentos deverão ser dirigidos para fortalecer experiências cooperativadas e de autogestão que impulsionem prioritariamente a geração de emprego e distribuição de renda (CUT, 1997, p. 55).

O ano de 1998 foi marcado por diversas mobilizações de combate ao desemprego. Em abril desse ano foi realizada uma "Marcha contra o desemprego" que no dia $1^{\circ}$ de maio chegou em Brasília. Em 1994, já havia sido criado pelo Codefat o Programa de Geração de Emprego e Renda (Proger), que entre outras atribuições promoveu a criação das comissões estaduais e municipais de emprego. A partir de então, a Secretaria de Formação da CUT começou a capacitar conselheiros sindicais para atuar nesses órgãos. Porém, somente em 1998, com o objetivo de utilizar as verbas do FAT, a central criou o Programa de Formação, Qualificação e Requalificação Profissional, sob os seguintes argumentos:

(...) é fundamental que todos os sindicatos e associações de movimentos populares, ONGs [Organizações Não-Governamentais] etc., habilitem-se e apresentem programas que, segundo critérios próprios, estimulem a demanda sobre os executivos municipais, estaduais e federal, especialmente através das comissões estaduais e municipais de emprego. (...) a demanda básica do desempregado não é a de receber o seguro-desemprego, benefício temporário e exíguo, mas sim a de conseguir nova ocupação condizente

\footnotetext{
${ }^{266}$ Nesse documento, apareceu como proposta a criação de "uma política para desempregados/excluídos, defendendo a anistia para as suas dívidas públicas (água, luz etc.)" (CUT, 1997, p. 61).
} 
com a que ocupava anteriormente. Para isso, deveria funcionar adequadamente o sistema de intermediação, que teria os postos dos SINEs como cadastro de vagas e de trabalhadores em busca de nova ocupação. ${ }^{267}$

Como se pode observar na análise desse período, a política cutista para os desempregados oscilou entre as propostas de representação e a construção de projetos para o oferecimento de serviços para esse segmento. O sindicalismo de serviços e cidadão, portanto, não deve ser visto como uma reação inevitável do sindicalismo nesse campo, mas um projeto vitorioso, em tensão com outros que foram considerados no interior da central.

\section{A Força Sindical}

Durante o período analisado neste item, a FS seguiu defendendo os pilares da plataforma neoliberal. No entanto, a central também se mobilizou contra o desemprego. O $1^{\circ}$ de maio de 1996 foi convocado "Pelo emprego e pela redução da jornada de trabalho para 36 horas". ${ }^{268}$ Em "Ato público por emprego e justiça”, realizado na Praça da Sé, em São Paulo, a FS convocou show com "grandes artistas" 269 e apresentou novamente esta mesma proposta. 270 Ademais, aderiu à greve geral de 21 de junho de 1996. Na convocatória do protesto, realizado em conjunto com a CUT e a CGT, a entidade assim expressou seu descontentamento com o governo:

Insiste o governo em manter a estabilização da moeda às custas do aumento da recessão, do desemprego, do arrocho salarial e do aumento da exclusão social. (...) A política econômica do governo, baseada principalmente nos juros altos e no aperto do crédito, já custou o desaparecimento de milhões de postos de trabalho e está jogando na informalidade milhões de trabalhadores, sem qualquer direito. ${ }^{271}$

A FS declarou que participaram da greve mais de quatro milhões de afiliados a seus sindicatos. Sobre o protesto, assim se expressou o então presidente da central, Luiz Antonio de Medeiros:

É evidente que a greve em si não pretende, nem poderia deixar de ser, obter resultados práticos para nossas reivindicações, como mais emprego e melhores salários. O que se pretende, e nisso vencemos, é

\footnotetext{
${ }^{267}$ O FAT. Constituição, fonte e destinação de recursos”. Informacut n. 268, jan. 1998, p. 17.

${ }^{268}$ Credencial. 1o. de maio". Força Sindical. $C M S, \mathrm{~s} / \mathrm{r}$.

269 "Convocatória. Ato público por emprego e justiça”. $C M S, \mathrm{~s} / \mathrm{r}$.

270 "A Força Sindical tem propostas para a geração de empregos”. 8 ago., $C M S$, s/r.

271 “Convocando a greve geral. CUT, FS e CGT”. CMS, s/r, Cx. 87, 31/05/1996. Trópia (2009) argumenta que o apoio da FS ao neoliberalismo não foi "incondicional". À medida que as políticas defendidas pela central, como a abertura às importações, começaram a afetar a base de seus principais sindicatos, como os metalúrgicos de São Paulo, especialmente por conta das demissões em massa, a entidade recuou e passou a reivindicar uma maior proteção à indústria nacional.
} 
pressionar o governo e mobilizar a opinião pública para a necessidade de exigir mudanças, na política econômica e social, que levem a esses objetivos. ${ }^{272}$

A convocatória da FS foi feita sob a consigna "O Brasil vai parar para que todos trabalhem". Para a central, o protesto se justificava pela "insatisfação com a ausência de uma política social efetiva do governo" e pela "rejeição à política econômica recessiva e de juros altos, que impede o crescimento econômico e faz aumentar o desemprego". A central apresentou como proposta para a criação de postos de trabalho uma "política emergencial de geração de empregos e jornada semanal de 40 horas, sem redução de salários". ${ }^{273}$ Porém, essas reivindicações e a participação da central em uma greve geral nacional, pela primeira e única vez em sua história, não excluíram sua defesa de um projeto de reformas, que contemplava o "fim dos monopólios" e as privatizações:

Todo mundo sabe que a única maneira de comprar uma coisa barata é ter várias pessoas vendendo a mesma coisa. Quando há concorrência o preço baixa. É por isso que a Força Sindical defende o fim dos monopólios. Qualquer monopólio. Do pão ao petróleo, do sabão ao telefone, é preciso ter muitos vendendo para que possamos escolher. Entendeu agora? A Força Sindical acha que o Estado pode até continuar procurando petróleo e instalando telefones em nossas casas - mas deve fazer isso associado com outras empresas, ou concorrendo com elas. Todo mundo sai ganhando quando muda para melhor.

Se o governo tivesse dinheiro sobrando, se não faltasse médicos e escolas, se as estradas não estivessem cheias de buraco, a Força Sindical não teria nada contra o Estado produzir aço ou qualquer outra coisa. Mas como isso não acontece, achamos que o Estado deve cuidar só de suas obrigações sociais, vendendo suas empresas e deixando os negócios para a iniciativa privada. Deu certo na CSN e na Usiminas, estatais que foram privatizadas. Elas pararam de dar prejuízos para o povo e a vida dos trabalhadores melhorou. Se melhorou, por que parar? $?^{274}$

A prática da FS se inseriu em uma concepção de sindicalismo propositiva, tal como fica evidente nessa passagem: “A Força Sindical aposta no diálogo, no acordo e no entendimento. A Força Sindical não puxa o saco do governo e dos patrões, mas aceita conversar com eles, na base do respeito e da colaboração". A ideologia da central também se fundamenta na idéia de um sindicalismo "moderno", que defende a mudança: "Quem não quer mudar é reacionário e conservador. Reacionário porque reage a qualquer mudança séria. E conservador porque quer conservar, deixar tudo do jeito que está". ${ }^{275}$

\footnotetext{
272 "Greve Geral. Levantamento da adesão dos trabalhadores da Força Sindical". CMS, s/r, Cx. 87, 24/06/1996.

273 "Convocatória. Greve Geral 21 de junho". CMS, s/r, Cx. 87, 21/06/1996.

274 "Reformas Sim. Reformar para mudar, mudar para melhor". CMS, s/r, Cx. 87, 31/05/1996.

${ }^{275}$ Idem.
} 
Sob essa perspectiva, em 1997 a FS e a Federação Metalúrgica do Estado de São Paulo apresentaram o "Programa de garantia de emprego e manutenção de postos de trabalho", um acordo coletivo firmado com as entidades patronais a ser aplicado às empresas que estivessem com "dificuldades econômicas e financeiras ou com redução na área produtiva". A partir do programa, durante 90 dias haveria redução da jornada de trabalho de $25 \%$ com redução salarial de 9\% em contrapartida da estabilidade no emprego de 6 meses. O acordo também previa a proibição de horas extras durante sua vigência e a possibilidade de compensação das horas não trabalhadas com o correspondente pagamento após seu término. A redução salarial não teria reflexo nos demais direitos trabalhistas e não poderia ser inferior ao piso da categoria. As empresas que aderissem ao programa deveriam solicitar ao sindicato local que convocasse uma assembléia com os trabalhadores para que a proposta fosse aprovada. ${ }^{276}$ Esse acordo, de ampla repercussão, demonstra o tipo de negociação feita pela FS sob o pretexto de manutenção do emprego, baseado na leitura de que é preciso que trabalhadores e patrões estejam dispostos a fazer concessões em prol do benefício comum.

Como parte de sua agenda permanente de lutas, a central formulou as seguintes propostas em relação ao emprego: "ampliação do seguro-desemprego", "garantia de emprego", "negociação dos impactos da reestruturação produtiva", "redução da jornada de trabalho" e "reforma agrária". Além disso, tal como a CUT, a entidade defendeu a "participação institucional" nos diversos conselhos tripartites, entre os quais destacamos o Conselho Nacional do Trabalho, o Codefat e o Programa Brasileiro de Qualidade e Produtividade (PBPQ). Propôs também uma relação de unidade na luta entre as centrais sindicais, no sentido de "buscar estabelecer, no campo sindical, um plano de lutas comum". 277

Sob o argumento de que "houve um tempo em que os sindicatos preocupavam-se somente com questões específicas de sua base, tais como reajustes de salário, greve, arrocho..." e de que "educação é assunto do trabalhador, sim", a central apresentou propostas de atuação em diversas áreas. Por exemplo, desenvolveu projetos educacionais, dando início, em 1997, ao Programa Nacional de Qualificação Profissional, com recursos do FAT. Segundo a central, passaram pelos cursos, como telemarketing, espanhol, informática, entre outros, 20 mil pessoas em 1997, 80 mil em 1998 e 140 mil em 1999. ${ }^{278}$

\footnotetext{
276 "Programa de garantia de emprego e manutenção de postos de trabalho". CMS, s/r, Cx. 87, 11/12/1997.

277 "Prioridades para o programa de organização da central". CMS, s/r, Cx. 87, 31/07/1997.

278 "Educação é ponto de honra da central". Revista da Força Sindical, Ano 9, n. 2, março de 2000, p. 44-46. 
Em seu $3^{\circ}$ Congresso Nacional, intitulado "Emprego, Educação e Justiça", a FS destacou a proposta de redução da jornada de trabalho para 36 horas, a partir da qual "tanto trabalhadores como empresários diminuam, num primeiro momento, respectivamente, um pouco dos salários e dos lucros, e o governo contribua com a redução dos impostos". ${ }^{279}$ Além dessa bandeira, a proposta de política de emprego da FS contemplou a formação e qualificação profissional, justificada pela central a partir do conceito de "empregabilidade":

As exigências de melhor qualificação profissional e nível de ensino tornam o trabalho inacessível para um grande contingente de pessoas que não se prepararam para as atuais exigências. Resta a estes trabalhadores - quando resta - aceitar um emprego precário, muitas vezes no setor informal da economia. Nesse contexto, aumentam a importância da formação profissional e da escolaridade básica, como fatores imprescindíveis para a "empregabilidade". A qualificação do trabalhador passa então a ser condição fundamental para se fazer frente às transformações decorrentes do processo de globalização dos mercados. É preciso garantir melhor qualidade dos produtos e aumentar a produtividade, para que os preços possam baixar e competir no mercado internacional globalizado. Mais do que nunca, o sistema produtivo e educacional precisam estar integrados. A formação profissional e a escola são apresentadas como respostas aos problemas de competitividade das empresas, da exclusão e da geração de empregos. $^{280}$

Apesar do apoio aos projetos levados a cabo pelo governo FHC, especialmente as privatizações e a flexibilização das leis trabalhistas, a FS possuía algumas críticas ao mesmo: "O atual modelo dificulta o desenvolvimento e a geração de emprego e renda, porque: mantém o câmbio valorizado; mantém os juros muito altos; cria déficit externo; corta gastos sociais". Como alternativa a esse modelo, a central propunha: "reforma administrativa; reforma tributária e fiscal; reduzir déficit público; baixar juros”. ${ }^{281}$ Para a central, a relação entre crescimento econômico, reestruturação produtiva e geração de emprego e renda se dava da seguinte forma:

A correção de rumos da estabilização permite a retomada do crescimento sustentado, mas isto, isoladamente, não resolve a questão do desemprego, já que a reestruturação produtiva das empresas e o

\footnotetext{
279 " $3^{\circ}$ Congresso Nacional da Força Sindical. A Força Sindical e a redução da jornada de trabalho". CMS, s/r, Cx. 87, 13/08/1997.

${ }^{280}$ Idem, p. 1. A idéia da FS era de que "o trabalhador do mundo de hoje precisa estar qualificado e bem qualificado, para as exigências da economia globalizada". Sua justificativa para investir na proposta de formação e qualificação profissional era muito semelhante à da CUT: "Este ainda é um tema novo para o movimento sindical brasileiro, que, no seu conjunto, sempre considerou a formação profissional como uma atribuição do Estado e do patronato. Só recentemente temos assumido que a discussão e formulação de propostas nesta área também é responsabilidade nossa". (Idem, p. 2). Nos anos seguintes, a central passou a interferir diretamente na execução de tais políticas através da implementação de uma série de serviços financiados com recursos do FAT. ${ }^{281}$ Idem, p. 2.
} 
progresso tecnológico poupador de mão-de-obra vêm provocando a diminuição da elasticidade empregorenda (cada vez é necessário mais crescimento econômico para gerar a mesma quantidade de empregos).

Como proposta de combate ao desemprego a FS propunha políticas ativas como a redução da jornada de trabalho, limites à realização de horas-extras, reforma agrária, "programas de investimento para ampliação e conservação da infra-estrutura", investimento no potencial turístico. Ademais, defendia a implantação de políticas passivas tais como educação profissional, seguro-desemprego, "intermediação de mão-de-obra no âmbito do sistema público de emprego" que, segundo a central, "se não resolvem o problema do emprego, atuam minimizando seus efeitos perversos". ${ }^{282}$ Da mesma forma que a CUT, a FS também aderiu à tese da fragmentação da classe trabalhadora: "As novas formas de produção estão rachando a classe trabalhadora, quebrando a solidariedade, dispersando e precarizando a maioria, mantendo uma pequena elite altamente qualificada como permanentes". ${ }^{283}$

Até esse momento, a representação dos desempregados não tinha sido desenvolvida pela central. A partir de 1997 se consolidou na entidade a perspectiva do sindicalismo "cidadão", o que a levou a buscar representar o setor da "economia informal" através de cooperativas e do oferecimento de serviços:

A Força Sindical tem aprimorado ações na perspectiva de um sindicalismo cidadão, neste aspecto o tema trabalho informal é uma preocupação fundamental. Entre outras ações a central desenvolve um programa de desenvolvimento de cooperativismo de trabalhadores, trabalho com crianças e movimento popular. $\mathrm{O}$ setor informal da economia, a reestruturação, a terceirização, a falência de empresa e a ação no movimento popular constituem campos de ação privilegiado deste novo tipo de trabalho. ${ }^{284}$

Para levar a cabo essa política, a central sustentava que seria necessário que o movimento sindical superasse seu "lastro cultural que bloqueia iniciativas inovadoras [e] busca as soluções no Estado e na fórmula jurídico-legislativa". ${ }^{285}$ Afirmava ainda que o sindicalismo devia "desenvolver ações junto à comunidade e aos governos locais para articular fóruns de debate sobre a política de emprego a nível municipal”. Como exemplo de tal política, argumentou que "As ações do cooperativismo desenvolvidas pela Central devem se dar dentro do princípio da integração inter-cooperativa e rural-urbana". Para a central, este era "um instrumento de organização gerador de emprego, distribuição de renda, formalização de trabalho [e] deve ser tomado como uma dimensão da estratégia sindical". Por último, a

\footnotetext{
${ }^{282}$ Idem, pp. 3-4

${ }^{283}$ A estratégia sindical no setor da economia informal. Força Sindical. CMS, s/r, Cx. 87, 28/03, p. 18.

284 "Editorial". A estratégia sindical no setor da economia informal. Força Sindical. CMS, s/r, Cx. 87, 28/03.

${ }^{285}$ A estratégia sindical no setor da economia informal. Força Sindical. CMS, s/r, Cx. 87, 28/03, p. 18.
} 
entidade sustentou que "Os sindicatos devem desenvolver uma política mais efetiva de acompanhamento da reforma da legislação de falências e concordatas e qualificar-se para intervir na recuperação de empresas falidas na forma de cooperativas ou empresas sociais". ${ }^{286}$

Porém, a estratégia de combate ao desemprego considerada pela central como a mais efetiva foi a implantação do Centro de Solidariedade ao Trabalhador (CST), inaugurado em 21 de julho de 1998, que se tornou um marco da política sindical em relação aos desempregados no sindicalismo brasileiro. No próximo item farei uma reflexão sobre as ações e representações da FS nesse terreno a partir da criação desse Centro.

$* * *$

A atuação da CUT entre 1995 e 1998 foi marcada, por um lado, pela mobilização. A central convocou uma greve geral em conjunto com a CGT e a FS, com ampla participação das organizações populares. Também realizou ações como campanhas e marchas que tiveram como eixo central as propostas de combate ao desemprego. A entidade defendeu a redução da jornada e a reforma agrária, além de políticas passivas para os desempregados. Em vários momentos se propôs a representar os desempregados por meio de associações, organizando-os para a luta. Por outro lado, nesse período a CUT investiu na participação nos fóruns tripartites, com destaque para o Codefat. A partir de sua inserção nesse conselho, a central passou a considerar a possibilidade de se tornar gestora direta dos recursos para propor cursos de formação e qualificação profissional que contemplassem os desempregados.

A FS seguiu defendendo o núcleo das políticas neoliberais, ainda que com algumas críticas pontuais ao governo de FHC, o que a levou a participar da greve geral em 1996. Sua leitura sobre as causas e possíveis soluções para o desemprego, bem como suas propostas para representar os desempregados, não diferiram substancialmente da CUT. No entanto, a central sustentou sua proposta de requalificação profissional e intermediação da força de trabalho, de maneira mais evidente, a partir do conceito de "empregabilidade". Por fim, a entidade criou o CST, em 1998, com o objetivo de nuclear essas políticas. Veremos a seguir como as centrais seguiram atuando diante dessas questões no período subseqüente.

286 "Conclusões, recomendações e linhas de ação tiradas no I Seminário O Setor Informal e a Estratégia Sindical”. A estratégia sindical no setor da economia informal. Força Sindical. CMS, s/r, Cx. 87, 28/03, p. 19. 


\subsubsection{Desempregados e sindicalismo cidadão: requalificação profissional, intermediação do emprego e economia solidária (1998 a 2002)}

A seguir, veremos como foi o comportamento da CUT e da FS no período de 1998 a 2002, quando se consolidou em ambas as centrais a prática de oferecimento de serviços justificada pela noção de sindicalismo "cidadão". Nesse período, as duas entidades passaram a investir na intermediação do emprego da força de trabalho e ampliaram seus programas de requalificação profissional. No caso cutista, ademais, ganhou força a estratégia no campo da economia solidária.

\section{A CUT}

As posições adotadas pela CUT a partir da $9^{\text {a }}$ Plenária Nacional marcaram um ponto de inflexão na história da central, pelo amadurecimento do sindicalismo propositivo, de serviços e cidadão que a caracterizou a partir de então. No entanto, como já argumentei, esse modelo sindical não significou o abandono dos protestos, tal como se evidenciou na “(...) mobilização de solidariedade contra a demissão em massa de trabalhadores na Ford", organizada pela CUT nos principais Estados e regiões metropolitanas", e o "Dia Nacional de Luta Contra a Política Econômica do Governo FHC e em Defesa do Brasil", no dia 26 de março (CUT, 1999, p. 15).

As resoluções desse encontro, ainda que não tenham expressado o interesse de propor uma política para os desempregados, voltaram a mostrar preocupação pela organização dos trabalhadores da "economia informal", considerando-a "tarefa da estrutura vertical e horizontal da CUT, em particular das organizações por ramo de atividade, nos quais esses trabalhadores exercem suas atividades" (CUT, 1999, p. 27).

Porém, a característica mais marcante desse período foi a consolidação do chamado sindicalismo de serviços, que já havia começado a tomar forma através de diversos programas. O Integrar, da Confederação Nacional dos Metalúrgicos (CNM), iniciado em 1996, foi levado a cabo com base em uma "concepção da prática educativa com trabalhadores adultos e desempregados" e uma "intervenção cidadã junto aos poderes públicos" visando "o enfrentamento da conjuntura atual e a disputa de hegemonia". Ademais, segundo a central, o projeto estava desenvolvendo “(...) um processo inovador de negociação da qualificação profissional dos trabalhadores empregados através da Pesquisa Participativa efetivada pelos trabalhadores nos locais de trabalho, a partir de negociações entre a CNM e as empresas" (CUT, 1999, pp. 51-52). Da mesma forma, destacou-se o Integral, promovido pela Secretaria 
de Formação da CUT (SNF/CUT), que tinha o objetivo de oferecer "capacitação de conselheiros para as Comissões Municipais de Emprego e Formação de Formadores em Qualificação Profissional". Essa capacitação estaria sendo desenvolvida para "atender à necessidade da Central de formar os representantes institucionais da CUT para atuarem em todo o território nacional nos conselhos tripartites e deliberativos", que está relacionado com a estratégia cutista de "intervenção em políticas públicas envolvendo qualificação profissional, com os recursos do FAT. Já os formadores de qualificação profissional, segundo a central, atuavam no sentido de "instituir novos modelos de educação e formação profissional, a partir dos princípios educacionais e metodológicos" construídos pela central (CUT, 1999, p. 52).

Em 1999 a SNF/CUT, por meio de um convênio com a Secretaria Nacional de Formação Profissional (Sefor) do Ministério do Trabalho e Emprego, criou o Projeto Nacional de Qualificação Profissional, experiência que foi um dos principais pilares da consolidação do sindicalismo de serviços no interior da central. O projeto envolveu "sete programas de educação, formação profissional e desenvolvimento solidário" (CUT, 1999, p. 52). Ciente de seus riscos políticos, a central destacou:

(...) as disputas em torno dos recursos do FAT e as experiências que vêm sendo desenvolvidas no campo da formação profissional não podem e não devem ofuscar ou secundarizar as atividades no campo da Formação Política e Sindical dos dirigentes, quadros intermediários e militantes da base cutista (CUT, 1999, p. 53).

A CUT argumentou que a "oportunidade" de execução de políticas públicas devia ser interpretada como base para novas relações com o Estado. Nesse sentido, destacou o papel do Sistema Público de Emprego (SPE), que deveria estar "fundado em princípios e recortes metodológicos que estimulassem a plenitude do desenvolvimento da cidadania" (CUT, 1999, p. 55). A entidade ressaltou ainda que este sistema depende do "desempenho mais geral do mercado de trabalho" e definiu o crescimento econômico, assim como políticas industriais, agrárias e agrícolas ativas como "a política de emprego mais eficaz que existe" (CUT, 1999, p. 57). No plano discursivo, a central não empregava o conceito da empregabilidade:

(...) as ações e projetos de formação profissional realizados no âmbito da CUT devem buscar o desenvolvimento de iniciativas e propostas que superem as concepções reducionistas de educação por meio de adestramento, bem como o conceito hegemônico de empregabilidade, no qual os trabalhadores são responsabilizados individualmente por sua (in)capacidade para adentrar e permanecer no mercado de trabalho (CUT, 1999, p. 65).

No entanto, como mostrei no item anterior, o efeito prático da noção segundo a qual a qualificação deve ser vista como uma estratégia de "enfrentamento" ao desemprego foi 
semelhante à presente na tese empregabilidade. A CUT não interpretou a falta de emprego como decorrente de um atributo individual, mas buscou inseri-la em um contexto mais amplo de "crescimento" econômico:

(...) a educação de qualidade [é um] direito fundamental dos trabalhadores, cuja importância da formação para o enfrentamento cultural, técnico e político da reestruturação produtiva, do desemprego e da exclusão de milhares de trabalhadores, não se reduz aos cursos de qualificação profissional, mas deve estar integrada a uma política de promoção de crescimento econômico, sustentável e solidário (...) (CUT, 1999, pp. 66-67).

A CUT passou a argumentar crescentemente sobre a necessidade de disputar os recursos do FAT, os quais, para a central, não deveriam ser usados para promover uma "reestruturação selvagem, sempre acompanhados da demissão em massa de trabalhadores". Como contrapartida, a entidade propôs uma "modernização produtiva" que fosse "negociada" e acompanhada de cláusulas sociais" (CUT, 1999, p. 58). Ao mesmo tempo, reconheceu a relativa ineficácia dos espaços institucionais tripartites, tais como as comissões de emprego:

Tratam-se de espaços que, na prática, têm oferecido poucas oportunidades de interferência nos rumos das políticas públicas de emprego e renda. A distância entre as atribuições efetivas das comissões estaduais e municipais de emprego e das Secretarias de Trabalho é enorme (CUT, 1999, p. 58).

Com aprovação da Executiva Nacional, a CUT passou então a investir na formação de uma Central de Atendimento Integrado ao Trabalhador em fins de 1998, com o objetivo de "transformá-la em experiência-piloto de desenvolvimento do espaço público não estatal" (CUT, 1999, p. 59). ${ }^{287}$ A CUT definiu os seguintes focos para o projeto: "envolvimento direto de entidades sindicais na gestão de políticas de emprego, trabalho e renda", "criação de uma rede de instituições cooperantes", "oferta articulada dos programas de seguro-desemprego, intermediação de mão-de-obra, educação e requalificação profissional, microcrédito, incubadoras de empresas, cooperativas de produção e populares e de iniciativas de estímulo ao primeiro emprego".

No plano discursivo, o desemprego passou a ser o principal tema da agenda política da CUT. Na avaliação da central, este problema e a precarização "passaram a se sobrepor à tradicional agenda dos sindicatos nas últimas décadas" (CUT, 1999, p. 63). Porém, prevaleceu um discurso ambíguo em que a central defendia a participação sindical na gestão pública,

\footnotetext{
${ }^{287}$ Sobre o tema, argumentava a entidade: "O Estado deve participar da execução de todas as iniciativas e dividir a responsabilidade com os atores organizados da sociedade, especialmente os sindicatos dos trabalhadores, na definição, acompanhamento, avaliação e sugestões de mudanças de rumos das políticas e programas" (CUT, 1999, p. 60).
} 
condenava a "desobrigação" do Estado e destacava a necessidade de um papel do empresariado nesse campo. ${ }^{288}$

Vale ressaltar que a CUT não concordava com as diretrizes da política de formação profissional propostas pelo governo federal: “(...) [A participação dos sindicatos] não pode e não deve substituir o sistema regular de ensino" (CUT, 1999, p. 69). Sobre este tema, acrescentou: “(...) a qualificação e a requalificação profissional para o desempenho de funções específicas nos locais de trabalho devem ser obrigação das empresas, e não podem onerar os trabalhadores (...)" (CUT, 1999, p. 71).

No Plano de Lutas, a central ressaltou que "Cada mobilização específica deverá incorporar também as bandeiras gerais da CUT e do Fórum Nacional de Luta por Trabalho, Terra e Cidadania" (CUT, 1999, p. 125). A Plenária aprovou para o dia 26 de agosto do presente ano, a "Marcha dos 100 mil sobre Brasília", que na avaliação da central poderia representar "um novo patamar de mobilização popular contra o governo", que previa uma paralisação nacional no mês de outubro com envolvimento de "toda a sociedade, desempregados, movimento popular, trabalhadores - dispostos ao enfrentamento com o governo FHC" (CUT, 1999, p. 126).

Nesse período, a CUT também convocou mobilizações contrárias à "guerra físcal". Juntamente com a redução da jornada com redução salarial e a flexibilização dos direitos trabalhistas, a redução dos custos para as empresas e a "descentralização produtiva" eram as principais propostas do governo para atrair investimentos e gerar postos de trabalho em outras regiões:

A guerra fiscal é a pilhagem dos recursos públicos - por meio de subsídios e incentivos fiscais dados pelos governos estaduais e recursos do Bndes mobilizados pelo governo federal (...). A guerra fiscal visa opor entre si as populações de Estados ou municípios, visa dividir os trabalhadores e seus sindicatos. (...) A 9 $9^{\text {a }}$ Plenária apóia a decisão da CNM de convocar uma greve nacional nas montadoras de veículos em 14 de setembro contra a guerra fiscal e em defesa de um Contrato Coletivo Nacional que assegure salários e direitos sociais unificados em todo o país (...) (CUT, 1999, pp. 128-129).

Nas mobilizações levadas a cabo pela central em 1999 o desemprego foi um dos temas de destaque. Por meio do "Fórum Nacional de Luta por Trabalho, Terra e Cidadania", a central realizou vários protestos contra a política econômica do governo FHC, como a Marcha

\footnotetext{
${ }^{288}$ Sobre o papel desse último, a CUT propôs uma "campanha de horas livres subsidiadas pelas empresas para a escolarização e a formação permanente dos trabalhadores" e ressaltou que, nesse sentido, "é necessário um compromisso da empresa em assumir o custo da requalificação profissional necessária à permanência no mercado de trabalho dos trabalhadores em situação de risco de desemprego" (CUT, 1999, p. 72).
} 
dos Cem Mil, realizada em Brasília no dia 26 de agosto, o Grito dos Excluídos de 7 de setembro, a Marcha em Defesa e Promoção da Educação Pública em 6 de outubro; a Marcha dos Sem Terra de 7 de outubro e o Dia Nacional de Paralisação e Protestos em Defesa do Emprego e do Brasil, marcado para novembro. ${ }^{289}$

No final de 1999 a CUT fundou a Central de Trabalho e Renda (CTR) de Santo André, considerada uma "iniciativa pioneira" por se tratar de um "espaço público", com o objetivo de "oferecer à população desempregada da região" "serviços integrados e articulados de habilitação ao seguro-desemprego, oferta de vagas oferecidas pelas empresas, orientação para o trabalho, cursos de educação profissional e o encaminhamento para programas de geração de trabalho e renda". A entidade também destacou o papel do "crédito às pequenas iniciativas individuais ou coletivas dos desempregados em gerar renda para o sustento de suas famílias". A partir desse momento, segundo sua avaliação, a CUT passou a representar os interesses dos desempregados, tanto na proposição de políticas contra as demissões como no oferecimento de serviços e na organização desse segmento para a atividade econômica:

A Central teve atuação destacada nas Câmaras Setoriais que resultaram no combate à recessão econômica e ao desemprego. Foi ainda pioneira na criação de iniciativas de desenvolvimento da agricultura familiar, de cooperativas de produção, empresas autogeridas e de educação profissional orientadas à reinserir os desempregados no mercado de trabalho, buscando realizar a dignidade e as aspirações cidadãs de todos os desempregados. $^{290}$

Outro evento que marcou a consolidação da perspectiva "cidadã" na CUT foi a criação da Agência de Desenvolvimento Solidário (ADS), no dia 3 de dezembro de 1999. Essa agência foi fundada para reunir as diversas experiências apoiadas pela central "inseridas no campo da "economia solidária" ("cooperativas de produção, de serviços, de crédito e de consumo, associações de produtores, empresas em regimes de autogestão, bancos comunitários e diversas organizações populares, no campo e na cidade" ${ }^{291}$. O projeto foi

\footnotetext{
289 "Paralisar em defesa do emprego e do Brasil". Informacut n. 269, nov. 1999, p. 05. Entre as propostas cutistas, além daquelas já mencionadas ao longo do trabalho, apareceram ainda bandeiras como o "Programa Nacional de geração do $1^{\circ}$ emprego, com jornada especial para os estudantes" e o "fim do trabalho infantil e adoção do programa nacional de bolsa-escola às famílias de baixa renda”.

290 “A Central de Trabalho e Renda de Santo André". Informacut n. 269, nov. 1999, p. 12

${ }^{291}$ Segundo a definição da própria CUT, "Economia solidária é uma nova forma de organização do trabalho e da produção, por meio de empreendimentos econômicos solidários e de interações entre os agentes produtivos econômicos solidários, nos quais a cooperação é um princípio fundamental. Os empreendimentos econômicos solidários se baseiam em princípios da autogestão, democracia, participação, igualitarismo, cooperação, autosustentação, desenvolvimento humano e responsabilidade social". Para a central, além de apresentar "grande potencial de ampliação das possibilidades de geração de novas oportunidades de trabalho", esse tipo de projeto também "propicia uma maior democratização do trabalho, valorização das relações humanas e distribuição da
} 
apresentado pela entidade com a justificativa de "incorporação dos trabalhadores desempregados e cooperados na base da CUT". ${ }^{292}$

Nesse momento a CUT avaliou como positiva sua participação no Codefat, já que este "constitui-se num dos mais importantes avanços democráticos na gestão das políticas públicas de emprego e crédito". Sustentou também que a interferência cutista no conselho "representa uma alteração fundamental e democratizante na gestão das políticas ali decididas”. Nesse sentido, ressaltou que "Praticamente todas as políticas ativas de mercado de trabalho executadas com recursos do FAT foram concebidas, propostas e tiveram sua implementação assegurada exatamente pelos esforços das representações cutistas". ${ }^{293}$

Nesse momento, o governo investia nas propostas de flexibilização do mercado de trabalho, por meio do projeto de alteração do Artigo $7^{\circ}$ da Constituição Federal. Para a central, as tentativas anteriores de flexibilização, como o contrato de trabalho por prazo determinado, "tiveram impacto praticamente nulo, justamente porque não havia rigidez nenhuma", argumento que sustentou a partir da idéia que "No Brasil, não existem grandes dificuldades para demitir (...)" ${ }^{294}$

As propostas da CUT de economia solidária ficaram evidentes no $7^{\circ}$ Concut, em que a central destacou sua importância para a representação dos desempregados: "Diante do aumento do desemprego e da informalidade, os sindicatos cutistas não podem se manter numa posição de omissão na qual a última relação que tem com os trabalhadores desempregados é a homologação da rescisão do contrato de trabalho". Ou ainda: "A 'economia solidária' tem se apresentado como uma nova forma de se constituir alternativa de luta contra o desemprego e diálogo concreto com os desempregados e demais setores marginalizados pelas grandes cadeias produtivas (CUT, 2000, p. 33).

Ao justificar tal ação, a entidade afira que o sindicalismo e o cooperativismo fazem parte de um mesmo projeto histórico, pois surgem:

\footnotetext{
renda". Dessa forma, a economia solidária pode "coexistir com o mercado capitalista ao mesmo tempo que o questiona" (“Agência de desenvolvimento solidário". Informacut n. 270, dez. 1999, p. 30).

${ }^{292}$ Idem.

${ }^{293}$ A central se referia ao Programa de Geração de Emprego e Renda, que foi responsável pela abertura de financiamento para o "setor informal, pequenas e micro-empresas, associações e cooperativas"; o Pronaf, um programa de financiamento de agricultura familiar; o Proemprego (I e II), voltado para o investimento em infraestrutura no setor público, e o Programa de Formação Profissional (Planfor), vistos pela central como a "primeira iniciativa de políticas públicas nessa área que rompe com o monopólio até então exercido pelo "Sistema S'", significando "a democratização dos recursos dos 'S', até hoje geridos exclusivamente pelas entidades patronais" (“A participação da CUT no Codefat e a democratização das políticas de emprego". Informacut n. 270 , dez. 1999, p. 34).

${ }^{294}$ Porque o governo quer mexer no artigo $7^{\circ}$. Informacut n. 271, abr. 2000, p. 16.
} 
(...) no início da industrialização, quando os trabalhadores qualificados construíram os "clubes de ofícios" (sindicatos) para defender os interesses da profissão e as sociedades de consumo (cooperativas) com vistas a possibilitar o desenvolvimento de trabalho, renda e acesso a produtos mais adequados aos seus associados (CUT, 2000, p. 33).

A CUT ressalta também que a economia solidária, especialmente as cooperativas, representa uma "contraposição às políticas neoliberais" (CUT, 2000, p. 34). Para a entidade, esta é uma "estratégia inovadora da CUT no combate ao desemprego e à exclusão social", através desse mecanismo se busca "ampliar as possibilidades de um desenvolvimento econômico com maior distribuição de renda e geração de novas oportunidades de trabalho, sob princípios da democracia e da autogestão" (CUT, 2000, p. 34). Na construção dessa proposta, a central afirmava que ia buscar "incentivar a organização de comitês de desempregados por categorias" e "exigir que, ao invés de usar o dinheiro público para empréstimos à privatização, os bancos públicos criem linhas de financiamento e crédito para as cooperativas de produção industrial e rurais" (CUT, 2000, p. 35). ${ }^{295}$

As propostas cutistas de "envolvimento direto de entidades sindicais na gestão de políticas de emprego, trabalho e renda" se inseriam em sua estratégia mais geral de participação institucional parlamentar e na administração do Estado, exercício fundamental para a formação dos quadros burocráticos nos governos municipais e estaduais do PT, o que se consolidou especialmente a partir de 2003 no governo Lula. A própria central reconheceu como objetivo "o papel complementar que as iniciativas de espaços públicos não estatais devem ter com a execução das políticas estatais de empregos dos municípios e dos governos estaduais” (CUT, 2000, p. 51). Ou ainda: “(...) a atuação da CUT sempre se pautou pela combinação da luta de massas com a luta institucional" (CUT, 2000, p. 52). Como se pode observar, o democratismo é, na própria definição da central, um aspecto constitutivo da ideologia político-sindical cutista. Retomarei esse argumento mais adiante.

A $10^{\text {a }}$ Plenária Nacional ocorreu a poucos meses das eleições de 2002. A central assim se posicionou sobre o tema: "Sempre recusamos o rótulo de "braço sindical" do PT e definimos como "pelego" o sindicato que, ao invés de defender os interesses dos trabalhadores, encaminha as propostas do governo" (CUT, 2002, p. 03). Porém, a entidade apoiou explicitamente a candidatura de Lula, que segundo a central faria "um governo para os

\footnotetext{
${ }^{295}$ Nesse contexto, a CUT definia sua luta contra o desemprego através dos seguintes princípios: “Construir uma Ampla Mobilização Contra o Desemprego, a Demissão Imotivada (pela Ratificação da Convenção 158 da OIT) e pela Redução da Jornada de Trabalho sem Redução de Salário” (CUT, 2000, p. 47).
} 
trabalhadores" e que seria "um governo de combate à exclusão, com crescimento econômico, distribuição de renda, mais empregos, proteção social e resgate da cidadania, comprometido com a ampliação da democracia e da participação popular (CUT, 2002, p. 04). Vale destacar que nessa plenária, a CUT reafirmou a necessidade de organização dos trabalhadores desempregados:

A prioridade da CUT na atual conjuntura deve ser (...) a constituição e o fortalecimento de sua organização, tanto no âmbito horizontal como vertical, por ramo de atividade. Isso envolve tanto um processo de unificação política e organizativa das diferentes categorias de cada ramo como também a unificação das lutas, a ampliação da participação e da adesão dos trabalhadores que já compõem a base tradicional dos sindicatos, a incorporação pelas nossas entidades dos trabalhadores e trabalhadoras terceirizadas $\left[{ }^{296}\right]$, além da organização dos trabalhadores desempregados e daqueles que sobrevivem na economia informal (CUT, 2002, p. 12). ${ }^{297}$

No entanto, a organização dos desempregados por parte da CUT se restringiu à representação de interesses imediatos por meio do oferecimento de serviços e da atividade econômica. A central se contrapôs ao sindicalismo praticado pela FS, que em sua avaliação se pautava especialmente no caráter assistencialista. Caracterizava a política de sua opositora como "sindicalismo neoliberal" e argumentava que sua "principal característica é o "desenvolvimento de uma estrutura de serviços assistenciais aos trabalhadores, na maioria dos casos com a utilização de recursos oriundos de fundos públicos e como forma de respaldar a reforma do Estado e suas políticas (CUT, 2002, p. 24). ${ }^{298}$

O tom de rivalidade da CUT com a Força Sindical teve seu ponto máximo na Resolução n 08 da Plenária: “A CUT deve se abster de fazer qualquer ação conjunta com estas centrais sindicais e caracterizar a Força Sindical como inimiga da classe trabalhadora brasileira e exigir apuração dos fatos que envolvam a utilização de dinheiro público e de empresários por estas centrais" (CUT, 2002, p. 32). No entanto, apesar de suas diferenças metodológicas e estratégicas, a central utilizou os mesmos recursos em sua política de formação:

\footnotetext{
${ }^{296}$ Sobre esse segmento, a CUT informou que "existem experiências bem sucedidas de incorporação desses trabalhadores a partir de ações visando o seu enquadramento na convenção coletiva da categoria" (CUT, 2002, p. 19).

${ }^{297}$ A Resolução no. 07 da Plenária é ainda mais explícita quanto à necessidade de organização dos desempregados ao afirmar sobre a necessidade de "desenvolver mecanismos que viabilizem" sua organização "no âmbito sindical" (CUT, 2002, p. 32).

${ }^{298}$ Segundo a CUT, "O sindicalismo de resultados, e sua evolução para um sindicalismo neoliberal, estabeleceu um novo patamar para essa disputa de projetos. Desde 1986/1987 as classes dominantes contam com o suporte de um setor do movimento sindical que, nos anos 1990, tem apoiado a implementação do projeto neoliberal. Trata-se de um sindicalismo subordinado ao horizonte político e ideológico da burguesia. (...) Num âmbito mais geral, o sindicalismo neoliberal apóia as iniciativas de flexibilização de direitos do governo federal e defende propostas prejudiciais aos trabalhadores como no caso do FGTS" (CUT, 2002, p. 24).
} 
A PNF, que atuava até então fundamentalmente voltada para um público interno, dialogando quase que unicamente com as estratégias gerais da CUT, agora passa a dialogar com trabalhadores e trabalhadoras desempregados(as), trabalhadores e trabalhadoras de setores informais da economia, ganhando neste novo contexto uma dimensão pública que antes não possuíam (CUT, 2002, pp. 48-49).

Segundo a CUT, "A estratégia da PNF no campo da educação dos trabalhadores, sintonizada com as ações e as políticas da Central, deve vincular a ação formativa com a organização e luta sindical no sentido de fortalecer a CUT como sujeito político na luta de transformação da sociedade" (CUT, 2002, p. 54). Nesse sentido, destacou a importância de investir em uma " concepção de formação anticapitalista, emancipadora, classista, socialista, potencializadora da mobilização, organização e luta dos trabalhadores e trabalhadoras (...)" (CUT, 2002, p. 55). ${ }^{299}$

Destaco, para finalizar essa descrição, que a CUT buscou ampliar, a partir dos anos 2000, as funções da ADS. Em sua 10ª Plenária Nacional, a entidade ressaltou que a Agência:

(...) foi criada com a missão de promover a constituição, fortalecimento e articulação de empreendimentos autogestionários, buscando a geração de trabalho e renda, através da organização econômica, social e política dos trabalhadores e inseridos num processo de desenvolvimento sustentável e solidário. A ADS está organizando complexos cooperativos em todo o país, com políticas de formação, assessoria na gestão, comercialização e desenvolvimento tecnológico e está organizando um Sistema Nacional de Crédito (CUT, 2002, pp. 90-91).

Como parte de sua estratégia a central também defendeu a organização sindical dos cooperativados: "É fundamental a construção de uma forte aliança de classe entre empregados e cooperativados, ou seja, uma organização do conjunto dos trabalhadores". A CUT também sustentou que "Para isto é necessário combinar duas estratégias políticas: a formação de uma organização nacional de representação dos empreendimentos autogestionários e a organização sindical dos trabalhadores em empreendimentos autogestionários". Por último, afirmou que "É fundamental a construção da unidade política entre os trabalhadores empregados assalariados e os cooperativados, os que atuam no mercado informal e os excluídos do mercado de trabalho (desempregados)" (CUT, 2002, p. 92).

Em minha avaliação, por todos os elementos presentes nessa descrição, é possível afirmar que a central ofereceu serviços aos desempregados e os organizou para a atividade

\footnotetext{
${ }^{299}$ Na avaliação da própria central, "A partir de 1996, com o advento de projetos financiados com recursos de fundos públicos, passamos a conviver com uma nova realidade. Objetivamente, passamos a conviver com melhores e maiores condições de avançar na relação pesquisa/formação/organização e com possibilidades de consolidarmos uma estratégia de formação que impulsione e qualifique, ainda mais, as intervenções da CUT nos campos do sindicalismo, desenvolvimento e políticas públicas" (CUT, 2002, p. 58).
} 
econômica, mas sem mobilizá-los para a luta, apesar de ter identificado, em diversos momentos, sua necessidade.

\section{A Força Sindical}

No ano de 1998, em ato definido pela central como "1º de Maio pelo Emprego", realizado no Pacaembu, a FS declarou ter comparecido 70.000 pessoas. Em um artigo no qual se referiu a essa manifestação, a entidade definiu sua política como um "sindicalismo de união, que sonha com um país melhor, mas que nunca tira os pés da realidade (...)”. A central revelou ainda a entrega de um documento a FHC intitulado "O Pacote Social da Força Sindical", em que propõe frentes de trabalho, requalificação profissional e um "programa de estímulo à agricultura exportadora" sustentado por meio de projetos-pilotos que realizou no norte do país para provar que a região pode produzir, alimentar seus habitantes e ainda exportar". Para a central, o desemprego podia ser combatido "com imaginação, através de idéias criativas e possíveis de serem colocadas em prática". 300

Um dos pilares do sindicalismo praticado pela Força Sindical é a defesa da negociação tripartite entre governo, empresários e trabalhadores. Em fevereiro de 1999, um acordo que envolveu o Sindicato dos Metalúrgicos de São Paulo (SMSP) e o Sindicato dos Metalúrgicos do $\mathrm{ABC}$, este último, ligado à CUT, previa a redução do Imposto sobre Produtos Industrializados (IPI) para "aquecer o setor". O acordo foi definido pela central como “(...) digno de um país moderno - cuja intenção é, ao mesmo tempo, evitar o desemprego, incentivar o consumo e baixar o preço das mercadorias (...)". 301

No dia 5 de março de 1999, Paulo Pereira da Silva, presidente do Sindicato dos Metalúrgicos de São Paulo e Mogi das Cruzes, foi eleito presidente da central, já que Luiz Antonio de Medeiros iria assumir seu cargo de deputado federal. Em discurso de despedida, Medeiros afirmou que o principal mérito da central foi: “(...) refundar o movimento sindical e antecipar-lhe a modernidade". Também fez referência aos ícones da FS: "o Palácio do Trabalhador, o Centro de Solidariedade ao Trabalhador, o maior primeiro de Maio dos últimos anos, a Qualificação Profissional intensiva, o Crescimento superlativo (...)”. 302

\footnotetext{
300 “1998: Força Sindical reúne mais de 70 mil trabalhadores no Pacaembu e prova sua capacidade de atuação". Revista da Força Sindical, Ano 9, n. 2, março de 2000, p. 6.

301 “Negociação reduz imposto para solucionar crise no setor automobilístico". Jornal da Força, n. 12, mar. 1999, p. 5.

302 "Missão cumprida. Editorial. Luiz Antonio de Medeiros". Jornal da Força, n. 12, março de 1999. No mesmo artigo, a central afirmou que o sindicalismo praticado por Medeiros se justificava pelo "bom senso, no lugar do 
Em 1999, o ato do Dia do Trabalhador, definido pela central sob a consigna " $1^{\circ}$ de Maio pelo Brasil - por Emprego e Qualificação Profissional”, trouxe novamente a temática do desemprego como eixo principal. O evento foi previamente definido como "Semana do Trabalhador", pela realização de atividades nos sete dias que o antecederam. O ato contou com a presença de 100 mil pessoas no Sambódromo de São Paulo. Houve apresentações musicais com grupos de pagode e a entidade, assim como em 1998, "sorteou dez carros novos e 90 eletrodomésticos". A ampla concentração foi definida como uma "demonstração do poder de influência" e "capacidade de união do trabalhador". A entidade afirmou que houve "discursos duros contra a recessão e o desemprego", já que se tratava de seu "ponto mais crítico da crise do emprego no Brasil". ${ }^{303}$

Diante da ameaça de demissão na Ford Ipiranga, a central avaliou que a negociação do SMSP garantiu os postos de trabalho até agosto de 2000: “(...) a empresa deu garantia de salário e emprego a todos os funcionários até agosto de 2000”. Em uma manifestação na empresa, o Sindicato e a central exibiam a faixa "Trabalhadores na luta pelo emprego: não à guerra fiscal". A Ford Ipiranga ameaçou fechar e demitir seus 1500 funcionários, na mesma época em que anunciava a abertura de uma unidade na Bahia, evento sobre a qual assim se expressou a FS: “(...) somos a favor de investimentos em outras regiões do País, principalmente no Nordeste, mas que isso não signifique desaparecimento de empregos em outros lugares". Houve paralisação dos trabalhadores: "A empresa concordou em garantir um ano de emprego e salário a todos os funcionários. Uma assembléia votou a favor da proposta e a greve chegou ao fím no começo de agosto". Também nesse período a central noticiou os casos do Mappin e da Mesbla, empresas do setor comerciário em processo de falência. Para garantir os nove mil empregos, o Sindicato da categoria, com apoio da central, realizou protestos e acampamentos. Após negociações, “(...) o Bndes comprometeu-se a ajudar as empresas dispostas a arrendarem o Mappin e a Mesbla. A Força, naturalmente, fez questão

pragmatismo ideológico" e pela "união e entendimento, no lugar do ódio entre as classes". Em avaliação sobre sua presidência na central, Medeiros afirmou: “(...) alguma peça não se encaixava no quebra-cabeças do movimento sindical. Sindicalismo era sinônimo de greve e radicalização. A imagem do sindicalista era a de um líder carismático, mas sem credibilidade para entender e participar das relações políticas e econômicas que se estabeleciam no país. Faltava capacidade de negociação; sobravam críticas e faltavam propostas claras" ("O líder que lançou o novo sindicalismo brasileiro". Revista da Força Sindical, Ano 9, n. 2, mar. 2000, p. 21).

${ }^{303}$ Nesse momento, as propostas da central para combater o desemprego eram as seguintes: "Incentivo ao setor sucroalcooleiro, proposta que acabou sendo adotada meses depois, reorganização do Proger (crédito para micro e pequenos empresários), bolsa-escola, ampliação do seguro-desemprego e as grandes e urgentes reformas a se fazer no país - agrária, da previdência, tributária, sindical e política (...)”. ("1999: No dia do Trabalho, a Força Sindical voltou a surpreender o Brasil e mostrar espírito de luta e de união”. Revista da Força Sindical, Ano 9, n. 2, março de 2000, p. 8). 
que o acordo garantisse os empregos dos funcionários". A entidade citou ainda o caso da metalúrgica Nardini, que entrou em acordo com o Sindicato "para criar uma comissão de funcionários" que iria "gerenciar a empresa".304

Além da negociação propositiva diante das demissões, a FS investiu no oferecimento de cursos de qualificação profissional, como principal estratégia de "luta contra o desemprego". $\mathrm{Na}$ avaliação da entidade, é necessário superar o corporativismo: "Nos dias de hoje, uma central sindical ou um sindicato que pretende ter influência decisiva por um Brasil melhor não pode se preocupar apenas com os trabalhadores de sua categoria". ${ }^{305}$ Nesse contexto, afirmou ainda que “(...) o Programa de Formação Profissional da Força Sindical estende os braços ao trabalhador que precisa de qualificação para acompanhar o mercado de trabalho". A FS considerou ainda essa uma maneira de "aplicar com critério e inteligência os recursos do FAT”. Relatou que passaram por seus cursos, em 1997, 20 mil alunos; em 1998, 70 mil; e em 1999, 75 mil, totalizando 165 mil participantes em três anos. Entre os cursos oferecidos se destacaram "telemarketing e telecomunicações sem fio", definidos como "profissões novas e em ascensão", além de "administração de crédito e cobrança, auxiliar contábil, inglês e espanhol e, claro, informática", pois, segundo a central, "hoje quem não domina o computador é considerado quase analfabeto". 306 A perspectiva de sindicalismo "cidadão" também foi assumida pela FS. No plano do discurso, essa era uma forma de se contrapor ao corporativismo e abrir espaço para a representação do conjunto da população, inclusive dos trabalhadores desempregados:

Agora, a preocupação não é só com o trabalhador de cada categoria e a necessidade de uma greve ou não; a Força Sindical e seus filiados tratam de assuntos que dizem respeito a todos os trabalhadores e cidadãos brasileiros, empregados ou não, e se intromete em áreas até então intocadas pelos sindicatos, como educação formal e profissional. ${ }^{307}$

Com base em um discurso anti-corporativista a FS argumentava: "O respeito que angariamos de toda a sociedade nesses anos todos não é, portanto, fruto do acaso. Hoje a

\footnotetext{
304 "Luta pelo emprego ganha as ruas". Jornal da Força, n. 14, agosto de 1999, p. 1.

305 "Educação faz parte da luta do trabalhador brasileiro". Jornal da Força, n. 14, outubro de 1999, p. 1.

306 Em 1999 foram criados ainda os cursos de "técnica de vendas, montagem e manutenção de microcomputadores e segurança desarmada".

${ }^{307}$ Nesse contexto, a FS também apresentou críticas à estrutura sindical, mas permaneceu com a defesa do diálogo entre as classes: "Para tomar a estrada da modernidade, enfrentamos corporativismos retrógrados, ao propor reforma na estrutura de arrecadação das entidades sindicais, ao opinar contra a unicidade e a favor da pluralidade sindical e a ter a coragem de formar o hábito de sentar à mesa de negociações com empresários e políticos, com atitudes firmes e decididas mas sem fomentar o ódio entre as classes" ("Editorial. Paulo Pereira da Silva". Revista da Força Sindical. Ano 9, n. 2, março de 2000).
} 
Força Sindical é reconhecida como a entidade mestra para a solução do maior problema que atinge o trabalhador nesse fim de século: o desemprego". ${ }^{308}$ É nesse sentido que a FS se define como "moderna, pluralista e democrática". A modernidade se justificaria pela "coragem de modificar a visão do sindicalismo e do trabalho em geral". O pluralismo, por conta da existência das "das mais diversas matizes ideológicas" na central, o que faz a entidade constatar: "Isso é ser democrático".309

Como já foi explicitado, a FS afirma que seu surgimento se remonta a uma "corrente inteligente" do sindicalismo, "que não concordava com o radicalismo estéril nem com o conformismo de outras centrais". A partir do final dos anos 90, apresentava-se como "a central que mais cresce no país, além de ser a maior central nacional do setor privado”, já que contava, em 1995, com 445 entidades e 4.215.927 trabalhadores na base, e em março de 2000, com 1.055 entidades associadas e 8.850.133 afiliados. ${ }^{310}$

Para a FS, "embora o desemprego seja um mal crônico de nossos tempos, muito se pode fazer para combatê-lo", com "trabalho, bom senso, criatividade, ação e solidariedade". O principal projeto da FS nesse terreno era o CST, definido pela entidade como, "mais que uma agência de empregos", a "maior agência integrada de serviços de combate ao desemprego do país". O CST foi desenvolvido através de uma parceria da FS com o SMSP e o Ministério do Trabalho, utilizando-se de recursos do FAT. Segundo a central, o Centro "concentra e desburocratiza as ferramentas de que necessita o trabalhador que perde seu emprego", tais como o seguro-desemprego, qualificação profissional e o crédito para a pequena empregadora, além da intermediação de "mão-de-obra", através de um banco de dados com um cadastro de vagas disponíveis. A primeira agência do CST foi instalada no Palácio do Trabalhador, no bairro da Liberdade, em São Paulo. ${ }^{311}$ Em março de 2000, a FS afirmou que o Centro já havia realizado 1.7 milhões de atendimentos desde a inauguração (com uma média de 3.500 atendimentos diários), com 680 mil trabalhadores cadastrados, 370 mil encaminhados, sendo que 74 mil conseguiram o emprego (ou seja, cerca de $11 \%$ dos

\footnotetext{
${ }^{308}$ Idem.

309 “O nascimento de um novo caminho". Revista da Força Sindical. Ano 9, n. 2, março de 2000, p. 4.

310 “A central que mais cresce no país”. Revista da Força Sindical, Ano 9, n. 2, março de 2000, p. 10.

311 Até o final de 2002, além do posto da Liberdade, o CST contava com agências em Itaquera, Santo Amaro e no Centro (no Instituto Paulista de Ensino e Pesquisa, IPEP), na cidade de São Paulo; em Diadema, Guarulhos, Suzano, Osasco e Santo André, na Grande São Paulo; em Recife, Olinda e Jaboatão, em Pernambuco, e em Camaçari, na Bahia.
} 
cadastrados e $20 \%$ dos encaminhados). Também relatou que havia 5 mil empresas cadastradas e 105 mil pessoas beneficiadas pelo seguro-desemprego por meio da agência. ${ }^{312}$

Além das políticas desenvolvidas pelo CST, a FS afirma ter sido a primeira entidade a "desafiar um dogma inviolável" do "movimento trabalhista", propondo reformas à CLT, sob o lema da "flexibilização" e o argumento de modernizar as relações de trabalho no Brasil. Para o presidente da central, Paulo Pereira da Silva, "O trabalhador não está mais protegido com o atual sistema, mas sim cavando sua própria sepultura, tal a inflexibilidade das leis trabalhistas". Ainda que a central defendesse que os empregos fossem gerados com "crescimento e desenvolvimento", afirmava que "algo precisava ser feito urgentemente" em relação à legislação. ${ }^{313}$

Entre as idéias defendidas pela central estava a de conceder "autonomia aos sindicatos e centrais para negociações coletivas": "Que o livre diálogo entre patrões e empregados amparados por entidades fortes - possa inclusive se sobrepor à CLT". A FS também propunha o "contrato temporário", visto como um "instrumento para facilitar admissões, e jamais demitir". Também argumentava a favor da "suspensão temporária", considerada uma "chance" dada pela empresa ao funcionário: "Quando o período for recessivo, o trabalhador não é demitido, mas afastado temporariamente e com muitos de seus direitos preservados, inclusive um curso de requalificação bancado pelo empregador". A entidade propunha ainda a criação de frentes de trabalho e de fundos de capitalização de renda com parte do FGTS destinados à compra de ações de empresas privatizadas. Porém, considerava que essas medidas eram "pontuais" e que "as conquistas dos trabalhadores podem, e devem, ser ainda maiores". 314

Sob o argumento de que os jovens são os mais afetados pelo desemprego, além de investir em sua organização sindical, a FS implementou uma série de programas voltados para esse segmento, como a "Capacitação e Orientação Profissional para Jovens", a "Campanha de

\footnotetext{
312 "O sucesso do Centro de Solidariedade". Revista da Força Sindical, Ano 9, n. 2, março de 2000, pp. 12-13.

${ }^{313} \mathrm{Na}$ sua proposta de combate ao desemprego a FS argumentava que era necessário "se sobrepor à CLT". Defendia ainda bandeiras como redução da jornada de trabalho, flexibilização das leis trabalhistas e garantias de estágio e meio-período. A entidade pregava também a "integração" "desburocratização" do atendimento ao trabalhador, onde se reuniria o oferecimento do seguro-desemprego, intermediação de mão-de-obra, qualificação profissional e apoio à pequena empresa ("O Brasil que queremos nos próximos anos". Revista da Força Sindical, Ano 9, n. 2, mar. 2000, p. 48).

314 "A modernidade no mundo do trabalho". Revista da Força Sindical, Ano 9, n. 2, mar. 2000, pp. 14-15. Como destaca Trópia (2009), o crescimento das demissões em sua maior base - os metalúrgicos de São Paulo - levou a FS a criticar as taxas de juros e a abertura às importações, ainda que sem abandonar o conjunto das políticas neoliberais, tal como demonstra a defesa da flexibilização trabalhista.
} 
Valorização do Primeiro Emprego" e o "Programa de Formação Profissional". ${ }^{315}$ No período estudado, a central investiu também em programas assistencialistas, a exemplo do projeto "Meu Guri”, inaugurado em 1997 pela central em parceria com o SMSP, e definido como a ação "dos trabalhadores para tirar as crianças da rua". O programa é liderado pela esposa do presidente da central, Elza da Costa Pereira, e em 2000 atendia 29 crianças, algumas delas mantidas pelos trabalhadores através de contribuição aprovada em assembléia, com a condição de não ultrapassar de 50 centavos. ${ }^{316}$

Ao longo do período estudado, a FS aderiu ao conceito de sindicalismo cidadão, tal como argumenta a Direção Executiva Estadual de São Paulo: "O sindicalismo moderno assume novas formas e, sem abandonar a defesa dos trabalhadores, investe em projetos sociais, cria alternativas de emprego e renda para famílias e, em muitos locais, substitui a ação que deveria ser do Estado". ${ }^{317}$ Entre os projetos da FS no campo do sindicalismo cidadão estão o Sindicato Criança, para "atender adolescentes em situação de risco social, de 14 a 17 anos, oferecendo cursos profissionalizantes", lançado em agosto de 1995; o Projeto Eremim, do Sindicato dos Metalúrgicos de Osasco, inaugurado em setembro de 1999, voltado para crianças de 7 a 14 anos, que participam de "atividades pedagógicas de reforço escolar", e para jovens de 15 a 21 anos, que "recebem aulas de qualificação profissional; e o já citado Meu Guri, do SMSP. ${ }^{318}$ No campo do cooperativismo, encontram-se nucleados na central a cooperativa habitacional do Sindicato dos Trabalhadores da Construção Civil, a Coopehat, que atua em âmbito nacional, os 122 cursos do CST, e o Apodi, um projeto de assentamento, irrigação e produção agrícola, no Rio Grande do Norte, que envolvia 30 trabalhadores. ${ }^{319}$

O Dia do Trabalhador de 2000 contou, segundo a FS, com 1.2 milhões de pessoas. Houve shows de artistas populares, exames de saúde e tiragem de documentos. Foram distribuídos dois milhões de cupons para o sorteio de prêmios (dez carros 0km, cinco apartamentos e cinco mobílias para casa). $\mathrm{O}$ ato foi definido pela central como uma

\footnotetext{
315 “A luta por um futuro melhor". Revista da Força Sindical, Ano 9, n. 2, mar. 2000, p. 40.

316 "Meu guri está crescendo". Revista da Força Sindical, Ano 9, n. 2, mar. 2000, pp. 42. Em 2002, quando atendia 33 crianças, seria construída uma nova sede para o projeto, que teria capacidade para receber 120 crianças ("Meu guri vai mudar de casa". Revista da Força Sindical, Ano 11, mai. 2002, p. 31).

317 A matéria ressaltou que o surgimento dessa perspectiva se deu na Itália, em 1976, "durante um congresso da Unione Italiana del Lavoro (UIL), em Firenze", no qual os sindicalistas discutiam que "os sindicatos deveriam cuidar não apenas dos interesses do trabalhador, mas também de todas as questões que envolvem seu cotidiano" ("De corpo e alma com a comunidade". Revista da Força Sindical de São Paulo, Ano 1, n. 1, dez. 2000, p. 10).

${ }^{318}$ Idem, p. 11.

${ }^{319}$ Idem, pp. 12-13.
} 
demonstração de um "sindicalismo moderno, alegre e atuante". ${ }^{320}$ Entre as bandeiras de luta da central se destacou a redução da jornada de trabalho para 40 horas. A proposta foi defendida em parceria com a CUT e a CGT, apoiada em um estudo do Dieese, segundo o qual uma redução para 40 horas significaria a criação de 1.7 milhões de postos de trabalho. ${ }^{321}$ Ainda no ato do Primeiro de Maio a central apresentou a bandeira de criação do Sindicato Nacional dos Aposentados, que foi fundado em junho desse ano. Ao argumentar que a "festa" não se tratava de um evento "apenas musical", o presidente da central afirmou: "Hoje em dia temos que combinar manifestação com show de música porque é o que a população quer". 322

Nesse momento, pode-se dizer que a FS teve um de seus pontos máximos de conflito com o governo, como explicitou Paulo Pereira da Silva, presidente da central:

Recebi um recado do presidente da República, com quem não falo há meses. Ele estaria irritado com as críticas da Força Sindical à sua política econômica e decepcionado com nossas advertências de que não está cumprindo com seus compromissos sociais. O presidente, segundo o intermediário deste recado, irrita-se principalmente porque a Força Sindical apoiou sua candidatura e seu programa de governo. Com a franqueza que sempre me caracterizou, digo que continuo admirando as qualidades pessoais do presidente, mas reafirmo que os resultados sociais de seu governo, por obra de sua equipe econômica, são muito pequenos diante de nossas necessidades e possibilidades. É por isso que neste $1^{\circ}$ de Maio do ano 2000 e dos 500 anos do Descobrimento os trabalhadores brasileiros pouco temos a comemorar. O governo se recusa a discutir civilizadamente o salário mínimo. As reformas de repercussão social não foram feitas - só o foram as de caráter econômico". 323

O lançamento da Campanha Salarial Unificada 2000 foi feito no dia 24 de setembro na Praça da Sé com a presença de 70 mil pessoas, com shows de artistas populares e sorteio de 5 carros $0 \mathrm{~km}$. Entre as reivindicações, novamente aparecia a redução da jornada de trabalho para 40 horas. ${ }^{324}$ Neste evento pela primeira vez a FS e a CUT realizam uma campanha salarial juntas, definida por Paulo Pereira da Silva como "um exemplo de que nas grandes lutas - naquelas indispensáveis para o bem estar do trabalhador - a classe está unida”. ${ }^{25}$

\footnotetext{
320 "O maior $1^{\circ}$ de maio de nossa história” Jornal da Força, n. 15, mai. 2000.

321 "Redução beneficia trabalhador". Jornal da Força, n. 15, mai. 2000. De acordo com a central, "em pouco mais de dois meses de lutas, a Central conseguiu fechar 16 acordos de 40 horas semanais, beneficiando 11.4 mil trabalhadores, utilizando a tática de greve por empresa e paralisação por tempo indeterminado" ("Central sai na frente fecha acordos de 40 horas". Jornal da Força, n. 16, ago. 2000, p. 1, p. 4).

322 "Festa do trabalhador reúne 1.2 milhão de pessoas". Jornal da Força, n. 15, mai. de 2000.

323 "Pouco a comemorar. Editorial. Paulo Pereira da Silva". Jornal da Força, n. 15, mai.2000.

324 "Lançamento da Campanha Unificada reúne 70 mil pessoas na Praça da Sé". Jornal da Força, n. 17, out. 2000 , p. 1.

325 "Momento histórico. Editorial. Paulo Pereira da Silva". Jornal da Força, n. 17, outubro de 2000, p. 2.
} 
Em outubro de 2000 a FS iniciou a Marcha para Brasília, que percorreu $1.100 \mathrm{~km}$ durante 40 dias, com a presença de 150 sindicalistas para reivindicar do governo um salário mínimo de 180 reais e pagamento do FGTS. ${ }^{326}$ O protesto foi assim definido pela central: "Durante a Marcha, cerca de 200 trabalhadores e sindicalistas percorrerão a pé 1.200 quilômetro durante 33 dias". ${ }^{327}$ Após o ato, em reunião com o governo que contou com a presença dos ministros do Trabalho e da Fazenda, a FS fechou o acordo que garantiu o pagamento das perdas do FGTS a 60 milhões de trabalhadores. ${ }^{328}$

Em março de 2001 a FS completa 10 anos. Em boletim da central, o presidente Paulo Pereira da Silva destacou o papel da central no combate ao desemprego ao afirmar que "milhares de demissões foram evitadas a tempo porque a Força Sindical foi à porta da fábrica e resistiu junto com os funcionários". 329

O ato do Dia do Trabalhador de 2001 contou com 1.5 milhões de pessoas no Campo de Bagatelle, em São Paulo. O evento foi batizado de "Festa do Trabalhador", e foi noticiado pela central como "o maior $1^{\circ}$ de Maio do mundo". Novamente houve shows de artistas populares e sorteio de dez carros zero, cinco apartamentos e cinco mobílias de casa. ${ }^{330}$ Entre as propostas da central citadas durante o ato estavam a "redução da jornada de trabalho para 40 horas", "melhor distribuição de renda", a "recuperação dos salários" e a "geração de empregos". Nas instalações do evento, segundo a central, foram oferecidos serviços a 240 mil pessoas. $^{331}$

No campo político, a FS defende um desenvolvimento que combine "crescimento econômico com justiça social, liberdade individual e política e respeito ao meio ambiente". 332 Apesar de ter defendido a plataforma do neoliberalismo, a central argumenta que as reformas não aconteceram da forma prevista: "O Estado foi enfraquecido, as estatais foram vendidas, mas o resultado desse processo se deu sem um plano estratégico, não contribuiu para tornar o Brasil competitivo diante do mundo, na área do comércio e das finanças". ${ }^{333}$ Ressalta, ademais, que "não existe uma indústria brasileira forte e competitiva, nem um mercado de

\footnotetext{
326 "Veja o roteiro da marcha para Brasília". Jornal da Força, n. 18, novembro de 2000, p. 4.

327 "Central sindical lutou e fez valer o direito dos trabalhadores". Jornal da Força, n. 20, mar. 2001, p. 3.

328 "Vitória no FGTS : trabalhador vai receber o seu direito". Jornal da Força, n. 20, mar. 2001, p. 1.

329 "Força Sindical faz 10 anos. A festa é dos trabalhadores". Boletim da Força Especial, mar. 2001.

330 "Realizamos uma festa democrática, pluralista e pacífica', diz Paulinho". Jornal da Força, n. 21, maio de 2001, p. 4.

331 "Estações de Atendimento: serviços gratuitos para mais de 240 mil pessoas". Jornal da Força, n. 21, maio de 2001 , p. 6.

332 "Brasil 2001. Um novo projeto para o Brasil". Revista da Força Sindical, Ano 10, setembro de 2001, p. 13.

${ }^{333}$ Idem, p. 21.
} 
consumidores capaz de mantê-las". Por último, a entidade sustenta que: "A abertura comercial (...) começou de forma desorganizada, brutal, matando empresas nacionais que poderiam ser fortalecidas - não pelo subsídio estatal, mas pelo apoio creditício e tecnológico - e acabaram morrendo, com perda de milhares de empregos". 334 Destaco também, desse mesmo documento, uma passagem que explicita um aspecto central da ideologia político-sindical defendida pela FS. Na visão da entidade, para que os trabalhadores consigam um aumento de sua renda, é necessário investir na melhoria da relação entre capital e trabalho, o que se deve dar de forma cooperativa, pois os empresários devem ter um aumento da produtividade. Nesse sentido, a central cita três fatores:

O primeiro, é que o conflito entre capital e trabalho é um dado natural da relação entre estes dois atores sociais em uma economia de mercado. Desta forma, o importante é criar mecanismos que administrem este conflito e não tentar reprimi-lo ou suprimi-lo. O segundo, as organizações de trabalhadores e de empresários devem ser fortes e representativas. Somente organizações realmente fortes são capazes de negociar responsavelmente e sem demonstrações desnecessárias de força; somente organizações fortes podem induzir à cooperação e não ao conflito, ao aumento da produtividade e não ao desinteresse pelo trabalho. O terceiro, as considerações anteriores sugerem que um dos problemas a serem atacados é a dessincronia entre a centralização da organização sindical e a descentralização do processo de negociações coletivas hoje vigente no Brasil. ${ }^{335}$

Nesse momento, a FS tinha o CST como seu principal cartão de visita. Segundo a central, este órgão contribuiu significativamente para a geração de empregos desde a sua criação. Para o coordenador do Centro, Tadeu Morais de Souza: "Só aqui no Centro de Solidariedade ao Trabalhador é que se encontram palavras diferentes. Por exemplo: 'temos vagas'. (...) Enquanto todo o mercado de trabalho reduz vagas, no Centro eles aumentam".336

Nos anos 2000 a FS passou a investir crescentemente em cooperativismo, como na Agrovida Força da Terra, um "projeto de assentamento que incentiva a produção familiar para posterior comercialização", fruto da parceria com o Banco da Terra, do governo do Estado e o Ministério do Desenvolvimento Agrário, do Governo Federal. Segundo a entidade, “o projeto beneficia atualmente 276 famílias em 14 municípios paulistas da região sudeste" e o objetivo da FS é "prestar auxílio às famílias na etapa de capacitação para a produção com valor agregado e na comercialização e distribuição". 337

\footnotetext{
${ }^{334}$ Idem, p. 22.

${ }^{335}$ Idem, pp. 24-25.

336 “Temos vagas. Editorial. Tadeu Morais de Souza”. Motivação, Ano 2, n. 12, dez. 2001, p. 2.

337 "Terra para quem precisa, oportunidade para quem não tem”. Jornal da Força, n. 26, outubro de 2002, p. 4. Em 2002 o SMSP criou uma cooperativa de crédito, a Metalcred, para "oferecer aos seus cooperados taxas de 
De acordo com a FS, o Dia do Trabalhador de 2002 contou com 1.7 milhões de pessoas reunidas na Praça Campo de Bagatelle, em São Paulo, e foi considerado pela central como "a grande festa do cidadão. ${ }^{338}$ Além de shows realizados na "Semana do Trabalhador", o evento se destacou pela promoção das "Estações Cidadania" que, segundo avaliação da central, recebeu 280 mil pessoas para tirar documentos e realizar exames de saúde, higiene bucal, cortar o cabelo e tratamento estético, entre outros. ${ }^{339}$

Nesse momento a central seguia crítica à maneira como o governo FHC conduzia a abertura às importações, considerada "indiscriminada" pela entidade. Quando se noticiou sobre a sobretaxa dos EUA às importações do aço para proteger da concorrência o setor siderúrgico, 500 trabalhadores da CSN, Usiminas e metalúrgicos de São Paulo realizaram um ato em frente ao Consulado Americano em São Paulo para criticar a medida, que afetaria o emprego no Brasil. Durante o evento, os manifestantes distribuíram hambúrgueres aos funcionários do consulado e à população, exibindo uma faixa com a consigna "Sim, nós temos bananas... e aço também! Yes, we have bananas... and steel too!". 340

Nas eleições presidenciais de 2002, Paulo Pereira da Silva se candidatou a vicepresidente de Ciro Gomes pela Frente Trabalhista (PPS, PTB, PDT ${ }^{341}$ ). No segundo turno, a entidade liberou o voto dos sindicalistas, o que foi considerado uma atitude de "natureza pluralista e democrática". ${ }^{342}$ Com a eleição de Lula a central se reuniu com o presidente eleito e apresentou suas propostas. ${ }^{343}$

juros abaixo dos cobrados pelo mercado". Para aderir ao programa, o trabalhador na época deveria pagar uma taxa de adesão no valor de 215 reais ("Metalúrgicos de São Paulo criam cooperativa de crédito". Revista da Força Sindical, Ano 11, mai. 2002, p. 32).

338 "Editorial. Paulo Pereira da Silva". Revista da Força Sindical, Ano 11, mai. de 2002.

339 "Estações Cidadania recebem 280 mil pessoas". Revista da Força Sindical, Ano 11, mai. 2002, pp. 28-29.

340 “A barra pesada do livre mercado". Revista da Força Sindical, Ano 11, maio de 2002, p. 5.

${ }^{341}$ PDT: Partido Democrático Trabalhista; PPS: Partido Popular Socialista; PTB: Partido Trabalhista Brasileiro.

342 "Força Sindical libera voto de sindicalistas para o 2o. Turno". Jornal da Força, n. 26, outubro de 2002.

${ }^{343}$ Entre as propostas da FS estavam as seguintes: "criação do Fórum Nacional do Trabalho (para discutir a reforma do sistema sindical); reajuste do salário para $\mathrm{R} \$ 240,00$ em 2003; desonerar de impostos a cesta básica; ampliar os programas Bolsa-Escola, Sistema Nacional de Emprego (Sine) e Qualificação do Trabalhador, com recursos do FAT; reduzir em 10\% a jornada de trabalho; ampliar o seguro-desemprego; criar frentes de trabalho rurais e urbanas; e criar as Câmaras Setoriais" ("Um novo projeto para o Brasil. Editorial. Paulo Pereira da Silva”. Jornal da Força, n. 27, dez. 2002, p. 2. Também constava na pauta de reivindicações a redução da jornada "sem redução dos salários" e se previa que "os empregadores teriam a contrapartida, para não perder competitividade, redução de impostos e incentivos fiscais". Ademais, a FS sustentava o aumento do segurodesemprego de 12 parcelas, além de vinculá-lo a um programa de qualificação profissional. Sobre as frentes de trabalho, a central afirmava que estas seriam vinculada a "qualificação profissional obrigatória à bolsa-trabalho, concedida unicamente para desempregados de baixa renda e baixa qualificação" ("Central apresenta propostas para a retomada do desenvolvimento do país". Jornal da Força, n. 27, dezembro de 2002, p. 3). 
Vale apresentar algumas palavras sobre o CST, já que este é considerado pela FS como sua principal resposta aos desempregados. A contracapa da primeira revista deste órgão resume o ideário do projeto. Segundo a própria entidade, seu princípio de "união dos interesses" se faz presente nas propostas apresentadas pela central para desempregados e empresário:

Se você está procurando emprego, venha fazer política com a gente. Política de apoio ao desempregado. São mais de 10 mil vagas oferecidas todos os dias: de empregada doméstica a engenheiro, operador de marketing a gerente industrial. Em três anos, esses serviços já arrumaram emprego para $300 \mathrm{mil}$ trabalhadores. Se você precisa contratar, venha fazer política com a gente. Política de RH da melhor qualidade, com programas de apoio ao empregador, que começa na maior base de dados do país: um cadastro de quase 2 milhões de candidatos. E a custo zero para a empresa. Quando existe união, os resultados aparecem para todos os lados. ${ }^{344}$

O CST é considerado pela FS como "a maior agência de serviços integrados de combate ao desemprego da América Latina". Segundo sua definição, o centro tem o objetivo de "reunir em um só lugar todas as ferramentas possíveis para lutar contra o desemprego". Na avaliação da entidade, "O atendimento não é frio, mas com o senso de respeito, dignidade e apoio integral":

Com o centro, o paradigma do movimento sindical virou pelo avesso. O padrão era que cada sindicato lutasse pela sua categoria. Agora a luta é também pelo desempregado. Pela educação, formal e profissional. Pelo aposentado. Pela busca do primeiro emprego. O Centro de Solidariedade não é só uma agência de empregos. É, sim, um projeto pioneiro e radical, um divisor de águas do sindicalismo. Um amadurecimento com conseqüências profundas, imediatas e a longo prazo, para o país e para a grande luta do trabalhador. ${ }^{345}$

A adesão da FS ao conceito de "empregabilidade" foi tão forte que a central passou a dar até curso sobre o tema: "Centro cria curso de empregabilidade, para ensinar ao trabalhador os atalhos para chegar ao emprego", entre os quais aponta que "o maior deles é superar o medo e o derrotismo". Segundo a central, o curso "resgata a motivação e a auto-estima de quem está desempregado". Ministrado por psicólogas especialistas em "recrutamento e seleção de pessoal", ou "recursos humanos", aborda temáticas como "preparação para entrevistas de emprego, para as dinâmicas de grupo, sobre como montar currículos, marketing pessoal, vocabulário, confiança, vestimentas e, finalmente, motivação". A mensagem veiculada pode ser resumida da seguinte forma: "não adianta querer vencer o desemprego na

\footnotetext{
344 "Trabalhadores, empresas e Estado. A Força fez a união". Revista Solidariedade, Ano 1, n. 1, dezembro de 2002.

345 “Ação e Solidariedade para mudar o país". Revista Solidariedade, Ano 1, n. 1, dezembro de 2002, pp. 4-5.
} 
base do desespero, só batendo de porta em porta. É preciso preparação. Isso se chama empregabilidade". Ou seja, a idéia da central é de que "a crise não é só do emprego, é também da cabeça das pessoas, de treinamento, de preparo". Nas palavras de uma das ministrantes do curso, "Têm de correr atrás. Há muitos cursos e palestras gratuitos ou baratos em São Paulo, e muitos não vão por comodismo. Não estão acostumados a buscar conhecimento". 346

O discurso de empregabilidade é construído através da responsabilização do trabalhador por sua situação do desemprego, explicado pelo fracasso e pela ausência de atribuições individuais. Ademais, essa noção pressupõe a existência de vagas no mercado de trabalho, que poderiam ser preenchidas mediante a atitude ou o acúmulo de determinadas características pessoais. É a base ideológica para o investimento em qualificação profissional por parte dos sindicatos, que desonera a política de treinamento e capacitação do empregador e a política de formação profissional do Estado. Também é conivente com as práticas do Departamento de RH das empresas e sua estratégia de psicologia motivacional, onde ganha espaço conceitos como o já citado "marketing pessoal”, gestão de pessoas, empreendedorismo pessoal, endogestão, etc.

Sob o discurso de que a solidariedade "tem derrotado o fantasma do desemprego", o CST divulga que em seus quatro anos de existência "empregou" 260 mil trabalhadores, formou em seus cursos de qualificação profissional 574 mil alunos (além de mais 261 mil que se formariam até o final de 2002), habilitou ("sem filas e sem burocracia") 370 mil segurosdesemprego, e efetuou seis milhões de atendimentos. ${ }^{347}$ Segundo a FS, entre as atribuições dos funcionários do CST está o serviço de captação de vagas pela cidade, o que os levaram a ser chamados, em Santo André, de "garimpeiros da esperança": "Eles visitam as empresas, apresentam o trabalho da agência e, em seguida, fazem um cadastro das que têm interesse de receber candidatos de acordo com suas necessidades". 348 De acordo com o relato da central, muitos empresários elogiam o trabalho do Centro: "Empregadores elogiam o Centro de Solidariedade, que oferece serviços e estrutura de alta qualidade para selecionar trabalhadores

\footnotetext{
346 “O emprego visto por outro ângulo". Revista Solidariedade, Ano 1, n. 1, dez. 2002, pp. 10-11.

347 "Remando contra o desemprego. E vencendo". Revista Solidariedade, Ano 1, n. 1, dez. 2002, pp. 16-17. De julho de 1998 a dezembro de 2004, a central afirma que o CST já havia formado 835 mil pessoas em qualificação profissional, realizado 11.3 milhões atendimentos, encaminhado 420 mil contratações, feito 580 mil habilitações em seguro-desemprego ("O caminho mais curto entre o trabalhador e o emprego". Centro de Solidariedade ao Trabalhador. CMS, s/r, Cx. 87, 15/06/2005).

348 “Temos vagas". Revista Solidariedade, Ano 1, n. 1, dez. 2002, pp. 26-27.
} 
dentro do perfil desejado. E o que é melhor: sem cobrar nada por isso". ${ }^{349}$ Vale destacar como a FS definiu o princípio de "solidariedade" do Centro, com uma citação bastante elucidativa:

Solidariedade é oferecer um atendimento de primeira, dando orientação e apoio ao trabalhador que busca um emprego. É tratar esse trabalhador com dignidade, e não apenas como mais um. É fazer uma radiografia completa do mercado de trabalho e descobrir onde o trabalhador pode conseguir o seu emprego. Se uma colocação não estiver fácil, solidariedade é dar oportunidade ao trabalhador de um curso de qualificação profissional, gratuito, com vale transporte e lanche incluídos. Que nesse curso o ensino seja de qualidade dos melhores cursos particulares, com professores competentes e bom material didático. E que seja uma escola realmente útil, com a formação direcionada para o mercado de trabalho. Onde o trabalhador vai encontrar um sorriso e quem o possa ajudar. Vai encontrar a seu dispor uma estrutura completa para empregar que já colocou no mercado de trabalho mais de 420 mil pessoas. E que se tornou sinônimo de política integrada de combate ao desemprego. Isto é Solidariedade. ${ }^{350}$

A partir da leitura da documentação, propus uma periodização para analisar a política das centrais diante do desemprego e dos desempregados.

(i) De 1990 a 1992 o sindicalismo brasileiro se caracterizou pela afirmação das principais bandeiras cutistas para enfrentar o desemprego (redução da jornada de trabalho e reforma agrária) e pela relativa resistência às demissões de alguns sindicatos. Este também foi o período correspondente à gestação do propositivismo nas negociações pela manutenção de postos de trabalho, tanto por parte da CUT quanto da nascente FS, que ademais, argumentava sobre a necessidade de se "modernizar as relações entre capital e trabalho" no país para gerar empregos.

(ii) De 1992 a 1995, especialmente a partir da experiência das Câmaras Setoriais automotivas, consolidou-se a política propositiva na CUT, ainda que sem o abandono das mobilizações reivindicativas. A FS cumpriu um papel ativo na defesa das políticas neoliberais, como as privatizações e a abertura comercial. Ambas as centrais passaram a buscar participação em espaços institucionais tripartites onde se discutia o emprego, mas ainda não concretizou uma política de representação dos desempregados. A entidade se

\footnotetext{
349 "Os melhores serviços a um preço imbatível: grátis". Revista Solidariedade, Ano 1, n. 1, dez. 2002, pp. 3031. Em outra passagem, a central definiu os benefícios que o centro oferece aos empresários (...) "O empregador pode conseguir o funcionário com o perfil ideal e contar com profissionais especializados para entrevistar, treinar, selecionar e aplicar testes psicológicos aos candidatos ou, se quiser, contar apenas com o espaço físico para fazer tudo isso" ("O caminho mais curto entre o trabalhador e o emprego". Centro de Solidariedade ao Trabalhador. CMS, s/r, Cx. 87, 15/06/2005).

350 "O caminho mais curto entre o trabalhador e o emprego". Centro de Solidariedade ao Trabalhador. CMS, s/r, Cx. 87, 15/06/2005.
} 
pautou no discurso de "evitar as demissões" a partir de uma atuação propositiva, firmando acordos que, supostamente, "todas as partes cediam e todos lucravam".

(iii) De 1995 a 1998 as duas centrais passaram a investir no oferecimento de serviços aos desempregados, através da política de requalificação profissional e intermediação de emprego da força de trabalho, com a criação do CST, pela FS, em 1998, e da CTR, pela CUT, no ano seguinte. Vale lembrar que essa política foi sustentada pela participação dessas centrais no Codefat. Ainda que ambas as entidades tenham levantado bandeiras em conjunto contra o desemprego, tal como na greve geral de 96, cresceu em seu interior a tese da "empregabilidade". Ainda que na FS tenha ganhado uma conotação mais evidente (por meio do discurso motivacional de seus cursos), essa noção também esteve presente, em estado prático, na ação sindical cutista (ainda que tenha se pautado na perspectiva paulofreiriana defendida por suas escolas sindicais).

(iv) De 1998 a 2002 a perspectiva de sindicalismo cidadão se consolidou tanto na FS como na CUT, embora nesta última foi mais presente a perspectiva de economia solidária, a partir da qual a entidade organizou os trabalhadores sem emprego para a atividade econômica. Essa prática foi justificada pela central pela necessidade de dar uma resposta à representação dos desempregados. Nas duas centrais aparecem experiências de cooperativas, que, por um lado, apontam para uma estratégia de alternativas de emprego e renda através de microempreendimentos, e por outro, para o oferecimento de serviços aos sindicalizados (cooperativas de crédito, habitação popular, etc.). A FS também se caracterizou por seu crescente investimento em "projetos cidadãos" (que vão desde a assistência a crianças exmoradoras de rua e restaurantes comunitários a uma política voltada para a expansão dos centros integrados de atendimento aos desempregados). Apareceu nessa central a perspectiva de sindicalismo alegre e festivo (como nos shows e premiações do Primeiro de Maio), e um sindicalismo de auto-ajuda, que deu um novo impulso ao discurso de "empregabilidade" através de conceitos como "marketing pessoal" na busca do emprego. Com base nessa perspectiva, a entidade inclusive promoveu palestras de empregabilidade e motivação ministradas pelos funcionários de seu departamento de "recursos humanos". 


\subsection{Representações dos quadros dirigentes sobre a organização dos desempregados}

Nesse item analisarei as representações dos quadros de dirigentes da CUT e da FS sobre a atuação do movimento sindical diante dos desempregados. A partir das questões que serão tratadas aqui, buscarei aprofundar temáticas não abordadas de maneira suficiente pela documentação. Com base na análise das entrevistas, buscarei compreender as explicações apresentadas sobre os limites da organização dos desempregados para a luta, as possibilidades da representação sindical de seus interesses e da construção de ações conjuntas com o sindicalismo.

\section{A CUT}

De maneira geral, os sindicalistas da CUT afirmaram que a central teve um papel fundamental na luta contra o desemprego nos anos 90. Segundo os dirigentes, a luta da entidade foi marcada, primeiramente, pela resistência às privatizações e às políticas econômicas neoliberais que provocavam a eliminação de postos de trabalho. Ademais, seus sindicatos resistiram às demissões com mobilização e por meio de uma estratégia propositiva, buscando construir alternativas.

Em sua própria avaliação, a central também representou os interesses dos desempregados. Primeiramente, por ter defendido o emprego de seus trabalhadores. Em segundo lugar, por ter feito a denúncia do desemprego em suas manifestações e por ter contemplado o tema em suas pautas de reivindicações, além de ter feito propostas para a geração de postos de trabalho em diversos espaços institucionais. A CUT argumenta ainda que cumpriu esse papel no oferecimento de serviços aos desempregados, por meio de cursos de requalificação profissional e de intermediação do emprego da força de trabalho. Por último, afirma tê-los organizado para a atividade econômica, com a política de cooperativismo e economia solidária que culminou na criação da ADS, em 1999. No entanto, a maioria dos entrevistados reconheceu que a central não organizou os desempregados para a luta, embora alguns tenham explicitado que a política de aliança com as organizações populares foi uma forma de construir a unidade com esse segmento, já que algumas organizações, como os sem-terra e os sem-teto, conta com essa parcela da classe trabalhadora em sua base social.

$\mathrm{Na}$ concepção cutista, a defesa do emprego é a principal do sindicalismo contra o desemprego e, portanto, deve ser vista como a primeira ação tipicamente sindical de 
representação dos interesses dos desempregados. De acordo com vários entrevistados, por um lado, o sindicato deve se mobilizar contra as demissões. Por outro, deve atuar em defesa de estratégias de promoção de políticas de geração de postos de trabalho. Como afirma um sindicalista representante da Contraf: "a principal reivindicação nossa é a garantia de emprego" (E1). Ademais, na visão dos dirigentes, as lutas mais gerais da central contra o neoliberalismo foram protestos contra o desemprego na medida em que este problema era causado por aquele modelo econômico. Com argumento semelhante, um dirigente da Contracs afirmou:

(...) por mais que a CUT não tenha um trabalho direto com os desempregados (...) eu acho que a CUT tem feito várias ações, tem cobrado, de todos os governos, (...) sempre discutindo a questão de redução dos juros, (...) [reivindicando] uma política voltada para o crescimento da economia (E3).

No entanto, a bandeira de priorizar a defesa do emprego serve, freqüentemente, para justificar a ausência de organização dos trabalhadores "informais" e desempregados, a partir do argumento de que esta política seria uma forma de legitimar a condição de "excluídos" desses segmentos, tal como sustentou um membro da Executiva Nacional da CUT:

Então, se você não tem uma legislação que protege o emprego, depois de correr atrás do prejuízo que é organizar politicamente o desempregado para... para que exatamente? Para continuar informal? Para continuar vivendo às margens da economia formal? Vai virar ambulante? É esta a expectativa do cara? A gente dizia nos anos 90: "a política da CUT para os excluídos é incluí-los no mercado formal de trabalho". Porque não dá futuro para ninguém você continuar sendo excluído para o resto da vida, ficar defendendo a sua condição de excluído (E16). ${ }^{351}$

Tal como expus ao longo do capítulo, a CUT implementou estratégias de representação de interesses dos desempregados com dois tipos de políticas: a requalificação profissional e a intermediação de postos de trabalho. Como pude verificar nas entrevistas, essas medidas são avaliadas como experiências positivas pela ala majoritária da central. Um entrevistado da Contracs citou o projeto "Todas as Letras", que incluía os desempregados em seu públicoalvo (E3) e um dirigente metalúrgico da CNM se referiu ao Integrar, que atuou entre 1995 e 2003, voltado para "ex-metalúrgicos desempregados". 352 Segundo esse dirigente,

\footnotetext{
${ }^{351}$ Este dirigente destacou que a organização dos desempregados é menos importante que a luta pela garantia da estabilidade no emprego: “(...) mais importante do que organizar politicamente o desempregado (eu não estou dizendo que não se deva organizar politicamente, mas já te dissemos que é muito difícil), é evitar o desemprego. O importante é estabilidade no emprego e curiosamente parece que virou tabu aqui no Brasil falar de estabilidade no emprego, quando o país até a ditadura militar tinha um regime de estabilidade no emprego" (E16). O entrevistado se refere ao regime de estabilidade após dez anos de exercício, existente no Brasil até 1966, quando os militares criaram o Fundo de Garantia por Tempo de Serviço (FGTS).

${ }^{352}$ Segundo este entrevistado, este programa foi desenvolvido através de um convênio com o Ministério do Trabalho, mas "a partir de 2003 foi cortado em função de contingência de verbas do Governo [Federal]" (E12).
} 
(...) durante este período nós tivemos cerca de 385.000 metalúrgicos que passaram por cursos de qualificação ou requalificação profissional, a maioria deles desempregado. Então, eu acho que isso é uma seara que os sindicatos podem atuar, no campo da qualificação profissional para o desempregado, mas é um programa que exige dinheiro (...) e também exige uma discussão política sobre se (...) é um papel do Sindicato ou se é um papel do poder público, de criar programas de qualificação e requalificação profissional (E12).

Uma ex-dirigente nacional cutista afirmou que, apesar de não ter conseguido "resolver essa história da representação", a central atuou no sentido de promover a "democratização de recursos", especialmente do FAT, e a "reinserção" do trabalhador no "mundo do trabalho". (E17). O entrevistado da Escola Sindical São Paulo (ESSP) ressaltou que foi contemplada pela CUT a organização dos trabalhadores desempregados durante os cursos de formação, mas que essa estratégia foi "subaproveitada" pelas direções:

[A organização dos desempregados] era um pressuposto. Era também uma forma de começar a falar de sindicalismo e tentar organizar este público. Agora, eu acho que ela foi subaproveitada pelas direções. (...) tinha dirigentes responsáveis políticos por um determinado grupo de trabalhadores (...). Mas de um modo geral o cotidiano dessas ações formativas ficava quase na mão do grupo técnico (...) (coordenação pedagógica). Os dirigentes (...) depois que estavam montadas as turmas, depois que começavam os cursos, eles se distanciavam disso e acho que aproveitaram muito pouco no sentido político (...) aproveitaram muito pouco a experiência de poder dialogar mais com esta população, sentir mais as suas demandas, de colocar o sindicato como um ator mais atuante para aquela comunidade, não só no curso, mas, enfim, em outras iniciativas de mobilização, de organização. (...). A CUT, através dos seus dirigentes, poderia ter explorado melhor isto (E2).

Sobre as razões desse "subaproveitamento", o entrevistado argumentou que as direções estavam "pouco preparadas e "não estavam entendendo a estratégia". Ademais, sustentou que "não estavam totalmente sintonizados com esta política da CUT de formulação da política, que era um novo momento do sindicalismo, que é a necessidade de dialogar com o trabalhador desempregado ou com risco de exclusão social” (E2). Por último, destacou o limite dos interesses e demandas cotidianas dos dirigentes:

(...) um dirigente tem sua agenda, sua demanda, ele cuida do imediato, do tradicional, do movimento sindical. Então ele achava [que] "estando as turmas organizadas" o curso está acontecendo, então o sindicato já fez a parte dele e não tinha mais a preocupação de estar mais presente no dia a dia no curso. Então, em alguns casos, o Sindicato era como uma escola, os trabalhadores chegavam, iam para as salas de aula, saíam e aquilo ia ficando assim num espaço não muito diferente de outra escola (E2). ${ }^{353}$

\footnotetext{
353 Para uma dirigente do Sindicato dos Bancários de São Paulo, as possibilidades de organização dos desempregados pelos sindicatos também se tornam limitadas por conta do excesso de demandas sindicais: “(...) a empresa ainda tem muita demanda para dar conta e isso acaba, então, deixando nebuloso um pouco este (...)
} 
Quando perguntado sobre como poderiam ser aproveitadas essas experiências do ponto de vista da organização política pela CUT, o entrevistado indicou, primeiramente, o "processo de politização" e a utilização do espaço "para fazer a disputa". Sustentou, ademais, que a central "não tinha nenhuma fórmula de organizar os desempregados", mas apontou algumas possibilidades:

(...) discutir com o próprio grupo, quais seriam as alternativas ali, o que o sindicato poderia fazer para ajudar na organização dos desempregados ou na organização ali daquele território, daquela comunidade, dependendo das demandas que iam aparecer. Então, aí eu acho que faltou a presença do dirigente para fazer isso porque isto é uma construção coletiva, (...) é uma construção cotidiana, (...) essa cultura de acolher o desempregado, não no sentido assistencialista, mas como um ator que faz parte do sindicato e que pode participar do sindicato e pode propor e pode atuar. Isso é muito incipiente, pelo menos aqui no Brasil (E2).

Para os defensores desse tipo de política na CUT, apesar de não resolver o problema do desemprego, o investimento em qualificação profissional era uma forma de viabilizar um trabalho de construção crítica com os desempregados a partir do conceito de "cidadania". Ademais, não se tratava de substituir o papel do Estado na promoção de políticas públicas, como argumentavam seus críticos, mas de levar a cabo uma estratégia de "disputa de hegemonia" e formação crítica do desempregado. Como ressaltou o entrevistado da Contracs:

Eu acho que a pessoa tem que saber porque ela está desempregada, porque... as condições que ela é submetida, ela não tem oportunidade, porque ela tem que se preparar para buscar oportunidade e eu acho que isso aí é importante, forma o cidadão, não só forma a função (E3). ${ }^{354}$

Para alguns entrevistados o sindicalismo cidadão foi uma estratégia da CUT que facilitou a construção de uma política para o desempregado. Um dirigente do Sindicato dos Metalúrgicos do ABC contou: "Nós consideramos que nosso Sindicato é um sindicato cidadão, nós não podemos olhar o Sindicato como sendo do portão para dentro, nós temos que olhar o Sindicato do portão da fábrica para dentro e para fora (...)" (E14). No entanto, destacou que a organização dos desempregados deve se dar através de diversas instâncias, nas quais os sindicatos podem atuar em conjunto por meio de parcerias:

Quando ele [o trabalhador] está desempregado, também discutir alternativas, agora para que você faça isso é necessário que o trabalhador possa participar e se organizar lá fora porque o sindicato ele não pode representar ele lá fora, mas o sindicato pode apoiar as instituições para poder cobrar políticas públicas

terreno de ajuda nesses outros segmentos, (...) os desempregados, este segmento mais vulnerável (...). O mercado de trabalho formal ainda também é muito problemático no Brasil e os sindicatos têm muita demanda” (E11).

${ }^{354}$ Esse entrevistado relatou que no curso de gastronomia promovido pelas escolas sindicais, por exemplo, "o pessoal não está aprendendo a fazer só um prato, ela está aprendendo a ser um cidadão” (E3). 
externas. Aonde se dá? Se dá através das associações de amigos de bairros, de Igrejas, ou seja, instituições e ONGs que estão ali para poder discutir aquela condição (E14).

Tal como já argumentei, a concepção de sindicalismo de serviços e cidadão foi funcional à estratégia cutista de participação sindical da gestão pública para a composição de quadros para os governos municipal, estadual e federal. Porém, essa estratégia sofreu críticas no interior da própria central. Um membro da Executiva Nacional pertencente a uma corrente minoritária explicitou:

(...) não é casual que foi o Vicentinho que inaugurou o termo [sindicalismo cidadão], e não é casual que os principais defensores deste tipo de sindicalismo sejam os metalúrgicos do $\mathrm{ABC}$ e tampouco é casual que o Presidente da República seja egresso desse setor, como a política do atual governo Lula, uma política abertamente de parceria entre trabalhadores e patrões. Basta ver a composição do Ministério do governo Lula, onde no Ministério da Indústria está o Miguel Jorge, que era quem negociava pelas montadoras os acordos salariais dos metalúrgicos e é o Miguel Jorge que esta semana anuncia na imprensa que virá uma nova rodada de redução de IPI para as montadoras. Não acredito que isentando o patrão de imposto, nós vamos resolver o problema do emprego, ao contrário, vamos resolver o problema dos patrões (E16). ${ }^{355}$

Para um entrevistado da FEM/CUT, a política da central foi acertada na sua apresentação de propostas para a geração de empregos. Porém, este sindicalista apresentou críticas quanto à política de requalificação profissional:

(...) eu acho que a CUT faz a política correta de conseguir emprego. (...) não adianta você formar as pessoas (...) para ir para o mercado de trabalho, [se] na verdade não tem mercado (...). Se a política econômica não vai, vai ter desempregado e vai ficar desempregado, não adianta você formar ele, você vai formar ele para estar disputando entre eles uma vaga, ao invés de você reduzir o índice de desempregado através das políticas, os juros altos (...) (E7).

O entrevistado da Conticom sustentou que "na verdade, quando tem crise (...) não tem emprego nem para quem é qualificado" (E9). Um dirigente químico do SQSP e da CNQ também afirmou que se trata de uma "uma política paliativa" e que "o sistema capitalista, quando ele quer profissional, ele forma". Citou o exemplo das empresas automobilísticas que,

\footnotetext{
${ }^{355}$ Sobre a possibilidade de se diminuir o emprego nas negociações tripartites, este entrevistado argumentou: "Nível de emprego, meu amigo, é ao longo dos três, quatro meses que tem a isenção do IPI, eu garanto o nível de emprego. Eu posso demitir 200 e contratar 200 com o salário mais baixo, o nível de emprego está garantido. Foi a política das Câmaras Setoriais nos anos 90, em pleno governo Collor, quando os metalúrgicos do $\mathrm{ABC}$, junto com as montadoras e junto com o governo, sentaram numa mesa, isentaram de impostos os patrões, garantindo o nível de emprego, teve menos demissão no setor metalúrgico. Só que este IPI que os patrões economizam e que o Estado não arrecada, vai faltar aonde depois? No serviço público. (...) A Central existe exatamente para unificar metalúrgicos, servidores públicos e camponeses na mesma luta contra o capital, portanto, ela não deveria admitir, como não admite na sua Carta de Princípios, mas na prática acaba admitindo, parcerias com os patrões (...)" (E16).
} 
como a Volkswagen, durante muitos anos "não esperavam o Senai formar, eles formavam dentro da própria empresa". O dirigente argumenta também que a proposta de requalificação "acabou jogando uma responsabilidade do desemprego para os trabalhadores, dizendo que eles estavam incapacitados":

Eu achei isso de uma maldade impressionante, embora a CUT também entrou neste processo aí de capacitação profissional. Eu acho que não é a capacitação profissional que gera emprego. O que gera emprego é o crescimento econômico, aonde os empregos aparecem e mesmo as pessoas não estando qualificadas, as empresas tem capacidade de qualificação no próprio trabalho (E10).

Apesar do discurso crítico de alguns, há sindicalistas cutistas que validam abertamente a idéia de empregabilidade, com argumentos muitos semelhantes aos apresentados pela Força Sindical. Um dirigente da Contracs sustentou da seguinte forma a importância dos cursos de qualificação: "na retomada do crescimento, muitas vezes tem alguns postos de trabalho que não são preenchidos por falta de qualificação". Por fim, argumentou sobre a necessidade de se "criar uma forma de as pessoas estarem desempregadas se qualificar" para não acabarem "perdendo espaço no mercado de trabalho" e poderem "vislumbrar um futuro melhor" (E3).

Um dirigente da Executiva Nacional argumentou que o objetivo principal da CUT não era substituir o Estado, mas "disputar a hegemonia" com outras entidades que promoviam a formação dos trabalhadores:

(...) nós não queremos e nunca quisemos ocupar o papel do Estado na questão da educação profissional

(...) o empresariado no Brasil através dessas organizações no sistema $\mathrm{S}$ continuam tendo uma visão, na nossa opinião, de atendimento ao mercado e não de atendimento ao desenvolvimento regional (...). Nós temos que discutir qual é a vocação da região (...), a qualificação profissional deveria estar ligada a este projeto mais amplo de educação (E13).

Este entrevistado considera a experiência da Central de Trabalho e Renda como "exitosa". Afirmou que esse tipo de política se inseria na CUT com a seguinte perspectiva: "Nós sempre defendemos na CUT de que era preciso criar um sistema efetivamente público de emprego e renda". O dirigente sustentou, no entanto, que essa medida não foi eficiente no impacto à geração de postos de trabalho: “(...) não é abrindo cada vez mais postos, seja das centrais sindicais, seja dos empresários, seja do SINE (...) que você vai resolver o problema do desemprego, e sim construindo um centro que fosse realmente público" (E13).

Em suma, a avaliação do setor majoritário da central é de que a requalificação profissional e a intermediação de força de trabalho foram experiências positivas, o que não quer dizer que tenham sido levadas a cabo pela central sem polêmicas internas. A respeito da estratégia da economia solidária, deve-se considerar inicialmente que esta abarcou 
experiências diversas, que vão desde o empreendedorismo social à recuperação de empresas que passaram a funcionar de modo autogestionário, sob o controle dos trabalhadores. Há uma tendência a se valorizar mais este último tipo de experiência. Segundo vários entrevistados, a orientação da CUT é de não abandonar as empresas em caso de falência e que os sindicatos devem persistir no objetivo de assumir o controle e transformá-las em cooperativas. Alguns sindicalistas observaram que a proposta de cooperativas não é uma saída global para a situação do desemprego, mas ameniza parcialmente a situação de alguns desempregados. Destaco dois relatos que sustentaram essa tese, respectivamente, de um ex e de outro atual membro da Direção Nacional da central:

(...) nesse período várias fábricas faliram e o dono da fábrica muitas vezes deixava as máquinas e caía fora, pegava o dinheiro acumulado em algum banco e a orientação que era dada era para os trabalhadores tomarem a empresa e tentar fazê-la retomar a produção. Que é um problema difícil, exige muito, o trabalhador não tem capital para poder girar, mas (...) isso tudo foi uma coisa importante para minimizar a questão do desemprego. Ela não resolve, mas dá uma minimizada para alguns trabalhadores (E5)

Nós orientamos, por exemplo, um trabalhador de uma fábrica falida, a ocupar a empresa. Por que às vezes a fábrica vai à falência, mas o dono não fica falido, o dinheiro está na conta dos parentes, da amante, o cara fica transitando no mundo todo e a empresa dele falida, e às vezes vende as máquinas, inclusive. Então ocupar as empresas para transformar isto numa cooperativa, ou então numa empresa gerenciada pelos próprios trabalhadores, é nossa posição. Nós incentivamos os trabalhadores a não abandonar as empresas num caso deste de empresas falidas (E15). ${ }^{356}$

O movimento de recuperação de empresas falidas é considerado pela CUT como um exercício de prática anticapitalista, que possui um caráter de classe progressista inato que é afrontar a propriedade privada, além de oferecer alternativas de emprego e renda aos trabalhadores como forma de resistência às demissões. Ademais, uma justificativa ideológica cutista, sustentada teoricamente pelo pensamento do economista Paul Singer, é de que o cooperativismo conformaria uma estratégia de superação das relações capitalistas. ${ }^{357}$ Nesse sentido, argumentou um dirigente: "Num conjunto de demitidos, a gente tem processos organizativos que (...) procuram organizar os trabalhadores mesmo por fora do capitalismo, montando empreendimentos augestionários e solidários, e que nós temos grandes exemplos

\footnotetext{
${ }^{356}$ É comum também no discurso cutista a oposição entre "cooperativas autênticas", como as construídas em sua base, e as "coopergatos", desenvolvidas por setores empresariais "para reduzir direitos trabalhistas" (E6), conforme ressalta um entrevistado da CNM.

${ }^{357}$ Desse autor, ver Singer (2000).
} 
nacionais" (E15). ${ }^{358}$ Esta questão gerou polêmica no interior da central, tal como explicitou um dirigente nacional:

A crítica que alguns companheiros nos faziam era a de que ao fazer isso você estava fazendo no âmbito do capitalismo, ou seja, que mesmo na economia solidária seria uma forma de trabalhar (...) com princípios que não são os princípios socialistas. Agora, se eu olhar as experiências destas cooperativas (...), eu diria que nós estamos muito mais avançados que muitas das experiências reais que a gente teve no mundo, de supostas transições socialistas, porque nessas cooperativas os trabalhadores são donos do meio de produção (E13).

Outra justificativa para o investimento na economia solidária é de que se trata de uma maneira de organizar os trabalhadores não sindicalizáveis, especialmente os desempregados, como uma forma de promover uma política para além da base de representação clássica no assalariado formal com carteira assinada. Para este mesmo dirigente cutista, “(...) se você olhar o histórico destas pessoas [organizadas no campo da economia solidária], grande parte delas que estão envolvidas neste debate são desempregados, são pessoas que foram desempregados da sua empresa de origem" (E13). Para outro membro da Executiva Nacional, existe uma "cultura sindical" predominantemente voltada para o trabalhador formal, e por isso "este campo não é olhado com tanta prioridade" (E15).

Um dirigente metalúrgico do $\mathrm{ABC}$ e da FEM relatou que em sua base há três ou quatro cooperativas. $\mathrm{O}$ dirigente ressaltou que esses projetos não surgem por iniciativa própria dos sindicatos, mas somente nos casos de empresas em processo falimentar onde existe a possibilidade de recuperação. Para este sindicalista, o caso mais bem sucedido foi o da Conforja (após a recuperação, Uniforja), em Diadema, por se tratar de uma empresa "muito grande", "que está já exportando" (E7). Sobre essa experiência específica, outro dirigente, também metalúrgico do $\mathrm{ABC}$ e da $\mathrm{CNM}$, afirmou: “A empresa faliu, mas nós constituímos uma cooperativa de trabalhadores e continuamos produzindo na empresa só com os trabalhadores. Depois essa cooperativa conseguiu superar todas as dificuldades, hoje é uma empresa modelo, de destaque (...)" (E6). Este entrevistado defende que é possível de se implementar experiências desse tipo: “(...) hoje nós conseguimos comprar o maquinário (...) os trabalhadores lá já estão investindo, ampliando o negócio e até quem sabe muito

\footnotetext{
${ }^{358}$ Este entrevistado revelou que a sustentação financeira dos projetos se dá pelo apoio de organismos públicos e do grande capital estatal e misto: “(...) a gente vive é mais de parcerias, prioritariamente com o Banco do Brasil, Petrobrás, Sebrae, Fundação Banco do Brasil e empresas mais do campo de empresas públicas, para construir estas alternativas" (E15). Um entrevistado da CNM ressaltou que esse tipo de política foi incorporada pelo sistema institucional no governo Lula: “(...) hoje já foi absorvido pela própria política do governo federal, o próprio Bndes tem linhas específicas para este tipo de demanda” (E6).
} 
rapidamente chegue até ao número de trabalhadores que nós tínhamos quando ela fechou, que é cerca de 800" (E6).

Um entrevistado do SQSP declarou não concordar com a política de requalificação profissional levada a cabo pela CUT, à qual opôs, como experiência positiva, a recuperação de empresas sob o controle de trabalhadores: “(...) formar e soltar na rua para procurar emprego, não é isso que gera emprego. Agora, organizar os trabalhadores, ter alguma coisa, algum ponto de apoio de gestar um trabalho, é outra coisa" (E10). A respeito das dificuldades do cooperativismo, este mesmo entrevistado argumentou:

(...) acho muito difícil de ser implantada (...) no sistema capitalista, no sistema de livre mercado aonde tudo é disputa (...). Você tem que trabalhar só com o mercado direto porque você não consegue trabalhar com outras empresas. Então, (...) uma cooperativa de auto-peças, (...) a Volkswagen vai comprar de uma cooperativa? Lógico que não (E10).

$\mathrm{Na}$ visão da ala majoritária da central, o conceito de economia solidária se enquadra na perspectiva de sindicalismo cidadão da CUT. Foi a partir desse referencial que a central criou a ADS, considerada como a resposta cutista aos segmentos da classe trabalhadora que não conta com emprego formal. Como ressaltou um dirigente nacional: “A ADS é uma estratégia para quem já está descartado do mercado de trabalho e que tem que sobreviver (...)" (E15). Segundo este entrevistado, enquadra-se, portanto, na necessidade de "disputar a hegemonia" na classe trabalhadora garantindo a representação e setores não sindicalizáveis: “ (...) a idéia foi de garantir a estes trabalhadores uma representação classista também” (E15). ${ }^{359}$

No entanto, há correntes minoritárias que criticam a proposta de sindicalismo cidadão dentro da central, tal como afirmou um membro da Executiva Nacional:

(...) do ponto de vista de concepção política sindical, não me parece uma alternativa nem coerente e nem positiva. Sindicalismo cidadão, no meu ponto de vista, na forma como ele surgiu no Brasil no debate histórico da CUT, é para borrar a concepção de sindicalismo classista. A própria idéia de cidadania não importa se você é burguês ou proletariado, todos são cidadãos. (...) Então a idéia de sindicalismo cidadão, muito generosa, (...)acobertou muitas coisas que eu acho que não seria e não deve ser atribuição de um sindicato (E16).

Este entrevistado defendeu a concepção clássica de sindicalismo classista e combativo para a CUT da seguinte forma:

\footnotetext{
359 Este sindicalista conceituou o sindicalismo cidadão da seguinte forma: “(...) foi uma proposta que o Vicentinho colocou (...) que tinha esta visão de que as centrais sindicais, os nossos sindicatos, não deveriam lutar única e exclusivamente [pelo] salário, mas entender o trabalhador e a trabalhadora como cidadão, com a amplitude de direitos (...)" (E15).
} 
(...) o Sindicato não é tudo, existem outras formas de organização (...). O sindicato tem um lugar na luta de classe. Ele é a organização elementar, unitária de todos os trabalhadores, independente de filiação política, ideológica, filosófica, num terreno de independência de classe. Nós estamos num lado, os capitalistas estão do outro (E16).

Este dirigente também criticou a noção de "sociedade civil", também difundida pela central para justificar o conceito de sindicalismo cidadão:

(...) a idéia, muito em voga, de "sociedade civil" é uma abstração. O que é uma sociedade civil? A sociedade real, concreta, é dividida em classes sociais com interesses antagônicos. E se existe uma razão de existir para o sindicato não é representar os interesses comuns da sociedade, não. O sindicato existe para representar o interesse de uma parcela da sociedade, os interesses da classe trabalhadora e estes interesses são opostos, contraditórios, antagônicos aos interesses da classe capitalista (E16).

Por último, o dirigente criticou as funções que as entidades cutistas passaram a exercer, com base na noção de sindicalismo cidadão. Apesar de longa, a citação é elucidativa:

(...) com a idéia de sindicalismo cidadão, por exemplo, os sindicatos cutistas (...) começam a ser, por exemplo, proprietários de escolas formais ou proprietários de uma rede hoteleira, ou passam a substituir o Estado no que o Estado deveria fazer, escola técnica federal, qualificação de mão de obra. Isso é tarefa do Estado, não é tarefa do sindicato. O sindicato é uma instituição de rede privado, o sindicato não é serviço público. A mania de que o sindicato é serviço público é porque a estrutura sindical brasileira, que era de Getúlio Vargas no velho estatuto padrão de sindicato, definia o sindicato como órgão de colaboração do poder público financiado por um imposto (...). Através desta idéia tão nebulosa que é a idéia de cidadania, acaba abrindo a possibilidade de você ficar fazendo negócios, que eu acho que não deve ser tarefa do sindicalismo. Quem quer fazer negócio, vá para outro lugar, sindicato é para defender a força de trabalho contra a exploração do capital, organizar a unidade dos trabalhadores para defender suas reivindicações, e se fizer isso já está jogando um papel político insubstituível porque hoje é uma pressão terrível. (...) Eu acho que isso fere o princípio fundamental da CUT que é o princípio da independência de classes. "Nós é nós e eles são eles, nós para cá, patrão para lá”, e a nossa relação é de conflito. Se aumenta o lucro do patrão vai faltar no nosso salário, se aumenta o nosso salário estamos tirando do lucro do patrão. Portanto, é conflito, não é de parceria e a idéia do sindicato cidadão aprofundou muito na CUT, hoje há setores na CUT que defendem uma política de parceria com os patrões. Não é um processo acabado, muitas vezes pode até não ser consciente, mas há sindicatos cutistas importantes como os metalúrgicos do ABC que fazem parceria com as montadoras para pedir ao governo Lula isenção de IPI para os automóveis, em troca de uma garantia do nível de emprego (E16).

Vale ressaltar que em 2009, quando foram realizadas as entrevistas, as experiências de cooperativismo na CUT haviam crescido em relação ao período estudado: "Eu não sei o número exato, mas eu acho que são mais de 25.000 trabalhadores acompanhados pela Unisol” (E6), destacou um dirigente da CNM. Tal como relatou um membro da Executiva Nacional, a expansão da CUT no campo da economia solidária levou a central a implementar, inclusive, 
uma "central de comercialização de produtos da economia solidária": “(...) você pode ter, por exemplo, uma empresa metalúrgica, de uma cooperativa que faz determinado material, uma estamparia, como é o caso da Uniforja, para ajudar a fabricar trator que vai ser utilizado na agricultura familiar" (E13).

Após essa explanação sobre a avaliação dos dirigentes a respeito das políticas cutistas levadas a cabo para os desempregados, chegamos ao ponto central da análise: que representações fazem os sindicalistas acerca da organização dos desempregados? Um diretor do SQSP argumentou que este papel deve ser da central e das confederações, e não do sindicato, que deve se restringir a elaborar um "cadastro de desempregados". Citou, como bandeira, que as entidades podem defender a isenção de serviços públicos e do transporte. Comparando com os anos 80, quando houve experiência de associação de desempregados químicos, para "fortalecer a reivindicação de políticas públicas", este dirigente ressaltou que “(...) na década de 90 a experiência não foi nessa direção, foi mais para poder minimizar os impactos do que de ter uma associação. O acompanhamento foi muito frágil, então, é outra relação". ${ }^{360}$ Um dos limites da representação dos desempregados pelos sindicatos no período destacado por este entrevistado foi a rotatividade intersetorial, que dificultou um trabalho nesse sentido, apesar do esforço de elaboração de um cadastro dos demitidos pelo setor de homologação. Nesse sentido, o dirigente destacou o papel da confederação na discussão de geração de empregos na categoria, pois esta tem "condição de fazer uma política industrial para minimizar o impacto de um setor, por exemplo, através da redução do IPI” (E8). Um dirigente nacional da CUT destacou que este papel teria de ser desenvolvido pela central, já que se trata do "interesse geral da classe trabalhadora:

(...) nós não podemos cobrar isso do sindicato porque apesar do sindicato de base ser um elemento importante, principalmente na tarefa de constituir um banco de dados de desempregados da sua categoria que auxilie depois nessa articulação e diminuição desta dispersão, e para isso o sindicato de base é fundamental, mas nós não podemos cobrar após a saída de um trabalhador de sua base que o sindicato desenvolva, com a mesma prioridade que ele vai cuidar do dia-a-dia do sindicato, esta ação de organização dos desempregados. (...) Isto tem que ser o papel da central. (...) No sindicato que tem já dificuldade de ter organização para o local de trabalho, que tem uma agenda enorme para cuidar, dos trabalhadores que tem carteira assinada e que estão no mercado formal, cobrar isso do sindicato é muito ruim. É muito difícil na nossa opinião. Então, o que a gente defende, criar um sistema aonde como é que

\footnotetext{
${ }^{360}$ O dirigente argumentou também que, nos anos 90, “como o desemprego foi muito sazonal (...), períodos muito diferentes, de contexto muito diferentes (...), a gente sempre teve uma política um pouco emergencial. (...). [Em] alguns momentos a gente teve algumas associações de desempregados para poder cobrar políticas públicas como também tentar recolocar no mercado (...) nos setores que a gente representa (...) (E8).
} 
eu sei que a pessoa ficou desempregada (...) Você cobra do sindicato certa obrigação que alguns sindicatos não vão conseguir fazer (...) grandes sindicatos, grandes organizações, aqueles mais preparados, com certeza tem mais poder para fazer isso, mas eu acho que o papel da Central sindical neste campo da organização dos trabalhadores, desempregados, precarizados, informais, terceirizados, é fundamental (E13).

Uma das tentativas da CUT de organizar os desempregados para a luta se deu em 2004, e foi assim relatado por um dirigente da central:

(...) nós fizemos um acampamento de dois dias debaixo do vão do Masp e abrimos uma linha aqui 0800 na CUT, ficaram diversas pessoas aqui do movimento social, atendemos, nós incentivamos os desempregados a ligarem para cá para a gente (...) foi interessante porque nós orientamos não só em São Paulo, mas no Brasil inteiro para fazer os acampamentos dos desempregados e excluídos (E15).

Outro dirigente do SQSP relatou que em alguns momentos foram organizadas manifestações sindicais em conjunto com os desempregados:

Teve um período que começamos a fazer manifestação inclusive na porta de mercado, na porta de banco, como uma forma de pressão, com alguns desempregados mais alguns dirigentes. Isso aí incomodava muito, mobilizava polícia, embora nunca teve confronto, mas criamos vários fatos políticos pressionando o governo (E10).

Um ex-membro da Executiva Nacional da CUT afirmou que houve protestos de desempregados no Brasil e destacou o papel das organizações populares na mobilização dessa fração da classe trabalhadora, especialmente o MST e os movimentos pela moradia:

Uma das saídas que os desempregados encontraram e aí acabam se organizando, quer dizer, com o desemprego gerou, fortaleceu os movimentos dos sem-teto, movimento de moradia, mas principalmente teve um movimento que cresceu muito com o desemprego que é as pessoas que vieram do campo para a cidade e com o desemprego tentou retornar para o campo e estes trabalhadores, trabalhadoras se organizaram principalmente no MST, no Movimento dos Sem Terra, e este foi o principal movimento que tentou, que desaguou estes desempregados, que é a pessoa tentando voltar para o local de origem dele, para onde ele saiu, do interior dos estados. Então, o movimento sem-terra ele foi, e é, um dos principais instrumentos dessas pessoas que querem voltar para a sua terrinha, sei lá, seu pedaço de quintal. (...) Se o movimento sindical não conseguiu organizar os desempregados, e isto é um fato, ele tentou, mas não conseguiu, então os desempregados eles tentaram outras saídas (...) além dos desempregados que se organizam, que é a parte mais pauperizada dos desempregados, são aqueles que não tem nada mesmo, então, estes tentam através do MST ter uma terra para plantar (E5). ${ }^{361}$

Segundo um dirigente nacional da CUT, a central sempre teve uma "íntima relação" com as organizações populares. Este sindicalista destacou o papel da comissão de luta por

\footnotetext{
${ }^{361}$ A questão levantada por este dirigente foi fundamental para a reflexão que será feita mais adiante sobre as formas de organização da reserva no Brasil, considerando suas diferentes parcelas e camadas.
} 
"Terra, Trabalho e Cidadania" durante o governo de FHC, em que participavam os "movimentos mais expressivos do país". Além da realização de diversas campanhas e atos conjuntos, o entrevistado também ressaltou o vínculo da central com o MST e sua participação na criação da Coordenação dos Movimentos Sociais (CMS), em 2003, "que se reúne periodicamente aqui na CUT, a cada 15 dias nós fazemos reuniões com todos os movimentos sociais do campo da esquerda (...)" (E4).

Os dirigentes cutistas citaram diversos limites para a representação dos desempregados, muito semelhantes aos apresentados pela bibliografia francesa a que fiz referência no primeiro capítulo desta tese. Primeiramente, foi muito comum a justificativa de que a mobilização sindical dos desempregados é, na realidade, construída através da estratégia de defender políticas de emprego. Os sindicalistas afirmaram, inclusive, que esta é uma reivindicação que o movimento sindical é o mais capacitado para fazer. Ademais, os dirigentes destacaram que não seria possível organizar um movimento cuja finalidade é o seu desaparecimento, tal como sustentou um membro da CNM:

O que a gente procurou motivar na CUT, sobretudo na década de 90, eram comitês de desempregados. Agora qual é o principal interesse do desempregado? Não é ficar desempregado o tempo todo, pelo contrário, é arrumar emprego, (...) fazer com que a economia e o mercado de trabalho abra oportunidades (...) o desempregado ele é muito objetivo, ele tem uma necessidade imediata, ele quer arrumar emprego. (E6).

Esse argumento, solidário ao desempregado, oculta uma dimensão fundamental do problema, que é a acomodação das entidades sindicais à estrutura sindical, tal como se depreende de uma declaração desse mesmo dirigente:

(...) a CUT acabou se estruturando dentro de uma estrutura sindical que não tem uma representação formal do desempregado. A luta fundamentalmente dos sindicatos é para abrir postos de trabalho, é abrir emprego, (...) é gerar políticas públicas para que este trabalhador tenha oportunidade de emprego (...). Nós nunca tivemos na CUT uma representação de desempregados ou de movimentos de desempregados no Brasil (...) (E6).

Este dirigente afirmou ainda que os protestos de desempregados são importantes, nos limites de suas reivindicações pontuais, mas argumentou que não é possível que se constitua como uma organização estável:

Boa parte das iniciativas que foram feitas, elas tinham sim um fim determinante, não era para constituir uma organização (...). A CUT optou em estimular as associações dos desempregados, que inclusive resultaram, boa parte destas associações, em busca de contrapartidas sociais, em relação ao Estado, em relação às prefeituras, em relação ao próprio governo (E6). 
Destaco, a seguir, os argumentos apresentados pelos membros do SQSP entrevistados, que apontaram a questão da rotatividade como um dos principais limites da organização dos desempregados:

(...) você começa a organizar um pessoal aí, onde ele começa a ter um mínimo de consciência dos direitos deles [e] ele vai trabalhar ou vai fazer um bico e a gente fica tendo que começar tudo de novo e o movimento não pega, não tem consistência (...). Hoje, você faz toda uma discussão sobre a mobilização por emprego, no mês seguinte aqueles lá já arranjaram emprego e os desempregados já são outros. Então, você não consegue dar uma dinâmica no movimento de organizar um movimento como deveria ser para ter reivindicação, não adianta (...), o desempregado hoje não é o de amanhã. O empregado de hoje é o desempregado de amanhã (E10).

Então, as pessoas mudam até pela questão social, temos outros interesses sociais e não é fácil, não é tão fácil. Em São Paulo já foi criado quantas associações de desempregados para químicos, bancários... Tem uma série de experiências, mas se você pegar qualquer sindicato não teve um êxito essa relação, pode ser que faça uma política solidária de um momento ajudar os desempregados ou sustentar um período, mas não tem uma coisa consistente, permanente dessa política.Tem muito assim: fecha uma empresa, aí vão ser solidários, você consegue manter (...) uma relação, mas depois de um período não consegue mais manter este grupo (...) (E8).

Este último entrevistado destacou que esse limite se deve à sazonalidade do desemprego e à dificuldade de constituição de um movimento de desempregados se estes não estiverem vinculados a uma demissão em massa:

(...) eu não sei se tem uma experiência de qualquer sindicato de associação de desempregados de setor econômico que consiga ter esta política permanente, porque a questão é da sazonalidade, pára um período, cresce emprego, aí tem um período de demissões, crise, as empresas começam a demitir. (...) na verdade são políticas pontuais em relação àqueles desempregados, e consegue ser solidário naquele período mesmo emergencial. Não consegue ter uma política de acompanhamento que nem eu acho que não consegue fazer isto. Eu acho que o Sindicato nem tem mecanismo para isto, por isso que têm as políticas públicas, SINE, para cadastrar, para poder acompanhar este processo (E8).

Outra questão citada por este mesmo dirigente é a imbricação entre o trabalho formal e informal como aspecto orgânico na estrutura ocupacional no Brasil. Segundo este argumento, mais do que o desemprego, os desempregados vivenciam cotidianamente o trabalho não formalizado em carteira. Como explicitou um dirigente da Conticom: “(...) foi muita gente fazer biscate, muita gente vender bugiganga na rua, essas ruas que estão ocupadas aí, se você perguntar a origem, (...) é um pessoal que trabalhava e não encontrou mais emprego, a única maneira que ele encontrou para sobreviver foi isso" (E9). Sobre o mesmo tema, afirmou um membro do SQSP: "ninguém consegue organizar o desempregado (...) porque eles tentam organizar o sindicato da economia [in]formal" (E10). Um dirigente nacional cutista destacou: 
(...) passado este período [o tempo de reação imediata, após uma demissão], se o cara não reencontra uma colocação no mercado de trabalho, a tendência qual é? Ele ir para a informalidade, virou camelô, nós podemos, inclusive ajudamos a organizar, a CUT ajuda, associações de camelô, associação de coletores de papel, de garrafa Pet, mas não é propriamente a relação capital/trabalho do mercado formal. Às vezes os caras dão até o nome de Sindicato, o Sindicato dos Ambulantes e tal, mas se você for analisar cientificamente quem é o patrão? (...) É um monte de autônomo que se junta para cobrar de quem, do patrão? Não, eventualmente pode cobrar do poder público que dê uma condição para ele expor a sua pequena mercadoria e vender (E16).

Alguns entrevistados destacaram que a saída sindical para os desempregados, na verdade, constituiu-se como organização do setor informal. Destaco, a seguir, três relatos elucidativos sobre experiências desse tipo, respectivamente, de um diretor do SQSP e de dois ex-membros da Executiva Nacional da CUT:

(...) começou a surgir também o sindicato dos trabalhadores informais, que é o Sindicato dos Ambulantes,

(...) ligado à CUT, inclusive. Mas (...) este Sindicato também pena, viu? Porque como não tem registro, não tem desconto de mensalidade, a contribuição é espontânea, se torna muito difícil arrecadar para manter a entidade deles em pé (E10).

A CUT, a partir de uma iniciativa aqui da CUT São Paulo, chegou a organizar um Sindicato de Trabalhadores Informais, buscando trabalhar com este segmento que não tinha carteira assinada, que faz bico, é camelô, ou enfim, tem uma relação de emprego, de trabalho, não de emprego formalizado (E17).

(...) uma das saídas que o desempregado tem procurado para se sustentar é a economia informal, (...) são os camelôs. O número aumenta muito e isto as centrais sindicais estão tentando, que é formar, inclusive já existe sindicatos de trabalhadores na economia informal (...). Na verdade, não é desempregado, ele vende qualquer coisa. Mas quem são os camelôs? Camelôs são, se você chegar num lugar e perguntar a profissão, antes de ser camelô o que você era? Vai falar que era metalúrgico, que era bancário, que era da construção civil, todos eles. Com raras exceções, vão dizer "não, eu já comecei a trabalhar de camelô ajudando meu pai”, a maioria esmagadora vai dizer a profissão que tem lá e a situação do desemprego é tão grande no Brasil (E5).

Essa intersecção orgânica da estrutura ocupacional brasileira entre o emprego e o subemprego, e entre a formalidade e a informalidade, expressa a existência de uma grande parcela que vive sob um vínculo de dependência na forma de um assalariamento encoberto. Para seguir a terminologia de análise da estrutura social adotada nesta tese, o Brasil se caracteriza pela existência de uma superpopulação relativa estagnada e crônica. Esta questão está na origem de outro aspecto desmobilizador dos trabalhadores como desempregados: o baixo nível de institucionalização do desemprego no país. A evidência mais concreta desse elemento é a impossibilidade de sobrevivência com os poucos recursos destinados a este 
segmento através das políticas de Estado, tal como explicita um dirigente da CNQ, ao comparar o caso brasileiro com o alemão:

(...) o impacto do desemprego na Alemanha... (...) o sistema de políticas públicas era de bem-estar social, era muito diferente. Então, o desempregado aqui do Brasil, comparado com o alemão não dá nem para comparar, as garantias que tem, uma série de questões, (...) a jornada de trabalho é menor, isenção de várias questões de tarifas públicas. Então, a sociedade paga para isso. O Brasil é o contrário, (...) o cara para pegar o ônibus, não cobre tarifa de transporte, ele precisa de dinheiro para procurar emprego, ele precisa ir para algum lugar e não tem o que fazer (...). Lá na Alemanha (...) [a sociedade] é organizada para isso. (...) Existe o desemprego, então tem que tratar dele. Diferente daqui, aqui cada um se vira. (...) O cara fala assim: "Eu estou desempregado". O cara fala assim: "Dá para você fazer um negócio aí?". O cara vai fazer bico (...), o cara não está preocupado, (...) "vou fazer um negocinho aqui”, e vai se virando... Não tem esta consciência de ir lá, se organizar, exigir do poder público uma série de questões. Teve uma época que foi até melhor isto, mas hoje é muito difícil (E8).

Por conta dessa questão, este entrevistado destacou que o desempregado no Brasil, em sua trajetória biográfico-subjetiva, não constrói um sentimento de desempregado:

(...) o desempregado não tem consciência que ele tem um papel social, de políticas públicas. A partir de que ele é desempregado ele já começa se adequar, quer dizer, ele não se enxerga como desempregado e que ele têm direitos para poder exigir, tanto do ponto de vista das políticas públicas como também de buscar alternativas neste sentido. (...) Diferente de alguns países que o desemprego já é considerado e tem políticas públicas para isto. No Brasil, muito pelo contrário, cada um tem seus limites e procura uma saída individual (E8).

Outro fator desmobilizador para os desempregados destacado foi sua situação psicológica de desmotivação e desalento. O entrevistado da Conticom argumentou:

(...) o trabalhador vai perdendo a sua emoção, o seu prazer de viver, até de vergonha porque tem gente que não consegue ficar desempregado, tem vergonha dos outros, (...) como psicologicamente ele está na família dele ou com o próprio vizinho, ele está totalmente desmotivado, quando ele vem falar que tem uma vaga ali, ele também não acredita (E9).

Um ex-dirigente nacional da CUT também destacou a descrença na eficácia da luta como inibidor da mobilização dos desempregados. Segundo este entrevistado, o movimento sindical "não tem feito o que é possível ser feito", mas sustentou que o desempregado também "não acredita muito no resultado deste tipo de coisa. (...) Porque é o que eu te digo, o problema do desempregado [...] é gerar emprego" (E5). Por fim, o dirigente argumentou que a falta de recursos e a situação de fragilidade, por conta do desespero da família, também são fatores determinantes para sua desmobilização:

Se você isolar o desempregado para ele tentar resolver [seu problema], ele não tem força para resolver porque ele já está fora do mercado de trabalho, portanto o poder de pressão dele é muito pequeno. Quem 
tem poder de pressão numa hora desta são os que estão empregados, é a sociedade organizada, esta tem poder de pressão. O desempregado é o que tem menos poder de pressão neste momento. Ele está fragilizado, ele está sem dinheiro, a sua família já começa a entrar em desespero (E5).

De acordo com um diretor nacional, "há uma necessidade de sobrevivência desses trabalhadores que está acima de qualquer coisa" (E13). Um dirigente da construção civil da Conticom ressaltou: "Quantas e quantas pessoas [desempregadas] não viraram mendigos, não viraram alcoólatras, que tinham emprego decente, que tinham salários decentes, porque não tinha perspectiva de vida?” (E9). Essa questão apareceu ainda nas palavras de outros dois sindicalistas, respectivamente, um dirigente nacional cutista e um membro do SQSP:

(...) a formação política dos desempregados é muito difícil de fazer. Desempregado quer comida, primeira coisa, ele quer se alimentar, ele quer alimentar o filho, ele tem o problema que ele pode ser despejado da casa dele porque paga o aluguel. Estes problemas de falta de uma cidadania ampla no Brasil são o que vem primeiro (...) é muito difícil você, sem dar estas condições para o companheiro desempregado, falar de formação política, você faz a partir de que ele esteja inserido com o mínimo de cidadania (E15).

O interesse teve, mas viabilizar é outra, já é uma situação que é difícil de representação. Eu conheço várias tentativas de representar os desempregados. Associação dos desempregados que não consolida porque a questão é uma questão que as pessoas precisam sobreviver... se ela não tem possibilidade num setor econômico ela vai buscar outro (...) interesse sempre teve, o sindicato é solidário com essa situação, temos cadastro, tenta vincular um acompanhamento mínimo do desempregado, mas não consegue (E8).

Segundo alguns sindicalistas, a ineficácia da organização dos sindicatos também foi determinada pela incapacidade sindical de resolver o problema do desemprego, o que acabou limitando a ação do sindicalismo diante desse segmento a campanhas de solidariedade, tal como afirmou um ex-dirigente da Executiva Nacional:

Quando o emprego é por conta de crises, então a solução também dele é macro econômica, não tem como você solucionar o problema do demitido e dos desempregados se a economia não cresce (...) a economia precisa crescer e aí não depende muito das centrais, as centrais não tem muito que fazer, tudo depende da política do governo, é o governo que tem a capacidade de ter uma política econômica (...). Então, o desempregado você acaba fazendo campanha de solidariedade, agora para gerar emprego, para trazer este pessoal, aí não depende muito da central, depende muito da política que o governo traça (...). Eu acho que o movimento sindical deve para ajudar os desempregados fazer uma grande campanha para que mude a política econômica no Brasil. (...) se você chamá-lo lá, ele vai, mas você vai propor para ele o quê? Que o desempregado ele precisa de emprego, então ele [o desempregado] não tem nem dinheiro para vir, você chama uma reunião ou um ato, quer dizer, não tem nem dinheiro para isto, então, foram feitas várias tentativas, mas o desempregado ele acaba indo, como se diz, correr atrás do prejuízo, procurar emprego... a última coisa que ele pensa é em se organizar, o que ele faz é sair todo dia para tentar arrumar emprego. Então, falta de iniciativa não houve, agora o resultado é muito pequeno, (...) nós não descobrimos ainda 
uma fórmula que a gente possa de fato atrair o desempregado, para criar um comitê dos desempregados (...), porque essas coisas não tem o efeito prático que ele precisa que é o emprego. Então, acaba começando até com um número expressivo de trabalhadores, mas rapidamente vai se esvaziando e a pessoa vai cuidar da vida (...), vai procurar emprego (E5).

A falta de recursos para se mobilizar também foi citada por uma dirigente bancária do SBSP, que destacou o apoio material que as organizações sindicais poderiam oferecer aos desempregados para sua mobilização:

(...) se não tiver um apoio de alguém para ele também é difícil porque não tem recurso financeiro (...) quando o sindicato quer fazer uma boa manifestação e ele percebe que ele não tem gente para isto, ele recorre aos movimentos sociais para manter ligação, a rede se comunica e é acionada. Então, o sindicato, por exemplo, pode colocar um ônibus para conseguir lotar e este pessoal ir em alguma manifestação. (...) Agora, com o desempregado (...), ele por outro lado (...) tem mais facilidade de ter acesso ao que está acontecendo pelas notícias ele vai, a gente percebe isto, mas (...) se não houver apoio das instituições que tem recursos como as instituições organizadas e consolidadas na sociedade que tem recurso próprio não ajudar, realmente fica uma situação bem difícil (E11).

Também apareceu nas respostas a questão da dispersão do segmento. Como argumentou um membro da direção central, "São segmentos dispersivos, individualizados, o sindicato (...) é uma instituição de luta coletiva" (E4). Na avaliação de outro diretor nacional este é um elemento central:

(...) você tem uma quantidade muito grande de pessoas trabalhando, os desempregados e a economia informal, muito disperso na sociedade. Não há uma entidade que organize, mas também não há uma forma de enxergar estes trabalhadores desempregados de uma forma mais organizada, é por isso que eu falo que é um desafio da CUT esta descentralização (...) (E13). ${ }^{362}$

Outro membro da Executiva Nacional chamou atenção para essa questão e acrescentou a perda do laço coletivo em relação a sua situação anterior de empregado:

O que fazer com os desempregados? É muito difícil (...) porque a situação do desemprego leva a uma dispersão, é natural (...). Nós muitas vezes arregaçamos as mãos para tentar organizar os desempregados, mas é muito difícil porque ele não vai mais ao local de trabalho, que é aonde ele socialmente pode se olhar e se autoconsiderar como membro de um coletivo, [de] uma classe social (E16).

A importância da militância prévia também foi destacada por um membro nacional da CUT: “(...) nem sempre ele mora num bairro aonde tem uma mobilização popular, onde tem uma sociedade de amigos de bairro, onde tem um movimento de moradores, aonde ele possa se articular". Esse entrevistado sublinhou também que, após perder o emprego, o

\footnotetext{
${ }^{362}$ Este entrevistado chamou a atenção para o individualismo e a competividade no interior desse segmento: “(...) a disputa entre estes trabalhadores que é muito ruim, há um sentimento de individualismo, (...) há muita competição, (...) é preciso superar este individualismo" (E13).
} 
desempregado, "se ele for militante de um partido político, ele vai continuar militando no seu partido, se ele é militante de um movimento popular ele vai continuar militando" (E16). Ressaltou, ademais, que a mobilização dos desempregados se expressa, na maioria das vezes, como resistência dos demitidos, e está vinculado a um tempo de "reação imediata":

(...) se você olhar historicamente se não há uma reação imediata, quando vem um facão e principalmente um facão coletivo, manda 200, 300 embora numa fábrica de 1000, por exemplo, isso é possível. Acontece e já aconteceu na história recente de nosso país. Se não há uma mobilização imediata, ficam os empregados acampados dentro da fábrica, não sair da fábrica ou fazer uma mobilização, ou entrar num ônibus e ir para Brasília, se você perde este tempo de reação inicial, a tendência depois é o cara sumir (...) do mapa da ação coletiva sindical (E16).

Apesar de todas as dificuldades de organização dos desempregados levantadas pelos entrevistados, uma dirigente do SBSP ressaltou que a necessidade imediata de resolver sua situação pode resultar um fator mobilizador positivo para esse segmento, além do tempo que estes têm para se mobilizar, que é uma das maiores dificuldades de organizar os próprios trabalhadores empregados:

(...) o desempregado, até pensando na situação que ele tem de maior vulnerabilidade, ele, se organizado, ele tem até mais tempo para reivindicar, ele tem até mais tempo para ter organização porque hoje em dia a gente tem que organizar o trabalhador da ativa, um dos primeiros empecilhos sabe qual é? É o tempo, o cara não tem tempo, trabalha o dia inteiro, pega condução, (...) muita gente gasta duas horas pra ir e duas horas para voltar, aí vai numa Assembléia, vai numa reunião dos sindicatos, isto tudo vai criando desestímulo. O desempregado ele já tem até mais tempo para fazer isso, para se inteirar, para acompanhar as notícias, para participar da reunião e ele seria uma massa em potencial para a gente fazer um movimento social (E11).

Como explicação para a dificuldade de construção de uma ação conjunta entre empregados e demitidos, um sindicalista do SQSP ressaltou o "individualismo", que leva a uma ausência de solidariedade entre ambos:

[o trabalhador] pensa em resolver o problema da família dele, esse é o ponto inicial. Então, não existe aí uma cultura de solidariedade aonde os trabalhadores consigam paralisar para poder fazer voltar os outros trabalhadores. (...) essa consciência de classe é um processo difícil, embora tenha um setor dentro da fábrica que topa, mas a maioria não topa (...) o próprio sistema induz as pessoas ao individualismo, (...) existe toda uma cultura que as empresas trabalham muito bem dentro das empresas, "você tem que pensar em você e na sua própria família, você não tem que pensar no que os outros fazem”. (...) Eu acho que o problema não é uma falha do movimento sindical, é uma disputa ideológica que nós perdemos (...) (E10).

Alguns dirigentes ressaltaram a dificuldade específica de alguns setores para a organização dos próprios empregados, tal como ressaltou um entrevistado do setor comerciário, membro da Contracs: 
(...) no nosso setor é muito difícil organizar os empregados, e acho que os desempregados é muito mais difícil ainda, (...) principalmente dentro do nosso segmento, tem muitos setores que são comissionados, a pessoa ganha por comissão e muitas vezes ele acha "Não, eu não dependo do Sindicato, (...) o meu salário depende de mim, eu dependo das vendas que eu faço". Então, (...) como é muito difícil tu organizar os próprios empregados que estão no dia-a-dia no trabalho, eu acho que o desempregado é um tanto mais difícil porque não tem essa cultura de se organizar, quanto menos o desempregado (E3).

Este sindicalista também destacou a questão da competitividade entre os trabalhadores sem emprego: “(...) o desempregado, ele sempre encara o cara que é companheiro dele que está desempregado (...) como um cara que está disputando uma vaga no mercado de trabalho" (E3). No entanto, ressaltou que o individualismo próprio dos desempregados se deve em parte ao movimento sindical, que não faz um trabalho anterior, para que estes formem sua "consciência de classe desempregada":

(...) o desempregado ele só consegue ir para começar a se organizar, começar a discutir, é quando ele passa por um período muito grande que ele não consegue retorno ao mercado de trabalho, por que ele sai, ele está sempre pensando: "eu vou fazer curso, vou fazer não sei o quê, para voltar ao mercado de trabalho". Ele pensa só nele, ele não pensa que tem um companheiro que está na mesma situação que ele. Mas isso é uma questão (...) que tem muita culpa do movimento sindical, porque como a gente trabalha muito pouco com ele, a gente podia já ter mudado esta questão (...). Então, por este motivo é que (...) não cria uma cultura de organização da classe desempregada neste país (E3).

Um entrevistado do SQSP ressaltou que a organização dos demitidos também depende das características da demissão:

(...) quando se demitia de uma forma de um aqui, um ali e um acolá, não é como o [setor] automobilístico que tinha 30.000 e eles demitem 1000, então, você com 1000 demitidos, você consegue fazer mobilização e organização. Agora, uma empresa que tem 100, demite 20, (...) se perde no caminho. (...) A nossa realidade foi devido à pulverização das empresas na categoria e nenhuma empresa demitiu assim em massa, ia na conta-gota, se torna muito difícil, [e] o que nós também nesta década administramos muito foi falência (E10).

$\mathrm{Na}$ avaliação de vários entrevistados, um dos limites para a ação conjunta entre empregados e desempregados é a própria pressão que este exerce sobre aquele. Destaco um relato de um dirigente do SQSP, e outro, da Executiva Nacional da CUT:

O desemprego quando ele vem de uma forma tão violenta, ele faz com que os trabalhadores se encolhem dentro das empresas (...). Tudo isso joga o movimento no recuo. No começo, eu tinha uma preocupação que era a responsabilidade: a culpa era nossa que não conseguia mobilizar. Mas depois conforme a gente foi fazendo as mudanças, as ações e chamando os trabalhadores, eles não respondiam, aí nós vimos que o problema não era nosso, o problema realmente era da conjuntura e das condições que o neoliberalismo estava impondo perante os trabalhadores (E10). 
Nem sempre é fácil, você sabe que quando tem um processo de demissão, principalmente demissão coletiva, em massa, os trabalhadores que estão empregados ficam sempre na dúvida se "o próximo serei eu" e tem muito medo de entrar numa mobilização para defender o emprego do outro, entendendo ainda, a tratar este processo de conscientização crítica de querer defender o emprego, ele está defendendo o emprego não é do outro, é do outro e o dele, porque está todo mundo junto defendendo o emprego, você tem mais condições de enfrentar e de resistir a este processo de demissão (E13).

Alguns entrevistados afirmaram que uma possível forma de resistência sindical às demissões é a constituição de fundos de greve para manter os demitidos na luta, tal como sustentou um dirigente do SQSP: “(...) o que tinha, eu acho que quase todo sindicato combativo da época [anos 80], uma entidade chamada Fundo de Greve em que era depois de fundo de greve passou a funcionar como apoio aos desempregados" (E10). Um dirigente nacional cutista também se referiu ao tema:

A CUT orienta esta constituição de organização de fundos de greve para que os demitidos dos bancários, por exemplo, não saiam, não vá simplesmente no sindicato aonde o processo jurídico para reintegração, mas que haja uma luta também da categoria pela reintegração desses companheiros de volta aos bancos aonde eles foram demitidos e assim por diante, processos de resistência primeiro nessa questão de não permitir que houvesse as demissões (E15).

Outro limitador para a construção de uma unidade entre empregados e desempregados destacado pelos dirigentes foi o corporativismo, ainda que alguns não tenham utilizado este conceito explicitamente e freqüentemente resistam a estabelecer uma relação entre a estrutura sindical e a representatividade sindical dos trabalhadores sem emprego formal. Tal como afirmou um membro da Executiva Nacional da CUT:

(...) na estrutura do movimento sindical brasileiro você tem um trabalhador que quando ele está numa empresa e portanto ele é sócio do sindicato (ou não, mas ele é representado por aquele sindicato), a sua relação é muito forte. Quando ele perde o emprego ele se torna desempregado, ele deixa de ser da categoria. Portanto, o sindicato deixa de ter um contato com este trabalhador (E13).

Quando questionado se estes elementos estariam relacionados com a estrutura sindical, um dirigente nacional cutista apontou para as características corporativas do sindicalismo em geral:

Eu acho que é um elemento, mas não é, nem diria para você que seja um elemento central porque o Sindicato ele organiza aquele que tenha emprego formal. O Sindicato (...) dos Metalúrgicos organiza os metalúrgicos que tenham emprego formal (...). Não é somente por causa da estrutura sindical. No mundo inteiro é assim (...). Na CUT o desempregado ele não é filiado, pode-se dizer se nós quiséssemos, vamos supor, criar um Sindicato da Economia Informal (...), que eu acho que não seja só um problema da estrutura sindical, a estrutura sindical ela tem coisa muito mais negativa do que este problema (...), mas eu não acho que ela seja culpada porque o setor informal é desorganizado, porque o desempregado é 
desorganizado, o desempregado ele poderia perfeitamente estar organizado dentro do Sindicato de origem do cidadão que é o desempregado. Que bom seria se todos os ex-metalúrgicos continuassem organizados sindicalmente no Sindicato dos Metalúrgicos, todos os ex-professores continuassem organizados no Sindicato de Professores e assim por diante, agora (...) eu acho que deve haver muito mais uma deficiência da estrutura do mundo do trabalho no país (E4).

No entanto, tal como ressaltaram alguns entrevistados, a representação sindical dos desempregados é possível em algumas entidades, legitimada inclusive por seus estatutos. Um dirigente metalúrgico do $\mathrm{ABC}$ ressaltou que a entidade permite um tempo de "carência" de sua sindicalização, ainda que a utilize basicamente para procedimentos jurídicos:

[o desempregado] permanece com os seus direitos de associado por 6 meses. Então, se ele precisar abrir algum processo, encaminhar um pedido de aposentadoria, benefício de INSS, então pode usar a estrutura do sindicato e também há um encaminhamento para os centros públicos de trabalho e renda (...). Mas, fora isso, o sindicato tem muita pouca política para os desempregados. Isso é um fato (E12).

Outro membro da Executiva Nacional destacou essa questão: "Os sindicatos em geral, nos seus estatutos admitem que os desempregados continuem associados até por prazo de até dois anos em alguns sindicatos, a média, eu acho que é seis meses (...) depois do desemprego o cara continua exercendo seu direito sindical, de votar, ser votado, participar de assembléias" (E16). Quando perguntados sobre os critérios de filiação sindical, um ex-dirigente nacional cutista também negou que este fosse um fator limitador:

(...) a maioria dos sindicatos que eu conheço, os trabalhadores (...) continuam tendo os mesmos direitos até por 6 meses depois de demitidos. Então, ele pode usar o Departamento Jurídico (basicamente o Departamento Jurídico), para ter assistência e tal. Então, eu acho que a dificuldade para ajudar os desempregados não está na [estrutura sindical], instrumentos tem, aí precisa ter (...) muita vontade política dos dirigentes sindicais (...) (E5).

Ainda que o corporativismo não tenha sido citado explicitamente, em várias entrevistas apareceu essa questão. Um membro da executiva da central fez a seguinte reflexão a respeito da organização dos trabalhadores não sindicalizáveis de maneira geral:

O que a gente sempre fez foi estimular os nossos sindicatos para que tivessem comitês de desempregados, internamente no sindicato, quer dizer, jamais abandonar um companheiro porque ele perdeu o emprego. Ele perdeu o emprego ele era de uma categoria, ia no sindicato, portanto, cabia ao sindicato organizar a luta dele, a resistência, se preocupar com a sua formação, com sua formação profissional, para que ele pudesse encontrar novas possibilidades de emprego. Mas há uma deficiência muito grande, não somente na CUT como em outras centrais sindicais brasileiras em como trabalhar com o terceirizado, com o desempregado, com os informais (E4). 
Porém, a questão do corporativismo apareceu quando os dirigentes se referiram a quem a CUT, de fato, representa. Destaco, a seguir, o relato deste último diretor da central, além de dois ex-membros da Executiva Nacional e um metalúrgico do ABC e da CNM:

(...) a nossa experiência histórica é trabalhar com o setor formal, aquele que tem carteira assinada e fazemos articulação política com os informais, terceirizados, desempregados em geral. (...) A CUT organiza os formais, ela não organiza os informais, você estabelece relação com eles como eu havia colocado,você estimula para serem filiados (E4).

Qual é o problema hoje do movimento sindical? É que a gente representa uma parte, só representa a parte que é formalizada, que é o pessoal que trabalha. Então, tanto a CUT quanto as outras centrais a gente não conseguiu ainda ter uma política eficiente para os desempregados (E5).

Isso não é uma questão resolvida até hoje na CUT (...) você tem uma tradição dos sindicatos brasileiros (...) de serem sindicatos que representam o trabalhador com a carteira assinada pelo patrão. Isso é uma tradição política e sindical, não só do Brasil, mas aqui no Brasil se configura desse jeito e que é muito difícil para as organizações sindicais pensarem quais são as alternativas para este trabalhador que não tem carteira assinada (E17).

Eu acho que teve uma coisa importante que a CUT ela se atentou para a questão dos desempregados. Era algo que não estava na pauta, por se tratar de uma Central muito vinculada ao Sindicato que cuida fundamentalmente daquele trabalhador que está empregado (E6).

Um entrevistado do setor metalúrgico do $\mathrm{ABC}$ sustentou que a ausência de organização sindical dos desempregados se deve a um "pragmatismo" dos sindicatos:

(...) eu acho que na verdade o que existe é um certo pragmatismo dos sindicatos, (...) uma vez que a pessoa está desempregada ela não faz mais parte "ele não é mais sócio, não contribui mais com o sindicato, não está mais na categoria, não é mais minha preocupação", quer dizer, [esta é a] mentalidade geral. Não estou dizendo que isso seja uma coisa intencional, mas é uma mentalidade pragmática de que o problema não faz mais parte. (...) Eu acho que é como eu falei, eu acho que é mais uma questão de pragmatismo mesmo, a maior dificuldade é que as demandas são tão enormes para os trabalhadores que estão na ativa que acaba ficando em segundo plano mesmo pensar em política para os desempregados (E12).

Quando perguntado se não seria mais apropriado denominar esse "pragmatismo" de "corporativismo", o dirigente respondeu:

Eu acho que sim, acho que sim, eu acho que é exatamente isso, não tem outra forma de explicar. Tem que fazer o corporativo mesmo, "eu represento a minha corporação, os meus sócios e quem não é mais sócio, não tem mais nada a ver com isso". Entendeu? Não estou dizendo que é uma coisa intencional, mas é uma coisa pragmática... (...) $\mathrm{Na}$ maioria dos países, o movimento sindical não tem política para o desempregado, (...) eu acho que o único lugar que a gente vê uma atuação bem forte em relação a isso é a Argentina, onde os desempregados (...) desempenham um papel importante na política dos sindicatos (...). 
Fora a Argentina, eu não vejo outro país em que esse tema seja (...) uma prioridade para os sindicatos. $(\mathrm{E} 12) .^{363}$

Um sindicalista da Contracs avaliou essa questão como "cultural":

Infelizmente no Brasil não tem uma cultura de trabalhar [com] os desempregados (...) tanto é que todos os nomes de sindicatos, pode pegar, sindicato dos empregados do comércio, sindicato dos empregados, não sindicato dos desempregados, então tem poucos sindicatos que tem (...) atuação referente aos desempregados (...). No Brasil, infelizmente o movimento sindical não tem a cultura de organizar os desempregados (...) eu não conheço nenhum sindicato que sindicalize o desempregado (...). O próprio movimento sindical chama nos atos os desempregados, mas (...) é muito pouco em relação ao que deveria de ser. Eu acho que o trabalhador brasileiro não tem ainda o hábito de se organizar (E3).

Como se depreende da interpretação destes últimos relatos, o corporativismo é um elemento jurídico-legal, mas também uma questão cultural, legitimada pelos agentes. Não se trata, pois, de uma barreira insuperável, como os próprios entrevistados indicaram. Nesse sentido, uma ex-dirigente nacional da CUT destacou que a ausência de representação dos desempregados se deve muito mais à política de organização do que aos critérios de sindicalização, já que a CUT possui setores afiliados de categorias que não se enquadram na típica categoria de assalariados:

(...) é um problema organizativo, que existe desde sempre, mesmo antes, do desempregado, de cooperativa, de economia solidária, sempre existiu e sempre foram filiados à CUT. Sempre a CUT teve sindicato rural filiado a ela que eram de agricultores ou de pequenos proprietários, é uma questão (E17).

Um entrevistado do SQSP sugeriu que o fator organizativo é o que determina a ação conjunta com os desempregados, apesar de que essa construção, em nível nacional, dependa muito da central sindical:

(...) não é o limite que a gente não pode fazer uma associação de desempregados, isso é possível fazer e ter uma relação, como a que nós já temos, ou criar, exigir do Estado, do município, políticas públicas para poder minimizar (...). Aí também tem a Central Sindical, tem que ter um papel (...) nós temos limite de representação, você entrar com uma representação nacional (...) mas a gente não tem esta condição para fazer esta, nem legalmente muitas vezes. Temos outra representação e porque nós conseguimos outra representação nacional. (...) Então, nosso limite é um pouco restrito, não é um limite de ação. Nós podemos fazer uma série de ações neste sentido para os desempregados, não é que o sindicato está fechado para esta relação. Ele está muito, está aberto para isto. Ele enxerga, vê esta questão, só que nós temos limites para fazer esta ordem tanto de representação como também de construir outros instrumentos para poder fazer discussão (E8).

\footnotetext{
363 Sobre a questão do corporativismo, um dirigente do SQSP acrescentou: "O sindicato representa os trabalhadores de carteira assinada, no fundo é isso também, os que estão vinculados à sua base de habilitação" (E8).
} 
O entrevistado da Contracs destacou ainda que a mobilização dos desempregados não é apenas um problema da organização sindical, mas deles mesmos:

(...) os próprios os desempregados não conseguem fazer uma organização, como aconteceu na Argentina.

Talvez se tivesse uma organização que realmente mobilizasse os desempregados com certeza o movimento [sindical] estaria junto, mas como eles mesmos não se organizaram, o movimento sindical não vai organizá-los, acaba não tendo um trabalho neste sentido (E3).

Uma entrevistada do SBSP também citou a organização dos terceirizados que, a rigor, não se enquadram nos critérios de filiação sindical de determinadas categorias:

(...) a nossa experiência diz que se houver vontade de se organizar não é o vínculo formal que vai atrapalhar. Aqui a gente organiza terceirizados e terceirizados não pode ser, ele não tem vínculo formal com o sindicato até porque um dos princípios da terceirização na convenção sindical, é estratégico para a empresa que ele seja filiado a outro sindicato, se quiser ser sindicalizados. (...) A gente organiza, faz greve, a empresa nunca recebe para negociar, recebe só em situações de greve, obviamente porque ela não tem interlocutor, o interlocutor é a gente, o trabalhador mesmo diz "vocês tem que conversar mesmo com o Sindicato dos Bancários, não adianta procurar o outro sindicato, o outro sindicato nunca veio aqui, tem que procurar o Sindicato dos Bancários" (E11).

Em relação à política de organização, questionei aos entrevistados se é possível relacionar a ausência de uma tradição de organização da base com uma política mais ampla de organização dos trabalhadores, contemplando os estratos não sindicalizáveis, como os desempregados. Ressalto, a seguir, as respostas dadas por um membro do SQSP e de uma exmembro da Executiva Nacional da CUT:

Com certeza, quando você tem nas empresas, no tempo que nós montamos comissão de fábrica, que ainda tinha emprego, que foi possível organizar, vamos dizer, os patrões para demitir tinha que negociar com a comissão, entendeu, isso foi no começo, quando tinha pleno emprego quando a gente gritava, os trabalhadores paravam e o patrão tinha medo. Depois com o desemprego (...) todo mundo se encolheu dentro das fábricas e não conseguimos fazer mais. Então, eu acho que a questão da organização dentro da fábrica é fundamental e devido a nossa ação sindical forte, as empresas desmontam qualquer organização que nós temos (E10).

(...) a questão da dificuldade da organização no local de trabalho, para além das acomodações possíveis em qualquer instituição, elas são naturais. Naturais não no sentido que tem que ser assim, é um fenômeno que as instituições por definição elas trazem em si mesmo o gérmen da conservação, de manter tudo como estava, mas independentemente disso eu acho que tem (...) tem uma profunda concepção autoritária no país e na sociedade brasileira em relação à questão da organização dos trabalhadores e da organização da sociedade. A sociedade brasileira ela é uma sociedade que viveu muito poucos momentos longos de democracia. Então, por exemplo, quando você coloca no Congresso Nacional a discussão da ratificação na Convenção 158 (...), os representantes do capital no Congresso Nacional vociferam argumentos altamente conservadores, altamente autoritários (E17). 
Quando perguntado se uma organização prévia de ação sindical no local de trabalho poderia facilitar a organização dos desempregados, um sindicalista do setor químico argumentou: "Poderia, só que nós quando enxergamos o trabalhador, enxergamos como empregado e não como desempregado futuro. (...) Você sabe que os limites do emprego e do risco do desemprego está colocado nas empresas. Deveria ser uma política também para o sindicato pensar" (E8).

A partir da argumentação feita até aqui, é possível estabelecer a seguinte indagação: o corporativismo, a acomodação à estrutura sindical e a ausência tradição de uma cultura de organização no local de trabalho têm relação com a inexistência de uma política de organização dos desempregados? Vários entrevistados não vêem, ou vêem "pouca relação" entre essas questões. Destaco dois relatos, respectivamente, de um dirigente da CNM e de um membro da Executiva Nacional da CUT

(...) Eu acho que a questão do não avanço da organização sindical ela não tem absolutamente nada a ver com a questão dos desempregados. O problema foi que a partir de 2003, se estabeleceu uma estratégia que não foi bem sucedida, ficamos dois anos e não conseguimos avançar porque se imaginou uma mudança muito global de toda a estrutura sindical (E6).

Eu acho que tem pouca relação esta questão da estrutura sindical, da acomodação das entidades sindicais, da estrutura sindical oficial com [a] organização dos desempregados. Não é que não tem nenhuma relação. Estou dizendo que tem pouca relação (...) do ponto de vista do sindicato de base que tem este papel formal da negociação, ela é um limitador, a figura hoje existente na institucionalização da negociação coletiva por parte dos Sindicatos e esta relação com os trabalhadores formais com carteira assinada, está dada a limitação (...) eu acho que é um limitador, a existência, mas no caso da central sindical há a possibilidade de você construir uma estrutura que vai além dessa questão que está colocada hoje na CLT (...). No caso especifico dos desempregados, o limitador existe pela legislação atual, mas não no caso da centrais sindicais, que eu acho que tem todas as condições de estabelecer um processo de organização mais ativo nesta área e mais propositivo (...) dentro mesmo dos marcos legais. Ao dizer que a central sindical será reconhecida para debater assuntos de interesses gerais da classe trabalhadora, o desempregado é classe trabalhadora, e portanto nós estamos aqui para discutir assuntos de interesse geral, inclusive dos desempregados (E13).

Um dos entrevistados não ressaltou que essa relação não proede e durante a entrevista buscou "desvendar" a hipótese desta tese. Para tanto, elaborou uma reflexão que não corresponde exatamente à que buscarei desenvolver, mas que apontou alguns de seus elementos centrais:

(...) eu não vejo nenhuma relação, honestamente não vejo nenhuma relação... já percebi qual é a hipótese da sua tese, a hipótese da sua tese é esta: na medida em que a CUT abandonou o seu projeto original de 
organização no local de trabalho, de combate ao imposto sindical, se adaptou à estrutura sindical oficial, ela não dá importância para a organização sindical dos desempregados, essa é sua tese... (E16).

Uma ex-dirigente nacional da CUT lembrou que esteve presente na central uma proposta de sindicato orgânico, que não foi amplamente defendida pelos sindicalistas. Na sua argumentação esse teria sido um primeiro passo para superar o corporativismo e a ausência de organização dos desempregados. A sindicalista assim explicitou a estratégia:

[o trabalhador] não se filia no sindicato, ele se filia numa central (...). Isso resolveria um problema: o cara hoje ele é metalúrgico, amanhã ele está desempregado, mas ele pertence à CUT, ele pertence a tal central e a central vai organizar esse segmento, ex-metalúrgico ou metalúrgico da maneira que ela achar que é a melhor naquele momento histórico. (...) Era uma maneira também de tentar dar uma resposta à questão da organização sindical dos desempregados, mas esta discussão ela foi muito polêmica (...) Por que no sindicato ainda é muito forte esta cultura do sindicato filiado? Porque você tem, pela lei, a unicidade sindical (...) portanto, a discussão com uma possível organização do trabalhador desempregado via central, ela ficou truncada (...), mas dificultou muito porque era uma alternativa você organizar o trabalhador desempregado na central e também era polêmico isso, por outro lado, porque tinha gente na CUT que dizia o seguinte: "mas nós somos central sindical, se a gente for começar a trazer desempregado, nós vamos virar uma ONG (E17).

Mas, além dos limites da cúpula sindical para a organização dos desempregados, existem conflitos de interesses da base para a representação desse setor? Para alguns entrevistados cutistas a ação sindical diante da ameaça de demissões deve ser feita através da construção da resistência no local de trabalho, para que, no caso de serem efetivadas, a entidade busque uma ação conjunta entre empregados e demitidos. No entanto, alguns dirigentes argumentam sobre a dificuldade desse tipo de luta, já que existem conflitos de interesses entre o empregado, o demitido e o desempregado, que provocam um antagonismo entre o protesto tipicamente sindical (por salário, jornada e condições de trabalho) e a mobilização contra as demissões e o desemprego (por emprego). Uma sindicalista do SBSP, por exemplo, sustentou que os sindicatos têm de construir estratégias para conter ou reverter a eliminação de postos de trabalho, mas também é obrigado a dar resposta aos que permanecem na ativa, que são sobrecarregados por conta das demissões e pressionados pelo desemprego. Por fim, a entrevistada explicitou que os interesses entre empregados e desempregados são "conflitantes":

Mesmo com o quadro de demissão, em qualquer categoria existem trabalhadores que estão lá que não foram demitidos. Então, o Sindicato (...) tem que fazer uma política que tanto pense em conter as demissões, ou em reverter as demissões (e reverter é dificílimo no Brasil) (...) mas ele também tem que fazer uma política sindical (...) para quem está na ativa e quem está na ativa normalmente fica mais 
sobrecarregado porque num processo de demissão, de enxugamento, reengenharia (...) você deixou tarefas daquelas pessoas (...) acaba sempre aquela pessoa que fica, ficando com uma sobrecarga de trabalho frente àquele outro que saiu. Então o sindicato tem de olhar para aquele trabalhador que continua ali, isto é, (...) ele tem que lutar pela manutenção do emprego, tem que cuidar dos desempregados, tem que parar, fazer o protesto, tem que dar uma boa assistência para quem está saindo, mas vai ter que também olhar para este trabalhador que ficou ali porque ele ainda tem as demandas dele, porque ele pensa assim: "eu fiquei, eu estou ficando, os outros estão saindo, mas eu estou ficando, e nessa situação eu vou querer que as minhas condições de trabalho sejam também observadas pelo sindicato, meu salário vai ter que aumentar, porque aumentou o meu trabalho, a minha jornada" (...) (E11)

Um entrevistado da Conticom destacou que a ação conjunta entre empregados e desempregados através das entidades sindicais é possível, mas se trata de interesses imediatos distintos: "É possível, (...) agora as lutas são totalmente diferentes porque o empregado está lutando para manter o emprego, para garantir o seu salário e o seu sustento. O desempregado vai lutar em prol política pública e assistência" (E9). Segundo este entrevistado, a divergência de interesses entre empregados e desempregados é decorrente da competição no interior da classe trabalhadora, que funciona como um instrumento eficaz de rebaixamento salarial, dada a pressão que um exerce sobre o outro: “(...) se o cara está ganhando 2000, ele aceita trabalhar por 500 porque a situação dele é desesperadora" (E9). As empresas também utilizam esse artifício para flexibilizar o emprego da força de trabalho. No Brasil, essa é uma questão recorrente. Porém, acontece de forma acentuada em setores cuja atividade predominante é exercida por empreitadas ou que estão expostos a fatores sazonais, como é o caso da construção civil, que em períodos de expansão necessita de uma "infantaria ligeira" (Marx, 1982) para as necessidades do capital, com um emprego flexível da força de trabalho e de rápido deslocamento: “(...) a rotatividade no setor [da construção civil] ela é conhecida porque é frente de trabalho, você pega um empreendimento, um prédio que hoje em dia ele não passa mais que dez meses, onze meses para construir um prédio" (E9).

Uma entrevistada do SBSP ressaltou a importância de se unificar a luta entre as duas frações:

(...) se os desempregados estão juntos com a CUT, eles vão também monitorar mais e pressionar mais o próprio Governo Federal e o próprio Ministério do Trabalho (...) se a gente faz um movimento unificado com este segmento dos desempregados com certeza a gente tem mais poder de mobilização porque tudo na sociedade funciona por relação de força. A elite faz o que quer por que também o outro lado deixa, até certa forma o outro lado fica quieto. Então, se a gente consegue ter voz ativa junto com os empregados com certeza o desenho social é outro (E11). 
As representações feitas pelos dirigentes da CUT sobre a ausência de organização sindical dos desempregados atestam a ambigüidade do discurso cutista em torno da estrutura sindical. Os argumentos contrários à unicidade, à investidura e ao imposto sindical são mobilizados pela central de maneira recorrente para criticar o caráter autoritário da legislação brasileira. Essa discussão é histórica no interior da entidade e remonta ao processo de sua criação, em que parte dos dirigentes que militavam na oposição se negaram a incorporar-se à estrutura oficial, e os fundadores da central buscaram construir a central atuando por dentro dos marcos legais para lutar por sua transformação. ${ }^{364}$ No entanto, os dirigentes negam qualquer relação entre a acomodação a esta estrutura corporativa e a representação dos trabalhadores desempregados. Ao contrário, recuam e explicam a desmobilização desse segmento a seus próprios limites (morfológicos, psicológicos e normativo-institucionais), com argumentos muito semelhantes aos destacados pela literatura francesa trabalhada no primeiro capítulo. O corporativismo é citado como um fator limitador, mas também se aponta a possibilidade de sua superação através de um trabalho organizativo.

\section{A Força Sindical}

De modo geral, as ações e representações dos dirigentes da FS diante do desemprego se inserem em sua concepção mais ampla de "sindicalismo de resultado". Nesse sentido, os sindicalistas dessa central argumentam que, diante das demissões, o melhor "resultado" é o maior saldo possível de trabalhadores que permaneçam em seus postos de trabalho. Vejamos como um metalúrgico de São Paulo ressalta essa concepção de prática sindical:

(...) eu penso que o importante é o resultado para o trabalhador, se você vai numa negociação e você consegue fazer uma negociação sem fazer greve, porque a greve é um instrumento do trabalhador, um instrumento para ele ter e fazer uma pressão para ele negociar (...). Por isso que temos sindicato de resultado, e nós não fugimos deste rótulo não. Resultado porque a gente entende assim: o importante é o resultado para o trabalhador, se ele tem o resultado, tanto que os acordos nossos aqui são os melhores (...) o nosso acordo aqui de São Paulo é maior do que das montadoras [do ABC] (E20).

A compreensão do tipo de ação da FS também está inserida em sua concepção de sociedade, na qual a relação capital e trabalho, ao invés de antagônica e conflituosa, expressase em um vínculo de colaboração e parceria. Para este mesmo entrevistado do SMSP, essa

\footnotetext{
${ }^{364}$ Como recorda a própria central em uma resolução congressual: "Na preparação do $1^{\circ}$ Congresso Nacional da Classe Trabalhadora surgiu o primeiro choque entre duas concepções sindicais distintas, através do polêmico artigo $8^{\circ}$ do Regimento Interno do Congresso. Do lado da CUT, ficaram os que defendiam a atuação dentro da estrutura oficial como ponto de partida para uma nova organização dos trabalhadores, baseada na liberdade e autonomia sindical" (CUT, 1994, pp. 49-50).
} 
perspectiva é coerente com o "trabalhismo", o qual define com a seguinte fórmula: "garantir o direito que você tem hoje e buscar mais direitos". ${ }^{365}$ Na visão desse sindicalista, o que difere o tipo de sindicalismo praticado pela FS e o da CUT não é a visão mais ou menos adepta ao socialismo, mas o ponto de partida da ação sindical: “o nosso não é o confronto, o nosso é o diálogo", este último compreendido sempre como o ponto de partida da negociação com os empregadores e com o governo nas suas diversas instâncias.

(...) são poucas as greves que eu vi de confronto para você conquistar (...). [Ademais,] como é que você conquista dentro do Congresso [Nacional]? É você dando pedrada lá no Congresso? A gente descobriu que se a gente for lá com 20.000 pessoas e ficar lá fora xingando não vai adiantar nada, mas (...) se nós formos lá com 100 sindicalistas, 200 sindicalistas, representantes de cada estado, com representatividade de cada estado, ele vai visitar gabinete por gabinete e vai pressionar o deputado (E20).

$\mathrm{Na}$ busca de soluções para os problemas, a orientação dos sindicatos da FS é de estabelecer uma relação de aliança e parceria com o empresariado para propor alternativas e cobrar políticas do governo. Nesse sentido, é preciso oferecer concessões ao patronato, como a diminuição dos encargos tributários. Esse modelo de ação sindical se insere na perspectiva segundo a qual é necessário desenvolver o capitalismo brasileiro com uma classe empresarial forte e competitiva, considerada pela central como condição indispensável para se obter vantagens para os trabalhadores. Uma dirigente do Sindicato das Costureiras de São Paulo e da Confederação Têxtil (Conaccovest) ligada à FS explicitou:

(...) nós entendemos que nós tínhamos que em alguns aspectos se unir ao empresariado para buscar na questão da carga tributária, fazer o governo, os governantes, olhar pro nosso setor [têxtil] porque é o segundo maior empregador. (...) Aqui mesmo em São Paulo o ICMS do setor era 18\%, hoje é 12, foi uma guerra nossa, junto com os empresários, trabalhadores e empresários, porque tem coisa que você tem que estar junto com o empresário. Porque quando vai só o empresário ou só nós, o governo olha com desconfiança, agora quando vão os dois, ele passa a prestar mais atenção no setor (E18).

Segundo essa dirigente, esse tipo de aliança não foi levada a cabo mais freqüentemente por conta da atitude empresarial: "não avançamos mais (...) porque o (...) o nosso setor tem muita empresa familiar e aquela coisa 'eu olho para o meu umbigo, eu não olho lá na frente"” (E18). Para a entrevistada, esta questão se remete a uma distinção que observei freqüentemente na FS entre o "bom" e o "mau” patrão, que, segundo esta dirigente, independe do tamanho da empresa:

\footnotetext{
${ }^{365} \mathrm{O}$ trabalhismo, o liberalismo e a social-democracia são as principais matrizes ideológicas da central, ainda que existam setores minoritários que defendem teoricamente o socialismo.
} 
(...) não importa, se ele for mau patrão e tiver 1.000 trabalhadores ele é mau patrão e a gente vai ter que buscar formas de arrumar isso. E se ele for um bom patrão e tiver 1.000 trabalhadores, ele vai ser um bom patrão e a gente vai ser parceiro naquilo que for necessário para defender o emprego. E a mesma coisa uma empresa menor (...) mesmo assim a carga tributária nossa é muito pesada para o empresariado, você paga $20 \%$ ao INSS (E18).

Esta entrevistada ressaltou também a importância de que os empresários não vejam os sindicatos como "bicho-papão", apesar de afirmar que as entidades não devem abdicar de defender as reivindicações dos trabalhadores. Esse argumento é explicitado pela sindicalista a partir da necessidade de se separar os direitos e deveres de cada uma das partes, ainda que estes não sejam vistos como irreconciliáveis:

(...) existem direitos e deveres, não sou aquela líder que fala "Não, você só tem direito. Não, isto aqui é teu, isto aqui é da empresa". Então, tem que trabalhar muito claro nesse sentido, para não cometer enganos depois e pagar o preço. E outra coisa: você tem que entender o seguinte, "nós não somos o bichopapão", se precisarmos de força, nós vamos dar uma força, mas se tiver que defender a empresa (sic)... o trabalhador, daquele mau patrão... (E18)

Como já ressaltei anteriormente, é muito comum no interior da FS a idéia de que a central seja plural e apartidária. Para desenvolver este argumento, a entidade se apóia na crítica ao vínculo histórico entre a CUT e o PT, que segundo a entidade se baseia no modelo de "correia de transmissão". Esta mesma entrevistada do setor têxtil de São Paulo ressaltou:

A Força Sindical, ela vem com uma proposta plural, tanto é que ela não é uma central sectária. (...) Nós temos pessoas do Demo [referindo-se ao DEM, Partido Democratas], que nem o pessoal fala, ao PT e nos respeitamos, porque qual é o nosso entendimento? O partido não pode nos usar, nós é quem vamos usar o partido, naquilo que for necessário, para defender os interesses dos trabalhadores (E18).

Uma das principais características do sindicalismo praticado pela FS é o seu caráter propositivo. Nas ações diante das demissões, suas entidades priorizam a busca de acordos que ofereçam concessões às empresas em troca da manutenção do emprego. Um entrevistado do setor metalúrgico de São Paulo cita exemplos da crise de 2008-2009, mas explicita que se trata de estratégias também levadas a cabo pela central nos anos 90:

[Diante da última crise,] o Sindicato primeiro começou a negociar com as empresas, dar férias coletivas. Depois, começou a (...) fazer o banco de horas, depois negociou licença remunerada, (...) e depois suspensão do contrato de trabalho para que o trabalhador não ficasse sem receber salário, ele seria pago pelo Fundo de Amparo do Trabalhador. E por último fizemos negociação de redução de salário e jornada (...) isto são exemplos que nós também fizemos na década de 90 (...) (E20).

$\mathrm{Na}$ visão da FS os sindicatos devem buscar informações para avaliar se a empresa tem ou não a necessidade de realizar as demissões. Essa perspectiva está de acordo com sua 
concepção mais geral de parceria e gestão empresarial, a partir da qual busca "ajudar" a administração da empresa, funcionando assim como uma extensão de seu departamento de RH. A central defende que os próprios empresários tenham um diálogo franco com os sindicatos, informando-os sobre a situação concreta da empresa. Caso contrário, como ressaltou um dirigente metalúrgico de Osasco: "a informação incorreta de hoje é a greve de amanhã”. E acrescentou: “essas informações ainda são uma caixa preta para a maior parte dos sindicatos, principalmente os sindicatos que têm um número muito grande de empresas de categorias diluídas (...)" (E22). O entrevistado explicitou esse método de ação do sindicato da seguinte maneira:

A primeira coisa é não demitir. Nós discutimos com a empresa que nos apresente a sua condição (...) chamamos os trabalhadores para fazer uma discussão no sindicato (...) para a gente apurar se o que estão dizendo reflete na produção de alguma maneira (E22).

A partir desse procedimento, o sindicato deve observar se a empresa passa por um "período de real dificuldade" ou por um "período de ganhos". Após essa avaliação, segundo o dirigente, "Nós vamos desde pensar a possibilidade de licença remunerada, de pensar se um Banco de Horas ajuda, até chegar o ponto de outras propostas que se discute com os outros trabalhadores (...)" (E22). Esses mesmos argumentos apareceram na fala de um dirigente da central e do Sintracon, que representa os trabalhadores da construção civil de São Paulo:

(...) muita gente transformou a crise [de 2008-2009] na crise do oportunismo, muitas pessoas acharam o caminho mais curto, que é o de demitir os trabalhadores (...) eu acho que quando a empresa demite os trabalhadores nós temos que verificar primeiro se há necessidade de demissão (...) (E23).

Uma das práticas mais comuns utilizadas pelo SMSP foram os acordos com redução da jornada com redução salarial, sobre os quais explicitou um dirigente:

Não é fácil você discutir uma redução, é muito fácil para o sindicalista (...) ir para uma porta de uma empresa e dizer numa assembléia (...) para o trabalhador: "olha, nós conseguimos $10 \%$ de aumento, conseguimos cesta básica, convênio médico, seguro saúde”, isso é muito bom para nós. Agora você ir na porta de uma empresa com uma multidão de trabalhadores e você (...) falar para eles que você está lá num acordo para reduzir salário, mesmo eles concordando, querendo... (...) e eu falava para os trabalhadores nas assembléias, "não é fácil um sindicalista vir aqui e fazer isso, mas ele também não pode se acovardar e deixar vocês direto com o empregador", porque é covardia quando o trabalhador se defronta direto com o empregador. [Este dirigente declarou ainda que se dirige aos trabalhadores sobre o tema da seguinte forma]: "olha a gente sente muito estar aqui, companheiros, mas não tem alternativa, é o momento, o sindicato não queria fazer isso aqui, nós estamos aqui fazendo isso, agora é uma decisão que vocês têm 
que tomar junto conosco. Vamos fazer ou não vamos fazer?” (...) a gente preferiu encarar (...) o trabalhador e dizer assim: "Você quer? Quero!" (E20). ${ }^{366}$

Segundo outro dirigente da central, os sindicatos da FS possuem uma prática de consultar os trabalhadores da base constantemente antes de tomar as decisões:

A primeira reação da central é ela nunca transpor ao Sindicato, (...) impor uma vontade nossa. (...) a segunda reação é orientar o Sindicato a perceber aquilo que o trabalhador acha que é melhor para ele. O sindicato, (...) porque representa o trabalhador, não pode ir lá e impor a vontade da Diretoria (E24).

De maneira geral, esse modelo de negociação é visto de maneira positiva pelos dirigentes metalúrgicos de São Paulo: "Nós fizemos acordos acima da lei, (...) nós não fizemos nenhum acordo com $25 \%$ de redução [o teto permitido pela lei para esse tipo de negociação], isso aí girou em torno de 18 , no máximo $20 \%$ e (...) sempre como uma garantia de emprego após o término da redução" (E24). O dirigente argumentou, ademais, que esse tipo de acordo sempre foi "bem feito": “(...) a gente criou até uma cartilhinha de como o sindicato se comportar para ele não ser pego na sabedoria do patrão" (E24).

Nas negociações em que os sindicatos não conseguem evitar as demissões, a postura da FS é de buscar algumas "vantagens" aos trabalhadores, como benefícios materiais extras ou cursos de requalificação patrocinados pela empresa, tal como argumentou um sindicalista metalúrgico de Osasco:

(...) o fato é que demissões ocorreram [na última crise] e não foram poucas, nós tivemos desde demissões que a gente conseguiu negociar alguma melhoria para os trabalhadores que estavam saindo e minimizar o impacto para quem fica, até aquelas que a gente não negociou (...) dentre eventuais benefícios que você negocia num processo de demissão, como extensão de convênio médico, extensão de cesta básica, alguns salários (...). A gente tem procurado colocar que a empresa patrocine cursos de qualificação, então ter a oportunidade da pessoa ir fazer um curso no Senai para ela (...) preparar mais ou para disputar uma vaga (...) ou para quando o mercado reaquecer e tiver uma melhor demanda de emprego ele também tenha a chance de ter uma melhor oportunidade no novo emprego, inclusive com o melhor rendimento à medida que ele se qualificou (E22).

Tal como já mencionei neste capítulo, o modelo sindical da FS prioriza o diálogo e o entendimento na negociação. Para a central, esse objetivo deve ser logrado através do consenso entre as partes, o que não exclui ações de protesto como greves para que as empresas abram o diálogo e a busquem soluções. No geral, é possível afirmar que a prática da

\footnotetext{
${ }^{366}$ Esse mesmo sindicalista ressaltou ainda o caráter "democrático" que os sindicatos da FS estabelecem durante o processo de negociação da proposta de redução de jornada e salário, já que sempre se trata de uma decisão discutida e votada pelos trabalhadores: "Uma das exigências nossas é que isso teria que ser votado em assembléia e a votação tinha que ser unânime, mas não aceitava que o trabalhador tivesse discordando porque o Sindicato ia assinar o acordo de redução de salário" (E20).
} 
FS buscou priorizar a negociação, ainda que a mobilização tivesse sido utilizada com a finalidade de garantir espaços negociadores. Destaco a seguir três depoimentos esclarecedores, um do dirigente metalúrgico de Osasco, outro do SMSP e o último, da direção da central:

Só acontece a greve quando o patrão não reconhece aquela demanda que (...) está acontecendo na fábrica dele, é por isso que acontecem as greves. Então, o sindicato pega um processo de negociação e esse processo tem que ser sempre acompanhado pelos trabalhadores (E24).

Se uma empresa anuncia que vai demitir, nossa primeira ação é conversar (...). Se não há espaço para conversar e quando é possível paralisar a empresa, nós vamos parar para conversar, se não é possível dessa forma, a gente tem outra ação que pode ser tomada para fazer com que a empresa converse, nós também vamos tomar (...), quando é o caso da justiça do trabalho (E22).

(...) eu quero ver um dirigente de sindicato que fez mais greve que eu. Eu, em um ano e pouco, eu fiz mais de 300 greves (...). Por que eu fazia greve? Por que eles não queriam negociar, entendeu? Então, este sindicato aqui [o SMSP] não foge da greve, mas se ele puder negociar e ter resultado sem greve do que com greve... (...) nós acampamos nas empresas, da mesma forma que nós fizemos a negociação (E20).

Um dirigente da central e do Sintracon ressaltou a importância de que o sindicato verifique se as demissões são realizadas “dentro da lei” ou se há "abuso" do empresário:

Então, o sindicato precisa estar atento politicamente e juridicamente. Primeiro para que juridicamente verifique se as demissões foram dentro da lei. Infelizmente no Brasil a empresa pode demitir e admitir a hora que ela quer, sem intervenção de ninguém. Os sindicatos, em avaliando que houve abuso (...), eles podem criar muitos movimentos, paralisações, greves para que chame a atenção das autoridades para que haja aí uma contenção nos excessos. Existem empresas que excedem em muitas vezes em momentos de crise (E23)

Como já explicitei ao longo deste capítulo, a perspectiva de sindicalismo de resultados, propositivo e de colaboração de classe da FS não significa que os sindicatos da central não realizem greves e outras ações de protesto, ainda que, como vimos, o binômio negociação/mobilização na central é visto freqüentemente sob a fórmula "negociar ou mobilizar para negociar". Porém, para alguns entrevistados, a ação que caracterizou a prática das entidades afiliadas à central nos anos 90 em relação às demissões foi a mobilização, tal como sustenta dois sindicalistas da central e metalúrgicos de São Paulo e Osasco:

(...) nós fizemos muitas passeatas, manifestações e fizemos muitas greves, foram muitas greves, inclusive greve geral em algumas categorias como o metalúrgico, aqui em São Paulo, (...) fizemos greves por empresas, greves de categoria, foram muitas (...) evidente que eu disse que nós fizemos muitas greves e foram muitas, mas (...) jamais o sindicalista pode esquecer a bandeira da negociação. Está certo, a gente faz a paralisação, mas tem que negociar (E24) 
(...) procuramos enfrentar a crise com os instrumentos das manifestações, com a pressão sobre o governo, com protestos e em alguns casos com greve (...) nós tentamos toda a sorte de alternativas para tentar evitar demissões, assim como agora se discutiu banco de horas ou redução de jornada, todas essas coisas foram discutidas, inclusive suspensão de contrato (...) tinha uma discussão de câmaras setoriais que a gente procurou tentar com isso de alguma forma segurar no setor automotivo (...) foram espaços também que nos permitiram de alguma maneira minimizar os impactos do desemprego naquele momento, essas foram as ações principais naquele período, um período que teve muita greve (...) (E22).

Essa perspectiva se insere na noção pragmática da central de priorizar o "resultado", mas também se justifica pela idéia de que o sindicato tem que agir conforme as condições impostas pela conjuntura: “(...) o sindicalista (...) tem que estar atento para dançar conforme a música, a forma como ele vai agir são várias, ele pode agir politicamente, pode agir com greve, com movimentos, protesto, passeata..." (E23), como sustentou um membro da Direção Nacional. Um dirigente metalúrgico explicitou que para estabelecer um processo de negociação é necessário primeiramente conciliar a compreensão da conjuntura do setor e da situação específica da empresa ("a gente procura se colocar dentro do momento em que a gente vive") com o "respeito pleno ao pensamento do trabalhador", o que justifica e legitima os acordos firmados: "nós só fizemos [acordos] aonde o trabalhador pediu para fazer" (E24).

Dois dirigentes da central chamaram a atenção para o fato de que o contexto de demissão massiva é marcado por uma contradição entre a necessidade de resistência ao desemprego e a inibição que a eliminação de postos de trabalho provoca na prática sindical de maneira geral:

(...) o trabalhador, sem ameaça ele reage. Ele reage colocando realmente a sua força, ou seja, ele vai à luta, ele vai à greve, os sindicatos têm respaldo de fazer movimentos. Com uma ameaça de emprego o trabalhador reage de forma diferente. Então, o sindicato ele nada mais é ou nada mais pode ser que o condutor dessa vontade do trabalhador (...) você tem momentos de ameaça, onde o trabalhador não põe a cabeça em jogo, não põe a cabeça em risco e o sindicato entende isso e aí obviamente sai em acordos salariais que não são (...) aqueles que propriamente o trabalhador necessita (E21).

Eu sinto que naquela época [na década de 90] era uma coisa muito difícil para os trabalhadores porque quando há demissão (...) você leva a ação sindical a um refluxo. Então, (...) se propõe, primeiro, obter vantagem do ponto de vista da indenização, obter acréscimos do ponto de vista de direitos sociais, de atendimentos médicos, cestas básicas (...) (E19).

Um dirigente metalúrgico do SMSP e da central explicitou que em um contexto de “crise” as demissões são inevitáveis: “(...) sempre que tem crise, existem as demissões. Então as ações do sindicato, primeiro é pensar em garantir emprego do trabalhador, garantir empregos e direitos, e aí você faz várias ações" (E20). A inevitabilidade do desemprego foi 
explicada pela necessidade constante de inovação tecnológica das empresas, como argumentou um dirigente da Sintracon e diretor da central:

Não tem jeito, não tem como, isso nós vamos ter sempre. Imaginar que em São Paulo há 20 anos atrás, (...) [se] construía 10 metros quadrados e 20 anos depois você está construindo 100 metros, só que para construir 10 metros quadrados há 100 anos atrás você tinha dois milhões de trabalhadores, e para construir 100 hoje eu tenho só 300.000 trabalhadores. Infelizmente isso não tem jeito, nós temos que qualificar para não perder o emprego (E23).

Segundo os dirigentes da FS, frente à impotência dos trabalhadores diante das demissões, a saída do sindicato é resistir ou lutar contra o desemprego nas suas bandeiras mais gerais de luta, tal como argumentou um membro da Direção Nacional da central: "eu sinto que o enfrentamento, ele se dava mais no local, no momento do desemprego e nas ações gerais dos trabalhadores exigindo mudanças na política econômica" (E19). Para esse mesmo entrevistado, a atitude defensiva dos sindicatos foi acentuada pela "guerra fiscal":

(...) nós éramos pressionados nesse momento porque as empresas começaram a mudar para outros estados do país. Então se você naquele outro local você não tinha 44 horas reduzidas você ficava (...) sem condições políticas do enfrentamento aqui porque o concorrente dele no mesmo país estava trabalhando mais que ele, então, nós sentimos muita dificuldade (...) (E19).

Um dirigente do Sintracon e da central argumentou que a representação dos interesses dos desempregados não deve ser apenas dos sindicatos, mas do governo, com políticas públicas como um seguro-desemprego mais amplo e vinculado a uma política de formação profissional: "Eu acho que a política não é só do sindicato, nós temos que ter uma lei [para os] desempregados, (...) como é em parte da Europa e nos Estados Unidos (...), ele recebe o seguro-desemprego, mas ele é obrigado a estar se qualificando" (E23). Esse mesmo entrevistado atentou para o fato de que o setor informal da economia (o qual denomina "empreendorismo") absorve muitas pessoas, e que o sindicato deve cumprir um papel no sentido de orientar os trabalhadores para essas atividades:

[se a pessoa] não tiver emprego você pode estar encaminhando para que ela possa ter emprego, mas muitas destas pessoas podem virar pequenos empreendedores dentro do próprio mercado, aí o sindicato pode orientar e muito nisso aí. Não dá para dizer, no mundo que nós vivemos hoje, que o sindicato vai fazer assistencialismo, vai dar cesta básica, isso aí não resolve (E23).

Até aqui, explicitei questões referentes à concepção da FS sobre a ação diante do desemprego e das demissões. Vejamos a seguir como os dirigentes se posicionaram diante dos desempregados. Os entrevistados argumentaram que a representação dos interesses dos desempregados na FS se deu, prioritariamente, por meio do oferecimento de serviços, 
sustentada sob um discurso "anti-corporativista" e de "sindicalismo cidadão". Sobre o tema, assim se referiram três dirigentes da entidade:

[A estratégia da FS] primeiro foi dar assistência a ele [o desempregado]. Porque é assim, (...) o sindicato ele não funciona só para quem está na ativa (...). Pensando dessa forma a gente criou aqui embaixo (...) o Centro de Solidariedade ao Trabalhador. Então, qual foi o nosso discurso: "por que a gente só trabalha para quem está empregado? Nós temos também que olhar para aquele que está desempregado. Esse cara precisa mais de nós do que o cara que está empregado". Nós criamos este espaço aqui embaixo (gratuito, claro, financiamento público), a gente descobriu que lá em Brasília teria dinheiro do FAT e esse dinheiro era para fazer isso e nós montamos este projeto que funciona aqui muito bem, tem um impacto muito grande, empregou muita gente, mais de 600.000 pessoas (...) que entraram no mercado de trabalho via Força Sindical (...) o cara que está desempregado precisa mais do sindicato do que quem está na ativa (E20).

Nos anos 90 nós tivemos muita dificuldade no país em torno da recessão, das mudanças tecnológicas que estavam havendo, então a nossa ação naquele momento foi uma ação de buscar meios (...) de como que nós poderíamos apresentar uma proposta aos desempregados também porque, normalmente no movimento sindical o que interessa (...) é o trabalho com o associado, com aquele que está na ativa. Por quê? Porque quem está na ativa paga a contribuição sindical obrigatória no mês de maio e se ele está na ativa, ele é uma pessoa disputada dentro da fábrica para se tornar sócio do sindicato. Quando ele é desempregado, o sindicalismo não tem uma ação efetiva para ele, o sindicalismo abandona (...) o desempregado (E19).

(...) o sindicato não é só reivindicação, greve, não é só isso, ele também tem a sua parte social e a filosofia da Força é o sindicato cidadão, é um sindicato de dentro para fora, interagindo com as comunidades e tal... é importante porque senão ninguém sabe o que você faz, você só é voltado especificamente para aquele setor, só para aqueles trabalhadores, então você também procura interagir na comunidade, nos bairros (E18).

No discurso dos dirigentes da FS não apareceu qualquer distinção entre representação dos interesses e organização para a luta dos desempregados, justamente porque a central não priorizou o trabalho político de mobilização desse segmento. Um dirigente do SMSP e da central destacou que a prática mobilizativa, mais comum nos anos 80 , foi substituída pela prestação de serviços:

(...) depois que foram instituídos os cursos de qualificação profissional, todos os sindicatos acabaram fazendo, construído essa prestação de serviço no sentido de ter um local aonde ele [o desempregado] pudesse buscar um novo emprego, onde ele pudesse se inscrever para a qualificação, onde o pagamento do seguro-desemprego era dado nesses locais e esses locais normalmente eram ligados ao sindicato. Nós acabamos melhorando esta tarefa de mobilização e de prestação de serviço, digamos assim, para o desempregado (E19). 
Esta prática enquadrou-se na tradição assistencialista dos principais sindicatos da central, ganhando inclusive contornos "motivacionais" a partir da década de 90. Quando perguntado sobre a possibilidade de uma ação conjunta entre empregados e desempregados, um membro do SMSP e da Direção Nacional da central respondeu: "Sim, tudo é possível na vida. (...) Tudo é possível motivando, conversando, sabendo que você não vai trazer todo mundo, mas se você trouxer um, você vai fazer a diferença" (E23). Perguntado sobre a política que a entidade que representa leva a cabo para os setores não sindicalizáveis, o dirigente ressaltou:

(...) o sindicato aqui mantém individualmente toda uma política de motivação. Então, nós temos aqui 60 carros, 180 pessoas que visitam (...) motivando em todas as áreas, nas áreas de segurança, nas áreas de formação, nas áreas de cidadania, transformar o sindicato no sindicato cidadão, não defender só o trabalhador, defender o cidadão como um todo porque nós achamos que não adianta em nada você preparar o cara e não preparou a família (E23).

Como argumentei no primeiro capítulo da tese, a competição no interior da classe trabalhadora se expressa na relação de conflito de interesses entre empregados e desempregados. Se o primeiro se encontra em uma situação fragilizada e busca soluções individuais para resolver seu problema, o segundo se sente pressionado pelo desemprego, o que dificulta a ação conjunta entre esses dois segmentos. Quando perguntado sobre o tema, um membro da diretoria da central ressaltou essa questão, mas explicitou que o CST foi a maneira que a FS encontrou de superar esse "antagonismo":

Existe o conflito de interesses sim e aí [se insere] o chamado exército de reserva (...) que o Marx já fala disso. Eu sinto assim que quando o (...) desemprego está muito alto, quem está trabalhando começa a também ficar mais acomodado porque tem uma pessoa ali fora querendo o emprego dele com um salário menor. Fizemos greve que às vezes a empresa anunciava a contratação e aparecia milhares de trabalhadores procurando emprego para substituir aqueles que estavam em greve. Eu acho que este conflito de interesses (...) é utilizado pelo patronato para jogar um contra o outro. Eu sinto que (...) ao buscar meios de também atender aos desempregados, eu sinto que o sindicalismo buscou uma forma de trabalhar com as duas parcelas. Aqui, por exemplo, nesse prédio, passam aproximadamente 5.000 pessoas procurando emprego aqui por dia. Então, ele [o desempregado] sente que o sindicato está tentando fazer alguma coisa, está abrindo (...) uma opção para ele e está prestando um serviço a ele. Então, nesse aspecto de tentar unir o desempregado com o sindicato, porque o sindicato é mais voltado até esse momento para aqueles que estão na ativa, eu sinto que é uma maneira de quebrar este antagonismo (E19).

A resposta da FS aos desempregados foi construída a partir do oferecimento de serviços a esse segmento, de acordo com a noção de que o sindicalismo não deve representar apenas o ativo. Essa estratégia esteve pautada essencialmente na noção de empregabilidade, que no 
campo das políticas de emprego, foi uma das principais evidências da adesão da central ao neoliberalismo. Ao argumentar sobre a necessidade de se qualificar, um sindicalista do Sintracon e da central ressaltou: “(...) do contrário, vai virar mendigo de rua mesmo, nem para vender banana na rua ele tem mais espaço, se ele não é qualificado". E acrescentou:

(...) com o avanço das novas tecnologias não tem mais serviço (...) não qualificado (...) a maioria das construtoras hoje não pega carteira assinada [de] pessoas que não sabe ler e escrever. (...) Nós já estamos até importando trabalhadores de engenharia, (...) soldadores, (...) porque não temos, infelizmente não temos. O Brasil tem aí uma imensidade de gente desempregada, praticamente dois milhões de pessoas desempregadas e você não consegue a mão de obra porque a mão de obra tem que ser qualificada, falta mão de obra (E23). ${ }^{367}$

Para este entrevistado, existe um comodismo de muitas pessoas por sua ausência de busca de estratégias individuais para superar o desemprego através da qualificação:

[o desempregado recebe] o seguro-desemprego enquanto vai trabalhar na informalidade, isso é uma coisa ruim. A mesma coisa acontece com o Bolsa Família, nego que se vicia em receber esmola e ele não se qualifica para acompanhar a evolução das novas tecnologias e ter emprego (E23).

A bandeira da qualificação é levantada da seguinte maneira por um dirigente metalúrgico de Osasco e pela sindicalista das costureiras paulistanas e da confederação dos setor vestuário, ambos da direção nacional:

(...) nós vimos situações muito críticas porque você não tinha emprego, as pessoas que procuram este serviço, uma parte tem qualificação, a outra parte não tem qualificação, a outra parte precisaria ainda ter uma progressão, precisa ter uma melhora na sua educação básica e muitos tem a deficiência muito grande, eram preocupações nossas e portanto, muitas pessoas não conseguiam em função de não ter as qualificações exigidas pelo mercado (...), acabavam ficando muito tempo na fila (...). Nós fazíamos aqui palestras aonde tinha gente que vinha aqui, vinha aqui por emprego, não vinha mais a procura de um emprego porque ele sabia que ia ter dificuldade, mas vinha para poder ter com quem conversar, surtia um efeito para o emocional da pessoa, para ela se alentar com as pessoas que estavam aqui, de poder conversar, de ouvir uma palestra, de estar ali, isso tem bastante (...). Resolve os problemas? Não resolve os problemas, mas ajuda bastante (...) (E22).

(...) nós temos que preparar o nosso trabalhador para isso [a inovação tecnológica]. Então nós iniciamos aí a guerra de qualificar estes trabalhadores e até procurar qualificar ele, se ele não tiver campo nesse setor, ele buscar alternativa, que é um setor que está crescendo que é o setor de serviços, setor de computação, essas coisas (...) não podemos ficar esperando as coisas acontecerem (E18).

Esta última entrevistada ressaltou que a política de formação e requalificação profissional levada a cabo pelos sindicatos se fez necessário para cumprir uma demanda das

\footnotetext{
${ }^{367}$ Um metalúrgico de Osasco também se referiu ao setor da construção civil da mesma forma: "até mesmo na construção civil, teve que se fazer toda uma reprogramação para se poder atender a demanda do setor porque não tinha gente qualificada para atender as necessidades do crescimento que teve a construção civil" (E22).
} 
empresas, já que essas não buscam mais investir em capacitação e treinamento: "Hoje as empresas não querem mais investir como elas faziam antes. Eu aprendi tudo dentro da fábrica (...). Então, nós assumimos um pouco este papel” (E18). Um dirigente metalúrgico e da central assim argumentou da seguinte forma a favor da tese da empregabilidade:

(...) [Nossa] bandeira número um é a empregabilidade. Um país não cresce, (...) um país não vai crescer com um número gigantesco ou com a imensidão de cidadãos desempregados (...) a Força Sindical ela não abre mão desta bandeira da empregabilidade porque nós entendemos que é o que faz um país crescer, ter um mercado interno forte, é com o cidadão empregado e é o que faz gerar renda (...) não é a única, lógico que nós defendemos a cidadania como um todo. Temos feito passeata para defender bandeiras as mais diversas, mas nós entendemos que a empregabilidade ela é fundamental (...). Muitos dos cidadãos que vêm ou das cidadãs que vêm ao Centro, às vezes, infelizmente ele volta frustrado porque a capacidade intelectual dele não atinge as exigências que a empresa faz. Isso para nós é muito frustrante e às vezes ele volta, e tem a vaga, e ele não tem habilitação profissional para ocupar aquela vaga, para nós é frustrante (E24).

A criação do CST foi considerada a principal resposta da FS ao desemprego e aos desempregados. A maioria dos entrevistados considera a experiência exitosa: “(...) era uma forma de ajudar os trabalhadores desempregados, (...) ajudar na mão de obra, ajudar na formulação de currículos, isso até hoje é feito e tivemos vários cursos, desde os cursos de auto-estima, palestras de auto-estima" (E22). Como ressaltou um membro da diretoria da central, o CST é uma "referência no que ele se propõe a fazer que é a intermediação da mãode-obra (...) a gente capta as vagas que tem no mercado, principalmente no setor de serviço e comércio, aonde há mais rotatividade, e normalmente aonde gera mais emprego" (E24). No entanto, este mesmo dirigente reconheceu as limitações do trabalho desenvolvido pelo centro:

Nós não temos recurso para o que nós gostaríamos de fazer, (...) a demanda é maior do que o recurso que nós temos e principalmente na questão de qualificação (...) não é o suficiente para a gente qualificar pessoas em áreas que requer uma qualificação um pouco mais refinada (...) o dinheiro que nós temos ainda é para áreas com o curso de pequena duração, cursos que requer menos tecnologia (E24).

Quando perguntado sobre como a central responde à crítica recorrente de que a política da FS desonera o Estado de suas atribuições, esse entrevistado respondeu:

Nós recebemos essas críticas de maneira lamentável porque a questão da qualificação, é verdade, é também um papel do Estado, mas se você pegar o Estado, o Estado é como um todo, nós também fazemos parte do Estado, nós somos uma entidade (...) de representação de trabalhadores. Então, por que nós não darmos essa contribuição? E a Força Sindical entende que nós temos que dar esta contribuição. Os empresários, (...) eles fazem curso (...) mas os empresários às vezes eles fazem lá uma lavagem cerebral e foi aonde nós entendemos que nós também teríamos que entrar (...) nessa fatia de nós 
qualificarmos os nossos trabalhadores e também tentarmos embutir uma cidadania que nós entendemos que é adequada para o trabalhador, para ele se formar como cidadão, como operário cidadão, e não como operário padrão (...). Nós entendemos sim que é papel nosso de se preocupar com a qualificação dos trabalhadores.

Mas este mesmo dirigente também afirmou que o êxito do programa depende do desempenho econômico:

(...) essa questão de você dar o curso e formar uma grande massa desempregada, com curso mas desempregada, bom, aí isso vai depender do mercado (...). Agora se você tiver uma grande massa desempregada, mas com certa qualificação, se o país reagir (...), você pode ter certeza que você vai ter um operário desempregado com muito mais possibilidade de se integrar novamente a um emprego do que se você tiver uma grande massa sem nenhuma qualificação (...) então, você pode ter uma grande massa desempregada como você não pode ter, isso vai depender do mercado de trabalho, eu acho que você não pode é ficar apenas no discurso da ideologia e deixar de cumprir com a sua parte social (E24).

Como já explicitei, a FS não diferencia a organização da representação de interesses e os dirigentes consideram que a entidade "organizou" os desempregados oferecendo-lhes serviços. Por isso foram poucos os limites organizativos dos desempregados e de sua ação conjunta com as entidades sindicais aos quais se referiram. Assim mesmo podemos encontrar algumas reflexões sobre essa questão. Um membro da direção nacional destacou a questão da auto-estima e da individualização que a situação do desemprego impõe por conta do perda de laço coletivo no local de trabalho e no sindicato:

(...) quando você é desempregado (...) você se sente para baixo, primeiro porque você está fora de seus companheiros, você se coloca para baixo porque você foi escolhido para ser cortado e depois você está individualizado na região, você está individualizado, fora do processo produtivo, fora das organizações, do sindicato (E19).

Sobre a possibilidade de se construir uma ação conjunta entre empregados e desempregados, este entrevistado reiterou: "Eu sinto que é difícil (...) Eu acho que ninguém separa os trabalhadores entre desempregados e empregados. Eu acho que a própria condição já não o atrai, compreende? (...) você está tão individualizado que você é incapaz de se mobilizar em torno disto" (E19). Por conta desses limites, este dirigente destacou que a organização dos desempregados não pode depender deles mesmos, mas deve partir dos trabalhadores ativos, até mesmo porque estes sofrem a pressão do desemprego sobre seus salários e condições de trabalho:

(...) eu sinto que a ação contra o desemprego não depende só dos desempregados, porque o desempregado normalmente ele está (...) individualizado. Nós precisamos aí de ações dos trabalhadores que estão na ativa, da sociedade em geral (e, claro, com o desempregado também), mas como ponta de lança são 
aqueles que estão empregados no movimento social e se sente até pressionado pelo desemprego por causa da redução de salário, dificuldades de trabalho, questões de condições de trabalho porque você fica cercado pelo desemprego e também no local do trabalho e acaba também diminuindo os seus direitos (E19).

Para alguns entrevistados, porém, além de necessária, a ação conjunta entre empregados e desempregados é possível, tal como ressaltou um sindicalista do SMSP e membro da Direção Nacional da FS:

Então, isso é possível sem dúvida nenhuma, fazer ação de desempregados e empregados (...). Eu acho que é um combustível a mais, principalmente na solidariedade, de quem está empregado sentir o efeito de quem está desempregado e vice-versa. Então, é possível e eu oriento as centrais sindicais, a Força Sindical, a fazer este tipo de movimento e eu acho que isso é muito importante (E24).

Antes de sintetizar os principais argumentos trabalhados neste capítulo e avançar na análise, farei uma breve referência à relação entre o movimento sindical e os desempregados nos anos 2000. Essa digressão, tal como a que foi feita sobre os anos 1980, será fundamental para sustentar minha tese sobre o porquê de não ter havido protestos de desempregados com peso significativo no Brasil tal como na Argentina. Também será fundamental para a compreensão da relação de unidade e fratura entre o ativo e a reserva no país.

\subsection{Sindicalismo e desempregados nos anos 2000}

O panorama sindical brasileiro nos anos 2000 sofreu importantes alterações após a eleição de Luis Inácio Lula da Silva para a Presidência da República por dois mandatos consecutivos (2003-2006; 2007-2010). A mudança mais notável nesse sentido foi a incorporação de sindicalistas ao governo do Estado, através de cargos políticos nas secretarias e ministérios. ${ }^{368}$ O Governo iniciou um processo de discussão com as centrais através do Fórum Nacional do Trabalho, que deu origem à reforma sindical aprovada em 2006. Com a legalização das centrais, em 2008, estas passaram a administrar parte dos recursos do imposto sindical. Esse evento, tal como o apoio cutista ao governo, explicam, em boa medida, a saída de correntes da CUT, mas também a fundação de outras entidades. Vejamos a seguir como se deu esse processo mais detalhadamente.

\footnotetext{
${ }^{368}$ A expressão máxima dessa tendência foi a nomeação de Luiz Marinho, presidente da CUT, para a pasta do Ministério do Trabalho, cargo que exerceu entre 2005 e 2007, quando migrou para o Ministério da Presidência Social, o qual comandou até 2008. Nesse cenário, houve espaço até mesmo para Luiz Antônio de Medeiros, adversário histórico da CUT, como Secretário de Relações de Trabalho do Ministério do Trabalho desde 2007.
} 
Em 2005, foi criada a Nova Central Sindical de Trabalhadores (NCST), com sede em Brasília, composta por sete Confederações, 136 Federações e cerca de 3.000 sindicatos (a maioria sem ligação com qualquer central), que representavam 12 milhões de trabalhadores em todo o país. Entre os lemas dessa central está a "defesa da unicidade sindical, da contribuição compulsória, do sistema confederativo de representação sindical, respeito ao artigo $8^{\circ}$ da Constituição Federal, por um Brasil com emprego, desenvolvimento e juros baixos". ${ }^{369}$ Em 2006, surgiu a Coordenação Nacional de Lutas (Conlutas), a partir da corrente cutista Convergência Socialista, vinculada ao Partido Socialista dos Trabalhadores Unificado (PSTU), dissidente do PT, de origem trotskysta e filiado à Liga Internacional dos Trabalhadores (LIT). ${ }^{370}$ Seu surgimento esteve motivado pelas divergências com a CUT em relação a sua postura desta diante do governo de Lula. Por motivos semelhantes, também em 2006 foi fundada a Intersindical por grupos de sindicalistas ligados a partidos de esquerda como o Partido Comunista Brasileiro (PCB), pela Alternativa Sindical Socialista (ASS) e por setores do Partido Socialismo e Liberdade (PSOL). A central surgiu como opositora à CUT, à qual acusa de haver barganhado reivindicações históricas como o direito à OLT, a ratificação da Convenção 87 da OIT, que fundamenta a liberdade e autonomia sindical "por uma reforma que centraliza poder na cúpula das centrais e abre caminho para que direitos garantidos dos(as) trabalhadores(as) sejam atacados na próxima reforma trabalhista a ser feita pelo futuro governo". 371

Em 2007, a Corrente Sindical Classista (CSC), ligada ao PCdoB, decidiu sair da CUT e criar a Central dos Trabalhadores e Trabalhadoras do Brasil (CTB), com cerca de 700 entidades. ${ }^{372}$ No mesmo ano, a Confederação Geral dos Trabalhadores (CGT), a SocialDemocracia Sindical (SDS), a Central Autônoma dos Trabalhadores (CAT) e sindicatos independentes fundaram a União Geral dos Trabalhadores (UGT). Em 2009, quando a Contag, com seus mais de quatro mil sindicatos representantes de cerca de 20 milhões de trabalhadores, decidiu se desafiliar da CUT, completa-se o quadro da expressiva perda de espaço da central no cenário sindical. A partir dessa última dissidência, a FS passou a se apresentar publicamente como a maior central brasileira em número de afiliados.

\footnotetext{
369 www.ncst.org.br. Acesso em 26/06/2009.

${ }^{370}$ www.conlutas.org.br. Acesso em 02/12/2009.

371 www.intersindical.org.br. Acesso em 26/06/2009. Em 2008, uma corrente interna decidiu construir uma Intersindical à parte. Ver www.intersindical.info.br. Acesso em 26/06/2009.

372 portalctb.org.br. Acesso em 09/12/2009.
} 
Com base nessa breve descrição, apresentarei algumas formulações adicionais sobre o tema estudado. Se no período anterior ao governo de Lula o campo político-sindical se encontrava relativamente polarizado entre a FS e a CUT, sendo que esta última conseguia unificar diversos setores da esquerda, atualmente as duas centrais compõem o bloco governista. A maior evidência dessa aliança se deu em torno da candidatura, da reeleição e da defesa das principais propostas de reforma do governo. ${ }^{373}$ As duas centrais estiveram juntas na mesa de negociações que firmou a legalização das centrais sindicais em 2007. No campo sindical, os protestos de oposição ao governo sofreram um refluxo, ainda que o número de greves não tenha sofrido uma redução drástica se comparada com o segundo governo de FHC, e atualmente vem sendo protagonizados por centrais opositoras como a Conlutas e a Intersindical.

Valem ainda algumas palavras sobre a posição atual do movimento sindical brasileiro diante da estrutura sindical. A maioria das entidades apóia os pilares do sindicato oficial, o que pode ser considerado um dos principais fatores explicativos de sua persistência. Ademais, se esta adesão não aparece explicitamente, nos discursos, fica evidente nas práticas das entidades. A FS, a CTB, a UGT, a Contag e a NCST defendem a investidura, a unicidade e o imposto sindical. ${ }^{374}$ A CUT possui uma política ambígua nesse terreno, pois apesar de apresentar o combate ao edifício corporativo como bandeira histórica em seus principais documentos, na prática defendeu recentemente a referida Reforma Sindical, que fortalece esse modelo. A Intersindical e a Conlutas também apresentam um discurso combativo sobre o tema, mas não possuem experiências significativas de ruptura com a estrutura sindical. A devolução do imposto sindical em algumas de suas entidades, por exemplo, é feita mediante a cobrança da taxa negocial, que também depende da tutela estatal para subsistir.

Em relação aos desempregados, as políticas de CUT e FS não apresentaram novidades com relação à década de 1990. É importante considerar que a partir de 2003 cresceu o emprego formal, tendência verificada pelo menos até a crise de 2008/2009. Uma novidade nessa conjuntura é que as agências de intermediação de força de trabalho perderam espaço a partir de 2003, quando, por determinação do Ministério do Trabalho, tornaram-se agências

\footnotetext{
${ }^{373}$ Ver Galvão (2006).

374 A FS defende o tripé da estrutura sindical. Em sua proposta de reforma da CLT, a central apresenta as bandeiras dos delegados nacionais, do contrato coletivo nacional e da legalização das centrais sindicais ("Estrutura sindical. Um gigante com os pés de barro". Revista da Força Sindical, Ano 11, maio de 2002, p. 11). Porém, a entidade não apresenta críticas à unicidade, ao imposto sindical e ao poder normativo da Justiça do Trabalho.
} 
públicas e deixaram de ser administradas pelas centrais, apesar da possibilidade de que estas continuem atuando em parceria. A CUT passou a investir crescentemente em cooperativismo e economia solidária. ${ }^{375}$ A FS seguiu investindo no CST e em políticas de qualificação profissional. Na Conlutas se fez presente a discussão de "central sindical e popular", especialmente após a incorporação da Coordenação de Movimentos Sociais (CMS) à estrutura organizativa da central. $\mathrm{Na}$ Intersindical, surgiu a proposta de construção de uma "central do mundo do trabalho", que pretende aglutinar, além dos trabalhadores formais, os outros segmentos da classe trabalhadora não sindicalizáveis, como os terceirizados, os precarizados e os desempregados. Em 2009, as duas entidades vêm debatendo essa questão no Seminário de Organização que buscará, em 2010, fundar uma nova central sindical.

Ressalto a seguir alguns elementos para refletir sobre a organização dos trabalhadores desempregados no período estudado. Ao longo da década de 1990 não houve mobilizações expressivas de desempregados no Brasil. Entre 1997 e 1998, encontramos apenas o Movimento Contra o Desemprego (MCD) de Campinas, que estudei em minha dissertação de mestrado. ${ }^{376}$ Em 2000, surgiu o Movimento dos Trabalhadores Desempregados (MTD), que ao longo dessa década se expandiu em diversos municípios do país. Sua origem esteve ligada ao MST, que remonta às experiências deste movimento de organização dos trabalhadores urbanos desempregados. Vejamos como se deu esse processo mais detalhadamente.

Os anos 1990 foram marcados pela intensificação das lutas no campo pela reforma agrária, consolidando o papel do MST como principal opositor aos governos de orientação política neoliberal, contexto em que as ações do movimento adquiriram um peso político crucial no conjunto da rebelião da classe trabalhadora brasileira. Como ressalta Coletti (2005), durante essa década a expansão das bases sociais do MST teve “(...) no recrutamento de trabalhadores desempregados e subempregados urbanos, um de seus pilares de sustentação" (p. 151). Na realidade, como argumenta o autor, “(...) os sem-terra sempre incorporaram às suas lutas os trabalhadores desempregados urbanos que, não mais encontrando condições de sobrevivência digna nas cidades, passaram a ver a luta pela terra como a única saída possível

\footnotetext{
${ }^{375}$ Esse período corresponde ao final da gestão de João Antônio Felício (2000-2003) e aos mandatos de Luiz Marinho (2003-2005); João Antônio Felício (2005-2006) e Artur Henrique da Silva Santos (2006-2009; 2009atual).

${ }^{376}$ Nesse trabalho verifiquei que, se por um lado os militantes do MCD de Campinas reconheceram que o Sindicato dos Metalúrgicos da região foi fundamental para a constituição do movimento, fornecendo estrutura e apoio material em seu início, por outro, a ausência de uma política de incorporação dos desempregados como parte da luta sindical foi apontada como o principal fator de sua desmobilização pelos militantes daquele movimento.
} 
para suas vidas" (p. 260). O autor cita um documento da Comissão Pastoral da Terra (CPT) que destaca esse fenômeno:

(...) o ano de 1995 marca o início de uma tendência que aponta para a sua consolidação nesta virada de século: grande contingente populacional que habita as periferias de cidades, sem perspectivas de vida, volta ao campo ocupando terras porque acredita que esta é uma possibilidade de garantir sua continuidade de vida. A maioria dos acampamentos de sem-terra, em 1995, conta com um grande número de pessoas oriundas de favelas e periferias urbanas. Para muitos, esta é uma volta às origens, que completa o círculo: da roça para a favela e dela para a roça (CPT, 1995, p. 22 apud Coletti, 2005, pp. 260-261). ${ }^{377}$

O MTD, criado em maio de 2000, em Porto Alegre, ainda segue em atividade. O movimento surgiu a partir dessa política do MST, que buscava adotar seu modelo de organização no movimento urbano, impulsionado pela criação do Consulta Popular. ${ }^{378}$ De acordo com Mangueira (2007), com essa estratégia, o movimento tinha como objetivo "organizar núcleos de desempregados para acamparem em terras próximas às regiões urbanas", constituindo, assim, assentamentos rururbanos. ${ }^{379}$ Sendo assim, segundo este autor, o MTD não se declara como um movimento rural, mas como "um movimento urbano, na medida em que tenta resgatar a identidade proletária das massas por ele mobilizadas" (p. 5). Por isso seus militantes não se definem como "camponeses", mas como "desempregados".

A partir de 2003, o MTD começou a se expandir pelo país e já atua em vários $\operatorname{estados}^{380}$. No Rio Grande do Sul, concentra-se na região metropolitana de Porto Alegre. Em Santa Catarina, o movimento chegou em 2003 no município de Criciúma, no interior do Estado, onde se constituiu experiências de empreendimentos produtivos baseados no conceito de "autogestão". Na Bahia, o movimento atua desde 2003 na periferia de Vitória da Conquista, no interior do Estado, onde atualmente possui sete acampamentos e dois "assentamentos rururbanos"; e desde 2005 na região metropolitana de Salvador, organizado a

\footnotetext{
377 Coletti cita outros estudos e documentos do próprio MST que apontam essa tendência. (Coletti, 2005, pp. 260-261). Entre as informações coletadas pelo autor, destaco as seguintes: entre as famílias assentadas no pontal do Paranapanema existe um contingente de $50 \%$ de ex-trabalhadores urbanos; entre os sem-terra que se instalaram no acampamento de Iaras, na região de Bauru, esse contingente chega a $80 \%$.

${ }^{378}$ O Consulta Popular é um "projeto político alternativo" organizado por intelectuais e militantes de diferentes organizações populares brasileiras em dezembro de 1997, que tem por finalidade articular as lutas em torno de uma transformação social do país, partindo, entre outros aspectos, da organização de diversos setores da classe trabalhadora, entre os quais, os desempregados. Ver Benjamin et allii (1998).

${ }^{379}$ Segundo este autor, para levar a cabo essa política o MTD parte da constatação de que a reforma agrária é um dos principais meios de superação do desemprego.

${ }^{380}$ Para Mangueira (2007), essa estratégia vem se consolidando a partir da participação do movimento na Coordenação dos Movimentos Sociais (CMS), que nesse momento integrava, entre outros, a CUT, a Central de Movimentos Populares (CMP), a União Nacional dos Estudantes (UNE) e a Confederação Nacional dos Bispos do Brasil (CNBB).
} 
partir de "grupos de trabalho urbanos". Na Paraíba, o movimento está organizado desde 2006 na capital, João Pessoa, e pelo menos desde 2008, em Campina Grande, principal cidade do interior do Estado. No Rio de Janeiro, o MTD está presente na capital desde 2006, e em 2007 começou a formar núcleos de trabalho em Volta Redonda e grupos de formação em Petrópolis. No Estado de São Paulo, estruturou-se desde 2007 em Campinas e na mesma época, começou a se constituir em Belo Horizonte, capital de Minas Gerais. ${ }^{381}$

Entre os dias 12 e 15 de abril de 2007, o MTD realizou o seu I Encontro Nacional, em Porto Alegre (RS). Durante o evento, o jornal Brasil de Fato publicou uma matéria digital com trechos de entrevistas com alguns militantes do movimento. De acordo com um dirigente, a organização dos desempregados se insere em um contexto mais amplo de construção de uma unidade de luta no interior da classe trabalhadora, considerando sua fração ativa e de reserva. Para a coordenadora do MTD de Minas Gerais, Diva Braga, “o MTD acredita no potencial revolucionário do trabalhador desempregado, tão negligenciado pela esquerda". ${ }^{382}$ Segundo o relato de alguns dirigentes, o MTD parte de uma interpretação de que "o desemprego é uma questão estrutural" e "não tem solução dentro do capitalismo". Por isso defende uma "mudança radical das formas de produção, dentro de um novo projeto de sociedade". Segundo Mauro Cruz, coordenador do MTD no Rio Grande do Sul, a luta do movimento "não é por emprego, é por trabalho. Nós não queremos organizar as pessoas para vender sua força de trabalho, mas para produzir de acordo com as suas necessidades". Durante o encontro, a estimativa do MTD era de que a organização contava com quatro mil militantes em todo o país, mas que não teria logrado se constituir como uma experiência de mobilização massiva de desempregados no nível nacional. Além da ausência de um movimento de caráter com peso político significativo no conjunto da rebelião brasileira, podese afirmar que nos anos 2000 também não houve experiências representativas de organização desse segmento para a luta levadas a cabo pelas entidades sindicais. A seguir, farei algumas considerações sobre a relação entre o movimento sindical e os desempregados no Brasil no período estudado.

Entre 1990 e 2002 as entidades sindicais analisadas apresentaram propostas para a geração de empregos em suas pautas de reivindicações junto ao governo e ao patronato.

\footnotetext{
${ }^{381}$ Sobre a experiência do Rio de Janeiro, Mangueira (2007) destaca: "O tráfico de drogas, as milícias armadas, as religiões evangélicas e o assistencialismo do Estado são os principais empecilhos para organizar os desempregados na capital".

${ }^{382}$ www.brasildefato.com.br. Acesso em 19/04/2007.
} 
Porém, a política desenvolvida para os desempregados se pautou no oferecimento de serviços e na organização desse segmento para o "retorno ao mercado de trabalho", mas também para a produção e o consumo, através de "alternativas de geração de emprego e renda" e da "economia solidária". Como base nessa leitura, cabe a seguinte indagação: é possível relacionar a política sindical com a ausência de mobilização dos desempregados?

Em uma primeira aproximação ao tema, é possível afirmar que o modelo hegemônico de ideologia sindical no Brasil no período estudado, pautado na concepção de sindicalismo "propositivo" e "cidadão", contribuiu de maneira crucial para a fratura entre o movimento sindical e os desempregados, mesmo no caso da CUT, que apelou constantemente ao discurso da necessidade de organização desse segmento para a luta. Ainda que a ausência de mobilização dos desempregados não se explique somente pelas estratégias do sindicalismo, pode-se afirmar que não foi a partir das entidades sindicais que este segmento se organizou. A FS apoiou, explicitamente, o receituário neoliberal. Na sua leitura sobre as causas e possíveis soluções para o desemprego, essa entidade adotou a noção de "empregabilidade". A CUT, por sua vez, não fez uso do conceito abertamente, mas o fundamento de tal tese também foi relativamente incorporado pela central. Ao que pese suas diferenças de conteúdo e metodologia, as duas centrais investiram na "reciclagem" do desempregado, o que, de maneira parcial, contribuiu para retirar do Estado o papel de gestor de políticas públicas e para desonerar o empregador de sua atribuição de oferecer treinamento. O Estado burguês, sob o neoliberalismo, incentiva a "sociedade civil organizada" (como ONGs e entidades sindicais) a contribuir para o oferecimento de políticas compensatórias focalistas e o desenvolvimento de projetos alternativos de economia solidária. De maneira geral, pode-se dizer que no caso da CUT, a formação política deu lugar, crescentemente, a uma política de formação profissional (Tumolo, 2002).

Nos anos 1990 também se aprofundou a acomodação do sindicalismo brasileiro à estrutura sindical, especialmente ao corporativismo, entendido aqui como a representação legal da categoria profissional empregada. A FS cresceu a partir do aparelho sindical oficial. A CUT manteve o discurso crítico ao mesmo, mas se distanciou de algumas de suas bandeiras históricas, especialmente a da organização no local de trabalho. Com relação a esta última questão, apesar de ressaltar a existência de fatores externos como a intransigência patronal e a falta de uma legislação que garanta a estabilidade dos delegados, a própria central reconhece sua parcela de responsabilidade pelo crescente distanciamento da base. 
A reprodução do sindicalismo de Estado na correlação de forças estudada foi um dos fatores desmobilizadores da organização sindical dos desempregados. O sindicalismo é o movimento orgânico da classe trabalhadora no enfrentamento com a classe capitalista. No entanto, sua forma de manifestação legal como Aparelho Ideológico de Estado constitui o lugar privilegiado do esvaziamento de experiências que possibilitam o processo de formação de uma tradição organizativa entre os trabalhadores, doravante acionada na situação de desemprego. O que não significa afirmar que nada pode ser feito; ao contrário, é possível que as práticas anti-corporativistas podem se concretizar a partir de ações e representações que busquem superar esses limites, ainda que estes existam se expressem elementos condicionantes.

O papel de organização poderia ter sido cumprido pelos próprios desempregados ou por outras organizações (e, de fato, quem mais investiu nesse terreno foi o MST). Porém, como este estudo se restringiu ao papel desempenhado pelo sindicalismo, posso concluir apenas que a instituição sindical não atuou nesse sentido. No limite, pode-se apresentar como hipótese que as centrais sindicais brasileiras, ao não priorizarem a organização dos desempregados para a luta, oferecendo-lhes serviços, contribuíram para sua desmobilização, ainda que esta não seja a única explicação da mesma. Essa opção política, por um lado, manifesta a parcial adesão do sindicalismo à ideologia neoliberal, por seu fundamento no discurso de empregabilidade, ainda que a defesa do neoliberalismo não seja uma condição necessária para a não organização dos desempregados. Ademais, essa foi uma forma de manifestação da acomodação das centrais ao sindicato oficial, pela reprodução do burocratismo corporativista, embora a relação entre o discurso e a prática não seja a mesma na CUT e na FS.

Neste capítulo, busquei propor uma conceituação e periodização das políticas das centrais sindicais brasileiras diante dos desempregados. Ressaltei que a história da CUT foi marcada pelo advento do sindicalismo propositivo, de serviços e cidadão, ainda que a perspectiva classista e combativa não tenha desaparecido de seu horizonte. Já a FS surgiu no começo da década de 1990 com uma proposta de sindicalismo "de resultados" e "governista", defendendo abertamente a plataforma neoliberal e uma prática de conciliação entre capital e trabalho. A evolução da ideologia político-sindical nessas centrais teve nas ações e representações específicas diante do desemprego e dos desempregados um de seus principais motores. Dito de outra forma, estas expressaram as mudanças ocorridas nos projetos mais gerais das centrais, ao mesmo tempo em que foram importantes meios dessas transformações. 
No plano da luta, a década de 1990 foi palco de movimentos de resistência às demissões. Como proposta de combate ao desemprego, as duas centrais defenderam a redução da jornada de trabalho, ainda que tenham concretizado acordos com flexibilização e perdas de salários. Estes foram feitos sob um clima negociador propositivo que tomou forma tanto na FS como nos setores majoritários da CUT, especialmente a partir da experiência das Câmaras Setoriais. Quanto à política de representação dos interesses dos desempregados, pode-se dizer que estes não foram mobilizados para a luta pelas centrais. Porém, a CUT atuou parcialmente com as organizações populares que organizam a reserva, especialmente o MST e movimentos pela moradia. A partir de 2003, a central passou a compor a CMP, onde atua aquela esta organização e o MTD. No entanto, o que caracterizou a política das centrais para os desempregados foi a adesão (parcial por parte da CUT, aberta por parte da FS) ao discurso de empregabilidade. A partir desse ideário, ambas as entidades passaram a investir em cursos de requalificação profissional e políticas de intermediação do emprego da força de trabalho. Essa estratégia foi o resultado e um dos principais pontos de partida do fortalecimento do propositivismo e do sindicalismo de serviços praticado por essas centrais. Por fim, as duas entidades passaram a investir crescentemente na organização dos desempregados para a atividade econômica através do cooperativismo. Nesse campo, houve diferenças substanciais entre as centrais. Enquanto a FS investiu mais em micro-empreendimentos e cooperativas de consumo, a CUT acrescentou a esse tipo de experiência, cooperativas de auto-gestão a partir da recuperação de empresas falidas. A FS justificou essa prática com base no argumento da busca de alternativas de emprego e renda. A CUT aderiu à perspectiva de economia solidária, justificando essa prática como uma forma de resgate do movimento socialista.

A ausência de organização política dos desempregados no Brasil não pode ser explicada apenas pela inexistência de relação desse segmento com o movimento sindical, que tal como sustentei, pode se expressar como unidade ou fratura, com aliança ou isolamento entre suas organizações. Minha pesquisa não permite concluir que os desempregados estiveram ao longo do período reunidos em algum lugar esperando que os sindicatos os organizassem. Somente uma ampla enquete com este segmento poderia contribuir para a análise de seu potencial mobilizativo e de suas diferentes formas de inserção organizacional, considerando sua heterogeneidade expressa nas diferentes parcelas e camadas que os compõem. Verifiquei, no entanto, que no tocante à política sindical, no período estudado as centrais não 
desempenharam um papel ativo nesse sentido, o que, no caso cutista, contrariou seus próprios princípios de central classista, tal como a entidade se auto-define. As políticas assistencialistas para os desempregados efetuadas pelas centrais podem ser consideradas uma forma de representação de seus interesses. Valeria investigar se esta teve um efeito desmobilizador, ou se ao contrário, cumpriu algum papel de formação política. Uma pesquisa com esse recorte revelaria também a efetiva disposição para a luta desse segmento. Como minha tese não trata dos desempregados, mas das ações e representações sindicais feitas em relação a este segmento, esta questão fica aberta. Porém, penso ser possível elaborar algumas hipóteses. Por que os desempregados não se constituíram como sujeitos da rebelião ao longo do período estudado? Nos anos 1980, a mobilização dos desempregados em São Paulo foi possível porque se deu nos bairros, por meio da mobilização popular, como classe trabalhadora organizada territorialmente em torno de reivindicações por melhores condições de vida. $\mathrm{Na}$ explicação dos dirigentes entrevistados, o apoio das CEBs, as experiências prévias de luta sindical e a tradição de organização de base foram os elementos fundamentais para a constituição desse movimento. Nos anos 90, em Campinas, a construção do MCD se deu a partir da organização prévia de militância partidária e sindical, com relativo apoio do Sindicato dos Metalúrgicos da região. Nos anos 2000, o MTD foi criado a partir de um vínculo direto com o MST. Durante o período estudado, essa foi a maior responsável pela organização da reserva no Brasil, recrutando não só a superpopulação relativa latente representada pelos camponeses, mas também desempregados urbanos pobres.

O processo de construção de unidade e fratura entre o sindicalismo e os desempregados no Brasil é expressão da tradição de luta do movimento operário do país e, ainda que não seja o fator único, compõe o quadro explicativo da ausência de organização desse segmento. Em um contexto de crescimento do desemprego, os trabalhadores sem emprego não possuíam experiências de luta prévias quando ativo que lhes permitissem se mobilizar de maneira massiva e em âmbito nacional. Ou ainda, mesmo possuindo esses pré-requisitos, não concretizaram um movimento "de desempregados", mobilizados como tal. Ao serem recrutados pelo MST (e parcialmente pelos movimentos de moradia), construíram suas reivindicações como sem-terra (ou sem-teto) e canalizaram seus objetivos no acesso à pequena propriedade rural como fonte de trabalho. A partir dessa experiência é que surge o MTD, que está longe de construir o peso político que o movimento de desempregados teve na Argentina. 


\section{CAPÍTULO 4 - SINDICALISMO E DESEMPREGADOS NA ARGENTINA: AS AÇÕES E REPRESENTAÇÕES DA CGT E DA CTA}

O presente capítulo tem o objetivo de realizar uma análise sobre a relação entre o movimento sindical e os desempregados na Argentina. Levarei em conta as duas centrais atuantes no país: a Confederación General del Trabajo (CGT) e a Central de los Trabajadores de la Argentina (CTA). No caso da CGT, avaliarei ainda as posições de correntes internas e setores dissidentes. Tomarei como base de minhas reflexões as mesmas questões sobre o caso brasileiro trabalhadas no capítulo anterior, enfatizando as ações e representações das entidades diante dos desempregados e das organizações criadas por estes entre o final da década de 90 e o início dos anos 2000. ${ }^{383}$ Pautei-me, a princípio, no mesmo intervalo estudado no Brasil, mas para construir a análise com base nos documentos, decidi me concentrar no período entre 1995 e 2002, pois este resultou suficiente para compreender a eclosão do movimento de desempregados no país, assim como a relação das centrais sindicais com esse segmento.

Para realizar a pesquisa, visitei a sede das duas centrais, em Buenos Aires, com o intuito de fazer um levantamento de documentos de fonte primária como jornais, revistas, boletins e resoluções de congressos. No caso da CTA, foi possível ter acesso a todo o material disponível no arquivo da Biblioteca do Centro de Documentação da central. Ademais, alguns documentos puderam ser consultados em seu sítio. ${ }^{384}$ No caso da CGT, no entanto, o funcionário responsável pelo arquivo (Instituto Jauretche) informou que a entidade não teve nenhuma publicação regular durante os anos pesquisados. Também relatou que todos os documentos oficiais do período "tinham-se perdido", não sendo possível consultá-los no local. ${ }^{385}$ Afirmou ainda que a CGT não realiza plenárias e congressos, sendo que sua instância máxima de deliberação, a assembléia de delegados, tem apenas a função de escolher o

\footnotetext{
${ }^{383}$ Versões preliminares de partes deste capítulo foram publicadas em artigos e comunicações (Souza, 2007, 2009a). Em 2009, a pesquisa de campo foi inserida no projeto integrado Articulación y conflicto entre el movimiento obrero organizado sindical y políticamente y los desocupados, sob a coordenação do professor Nicolás Iñigo Carrera. A publicação de seus resultados se encontra no prelo. Contribuí, nesse projeto, com um estudo sobre as ações e representações das centrais sindicais argentinas diante do desemprego e dos desempregados, e outro, em parceria com Fabián Fernández, sobre as representações dos quadros de dirigentes sindicais e de desempregados diante dessa mesma temática.

${ }^{384}$ wWw.cta.org.ar.

${ }^{385} \mathrm{O}$ sítio da central não disponibiliza documentos para consulta (www.cgtra.org.ar).
} 
presidente. Ainda assim, tive acesso a alguns relatórios elaborados pela central a partir de 2000.

Para superar essa dificuldade e construir parâmetros comparativos relativamente equivalentes, decidi realizar a pesquisa com base em fontes jornalísticas, a partir das quais pude consultar dois tipos de documento que expressam o posicionamento oficial das centrais: as notas assinadas pelas entidades e as declarações dos dirigentes. ${ }^{386}$ A consulta foi feita nos jornais de abrangência nacional com maior circulação no país: Clarín, La Nación e Página/12, entre outros, de acordo com a disponibilidade dos acervos consultados. Esse procedimento foi possível pela própria característica do sindicalismo argentino, que por seu poder e legitimidade social, possui um espaço mais considerável na imprensa escrita do que no Brasil. Na Argentina, as questões sindicais mais importantes são noticiadas pelos jornais e os principais dirigentes são conhecidos publicamente.

Para cumprir essa etapa, visitei o Archivo del Sindicalismo Argentino Santiago Senén González (Asassg), da Universidad Torcuato di Tella ${ }^{387}$ para os anos de 1990 a 1999. O período de 2000 a 2002 foi consultado no arquivo do Programa de Investigación sobre el Movimiento de la Sociedad Argentina (Pimsa). Durante a consulta, foi feita a transcrição das declarações e trechos selecionados das notas das entidades, a partir da qual elaborei um relatório de aproximadamente 200 laudas.

Para aprofundar a análise das representações dos quadros de dirigentes sindicais e das organizações de desempregados, realizei entrevistas semiestruturadas, aplicadas na região metropolitana de Buenos Aires, em 2007 e 2009. No total, entrevistei 24 militantes, sendo 16 dirigentes sindicais e oito representantes das organizações de desempregados. As entrevistas foram realizadas individualmente e tiveram a duração média de uma hora. O procedimento de análise adotado foi o mesmo do caso brasileiro. Após a transcrição e tradução das entrevistas, realizei a tabulação das falas dos dirigentes com base nas questões levantadas.

Entre os sindicalistas, entrevistei: cinco membros da direção executiva das centrais sindicais (um da CGT e quatro da CTA), oito dirigentes de sindicatos nacionais (seis da CGT

\footnotetext{
${ }^{386}$ Salvo para informações pontuais, não utilizei os textos dos jornalistas para a análise, pois este trabalho não pretende interpretar o discurso da chamada grande imprensa sobre o sindicalismo. Reconheço que a seleção e edição das falas implica uma tomada de posição dos jornais, e por isso desconsiderei as declarações descontextualizadas ou desprovidas de conteúdo analítico.

${ }^{387}$ O arquivo, composto por recortes dos principais jornais do país doados pelo jornalista sindical Santiago Senén González, possui um rico acervo sobre a história do sindicalismo argentino correspondente ao período de 1957 a 2000 (http://www.utdt.edu). As fontes incompletas serão indicadas com a referência Assasg, s/r.
} 
e dois da CTA), além de três militantes de base de correntes internas opositoras à condução nacional de sindicatos cegetistas. O principal critério para a escolha dos sindicatos foi o de contemplar, ao máximo, setores afetados pelas demissões em massa e pelo desemprego no período estudado (metalúrgico, bancário, construção civil, têxtil, comerciário, telefônico e funcionalismo público). Os sindicatos contemplados pela pesquisa foram os seguintes: Asociación Obrera Textil (AOT), Asociación Bancaria (AB), Sindicato de Empleados de Comercio de Buenos Aires (SEC), Federación Argentina de Empleados de Comercio y Servicios (Faecys), Unión Obrera Metalúrgica (UOM), Unión de Empleados de la Justicia de la Nación (UEJN), Unión Obrera de la Construcción de la República Argentina (Uocra) e Federación Argentina Sindical del Petróleo y Gas Privado (Faspygp), filiados à CGT; Federación de Obreros y Empleados Telefónicos de la República Argentina (Foetra) e Asociación de Trabajadores del Estado (ATE), filiados à CTA.

As organizações de trabalhadores desempregados escolhidas foram: o Movimiento de Trabajadores Desocupados de San Francisco Solano (MTD-Solano), o Polo Obrero (PO), o Movimiento Territorial de Liberación (MTL), o Movimiento Independiente de Jubilados y Desocupados (MIJD), a Corriente Clasista y Combativa (CCC), o Barrios de Pie (BP), a Federación de Tierra y Vivienda (FTV) e o Movimiento de Trabajadores Desocupados de La Matanza (MTD-La Matanza). A escolha dessas organizações foi pautada nos seguintes critérios: (a) as maiores organizações em número de participantes e extensão territorial (FTV e CCC); (b) algumas que tivessem, ou tenham tido, um vínculo institucional com as centrais sindicais ou atuação no movimento sindical (PO, MTL, CCC, BP e FTV); (c) algumas que se autodenominam como independentes em relação a partidos e sindicatos (MIJD e os MTDs); (d) a maior diversidade possível de correntes ideológicas, especialmente entre as que possuem filiação partidária (nesse sentido, busquei contemplar diferentes correntes peronistas e socialistas). ${ }^{388}$

Para realizar a análise, dividi este capítulo em quatro itens: 4.1) No primeiro, farei referência às principais transformações no capitalismo argentino e à atuação do movimento sindical durante o período estudado. 4.2) No segundo, realizarei um exercício de periodização da ação sindical diante dos desempregados, circunstrito ao recorte escolhido. 4.3) A terceira parte trará um aprofundamento das questões trabalhadas no item precedente e foi construída com base nas representações dos quadros de dirigentes sindicais e das organizações de

\footnotetext{
${ }^{388}$ Para um resumo das principais características dessas organizações, ver Quadro I nos Anexos.
} 
desempregados. 4.4) A quarta será dedicada a compreender a relação entre o sindicalismo e a eclosão do movimento de desempregados no país.

\subsection{O sindicalismo argentino de 1990 a 2002}

O processo de constituição da hegemonia do capital financeiro na Argentina se iniciou na ditadura militar vivida no país de 1976 a 1983. Esse período foi marcado pela ofensiva da burguesia e das classes dominantes contra a resistência dos trabalhadores. A repressão ao movimento operário provocou o desaparecimento de uma geração de militantes sindicais, especialmente de delegados de base, de acordo com os dados já apresentados no segundo capítulo. A orientação neoliberal no país se sustentou relativamente nos anos posteriores, no governo de Raúl Alfonsín (1983-1989), mas chegou a seu auge nas duas presidências de Carlos Saúl Menem (1989-1995; 1995-1999) e no governo de Fernando De la Rúa (19992001). Durante esse período, além de uma reestruturação técnica das empresas de capital concentrado instaladas no país, o país viveu o aprofundamento das políticas neoliberais.

As transformações ocorridas no capitalismo argentino verificadas nesse quartel de século alteraram profundamente a composição de sua classe trabalhadora. A mudança mais notável nesse sentido foi o expressivo crescimento de sua superpopulação relativa (Carrera, 2006). O país, que ao longo do século XX havia passado por um intenso processo de assalariamento formal, a partir da década de 1990 passou a conviver com altos índices de desemprego e subemprego (Ver Tabela 16).

Com base em sua ligação histórica com o Partido Justicialista (PJ), a CGT defendeu a candidatura de Menem, cuja principal proposta era levar a cabo uma "revolução produtiva" no país. Logo nos primeiros meses do governo menemista, a central sofreu uma divisão interna, motivada pela divergência diante da reforma trabalhista anunciada pelo presidente. De um lado, ficou a CGT-Azopardo, liderada por Saul Ubaldini ${ }^{389}$, que havia adotado uma posição crítica a tal medida e, de maneira geral, à política de Menem e de seu ministro da economia, Domingo Felipe Cavallo. Do outro lado, ficou a CGT-San Martín, que apoiava as medidas governamentais, apesar da participação restrita, em relação à que almejava, no alto escalão tanto do executivo quanto do legislativo.

\footnotetext{
${ }^{389}$ Ubaldini foi presidente da CGT de 1980 a 1989 e da CGT-Azopardo, de 1989 a 1992. Durante o governo de Alfonsín, liderou as conhecidas 13 greves gerais.
} 
Em 1991, parte do grupo que conformava a CGT-Azopardo, composto fundamentalmente por dois grandes sindicatos do funcionalismo público, a Confederación de Trabajadores de la Educación de la República Argentina (Ctera) e a Asociación de Trabajadores del Estado (ATE), realizou um encontro de dirigentes sindicais em 1991 que daria origem, em 1992, ao Congreso de los Trabajadores Argentinos (CTA). O CTA surgiu com uma proposta de sindicalismo alternativo ao praticado pela CGT. Sua concepção de prática sindical se baseia nas noções de "autonomia sindical com relação ao Estado, aos patrões e aos partidos políticos"; "abertura a outras organizações sociais que expressam as múltiplas demandas dos setores populares"; "democracia sindical" em oposição ao "sectarismo" e "revalorização da ética sindical” frente "à corrupção e ao pseudo-pragmatismo com o qual as direções caducas terminam legitimando o arrocho". (CTA, 1991). ${ }^{390}$ A entidade também se fundamenta na idéia de "unidade dos trabalhadores" e de constituição de um "movimento político e social" que e torne uma "referência nacional para uma estratégia de poder nacional". Defende ainda "outro modelo de país" e uma revisão da "forma tradicional de organização sindical" e das "tradições de luta do movimento operário argentino". Por último, argumenta sobre a necessidade de se construir "novas formas e métodos de organização e de luta". Sobre esse tema, afirmava que pretendia investir em "formas organizativas territoriais", tomando essa estratégia como um "desafio patriótico". (CTA, 1992a).

A CTA não rompe com a ideologia peronista, o que pode ser atestado pela defesa que faz de uma política de aliança de classe com a burguesia do país. Nesse sentido, a central ressalta o método de "definir uma estratégia com os setores do empresariado nacional" com o objetivo de estabelecer "linhas de trabalho em comum que permitam afrontar as atuais políticas de abertura global sobre nossas economias" (CTA, 1992a). ${ }^{391}$ Em outro documento, o CTA defende a participação democrática da classe trabalhadora no Estado tal como havia sido concretizado no governo de Perón: “(...) [é necessário] concretizar novas formas de construção política e social, capazes de reinstalar o poder dos trabalhadores e do povo no cenário nacional". (CTA, 1991, grifo meu).

\footnotetext{
${ }^{390}$ Todas as traduções de entrevistas, documentos e textos cujas referências estão em espanhol são minhas.

${ }^{391}$ A respeito especificamente do Mercosul, o CTA afirma sobre a necessidade de se "evitar os efeitos negativos que uma pseudo integração (...) pode ter sobre pequenos e médios empresários, as economias regionais e os trabalhadores".
} 
O CTA surgiu a partir de uma leitura crítica do neoliberalismo, especialmente das privatizações, do plano de convertibilidade, da abertura às importações e da redução dos direitos sociais e trabalhistas. Opôs-se a todos os projetos do governo que afetavam os trabalhadores: a Lei de Emprego, que permitiu a formulação de contratos flexíveis; a reforma da lei de acidentes; o estabelecimento de um topo para as indenizações por demissão, o projeto de escalonamento do $13^{\circ}$ salário; a reforma do sistema previdenciário sustentada pela eliminação das contribuições patronais e pela abertura para companhias de seguros privados. (CTA, 1992b).

Uma especificidade do CTA foi a introdução da "afiliação direta" de seus membros, que abriu a possibilidade de representação não apenas dos "trabalhadores ativos", mas também dos "trabalhadores sem emprego", dos "trabalhadores beneficiários de alguma das prestações do regime previdenciário público ou privado, nacional, provincial ou municipal" e dos "trabalhadores autônomos e por conta própria desde que não tenham trabalhadores sob sua dependência" (CTA, 1996b).

As entidades opositoras que decidiram não participar da fundação da CTA voltaram para a CGT em 1992. Após um curto período de dois anos, em 1994 esta última sofreu uma segunda divisão, provocada pelo posicionamento diante da flexibilização trabalhista e pelo aumento do desemprego. De um lado, ficou a ala majoritária da central, cuja posição governista se tornou evidente no apoio à reeleição de Menem, em 1995. Do outro, foi criado o Movimiento de los Trabajadores Argentinos (MTA), que apesar de não ter se separado organicamente da entidade, construiu uma oposição interna a partir das críticas às principais medidas governamentais encabeçadas por Cavallo, que segundo a corrente era o responsável pela recessão e pelas demissões em massa. Em 1996, o CTA aprovou seu estatuto e conformou a Central de los Trabajadores Argentinos. ${ }^{392}$ Durante a década de 1990, a CTA e o MTA se caracterizaram pelo combate às políticas neoliberais que vinham sendo implantadas no país, protagonizando importantes mobilizações de oposição ao governo menemista.

Como explica Fernández (2002, p. 11), diferenças internas sempre estiveram presentes no interior da CGT. Tal como já foi apresentado no segundo capítulo, segundo este autor, é possível estabelecer uma "matriz compreensiva das divisões do movimento operário argentino, desenvolvidas desde 1960-1970”, que podem ser resumidas nas tendências

\footnotetext{
392 Em 2009, a central muda seu nome para Central de Trabajadores de la Argentina a fim de contemplar os trabalhadores imigrantes do país, composto especialmente por bolivianos, paraguaios e chilenos.
} 
participacionista, propositiva (ou "negociador", segundo o termo original), confrontacionista e combativa (ou classista). No entanto, como observa Fernández, se anteriormente esses agrupamentos pertenciam a uma mesma filiação sindical, a partir de 1989 verifica-se um processo de fraturamento que culminará em algo inédito na história da CGT, com o surgimento de uma central opositora. Ao interpretar a conjuntura a partir do referencial analítico citado, o autor mapeia as seguintes tendências: como expressão do alinhamento "participacionista-negociador", estaria a ala majoritária da CGT; na linha "confrontacionista" se inseriria a CTA e o MTA, enquanto o setor "combativo" se reservaria à CCC. ${ }^{393}$

A relação dos sindicatos com o governo de Menem, especialmente no seu primeiro mandato, marcou um ponto de inflexão na história do sindicalismo argentino, com o processo de rupturas e dissidências internas pelo qual sofreu a CGT. De acordo com diversos analistas, a política hegemônica do setor majoritário dessa central diante das chamadas reformas de mercado foi de "adaptação", o que atestaria a hipótese de que, nesse momento, tinha mais peso sua aliança histórica com o peronismo e o PJ do que a oposição a políticas essencialmente contrárias aos interesses dos trabalhadores (Bosoer e González, 1999; Fernández, 1997; Murillo, 1997). No entanto, como veremos, durante o período menemista, apesar da aliança da CGT com o governo e do apoio aos aspectos centrais de sua plataforma neoliberal, a entidade protagonizou ações de protesto, especialmente quando após a reeleição do presidente, seguiu sem participação nos cargos nomeados pelo executivo. Ademais, a pressão interna fez com que a CGT se mobilizasse diante das principais propostas do governo de desregulamentar as obras sociales (o sistema de saúde administrado pelos sindicatos), além de assumir, em diversos momentos, uma postura oficialmente crítica a aspectos da flexibilização trabalhista. Nesse contexto, a central declarou uma greve geral em 1995 e duas em 1996, que somadas às que haviam sido convocadas apenas pela CTA e pelo MTA, totalizaram nove eventos desse tipo no governo de Menem. Esses acontecimentos minimizam a retórica bastante comum na bibliografia de que a CGT não se mobiliza quando o PJ está no governo e, conseqüentemente, não se mobilizou no período menemista (Carrera, 2001).

Em 1998, a CGT e o MTA se reunificaram para apoiar o candidato justicialista Eduardo Duhalde para a presidência. Com a vitória da Alianza Unión Cívica Radical/Frente País

\footnotetext{
${ }^{393}$ A CCC é uma organização político-sindical vinculada ao Partido Comunista Revolucionario (PCR) que, desde 1994, atua como uma corrente minoritária do sindicalismo argentino na condução de algumas entidades e na oposição interna a sindicatos cegetistas. Seu principal líder é Carlos Santillán, do funcionalismo público municipal de Jujuy. A partir de 1998, sob a liderança de Juan Carlos Alderete, a CCC passour a atuar também como uma organização de desempregados.
} 
Solidario (UCR/Frepaso), em 1999, o presidente eleito Fernando de La Rúa iniciou uma ofensiva para aprovar a lei de flexibilização do trabalho. A CGT sofre uma nova divisão e, em março de 2000, conformou-se a CGT-Daer e a CGT-Moyano. Esta última, encabeçada pelo dirigente caminhoneiro Hugo Moyano, do MTA, foi formada por sindicatos que se opunham à reforma trabalhista que estava sendo tramitada na Câmara de Deputados com o apoio da direção oficial da CGT exercida por Rodolfo Daer. Em aproximadamente dois anos, as três centrais do país convocaram oito greves gerais contra o governo de De la Rúa. ${ }^{394}$

Carrera e Donaire (2002) analisam a "fisionomia" das centrais sindicais argentinas e sua "relação com as distintas frações e camadas sociais que constituem a classe operária" (p. 137), vinculando o "interesse imediato" expresso nessas organizações com a "menor ou maior combatividade de seu discurso e de suas ações" (p. 192). Os autores propõem a seguinte classificação: (i) a CGT-Daer “(...) se caracteriza centralmente por agrupar os principais sindicatos dos ramos de atividade econômica onde se encontram os capitais mais concentrados e a maioria das empresas privatizadas (...)" (p. 150), tais como exploração de petróleo e gás, eletricidade, água, telefonia, transporte ferroviário, construção, bancos e comércio; (ii) a CGT-Moyano não exclui a presença de grandes capitais, mas "em geral estes não alcançam o grau de concentração dos capitais presentes nos ramos onde se encontram os sindicatos da CGT-Daer", pois agrupa, principalmente, "assalariados da atividade produtiva (particularmente transporte), onde tem presença de capital menos concentrado e local” (p. 151); (iii) e por último, a CTA, que representa principalmente a pequena burguesia assalariada em processo de proletarização e pauperização (como docentes e profissionais da saúde, entre outros) e uma parcela da população sobrante, como é o caso de parte dos empregados estatais. Essa fração conflui na CTA com outras camadas pobres que constituem a superpopulação para as necessidades do capital, organizados na FTV e, até o ano de 2000, no Barrios de Pie.

A caracterização jornalística das três centrais classifica a CGT-Daer como "dialoguista" ou "oficialista", a CGT-Moyano como "rebelde" e a CTA como "contestatória". No entanto, Carrera e Donaire (2002) observam que, durante a década de 1990 e início da de 2000, enquanto a CGT-Daer negociou com todos os governos sem descartar a confrontação, a CGT-

\footnotetext{
${ }^{394}$ Na CGT, o período pesquisado abarca as gestões de: Saúl Ubaldini na CGT-Azopardo e Guerino Andreoni na CGT San Martín (1989-1992); uma Comissão Diretiva composta por Oscar Lescano, José Rodríguez, José Pedraza, Aníbal Martínez e Ramón Baldassini (1992-1993); Naldo Brunelli (1993-1994); Antonio Cassia (19941995); Gerardo Martínez (1995-1996); Rodolfo Daer (1996-2000); Rodolfo Daer na CGT oficial e Hugo Moyano na CGT dissidente (2000-2002). Na CTA, corresponde à presidência de Víctor De Gennaro (19912006).
} 
Moyano e a CTA apresentaram um discurso de confronto, mas não deixaram de negociar. Segundo os autores, a CGT-Daer apresentou uma política de diálogo explicitamente nãoclassista, esteve de acordo com o "pacto social" entre o empresariado e os sindicatos com mediação do governo, na qual os primeiros devem se tornar responsáveis pelos "deveres sociais derivados da empresa". Também defendeu uma melhor qualidade de vida dos representados por meio de um "Estado ativo" que garantisse eqüidade, "justa distribuição da riqueza" e "controle dos preços", além da "expansão da atividade econômica e da ocupação". Ademais, defendeu um projeto desenvolvimentista-industrializador que privilegiasse a produção e onerasse o capital especulativo pela crise. A CGT-Moyano não apresentou um discurso muito distinto, pois também sustentou a necessidade de uma "grande concertação nacional" e de um "caminho alternativo de desenvolvimento com justiça social" pela “independência nacional contra a ditadura financeira". Por último, a CTA, apesar de ter dado maior ênfase à luta contra o desemprego e a pobreza como meta de "justiça social" e "recuperação econômica", também defendeu a concertação como alternativa para a construção de um projeto de sociedade sob outro modelo para a Argentina. ${ }^{395}$

Entre 1989 e 2001, durante os governos de Menem e de De la Rúa, as centrais sindicais argentinas convocaram 19 greves gerais. Além desses protestos, vale mencionar, a partir de um registro sistemático feito pelo Pimsa, que entre 1993 e 2001 os assalariados foram os principais sujeitos convocadores, e no interior destes os empregados foram os que mais ações convocaram, sendo as organizações sindicais em suas diversas instâncias (centrais, sindicatos e comissões internas) as principais protagonistas (Carrera e Cotarelo, 2004). Ademais, as greves foram o segundo instrumento de luta mais utilizado depois das manifestações (marchas, passeatas, atos, etc.) e, considerando o instrumento bloqueios de ruas e avenidas, "vulgarmente atribuídos aos desempregados", o movimento sindical ocupou um lugar proeminente como segundo maior convocador seguido das organizações de pequenos proprietários e de outros segmentos da pequena burguesia, entre 1993 e 1999, e das organizações de desempregados, entre 2000 e 2001 (Carrera e Donaire, 2002). Esses dados confirmam a centralidade do movimento operário na Argentina atual.

\footnotetext{
${ }^{395}$ Em resumo, apesar da atitude mais confrontativa, pode-se afirmar que a CGT-Moyano e a CTA não recusaram a concertação. Sobre esta última, por exemplo, os autores fundamentam: "O eixo de seu discurso está na construção de outro modelo, que acabe 'com a imoralidade desse projeto dos setores financeiros e econômicos mais concentrados', mediante uma divisão da riqueza, tendo como medida principal um 'salário social', um subsídio de emprego e formação" (Carrera e Donaire, 2002, p. 155).
} 
O ciclo de lutas de 1993 a 2001 se iniciou com o motim realizado em Santiago del Estero, em 1993, e se estendeu até a insurreição espontânea que, em dezembro de 2001, levou à queda de De la Rúa (Carrera e Cotarelo, 2004). ${ }^{396}$ Entre os principais marcos desse período, destacam-se os cortes de ruta ${ }^{397}$ ocorridos em Cutral-Có e Plaza Huincul, na província de Neuquén, em 1996, e General Mosconi e Tartagal, em Salta ${ }^{398}$, no ano de 1997. 399

Segundo Pereyra e Svampa (2003), esses eventos demarcaram os dois "afluentes" do movimento de desempregados no país. O primeiro deles teria se dado em torno das puebladas $^{400}$ ocorridas no interior, resultado de uma "nova" experiência social comunitária vinculada ao colapso das economias regionais e à privatização acelerada das empresas estatais nos anos 1990. O segundo se baseia em uma ação territorial e organizativa originada no conurbano bonaerense $e^{401}$, e ligado às lentas e profundas transformações do "mundo popular", produto de um processo de industrialização e empobrecimento crescente da sociedade argentina a partir do final dos anos 70. Para Klachko (2007), esses foram os antecedentes do surgimento do movimento de desempregados que, segundo essa autora, só pode ser considerado como tal entre fins da década de 1990 e início da de 2000, quando os protestos chegaram a Buenos Aires e, a partir daí, adquiriram dimensão nacional e massiva com a difusão de seu principal instrumento de luta: o piquete. ${ }^{402}$ Esses argumentos se encontram na linha oposta às análises que consideram os desempregados como "novos atores" e suas organizações como "novos movimentos sociais" que teriam atestado o fim do protagonismo do movimento operário na Argentina (Korol, 2003; Seoane, 2002; Pereyra e Svampa, 2003; Zibechi, 2003). Esses autores, e muitos outros, destacam que as organizações de

\footnotetext{
${ }^{396}$ Ao estudar este ciclo de lutas, os autores verificam um primeiro momento ascendente de dezembro de 1993 a agosto de 1997; um momento descendente até 1999; e um segundo momento ascendente de 2000 a 2001.

${ }^{397}$ Traduzo cortes de ruta e cortes de calle como bloqueios de rodovias e bloqueios de ruas ou avenidas.

${ }^{398}$ Para a localização dessas e das demais províncias argentinas citadas ao longo do trabalho, ver o mapa do país nos Anexos.

${ }^{399}$ Essas cidades tinham sua economia baseada no ramo petrolífero, monopolizado pela Yacimientos Petrolíferos Fiscales (YPF), principal empresa estatal do país, privatizada em 1993, ainda na primeira gestão de Menem. Após a privatização, nos anos seguintes houve demissões e planos de demissão voluntária. Com o desemprego crescente na região, os trabalhadores começaram a se organizar por meio de bloqueios de rodovias.

${ }^{400}$ Levante popular semelhante ao que a literatura clássica denomina de motim.

${ }^{401} \mathrm{O}$ conurbano bonaerense é composto pelas cidades da região metropolitana de Buenos Aires, excluindo a capital federal.

${ }^{402}$ A maior justificativa para o piquete é de que os trabalhadores desempregados, sem a possibilidade de parar a produção das mercadorias nas empresas, como ocorre com a luta sindical, paralisam sua circulação nas avenidas e rodovias. A expansão desse instrumento de luta entre as organizações levou muitos analistas a chamar o movimento de desempregados no país de movimento piqueteiro. Não considero adequada tal denominação. Por razões que serão explicadas mais adiante, chamarei os agrupamentos de organizações político-sindicais de desempregados.
} 
desempregados só puderam se constituir porque seus representantes decidiram atuar por fora e em oposição à estrutura sindical tradicional, majoritariamente vinculada ao PJ. Tais interpretações, sem o apoio em uma base de dados que demonstrem o desaparecimento das ações tipicamente sindicais, não levam em conta que foi somente no ano de 2002 que os protestos de desempregados superaram os dos empregados (Carrera e Cotarelo, 2004) (Ver Tabela 17).

Ademais, esses autores, partindo do fato de que os movimentos tenham surgido por fora do aparelho sindical, desconsideram o papel de setores do sindicalismo para a sua expansão e as experiências prévias de lutas sindicais do núcleo fundador presente em diversas organizações. Ademais, como será demonstrado no decorrer do capítulo, cumpriu um papel fundamental a tradição sindical do país, que funcionou como uma "ideologia inerente" (Rudé, 1982) adaptada pelos desempregados como uma continuidade das formas e instrumentos de luta do movimento operário.

Com a diminuição das mobilizações de desempregados e o aumento dos protestos sindicais, a partir de 2005, uma autora citada afirma: "estamos diante do início de um novo ciclo de ação sindical" (Svampa, 2006, p. 6). No entanto, como se pode interpretar a partir dos dados, o sindicalismo jamais deixou desempenhando um papel central no conjunto dos protestos sociais na Argentina. Verificarei ao longo deste capítulo qual foi sua importância para a constituição das organizações de desempregados, aparentemente tão alheias ao movimento sindical.

A análise do sindicalismo argentino diante do desemprego e das demissões em massa deve levar em conta, primeiramente, que a CGT concentrava no período estudado os sindicatos dos setores mais afetados pelas demissões em massa realizadas nos anos $1990 .{ }^{403}$ Ademais, a central não organizou os desempregados para a luta. A CTA, por sua vez, investiu na representação desse segmento como parte de sua política sindical. A maior expressão dessa estratégia foi a incorporação da FTV a sua estrutura organizativa, o que foi fundamental para que este movimento adquirisse caráter massivo e nacional. ${ }^{404}$ Que papel desempenhou o

\footnotetext{
${ }^{403}$ Não pude avaliar, de maneira sistemática, a magnitude da resistência sindical às demissões na Argentina. Em sua pesquisa sobre o setor automobilístico, Santella (2007) ressalta que nesse período predominou o caráter "defensivo" da política sindical em torno da questão.

${ }^{404}$ Uma informação importante fornecida por Carrera e Donaire (2002, p. 152) é de que "[...] até meados de 2002, as organizações de desempregados vinculadas à CTA controlavam 45.000 auxílios do Programa Jefas y Jefes de Hogar [Chefas e Chefes de Família] (35\% do total de planos distribuídos através de organizações de desempregados) (...)". Mais adiante explicarei melhor do que se trata este programa.
} 
sindicalismo no surgimento dessas organizações? Como se deu o processo de construção de unidade e fratura entre as centrais sindicais e os diferentes movimentos? Este capítulo busca refletir sobre essas questões.

O peso político que o movimento de desempregados adquiriu no conjunto das lutas sociais da Argentina foi algo inédito na história do país. Há referências na bibliografia de organizações desse tipo na primeira metade dos anos 1930 (Carrera e Fernández, 2007), além de algumas manifestações pontuais anteriores, nos anos 1890. No entanto, o caráter massivo e nacional que alcançou entre o final da década de 1990 e início dos anos 2000 não teve precedentes. No momento em que escrevem, Pereyra e Svampa (2003) informam a existência de mais de 70 organizações de desempregados em todo o país, que aglutinavam, no total, mais de 500.000 trabalhadores $^{405}$. Segundo esses autores, em seu interior, bastante heterogêneo, encontram-se os que possuem alinhamento sindical, os filiados a tendências políticopartidárias e os que se denominam autônomos, por defender a independência política de partidos e sindicatos. ${ }^{406}$

A principal reivindicação do movimento de desempregados desde sua constituição se deu em torno dos programas de emergência ocupacional lançados pelos governos a partir da segunda metade da década de 1990. Esses planos, voltados para os trabalhadores desempregados, tais como o Trabajar I, II e III (do governo nacional) e o Barrios Bonaerenses (da província de Buenos Aires), assim como o mais conhecido, Jefas y Jefes de Hogar, contemplavam a entrega de subsídios monetários com contraprestação na forma de trabalho. ${ }^{407}$ Segundo Pereyra e Svampa (2003), enquanto o governo de Menem utilizou a rede clientelista do PJ para distribuir os auxílios, a gestão de De la Rúa, para afastar o punterismo $^{408}$ político do partido opositor, favoreceu a consolidação das organizações piqueteras como gestoras diretas dos mesmos. Para estes autores, este foi o principal motor do

\footnotetext{
405 Apesar de desatualizado, o dado é significativo para se ter idéia do peso que o movimento adquiriu.

${ }^{406}$ É importante destacar que apesar dessa separação entre o alinhamento sindical e político-partidário, algumas organizações atuam tanto em partidos quanto em sindicatos, como é o caso da CCC e do PO.

${ }^{407}$ Estes planos atualmente se encontram reduzidos, além de terem aparecido outros programas, tais como o Manos a la obra, e financiamentos de microcrédito. Sobre o tema, ver Enríquez (2007).

408 O punterismo político é a forma mais comum de designar a prática clientelista dos partidos políticos na Argentina. Os militantes são chamados de punteros e atuam nos bairros populares por meio da concessão de benefícios à população em troca de apoio político a um dirigente ao qual estejam ligados.
} 
movimento, que reivindicava, com piquetes, a extensão do benefício e o aumento de seu valor de 150 pesos. $^{409}$

O movimento de desempregados atingiu o auge de suas atividades a partir de 2001, tendo contribuído de maneira decisiva para o acúmulo de experiências do ciclo de lutas que resultou na queda de De La Rúa. Korol (2003) afirma que a "rebelião" de 19 e 20 de dezembro de 2001 resultou da organização prévia das "puebladas" realizadas no interior do país, estando intimamente ligada à luta dos "piqueteros". Zibechi (2003) argumenta que o Argentinazo, como ficou conhecido o evento, só foi possível porque se constituiu como uma crise de representatividade e não apenas uma crise de representantes, através do lema que se vayan todos ("que todos se mandem"), dirigido aos políticos do país. Para o autor, o protesto levou a um profundo debate no interior da esquerda sobre o papel dos sindicatos e dos partidos políticos. Apesar de reconhecer a relativa importância das instituições, Zibechi afirma que "foi preciso algo mais". Argumenta também que quando foi decretado estado de sítio, as centrais sindicais e os partidos de esquerda "fizeram somente o que sabem fazer": as primeiras convocaram uma greve geral; os últimos, enquanto o povo estava na rua, distribuíam folhetos e faziam propaganda política. Ademais, sustenta que, se os eventos de 19 e 20 de dezembro tivessem ficado por conta das organizações estabelecidas, o máximo que iriam fazer era redigir uma moção de repúdio dirigida aos governantes.

Cumpre destacar que esses autores valorizam as experiências "autônomas" das organizações de desempregados em relação a partidos políticos e sindicatos. Korol (2003), por exemplo, afirma que a diferença desses agrupamentos minoritários está na forma de administração dos planos sociais, baseada na organização coletiva da produção, em que se forja uma "nova consciência social", e um autêntico "poder popular democrático e horizontal”. Esses autores seguem as interpretações de autores como Holloway (2002) e Negri (2001). Críticos do que consideram ser o marxismo-leninismo, sustentam que as organizações piqueteras são um exemplo de que a estrutura partidária e sindical teria se tornado anacrônica, ou ainda, de que o modelo de ação política dos sindicatos e dos partidos estaria esgotado historicamente, especialmente a partir de 1989, com a queda do muro de Berlim. ${ }^{410}$

\footnotetext{
${ }^{409}$ Essa interpretação, muito comum nas explicações dos dirigentes sindicais, pode ser relacionada ao modelo interpretativo da teoria da ação racional proposto por Olson (1966), segundo o qual o interesse pela obtenção de vantagens materiais comuns cria uma situação latente de protesto que, de acordo com as estratégias individuais, podem desencadear uma mobilização coletiva. Voltarei a este ponto ao longo da análise.

${ }^{410}$ Holloway (2002) afirma que, no atual contexto, as lutas políticas, partidárias e sindicais teriam perdido sua relevância. Segundo este autor, para lutar contra o capitalismo, não faz mais sentido falar em um grande dia 
Uma interpretação alternativa a essa linha pode ser encontrada em Carrera e Cotarelo (2004), segundo os quais a insurreição espontânea de 2001 se insere em um contexto mais amplo da história das formas de luta da classe operária argentina na década de 1990, que tiveram a greve geral como uma das principais estratégias de mobilização. Esses autores afirmam que a organização sindical foi o principal sujeito desse evento, que começou com os atos convocados pelas centrais, como a greve geral de 13 de dezembro, ainda que tenha sido levado a cabo por outros setores do proletariado, tais como os desempregados e frações da pequena burguesia assalariada e não-assalariada.

Feita essa explanação, vale indagar: qual foi a participação de empregados, demitidos e desempregados nos protestos ao longo do período estudado? Como já foi dito, do total de eventos dos assalariados, os empregados foram os que mais ações convocaram. Chama a atenção também que os eventos dos demitidos, que alcança seu auge no período 2001-2002, são minoritários no conjunto dos protestos. Por sua vez, os desempregados constituíram o segundo principal sujeito convocador, com um pico no período de 2000 a 2005, chegando a ser o maior protagonista em 2002 (Ver Tabela 18).

Entre 2000 e 2002, a unidade entre o ativo e a reserva alcançou seu mais alto grau. Para avaliar esse elemento, isolei do conjunto os eventos em que estiveram presentes os desempregados e os demitidos. Assim, foi possível medir seu grau de fratura (quando se mobilizaram por separado) e unidade (quando se mobilizaram com os empregados). Considerando o conjunto dos eventos em que participaram desempregados ou despedidos em conjunto ou não com os empregados, as ações conjuntas de "empregados e desempregados" somam 10.6\% em 2000, 18.4\% em 2001 e 7.9\% em 2002. Nos três anos seguintes, essas cifras reduzem consideravelmente (4.0\% em 2003, 6.4\% em 2004 e 6\% em 2005). Do total de eventos nos quais participaram desempregados ou despedidos em conjunto com os empregados, o índice de participação das ações de "empregados e desempregados" e “empregados e despedidos" alcança 16.8\% em 2000, 23.4\% em 2001 e $17.9 \%$ em 2002. Nos três anos posteriores essas cifras caem para cerca de 4.5\%, 9.1\% e 6\% (Ver Tabela 19). Apesar da idéia comum de que as lutas dos desempregados e dos demitidos são levadas a cabo em relação de fratura, verifiquei que em 2002, no auge dos protestos desses segmentos,

revolucionário. Para ele, é necessária a construção de uma rede alternativa, por meio de "movimentos" que busquem "cambiar el mundo sin tomar el poder" ("mudar o mundo sem tomar o poder"), como o título de seu livro sugere. Por isso, Holloway destaca a importância da construção de mecanismos de produção e consumo que se baseiem em um conceito diferente de trabalho.Uma crítica contundente às posições desse autor pode ser encontrada em Borón (2003). 
quase um quarto dos eventos foram desenvolvidos em conjunto com os empregados (o que remete a suas organizações sindicais, ou seja, as centrais, os sindicatos e as comissões internas).

Se levarmos em consideração a taxa de desemprego na Argentina (ver Tabela 16) no período tratado por este capítulo, observa-se que ao considerar os dois picos de desemprego (1995-1996 e 2001-2002), somente no segundo se produziu uma quantidade importante de ações conjuntas entre o ativo e a reserva. Este fato se deve a diversos fatores que não estiveram presentes na primeira conjuntura: o acúmulo de forças do ciclo de lutas de 19932001, a expansão das organizações de desempregados e a consolidação de setores sindicais que investiram na representação e organização para a luta desse segmento.

Esses anos também concentram a maior parte das greves gerais convocadas desde a posse de Menem até o ano de 2002. Das nove greves gerais convocadas nos dez anos de menemismo, cinco se realizaram entre 95 e 96. Nos três anos seguintes, que contemplam o governo de De la Rúa e o primeiro ano de Duhalde, esse instrumento foi utilizado catorze vezes, dos quais dez se concentram entre 2001 e 2002. Ou seja, entre 1989 e 2002, das vinte e três greves gerais realizadas, quinze foram convocadas durante os anos de maiores índices de desemprego. (Ver Quadro II). Tendo em conta que a partir do segundo pico de desemprego verificou-se a maior quantidade de ações conjuntas entre o ativo e a reserva, verifiquei como se expressou essa unidade nas greves gerais convocadas durante o período analisado.

\subsection{Sindicalismo e desempregados (1995 a 2002)}

Uma das dimensões da unidade e fratura entre o ativo e a reserva é a relação entre o movimento operário organizado sindicalmente e os desempregados. Entre as diferentes maneiras pelas quais esse vínculo se expressa está o posicionamento dos dirigentes sindicais a respeito do desemprego e as propostas das organizações sindicais para os desempregados. Este item pretende descrever as ações e representações construídas pelas cúpulas das principais correntes atuantes no sindicalismo argentino entre 1995 e 2002.

O período escolhido abarca os dois maiores picos de desemprego já vividos no país (1995-1996 e 2001-2002) e compreende o final do primeiro e a totalidade do segundo mandato de Menem, o governo de De la Rúa e o primeiro ano da presidência de Eduardo Duhalde. Nesse contexto, a principal discussão acerca do desemprego girou em torno da 
proposta de reforma trabalhista, centrada especialmente na chamada "flexibilização" do "mercado de trabalho". Para alguns dirigentes, esta seria a solução para o desemprego. Para outros, somente aprofundaria o problema.

Dividi o período em quatro fases, que correspondem às mudanças da conjuntura e das estratégias sindicais. Serão analisadas as posições dos dirigentes a respeito das causas e possíveis soluções para o desemprego, da flexibilização e da política para os desempregados. Também terei em conta como essas questões apareceram nas mobilizações mais importantes do período, especialmente nas greves gerais, definidas aqui como o momento, por excelência, em que o movimento operário protesta em conjunto, ainda que com diferentes graus de unidade.

A primeira fase abarca de janeiro a setembro de 1995, período em que o desemprego alcançou um recorde histórico até então. Nesse momento, ocorreram importantes protestos contra as demissões e se realizaram as eleições presidenciais. Ainda que tenha havido resistências internas, a CGT se caracterizou por seu respaldo ao governo de Menem. Na segunda fase, de setembro de 1995 a dezembro de 1996, o conjunto do movimento operário argentino realizou quatro greves gerais, nas quais o tema do desemprego foi crucial. $\mathrm{Na}$ terceira fase, correspondente ao período de 1997 a 1999, surgiram as primeiras organizações de desempregados. No entanto, nesse intervalo o desemprego caiu e deixou de ocupar centralidade nas preocupações sindicais. Por último, a quarta fase, que compreende os anos de 2000 a 2002, corresponde ao maior pico de desemprego já registrado na história argentina, à convocação de oito das greves gerais, algumas delas com alto grau de unidade dos diferentes setores do movimento sindical, além da explosão dos protestos de desempregados e ao auge das ações conjuntas entre o ativo e a reserva.

A descrição será feita considerando a CTA e a CGT. Também serão levadas em consideração as distintas correntes no interior desta última, representadas pelo Movimiento Obrero con Propuestas (MOP), o setor menemista do sindicalismo que conduziu a central com Antonio Cassia até meados de 1995; e o Movimiento de los Trabajadores Argentinos (MTA)/CGT-Moyano, a corrente mais crítica ao governo de Menem. Diferenciarei esses dois últimos setores da Direção Nacional da CGT. ${ }^{411}$

\footnotetext{
411 O Conselho Diretivo (Consejo Directivo) cumpre a mesma função da Direção Executiva Nacional das centrais brasileiras, com a diferença de que não é escolhido através de eleições abertas, mas pela representatividade das entidades. Por este motivo, os sindicatos com maior "peso" na condução da central, por 
Nos três primeiros itens, o volume de material encontrado referente aos diferentes setores sindicais foi díspar. Dado que a maior quantidade de declarações coletadas corresponde aos dirigentes da Direção Nacional da CGT, em alguns momentos dividirei a parte destinada a esta central em subitens (flexibilização, desemprego/desempregados e eventos mais importantes do período), de acordo com a necessidade de facilitar a exposição. Para a quarta parte, não encontrarei declarações do MOP, e por esse motivo não foi possível realizar uma análise da atuação dessa corrente nesse momento. A partir de 2000, a CGT será chamada de CGT-Daer, e o MTA, de CGT-Moyano.

Não tenho como objetivo avaliar as contradições entre o discurso dos dirigentes e as ações de suas organizações. Considero que as políticas e as representações da cúpula não possuem uma correspondência direta com o nível de conflitividade da base. Porém, levo em conta que as declarações oficiais dos dirigentes expressam uma posição institucional. Pelo poder de convocação que o sindicalismo possui na Argentina, o discurso dos dirigentes é um indicativo do grau de unidade do movimento operário. Passemos doravante à análise.

\subsubsection{Pico de desemprego e protestos contra as demissões (janeiro a agosto de 1995)}

O ano de 1994 terminou com um recorde histórico do índice de desemprego na Argentina até então. Na primeira medição desse ano, a cifra oficial do Instituto Nacional de Estadísticas y Censos (Indec) foi de 10.7\%, que pela primeira vez ultrapassou os dois dígitos, não voltando a diminuir desse patamar durante todo o período analisado. Em outubro, a taxa passaria a $12.1 \%$ e em maio de 1995 chegaria a 18.4\%, a mais alta de todo o período menemista. Nesse contexto, o desemprego foi um dos principais temas abordados em todos os jornais consultados. Nessa descrição observarei como a cúpula sindical, em suas diferentes correntes, posicionou-se frente à questão, interpretando as causas do desemprego, propondo soluções ao problema e justificando sua postura diante das propostas governamentais.

Logo após a divulgação dessas taxas, a solução de emergência apontada por Menem foi pressionar os legisladores para aprovar um regime de flexibilização trabalhista: "Essa situação é em alguma medida responsabilidade dos legisladores. Já não sabemos como lhes pedir que

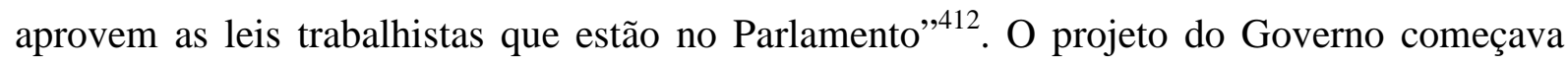

possuírem o maior número de afiliados, são chamados de "gordos". Para facilitar a exposição, traduzirei o termo como Direção Nacional.

${ }^{412}$ La Nación, 05/01/1995, ASASSG, s/r. 
pelas pequenas e médias empresas, e também previa a permissão do pagamento escalonado do décimo terceiro, a elasticidade horária, a redução das indenizações por demissão e uma lei de acidentes de trabalho para diminuir os custos laborais, medidas que, segundo o presidente, gerariam emprego. A princípio, a intenção do Ministério do Trabalho, nesse momento conduzido por Armando Caro Figueroa, era aprovar essas leis por meio de um "decreto de necessidade e urgência" ${ }^{413}$. Mas logo esse procedimento foi descartado para que o projeto entrasse em tramitação no Congresso por intermédio de uma “discussão parlamentar"414, ou de um "consenso legislativo" 415 . Esses eventos desencadearam uma forte discussão no interior do sindicalismo.

\section{A CGT}

No período considerado a CGT se encontrava dividida, desde 1994, por conta da formação do MTA. A condução da central tinha Antonio Cassia como presidente. O dirigente, que pertencia à ala mais menemista da entidade, não hesitava em se declarar como um aliado sindical do presidente. Veremos a seguir as posições cegetistas frente à flexibilização, o desemprego e os desempregados, e frente aos principais eventos do período: os protestos contra as demissões e as eleições presidenciais.

\section{A flexibilização}

Inicialmente, a proposta de reforma trabalhista do Governo foi respaldada pela Direção Nacional da CGT. Como expressou o titular da central, Antonio Cassia, em uma declaração dirigida aos legisladores de extração sindical: "Diante da convocação do Governo para aprovar as leis que já se encontram no Parlamento, como no caso da [que trata dos] acidentes de trabalho, avaliem e apóiem rapidamente a sanção desses projetos". ${ }^{416}$ Com respeito à lei de flexibilização trabalhista para as Pequenas e Médias Empresas (PMEs) ${ }^{417}$, o dirigente afirmou: "Tenho certeza de que é uma grande iniciativa e que vai diminuir os índices de

\footnotetext{
${ }^{413}$ Clarín, 07/01/1995, p. 16, ASASSG, s/r.

${ }^{414}$ Clarín, 10/01/1995, p. 3, ASASSG, s/r.

${ }^{415}$ Página 12, 10/01/1995, p. 4, ASASSG, s/r.

${ }^{416}$ Página/12, 11/01/1995, p. 07, ASASSG, s/r.

${ }^{417}$ Nesse momento, enquadra-se na categoria de Pequeñas y Medianas Empresas (PYMEs) os estabelecimentos com menos de 50 empregados.
} 
desemprego”, ou ainda, “(...) nada disso é ruim se dá emprego, que é o que necessita o país. Por isso o apoiamos". 418

Porém, apesar da aparente unanimidade quanto ao apoio oficialista às propostas governamentais, desde o início houve resistências ao projeto no interior da central, tanto regionalmente como setorialmente. Ademais, como veremos, em diferentes ocasiões no período estudado é possível encontrar críticas pontuais ao Governo, ainda que essas fossem mais freqüentes em momentos de disputas partidárias internas e quando os sindicatos avaliavam que seus interesses organizacionais estavam sendo ameaçados. $\mathrm{O}$ dirigente comerciário Armando Cavalieri, presidente do Sindicato de Empleados de Comercio de Buenos Aires (SEC), advertiiu: "Não nos peçam mais flexibilização trabalhista: já demos tudo". Por sua vez, Juan Zanola, da Asociación Bancaria (AB), afirmou: "sem fluxo de capitais, não sei quanto durará o plano de convertibilidade”. Carlos West Ocampo, da Federación de Asociaciones de Trabajadores de la Sanidad (Fatsa), ligada ao setor de saúde, declarou que o sindicalismo, durante um governo peronista, "cai no erro da desmobilização". ${ }^{419}$ O próprio Cassia chegou a dar declarações contra determinados aspectos da política do Governo, ainda que sem criticar diretamente a Menem: "Se há uma rede de auxílio para salvar os bancos, também teria que haver uma malha de seguridade que neutralize os efeitos do desemprego e da crise das economias regionais". 420

Apesar da orientação do presidente da central a favor da proposta de reforma trabalhista, houve diferentes posicionamentos dos sindicalistas na Câmara de Deputados. Naldo Brunelli, da Unión Obrera Metalúrgica (UOM), votou a favor do projeto. ${ }^{421}$ Porém, José Rodríguez, do Sindicato de Mecánicos y Afines del Transporte Automotor (Smata), votou contra e logo após renunciou ao cargo na Secretaria de Vivienda y Turismo da central. Ao justificar sua decisão, o dirigente afirmou que "a CGT tinha que deixar de ser tão oficialista" econômicos e sociais do país não vão ser resolvidos com uma CGT que diga sim a todas as decisões do Governo". Rodríguez sustentou também que a central aceitava a redução salarial e a perda de qualidade do sistema de saúde. ${ }^{423}$ Em uma nota assinada pelo Smata, esta entidade argumentou que sua decisão se deu por "diferenças de critérios" em relação ao

\footnotetext{
${ }^{418}$ Página/12, 19/02/1995, p. 10, ASASSG, s/r.

${ }^{419}$ Clarín, 22/03/1995, p. 16, ASASSG, s/r.

420 "Nueva peregrinación de la CGT a la Casa Rosada", Clarín, 12/04/1995, p. 22.

${ }^{421}$ Clarín, 09/02/1995, ASASSG, s/r.

${ }^{422}$ Clarín, 13/03/1995, p. 17, ASASSG, s/r.

${ }^{423}$ Clarín, 16/03/1995, p. 13, ASASSG, s/r.
} 
“tratamento da denominada 'lei de flexibilização' trabalhista para as PMEs”. O sindicato afirmou também que "a diminuição do nível de proteção dos trabalhadores e a precarização do emprego, não configuram o caminho idôneo para a criação de novos postos de trabalho". Segundo o documento, provas disso eram a Ley Nacional de Empleo, sancionada em 1991, que "mesmo prevendo novas formas 'flexíveis' de contratação trabalhista, não serviu para incrementar os níveis de ocupação", e a redução das contribuições patronais às obras sociales, que significou somente "um aumento dos lucros dos empresários e uma grave deterioração para a saúde dos trabalhadores". 424

Assim, durante os meses que antecederam as eleições e o começo do segundo mandato de Menem, é possível observar diferentes posturas sobre a flexibilização na CGT, embora o posicionamento oficial de seu titular fosse de apoio aos projetos do Governo. Quando a central mudou sua condução, o novo presidente, Gerardo Martínez, lembrou que "a CGT aceitou a flexibilização", referindo-se à Ley de Empleo, à flexibilização das PMEs e ao novo regime previdenciário. Nesse sentido, argumentou que a postura da entidade "nunca obstruiu o entendimento". Ademais, Martínez sublinhou que "o sindicalismo acompanhou as mudanças estruturais com maturidade e sem alterar a paz social”, o que o levou à seguinte conclusão: "Nossos detratores não têm mais desculpas". ${ }^{425}$

\section{As causas do desemprego e as políticas para os desempregados}

Nas declarações feitas durante o período considerado nesta parte, Antonio Cassia atribuía o problema do desemprego à presença dos estrangeiros que "tiram o trabalho dos argentinos". Segundo o dirigente, "há muitos que trabalham en negro ${ }^{[426]}$ e ocupam postos de trabalho argentino e, além disso, estão sendo explorados". Sobre sua incidência no nível de desemprego, Cassia afirmou: "Não são os 12.2 por cento registrado, mas se fazemos a conta influem. Há empresas construtoras que tem 80 por cento de bolivianos que trabalham informalmente. Ou no sul, nas plataformas submarinas, onde 90 por cento são chilenos". 427 Por último, acrescentou:

Ainda que a economia esteja globalizada e não tenha fronteiras, na imigração sim existe. Todos devem se ajustar às normas. Ninguém nega o direito aos trabalhadores estrangeiros, mas eles devem submeter-se às

\footnotetext{
424 “Una conducta al servicio de los trabajadores”. Solicitada del Smata, Clarín, 23/03/1995, p. 23.

425 "Desde la CGT movilizaremos las ideas". El Cronista, 17/07/1995, p. 4.

${ }^{426}$ Essa expressão, semelhante ao conceito francês de travail au noir, será traduzida como trabalho informal.

${ }^{427}$ Página/12, 19/02/1995, p. 10, ASASSG, s/r.
} 
leis. O que acontece é que as condições salariais entre os países são distintas e não há uma legislação a respeito. ${ }^{428}$

O início da condução de Gerardo Martínez foi marcado pela continuidade à política sindical de seu antecessor em vários aspectos. O novo presidente da central também buscava não responsabilizar o Governo pelo problema: "Não aceito que se faça uso político do tema. O Governo não é o responsável exclusivo do desemprego. Todos temos uma quota de responsabilidade". O dirigente afirmava também que "se politiza o tema para desprestigiar o Governo". De maneira similar a Cassia, Martínez também utilizava o argumento da presença excessiva de estrangeiros no país: "Acredito, inclusive, que os imigrantes são os grandes responsáveis pelo crescimento do desemprego". Para justificar tal posição, o dirigente afirmou que "Na construção há muita mão de obra ilegal que trabalha por 20 por cento menos do que corresponderia a um operário argentino". A respeito das políticas diante do desemprego, declarou ser contra a redução da jornada de trabalho e à suspensão do pagamento da dívida externa, mas confessou que também não tinha uma "fórmula própria". ${ }^{429}$

Ainda que essa fosse a posição de outros membros da Direção Nacional, é possível afirmar que esta visão não era compartilhada pelo conjunto dos dirigentes cegetistas. Havia no interior da central os que interpretavam o desemprego como parte das políticas macroeconômicas do Governo. Para o bancário Juan José Zanola, o sistema financeiro estava “a serviço da especulação e não da produção, que é a única maneira de lograr eqüidade e justiça", crítica que foi feita pelo sindicato que representa em várias notas publicadas ao longo do período estudado. Por sua vez, o comerciário Armando Cavalieri argumentava a favor de "uma maior planificação da política de abertura econômica para que não volte a repetir esta crise". ${ }^{430}$

Também apareceram críticas em alguns sindicatos de setores industriais afetados pelas importações. A respeito da crise no setor automobilístico, o titular do Smata, José Rodríguez, afirmou que "estão sendo importados automóveis demais da conta". Por sua vez, o sindicalista metalúrgico Francisco Gutiérrez, da UOM-Quilmes declarou que "O problema não está focalizado na indústria automobilística, mas na falta de um perfil industrial no país". ${ }^{431}$ O Sindicato de Luz y Fuerza ${ }^{432}$, que durante a primeira gestão de Menem apoiou as

\footnotetext{
${ }^{428}$ Idem.

429 “Menem está haciendo las cosas bien”. Entrevista Gerardo Martínez. Página/12, 11/07/1995, p. 2.

${ }^{430}$ 22/03/1995, ASASSG, s/r.

431 "Preocupación gremial por la crisis automotriz", Clarín, 06/0/1995, p. 12.

${ }^{432}$ Semelhante a um Sindicato dos Eletricitários, no Brasil.
} 
privatizações no setor, passou a apresentar críticas a esta medida: "a privatização indiscriminada e alheia a toda política de participação dos setores envolvidos, das distribuidoras elétricas provinciais, significa desfinanciar as respectivas economias locais e agravar o desemprego nas zonas mais castigadas". Sobre a situação específica do setor, a entidade advertiu: "Para que serviram então as privatizações anteriores? Se o país aumentou seu endividamento, o déficit fiscal resulta tão intolerável como antes, e agora, ademais, há um exército de desempregados, vítimas dos serviços públicos privatizados?". 433

Ao não confrontar diretamente com Menem, a estratégia discursiva da CGT nesse momento foi atribuir a responsabilidade pelo desemprego a fatores "exógenos" ao Governo, como a já citada presença dos estrangeiros. Nesse sentido, também apareciam explicações que se apoiavam na "atitude empresária" e no "contexto mundial". Em meio a uma situação conflituosa em Ushuaia, na província de Tierra del Fuego, que terminou na morte de um operário, a UOM dirigiu sua crítica aos empresários por sua “dualidade" em apoiar o programa econômico do Governo e, ao mesmo tempo, responsabilizá-lo pelo desemprego:

Nós, trabalhadores metalúrgicos, hoje como sempre, contribuímos com o esforço generoso dos braços para a capacitação técnica, mas ao mesmo tempo exigimos do empresariado argentino uma mudança rotunda de mentalidade e orientação, com o abandono dessa atitude dual de elogiar publicamente o programa econômico, e responsabilizá-lo logo, em particular, pelas demissões e suspensões que decidem.

Nesse documento, o sindicato afirmou também que “(...) o empresariado está afetando a estabilidade social e institucional, com atitudes como a transferência do aumento do IVA ${ }^{[434]}$ aos preços, e as demissões e suspensões, que não são precisamente mostras de apoio à política econômica que dizem defender" ${ }^{435}$ O comerciário Armando Cavalieri também atribuía a responsabilidade pelo desemprego aos empresários argentinos por conta da "falta de investimentos" para a criação de empregos, o que o leva a concluir: "Por isso, eu gostaria de ser dirigente operário de empresários como os brasileiros". 436

\footnotetext{
433 "La gente importa. Las economías provinciales también". Solicitada de la Federación Argentina de los Trabajadores de Luz y Fuerza. Clarín, 04/04/1995.

${ }^{434}$ O IVA é o Impuesto al Valor Agregado, correspondente, no Brasil, ao Imposto sobre Circulação de Mercadorias e Serviços (ICMS).

435 "La desocupación de los trabajadores metalúrgicos". Solicitada del Secretariado Nacional de la UOM. Clarín, 12/04/1995, p. 46

436 "La CGT teme más recortes en los salarios". Clarín, 19/06/1995, p. 4. Essa idéia é bastante comum no interior da CGT e apareceu em várias entrevistas e conversas com os dirigentes da central. No meu entender, a noção expressa a bandeira peronista de que é necessário desenvolver o capitalismo no país através de uma política de Estado e de um empresariado forte, condição necessária para a formação de uma classe trabalhadora organizada. Apesar dessa admiração pela classe capitalista brasileira, os líderes sindicais recuam quando 
Em uma nota assinada pela CGT para o $1^{\circ}$ de maio, a central contextualiza a situação econômica da Argentina no nível mundial e argumenta sobre sua estratégia de diálogo diante dos problemas do país. A entidade afirma que tem como objetivo "contribuir com propostas responsáveis às mudanças que na atualidade se operam em nossa pátria, como consequiência de um fenômeno mundial de renovação de antigas estruturas". O dirigente do Smata, José Rodríguez, afirma ser favorável à redução da jornada de trabalho, proposta que era pouco considerada no interior da central nesse momento: "Eu sempre estive de acordo com uma redução dos horários, mas é evidente que a política do Governo passa por outro lado”. 437

Vale notar também que, nesse período, os dirigentes não assinalaram propostas de políticas para os desempregados. Nos documentos consultados, os interesses desse grupo foram destacados pela primeira vez em uma fala de Martínez, que apresentou a idéia da criação de um fundo para a ampliação do seguro-desemprego: "O país necessita de uma malha de proteção social e não somente concessões para o sistema financeiro e aos empresários". ${ }^{438}$ Segundo o dirigente, a ausência de um paliativo para os trabalhadores sem emprego era responsabilidade do poder executivo federal: "O Governo é responsável por não haver previsto esta situação e não haver gerado as políticas para dar um paliativo aos companheiros desempregados". ${ }^{439} \mathrm{O}$ secretário nacional cegetista não culpava o governo pelo desemprego, situando o problema no contexto mundial e argumentando que os postos de trabalho não são gerados por lei. Porém, Martínez passou a apresentar uma preocupação por uma política de Estado para os desempregados:

Sabemos que o problema do desemprego não é exclusivo da Argentina, mas sim deveria haver um Estado provedor (...) que dê as garantias necessárias para que os desempregados tenham uma rede de assistência social. Também estou seguro de que o trabalho não surgirá por uma questão de política legislativa. ${ }^{440}$

Com base nos discursos da cúpula cegetista é possível concluir que os dirigentes da central tiveram diferentes estratégias discursivas diante do desemprego. A leitura feita por alguns dirigentes destacou fatores "exógenos" ao Governo. No entanto, alguns setores

questionados sobre as condições de trabalho e salário no Brasil, que são historicamente inferiores às da Argentina.

437 " $1^{\circ}$ de Mayo. Una vez más en su vida, los trabajadores reivindican su lucha por la dignidad". Solicitada de la CGT. Clarín, 30/04/1995, p. 5.

438 “Menem está haciendo las cosas bien”. Entrevista Gerardo Martínez. Página/12, 11/07/1995, p. 2.

439 "Para la CGT, el Gobierno es el 'responsable"”. Clarín, 12/07/1995, p. 8.

${ }^{440}$ Um dos poucos sindicatos da CGT que desenvolveu uma política ativa para os desempregados foi a Uocra, sindicato conduzido por Martínez. De acordo com a declaração do dirigente, "A Uocra criou há três anos uma Fundación de Educación y Capacitación Profesional, e há cinco iniciamos a requalificação profissional. A fundação controla e gera políticas educativas e de formação profissional para cada um dos centros que criamos" ("Desde la CGT movilizaremos las ideas". El Cronista, 17/07/1995, p. 4). 
criticaram aspectos pontuais da política econômica, ainda que sem fazer referência à figura de Menem. A respeito das possíveis soluções para o problema, foi possível observar distintas propostas, que apontaram sempre para o papel do Estado como promotor de políticas ativas, especialmente por meio de uma política industrial que diminuísse as importações e o investimento especulativo. Encontra-se também a proposta de "redução da jornada de trabalho" feita por um setor, mas que não adquire força dentro da central. Também se pode observar que as conduções de Cassia e Martínez não apresentaram uma visão única sobre o tema. Apesar do ponto comum a respeito do trabalho dos imigrantes, Cassia defendia mais abertamente a proposta do Governo de "flexibilização trabalhista". Outro ponto que merece ser destacado é que o desempregado passou a ocupar um lugar importante nos discursos de Martínez, que introduziu a bandeira de ampliação do seguro-desemprego para esse segmento. A seguir, veremos como a CGT se posicionou sobre dois eventos chaves do período: os protestos contra as demissões em Tierra del Fuego e as eleições presidenciais.

\section{Os protestos contra as demissões em Tierra del Fuego}

Em 1995 houve um considerável crescimento dos protestos protagonizados por despedidos, e se registraram as primeiras mobilizações de desempregados. Entre 1994 e 1999, esse foi o ano em que ocorreu a maior quantidade de eventos desse segmento, tal como foi apresentado no início deste capítulo. Auto-convocadas ou realizadas a partir dos sindicatos de base, houve resistências importantes contra as demissões, entre as quais a de maior repercussão foi a ocorrida em Ushuaia, na província de Tierra del Fuego, em abril de 1995, conduzida pela UOM local. Os trabalhadores da Continental Fueguina ocuparam a fábrica para se opor ao pedido de falência da empresa. A justiça decidiu pelo desalojamento, que se efetuou com uma intensa repressão. A violência policial terminou com "quinze feridos" com a morte do operário da construção civil, Víctor Choque, a primeira vítima do movimento operário após o fim da ditadura no país. ${ }^{442}$

Poucos dias depois, o Governo nacional decidiu abonar um adiantamento do segurodesemprego no valor de trezentos $\operatorname{pesos}^{443}$ aos desempregados, o que não impediu que a UOM nacional convocasse uma greve no setor "em repúdio pela repressão policial” na mesma

\footnotetext{
441 “Ushuaia: desalojo y quince heridos". Clarín, 12/04/1995, p. 28.

442 "Polémica por quien carga el muerto: para Estabillo, fue la izquierda". Página/12, 15/04/1995, p. 5.

443 "Seguro de desempleo para los fueguinos". Clarín, 18/04/1995, p. 18.
} 
data da greve geral realizada pela CTA e pelo MTA. ${ }^{444}$ Em um comunicado firmado por Lorenzo Miguel e pelo deputado de extração sindical Naldo Brunelli, ambos da UOM, a entidade expressou: "não se pode permanecer impassível quando se golpeia trabalhadores indefesos que somente cuidam de suas fontes de trabalho e o reconhecimento de seus direitos". O documento também fez referência à "selvagem repressão policial" e à conduta dos empresários, vistos como os responsáveis por essa situação. ${ }^{445} \mathrm{Na}$ convocatória da paralisação, a entidade avaliou a situação na província da seguinte maneira:

(...) a conflituosa situação que atravessa a atividade metalúrgica em Tierra del Fuego está originada na repudiável conduta dos empresários que em lugar de fazer esforços em defesa das fontes de trabalho está despedindo os trabalhadores sem pagar sequer os direitos e indenizações, jogando-os assim ao total desamparo, em uma mostra mais de seu egoísmo e insensibilidade.

A UOM também expressou sua "solidariedade com os abnegados companheiros fueguinos em seu legítimo acionar pela defesa de seus postos de trabalho”. No documento se lê que o sindicato tomou a resolução de "convocar uma paralisação geral de atividades em todos os estabelecimentos metalúrgicos do país, por 24 horas, de acordo com os turnos, modalidades e previsões de prática de cada seção". Também apareceu em uma das resoluções a proposta de "responsabilizar o setor patronal por ser o gerador dessas graves alterações da paz social e propiciar as demissões e as perdas das fontes de trabalho (...)". 446

Ainda que a CGT não tenha convocado nenhum protesto, a greve da UOM foi respaldada e considerada legítima pela central, tal como afirmou Cassia: "a greve da Unión Obrera Metalúrgica tem uma motivação especial que é o repúdio aos atos de violência de Ushuaia e à morte do companheiro Víctor Choque, e conta com o aval da CGT" ${ }^{447}$ Em razão da coincidência de data com a greve geral convocada pelo MTA e pela CTA, a entidade buscou se diferenciar dos setores opositores. Lorenzo Miguel afirmou que a greve era "metalúrgica", e Cassia acrescentou: "enquanto alguns sindicalistas se dedicam a convocar greve, a CGT encontra soluções ao tema Ushuaia na mesa de negociações". ${ }^{448}$

Desse modo, é possível afirmar que a entidade não assumiu a mesma posição de sua filial local, que nesse momento responsabilizava a política de abertura às importações levada

\footnotetext{
444 “La UOM lanzó un paro nacional”. Clarín, 18/04/1995, p. 21.

445 “UOM: paro el viernes”. Página/12, 18/04/1995, p. 6.

446 "Tierra del Fuego: paro nacional metalúrgico". Solicitada del Consejo Directivo de la UOM. Clarín, 20/04/1995, p. 24.

447 "Para Ubaldini y Palacios, la medida es un éxito". La Razón, 21/04/1995, p. 3. Ver também: “El paro se sintió en el interior". Clarín, 22/04/1995, pp. 8-9.

448 “Alto índice de acatamiento entre los metalúrgicos”. Clarín, 22/04/1995, pp. 8-9.
} 
a cabo pelo Governo como principal causa das demissões massivas na província, posição semelhante à assumida pelo sindicalismo opositor. Esse evento demonstrou que, considerando os sindicatos nucleados no setor majoritário da central, houve resistências locais contra as demissões e discordâncias com a política menemista e a condução nacional dos grandes sindicatos. A UOM sustentava que tal situação era provocada exclusivamente pelos empresários. Porém, nas declarações dos dirigentes fueguinos se observa uma visão crítica ao Sindicato nacional, que segundo eles não havia assumido a luta direta dos demitidos, embora tenham se solidarizado com a morte de Choque.

\section{As eleições presidenciais}

No período analisado, o setor majoritário da CGT apoiava Menem, o que pode ser verificado nas declarações dos dirigentes nacionais. Ao definir o presidente, Cassia sublinhou: "É um político de raça, único, capaz de tirar o país do fundo do poço e resolver o problema do desemprego". A respeito de sua associação com o Governo, o dirigente declarou: "Sim, sou o operador político de Menem na CGT (...). É que Menem gosta muito de mim, somos amigos de anos (...)". ${ }^{449}$ Em semelhante declaração, logo após assumir a condução da central, Martínez afirmou: "Menem, de quem gosto e estimo muito, está fazendo bem as coisas". 450

Nesse contexto de aliança entre a central e o Governo, prevaleciam as estratégias propositiva e participacionista. Para Cassia “(...) as soluções não passam por fazer marchas e barulho. (...) Isso é o que vale: dialogar e fazer propostas”. Sobre essa questão, o sindicalista argumentou: "Pergunte aos trabalhadores o que querem: se estar de greve ou que seus dirigentes se dediquem a encontrar soluções aos problemas". ${ }^{451}$ Ou ainda: "Com esta condução logramos que o Governo voltasse a abrir suas portas para escutar a posição do movimento operário. (...) nesta gestão evitamos uma flexibilização do trabalho selvagem e também impedimos a desregulamentação das obras sociales" ${ }^{452}$ Uma síntese das representações do dirigente acerca desse tema pode ser observada na seguinte declaração:

\footnotetext{
${ }^{449}$ Página/12, 19/02/1995, p. 10, ASASSG, s/r.

450 “Menem está haciendo las cosas bien”. Entrevista Gerardo Martínez. Página/12, 11/07/1995, p. 2.

${ }^{451}$ Página/12, 19/02/1995, p. 10, ASASSG, s/r.

452 "Preparan una maniobra para desplazar a Cassia de la CGT", Clarín, 05/04/1995, p. 26.
} 
Participar é o caminho; fazendo escutar nossas queixas, propondo melhoras, estudando causas e efeitos de cada mudança, incentivando a incorporação dos trabalhadores ao capital das empresas e, em definitivo, modificando o papel auditor do sindicalismo para (...) ser gestor da transformação. ${ }^{453}$

Como já foi dito, a aliança da CGT com o Governo nesse momento se explicava em parte pela expectativa dos dirigentes de serem nomeados para as candidaturas nas eleições internas do PJ e em cargos ministeriais designados pelo Poder Executivo Federal. Nesse momento, os interesses da central pela manutenção do poder sindical (sustentado pelas negociações coletivas centralizadas e pela gestão do sistema de saúde) ainda não haviam sido ameaçados. Na medida em que se aproximavam as eleições presidenciais de 14 de maio, em muitas situações Cassia expressou publicamente essa posição. Diante da eventual saída do ministro Caro Figueroa, o dirigente afirmou que o cargo deveria ser ocupado por um dirigente sindical. ${ }^{454}$ Em outra declaração, o titular cegetista assim justificou o ponto de vista da central: "A CGT busca promover seus dirigentes para os distintos cargos eletivos, porque considera que os trabalhadores têm que ser escutados no Parlamento por intermédio de seus próprios representantes". ${ }^{455}$

A divulgação da cifra de desempregado foi feita poucos dias antes das eleições presidenciais. Porém, o apoio à candidatura de Menem era consensual na CGT, que nesse momento evitava responsabilizar o Governo. Em uma nota assinada por várias entidades, como a Unión Personal Civil de la Nación (UPCN), a Asociación Obrera Textil (AOT), a Unión Ferroviaria, a Unión Obrera de la Construcción de la República Argentina (Uocra), Sindicato Único Petroleros del Estado (SUPE) e a UOM, lê-se:

O movimento operário argentino tem claro que: assim como sempre lhe tem tocado pôr a maior quota de sacrifício e abnegação em todas as lutas que tem feito a sociedade argentina para alcançar seu destino de justiça, soberania e liberdade, hoje não terá dúvida em combater com firmeza um flagelo mundial: o desemprego e o subemprego (...). Consciente que entre os direitos inalienáveis do homem está o direito a trabalhar, consciente também que em nosso modelo de sociedade o Estado tem funções e responsabilidades que são indelegáveis, entre outras, a de definir políticas e ferramentas econômicas que possibilitem a plena ocupação. (...) Como conseqüência: RATIFICAMOS PLENO APOIO - PARA AS ELEIÇÕES DO PRÓXIMO 14 DE MAYO - À FÓRMULA PRESIDENCIAL MENEM-RUCKAUF e a

\footnotetext{
${ }^{453}$ Cassia, Antonio. "La protesta no es el camino”, Clarín, 12/04/1995, p. 17.

${ }^{454}$ Clarín, 24/02/1995, p. 4, ASASSG, s/r.

${ }^{455}$ La Prensa, 14/03/1995, p. 10. Ver também: "Quieren cargos en el gobierno - la CGT tiene que juntar paciencia", Clarín, 16/03/1995, p. 27; "La CGT piensa en el perfil del futuro ministro de Trabajo", La Nación, ASASSG, s/r.
} 
todos os candidatos do justicialismo, para que ninguém pretenda relegar a participação dos trabalhadores organizados na mesa de decisões estratégicas. ${ }^{456}$

A UOM também demonstrou seu apoio à candidatura de Menem para presidente e de Duhalde para governador da província de Buenos Aires: “a UOM foi, é e será peronista!". 457 Em demonstração similar, as 62 Organizaciones Peronistas $(62 \mathrm{OP})^{458}$ assim justificaram seu apoio à reeleição:

Desde que o general Perón irrompeu na cena política argentina, nós, trabalhadores, nos identificamos com sua doutrina e sua luta. Os golpes, perseguições e desterros que teve de suportar, nos fortaleceram a convicção de que só o PERONISMO representa os interesses da Nação e de seu povo. ${ }^{459}$

Também nas entrevistas com sindicalistas menemistas se observa o apoio que Menem tinha no setor majoritário da CGT, como fica evidente na declaração do dirigente gastronômico, Luis Barrionuevo: "O Presidente disse que seu único herdeiro é o povo. Eu me sinto o povo. E eu quero Menem por quatro anos mais a partir de 1999". ${ }^{460}$

Menem conseguiu ser reeleito mesmo com uma cifra recorde de desemprego. Logo após as eleições, Cassia deixou a condução da CGT para ser substituído por Martínez, da Uocra. Porém, a mudança na direção não significou uma alteração da posição assumida frente ao Governo, pelo menos nos primeiros meses. Em entrevista a um jornal, quando perguntado se concordava com a política trabalhista do Governo, Martínez afirmou que "Em geral [Menem] têm feito coisas boas. Esse país não é o mesmo que o de 89, quando havia saques". Sobre a situação geral do país, assinalou: "Eu quero que me entendam: eu tenho uma análise positiva do que está ocorrendo no país. Não sou dos que querem voltar para trás. O resultado eleitoral (de 14 de maio) foi o que foi e por algo será". 461

Apesar do apoio a Menem, a CGT perdia espaço nas internas do PJ, não funcionava sua pressão pela obtenção de mais cargos, além do fato de que o Governo contrariava seus interesses ao apresentar a proposta de desregulamentação das obras sociales e de flexibilização das negociações coletivas. A partir de então, os sindicalistas assumiram uma postura mais crítica e de confrontação. Como veremos no item seguinte, durante a condução

\footnotetext{
456 "Para que no se equivoquen los que pretenden medrar con la lucha y el esfuerzo de los trabajadores argentinos". Solicitada, UPCN y otros. Clarín, 12/04/1995, p. 2.

457 "La UOM es orgánica y peronista". Clarín, 11/05/1995, p. 16.

${ }^{458}$ Trata-se das 62 entidades sindicais cegetistas mais importantes, também conhecidas como 62 Organizaciones Justicialistas.

459 "Hoy como ayer, peronistas!”. Solicitada de la Mesa Nacional Confederación 62 Organizaciones Justicialistas. Clarín, 11/05/1995, p. 20.

460 "Quiero cuatro años más". Entrevista de Luis Barrionuevo. Página/12, 19/05/1995, p. 7.

461 “Menem está haciendo las cosas bien”. Entrevista Gerardo Martínez. Página/12, 11/07/1995, p. 2.
} 
de Martínez alguns sindicalistas começaram a se opor a alguns aspectos gerais da política econômica e ao projeto de reforma trabalhista que decidiram deixar de apoiar. Ainda que essa atitude não tenha significado um abandono da estratégia dialoguista e do apoio a Menem, entre o segundo semestre de 1995 e o ano de 1996 a central convocou quatro greves gerais.

$$
* * *
$$

Durante o período tratado neste item, que tem como cenário a divulgação da mais alta taxa de desemprego da história argentina até esse momento, a principal estratégia da CGT foi buscar a concertação. A central não participou de importantes mobilizações, a exemplo da greve geral convocada pela CTA e pelo MTA em repúdio ao assassinato do operário Víctor Choque, embora a UOM nacional tenha convocado uma paralisação por este motivo. Os principais dirigentes apoiaram abertamente a flexibilização e buscaram justificativas externas ao Governo para explicar o alto índice de desemprego no país. Outros adotaram uma atitude contrária ao setor majoritário na Direção Nacional, e assumiram uma posição crítica frente à política econômica e à reforma trabalhista. Logo após a reeleição de Menem, que foi apoiada pela central, o não atendimento a determinados interesses da entidade levou a uma mudança em sua condução, a qual passou a ter uma postura crescentemente mais crítica ao Governo.

\section{O MTA}

Desde 1994, quando foi formado, o MTA já vinha se consolidando como um setor interno da CGT com posições mais críticas em relação à Direção Nacional. Analisarei a seguir as ações e representações desse grupo a respeito da temática tratada. A partir da análise dessa corrente nos anos 90, é possível afirmar que o vínculo histórico da CGT com o PJ não resultou na aliança de todos os dirigentes da central com o Governo. Apesar de não haver se separado organicamente da central, o MTA, com uma condução paralela, atuou com autonomia convocando protestos e mobilizações contra a política econômica.

A proposta de flexibilização trabalhista foi rejeitada desde o início por este setor. Sobre o tema, Juan Manuel Palacios, da Unión Tranviarios Automotor de la República Argentina (UTA), argumentou: “[com esse tipo de medida] não [se] geraram novos empregos e isto provocará mais angústia e sofrimento na família trabalhadora" ${ }^{462}$ Para Saúl Ubaldini, também nucleado neste agrupamento, “As fontes de trabalho não se podem criar por decreto ou por lei.

\footnotetext{
${ }^{462}$ Página/12, 11/01/1995, p. 07, ASASSG, s/r.
} 
A solução para o problema do desemprego deve ser buscada sem desumanizar o tratamento aos trabalhadores, resguardando sua dignidade e seus direitos". Essa opinião também foi validada pelo caminhoneiro Hugo Moyano, para o qual essas leis “não vão dar resposta para reduzir o desemprego". Ao contrário, afirmou que as mesmas "deixarão o trabalhador sem respaldo social nem legal" e que "os projetos colocam os trabalhadores à beira da exploração". ${ }^{463}$ Em uma nota intitulada "Governar é criar trabalho, não emprego com escravidão", firmada, entre outros, pelos mesmos Palacios, Ubaldini e Moyano, o setor dissidente da CGT assim se expressou:

O Governo Nacional, refém dos Bancos e dos grandes grupos econômicos, decidiu pela entrada dos trabalhadores argentinos a condições evidentes da escravidão. Um fracasso sustentado na política social e de emprego, tem levado as autoridades e a mesma CGT como representante do ministro Cavallo diante do Movimento Operário, a tentar o último golpe à dignidade do trabalhador e um novo engano aos dois milhões de desempregados, vítimas daquele fracasso. (...) [O MTA] denuncia o projeto escravista e a responsabilidade que cabe a quem, tendo sido dirigentes, converteram-se em funcionários, fazendo da Central Operária uma sucursal do governo. Não sabemos a que preço se acordou tudo isso. Mas seus efeitos podem ser previstos: converter o povo argentino em uma reserva asiática de trabalho e salários de miséria. $\mathrm{O}$ [MTA] e os dirigentes sindicais que ainda consideram a justiça e o direito dos humildes, crêem que chegou o momento de pensar em uma representação autêntica, solidária, democrática e social dos trabalhadores. ${ }^{464}$

Para combater o projeto de lei de reforma trabalhista, o MTA convocou uma mobilização para 22 de fevereiro de 1995 em conjunto com a CTA. Esse ato foi definido por Palacios como um "protesto multitudinário para dizer não à flexibilização",465. Entretanto, o projeto foi aprovado pela Câmara de Deputados, com apoio de alguns legisladores de origem sindical. Sobre o tema, Hugo Moyano afirmou: “(...) a flexibilização é uma farsa, mas, sobretudo sabemos que os deputados sindicais que a aprovaram (...) são uns traidores à causa de Eva e Perón". 466 O MTA afirmou que a CGT já não representava os interesses dos trabalhadores por conta de sua associação com Menem. Em relação a este tema, Palacios afirmou que "estas cúpulas, desviadas de sua finalidade e divorciadas de seus representados, vendem-se, prostituindo o conceito de 'negociação', privilegiando e antepondo seus interesses aos de seus representados (...) observe o que acontece na CGT", 467

\footnotetext{
${ }^{463}$ Clarín, 16/01/1995, p. 3, ASASSG, s/r.

${ }^{464}$ MTA. Solicitada. Clarín, 20/01/1995, p. 29.

${ }^{465}$ Página/12, 21/02/1995, p. 4, ASASSG, s/r.

${ }^{466}$ Página/12, 23/02/1995, p. 5, ASASSG, s/r.

${ }^{467}$ Palacios, Juan Manuel. "El sindicalismo lucha o no existe". Clarín, 12/04/1995, pp. 16-17.
} 
Logo após o assassinato de Víctor Choque, o MTA e a CTA convocaram a uma “jornada nacional de luto" para 17 de abril, com concentração em frente ao Congresso da Nação. ${ }^{468}$ Na convocatória desse protesto, as entidades assim se expressaram: "O desemprego e a desindustrialização, frutos diretos da política monetarista, são [as] causas da morte do companheiro Víctor Choque". ${ }^{469}$ No dia 21 de abril, na mesma data do protesto da UOM, os dois setores convocaram uma greve geral em repúdio à repressão ocorrida nesse evento.

Não encontrei declarações do MTA referentes a esse período que apontassem para uma proposta em relação aos desempregados. O setor denunciou o desemprego, ainda que sem ter uma política de representação ou organização para a luta daquele segmento. Mas, a partir do material consultado, pode-se concluir que predominou nesse setor uma postura crítica à flexibilização, medida considerada ineficaz para combater o desemprego, que precarizaria ainda mais as condições de trabalho. As causas do desemprego foram explicadas por essa corrente pela "política monetarista", o que evidencia a postura de responsabilizar o Governo pela situação vivida no país. O MTA adotou uma postura de enfrentamento em relação a Menem, em quem não votou nas eleições presidenciais. Argumentou contra sua política econômica e quando Víctor Choque foi assassinado, convocou uma jornada de luto e uma greve geral em conjunto com a CTA em repúdio à repressão.

\section{A CTA}

O volume de declarações dos dirigentes da CTA publicados nesse período nos jornais consultados foi insuficiente para aprofundar a análise. Assim mesmo, pode-se observar em linhas gerais qual foi a postura dessa central diante da flexibilização, do desemprego e dos desempregados, assim como as estratégias adotadas nos principais eventos do período. Desde a Marcha Federal ${ }^{470}$, realizada em julho de 1994, a CTA já demonstrava sua preocupação pelo tema do desemprego. Em 1995 a entidade se posicionou contra as propostas do Governo de flexibilização trabalhista, convocando uma "jornada nacional de protesto" em conjunto

\footnotetext{
468 "Polémica por quien carga el muerto: para Estabillo, fue la izquierda". Página/12, 15/04/1995, p. 5.

469 "La fuerza es el derecho de las bestias". Solicitada de CTA y MTA. Crónica, 16/04/1995, p. 14. Ver também "El sindicalismo opositor llama a una huelga general para mañana". Página/12, 20/04/1995, p. 7; "La fuerza es el derecho de las bestias". Solicitada de CTA y MTA. 20/04/1995, ASASSG, s/r.

${ }^{470}$ Marcha da CTA pelo interior do país, que teve como bandeira a luta contra o desemprego. Sobre este protesto e outros eventos protagonizados pela central entre 1991 e 1997, ver Del Frade (2004).
} 
com o $\mathrm{MTA}^{471}$. O ato foi definido por seu presidente, Víctor De Gennaro, como "multitudinário", e que a partir do mesmo se colocaria um freio "nessa norma que legaliza a escravidão". ${ }^{472}$ Em uma nota jornalística, a central afirmou que "a modificação da legislação não influenciou nem influenciará na criação de postos de trabalho; ao contrário, precarizará os empregos estáveis". ${ }^{473}$ Nesse documento, a entidade argumentou sobre a impossibilidade de que o desemprego pudesse ser resolvido por lei. Também se depreende de sua leitura que a posição oficial da CTA, ao contrário da CGT, era de responsabilizar a política econômica do Governo como a principal geradora do desemprego no país: “As soluções devem ser buscadas na totalidade da estrutura ocupacional apontando fundamentalmente à modificação da política macroeconômica, primeira causa do desemprego". 474

A CTA apresentava uma proposta de representação para os desempregados. Propunha a construção de uma ação conjunta entre ativo e reserva, e considerava a representação dessa última como parte de sua estratégia sindical. Para De Gennaro, a saída para o desemprego seria "reconstruir a unidade da classe trabalhadora a partir da afiliação dos companheiros com estabilidade trabalhista, os precários, os aposentados, os desempregados e os subempregados; seja por meio de seus sindicatos ou federações, seja de forma individual"475. No dia 21 de abril, a CTA convocou uma greve geral em repúdio à morte de Víctor Choque, em conjunto com o MTA.

$$
* * *
$$

As declarações da CTA apontaram uma constante crítica à política econômica e a Menem. Não votou no presidente nas eleições e, ao contrário, responsabilizou-o pela situação vivida pelo país. Também rejeitou a flexibilização trabalhista e propôs uma política de representação dos desempregados baseada no mecanismo de filiação direta dos trabalhadores independente de seu vínculo de trabalho. Entre os três setores analisados, foi o único que se propôs organizar os desempregados, apresentando a unidade da classe trabalhadora como um dos objetivos de sua proposta de ação sindical.

\footnotetext{
${ }^{471}$ Clarín, 13/02/1995, p. 13, ASASSG, s/r.

${ }^{472}$ Página/12, 21/02/1995, p. 4, ASASSG, s/r.

${ }^{473}$ Clarín, 16/02/1995, p. 15, ASASSG, s/r.

${ }^{474}$ Clarín, 16/02/1995, p. 15, ASASSG, s/r. Para De Gennaro, o presidente Menem como o ministro Cavallo não são "neutros", já que "a convertibilidade beneficia aos grandes grupos econômicos e prejudica à grande maioria do povo trabalhador". (Clarín, 20/02/1995, p. 10, ASASSG, s/r).

${ }^{475}$ De Gennaro, Víctor. Sin Título. Clarín, 12/04/1995, pp. 16-17.
} 


\subsubsection{Unidade do movimento operário e mobilização contra o desemprego (setembro de 1995 a dezembro de 1996)}

Até aqui, foi possível identificar dois grupos no sindicalismo argentino. No primeiro se encontrava a CGT, nesse momento majoritariamente menemista. De modo geral seus dirigentes defenderam os principais projetos do Presidente, tais como a reforma trabalhista, analisando o desemprego a partir de fatores alheios à política econômica. Essa visão predominante não excluiu a existência de divergências no interior da central, tanto setorialmente como regionalmente. O segundo grupo era composto pela CTA e pelo MTA, que se opuseram de maneira veemente ao Governo, não apoiaram a reeleição do presidente e se mobilizaram com mais contundência, como ficou claro nas manifestações em repúdio à morte de Víctor Choque. Porém, somente a CTA se propôs representar os desempregados, ainda que essa política não tivesse sido desenvolvida pela entidade até esse momento.

O período que será analisado neste item pode ser considerado o de maior enfrentamento das centrais com o Governo de Menem. Decepcionada com as decisões que vinham sendo tomadas pelo presidente, a CGT convocou quatro greves gerais em pouco mais de um ano e três meses, o que significou o auge da mobilização sindical durante a década menemista. A partir desse momento, a corrente mais ligada ao presidente, liderado por Cassia seguiu militando por meio de uma linha interna na central, o Movimiento Obrero con Propuestas (MOP), que defendia abertamente todas as propostas do Governo, especialmente a flexibilização das leis trabalhistas. Farei algumas observações sobre esse setor. Tanto a CTA como o MTA participaram das paralisações, apesar de ressaltar sua posição contrária às adotadas pela CGT. Isso comprova que a unidade do movimento operário argentino na luta nesse momento dependeu da convocação cegetista, que ao representar a maioria dos trabalhadores, foi a que garante a alta adesão verificada nesses protestos. Os setores minoritários seguiram sem um canal de diálogo direto com o Governo, já que foi somente a CGT quem se sentou nas mesas de negociações. Apesar do alto índice de desemprego, não se verificou um nível considerável de ação conjunta com os desempregados nesses eventos, o que pode ser explicado pelo caráter ainda embrionário de suas organizações.

\section{A CGT}

A partir da condução de Gerardo Martínez, a CGT adotou um discurso crescentemente mais crítico em relação a determinadas políticas do Governo, assumindo a posição oficial de 
não mais apoiar a reforma trabalhista. Nesse período, denunciou o desemprego de maneira mais sistemática, reivindicando uma política pública de assistência aos desempregados, assim como políticas de geração de postos de trabalho. Ademais, considerou que os projetos do Governo representavam uma ameaça a seus interesses, a exemplo da desregulamentação das obras sociales.

\section{A flexibilização}

Embora a cúpula cegetista tenha assumido um discurso crescentemente contrário à flexibilização, os sindicatos de base não descartavam negociar a redução da jornada e dos salários para evitar demissões. Em outubro de 1995, a UOM e a empresa Sevel firmaram um acordo com base nesses parâmetros em troca do comprometimento da empresa de não realizar demissões. ${ }^{476}$ Em uma nota, o sindicato assim justificou o convênio:

O acordo está em andamento; os suspensos estão trabalhando, e entre todos, com o esforço compartilhado de trabalhadores e dirigentes, logrou-se evitar suspensões e demissões que, nesse contexto de desemprego, teriam afetado a paz social. Os conflitos são mais fáceis de gerar que de encaminhar, e somente a sensatez, prudência e maturidade das partes tem podido encaminhar e superar esta situação. ${ }^{477}$

Porém, no plano discursivo a CGT já não aceitava a proposta de flexibilização com o mesmo entusiasmo. Demarcando o que seria uma nova postura da Direção Nacional acerca do tema, Martínez afirmou: "Basta de flexibilidade trabalhista. Não vamos discutir iniciativas desse tipo". Para o sindicalista, o Governo tinha que "dar soluções ao problema do desemprego", pois com tal atitude estaria "levando o movimento operário a uma situação de conflito". 478

O ano de 1995 terminou com um crescente descontentamento da CGT em relação às políticas do Governo. Nesse momento, o Sindicato de Luz y Fuerza assim demonstrou sua rejeição à flexibilização:

A clamada flexibilização trabalhista não é outra coisa que o corte sistemático das condições de trabalho dos assalariados e da capacidade de representação de seus sindicatos. Esta está destinada para que a "mão

\footnotetext{
476 “Avaló Economía el pacto de UOM”. Clarín, 12/12/1995, p. 12.

477 "Alcances del acuerdo 'UOM-Sevel'”. Solicitada de la UOM. Clarín, 30/10/1995, p. 26. Acordo semelhante foi levado a cabo entre o Smata e a automobilística Ciadea, com o adiamento das supensões de 500 trabalhadores, cf. "Acuerdo entre Smata y Ciadea para atravesar la crisis". Clarín, 28/10/1995, p. 19. Outro evento desse tipo destacado pelos jornais foi o acordo firmado no início de 1996 pelo mesmo Sindicato com a Fiat, que contemplou a redução da jornada e condicionou os salários à produtividade para "evitar" suspensões. "FIAT y Smata flexibilizan las futuras relaciones laborales" e "General Motors y Sevel tienen acuerdos similares. El trabajo cambia sin leyes". Clarín, 18/01/1996, p. 20.

478 “La CGT no quiere más flexibilización”. Clarín, 05/11/1995, p. 23.
} 
de obra barata" gere maiores lucros aos empregadores para que participem mais facilmente nos mercados mundiais. O preço da competitividade da economia é pago pelos que menos têm. ${ }^{479}$

Em setembro de 1996, Rodolfo Daer assumiu a central. O dirigente manteve, inicialmente, posição contrária à flexibilização trabalhista, vista como "uma forma mais de aumentar a exploração sobre os trabalhadores". ${ }^{480}$ Nesse momento, a UOM também se posicionava de modo semelhante:

(...) nós, trabalhadores metalúrgicos, rejeitamos as tentativas de flexibilização trabalhista, resistindo ao repetido argumento patronal da inevitabilidade da reforma (...), apresentada como consequência inevitável da globalização do mercado, apesar de que a própria OIT tem expressado que a flexibilização não gera emprego. ${ }^{481}$

Declaração semelhante também se encontra nas 62OP: "Nos opomos à flexibilização trabalhista entendida como forma de escravizar o trabalhador e precarizar seus direitos constitucionais". Essa entidade também se opunha à forma como o governo procurava implementá-la: "Repudiamos as ameaças de legislar por decreto, ignorando o Poder Legislativo e agravando o sistema constitucional e democrático". Para combater o desemprego, a entidade apresentou a proposta de "investimentos genuínos e criação de trabalho, sem afetar os direitos dos trabalhadores". 482

Porém, apesar da pressão cegetista, em dezembro de 1996 o Governo aprovou por decreto a lei de flexibilização trabalhista, o que levou a CGT a convocar uma greve no dia 26 desse mês em repúdio à medida. Para justificar o protesto, Daer afirmou que "Os decretos do Presidente golpeiam as costas dos trabalhadores e vêm demonstrar como se quer privilegiar os grupos de concentração econômica". Por sua vez, Ocampo argumentou: "Eu não posso dizer 'sim' a um regime de demissão que quer ser o mais barato do Mercosul". ${ }^{483}$ Outras fontes trouxeram declarações semelhantes de Daer, que apontou uma incoerência do conteúdo do decreto com a política peronista: "Para a CGT, se um peronista apóia estas mudanças deixa de

\footnotetext{
479 "Luz y Fuerza al país". Solicitada de la Federación Argentina de Trabajadores de Luz y Fuerza. Clarín, 18/12/1995, p. 8. Em uma declaração sobre o tema, Martínez explicitou: "Diante das reivindicações por uma maior desregulamentação do mercado de trabalho, de um regime de negociação coletiva sem a participação dos sindicatos, respondemos que são muitos os trabalhadores que sofrem o desemprego ou o subemprego". ("Discurso en la OIT. La CGT no quiere más flexibilización". Clarín, 16/06/1996, p. 15). Contra a pressão empresária pela flexibilização, o dirigente acrescentou: "Se avançou sensivelmente na flexibilização trabalhista, mas o objetivo de criar novos empregos esteve muito longe de se conseguir" ("Desocupación: cada uno defiende su libreto". Clarín, 06/07/1996, p. 9).

480 "Lorenzo le apuntó otra vez a Menem". Clarín, 19/10/1996, p. 5.

481 "La globalización y la justicia social". Solicitada de la UOM. Clarín, 06/12/1996, p. 32.

482 "La soberanía nacional y los trabajadores". Solicitada de la Confederación 62 Organizaciones Sindicales Justicialistas. Clarín, 20/11/1996, p. 41.

483 "Rechazan la flexibilización laboral por decreto. La CGT convocó a un paro para el 26". Clarín, 21/12/1996, p. 2.
} 
ser automaticamente peronista. Ninguém (...) pode se pronunciar a favor dos decretos. Nós, peronistas, nos envergonhamos disso" ${ }^{484}$. Ou ainda: "Sinto vergonha de que um governo peronista, que surgiu com o voto majoritário do povo, queira destroçar por meio de decreto o mundo das relações operário-patronais, que têm uma história de 45 anos". 485

No entanto, uma sentença suspendeu a aplicação dos decretos de flexibilização. Sobre esse evento, Daer assim se expressou: “A justiça está dizendo ao Governo: basta de decretos". ${ }^{486}$ Em outra declaração o presidente da CGT manifestou a discordância da central sobre o tema: "Nada de política trabalhista. Aqui o que temos que discutir é a política econômica, porque se não, não há diálogo". ${ }^{487}$ Em seguida, Ocampo afirmou: "Chegamos a nosso melhor momento e o Governo vem se debilitando. Reinstalamos o diálogo (...). E vamos em busca da concertação social". ${ }^{488}$ A postura da CGT seria mantida até o final do período analisado. A exemplo disso mencionamos a seguinte afirmação de Daer: "[a flexibilização] visa precarizar a vida do trabalhador e é a instrumentação legal do rebaixamento massivo dos salários. Ademais, não vai ajudar a reduzir o desemprego se não se modifica o modelo". 489

\section{As causas do desemprego e as politicas para os desempregados}

A partir da documentação consultada, pode-se concluir que as propostas feitas pela CGT para combater o desemprego nesse período apontavam para o papel central da mediação do Estado para o desenvolvimento de políticas ativas de desenvolvimento industrial, o incentivo às PMEs, a promoção de obras públicas, políticas passivas de assistência aos desempregados, como o seguro-desemprego, a intermediação do pacto social com os empresários para que estes garantissem a geração de empregos e a proibição das demissões por lei. As proposições cegetistas foram resumidas pelo jornal Clarín a partir dos seguintes pontos: "subsídio para todos os desempregados; não mais demissões nem suspensões; fechar a importação de produtos que possam ser feitos no país; não à redução da jornada de trabalho; reativar mecanismos de concertação social". O artigo também apresenta os argumentos de alguns dirigentes. Segundo o secretário de Relações Institucionais da CGT, Andrés

\footnotetext{
484 "Paro y castigo en las urnas". Página/12, 20/12/1996, p. 11.

485 “Sexto paro contra el gobierno de Menem”. Clarín, 26/12/1996, p. 3.

486 “Optimismo en la CGT. Daer: 'La Justicia dice basta de decretos". Clarín, 07/01/1997, p. 5.

487 “La apuesta luego del segundo fallo contra los decretos. Rueda de la fortuna”. Página/12, 15/01/1997, p. 5.

488 “El Gobierno y la CGT vuelven a la negociación”. Clarín, 16/01/1997, p. 12.

489 “Advertencia de Daer: 'Vendrá la rebeldía popular””. Entrevista a Rodolfo Daer. Clarín, 27/01/1997, p. 5.
} 
Rodríguez, "Chegou o momento de pedir que se dê prioridade à obra pública e aos microempreendimentos para que as pessoas comecem a sair do fundo do poço”. Para o titular da central, Gerardo Martínez, “desde que me pus à frente da central operária venho reivindicando do Governo que fabrique o quanto antes uma rede de assistência social". Por sua vez, o eletricitário Oscar Lescano afirmou: "Basta de formar comissões e de elaborar diagnósticos, o Governo tem que nos dizer amanhã quanto vai juntar para pagar aos desempregados e como vai fazer para gerar postos de trabalho". ${ }^{490}$ Outras propostas foram citadas em outra matéria do mesmo jornal: "Formar o Consejo Nacional del Empleo; Promulgar uma lei que impeça as demissões e as suspensões durante um ano; Ampliação do montante e da cobertura do segurodesemprego; Moratória para os pagamentos de serviços e impostos [aos] desempregados e aposentados; Reativação da obra pública; Não reduzir os benefícios sociais". 491

De acordo com a central, a proibição das demissões deveria ser aprovada por meio de um "decreto de necessidade e urgência". Sobre tal medida, Martínez sustentava: "As cifras do desemprego são monstruosas e o Governo não pode perder tempo. Deve-se convocar a uma emergência ocupacional através de uma lei que impeça a demissão e suspensões dos trabalhadores por um ano". ${ }^{492}$ A proposta foi rejeitada tanto por Menem como pela Unión Industrial Argentina (UIA). Essas propostas não significaram, na prática, que a CGT tenha abandonado sua estratégia de dialogar e acordar para buscar soluções, tal como afirmou Martínez: "Deve haver uma grande convocação tripartite, na qual participe o Estado, os empresários e os trabalhadores, para definir medidas que sirvam para gerar emprego (...)". 493

Sobre as causas do desemprego, nesse momento Martínez responsabilizava os empresários, sobre os quais afirmou que "não podem mais se fazer de distraídos". Também exigiu do Governo a implementação de um plano que tivesse o objetivo de "criar 330 mil trabalhos por ano". ${ }^{494}$ Em uma entrevista ao jornal La Nación, o presidente da central assim se expressou:

(...) como o desemprego não vai ser resolvido de um dia para outro, não podemos esquecer de que o

Estado tem uma missão indelegável, que é gerar uma rede de proteção social. É como um circo com acrobatas, onde a primeira responsabilidade do dono é ter uma rede para evitar acidentes. Não há uma fórmula mágica para sair do desemprego. Creio que assim como na ocasião da crise bancária o Governo

\footnotetext{
490 “La CGT reclama al Gobierno ampliar el seguro de desempleo". Clarín, 17/07/1995, p. 2.

491 "Buscan un acuerdo entre CGT y empresarios por el desempleo". Clarín, 18/07/1995, p. 3

492 “Sin despidos por ley”. Página/12, 18/07/1995, p. 9.

493 "Insólita CGT: pidió prohibir la desocupación por decreto". Ámbito Financiero, 18/07/1995, p. 4.

494 "Gobierno, empresarios y CGT discutirán soluciones para el desempleo". Clarín, 20/07/1995, p. 8. 
saiu para buscar fundos de qualquer lado para o fundo fiduciário, deveria se fazer o mesmo para criar uma rede de assistência social. ${ }^{495}$

Nesse momento, Martínez era um dos poucos a defender uma política de formação profissional: "não sou dos que pensam que a essas pessoas tem que dar 300 pesos de subsídio pelo desemprego e nos lavamos as mãos. Temos que pensar em capacitá-los". O dirigente acrescentou que a política trabalhista deve ter como pressuposto o controle da inflação: “(...) nenhuma solução poderá ser dada fora da base da estabilidade econômica. A estabilidade não é um meio nem um fim, se não uma necessidade, e rompê-la é entrar em uma rua sem saída". ${ }^{496}$

A outro jornal, esse dirigente assim se expressou: "Não se pode dizer que falar de subsídio para o tema do desemprego é ruim, mas quando se fez para ajudar o mercado financeiro ninguém dizia que era grave". Martínez argumentava também que "dentro da estabilidade é possível e necessário que exista justiça social" e que "é impossível a solidariedade social com base em um modelo econômico que está concentrado em dez grupos empresariais". 497

Porém, diante da situação de agravamento do desemprego, a própria CGT demonstrou sua incapacidade de oferecer uma assistência aos desempregados. Diante da proposta do Governo de assistência a este setor, brindando-os com cobertura médica gratuita, a central argumentou que tal medida provocaria um "colapso" no sistema de saúde. Para o secretário dessa área, José Rodríguez, "É impossível oferecer prestações a custo zero porque os gastos das obras sociales não somente aumentaram nos últimos anos em forma vertiginosa, mas também sofreram uma queda nas arrecadações". 498

Nesse contexto Martínez endurecia suas críticas ao Governo, enfatizando que suas políticas eram contraditórias ao justicialismo: "É inacreditável que um governo de signo justicialista não reaja para atender os problemas sociais e satisfaça todas as demandas empresariais". ${ }^{499}$ Chama a atenção também acerca das posições dos principais sindicatos industriais do país. O Smata seguia argumentando contrariamente às medidas flexibilizadoras

\footnotetext{
495 “Dura autocrítica del jefe de la CGT”. La Nación, 24/07/1995, p. 4.

${ }^{496}$ Idem.

497 "Reclamo de la CGT al bloque del PJ y al ministro de Acción Social. Piden un fondo para desocupados". Clarín, 22/07/1995, p. 5.

498 "Las obras sociales dicen que no podrán cubrir a los desocupados". Página/12, 22/07/1995, p. 6.

${ }^{499}$ Clarín, 09/08/1995, p. 5, ASASSG, s/r.
} 
propostas pelo Governo e destacando a importância do papel social que cumpriam os empresários sobre a geração e manutenção do emprego. ${ }^{500}$

O presidente da UOM, Lorenzo Miguel, enfatizava mais diretamente a responsabilidade do Governo sobre o crescimento do desemprego. O dirigente criticou a política comercial e industrial, e se opôs às reformas sugeridas a partir do argumento do custo trabalhista: "Eu não creio que, como diz o Governo, com isso (...) vai haver mais trabalho, porque nos esquecemos da indústria nacional; nos esquecemos da importação que a está destruindo (...)". 501 A CGT jamais esteve de acordo com a tese do "custo do trabalho", sustentada pelo argumento patronal de que a redução das contribuições geraria postos de trabalho. Em uma nota referente ao $1^{\circ}$ de maio, a central assim se expressa sobre o tema:

Para o enfoque neoliberal, o mal chamado 'custo do trabalho é a única causa do desemprego, responsabilizando assim, pela crise existente, os trabalhadores, suas organizações sindicais e a própria sociedade. Essa visão motivou diversas medidas oficiais para desregulamentar o sistema trabalhista e reduzir as contribuições patronais às obras sociales. Supunha-se que este era o caminho para criar novos empregos. $^{502}$

Martínez expressava uma posição contrária à redução da jornada de trabalho como proposta para combater o desemprego, mas alguns setores a defendiam sem que jamais tenha adquirido um peso hegemônico na central. ${ }^{503}$ Nesse contexto, alguns sindicatos exigiam uma postura mais combativa da CGT em relação ao Governo e aos empresários. Por exemplo, a UOM reivindicava da central uma "atitude mais frontal e decidida em defesa dos trabalhadores". Sustentava também que "O diálogo e a concertação são úteis quando se fazem de boa fé, mas se só servem para dilatar soluções, são um engano para os trabalhadores”. Essa entidade apresentou uma crítica ao Governo, reivindicando do mesmo uma política industrial

\footnotetext{
${ }^{500}$ Em uma nota do Sindicato lê-se: “(...) rejeitamos a imposição de normas que consagrem a denominada 'flexibilização trabalhista', na medida em que ficou plenamente demonstrado - no nível nacional e internacional - que não cria novos empregos e que, pelo contrário, somente serve para precarizar os já existentes e para incrementar os lucros dos empresários”. Sobre os empresários, destacou que estes "(...) menosprezando sua responsabilidade social como tais, tratam de fazer recair todo o peso da crise nas costas dos trabalhadores". "Smata. Declaración del IV Congreso Nacional de Delegados del Movimiento Nacional Automotriz". Solicitada. Clarín, 04/08/1995, p. 23.

501 “Severa crítica de Lorenzo Miguel al Gobierno". 27/08/1995, p. 15, ASASSG, s/r.

502 "1 $1^{\circ}$ de Mayo. Día del Trabajo. Trabajemos juntos para que el país se ponga de pie". Solicitada de la CGT. Página/12, 30/04/1996, p. 6. Setores internos da CGT também faziam críticas pontuais a determinadas políticas do Governo. Entre as resoluções do $23^{\circ}$ Congreso Nacional de la Asociación Bancaria, se encontram: "Rejeitar as propostas de privatização das instituições financeiras estatais"; "Repudiar o rebaixamento das contribuições patronais"; e "Denunciar o Ministério do Trabalho que, atuando como apêndice do Ministério da Economia, favorece o setor empresário". "Asociación Bancaria. 23 Congreso Nacional Bancario". Solicitada de la Asociación Bancaria. Clarín, 20/06/1996, p. 9.

503 “La CGT propondrá menos horas de trabajo para crear empleos". La Nación, 29/04/1996, p. 6
} 
e de comércio exterior mais favorável para a geração de emprego no país. Ademais, argumenta que:

É imperioso gerar, a partir da condução econômica, uma verdadeira política industrial, que apóie e fomente o papel transformador da indústria argentina, em sua dupla função de produtora da riqueza e fonte de trabalho para a sociedade. Há que terminar com a absurda abertura da economia, que inunda de produtos estrangeiros nosso país, enquanto aqui se fecham as fábricas e se joga os trabalhadores no desemprego. ${ }^{504}$

Apesar da proposta de criação de uma "rede de assistência social" aos desempregados, houve quem afirmasse que a central não representou esse setor como deveria, tal como se pode observar na declaração do sindicalista eletricitário, Oscar Lescano: "não podemos nem passar na frente de uma fila de desempregados; creio que até nos pegariam". 505 Questionado por outro órgão da imprensa sobre essa afirmação, o dirigente reiterou: "disse isso porque tenho consciência e porque sei que não defendemos os trabalhadores como corresponde". 506

No período analisado a CGT jamais expressou uma preocupação pela organização dos desempregados para a luta, focalizando sua estratégia em reivindicar do Governo uma solução para o desemprego a partir de um "acordo social". Ao longo de 1996, suas bandeiras não se modificaram consideravelmente, pois se baseavam, de um lado, na proposta de assistência aos desempregados, e do outro, na reivindicação de uma política de estímulo à produção e às PMEs, vistas pela central como as principais geradoras de emprego. Sobre o tema, Martínez sustentou:

Temos que buscar soluções entre os diferentes setores envolvidos. Nós, trabalhadores, consideramos que políticas de incentivo ao desenvolvimento das pequenas e médias empresas pode ser um elemento importante para diminuir o desemprego. Há que se estimular a produção, redistribuir a riqueza e procurar evitar as assimetrias sociais. ${ }^{507}$

Entre agosto e setembro de 96 a CGT convocou duas greves gerais que significaram o momento de maior conflitividade da central durante o governo de Menem. Depois dessas paralisações, o Governo seguiu com sua tentativa de aprovar a flexibilização, mas encontrou muitas críticas da entidade. Nesse momento, o secretário de imprensa da central, West

\footnotetext{
${ }^{504}$ Sobre o impacto das políticas econômicas sobre o desemprego, a UOM declarou: "Frente a esta realidade social grave e injusta, rejeitamos que em nome da pseudo-filosofia do 'mercado' se tente aprofundar o ajuste econômico, provocando maior marginalidade, desocupação e perda de direitos sociais dos trabalhadores". "Declaración de principios del Congreso Nacional de Delegados de la UOM". Congreso Nacional de la UOM. Solicitada de la UOM. Clarín, 18/12/1995, p. 48.

505 "La CGT anunció otro paro general". Clarín, 14/02/1996, p. 15.

506 “Cada día nos engañan más”. Entrevista a Oscar Lescano. Página/12, 17/02/1996, p. 6.

507 "Estimular la producción”. Entrevista a Gerardo Martínez. Clarín, 14/04/1996, p. 5.
} 
Ocampo, por exemplo, afirmava que a proposta "busca desumanizar o trabalho, reduzir o salário e terminar com a unidade familiar". ${ }^{508}$ Nessa conjuntura, a CGT apresentou um projeto intitulado Contra el desempleo y el crecimiento sin conflito social, no qual expôs suas propostas "para combater o desemprego e reativar a economia". Nesse documento a central defendeu a "redução das horas de trabalho sem redução dos níveis salariais" e "aplicar seletivamente o IVA (uma menor taxa para bens de consumo massivo e maior para bens de consumo supérfluos)". Em seu diagnóstico a CGT afirmava que a flexibilização trabalhista "não é uma ferramenta eficaz para gerar emprego". A entidade também expôs entre suas bandeiras uma política comercial que estimulasse a exportação e a produção de bens (...) de alto valor agregado" e uma importação seletiva, "pondo ênfase naqueles indispensáveis para o desenvolvimento da produção e não de bens meramente de consumo que "terminam desprotegendo' a economia local". Por fim, a CGT também considerou importante uma política de reindustrialização, que se baseasse no "investimento de fontes de trabalho orientado à produção de bens". 509

Apesar da crescente resistência cegetista, o Governo aprovou por meio de um decreto a desregulamentação das obras sociales, que passariam a ser livremente escolhidas pelos trabalhadores. ${ }^{510}$ A partir desse momento, os principais sindicatos da CGT expressaram uma atitude mais conflituosa com o Governo, responsabilizando-o pela situação do país. Lorenzo Miguel, da UOM, afirmou que "A presidência do companheiro Menem não está ajustada à realidade do justicialismo" ${ }^{511}$, e em uma nota do Sindicato de Luz y Fuerza, lê-se:

Teria sido ingênuo pensar que os sindicatos e seus dirigentes não iam pagar um alto preço por dizer 'basta' ao insaciável afã de lucro dos patrões e à indiferença cúmplice de alguns funcionários oficiais. (...) Os trabalhadores têm as costas largas, mas não têm uma paciência infinita. Os que querem ouvir devem saber [que] se terminaram as palavras (...). ${ }^{512}$

\footnotetext{
508 "Rechazo a la flexibilización. La CGT, en estado de alerta”. Clarín, 04/10/1996, p. 4.

509 "Propuesta de la CGT: cada maestro con su librito". Página/12, 05/10/1996, p. 6. Em um artigo no qual expôs os "programas para combate à emergência ocupacional" de várias entidades, o jornal Clarín assim resumiu as propostas da CGT: "aumento de recursos e de beneficiados do seguro de desemprego"; "vantagens tributárias e financeiras para as empresas que criem postos de trabalho estáveis"; "reforma do sistema tributário pondo maior pressão fiscal nos setores que obtém maiores lucros e reduzindo o IVA para os bens de consumo massivo"; "fortalecimento do papel dos sindicatos e das negociações coletivas"; "redistribuição da jornada de trabalho tendo a redução horária sem redução dos salários e com cobertura das horas vagas com novos contratos". "Flexibilización: propuestas alternativas". Clarín, 06/10/1996, p. 9.

510 “Los trabajadores podrán elegir libremente su obra social”. Clarín, 08/10/1996, p. 2.

511 “Lorenzo le apuntó otra vez a Menem”. Clarín, 19/10/1996, p. 5.

512 "Las espaldas bien anchas. No es la primera vez que ocurre, ni tampoco será la última". Solicitada de la Federación Argentina de Trabajadores de Luz y Fuerza. Clarín, 29/10/1996, p. 20.
} 
Assim, as críticas dirigidas ao Ministério da Economia tomaram a forma de manifestações contra o Governo e Menem, conforme explicitou o presidente da central, Rodolfo Daer: “(...) não tenho dúvida de que o caminho que [o presidente] está levando adiante não é o correto. Quero ser claro: Menem é quem elege seus ministros e é o responsável de que não haja uma justa distribuição da riqueza". 513

Em meio a acusações de corrupção na Alfândega, a CGT decidiu realizar uma "marcha sem paralisação" até a instituição. O protesto foi convocado "em repúdio aos atos de corrupção que se detectaram nesse organismo e que 'significaram a perda de milhares de postos de trabalho"” e as "indiscriminadas políticas de abertura". Para Daer, "A marcha à Alfândega tem uma explicação concreta: esse lugar tem se convertido em um centro de corrupção que destruiu as economias regionais e que fez perder inúmeras fontes de emprego". ${ }^{514}$ Após a reunião em que se decidiu realizar esse protesto, Ocampo deu a seguinte declaração: “Os 3.5 milhões de desempregados são nossos e não de um partido político. Se não os representamos, quem vai defendê-los?". ${ }^{515}$ Nesse contexto, a posição contrária ao Governo de Menem se aprofundou. Vejamos como se expressa o Smata sobre esse processo:

No ano de 1989, nós, trabalhadores argentinos, majoritariamente apoiamos, de forma desinteressada e sem condicionamentos, o Governo Justicialista, porque acreditávamos sinceramente (...) que encarnava o projeto que melhor garantia a instauração de uma Democracia com Justiça Social. Durante os anos seguintes, aceitamos responsavelmente os sacrifícios que nos impunham - além de que buscávamos ser escutados para advertir que as cargas não estavam sendo repartidas equitativamente entre todos os setores da sociedade -, no entendimento que estávamos coadjuvando, com isso, a capitalizar o País e a pôr em andamento suas estruturas produtivas. Hoje, depois de mais de sete anos de Governo, os resultados estão à vista: uma taxa de desemprego e subemprego que constitui um triste recorde na história de nosso País $(\ldots) .^{516}$

A preocupação principal da CGT nesse momento, de acordo com seu secretário geral, Rodolfo Daer, era de instalar "um profundo debate para resolver o problema do desemprego", que segundo o dirigente não se resolveria somente com "modificações na legislação trabalhista, mas discutindo temas mais profundos que tem a ver com a política econômica do

\footnotetext{
513 “Nuestro candidato es Eduardo Duhalde”. Entrevista a Rodolfo Daer. Página/12, 29/10/1996, p. 14.

514 "Marcha a la Aduana sin paro. La CGT dosifica su protesta". Clarín, 12/11/1996, p. 10.

515 “Se decidió en Mar del Plata el nuevo paro de la CGT”. La Nación, 11/11/1996, p. 8. Nessa fala se encontra uma pista importante para compreender a política cegetista para os desempregados. Para a central, esse segmento deve ser contemplado por meio da pressão sindical, que deve buscar evitar as demissões e propor políticas para gerar postos de trabalho.

516 "El voto: una herramienta fundamental en manos de los trabajadores". Solicitada del Smata. Clarín, 05/12/1996, p. 62).
} 
Governo". A CGT defendia nesse momento a incorporação das PMEs nas discussões porque, segundo Armando Cavalieri, a Unión Industrial Argentina (UIA) e o Consejo Empresario Argentino (CEA) representam setores que "não são os que dão emprego". 517 Nessa mesma linha, Ocampo afirmou: "Não queremos negociar com banqueiros que recebem as taxas mais altas do mundo (...). E pretendemos que estejam as pequenas e médias empresas, que são as que efetivamente dão trabalho". 518

Alguns sindicatos também apresentaram propostas de redução da jornada de trabalho. Na UOM, por exemplo, Francisco Gutiérrez afirmou: “Aqui há um problema que é o desemprego. Então, por que não começamos a estudar a redução das horas semanais de trabalho para poder ocupar mais gente?". O dirigente declarou também que os empresários, "valendo-se do alto índice de desemprego, querem impor a perda de direitos". Também ressaltou que "A CGT fez uma agenda para discutir este modelo econômico que é o que produz desemprego: desde a convertibilidade, até a abertura, passando pela política financeira". Por último, Gutiérrez argumentou:

O Governo dizia que com a redução de contribuições se criaram empregos. Dessa maneira os empresários pouparam 3.500 milhões de pesos, mas não criaram nem um só posto [de trabalho]. Depois disse que essa mudança, ao menos, melhoraria a arrecadação fiscal. Mas também não sucedeu. ${ }^{519}$

A respeito do setor empresarial, Daer sustentava que os empresários argentinos eram "de quarta [categoria]" e que não tinham uma "concepção de país", o que se remete à defesa da aliança com a burguesia nacional almejada pela CGT. Sobre a proposta cegetista para o desemprego, Daer defendia nesse momento:

Que o seguro-desemprego seja para todos os desempregados, não para uma ínfima porção. Que haja prêmios e castigos para os empresários de acordo aos postos de trabalho que gerem. Que existam políticas de crescimento, uma estratégia agressiva de fomento às exportações. ${ }^{520}$

\section{As greves gerais do período}

A seguir apresentarei uma breve descrição das quatro greves gerais convocadas pela CGT durante o período considerado neste item. Enfatizarei como foram tratadas nesses

\footnotetext{
517 “Diálogo con empresarios y gobierno. La CGT preparó su libreto”. Clarín, 23/01/1997, p. 5.

518 "La CGT quiere que las Pymes se sumen al diálogo". Clarín, 30/01/1997, p. 8.

519 "El hombre de Lorenzo en la CGT. 'O los tres decretos o nosotros"”. Página/12, 28/01/1997, p. 8.

520 “Advertencia de Daer: 'Vendrá la rebeldía popular’”. Entrevista a Rodolfo Daer. Clarín, 27/01/1997, p. 5. Por último, o sindicalista advertiu também que se não abaixasse o desemprego, viriam "tempos de rebeldia popular, porque as pessoas se cansam".
} 
eventos as causas e possíveis soluções para o desemprego, a política para os desempregados e a reforma trabalhista, tendo em conta a leitura que a central fazia da conjuntura nacional.

\section{A greve geral de 6 de setembro de 1995}

No contexto de aumento da pressão cegetista por uma resposta do Governo para a situação do país, a central decidiu convocar uma paralisação nacional para o dia 6 de setembro "contra o plano econômico", "contra o desemprego" e "em defesa do pleno emprego". Sob a consigna "Para que o país se levante" e batizada de "Marcha pelo Trabalho", o protesto logo teve a adesão da CTA e do MTA. Em uma nota, a entidade assim descreveu a conjuntura:

Um país onde o crédito fomenta a especulação, onde não se protege a pequena e média empresa e há 3.000.000 de desempregados, é (...) um país onde a produção não importa; onde muitos poucos são donos do capital; onde 18.6 não é só um número frio, mas milhões de famílias que estão passando fome. É um país pequeno, para poucos. ${ }^{521}$

Em outro documento a central expressou que o movimento operário “(...) adotou a filosofia justicialista desde o momento em que foi formulada. E para o Justicialismo a base da sociedade é a cultura do trabalho, a justiça social e a afirmação da Nação. É absolutamente contraditório que o Peronismo provoque desemprego". Também afirma que "O Movimento Operário Organizado aceita a discussão de todos os temas que se estime conveniente, mas em forma orgânica e institucionalizada, porque nós, trabalhadores, temos direito a participar da tomada de decisões dos temas que nos afetam. ${ }^{522}$ Nessa passagem fica claro como se justifica a política participacionista defendida pela CGT, tal como mencionei no início deste capítulo.

Logo após a greve, o governo aprovou uma nova lei de acidentes que, sob o argumento de reduzir os custos trabalhistas e acabar com a "indústria dos processos", entre outras medidas estabeleceu o topo de indenizações e a criação das Aseguradoras de Riesgos de

\footnotetext{
521 "Marchamos todos al congreso". Solicitada de la CGT. Clarín, 05/09/1995, p. 26.

522 Entre as propostas para o desemprego, o documento destacava "promover a obra pública com sensatez e atendendo objetivos de rápida incidência social"; "as pequenas e médias empresas devem receber um apoio creditício incondicional"; "Defender a industrial nacional (...)"; "o comércio exterior deve ser uma prioridade (...); “(...) defender nossa produção do dumping internacional”; “(...) reestruturação do sistema financeiro, para direcioná-lo ao serviço da produção”; “(...) taxas de juros não usurárias; “(...) ampliar o seguro-desemprego para cobrir a todos os chefes de família, possuam ou não ambigüidade em sua última ocupação" ("En defensa de la producción y el trabajo". Solicitada de la CGT. Clarín, 06/09/1995, p. 5; Página/12, 06/09/1995, p. 4). Em uma nota sobre a greve, a UOM, ao apresentar suas propostas para gerar emprego, ressaltou: "Que ninguém veja arrogância em nossa convocação. É somente o cumprimento do compromisso histórico entre a Unión Obrera Metalúrgica, o peronismo e o povo trabalhador" ("Todos unidos triunfaremos. La UOM y la marcha del 6 de septiembre". Solicitada de la UOM. Clarín, 05/09/1995, p. 31).
} 
Trabajo (ART), empresas de seguro de acidentes de trabalho. ${ }^{523}$ Nesse contexto, o presidente da CGT continuava demonstrando sua insatisfação com os rumos do país: “(...) o Governo não deu a importância que tem ao problema do desemprego". Porém, seguiu com o discurso de não responsabilizá-lo a partir do argumento da "politização" do desemprego: "É necessário despolitizar o tema e começarmos a trabalhar seriamente; basta de palavras e vamos aos fatos, as pessoas estão se cansando de palavras, discursos e justificativas". ${ }^{524}$

A greve teve como a abertura de um canal de diálogo e concertação. A partir de outubro, governo, empresários e a central se sentaram para discutir o problema do desemprego. ${ }^{525}$ Martínez se expressou de maneira positiva sobre a iniciativa: "Esta mesa é a alternativa para levar adiante as distintas fórmulas para resolver o problema da falta de emprego. O desemprego é uma consequiência, e portanto, esta mesa tem que se dedicar a analisar as causas que o originou". 526

\section{Convocação e suspensão da greve geral de 26 de março de 1996}

Em março de 1996, a CGT convocou uma paralisação, sob o argumento da ausência de políticas de Governo para combater o desemprego. O sindicalista eletricitário Oscar Lescano afirmou que esta greve se justificava porque “(...) o Governo não se ocupa dos que estão fora do mercado, que são 3.5 milhões de desempregados". O dirigente assinalou também a posição da central nesse momento a respeito do Governo: “A CGT historicamente é peronista e é parte do Governo. Mas nos comprometemos no último congresso a ser independentes (...)". A partir dessa declaração pode-se dizer que se até os primeiros meses da condução de Martínez, as ações e representações feitas pela central estavam comprometidas com a associação da cúpula com Menem, a partir da greve de setembro se verificou uma mudança de postura. Questionado se esta reação não havia sido tardia, Lescano respondeu: "Mas agora basta. Basta. Estamos nos dando conta de que cada dia nos enganam mais”. Por último, vale destacar sua declaração a respeito das privatizações:

Eu apoiei as privatizações e tudo isso. É verdade. Mas hoje estou arrependido. Se tenho 50 por cento menos de afiliados, alguns trabalhando com contratos temporários, de maneira degradante, sem segurança, com quase 50 por cento menos de salário... como posso estar de acordo [?]. Agora,

\footnotetext{
${ }^{523}$ Clarín, 14/09/1995, p. 24, ASASSG, s/r.

524 “Desocupación: negro vaticinio de la CGT”. Diario Popular, 05/10/1995, p. 2.

525 "Mesa de tres patas para la desocupación". Clarín, 07/10/1995, p. 10.

526 "Sólo intenciones para combatir el desempleo". La Nación, 07/10/1995, p. 3.
} 
simultaneamente, te digo que o país [está melhor] em minha área, tem mais investimento e não tem os padecimentos que tinha em ' 88 (...). ${ }^{527}$

Em diversos momentos se verifica a estratégia da central de confrontar para negociar sob um pacto social tripartite, este último visto como uma reivindicação em si mesma. No Brasil, como vimos no capítulo anterior, esse tipo de estratégia é um elemento fundante da ideologia político-sindical da Força Sindical. Na Argentina, essa fórmula, consagrada historicamente pelo setor propositivista/participacionista da CGT, é verificável na convocatória da paralisação de 26 de março, na qual a central propôs um "amplo Acordo Social para lograr um desenvolvimento produtivo que acabe com o hiperdesemprego, o subemprego e a miséria dos aposentados". Nesse documento se reafirmaram as propostas para o desemprego apresentadas na greve de 6 de setembro de 1995. ${ }^{528}$ Para Martínez: "Sempre há a possibilidade de se chegar a um acordo por meio do diálogo, porque minha intenção é somente resolver os problemas dos trabalhadores sem nenhuma outra especulação política". ${ }^{529}$ Por sua vez, Ocampo, secretário de imprensa da central, afirmou: "Estamos cheios de conversações". ${ }^{530}$ Sobre as causas da paralisação, este mesmo dirigente esclareceu a outra nota que a central buscava uma: "Solução para o desemprego e as economias regionais, a reativação industrial e os problemas originados pela falta de proteção à indústria nacional e de crédito para as PMEs". Entre as reivindicações feitas pela CGT na convocatória do ato, o governo aceitou a criação do Consejo Nacional del Trabajo y del Empleo, como uma instância de diálogo para discutir saídas para a problemática, o que levou a central a suspender a greve:

Suspendemos a paralisação do último dia 26 de março porque o Governo aceitou nossa proposta e criou o Consejo Nacional del Trabajo y del Empleo. Entendemos que o mesmo é um âmbito propício para o diálogo concertativo e para lograr uma imediata trégua social que possibilite um grande acordo de todos os setores. A defesa dos direitos dos trabalhadores não vamos negociar. ${ }^{531}$

Em meados de julho, o Governo reduziu as asignaciones familiares ${ }^{[532]} \mathrm{e}$ eliminou a isenção de tarifas sociais dos tickets canasta $^{[533]}$. Essas medidas levaram a CGT a ameaçar

\footnotetext{
527 “Cada día nos engañan más”. Entrevista a Oscar Lescano. Página/12, 17/02/1996, p. 6.

528 "Paro general el 26 de marzo. Protesta y propuesta de la CGT para que el país se ponga de pie. Trabajo y dignidad para todos los argentinos". Solicitada de la CGT. La Nación, 25/02/1995, ASASSG, s/r.

529 "La CGT le pone fecha al paro y después negocia con el Gobierno". Página/12, 20/02/1996, p. 6.

530 "La CGT ratificó que habrá paro general”. Clarín, 23/02/1996, p. 19.

531 "Pesimista, la CGT se reúne con el Gobierno". 21/02/1996, ASASSG, s/r.

532 Trata-se de um benefício pago aos trabalhadores formais correspondente a um adicional no salário proporcional ao número de filhos.

${ }^{53}$ Semelhante ao nosso vale alimentação.
} 
com uma greve geral e se retirar do conselho. ${ }^{534}$ Este evento marcaria um novo momento de confrontação.

\section{A greve geral de 8 de agosto de 1996}

Em fins de julho, a CGT propôs uma greve para o mês de agosto, que contou com a adesão do MTA e da CTA. Segundo Gerardo Martínez, presidente da central, tratava-se de uma greve "contra o Governo em seu conjunto, que é responsável pelo que está ocorrendo. Não sei porque o Governo, que tem que velar pelo bem comum, não entende esse momento de miséria, de marginalização". ${ }^{535} \mathrm{O}$ dirigente justificou sua postura com o argumento de que, por ser parte do Governo, deveria ser consultado institucionalmente sobre as principais decisões do país. Em outra declaração, o dirigente afirmou:

É que não nos consultaram e acreditamos que esses anúncios aprofundam o atual modelo de exclusão social e deixam mais indefesos os trabalhadores, que terminam sendo a variável de ajuste da má administração orçamentária dos funcionários do Ministério da Economia e do Trabalho. ${ }^{536}$

Em uma nota, a Uocra assim apresentou a bandeira da greve: "em defesa do salário dos trabalhadores, degradado ainda mais pelas últimas medidas econômicas implementadas pelo governo". ${ }^{537}$ A paralisação teve uma alta adesão, fato reconhecido inclusive pelo ministro de Trabalho, Armando Caro Figueroa: "É a greve mais importante que fizeram contra nós". 538 Para os dirigentes cegetistas, após a paralisação, a reabertura do diálogo com o Governo estava condicionada a mudanças na política econômica. Nesse contexto, Martínez declarou: "Se soubéssemos desses resultados, não teríamos acompanhado esta transformação". 539

\section{A greve geral de 26 e 27 de setembro de 1996}

Mas os rumos políticos não mudaram e, no final de agosto, depois de um conflituoso processo de decisão, com troca de tiros entre os grupos de choque da CGT e do MTA, a central convocou uma greve geral de 36 horas com mobilização. ${ }^{540}$ Nesse contexto, Gerardo Martínez renunciou à condução da CGT, sendo substituído por Rodolfo Daer. Em uma

\footnotetext{
534 “La CGT pegó un portazo en el Consejo y va al paro”. Página/12, 16/07/1996, p. 4.

535 Para Moyano, "Não podemos suportar esse plano de fome nem esperar para o que faz a condução dessa CGT inexistente".

536 "El paro es contra el Gobierno". Clarín, 26/07/1996, p. 18.

537 "Paramos porque el amor a la justicia y la equidad social enciende nuestros reclamos". Solicitada de la Uocra. Clarín, 30/07/1996, p. 10

538 “Es la huelga más importante”. Clarín, 09/08/1996, p. 4.

539 "El Gobierno quiere dialogar, pero la CGT pone condiciones". Clarín, 09/08/1996, p. 5.

540 “CGT aprobó paro y marcha. Cambio de cúpula. Un pasito adelante, María”. Página/12, 24/08/1996, p. 7.
} 
declaração, aquele dirigente afirmou: "Apesar de muitos dizerem que sou oficialista, fiz duas greves contra o Governo e agora convoquei uma terceira que se fará antes do final de setembro". A respeito das políticas frente ao desemprego, Martínez afirmou: "A flexibilização trabalhista, a abertura econômica indiscriminada, a precarização do trabalho e desmantelamento do Estado jamais poderão ser os meios adequados para garantir o emprego". ${ }^{541}$ Em relação à greve, o dirigente sustentou: "Esgotamos as instâncias de concertação. Esforçamo-nos ao máximo, mas o Governo nos golpeou; não considerou nossas propostas. Temos agora todo o direito de transitar o caminho da luta". ${ }^{542}$ A greve geral, convocada contra a política econômica e a flexibilização trabalhista, se realizou no dia 26 e 27 de setembro, com adesão do MTA e da CTA. Teve uma alta adesão, e o ato na Plaza de Mayo foi o mais numeroso da década, com 70.000 manifestantes. O movimento operário chegou a seu mais alto grau de unidade no período menemista. Porém, o Governo afirmou que a aprovação da lei de flexibilização seria feita por decreto, o que fez a CGT ameaçar com uma greve geral por tempo indeterminado em 18 de novembro. O Governo se viu debilitado, sendo obrigado a retroceder em sua decisão, ao menos temporariamente.

\section{A greve geral de 26 de dezembro de 1996}

Apesar da pressão sindical, o Governo aprovou a flexibilização trabalhista por decreto no mês seguinte. Diante dessa medida, a CGT convocou a uma greve geral de 24 horas sem mobilização para o dia 26 de dezembro, em conjunto com a CTA e o MTA. A medida teve uma adesão parcial, e foi classificada pela imprensa como um "prolongamento do feriado" e, por isso, logo foi batizada de "greve natalina". A respeito dos resultados do protesto, o presidente da central, Rodolfo Daer, declarou: "Esperamos que [o Governo] reaja e habilite uma mesa para concertar. E que, ademais, retire os decretos, que não só prejudicam os trabalhadores, mas criam insegurança jurídica”. Daer considerava que esses decretos eram “infames e inconstitucionais" e que cumpria exigências externas, e que o presidente Menem estava sendo pressionado pelas instituições financeiras internacionais: "As exigências do Banco Mundial estão acima das exigências dos empresários argentinos". 543

$$
* * *
$$

\footnotetext{
541 "Flexibilización: Martínez volvió a cargar contra el Gobierno". Clarín, 02/09/1996, p. 7.

542 “El paro viene como feriado largo". Página/12, 03/09/1996, p. 5.

543 “El día que el jueves se transformó en sábado”. Página/12, 27/12/1996, p. 2.
} 
A atuação da CGT entre setembro de 1995 e dezembro de 1996 relativiza a idéia de que não houve resistência da central em relação às políticas levadas a cabo por Menem. Durante esse período de um ano e três meses a central convocou quatro greves gerais contra o desemprego, a flexibilização e em oposição a determinadas medidas anunciadas pelo Governo. A CTA e o MTA participaram desses protestos, que tiveram um alto grau de adesão e representaram o momento de maior unidade na ação do movimento operário argentino do período. Esses eventos também testemunharam o forte poder de convocação da CGT, que por representar os principais sindicatos nacionais foi a única que ainda conseguia paralisar o conjunto das atividades produtivas do país.

\section{O MOP}

Depois de deixar a condução da central, o grupo representado por Antonio Cassia conformou uma corrente denominada Movimiento Obrero con Propuestas (MOP), caracterizada por sua posição menemista e apoio explícito a todas as propostas do Governo. Nesse período, o discurso oficial dos sindicatos nucleados nesse setor (tais como Supe, Foetra, AOT, etc.) diante da convocação da greve de 8 de agosto recomendar a suspensão do protesto. Segundo Cassia, o movimento operário "corre o perigo de ficar isolado" já que "todos os setores abriram um crédito ao novo ministro da Economia, e a CGT deveria seguir o mesmo caminho". ${ }^{544}$ A postura oficialista desse setor pode ser confirmada nas declarações de seus dirigentes e em algumas notas, como a que publicou contra a marcha à Alfândega convocada pela CGT:

Confiamos que o Partido Justicialista ao qual majoritariamente pertencemos ocupe o lugar natural no acompanhamento ao nosso Presidente, que tem demonstrado que com seu próprio esforço tem sido capaz de superar problemas, ofensas e difamações sem alterar sua decisão de pôr em marcha uma Argentina que garanta eqüidade e igualdade de oportunidades no marco da democracia e do pleno exercício das liberdades. ${ }^{545}$

Nesse mesmo documento se lê uma avaliação a respeito do ato: "Não basta dar um abraço simbólico a um edifício para defender a justiça independente nem caminhar até a Alfândega para combater a corrupção ou repetir até o cansaço que 'o modelo está esgotado' ”. O grupo argumentou também que:

\footnotetext{
544 "La CGT ratificó el paro. Los gremios menemistas quieren dar marcha atrás". Clarín, 30/07/1996, p. 6.

545 "El rol del movimiento obrero". Solicitada de la "Mesa Nacional por un Movimiento Obrero con Propuestas". Clarín, 18/11/1996, p. 10.
} 
As organizações sindicais têm um espaço muito mais amplo que o reivindicativo e excluir-nos da mesa onde se discutem as políticas significa deixar em mãos de outros a problemática dos trabalhadores para favorecer as aspirações de quem põe em dúvida a legitimidade de nossa existência. ${ }^{546}$

A postura do MOP se baseava na estratégia de não responsabilizar o Governo pelo problema do desemprego, destacando o contexto mundial e a necessidade de ampliar as reformas, os mesmos argumentos utilizados por Menem e pelo Ministério do Trabalho naquele momento: "Hoje no mundo, o emprego é um bem escasso e nosso país não é uma exceção dentro dessa realidade, que reconhece causas comuns e outras próprias vinculadas a seu próprio desenvolvimento". O MOP também argumentava que os setores opositores "politizavam" a discussão sobre o desemprego: "Para combater o desemprego não há fórmulas mágicas possíveis, nem é eficaz a politização oportunista, as posições extremas ou as promessas que não podem ser cumpridas". Por último, afirmava que o Governo estava tentando resolver o tema: "A alta taxa de desemprego em todas suas formas é uma das maiores preocupações do governo, que sem dúvida compartilhamos, e que requer por parte dos atores sociais um profundo debate e um compromisso sério e responsável”. Em defesa da estratégia de concertação, argumentava: "Devemos recuperar esta instância através do Consejo del Trabajo y del Empleo já que a atual etapa de modernização da legislação não será suficiente sem a criação de emprego genuíno e o investimento comprometido com a produção". ${ }^{547}$ Sobre a flexibilização trabalhista sustentava que esta "também tem se convertido, no mundo, em sinônimo de precarização total das condições de trabalho como conseqüência de exigências desmedidas por parte do poder econômico". ${ }^{448}$ Porém, em outra nota defendeu a medida: "pactuar condições de trabalho flexíveis e modernas NÃO significa precarizar o trabalhador e desconhecer as Organizações representativas de seus interesses, salvo que a real pretensão resulte estabelecer uma hegemonia de poder para uma só das partes". ${ }^{549}$ Ao longo do último período analisado, esse setor ficou cada vez mais isolado, na medida em que a Direção Nacional e os sindicatos mais poderosos passaram a se posicionar contra a flexibilização. Porém, levamos em consideração como uma importante corrente dentro da CGT que, se já não era mais majoritária na central, ainda seguia fazendo eco.

\footnotetext{
${ }^{546}$ Idem.

547 "El desempleo: especulación de algunos, responsabilidad de todos". Solicitada de la Mesa Nacional por un Movimiento Obrero con Propuestas. Clarín, 17/01/1997, p. 10.

${ }_{548}$ Mesa Nacional Movimiento Obrero con Propuestas, enero 1997, ASASSG, s/r.

549 Solicitada de la Mesa Nacional del Movimiento Obrero con Propuesta. 01/04/1997, ASASSG, s/r.
} 


\section{O MTA}

A estratégia do MTA durante o período analisado neste item foi de mobilização constante. O setor seguiu sua posição crítica ao Governo e à política da CGT. A respeito dessa última, Juan Manuel Palacios, da UTA, declarou: “Os dirigentes que estão na CGT são os que aprovaram a lei de falências e de acidentes de trabalho, a reforma do Estado e as privatizações". ${ }^{550}$ O movimento convocou um ato para o dia 20 de novembro de 1995, na Plaza de Mayo, "contra o desemprego e a política econômica e social de Carlos Menem”, que contou com a adesão da CTA e da CCC. A manifestação foi assim definida pelo mesmo Palacios, "No dia 20, em coincidência com o Dia da Soberania Nacional, mobilizaremos com a consigna de resistir ao modelo econômico anti-operário e anti-nacional do governo de Carlos Menem". 551

Durante o ano de 1996, o MTA também manteve uma postura contrária à flexibilização e seguiu responsabilizando o Governo pelo desemprego. Quando da decisão do Governo decidiu o corte das asignaciones familiares e o fim do subsídio dos tickets canasta, o MTA realizou uma marcha à Plaza de Mayo contra essas medidas ${ }^{552}$, assim justificada por Hugo Moyano: "Não podemos suportar esse plano de fome nem esperar para ver o que faz a condução dessa CGT inexistente" ${ }^{, 553}$. Segundo o jornal Clarín, no dia 26 de julho "15 mil pessoas marcharam para reclamar uma mudança da política econômica do governo". ${ }^{554}$ De acordo com matéria publicada no Página/12, as reivindicações do setor opositor eram as seguintes: "trégua social que evite demissões no setor público e privado", "redução da jornada de trabalho sem redução de salários"; "recuperação da indústria nacional"; "apoio às pequenas e médias empresas"; "priorizar a dívida social interna e recuperar o nível de emprego". 555

Quando a CGT convocou a greve de 8 de agosto, o grupo aderiu ao protesto. Isso demonstra que o poder de convocação cegetista era reconhecido pelos rivais, que jamais se opuseram a se somar às paralisações daquela central: "É muito difícil dizer não a uma greve da CGT", afirmou um porta-voz da corrente. ${ }^{556}$ Após a participação nessa greve, o MTA se

\footnotetext{
${ }^{550}$ Clarín, 30/07/1995, p. 7, ASASSG, s/r.

551 "El sindicalismo opositor convocó de nuevo a la Plaza para el 20”. Página/12, 04/11/1995, p. 10). Ver também "El gremialismo combativo, en una marcha a la Casa Rosada", La Nación, 04/11/1995, p. 10.

552 "Marcha del MTA en contra de las medidas económicas". Clarín, 26/07/1996, p. 18; “También es contra los muchachos de la CGT". Página/12, 26/07/1996, p. 6

553 "El paro es contra el Gobierno". Clarín, 26/07/1996, p. 18.

554 "Masiva protesta de gremios opositores en Plaza de Mayo". Clarín, 27/07/1996, ASASSG, s/r.

555 “'La oposición en Plaza de Mayo. 'Cambiar el perro, no el collar'”. Página/12, 27/07/1996, p. 11.

556 "El paro es contra el Gobierno". Clarín, 26/07/1996, p. 18.
} 
reincorporou à CGT. Em setembro os dois setores convocaram juntos uma nova greve, realizada nos dias 26 e 27, e em novembro realizaram uma marcha à Alfândega que terminou em um conflito entre seus grupos de choque. O fato provocou o afastamento de Moyano da central, assim justificada pelo dirigente: "Vou embora da CGT porque estou cansado dos cagüetes do Governo que traem os trabalhadores". E acrescentou: "não se pode seguir aguentando o duplo discurso de seus dirigentes e suas reuniões secretas com funcionários do Governo". ${ }^{557}$ Porém, em dezembro o MTA aderiu à greve geral convocada pela CGT para o dia 26 desse mês.

Durante o período tratado neste item, o MTA participou das quatro greves gerais convocadas pela CGT. Nesse momento os dois setores alcançaram um relativo grau de unidade na luta. No entanto, suas diferenças permaneceram, especialmente na crítica ao Governo de Menem e nos métodos adotados para enfrentá-lo.

\section{A CTA}

Em seu discurso de abertura do Primeiro Congresso Nacional de Delegados, Víctor De Gennaro, presidente da CTA, afirmou que o desemprego era conseqüência irreversível do projeto de acumulação dos grandes grupos econômicos (CTA, 1996a, p. 11). Como contraposição a este modelo, a CTA propunha que "O Estado deve recuperar seu papel de regulador social como forma de proteger as maiorias destruídas pela ideologia de mercado" (p. 40). Nesse evento a entidade decidiu investir em sua "organização territorial", e especialmente na representação dos desempregados: “(...) é preciso facilitar a organização dos companheiros desempregados no interior de nossa central e, em tal sentido, promover um Encontro Nacional de Trabalhadores Desempregados da CTA” (CTA, 1996a, p. 31). Para levar a cabo tal medida, a central passou a investir na "filiação direta", o que segundo a entidade, “(...) permite que os que não integram estruturas sindicais e os que são parte de estruturas irrecuperáveis, incorporem-se a um novo âmbito de representação" (CTA, 1996d). A estratégia de superação do corporativismo promovido pela central se justifica por três pressupostos:

(...) o esgotamento do ciclo político tradicional expressa na gestão dos dois partidos políticos tradicionais; as dificuldades de vertebrar uma força política de novo tipo por uma via de luta exclusivamente

557 “Crisis en la central sindical: hablan de 'traidores' en la CGT”. Clarín, 23/11/1996, p. 7. 
institucional; os limites que exibem nossa própria organização em suas lutas setoriais (CTA, 1996d, p. 17).

Entre as influências ideológicas da CTA, está a militância católica que, embora não tenha sido tão presente quanto no Brasil, desenvolveu-se na esquerda peronista no campo da organização popular. Por tal motivo, a central defendia a necessidade de "(...) articular a experiência da central com uma iniciativa político-territorial mais ampla" o que, segundo o documento citado, significaria “(...) integrar no plano social, três expressões notórias de militância comunitária dos 'últimos tempos'”, quais sejam: Igreja, ONGs e outros movimentos sociais, [além de] meios alternativos". (CTA, 1996d).

A estratégia da CTA, em sua conformação como central, definia-se pela "capacidade de restituir equilíbrios elementares entre os atores", ou "equilíbrios comunitários", a partir das organizações sociais em direção a um "novo esquema de representação", que teria o objetivo de constituir um "bloco social que permita fundar um novo tipo de Estado, cujo sentido, como tal, define-se em sua possibilidade de regulamentar o comportamento dos poderosos". Para tanto, a CTA afirmava que era necessário "governar ainda que sem ser governo", ou seja, “produzir efeitos no terreno político, jurídico, institucional, ideológico e econômico”. Em outras palavras, defendia como objetivo “organizar a demanda social e analisá-la e canalizá-la institucionalmente" (CTA, 1996e, p. 30). ${ }^{558}$

A CTA partia da concepção que a CGT representava o "menemismo sindical", que recebia "como contraprestação a possibilidade de desfrutar 'regalias' do governo e de transitar os despachos oficiais sob o aplauso dos funcionários". Ademais, a entidade ressalta:

O sindicalismo empresarial por sua parte viu crescer seu poderio econômico. Encarou negócios ligados à saúde transformando suas próprias 'obras sociales' em planos de saúde privado. Abandonou a luta pela Previdência Social para transformar-se em donos, sócios ou concessionários das 'Administradoras de Fondos de Jubilaciones y Pensiones' [AFJP]. Avançou com critério comercial na hotelaria, no turismo e na recreação, e participou, inclusive, do 'desmantelamento do Estado, vivendo uma paradoxal transformação: modificou seu papel de representante trabalhista pelo de expressão patronal (CTA, 1996f, pp. 33-34).

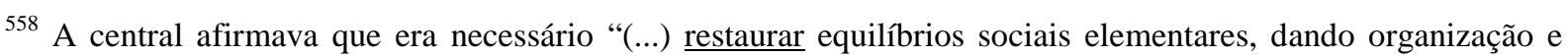
textura institucional às demandas dos trabalhadores", ou ainda, "dotar de maior simetria as relações sociais comunitárias hoje governadas pela lógica revoltante de um só ator social dominante: os grupos econômicos mais poderosos" (CTA, 1996d, p. 31). Outro documento fez referência a uma "estratégia fundada na democratização do movimento operário e dirigida a consolidar uma nova forma de organização dos trabalhadores capaz de restituir poder ao conjunto dos setores populares, excluídos há tempos do modelo cultural, político e econômico que se aplica na Argentina" (CTA, 1996e, p. 33).
} 
No período analisado neste item, a CTA se mobilizou constantemente. Convocou diversos protestos e participou das greves da CGT. Também aderiu à greve de setembro de 1995 com um discurso crítico ao Governo: "para os trabalhadores, na presente política econômica o emprego não existe como objetivo, sua agenda só inclui o custo do trabalho". Na convocatória do ato, a central apresentou as seguintes reivindicações:

(...) mobilizar todos os recursos da Nação com o objetivo de criar fontes de trabalho; (...) derrogar a legislação trabalhista que em nome da modernização e da flexibilização tem conduzido à total desproteção dos trabalhadores e cujo objetivo principal tem sido facilitar a demissão; (...) constituir um Tribunal arbitral com representação operário-patronal que intervenha nos conflitos laborais a fim de evitar novas demissões; (...) criar um Instituto Nacional de Empleo (...) [para] coordenar as estratégias de luta contra o desemprego garantindo subsídios e cobertura de saúde a todos os chefes de família desempregados, vinculando a concessão desses recursos com programas de treinamento e qualificação profissional; (...) incrementar o nível de recursos públicos destinados a financiar políticas de emprego (...); defender a Pequena e Média Empresa (...) que permita um tratamento diferencial em matéria tributária, creditícia e tarifária; (...) defesa dos postos de trabalho no âmbito das grandes empresas da produção; (...) defesa da indústria nacional e políticas de reindustrialização. ${ }^{559}$

No dia 20 de novembro a CTA realizou uma marcha até a Plaza de Mayo. Na convocatória do protesto, De Gennaro afirmou que "se este modelo econômico segue um minuto mais em nosso país, em seis meses mais vamos ter oito milhões de desempregados, porque temos que reconhecer que estamos em uma verdadeira emergência nacional". ${ }^{560} \mathrm{Um}$ mês depois, a CTA convocou uma "Jornada Nacional de Protesto" para o dia 21 de dezembro, justificada pelo presidente da central como uma "oposição a um segundo desmantelamento do Estado, à privatização e ajustes sobre as províncias e à tentativa de outorgar poderes extraordinários ao presidente da Nação". 561

Em 1996, a CTA já buscava representar os desempregados. Uma tentativa de organização desse setor se conformou na adesão da Unión de los Trabajadores Desocupados (UTD) à central, uma experiência pioneira iniciada em Rosario, em 1985. Com condução nacional de Jorge Pendino, naquele ano o movimento nucleava 3.000 desempregados e atuava por meio de uma "pequena empresa-cooperativa" e da "militância sindical". Segundo uma fonte jornalística, a organização tinha como uma de suas atividades mais importantes a

\footnotetext{
559 "Por un país con empleo y dignidad. Para cambiar el modelo de la desocupación. Paro y movilización". Solicitada de la CTA. Página/12, 06/09/1995, p. 9.

560 "El sindicalismo opositor convocó de nuevo a la Plaza para el 20”. Página/12, 04/11/1995, p. 10). Ver también "El gremialismo combativo, en una marcha a la Casa Rosada", La Nación, 04/11/1995, p. 10.

561 “Hoy, protesta del CTA”. Página/12, 21/12/1995, p. 6.
} 
capacitação dos desempregados através de escolas de formação em todo o país, e já havia conquistado algumas metas como "o meio boleto para desempregados, em Rosario, e a assistência de uma obra social à raiz de um convênio inédito com o Sindicato dos Ceramistas". 562

Em fevereiro de 1996, diante da ameaça de greve por tempo indeterminado pela CGT, De Gennaro, da CTA, declarou: “(...) esta é a mesma CGT que um dia pinta a cara e no outro firma a redução das contribuições patronais às obras sociales. Ou seja, a perda de 3.200.000 dólares mensais que poderiam ser destinados ao subsídio de 720 mil chefes de família desempregados". ${ }^{563}$ Apesar das críticas, em seguida a central aderiu às greves convocadas pela CGT de agosto e setembro de 1996.

No período analisado nesta parte, entre as propostas da central para combater o desemprego aparecia o estabelecimento de "uma contribuição de emergência equivalente a $20 \%$ dos benefícios líquidos das 50 primeiras empresas do país" "564; a restituição das "contribuições patronais"; "a redução da jornada de trabalho", "o encarecimento das horas extras"; "a discussão do salário por produtividade para as grandes empresas"; "promoções fiscais para os contratos temporários". 565

A oposição da CTA aos projetos de reforma trabalhista do Governo foi constante. Sobre o tema, De Gennaro afirmou: "estamos preocupados com a tentativa de se legalizar a flexibilidade trabalhista, mas estamos muito mais preocupados porque hoje a melhor flexibilidade trabalhista são os dois milhões e meio de companheiros desempregados". 566

Em 20 de novembro de 1996, a CTA organizou uma marcha ao Congresso para reivindicar uma lei de emergência nacional. Para De Gennaro, “As demissões devem ser evitadas por lei, tanto no setor público como no setor privado, em todo o território nacional e que se derroguem todas as formas de contratação trabalhista temporária". ${ }^{567}$ Um mês depois, a central aderiu à greve convocada pela CGT contra a aprovação da reforma trabalhista.

\footnotetext{
562 “La UTD, un gremio que espera perder afiliados”. El Expreso, 29/01/1996, p. 4.

563 "La CGT le puso fecha a la huelga. El 26, paro sin movilización”. Página/12, 23/02/1996; p. 8.

${ }^{564}$ Segundo o jornal Clarín, em sua proposta, a CTA reivindicou a criação do Instituto del Empleo, que deveria ser financiado (...) com um imposto às 50 empresas líderes e com fundos reservados da Presidência". ("Marcha del sindicalismo opositor. La CTA pide su reconocimiento”. Clarín, 6/11/1996, p. 18).

565 "Flexibilización: propuestas alternativas". Clarín, 06/10/1996, p. 9.

566 "El CTA estrena un encuentro nacional”. La Nación, 1/11/1996, p. 11.

${ }^{567}$ Segundo a fonte consultada, estiveram presentes no ato cerca de duas mil pessoas ("La CTA de marcha y carnaval. Dos mil contra la flexibilización”. Página/12, 21/11/1996, p. 6).
} 
No período estudado nesta parte fica claro que, apesar de participar das quatro greves convocadas pela CGT, a CTA também desenvolveu uma política independente, convocando mobilizações próprias. Ademais, a entidade votou em seu estatuto a afiliação direta de seus membros e investiu na política de representação dos desempregados, incorporando a UTD de Rosario a sua estrutura organizativa.

$$
* * *
$$

No período analisado neste item, a CGT mudou de direção e passou a investir de maneira mais contundente na mobilização contra a política econômica. Também rejeitou aspectos da flexibilização trabalhista, entre outras medidas anunciadas pelo Governo. O MTA manteve sua linha crítica a Menem. Não apresentou uma proposta de organização dos desempregados, mas se mobilizou constantemente contra o desemprego. Entre os três setores, a CTA foi a única que se envolveu diretamente com a representação dos desempregados, abrindo seu estatuto para sua filiação direta. Esse período se caracterizou pelo maior grau de unidade na luta do sindicalismo argentino durante a época de Menem. Foram quatro greves gerais convocadas pelo conjunto das organizações em pouco mais de um ano, duas delas realizadas em um intervalo de um mês e meio com alta adesão e mobilização massiva.

\subsubsection{Os bloqueios de rodovias, o "efeito caipirinha" e o surgimento das organizações de desempregados (janeiro de 1997 a novembro de 1999)}

Com a redução de seus índices, entre o segundo semestre de 1997 e o primeiro semestre de 98, o desemprego perdeu espaço nos jornais consultados, voltando a se tornar central quando a Argentina foi afetada pela desvalorização do real no Brasil no final de 1998. O prolongamento do tempo médio de permanência no desemprego e o aprofundamento do processo de pauperização explicam parcialmente os bloqueios de rodovias, em Neuquén e Jujuy, entre 1996 e 1997. Ademais, com o descrédito do Governo, o justicialista Eduardo Duhalde perdeu as eleições para o candidato radical, Fernando De la Rúa.

\section{A CGT}

Neste item, além das temáticas que vem sendo tratadas, verificarei a seguir as posições tomadas pela CGT acerca do surgimento das organizações de desempregados. Durante esse período, a fratura com o MTA permaneceu até o fim de 1999, quando os dois grupos 
coincidiram no apoio a Duhalde para as eleições presidenciais. A central seguiu sendo conduzida por Rodolfo Daer, que passou a adotar uma postura predominantemente de concertação com o Governo.

\section{A flexibilização}

No primeiro semestre de 1997, as declarações da CGT expressavam uma rejeição às propostas de flexibilização trabalhista. Baseando-se na leitura de que essa medida não configuraria uma saída para o desemprego, mas que, ao contrário, provocaria precarização dos empregos existentes, a central afirmou:

É indispensável corrigir o mau funcionamento do mercado de trabalho e devem ser criadas condições objetivas que, preservando a estabilidade, a competitividade e o crescimento, assegurem trabalho e uma distribuição equiitativa da riqueza. (...) A desregulamentação trabalhista tem tirado segurança no emprego e tem reduzido a proteção social. ${ }^{568}$

Porém, em junho de 1997 a central chegou a um acordo com o Governo e firmou a chamada Acta de Coincidencias. Segundo a CGT, este documento estava a favor: "da segurança e estabilidade no trabalho"; "de reafirmar o modelo de negociação coletiva, democrática e equilibrada"; "de revitalizar o modelo de organização sindical vigente, garantindo a associação com personería gremial, e sua intervenção necessária na concertação de convênio e acordos coletivos"; "da democratização da empresa"; "das obras sociales sindicais, administradas por e para os trabalhadores, respeitando os princípios essenciais de solidariedade e universalidade"; "de instrumentar eficientemente a luta contra o trabalho informal"; "da criação de empresas social-comunitárias mediante a sanção das leis respectivas, tais como a de sociedades anônimas de trabalho". 569

A posição da Direção Executiva não foi respaldada por algumas entidades. A UOM, a Asociación Bancaria, entre outros sindicatos, não apoiaram o pacto da CGT, por considerar seu conteúdo "lesivo aos direitos trabalhistas garantidos pela Constituição Nacional”. Para essas entidades, "não é conveniente, prudente e nem necessário promover modificações legais que precarizarão ainda mais o contrato de trabalho, sem que se atentem nem garantam as possibilidades de gerar emprego". No documento se afirmava também que:

A modificação do regime de convênios coletivos, a caducidade a prazo fixo da ultra-atividade, a alteração das indenizações por demissão e pré-aviso, os projetos de acabar com a estabilidade do empregado

\footnotetext{
568 "Nuestra exigencia y reclamo, en este $1^{\circ}$ de mayo es posibilitar un nuevo contrato social que asegure trabajo estable y digno, para todos, con crecimiento y justicia social". Solicitada de la CGT. Clarín, 30/04/1997, p. 26. 569 "En favor...". Solicitada de la CGT. Clarín, 08/06/1997, p. 14.
} 
público, o ataque aos Estatutos Especiais, são algumas das portas que o 'pacto' deixa abertas à voracidade patronal, aumentando a desproteção (....). ${ }^{570}$

Diante do acordo, o sindicalismo opositor convocou uma greve, com participação de alguns sindicatos cegetistas nucleados nas 62OP. Sobre esse protesto, Daer afirmou: "Está demonstrado que só se paralisa o país quando é a CGT que convoca à ação direta". O dirigente sustentou também que "Esta greve é uma iniciativa inorgânica da qual não vamos participar. Firmamos com o governo uma concertação social que inclui os temas trabalhista e econômico, por isso não paramos". E acrescentou: "No último ano fizemos três greves gerais, impugnamos os decretos infames do Governo sobre flexibilização do trabalho; quebramos o braço do Poder Executivo e dos grandes grupos econômicos com o acordo trabalhista que derrubou os decretos presidenciais”. Sobre o setor opositor, destacou: “(...) os dirigentes do MTA participaram da estratégia dialoguista. Não entregamos nada. Conseguimos eliminar os contratos 'basura' [temporários]",571, manter o poder para negociar os convênios laborais (...)”. Por último, Daer sublinhou que “(...) os sindicatos nacionais negociarão os convênios laborais e administrarão as obras sociales, se reduzirá a indenização para criar empregos permanentes e se eliminarão as modalidades promovidas, conhecidas como contratos basura". ${ }^{572}$ Por sua vez, as $62 \mathrm{OP}$ justificaram sua adesão à greve, entre outros fatores, pela "má conduta de alguns dirigentes sindicais que, sem consultar, firmaram a denominada 'Acta de Coincidencias', com a cumplicidade de alguns empresários, empenhados em apoiar toda reforma que precarize o contrato de trabalho". 573

Em meio a essa polêmica, a CGT apresentou propostas para que fossem sancionadas no Congresso da Nação por meio de uma nota sob a consigna "contra a hipocrisia e o oportunismo, lutemos seriamente pelo emprego, a saúde solidária e os direitos dos trabalhadores”. Sobre a abertura da economia, a central afirmou: “(...) falta proteção à indústria nacional para defender o trabalho dos argentinos e exigimos do Governo mudanças de política alfandegária". A respeito do tema da flexibilização, a central sustentou: "Não estamos de acordo. Apostamos em uma reforma trabalhista de consenso e sancionada pelo

\footnotetext{
570 "En contra del pacto entreguista. A favor de los trabajadores". Solicitada de la UOM y otros. Clarín, 27/06/1997, p. 33.

${ }^{571}$ Basura em espanhol significa "lixo", e contratos basura foi a maneira como ficaram conhecidos os contratos por tempo determinado na Argentina. Traduzirei essa expressão simplesmente como contrato temporário.

572 “Daer: 'la única central gremial que paraliza el país es la CGT'”. La nación, 21/07/1997, p. 6.

573 "El paro es un hecho". Solicitada de la Confederación de las 62 Organizaciones Peronistas. Clarín, 13/08/1997, p. 34.
} 
Congresso que favoreça a criação de novos empregos e termine com os contratos temporários, o trabalho informal e a instabilidade no trabalho". 574

Nas eleições legislativas de 26 de outubro de 1997 as posições no interior da CGT convergiram. As 62OP expressam seu apoio ao PJ, sob o argumento da "monolítica unidade" e "identificação peronista". ${ }^{575}$ Porém, após a derrota do partido, Daer afirmou: “(...) houve um claro voto castigo dos trabalhadores, mas agora não se poderá dizer que nós, sindicalistas, fomos os responsáveis; dessa vez os responsáveis pela derrota são os políticos do peronismo". 576

Em 1998, o novo Ministro do Trabalho, Ermán González, levou a cabo uma nova tentativa de aprofundar a flexibilização do trabalho por meio de uma proposta, que foi inicialmente aceita pela CGT. Para Daer, "Se prosperar a reforma, o pessoal que seja admitido por pouco tempo pelo menos será indenizado". ${ }^{577}$ A central declarou formalmente seu apoio à reforma em uma nota publicada em jornal:

A economia argentina sofreu uma transformação acelerada, a qual o Movimento Operário contribuiu com sua compreensão e sacrifício. Mas esse sacrifício produziu conseqüências indesejáveis em relação à instabilidade no emprego, às condições laborais, à solidariedade e aos salários dos trabalhadores e aposentados. Ainda que acompanhemos e apoiemos as circunstâncias que geraram a transformação, temos hoje a convicção que corresponde restabelecer o equilíbrio. Por isso resulta incompreensível que digam que a reforma trabalhista 'debilita a competitividade ${ }^{[578]}$, cujo conteúdo está de acordo com a realizada pelos países do primeiro mundo, que tende a restabelecer o princípio de equidade. ${ }^{579}$

Alguns setores internos se opuseram à posição oficial adotada pela central, tal como expressou Lorenzo Miguel, da UOM: “Observam-se com profunda preocupação as possibilidades de que a normativa vigente em matéria de convenções coletivas seja degradada em prejuízo dos trabalhadores". 580 Porém, em maio de 1998 o Senado aprovou a lei de flexibilização acordada entre a CGT e o Governo. A partir desse momento, até a posse de De la Rúa, o tema não voltaria a ocupar um lugar central nas discussões sindicais. Em uma das

\footnotetext{
574 “Dejen de mentir. ¿Quiénes están realmente en contra de la flexibilización?”. Solicitada de la CGT. Clarín, 12/08/1997, p. 8 .

575 “Ante todo, peronistas". Solicitada de la Confederación de las 62 Organizaciones Peronistas. La Razón, 09/10/1997, p. 15.

576 " “La CGT pasa la factura al PJ”. Clarín, 29/10/1997, p. 26.

577 “La CGT concreta hoy su declamado amor por Erman”. Página/12, 12/02/1998, p. 8.

${ }^{578}$ A central faz referência a uma nota da Unión Industrial Argentina (UIA), na qual esta afirma que os projetos de reforma trabalhista "vão na contramão da necessidade competitiva" ("Los proyectos de reforma laboral e impositiva debilitan la competitividad". Solicitada de la UIA. 1998, ASASSG, s/r).

579 "Nueva reforma laboral: equilibrio en las relaciones sociales". Solicitada de la CGT. 1998, ASASSG, s/r).

580 "El loro muestra los dientes. Miguel exige que la CGT rechace la reforma laboral". Página/12, 13/02/1998, p. 9.
} 
poucas declarações encontradas, Daer reafirmou sua oposição à flexibilização do trabalho: "É uma mentira que para resolver o problema do desemprego tenha que se flexibilizar ainda mais as relações laborais". ${ }^{581}$ Em uma declaração semelhante dirigida ao Ministro da Economia, o dirigente afirmou: "Cavallo é o responsável da destruição do aparato produtivo, da desnacionalização da economia e do desamparo da classe média". 582

\section{As causas do desemprego e as politicas para os desempregados}

Em 1997 aumentaram as mobilizações de desempregados. Em um protesto em Neuquén, a forte repressão policial culminou na morte de Teresa Rodríguez, sobre a qual a CGT declarou:

A Confederación Nacional del Trabajo, em nome de todos os trabalhadores argentinos, expressa seu profundo repúdio e preocupação pelos lamentáveis episódios de violência física que sofreram os povos de Neuquén e Jujuy. A repressão como resposta a legítimos reclamos dos trabalhadores relembra um tempo autoritário, antidemocrático e de desencontros entre os argentinos que, em conjunto, havíamos arquivado no passado. ${ }^{583}$

Nesse documento a entidade explicitou que "o ajuste econômico selvagem nas províncias é violência"; "o desemprego generalizado é violência"; "o ataque constante aos direitos dos trabalhadores é violência":

Em repúdio a todas as ações de violência denunciadas, em homenagem à companheira Teresa Rodríguez, para que se retirem as forças de Gendarmería ${ }^{[584]}$ de Neuquén, e para que se encontrem as soluções às justas reivindicações dos trabalhadores, convocamos a uma jornada nacional de luto e protesto para quinta, 17 de abril, efetuando greves de uma hora por turno em todo o país. ${ }^{585}$

Diante da continuidade das medidas repressivas levadas a cabo pelo Governo, a CGT publicou outra nota para expressar seu repúdio à violência oficial:

Nós, trabalhadores argentinos confederados na central mãe CGT, repudiamos a repressão que se está levando a cabo contra os que, pelo desemprego, pela fome e pela miséria buscam se expressar para ser escutados, diante da falta de sensibilidade dos governos provinciais e nacional. ${ }^{586}$

Enquanto o Governo apresentava sua argumentação contrária aos bloqueios de rodovias a partir do discurso do direito constitucional de liberdade de trânsito, a CGT manifestou sua

\footnotetext{
581 “La CGT quiere dialogar con De la Rúa y no con Cavallo”. La Prensa, 31/07/1999, p. 6.

582 "Propuesta para desmontar la estructura de los gremios. Cavallo: guerra con los sindicatos". Clarín, 26/07/1999, p. 7.

583 "Jornada nacional de duelo". Solicitada de la CGT. Clarín, 16/04/1997, p. 16.

${ }^{584}$ Instituição não vinculada ao Exército encarregada dos conflitos internos e do controle das fronteiras do país.

585 "Jornada nacional de duelo". Solicitada de la CGT. Clarín, 16/04/1997, p. 16.

586 "Los cortes de ruta. La libertad de cada uno y el derecho de los demás". Solicitada de la Presidencia de la Nación. La Capital, 22/05/1997, p. 13.
} 
defesa do "Estado de direito" e da "livre expressão dos que sofrem". ${ }^{587}$ Porém, apesar de tal posição, os desempregados não foram organizados para a luta pela central.

A partir do segundo semestre de 1997 e durante o ano de 1998 o desemprego diminuiu e os protestos de desempregados também reduziram. Após um período em que deixou de ocupar um espaço importante nas discussões sindicais, o tema ressurgiu nos jornais a partir do final de 1998, quando ocorreu a desvalorização do real no Brasil. O Smata argumentou que esta foi causou uma crise no setor, a primeira depois de uma "frutífera etapa" iniciada no começo da década de 1990:

Hoje, a indústria automobilística nacional atravessa um momento crítico, produto de uma crise global que tem afetado, principalmente, as 'economias emergentes'. O Brasil (o principal cliente de nossas exportações automobilísticas), está sofrendo as piores consequiências dessa situação e atravessa uma etapa recessiva que impacta negativamente sobre o trabalho dos argentinos". [...] No âmbito do Mercosul e, especificamente, em relação ao Brasil, a postura dos negociadores argentinos deverá ser marcada firmemente pela defesa da indústria automobilística argentina, evitando, basicamente, que eventuais assimetrias nas condições de radicação e de produção operem como elementos desencadeantes de desinversões na atividade. ${ }^{58}$

O setor têxtil também se encontrou em crise por fatores semelhantes, tal como afirmou a AOT em uma nota:

(...) o governo não quis ou não foi capaz de frear a avalanche do exterior, embora sabia perfeitamente que a maioria desses produtos importados provinha de países que subsidiam de forma encoberta, ou não tanto, sua produção e tenham sido fabricados com salários e em condições de trabalho quase escravas. ${ }^{589}$

Até o começo de 1999, a discussão principal da CGT foi a desvalorização do real no Brasil e seu "efeito caipirinha" sobre a economia argentina. O impacto da crise foi sentido especialmente no setor automobilístico, que logo após começou a demitir trabalhadores por conta da redução nas importações. Os jornais afirmavam que desde o final de janeiro já haviam sido despedidos 2.600 na Fiat, 2.600 na Renault e 1.400 na Ford. ${ }^{590}$ Uma nota da

587 "Las necesidades impuestas por el actual modelo económico no se cubren con gases, palos o balas". Solicitada de la CGT. Clarín, 24/05/1997, p. 16.

588 "La industria automotriz, el Smata y la defensa del trabajos de los mecánicos”. Solicitada del Smata. Clarín, 03/12/1998, ASASSG, s/r.

589 "Evitemos la desaparición del sector textil. No nos lavamos las manos antes y no lo vamos a hacer ahora". Solicitada de la AOT. Clarín, 23/12/1998, p. 58. O documento destacou que o comportamento empresarial argentino, por sua "falta de vocação industrial", "insensibilidade social" e "ansiedade pelo lucro imediato", "acabou fechando muitas fábricas".

590 "El impacto de la menor demanda brasileña. Los fabricantes de autos suspenden aún más personal". Clarín, 28/01/1999, p. 6. Ver também "Medidas de protección. Buenos Aires ya siente el impacto". Clarín, 30/01/1999, p. 7. Sobre o setor papeleiro e têxtil, ver "Suspensiones en aumento, un coletazo de la crisis". Clarín, 10/02/1999, p. 20. No setor bancário houve mais de 1.000 demissões suspensões de janeiro a meados de maio. Segundo o secretário geral da Asociación Bancaria, Juan José Zanola, "em cada uma dessas situações, 
UOM informou que a crise no ramo metalúrgico nesse momento havia afetado 15.000 trabalhadores entre "demissões, suspensões ou fechamento de estabelecimentos". Nesse momento, esse Sindicato propunha: "fortalecer a indústria nacional, defendendo-a da importação desleal a preços subsidiados"; "proteger o mercado interno, melhorando a capacidade de consumo da população, hoje absolutamente decaída pelos baixos salários"; "opor-se à precarização do trabalho, que fomenta a exclusão social de grandes setores da população"; "apoiar o Mercosul, mas exigindo a aplicação de precauções técnicas que defendam nossa indústria"; "repudiar o alto custo financeiro, que afoga a economia e desalenta a inversão produtiva"; "promover uma agressiva política exportadora, saindo do esquema agro-importador mediante a exportação (...) de produtos manufaturados, que têm o valor agregado da mão de obra argentina"; "assegurar a defesa do emprego, mediante regimes de proteção e assistência ao desempregado". ${ }^{591}$ Em nota publicada para o $1^{\circ}$ de maio a CGT manifestou sua preocupação a respeito do tema:

O desemprego, o trabalho informal, a crise importada, a evasão fiscal generalizada, (...) a insegurança social, o apetite financeiro desmesurado, as ameaças do FMI e do Banco Mundial, o empobrecimento dos trabalhadores e das pequenas empresas, constituem chagas que obscurecem a comemoração militante de nosso dia. Nós, trabalhadores e suas organizações sindicais, não aceitamos continuar sendo vítimas da desvalorização social e rejeitamos qualquer tentativa de rebaixamento de salários e aposentadorias. Recuperar o trabalho para todos os argentinos deve ser o único e grande objetivo de qualquer política econômica e o compromisso de toda a classe política. ${ }^{592}$

Em 1999, houve crescimento das importações em vários setores, o que levou a manifestações sindicais, como no setor de calçados no qual “empresários e operários” fizeram uma marcha solicitando limitação de entrada de produtos estrangeiros, especialmente brasileiros. ${ }^{593} \mathrm{Um}$ ato semelhante se produziu dias depois, em que a UOM marchou junto a representantes das Câmaras Empresariais para pedir proteção ao setor. ${ }^{594}$

especialmente nos casos de falências, a melhor negociação deixa um saldo de empregados na rua" ("Casi 1000 despidos en el sistema bancario. Ajuste a sola firma”. 22/05/1999, ASASSG, s/r).

591 "La crisis de la actividad metalúrgica". Solicitada de la UOM. Clarín, 24/03/1999, p. 28.

592 "Un $1^{\circ}$ de Mayo que todos podamos celebrar". Solicitada de la CGT. Clarín, 30/04/1999, p. 16.

593 "Exigen al Gobierno frenar la entrada de calzados brasileños". La Prensa, 30/07/1999, ASASSG, s/r.

594 "La crisis los barre a la misma vereda". Página/12, 23/07/1999, p. 13. Nesse contexto, com a justificativa da crise vivida no setor metalúrgico, a UOM solicitou ao Ministério do Trabalho "procedimiento preventivo de crise" (medida quando se quer demitir entre 5 e 15\% dos empregados) para dispensar funcionários da obra social. "Ajuste en el sindicato y en la obra social. La UOM pide autorización para despedir personal y bajar sueldos". Clarín, 29/09/1999, p. 24. Para detalhes sobre a crise no setor metalúrgico, ver: MIGUEL, Lorenzo. UOM: las razones de la crisis. Clarín, 23/11/1999, p. 19. Para a crítica a sua versão da crise, ver PICCININI, Alberto. "UOM: la crisis no es solo culpa del modelo". Clarín, 01/12/1999, p. 20. 
Com o aprofundamento da crise, o Smata se manifestou da seguinte maneira: "O governo argentino deve defender a indústria e o trabalho nacionais". A entidade afirmou também que “(...) deve haver um Compromisso Produtivo por parte do empresariado que estabeleça pautas de produção e manutenção do emprego argentino”. Por último ameaçou com uma greve em protesto pela situação vivida no setor:

O Smata não faz nem fez jamais do direito de Greve e Mobilização uma utilização irresponsável e fora de lugar. Por isso, quando temos a necessidade de recorrer a essas ações, o fazemos com a autoridade e a força do que está em jogo, que não é outra coisa senão nossas fontes de trabalho. Esperamos que nossos reclamos sejam escutados e compreendidos, e se traduzam em soluções para os trabalhadores, se não, o caminho da Ação Sindical será o único que nos veremos obrigados a transitar. ${ }^{595}$

Com a eleição de Fernando De la Rúa, em princípio a postura da Direção Nacional da CGT foi de abertura para o diálogo, o que se pôde confirmar nas declarações de alguns de seus dirigentes logo após o processo eleitoral, como o comerciário Armando Cavalieri:

Vamos ver o que decidem fazer os homens da Alianza. Há que dar-lhes tempo. Eles chegaram com um grande apelo social, sobretudo por eqüidade distributiva. (...) não há possibilidades de realizar greves. (...) Nas greves não participam todos, nas eleições participam 35 milhões de pessoas. ${ }^{596}$

No começo de dezembro, ocorre a primeira reunião entre a CGT, De la Rúa e o ministro do Trabalho, Alberto Flamarique, que assim definiu o encontro: "Demonstrou-se que o próximo Governo e a CGT podem se sentar na mesma mesa. Os sindicalistas estão com muito boa disposição e De la Rúa começou a impor seu estilo de negociação". 597

****

Durante o período tratado neste item, a CGT não participou das duas greves gerais ocorridas, a primeira delas convocada pela CTA, pelo MTA e pela CCC, que contou com a participação das 62OP e da UOM, e a segunda realizada apenas pela CTA. O período correspondeu ao crescimento dos bloqueios de rua e ao surgimento das organizações de desempregados. Diante de um contexto de criminalização desse tipo de protesto pelo Governo, a central não investiu na representação desse segmento, mas defendeu oficialmente sua mobilização.

\footnotetext{
595 “Los trabajadores mecánicos, la industria automotriz nacional y la defensa del empleo". Solicitada del Smata. Clarín, 29/08/1999, p. 29.

596 "Qué hacer frente al nuevo gobierno". Página/12, 22/11/1999, p. 8.

597 "De la Rúa convocó a la CGT a trabajar contra la desocupación”. Clarín, 2/12/1999, p. 2.
} 


\section{O MOP}

Durante o período analisado neste item, a postura defendida pelo MOP foi de defender a concertação, expressando seu apoio à Acta de Coincidencias firmada entre o Governo Nacional e a CGT:

Fizemos convencidos de que reflete nossa posição em temas de tanta responsabilidade como a atualização da legislação trabalhista porque preserva a Negociação Coletiva com o Sindicato Nacional, derroga modalidades contratuais que têm sido abusivamente utilizadas sem respeitar o espírito da lei que lhes deu origem, busca uma ferramenta útil para a luta contra o desemprego e salvaguarda o sistema solidário de saúde. $^{598}$

Nas eleições provinciais de 26 de outubro de 1997, o MOP expressou seu apoio ao governo menemista: “(...) conhecemos as conquistas concretizadas entre todos os argentinos no governo do Dr. Carlos Saúl Menem. Conseguimos a estabilidade econômica, agora podemos crescer". ${ }^{599}$ Nas eleições presidenciais, Antonio Cassia defendeu a estratégia de seguir dialogando com o Governo eleito, o que confirma a hipótese do caráter participacionista do MOP:

Nós, dirigentes sindicais, temos amadurecido muito. Fomos partícipes de um processo histórico na Argentina. O marco é distinto e os dirigentes políticos e sindicais pensam de outra forma. Os problemas não se resolvem com uma paralisação, mas sentando para conversar, contribuindo com soluções. Seja De la Rúa ou Duhalde o ganhador, não poderão por si só solucionar problemas como o desemprego. Está faltando dirigentes que não tenham ficado no passado, mas homens capacitados que tenham aprendido o que é a globalização e o que se discute no mundo. Os argentinos podem ficar tranqüilos, ganhe quem ganhe, porque tudo se discute com altura. Esquecemos então das greves gerais e apostemos pela convivência e pelo futuro. ${ }^{600}$

\section{O MTA}

Quando a CGT firmou a Acta de Coincidencias com o Governo, o MTA convocou uma mobilização em conjunto com a CTA, a CCC e a UOM. Sobre esse acordo, assim se expressou o dirigente metalúrgico Gutiérrez: "Essa ata não é mais que um aprofundamento da flexibilidade do trabalho. E todos sabemos que a flexibilidade não gerou emprego". O

\footnotetext{
598 “Responsabilidad u oportunismo?”. Solicitada del Movimiento Obrero con Propuestas. Clarín, 14/08/1997, p. 8 .

${ }^{599}$ Solicitada del Movimiento Obrero con Propuestas. Clarín, 06/10/1997, p. 12.

600 “'Olvidémonos de los paros generales', aseguró Cassia”. Los Andes, 21/10/1999, p. 4.
} 
dirigente afirmou também que a ata foi firmada "para se obter algum cargo nas listas de candidatos do oficialismo". 601

No dia 11 de julho, realizou-se a Marcha Federal por el Trabajo até a Plaza de Mayo contra a flexibilização, o desemprego e o modelo econômico. O protesto, convocado sob a consigna "trabalho para todos, com educação, saúde, aposentadoria e justiça", contou com a presença de Lorenzo Miguel, presidente da UOM. ${ }^{602}$ Segundo o jornal consultado, estiveram presentes no ato entre 25 e 70 mil pessoas. ${ }^{603}$

Em 8 de agosto, o MTA convocou uma greve geral, juntamente com a CTA, a CCC, as 62OP e a UOM. Declarada contra o modelo econômico e a flexibilização, a paralisação teve uma alta adesão. Durante o protesto, realizaram-se vinte bloqueios de rodovias no interior do país e houve repressão por parte da polícia. Essa greve geral foi a primeira em que se verificou ações conjuntas entre o ativo e a reserva, o que seria uma constante a partir desse momento.

Em março de 1998, o MTA e a CTA organizam uma marcha contra a negociação de Daer com o Governo, sobre o qual assim se expressou o dirigente da UTA, Juan Palacios:

O pacto da CGT foi um fracasso porque muitas organizações disseram não. Todos os acordos que fez a CGT, fracassaram; esta foi uma concessão mais. (...) para nós a central operária não existe, está vazia de conteúdo político e sindical. Na CGT querem ficar bem com o Governo para ocupar um lugar nas listas eleitorais do PJ. ${ }^{604}$

Sobre este tema Moyano sublinhou: "A CGT, do ponto de vista da representatividade, desapareceu. Sua condução não existe, o acordo não tem consenso e, como disse Palacios, significou sua capitulação". ${ }^{605}$

Com a eleição de De la Rúa, o MTA expressou sua preocupação com a orientação política do governo, tal como sustentou Palacios:

O MTA nasceu para se opor ao modelo neoliberal que precarizou a vida dos trabalhadores, gerando uma inédita marginalização e exclusão social. Se há um caminho que vamos percorrer é o caminho da

\footnotetext{
601 "Palacios y De Gennaro antes de la Marcha por el Trabajo”. Página/12, 10/07/1997, p. 6.

602 "Marcha contra la desocupación y el plan económico". Clarín, 11/07/1997, p. 13.

${ }^{603}$ Ver "A la Plaza de Perón, criticando al cacatúa y la flexibilización”. Página/12, 12/07/1997, p. 10; "El sindicalismo opositor apuntó a la flexibilización". La Nación, 12/07/1997, p. 8; "La protesta opositora en la Plaza de Mayo fue masiva”. Clarín, 12/07/1997, p. 4; “Ahora, huelga contra el modelo”. Página/12, 12/07/1997, pp. 2-3.

${ }^{604}$ Este dirigente afirma que seu setor deve "continuar com a confrontação contra o modelo econômico e a ineficiência total da CGT nacional que constantemente confunde as pessoas". O dirigente sustenta ademais que Daer "engana as pessoas quando diz que não tem nenhum compromisso com o Governo em relação à flexibilização laboral" ("Propuesta de los gremios opositores". La Nación, 07/03/1998, p. 8). ${ }^{605}$ Idem.
} 
coerência. Assim como ontem estivemos contra os contratos temporários ou rebaixamento das indenizações hoje não existe nenhuma razão para que mudemos. Por outro lado, esta luta contou com o respaldo dos partidos da Alianza. Preocupam-nos as pressões do Consejo Empresario Argentino [CEA] ou como fazem lobby alguns setores empresariais. ${ }^{606}$

Durante o período analisado neste item, o MTA convocou uma greve geral em conjunto com a CTA, em 1997. Porém, apesar de sua constante crítica ao Governo de Menem e denúncia da situação do país, o setor não investiu na representação política dos desempregados, apesar de não ter se oposto aos bloqueios de rodovias organizados por esse segmento. Opôs-se constantemente à direção de Daer na CGT, convocou marchas contra a reforma trabalhista e a política econômica, mas não participou da paralisação nacional convocada pela CTA, em 1999.

\section{A CTA}

A posição de enfrentamento que teve a CTA durante o período investigado pode ser demonstrada nas declarações de seu secretário geral, Víctor De Gennaro. Para este dirigente, a política cegetista estava submetida aos interesses do poder executivo federal:

Estou convencido de que os dirigentes da CGT estão subordinados à política do Governo e estão na direção interna do PJ. Pensam em resolver a questão trabalhista, mais que nos problemas dos trabalhadores. Tudo foi uma comédia de enredo, com a qual se subestimou a realidade argentina. É uma vergonha". 607

Em outra ocasião De Gennaro declarou que "Se o Governo diz que somos combativos é porque há negociadores e claudicantes. Não é um problema de dureza, mas de firmeza diante do poder". ${ }^{608}$ Sobre a Acta de Coincidencias, o dirigente afirmou: "Esse acordo é lamentável: se fez para resolver o negócio de alguns sindicatos com as verbas das obras sociales e para ver quem discute nas negociações coletivas". ${ }^{609} \mathrm{O}$ conflito gerado a partir desse acordo levou

\footnotetext{
606 “Qué hacer frente al nuevo gobierno”. Página/12, 22/11/1999, p. 8.

607 "De Gennaro: 'algunos sindicalistas cada día tienen más plata"”. La Nación, 23/01/1997, p. 7.

608 “El ala dura sindical se pone a prueba”. La Nación, 21/07/1997, p. 6.

609 "Palacios y De Gennaro antes de la Marcha por el Trabajo". Página/12, 10/07/1997, p. 6. Sobre esses temas, Página/12 informou que "a ata original limita a desregulamentação às entidades de origem sindical. Os empresários e o Ministério da Economia, ao contrário, querem que em um prazo de dois anos também participem da concocrrência as empresas privadas de plano de saúde". Sobre os convênios coletivos, ressaltou que "a ata respeita a atribuição dos sindicatos firmantes do convênio para representar os trabalhadores durante as paritarias. O Grupo de los Ocho - que continuará nesses dias elaborando novas propostas - insiste na necessidade de poder negociar diretamente com as comissões internas, já que cada empresa 'tem características próprias'. As pretensões empresariais também vão na direção da modificação do conceito de horas extras, a fim
} 
a CTA a convocar, em conjunto com o MTA, a CCC, as 62OP e a UOM, uma greve geral para o dia 14 de agosto de 1997 contra a reforma trabalhista. O protesto teve uma alta adesão e expressou o momento de maior conflito dos setores opositores à condução cegetista. Também se destacou por ser a primeira greve do período que contou com a mobilização dos empregados e bloqueios de rodovias dos desempregados, que se realizaram principalmente no interior do país.

Em seu Segundo Congresso Nacional, realizado em La Plata sob a consigna "Trabajo para todos", a CTA apresentou a proposta de um seguro-desemprego de 500 pesos para todos os chefes de família e a redução da jornada de trabalho. Em uma declaração sobre o subemprego, De Gennaro afirmou que "O problema na Argentina não é a falta de trabalho, mas a falta de emprego. Não há vontade de pagar os trabalhadores”. 610

Recordando os cinco anos da Marcha Federal de 1994, a CTA convocou uma greve geral com mobilizações para 6 de julho em todo o país, a primeira sem adesão de outras organizações. O protesto foi convocado sob a consigna “'Trabajo Ya! El problema de los argentinos es la desocupación" ${ }^{611}$, tema sobre o qual a CTA responsabilizava constantemente a política econômica do Governo. Sobre sua proposta de redução da jornada de trabalho, a central afirmou que: "Se o total dos assalariados formais trabalhasse 8 horas (e não 10 horas) se gerariam imediatamente 988.230 postos de trabalho". ${ }^{612}$ A adesão foi parcial e houve bloqueio de estradas durante o protesto no interior e na capital federal.

Nas eleições presidenciais, a CTA apoiou a Alianza. Com a vitória dessa última, assim se expressou De Gennaro:

O novo Governo tem recebido um forte alento ao 'Tchau Menem', ao 'basta disso'. A mensagem das urnas é clara: não há consenso para um ajuste. Há, sim, para selar um acordo social para mudar este modelo. A Alianza tem possibilidades para mudar a realidade. Para dar um shock redistributivo para as pessoas e não um shock de confiança para os mercados. Aqui é ajuste ou democracia, não há outra. O país está em emergência ocupacional, previdenciária, educativa, sanitária e judicial... ${ }^{613}$

$* * *$

de evitar pagá-las" ("Menem prometió a la CGT la aprobación de la legislación laboral. La palabra del compañero presidente". Página/12, 23/07/1997, p. 11).

610 "Segundo Congreso Nacional de la CTA, en Mar del Plata. Protesta sindical en marcha". Clarín, 30/05/1999, p 15.

611 "Trabalho já! O problema dos argentinos é o desemprego!"

612 "Trabajo Ya! El 6 de julio paros y movilizaciones en todo el país”. CTA. Central de los Trabajadores Argentinos, 1999, ASASSG, s/r.

613 "Qué hacer frente al nuevo gobierno". Página/12, 22/11/1999, p. 8. 
Nesse período a CTA manteve sua política de mobilização contra a reforma trabalhista e a política econômica. Realizou duas greves gerais, sendo que a primeira contou com outros setores sindicais. O tema do desemprego foi constante em seus protestos sindicais, e os desempregados começaram a aparecer como sujeitos convocadores. Durante as mobilizações ocorreram bloqueios de estradas organizados pelos desempregados, o que seria uma característica das greves a partir desse momento. Ganhou força na central a proposta de um seguro-desemprego e de redução da jornada de trabalho. A entidade apoiou oficialmente o candidato da Alianza nas eleições presidenciais.

$* * *$

No período analisado neste item, o Governo aprofundou a pressão pela aprovação da reforma trabalhista, que se na etapa anterior havia sido rejeitada pela CGT, nesse momento foi parcialmente aceita pela central por meio da Acta de Coincidencias. Esse acordo sofreu fortes resistências internas que levaram a uma situação de conflito na entidade. Em agosto de 1997, a CTA, o MTA e setores representativos da CGT, como a UOM e as 62OP, realizaram uma greve geral contra a reforma trabalhista. Observa-se um período descendente da rebelião, no qual a fratura no movimento operário ficou cada vez mais evidente. Os diferentes setores sindicais atuaram separadamente e na greve geral convocada pela CTA em julho de 1999, o MTA não participou. Nesses eventos houve bloqueios de estrada protagonizados por desempregados simultaneamente às mobilizações dos empregados, o que evidenciou o começo da formação de uma relativa unidade entre os dois segmentos. Diante do surgimento das organizações de desempregados, as estratégias sindicais foram díspares. A CGT e o MTA apresentaram propostas de representação dos interesses desse segmento por intermédio de políticas de emprego, mas só a CTA se ocupou efetivamente de sua organização para a luta.

\subsubsection{Expansão das organizações de desempregados, greves gerais e insurreição espontânea (dezembro de 1999 a dezembro de 2002).}

O período analisado neste item corresponde à totalidade do Governo de Fernando de La Rúa e ao primeiro ano da presidência de Duhalde. ${ }^{614}$ Sua delimitação se explica

\footnotetext{
${ }^{614}$ A rigor, esse período abarca dois momentos diferentes. O primeiro, que vai de dezembro de 1999 a dezembro de 2001, foi um momento de greves gerais e de unidade do movimento operário. No segundo, que se estende até 2002, o movimento se fragmentou, as greves diminuíram e não foram apoiadas por todas as centrais. Cotarelo (2005) caracteriza a conjuntura de 2002 como uma situação de trégua nas duas CGTs e de fratura do movimento
} 
principalmente por se tratar de um momento ascendente do ciclo de lutas na Argentina, que culminou nos eventos produzidos em 19 e 20 de dezembro de 2001. Nesses anos, se consideramos isoladamente a quantidade de protestos convocados pelos desempregados, observa-se algumas especificidades. $\mathrm{O}$ auge do movimento protagonizado por esse setor se deu entre 2000 e 2005, mas foi só em 2002 que os eventos de desempregados superaram os de empregados. Também foi nesse período que se produziu a maior quantidade de ações conjuntas de empregados e desempregados, que alcançaram seu nível mais alto entre 2000 e 2002. Em 2001 se iniciou um novo pico de desemprego. Na medição feita em maio chegou à cifra de $16.4 \%$ e em outubro praticamente voltou ao recorde histórico de maio de 1995, com $18.3 \%$, tendo sido maior a soma de desempregados e subempregados em relação ao período anterior (Ver Tabela 16). Em dezembro de 2001 o ministro Cavallo anunciou o corralito, medida que limitou os saques bancários a 1.000 pesos semanais. Nesse contexto se realizou a insurreição espontânea (Carrera e Cotarelo, 2003) que levou à renúncia de De la Rúa. Durante o protesto, o Governo decretou estado de sítio e houve intensa repressão.

Depois de um período de transição, assumiu Duhalde, que a princípio teve o respaldo da maioria do sindicalismo, mas logo passou a ser criticado pela continuidade em relação a diversas medidas adotadas pelo Governo anterior. A primeira medição de desemprego de seu mandato chegou ao nível máximo registrado da história argentina (21.5\%) e em abril o presidente inaugurou o Plan Jefas y Jefes de Hogar Desocupados, considerado como um "direito familiar de inclusão social”, com um subsídio de 150 pesos em troca de tarefas comunitárias, laborais ou de capacitação. ${ }^{615}$ Os protestos de desempregados chegaram a seu auge e, em decorrência da repressão, dois militantes foram assassinados em Avellaneda, na Grande Buenos Aires. Nesse cenário conturbado, veremos como atuaram os diversos setores do sindicalismo. Vale ressaltar desde já que a CGT permanece fraturada depois de um curto período de reunificação. A partir dessa parte da exposição, adotarei a denominação mais comum aos setores sindicais cegetistas, baseada no nome de sua liderança: CGT-Daer e CGTMoyano.

popular. No entanto, optamos por essa periodização por se constituir como o triênio de auge da unidade parcial entre as organizações de empregados e desempregados.

615 "Derecho Familiar de inclusión social". Solicitada de la Presidencia de la Nación Argentina". Crónica, 07/04/2002, p. 5 . 


\section{A CGT-Daer}

É muito comum nas discussões sobre o sindicalismo argentino a afirmação de que a CGT só se mobiliza nos governos radicais. Na análise apresentada até o momento, a atuação da central em determinados momentos, e a atuação do MTA, como uma linha opositora interna, atesta que houve significativa resistência cegetista durante a década menemista. $\mathrm{O}$ período que será tratado neste item é crucial para compreender a atuação da entidade, pois é o momento das maiores taxas de desemprego e do maior grau de unidade entre os empregados e os desempregados.

Em dezembro de 1999, a repressão ordenada pelo novo governo a um protesto de funcionários públicos, docentes e desempregados na província de Corrientes termina com mortos, feridos e presos. Diante desse evento, a CTA convocou a uma greve geral, à qual a CGT não aderiu. Em um comunicado à imprensa, Daer reivindicou uma "atitude das autoridades nacionais diante da justa reivindicação do povo correntino". ${ }^{616}$

Em seguida, o governo de De la Rúa tentou aprovar uma reforma trabalhista que logo foi criticada pelos principais setores do sindicalismo. Sobre o tema, o titular da CGT, Rodolfo Daer, assumiu a seguinte posição: "longe de criar novos empregos, o projeto de flexibilização que impulsiona o Poder Executivo precarizará muito mais a situação dos trabalhadores”. O dirigente também argumentou que "O governo investirá pesado por uma modificação da atual lei trabalhista que, sob as bandeiras da criação de postos de trabalho, não fará outra coisa que promover uma maior competitividade entre os trabalhadores e aumentará a precarização do trabalho". Por último, ressaltou que "é um erro deixar cair a ultra-atividade, porque os trabalhadores corriam o risco de perder os convênios laborais com as empresas" e que "seria uma incoerência dos aliancistas promover uma reforma trabalhista quando antes rejeitaram a flexibilização que agora querem aplicar". ${ }^{617}$ Apesar da oposição à proposta do Governo, a estratégia da central foi investir no diálogo, como demonstra Daer: "Vamos rejeitar todos os pontos da reforma. Nos informamos pelos jornais. Agora vamos pedir uma reunião com De la Rua (...) para que se sente a discutir conosco as mudanças das normas laborais". 618 Depois da reunião com o ministro do Trabalho, Flamarique, o dirigente comerciário Cavalieri declarou: "Vamos esgotar a via do consenso (...) Hoje não escutamos nenhuma novidade. Queremos

\footnotetext{
616 “Primer paro para el nuevo gobierno. La CTA a huelga para el lunes en repudio a la represión”. Página/12, $18 / 12 / 1999$, p. 8.

617 "Críticas de la CGT a la reforma laboral impulsada por el Gobierno”. La Nación, 04/01/2000, p. 9.

618 “La CGT pedirá una reunión con el Presidente”. La Nación, 12/01/2000, p. 5.
} 
corrigir o trabalho informal e legalizar a convenção coletiva. Eles propõem a extensão do período de prova; dissemos que isto já provamos". ${ }^{619}$ A opinião do presidente da central, Rodolfo Daer, assim foi expressa: "Creio que a proposta não vai ser aprovada tal como está; nenhuma dessas medidas resolve o desemprego". 620

Em relação à anulação de um decreto de Menem que permitia aos sindicatos a administração do Fondo de Redistribución de las Obras Sociales, Daer deu a seguinte declaração: "Isto é uma chantagem, pretendem silenciar as opiniões críticas dos dirigentes sindicais". Sobre o tema este dirigente afirmou: "O risco que se corre agora com a administração desses fundos de forma exclusiva pelo Governo é que se manipule politicamente as obras sociales, pretendendo minimizar as posições que podemos ter os dirigentes sobre atos de governo". ${ }^{621}$ Em outra declaração acerca da reforma trabalhista, assim se expressou Daer: "Tudo isto está direcionado para que desapareça o trabalho estável na Argentina. Que se esconde nessa reforma ao pretender debilitar as organizações sindicais, criando negociações regionais ou provinciais? O único que vai gerar são 3.800 .000 desempregados, com 40 por cento dos trabalhadores informais...". 622

Nesse contexto, a CGT começou a levar a cabo, juntamente com os legisladores peronistas de extração sindical, um projeto intitulado "Empleo y modelo de desarrollo económico". Segundo o jornal La Nación este projeto apresentava, entre outras propostas, a criação de um seguro-desemprego que visava a "formação, capacitação e requalificação dos desempregados". 623

Entre ameaças de mobilização e busca de entendimento, a CGT apresentou um projeto alternativo à reforma trabalhista do Governo. ${ }^{624}$ Isto confirma a postura de Daer de "esgotar a via do diálogo": "Me daria por satisfeito se o Governo convocasse uma mesa de diálogo com empresários e a CGT para discutir como melhoramos a competitividade e atendemos os problemas da agenda social". O dirigente afirmou também que "O Presidente tem que fazer equilíbrio entre os setores populares e os representantes do establishment econômico. Esta última linha é a que hoje expressam [os ministérios da] Economia e do Trabalho". ${ }^{625} \mathrm{O}$

\footnotetext{
619 “La CGT pidió al Gobierno que no le corte su poder de negociación”. La Nación, 13/01/2000, p. 7.

620 "Sigue la pela por la reforma laboral”. La Nación, 14/01/2000, p. 6.

621 "El gremialismo está listo para dar batalla". La Nación, 19/01/2000, p. 5.

622 "La CGT se queja, pero no para". La Nación, 20/01/2000, p. 6.

623 "La CGT propondrá una ley contra el desempleo”. La Nación, 31/01/2000, p. 5.

624 "Con presiones, la CGT intenta acordar la reforma laboral”. La Nación, 08/02/2000, p. 8.

625 "El debate por la reforma laboral. Podrían hacer una consulta popular". La Nación, 01/02/2000, p. 5.
} 
dirigente sustentou também que a reforma trabalhista "visa romper as estruturas sindicais, que é a única forma de participação democrática dos trabalhadores". ${ }^{626}$ Essas declarações atestam a tendência de parte do sindicalismo peronista argentino de reivindicar a participação na tomada de decisões por meio de um acordo entre os setores representantes do capital e do trabalho, com mediação do Estado.

Apesar da abertura ao diálogo por parte da CGT, o Governo seguiu sua ofensiva para aprovar a lei, o que levou a central a convocar sua primeira greve geral do governo de De la Rúa. Porém, depois de realizar um acordo com o Governo, a CGT suspendeu o protesto. Sobre esta decisão, assim se expressou Daer: "Diante da resposta positiva do Governo a nossas reivindicações, o senso comum indica que chegamos a um grande acordo onde não há espaço para a confrontação", ${ }^{627}$ Porém, a Câmara de Deputados aprovou a reforma trabalhista, a qual deveria ingressar no Senado para ser convertida em lei, o que gerou polêmica entre os diferentes setores da central. Nesse contexto Daer deu a seguinte declaração: "Não sou um traidor nem um filho da puta. Todos somos produtos da luta e temos que ter respeito um ao outro". ${ }^{628}$ Frente à idéia do Governo de reduzir a jornada de trabalho dos assalariados que trabalhavam mais de 48 horas semanais, o presidente da central se posicionou da seguinte maneira: "Se forem reduzidas as horas de trabalho que se trabalha fora da lei não deverá ser tocado um centavo do salário dos empregados". 629

As divergências no interior da central provocaram uma nova separação e o grupo antes nucleado no MTA fundou a CGT-Moyano. Daer afirmou ser contrário a essa decisão: "Ficou demonstrado, ao longo da história do movimento operário argentino, que a ruptura ou as frações, fundamentalmente, não favorecem as pessoas nem os trabalhadores em particular, ao contrário, os debilitam". ${ }^{630}$ Uma das justificativas da ala moyanista para a separação foi a postura da CGT em relação à reforma trabalhista. A respeito do tema, Daer argumentou: "Nós não firmamos nenhum acordo. Nos vimos obrigados a debater o projeto e o melhoramos em tudo o que pudemos". ${ }^{631}$ Diante da convocação de uma greve por Moyano, Daer comentou:

\footnotetext{
626 “Acordarían la reforma laboral”. La Nación, 09/02/2000, p. 4. Em outra passagem, Daer sustenta que a iniciativa oficial tem o objetivo de "destruir as organizações sindicais, os convênios coletivos de trabalho, a precarizar, flexibilizar e criar condições jurídicas do rebaixamento do salário". ("La CGT ratificó el paro del jueves próximo". La Nación, 18/02/2000, p. 9).

627 "Virtual fractura en la central obrera". La Nación, 23/02/2000, p. 4.

628 “Al final, el PJ apoyó algunos puntos de la reforma laboral”. Clarín, 26/02/2000, p. 8.

629 “Apoyo parcial a la reducción laboral”. La Nación, 07/03/2000, p. 6.

630 "De la Rúa lamentó la ruptura y Daer criticó a sus rivales”. La Nación, 18/03/2000, p. 8.

631 "Daer ahora quiere cambiar la reforma". La Nación, 23/03/2000, p. 7.
} 
"Moyano perdeu a batalha. Convocou uma greve desnecessária pensando que os senadores do PJ não conseguiriam introduzir as mudanças propostas pela reforma trabalhista" ${ }^{632}$ A CGTMoyano, a CTA e a CCC realizaram uma greve geral no dia 5 de maio contra a flexibilização. No dia 11, o projeto foi aprovado e convertido em lei.

No final de maio, o Governo anunciou um plano de ajuste sob o argumento de "equilíbrio fiscal", que contemplava entre outras medidas, um rebaixamento salarial de $12 \%$ para os empregados públicos que recebiam entre 1000 e 6500 pesos. ${ }^{633}$ Contra a medida, as duas CGT decidiram realizar uma greve no dia 9 de junho, com adesão da CTA. Para Daer, "a decisão política de implementar o ajuste aprofunda a recessão e golpeia os setores médios e baixos". Segundo o dirigente, "Hoje não existe na Argentina diálogo social como caminho para encontrar a concertação para a produção e o emprego e para estabelecer, a partir do Estado, políticas para resolver o desemprego". ${ }^{634}$ A respeito do protesto, o dirigente declarou: "Se o Governo não convoca à concertação, o protesto vai se generalizar em todo o país. (...) Vamos constituir uma frente nacional de defesa da produção e emprego". ${ }^{635}$ A greve teve uma alta adesão: $60 \%$ segundo o Governo, entre $80 \%$ e $90 \%$ segundo os organizadores. ${ }^{636}$ Depois da paralisação, Daer solicitou a De la Rúa uma mesa de diálogo para buscar uma "saída concertada em defesa da produção e do trabalho", ${ }^{637}$

Logo após sua reeleição na CGT, Daer seguiu demonstrando disposição para o diálogo com o Governo. As propostas concretas da central para o desemprego e para os desempregados nesse momento podem ser resumidas pela seguinte declaração do dirigente: "Necessitamos reativar a produção. Por exemplo, limitando a entrada de produtos estrangeiros. Pediremos que haja um subsídio às PMEs que empreguem. Basta da vergonha do Plan Trabajar! O dinheiro tem que ir para a produção, não para o clientelismo político". ${ }^{638}$ Aqui temos uma pista importante para a compreensão das propostas da CGT para os desempregados. Além da defesa de políticas passivas, como o seguro-desemprego, a central concentrava seu esforço em reivindicar geração de postos de trabalho.

\footnotetext{
632 “'Perdió la batalla', dijo Daer”. La Nación, 27/04/2000, p. 6.

633 "Salió el ajuste y muy poca anestesia".Crónica, 30/05/2000, p. 2-3.

634 "Por el ajuste, toda la CGT va unida al paro". Crónica, 30/05/2000, p. 10-11.

635 "El sindicalismo ratificó el paro y fustigó al Gobierno". Clarín, 07/06/2000, p. 8.

636 "Los trabajadores dijeron basta al ajuste". Crónica, 10/06/2000, p. 2.

637 "Daer le pidió al Gobierno que no se aísle". Crónica, 10/06/2000, p. 8.

638 "El Gobierno y la CGT de Daer retoman el diálogo". La Nación, 12/08/2000, p. 7.
} 
Em novembro de 2000, a CGT-Daer convocou uma greve de 24 horas para o dia 23 desse mês contra a política econômica e os projetos de reforma do sistema previdenciário. Segundo Daer, a principal reivindicação da central nesse momento era o "diálogo social", definido como "um chamado à concertação nacional, onde estejam representados os setores do trabalho e da produção, com grande respaldo político". Durante o protesto, o dirigente acrescentou: "Não queremos que seja um diálogo de surdos, queremos que se faça com base em uma agenda social que contemple as urgências dos trabalhadores e dos desempregados". ${ }^{639}$ Outra reivindicação da CGT era o estabelecimento de "uma agenda social, que incluísse a discussão sobre o crescimento, a produção e a geração de emprego decente". ${ }^{640}$ Ao avaliar a greve, o dirigente afirmou: "Foi massiva em todo o país, não somente nos setores de trabalho, mas do resto da sociedade. Na rua não houve uma alma. $\mathrm{O}$ Governo tem que se dar conta de que o povo votou contra a voracidade do mercado". ${ }^{641}$

No dia 19 de dezembro, a CGT-Daer realizou uma marcha contra o projeto de lei de aumento da idade de 60 para 65 anos da aposentadoria da mulher e pela manutenção do regime previdenciário estatal e da cobertura médica universal. ${ }^{642}$ No entanto, esse contexto também estava ameaçado pela desregulamentação do sistema de saúde administrado pelos sindicatos: "Nos opomos que o Governo entregue as obras sociales sindicais aos financistas do mercado, que terminarão destruindo o sistema de saúde". ${ }^{643}$ Vejamos mais detalhadamente como a questão se expressou na central nas palavras de seu presidente:

(...) defendemos o dinheiro de 11 milhões de pessoas. (...) não se pode confundir o povo porque fomos os criadores das obras sociales sindicais e essas foram as mesmas que durante décadas deram resposta eficiente à problemática da saúde. Então, quando se modifica um sistema onde só estão envolvidos os tecnocratas do [Ministério da] Economia, os agentes financeiros e detrás termina o FMI, temos a absoluta suspeita de que é parte de uma entrega indireta da privatização aos setores bancários financeiros e que não será para melhorar a qualidade da saúde dos trabalhadores, mas que se toma como um negócio. E tanto na saúde como na educação, a solidariedade joga um papel chave. ${ }^{644}$

Em um dos poucos documentos da CGT que tive acesso, pode-se compreender mais detalhadamente a análise de conjuntura e as propostas para o desemprego feitas pela central.

\footnotetext{
639 "El sindicalismo se sintió ganador, pero sin euforia”. Clarín, 25/11/2000, p. 12.

640 “"La huelga la organizó el Gobierno”. Clarín, 25/11/2000, p. 12.

${ }^{641}$ A outra fonte Daer explicitou os objetivos do protesto da seguinte maneira: "A CGT reivindica do governo o diálogo social para uma política de produção e de emprego decente" ("Daer: "Esto fue un plebiscito contra la política económica'”. Crónica, 25/11/2000, p. 11).

642 "La CGT oficial marcha hoy contra la reforma previsional”. La Nación, 19/12/2000, p. 10.

643 “Daer amenazó con echar al Gobierno”. La Nación, 20/12/2000, p. 10.

644 “Condena general al discurso de Daer”. La Nación, 21/12/2000, p. 6.
} 
Para a entidade, "a economia argentina, com a convertibilidade e o peso atado ao dólar eliminou a hiperinflação, consagrando uma notável estabilidade". O documento ressalta anda o aumento da produtividade, embora reconheça seu efeito para a geração de desemprego e "precariedade do trabalho. Em suma, para a central, o crescimento e a estabilidade não foi acompanhada por "eqüidade social” (CGT, 2000, p. 1). Nesse contexto, destaca que “(...) não houve resistência, mas compreensão dos trabalhadores em relação às mudanças estruturais" e que estes souberam reconhecer a importância da modernização e da competitividade "suportando" a perda de fontes de trabalho causada pela "abrupta abertura da economia".

Nesse documento a CGT assume a defesa da venda de estatais, mas reconhece que estas não provocaram uma diminuição da dívida externa: "A central defende abertamente as privatizações: entre 1991 e 1999, apesar de importantes privatizações e venda de ativos, que contribuíram para reduzir a dívida, o endividamento externo mais que duplicou” (p. 11). Mais adiante, explicita que sem essa estratégia "teria sido pior". Também argumenta que "A privatização de serviços públicos terminou com uma oferta insuficiente e ineficiente", apesar de criticar os altos preços dos serviços das empresas privadas, especialmente para os que possuem salários médios e baixos (p. 13). Reconhece como causa do desemprego a abertura para a concorrência exterior e seu efeito para as mudanças no processo produtivo: “(...) com a abertura abrupta (...) grande parte do equipamento do capital produtivo pré-existente passou a ser obsoleto (...)" (p. 17). Afirma ainda que os investidores estrangeiros que compraram as estatais priorizaram a "eficiência" e a "produtividade" mais do que as "ampliações produtivas". (p. 18). A entidade destaca também o papel exercido pelas indenizações nas "demissões voluntárias", que difundiu a idéia de trabalho por conta própria: "A idéia de ingressar no trabalho por conta própria com o capital recebido nas demissões voluntárias impediu apreciar com toda amplitude a perda de postos de trabalho na relação de dependência". No entanto, a central afirma que somente quando este mercado se saturou e os "empreendimentos individuais se descapitalizaram" é que se pôde verificar sua contribuição para o crescimento do desemprego (p. 19). O documento sublinha que a paridade entre o peso e o dólar restringiu as vendas ao exterior e facilitou a entrada de produtos importados (p. 20). Porém, ressalta que "a contribuição dos trabalhadores ao processo de convertibilidade foi ampla, generosa e oportuna, encarregando-se da pior parte", como o desemprego e a redução salarial, apesar de sua importância para o aumento da produtividade (p. 25). 
Em fevereiro de 2001, a CGT discutia a convocação de uma greve geral. Segundo o comerciário Armando Cavalieri, o protesto da entidade se justificava pelas seguintes propostas: "Há que recriar emprego, acalmar a situação social, deve ser implantado um seguro-desemprego urgentemente, deve se lograr a reativação do mercado interno, reduzir o IVA (...)" ${ }^{645}$ Diante da disposição do Governo de abrir uma mesa de diálogo, a central suspendeu a greve, medida assim justificada por Daer: "Frente ao chamado do Presidente, a CGT decidiu postergar as jornadas de protesto". A mesa de negociações convocada pelo Governo foi considerada "um triunfo" pelo sindicalista: "sempre reivindicamos o diálogo social, mas não um diálogo de surdos, mas um âmbito de debates, de construção e de consenso". ${ }^{646}$ No dia 21 de março a CGT-Moyano, a CTA e a CCC realizaram uma greve da qual a CGT-Daer não participou.

Após uma reunião da Área de Livre Comércio das Américas (ALCA) em Buenos Aires, a CGT-Daer realizou um ato em 5 de abril de 2001 em repúdio à formação do bloco. Durante o evento, Daer argumentou que sua formação significaria "instaurar o neoliberalismo e um capitalismo selvagem". 647

No dia 8 de junho se realizou uma nova greve convocada pela CGT-Moyano, pela CTA e pela CCC, da qual a CGT-Daer não participou. Porém, em virtude do anúncio dos cortes nas aposentadorias e nos salários dos estatais pela Ministra do Trabalho, Patricia Bullrich, as organizações sindicais convocaram uma greve geral para 19 de julho. ${ }^{648} \mathrm{O}$ protesto foi realizado porque "se sujeitou o salário dos estatais à arrecadação, no marco da Lei de Déficit Zero" ${ }^{649}$ Em um documento a central expressou que o modelo econômico levado a cabo no país "é deficitário, destruidor de emprego, recessivo, dependente, desintegrador do território e essencialmente gerador de insegurança e exclusão social". ${ }^{650}$ A greve das três centrais, a sexta da administração de De la Rúa, teve uma alta adesão, segundo os sindicalistas. ${ }^{651}$

Em 8 de agosto a CTA realizou uma greve geral contra a política econômica e o desemprego, da qual não participou a CGT. Em seguida, em um protesto contra o ajuste, as

\footnotetext{
645 “La CGT oficial decidirá pasado mañana la suspensión del paro”. La Nación, 24/02/2001, p. 10.

646 "La CGT oficial levantó el paro para dialogar con el Gobierno”. La Nación, 28/02/2001, p. 10.

647 “Alca : la CGT oficial encabeza el repudio”. Crónica, 06/04/2001, p. 2.

648 "Las CGT convocaron a un paro de 24 horas para pasado mañana". La Nación, 17/07/2001, PIMSA, s/r.

${ }^{649}$ Trata de uma lei semelhante à Lei de Responsabilidade Fiscal brasileira ("Rige el paro general de las dos CGT". Crónica, 13/12/2001, p. 10).

650 "Piden a gremialistas bajar sus sueldos". La Nación, 18/07/2001, p. 8.

651 “La huelga fue total”. Crónica, 20/07/2001, p. 5-11. Ver também Clarín, 20/07/2001, pp. 14-17; La Nación, 20/07/2001, pp. 8-9.
} 
duas CGTs voltaram a realizar uma marcha com concentração na Plaza de Mayo no dia 29 de agosto, sob a consigna "basta de arrocho e de um modelo econômico de fome". ${ }^{652}$ Para o dirigente, "O neoliberalismo quer destruir os partidos políticos e os sindicatos, mas sem sindicatos os salários sempre vão ser baratos e o personagem de turno que quer destruir os sindicatos é a senhora Ministra do Trabalho [Patricia Bullrich]". ${ }^{653}$

Com a divulgação da cifra de desemprego, superior a 18\%, a entidade reforçou a proposta de aprovação de um seguro-desemprego ${ }^{654}$ Nesse contexto, o Governo anunciou o corralito, e a CGT-Daer aprovou uma greve geral para o dia 13 de dezembro, realizada em conjunto com a CGT-Moyano e a CTA. Para Daer, a concertação "não pode ser feita sobre fatos consumados, como é este novo atropelamento sobre o salário dos trabalhadores". ${ }^{655} \mathrm{O}$ dirigente declarou também que "Nossa reivindicação pela intangibilidade do salário é invariável e por isso ampliaremos as medidas de força. Mas não queremos facilitar situações de convulsão social das quais somos alheios". ${ }^{656}$ Os jornais consultados reconheceram a alta adesão à greve, o Governo afirmou haver sido "importante" e as três organizações a consideraram "contundente". Para todos, foi a mais significativa da administração de De la Rúa. ${ }^{657}$ Durante o protesto foram realizados bloqueios de avenidas pelas organizações de desempregados em várias pontes de acesso à capital federal. ${ }^{658} \mathrm{Em}$ avaliação posterior sobre os eventos, Daer afirmou que a greve de 13 de dezembro da CGT se deu contra a bancarização compulsiva: "O sindicalismo é totalmente solidário com os poupadores que acreditaram no sistema financeiro e na intangibilidade dos depósitos". Porém, o dirigente também declarou que "os cacerolazos não era assunto dos sindicatos, mas da classe média" ${ }^{659}$ Logo após a mobilização, Daer solicitou uma reunião com De la Rúa e advertiu

\footnotetext{
652 "Las dos CGT declararon la guerra a Cavallo". Crónica, 30/08/2001, p. 10. Durante o ato, Daer criticou as propostas do ministro Cavallo de privatizar a Anses [Administración Nacional de Seguridad Social], o PAMI [Programa de Atención Médica Integral] e até as universidades". "Las CGT pidieron derrotar en las urnas el modelo económico". La Nación, 30/08/2001, p. 8.

653 "El sindicalismo copó la Plaza para repudiar los ajustes". Clarín, 30/08/2001, s/r.

654 "Un encuentro en el que abundaron diferencias". La Nación, 27/11/2001, p. 6.

655 "Las CGT analizan una huelga". La Nación, 5/12/2001, p. 13.

656 "Amenaza del Gobierno por la huelga". La Nación, 12/12/2001, p. 9. No dia 12, a Coordinadora de Actividades Mercantiles (CAME) e outras entidades convocaram a um cacerolazo e um bocinazo. ("Apagones, bocinazos y marchas dominaron la víspera del paro". La Nación, 13/12/2001, p. 12). Cacerolazo: ação de protesto em que os manifestantes batem panelas vazias para demonstrar a piora de suas condições de vida. Bocinazo: ação de protesto cuja ferramenta utilizada são as buzinas dos automóveis, tocadas de maneira massiva, geralmente no local em que se realiza uma manifestação, como forma de demonstrar o apoio.

657 "Fue fuerte el paro en contra del plan económico". Clarín, 14/12/2001, p. 3.

658 "Los piquetes dificultaron el acceso a la Capital". La Nación, 14/12/2001, p. 11.

${ }^{659}$ A respeito dessa declaração, Cavalieri fez o seguinte comentário: "Mas como diz isso? Está buscando que nos façam um cacerolazo? Um dirigente operário de caráter nacional não pode se isolar e mostrar condutas 
que a CGT iria participar da marcha do dia 20 convocada pela CGT-Moyano. O objetivo do encontro era a derrogação das medidas sobre asignaciones familiares anunciadas no decreto 1382 "de necessidade e urgência". Com o não atendimento de suas reivindicações, a CGT convocou uma greve geral para o dia 20 de dezembro. No entanto, a medida não ganhou força diante dos protestos que levaram à queda de De la Rúa. Para Rodolfo Daer, o presidente foi o "responsável pelas mortes e pelo caos social”, referindo-se à intensa repressão policial. ${ }^{660}$

Quando assumiu provisoriamente o Governo, Adolfo Rodríguez Saá se reuniu com Daer e Moyano, que reivindicaram medidas para a geração de emprego e o aumento do salário mínimo. ${ }^{661}$ Depois de um período de transição, assumiu Eduardo Duhalde. Este, como novo presidente, nomeou o dirigente da CGT, Alfredo Atasanof, para assumir o Ministério do Trabalho. Em seguida, a CGT-Daer pediu ao presidente para que convocasse o conselho do salário mínimo e a devolução dos $13 \%$ do salário aos estatais e aos aposentados. ${ }^{62}$ Com o anúncio da Lei do Orçamento Nacional, Daer não convocou nenhum ato, mas demonstrou sua insatisfação. Segundo o dirigente, essa situação estava levando o país a um "estallido"663. Nesse contexto, Andrés Rodríguez, da UPCN, afirmou: "estamos dispostos a ações diretas, que podem ser greves, porque não vamos deixar que o empregado público trabalhe de graça". ${ }^{664}$ Apesar dessas críticas, foi evidente o apoio político da CGT a Duhalde, como demonstram as $62 \mathrm{OP}$ em uma nota:

(...) respaldamos o Governo do Dr. Eduardo Duhalde convencidos de que é a última oportunidade que nós, argentinos, temos para encaminhar, em paz e em democracia, a saída do nefasto modelo que vimos suportando (...). Companheiro presidente: estamos do seu lado, levantando as bandeiras que nunca deverão ser arriadas, convencidos de que há que voltar [aos ideias de] Perón para salvar a Nação. ${ }^{665}$

Como se pode observar, alguns setores demonstravam expectativas positivas com o novo presidente. Para alguns, o Governo geraria uma política industrialista no país. Para outros, criaria um contexto favorável à discussão dos salários. A respeito do tema, destaco a seguinte declaração da UOM:

\footnotetext{
classistas. O chefe da CGT deve se preocupar por todos os setores. Sua obrigação é enfatizar a ineqüidade que se cometeu no país, onde se converteram em pesos as dívidas e se dolarizaram os preços". "Bajón de Moyano y rectos a Daer". Clarín, 13/02/2002, p. 17.

660 "Normalizaron servicio de trenes". Crónica, 22/12/2001, p. 12.

661 "Las CGT recibirán al Presidente y esperan anuncios salariales”. La Nación, 26/12/2001, p. 7.

662 "Moyano dio un apoyo crítico al presidente". La Nación, 29/01/2002, p. 8.

${ }^{663}$ Expressão que designa uma situação social limite que provoca uma explosão de protestos.

664 "Daer vaticinó que habrá estallidos si no cobran los estatales". La Nación, 23/02/2002, p. 10.

665 "Es hora de definiciones". Solicitada de las 62 Organizaciones Gremiales Peronistas. Crónica, 23/02/2002, p. 5.
} 
É muito cedo para que se vejam os resultados, mas há indícios alentadores: depois de muitos anos de se privilegiar o setor financeiro, em detrimento do trabalho e da produção, este Governo tem se animado a tomar esse rumo, e apoiar decididamente a indústria nacional (...). Com um tipo de mudança que lhe permita ser mais competitiva, a produção nacional poderá ser exportada ao mundo em busca das divisas que o país necessita para crescer. Essa Indústria deverá ser a alavanca da geração de mais postos de trabalho, que os argentinos reivindicam para dignificar sua existência, fortalecendo o mercado interno. ${ }^{666}$

$\mathrm{O}$ ano de 2002 seria marcado pelo crescimento dos protestos das organizações de desempregados. A principal política do Governo para tratar o desemprego era o Plan de Jefas y Jefes, sobre o qual o dirigente Armando Cavalieri afirmou: “o subsídio de 150 pesos para os desempregados, além de ser uma cifra insignificante, ficou completamente superado pelo aumento dos preços". ${ }^{667}$ Nesse contexto, a questão salarial passou a ser crucial nas discussões sindicais. Sobre o tema, Daer afirmou que "O Presidente compartilha a definição da CGT de que há que impedir que se liquidem os salários e deu instruções para que nos próximos dias se ponha em marcha uma comissão intersetorial tripartite de juros, preços e salários". ${ }^{668}$ Quando Graciela Camaño ${ }^{669}$ assumiu o Ministério do Trabalho, logo se reuniu com a CGT e solicitou uma comissão negociadora intersetorial para discutir o tema com os empresários. ${ }^{670}$

Ao longo de 2002, alguns setores cegetistas se mobilizaram para se opor à política econômica de Duhalde. No dia 23 de maio, os bancários realizaram uma paralisação com mobilização frente ao Congresso fora do horário de atendimento ao público em "defesa das fontes de trabalho" e por "um sistema financeiro produtivo". ${ }^{671}$ Novamente a questão salarial apareceu como questão prioritária para a CGT, tal como explicitou Daer: "Estou em conversações com o Ministério do Trabalho e com os setores empresariais para reconstruir o poder aquisitivo dos assalariados". ${ }^{672}$ No dia 14 de junho, em reivindicação pela reativação do setor da construção, sindicalistas da Uocra e empresários entregaram um documento à Casa Rosada solicitando "uma política de Estado" para "a geração de emprego e justa distribuição da renda". 673

\footnotetext{
666 "La lucha continúa". Solicitada de la Mesa Nacional Agrupación Nacional Peronista Augusto T. Vandor. Crónica, 11/03/2002, p. 7.

667 "La CGT oficial pedirá al Gobierno planes económicos alternativos". La Nación, 27/03/2002, p. 7.

668 "Duhalde le dijo a Daer que analiza una variante para subir los sueldos". La Nación, 17/04/2002, p. 8.

${ }^{669}$ Camaño, que também era dirigente da CGT, substituiu Atasanof quando este passou a ser chefe de gabinete do Governo.

670 "Apoyo a la CGT para que discuta los sueldos". La Nación, 10/10/2002, p. 10.

671 "Bancarios: paro con atención". Crónica, 23/05/2002, p. 8.

672 "Daer postergó el viaje a la OIT". La Nación, 01/06/2002, p. 9.

673 "Marchan sindicatos y empresarios del área de la construcción". La Nación, 14/06/2002, p. 8. Ver também "Empresarios y obreros, con igual reclamo". La Nación, 15/06/2002, p. 6.
} 
Sobre o tema dos salários, Daer afirmou em uma entrevista que os empresários "não podem se fazer de distraídos em uma situação dramática de queda salarial e de crescimento da pobreza não só dos desempregados mas dos que têm trabalho mas seus salários não alcançam nem para comer". Como se depreende da leitura dos documentos, a prioridade da CGT nesse momento era a defesa do salário dos empregados, e a mobilização dos desempregados não foi tomada como bandeira pela central. Em relação ao acordo do Governo com o FMI, sustentou: "os tempos do FMI não são os das pessoas". ${ }^{674}$ No final de junho ocorreu o massacre de Puente Pueyrredón, em Avellaneda, no qual morreram dois militantes desempregados. A CGT não aderiu ao ato das organizações em repúdio à repressão, nem à greve da CGTMoyano e da CTA. No segundo semestre se acentuou no interior do sindicalismo uma discussão a respeito das eleições e a CGT-Daer priorizou a discussão partidária. ${ }^{675}$

Em 2002, a CGT-Moyano realizou diversas mobilizações e a CTA convocou três greves gerais. $\mathrm{O}$ ano terminou com um forte debate acerca do apoio dos diferentes setores do sindicalismo aos presidenciáveis. A CGT-Moyano apoiou Rodriguez Saá, a CTA propôs um projeto político distinto para o país sem fazer referência a um candidato, o MOP Cassia apoiou Menem e a CGT-Daer esperava a reunião interna do PJ para se posicionar ${ }^{676}$.

$* * *$

Entre 2000 e 2002 a CGT-Daer manteve divergências com a CGT-Moyano, mas em determinados momentos ambas atuaram em conjunto, enfrentando algumas das principais medidas anunciadas pelo Governo da Alianza. Durante o período considerado neste item, a central seguiu sua política de concertação sem deixar de realizar manifestações e greves. Opôs-se à política econômica levada a cabo por Cavallo, como as reduções salariais e o corralito. Apresentou propostas para o desemprego, mas seguiu sem uma política de organização dos desempregados para a luta. Defendeu o seguro-desemprego, mas se opôs aos programas assistencialistas para os desempregados, por considerá-los parte do clientelismo político. Como alternativa, apresentou a bandeira do investimento na produção. Das dez greves convocadas entre 2000 e 2001, a CGT participou de cinco, sendo que a de 13 de dezembro de 2001 teve uma alta adesão e expressou o momento de maior grau de unidade do movimento operário organizado sindicalmente em todo o período analisado neste capítulo.

\footnotetext{
674 “'El aumento salarial no se puede postergar más””. La Nación, 24/06/2002, p. 8.

675 "La puja del PJ divide a las CGT". La Nación, 05/11/2002, p. 6.

676 "La CGT espera una tregua en el PJ para apoyar a un candidato". La Nación, 27/12/2002, p. 8. 
Em 2002, não participou das três greves gerais convocadas pela CTA, nem da paralisação nacional realizada pela CGT-Moyano.

\section{A CGT-Moyano}

Logo após a posse de De la Rúa, quando a CTA decidiu convocar uma greve contra a repressão em Corrientes, em dezembro de 1999, a CGT-Moyano não aderiu ao protesto e, em um comunicado de imprensa, declarou: “o impuestazo ${ }^{[677]}$, a pressão sobre as províncias e a designação de Ramón Mestre como interventor são sinais de alarme porque indicam a continuidade das políticas mais regressivas sofridas nos últimos anos". 678

Nesse momento, as críticas do setor cegetista liderado por Hugo Moyano à reforma trabalhista proposta pelo governo aliancista não se diferenciaram muito das que foram feitas pela Direção Nacional da CGT. Para Ubaldini, "Na reforma existe uma armadilha para tirar representatividade das organizações sindicais". ${ }^{679}$ De acordo com Moyano, os legisladores da Alianza também não deveriam votá-la "porque são os mesmos que nos acompanharam em nossas marchas de protesto durante o anterior governo" e que "em tão pouco tempo não podem ter mudado de idéia". 680

Sobre a anulação de um decreto de Menem que permitia aos sindicatos a administração do Fondo de Redistribución de las Obras Sociales, Moyano afirmou: "Isso é uma provocação ao movimento operário e não vamos ficar com os braços cruzados". O dirigente argumentou também que:

Se a idéia de De la Rúa é seguir o caminho que tentou (Raúl) Alfonsín, o sindicalismo vai responder da mesma maneira que fez entre 1983 e 1989. (...) Tentam nos ameaçar, mas o Governo volta a cometer o mesmo erro que cometeu Alfonsín, ao querer ignorar, enfrentar e destruir as organizações sindicais. ${ }^{681}$

Para Ubaldini, o Governo decidiu tirar da CGT a administração das obras sociales como forma de “(...) represália pela oposição que temos mostrado diante da reforma trabalhista". Ao comparar este projeto com o outro que o PJ votou durante o Governo de Menem, o sindicalista afirmou: "Não, nunca o peronismo aceitaria que fossem afetadas as convenções coletivas de trabalho. Ademais, a lei trabalhista do PJ terminou com os contratos

\footnotetext{
${ }^{677}$ Forma denominar um grande aumento dos impostos.

678 "Primer paro para el nuevo gobierno. La CTA a huelga para el lunes en repudio a la represión". Página/12, 18/12/1999, p. 8.

679 “Sigue la pelea por la reforma laboral”. La Nación, 14/01/2000, p. 6.

680 “Amenaza de la CGT al Gobierno". La Nación, 18/01/2000, p. 6.

681 "El gremialismo está listo para dar batalla". La Nación, 19/01/2000, p. 5.
} 
temporários". ${ }^{62}$ Aqui é possível ressaltar o argumento de que a central se mobilizou com mais veemência quando o poder sindical foi ameaçado, defendendo os interesses da organização, por sua vez consideradas conquistas históricas da classe trabalhadora advindas da luta e legitimadas pelo por Perón. Sobre a flexibilidade do trabalho proposta pelo Governo, Moyano afirmou:

A recusamos porque, ademais de não solucionar o problema mais grave, que é o desemprego, prejudica os trabalhadores porque aponta diretamente para a queda dos convênios coletivos de trabalho. E isso significa o rebaixamento de salários porque hoje ninguém, nem sequer as centrais nacionais, está em condições de discutir salários. Se cai o convênio coletivo, por mais que bloqueie as estradas e pare todas os ramos de atividade, não estou em condições de discutir salários porque sei que não vou lograr melhoras. $^{683}$

Porém, nesse setor as "medidas de força" não estavam descartadas: "Se as autoridades insistem teimosamente em afundar a crise arrancando dos assalariados conquistas históricas, não resta outro caminho a não ser recorrer à luta (...)". ${ }^{684}$ Em outra situação, Moyano declarou: "Vamos defender os trabalhadores com toda nossa força, com mobilizações ou com o que for necessário". ${ }^{685}$ Por último, sobre a flexibilização, o dirigente sustentou: "havendo tantos temas importantes para discutir para melhorar a economia do país e reduzir o desemprego, se discute uma reforma trabalhista que não ajudará em nada". ${ }^{686}$

Apesar da suspensão da greve de fevereiro convocada pela CGT-Daer, a linha liderada por Moyano manteve o protesto, o que instaurou um novo clima de oposição no interior da central. O dirigente acusou aquela central de "trair os trabalhadores, que é o mesmo que trair à Pátria”, convocando a uma paralisação de atividades com marcha à Plaza de Mayo ao meiodia de 24 de fevereiro, na qual participaram 87 sindicatos, entre eles o Smata, a UOM e a Uocra. ${ }^{687}$ No protesto, o metalúrgico Francisco Gutiérrez afirmou: "Viemos denunciar os traidores do movimento operário". Por sua vez, Hugo Moyano declarou: "que não se equivoquem aqueles homens do Governo que crêem que porque dão algumas regalias a alguns dirigentes vão convencer o conjunto dos trabalhadores. Os que criticavam a condução da CGT hoje negociam com a cúpula contra os trabalhadores". ${ }^{688}$ O dirigente também

\footnotetext{
682 “Ubaldini: 'Un sector del Gobierno agravia aún al sindicalismo'”. La Nación, 20/01/2000, p. 6.

683 "Yo no soy Ubaldini; no es el momento para hablar de paros". Moyano, Hugo. Entrevista. La Nación, 23/01/2000, p. 3.

684 “Dura advertencia de Moyano al Gobierno por la reforma laboral". La Razón, 03/02/2000, p. 2.

685 "La cúpula sindical endureció su postura”. La Nación, 03/02/2000, p. 7.

686 “Acordarían la reforma laboral”. La Nación, 09/02/2000, p. 4.

687 "Si hicimos trece paros, podemos hacer el doble". Crónica, 23/02/2000, p. 2.

688 "El día de la CGT de los disidentes". La Nación, 24/02/2000, p. 7.
} 
sustentou sua disposição de seguir se mobilizando: "Não vamos abdicar da luta". ${ }^{689}$ Durante o ato, Moyano argumentou:

Cansei de escutar de boca do presidente da Nação, do vice-presidente (Carlos Alvarez) e da ministra de Desenvolvimento Social (Graciela Fernández Meijide) que eles iam se diferenciar do governo anterior, que ia predominar a ética e que o Governo ia ser cristalino... e resulta que vão e negociam e pactuam com os que eles permanentemente repudiaram. ${ }^{690}$

Moyano assinalou nesse momento também que "A cúpula da CGT não representa ninguém. E o projeto de reforma trabalhista é o projeto do Fundo Monetário e dos traidores". ${ }^{691}$ Em outra fonte, lê-se a seguinte declaração: "por mais que o governo tenha se esforçado para explicar o inexplicável e por mais que queiram nos convencer que a lei vai criar trabalho, é mentira; esta lei é para rebaixar os salários e ficar com o pouco que resta aos trabalhadores". ${ }^{692}$ Lorenzo Miguel também expressou seu descontentamento com a condução da CGT, ao afirmar que os trabalhadores "vão fazer quantas greves sejam necessárias" e que a cúpula cegetista "cometeu um erro histórico", referindo-se a sua estratégia de não confrontar com o Governo. Por fim, acrescentou que "entre quatro e cinco dirigentes não pode resolver um problema que é importante para todas as organizações sindicais". 693

Em março de 2000 foi criada outra "CGT”, com Hugo Moyano como titular. ${ }^{694}$ No dia 20 desse mês o setor realizou uma marcha em Córdoba. Diante da declaração do presidente de que os sindicatos que se recusassem a apoiar a reforma trabalhista eram defensores do trabalho informal, Moyano argumentou: "O emprego informal não se resolve com uma lei, resolve-se colocando em funcionamento o Ministério do Trabalho". Ainda a respeito do tema, o dirigente acrescentou: "Não estamos a favor do trabalho informal e esta lei só serve para que se caiam os convênios e se reduzam os salários. O Presidente está mal informado ou entende pouco de legislação trabalhista". 695

\footnotetext{
689 "Daer intentó disimular la fractura de la CGT”. La Nación, 24/02/2000, p. 6.

690 “La movilización quedó en deuda”. La Nación, 25/02/2000, p. 4.

691 "La cúpula no representa a nadie". Página/12, 25/02/2000, p. 3.

692 "Plaza de Mayo 'hirvió' de bronca contra la reforma". Crónica, 25/02/2000, p. 11.

${ }^{693}$ A respeito do protesto, Lorenzo Miguel argumentou: "esta multidão demostrou que uma parte importante do movimento operário está contra esta lei" e que "jamais a CGT cumpriu o papel de uma paritária e aqui assumiu um papel que não lhe corresponde. Ademais, de forma inorgânica, tem aceitado uma lei que os trabalhadores recusam e que trará graves problemas". Para Miguel, "As conquistas dos trabalhadores não devem diminuir mas se somar e o que faz esta lei é tirar direitos trabalhistas". "Miguel amenazó con mas paros". Diario Popular, 25/02/2000, p. 6.

694 “Moyano resistirá la reforma laboral”. La Nación, 17/03/2000, p. 6.

695 “Moyano desafió al Gobierno”. La Nación, 21/03/2000, p. 8.
} 
A crítica de Moyano à reforma trabalhista também abarcava a questão do vínculo desta com a pressão das organizações financeiras internacionais, qualificando-a como uma "diretiva do (...) FMI e não uma iniciativa para melhorar a vida dos trabalhadores". ${ }^{696}$ Em maio a CGTMoyano analisou convocar outra greve contra a reforma trabalhista: "não resta outro caminho que não seja o da confrontação". ${ }^{697}$ A entidade decidiu realizar uma "manifestação de protesto ao Congresso com paralisação de atividades" no dia 27, para se opor ao projeto aprovado pela Câmara de Deputados, que nesse momento ainda seria analisado pelo Senado. ${ }^{698}$

Na madrugada de 18 de abril, a central realizou um protesto contra a aprovação da reforma trabalhista. A manifestação terminou com uma intensa repressão, com cerca de 30 operários feridos, segundo o Crónica ${ }^{699}, 37$ feridos e 45 detidos segundo La Nación. ${ }^{700}$ A sessão no Senado foi interrompida e o debate acerca da flexibilização do trabalho foi postergado. Na semana seguinte a entidade ameaçou com uma nova greve caso os senadores decidissem sancioná-la. ${ }^{701}$ Depois de negociar com a central a continuidade dos sindicatos nacionais nas negociações coletivas, o Governo conseguiu aprovar a lei ${ }^{702}$, sob a suspeita de pagamento de subornos aos senadores. A CGT-Moyano protestou em frente ao Congreso, onde estiveram presentes, segundo o Clarín, 20.000 pessoas. Também participaram do ato a CTA e a CCC. ${ }^{703}$ A lei foi aprovada e a CGT-Moyano convocou uma greve para o dia 5 de maio, novamente em conjunto com a CTA e a CCC. Para Hugo Moyano, "O motivo da greve não é só a reforma trabalhista. A reforma é parte do mal maior, que é o modelo econômico". ${ }^{704}$ O protesto teve adesão da CTA e de alguns sindicatos industriais importantes como a UOM e o Smata. Sobre o protesto o dirigente fez a seguinte avaliação: "A alta adesão à greve significa um chamado de atenção para o Governo". Moyano sustentou também que deveria ser convocado um "plebiscito para que o povo se manifeste a favor ou contra a reforma trabalhista". ${ }^{705} \mathrm{O}$ dirigente argumentou, ademais, que:

Essa não é uma greve contra o Governo, mas uma greve que se faz contra o modelo econômico, porque faz dez anos que vimos protestando contra este modelo e contra o poder externo que o impõe. Se este

\footnotetext{
696 “Quejas de Moyano”. La Nación, 28/03/2000, p. 9.

697 "La CGT de Moyano analiza otro paro". La Nación, 05/04/2000, p. 7.

698 "La CGT rebelde se moviliza para presionar al Senado". La Nación, 11/04/2000, p. 9.

${ }^{699}$ Ver "Brutal represión a los obreros en Congreso". Crónica, 19/04/2000, pp. 2-9.

${ }^{700}$ Ver "Los graves incidentes frenaron la ley laboral”. La Nación, 20/04/2000, pp. 6-8; "Un día de violencia dejó sin sanción a la reforma". Clarín, 20/04/2000, pp. 3-10.

701 "La CGT disidente amenaza con un paro contra la reforma laboral”. La Razón, 25/04/2000, p. 3.

702 "Después de negociar, el Gobierno logró la reforma”. Clarín, 27/04/2000, p. 3.

703 "La CGT rebelde protestó y llamó a una huelga para el 5 de mayo". Clarín, 27/04/2000, p. 8.

704 "Moyano convocó a un paro nacional para el 5 de mayo". La Nación, 27/04/2000, p. 6.

705 "Fue masivo el primer paro nacional contra el Gobierno". Crónica, 06/05/2000, p. 9.
} 
Governo o aprofundou a dois ou cinco meses, não é um problema nosso. Se o segue aprofundando, seguiremos fazendo greves. ${ }^{706}$

A partir de então, a CGT-Moyano convocou vários protestos contra o Governo. No dia 30 de maio realizou uma marcha contra o FMI, à qual a CTA aderiu. ${ }^{707}$ Em seguida, participou da greve geral, convocada em conjunto com a CGT-Daer, a CTA e a CCC, no dia 9 de junho, contra o rebaixamento salarial dos empregados públicos. Na convocatória do protesto a central Moyano deu a seguinte declaração: "Vamos fazer cacerolazos, apagões, vamos pegar onde dói, vamos organizar com as PMEs, com o setor agrícola, vamos chamar a uma desobediência fiscal para que o esforço dos argentinos não o leve a dívida externa". 708 Porém, apesar da disposição para a luta, a CGT-Moyano não descartava a negociação: "Se o Governo nos convoca a uma concertação, iremos, e é claro que isso será benéfico. Nós não queremos parar, preferimos o diálogo. Tampouco queremos que façam tudo o que dizemos, mas reivindicamos que nos deixem discutir com eles". ${ }^{709}$ No protesto foi fundamental a participação das organizações de desempregados, que utilizaram o piquete como instrumento de luta, tanto na capital federal como no interior do país. ${ }^{710}$ Esse momento marcaria o início da construção de unidade entre setores do movimento de desempregados e do sindicalismo, que ainda estaria por conhecer seu momento de maior grau de integração.

Nos meses seguintes a CGT-Moyano realizou vários protestos contra o Governo. Em julho, em uma marcha ao Congresso Nacional, Moyano se posicionou favorável à suspensão do pagamento da dívida externa e à desobediência fiscal. ${ }^{711}$ Poucos dias depois, Daer conseguiu sua reeleição na condução da CGT. Em setembro, o setor dissidente organizou um "protesto em reivindicação da anulação da lei trabalhista e contra o ajuste de salários", no qual, segundo La Nación, havia pouco mais de 2.000 participantes. ${ }^{712}$ Em outubro, convocou outra marcha com paralisação de atividades desde o meio-dia contra o modelo econômico do

\footnotetext{
706 “Moyano: 'Vamos a seguir con los paros"”. La Nación, 06/05/2000, p. 7.

707 "Marcha de repudio al FMI”. Crónica, 30/05/2000, p. 9.

708 “Masivo acto contra el FMI en Plaza de Mayo". Clarín, 01/06/2000, p. 3. Ver também "Heterogénea marcha contra el FMI". La Nación, 01/06/2000, p. 6.

709 "Moyano se mostró cauto y pidió diálogo". La Nación, 10/06/2000, p. 14”. A outra fonte, Moyano expressou seu desejo de "contribuir com o Governo para que mude este modelo econômico" e que "não queremos que o Governo apareça debilitado e se tem a grandeza de convocar todos os setores da sociedade, vai sair fortalecido". “"Fue un grito del pueblo"”. Crónica, 10/06/2000, p. 9.

710 "Piqueteros jugaron un papel clave". Crónica, 10/06/2000, p. 13". Ver também "Piquetes, piedrazos y amenazas desde La Quiaca hasta Ushuaia". Clarín, 10/06/2000, p. 6".

711 "Moyano llamó a no pagar la deuda e insistió en la desobediencia fiscal". Clarín, 27/07/2000, p. 8.

712 “Débil respaldo a la movilización de la CGT disidente”. La Nación, 07/09/2000, p. 10.
} 
Governo, na qual expressou seu descontentamento com "a reforma trabalhista, o corte salarial e o impuestazo". 713

Nos dias 23 e 24 de novembro a CGT-Moyano realizou uma greve geral de 36 horas em conjunto com a CGT-Daer e a CTA. Durante o protesto ocorreram mobilizações, piquetes, bloqueios de ruas, avenidas e rodovias, cacerolazos e ollas populares ${ }^{714}$, ampliando a construção da unidade entre o movimento operário organizado sindicalmente e os trabalhadores desempregados. Em defesa da utilização do piquete como instrumento de luta durante a greve, Moyano argumentou: "Violência não é cortar uma rodovia ou uma rua. Violência é deixar os argentinos sem trabalho, descontar o salário dos empregados públicos, presentear o patrimônio nacional, eliminar as conquistas dos trabalhadores". ${ }^{715}$ Durante o protesto, o dirigente afirmou que a ministra Bulrich "se lembrou tarde dos trabalhadores porque [o Governo] aprovou uma reforma trabalhista mediante o suborno, impuseram o impuestazo e o rebaixamento salarial, e agora querem fazer uma reforma previdenciária". A medida foi assim justificada por Moyano: "De la Rúa não sabe por que paramos. Paramos pelos 2 milhões de desempregados, os 14 milhões de argentinos empobrecidos, as 55 crianças que morrem por dia, o endividamento e o desemprego que tem aumentado". ${ }^{716}$ Em outra declaração o dirigente afirma que: "O modelo econômico é o mesmo (...) e não permitem mudá-lo porque há uma dependência econômica total e uma subordinação mental dos funcionários ao pensamento único imposto. Nós temos a obrigação de confrontar e tratar de mudar o modelo". Acerca da solidariedade entre o ativo e a reserva o dirigente declarou:

Quem quiser trabalhar pode fazê-lo, sempre foi igual. As greves nunca são cem por cento. Quem nega a liberdade de trabalho a milhões de desempregados é o Governo. Ademais, quem quiser trabalhar tem que pensar que se não impomos respeito, algum dia também vai ficar sem emprego. ${ }^{717}$

Demonstrando seu apoio à ação conjunta dos dois setores, Moyano destacou a participação dos desempregados na greve: "o trabalhador com trabalho não vai trabalhar, mas o sem trabalho bloqueia uma rodovia, porque também quer que o levem em consideração,"718 Durante o protesto, os trabalhadores da Ford e da Volkswagen (cerca de dois mil, segundo o Clarín) cortaram a Panamericana. ${ }^{719}$ Sobre o evento, o presidente do Smata, José Rodríguez,

\footnotetext{
713 “Moyano prometió más paros y marchas”. La Nación, 12/10/2000, p. 12.

${ }^{714}$ Refeição comunitária realizada em lugares públicos como forma de manifestação.

715 “Si continúan el hambre y la miseria, seguirán las protestas”. Crónica, 23/11/2000, p. 4-5.

716 "Entre advertencias, se viene el paro”. Crónica, 23/11/2000, p. 10.

717 “"El estallido está instalado””. Moyano, Hugo. Entrevista. Clarín, 23/11/2000, p. 9.

718 "Moyano: 'No hay que tenerle miedo a la gente"”. Crónica, 24/11/2000, p. 10.

${ }^{719}$ Uma das mais importantes rodovias de acesso a Buenos Aires.
} 
declarou: "Se vier algum juiz vai ter que me prender, porque o responsável por este bloqueio de rodovia sou eu". A respeito da indústria automobilística argentina o dirigente advertiu:

Se [a Argentina] não entra rapidamente em um processo produtivo, em três anos desaparece e o Brasil abocanha. Por isso eu prefiro cortar a Panamericana agora, com os companheiros que trabalham, e não fazer um piquete dentro de alguns meses com um grupo de desempregados para pedir bolsas de comida ou planos Trabajar. ${ }^{720}$

Nesse contexto, o Governo sustentava que a greve criava um clima de violência, e que a adesão à mesma foi devido aos piquetes e à paralisação dos transportes. Sobre essa questão Moyano afirmou:

Não vamos entrar em provocações e a violência com que nos quer responsabilizar o Governo. Não lhes vamos dar esse gosto porque eles têm que ser responsabilizados pela violência que significam as demissões, o impuestazo, o ajuste salarial, os mortos em Corrientes e em Salta. ${ }^{721}$

Em 2000, a CGT-Moyano permaneceu mobilizada durante quase todo o ano, como demonstrou o protesto convocado para o dia 13 de dezembro contra o aumento da idade de 60 para 65 anos da aposentadoria feminina, que terminou com uma manifestação frente ao Congresso. ${ }^{722}$ No ano seguinte também foi assim. Em meio à crise vivida no país, a entidade, juntamente com a CTA e a CCC, realizou uma greve geral no dia 21 de março. Segundo as fontes consultadas, o protesto, convocado contra o modelo econômico do Governo, teve uma alta adesão. ${ }^{723}$ Novamente esteve presente a utilização de piquetes pelas organizações de desempregados como instrumento de luta. ${ }^{724}$

As posições da CGT-Moyano a respeito do desemprego se assemelhavam às da CTA, como demonstra a defesa de um seguro para os trabalhadores sem emprego: "Apenas assumiu Cavallo e pedimos o subsídio para os desempregados e a necessidade de reunir a mesa do conselho de salário mínimo. (...) De toda maneira, esperamos que não haja discriminação no subsídio e que se amplie a todos os desempregados". 725

Depois do protesto da CGT-oficial no dia anterior pelo mesmo motivo, a CGT-Moyano e a CTA se mobilizaram contra a reunião da ALCA no dia 6 de abril. Sobre esse protesto, Moyano afirmou: "Dissemos ao Governo que não se comprometam porque o povo argentino

\footnotetext{
720 “En la Panamericana, el Smata volvió a la calle”. Clarín, 24/11/2000, p. 16. Também houve bloqueios de rodovias nas principais linhas de trem, organizados por desempregados e empregados ferroviários de $L a$ Fraternidad, como é conhecido o Sindicato do setor. ("Cortes de vías: la novedad que paralizó los trenes". Clarín, 25/11/2000, p. 6; "Piquetes en las vías y ataques a colectiveros". Crónica, 25/11/2000, p. 80).

721 "Moyano: "Vamos a seguir en la lucha"”. La Nación, 24/11/2000, p. 8.

722 "Moyano defendió la jubilación estatal”. La Nación, 14/12/2000, p. 11.

723 "Masivo acatamiento". Crónica, 22/03/2001, p. 2.

724 "Piquetes, marchas y vidrios rotos". Clarín, 22/03/2001, p. 25.

725 "Moyano admite que con Cavallo hay un cambio de expectativas". La Nación, 31/03/2001, p. 9.
} 
não vai aceitar mais que nos queiram converter em escravos". O dirigente acrescentou que a ALCA é uma "associação ilícita" e que foi "pensado e diagramado pelos Estados Unidos para explorar mais nosso povo". ${ }^{726}$

No dia 8 de junho de 2001 a central convocou outra greve geral para declarar "guerra ao desemprego" e "contra o modelo econômico de escravidão". 727 O protesto teve a participação da CTA e da CCC, e foi a sexta paralisação nacional durante o Governo de De la Rúa em 18 meses de gestão. Para Moyano, o ato foi uma "expressão da oposição categórica e contundente ao modelo econômico de fome e miséria". ${ }^{728}$ Em 19 de julho, juntamente com a CGT-Daer, a CTA e a CCC, a CGT-Moyano realizou uma nova greve avaliada por todos os setores como de alta adesão e com mobilização massiva. No dia 8 de agosto, não participou da paralisação da CTA e no dia 29 de agosto do mesmo mês, marchou com a CGT-Daer contra o plano de ajustes. Com a divulgação da cifra recorde de desemprego e subemprego, e o anúncio de medidas como o rebaixamento de salário dos estatais e dos aposentados, e a limitação de saque bancário, o corralito, a CGT-Moyano convocou uma greve geral para o dia 13 de dezembro, juntamente com as outras organizações sindicais. Julio Piumato, secretário de imprensa da central, afirmou que os decretos "imobilizam os salários depositados nos bancos" e "reduzem os salários" de "ilegais" e "inconstitucionais". ${ }^{729}$ Quando se produziram os eventos de 19 e 20 de dezembro, o Governo declarou estado de sítio, a CGT Moyano convocou uma greve por tempo indeterminado e a CGT-Daer, uma paralisação de 30 horas. No entanto, a greve de ambos os setores passou desapercebida diante da magnitude da insurreição.

Depois de participar das greves de julho, agosto e dezembro, após a insurreição espontânea de dezembro de 2001, a CGT-Moyano levou uma lista de reivindicações a Duhalde que contemplou a proibição de despedir e suspender pessoal, um salário de inclusão de 400 pesos para chefes e chefas de família desempregados e a derrogação da lei de reforma trabalhista $25.250 .^{730}$ Sobre esta lei, vale mencionar que Hugo Moyano havia denunciado que

\footnotetext{
726 “Alca: repudio de gremios combativos”. Crónica, 07/04/2001, p. 10.

727 "Moyano convocó a otra huelga”. La Nación, 01/06/2001, p. 8.

728 “Moyano se reunirá con Cavallo”. Crónica, 09/06/2001, p. 8.

729 “Amenaza del Gobierno por la huelga”. La Nación, 12/12/2001, p. 9.

730 "La CGT de Moyano se suma a la concertación convocada por Duhalde". La Nación, 15/01/2002, p. 10. 
o ministro do Trabalho da época, Alberto Flamarique, o havia informado de que tinha um "Banelco"731 para convencer aos senadores de que a aprovassem. ${ }^{732}$

Diante do que Moyano considerava uma "ausência de respostas que atendam à necessidade imediata do Povo Argentino" e à "falta de medidas que atendam à reativação da economia", o dirigente interpretou que as medidas previstas no Orçamento Nacional eram "inconstitucionais e injustas", e "aprofundam a recessão". Entre os pontos apresentados na Mesa de Diálogo, o sindicalista fez referência à "intangibilidade dos salários, ao direito à saúde, [e à questão] das economias regionais [e] dos desempregados". ${ }^{733}$ A CGT Moyano mostrava descontentamento com o governo Duhalde e passou a exigir respostas sobre os problemas do país, a começar pela devolução dos $13 \%$ aos aposentados e estatais. Para Julio Piumato, "o problema passa pela necessidade de definições e não só pelas palavras". ${ }^{734}$ Em outra declaração, Piumato afirmou que a continuidade "é seguir com a lógica de Cavallo". 735 A partir do final de fevereiro, a CGT-Moyano começou a considerar a convocação de uma mobilização que, segundo o dirigente, tinha como principal reivindicação "combater o desemprego". Moyano demonstrou sua "preocupação pelo atraso na tomada de medidas que permitam a reativação econômica e com ela a geração de emprego genuíno". ${ }^{736}$ Apesar da expectativa de mudanças, já nos primeiros meses de administração, o Governo de Duhalde havia frustrado a CGT-Moyano. Para um dirigente da central, Juan Carlos Schmid, "Se é verdade que Duhalde busca substituir a política de aliança entre o financeiro e o político por uma de trabalho e produção, deverá quebrar a lógica que impede discutir o salário e uma melhor distribuição da renda na Argentina". 737

Diante de tal insatisfação, a CGT-Moyano convocou uma greve com mobilização para o dia 14 de maio. Em uma demonstração de oposição ao Governo, o dirigente afirmou: "Se o Presidente vai seguir aceitando as imposições do Fundo Monetário Internacional e, ademais, não lhe vão dar nenhum tipo de ajuda ao país, que sentido tem que siga Duhalde conduzindo os destinos deste país?"738 O protesto de 14 de maio foi suspendido por "más condições

\footnotetext{
${ }^{731}$ Empresa de caixa eletrônico na Argentina. A expressão significa que havia um cartão de saque disponível para o pagamento de suborno aos legisladores.

732 “Una ley que terminó en escándalo". La Nación, 27/12/2001, p. 7.

733 “Críticas de la CGT Moyano”. Crónica, 20/02/2002, p. 3.

734 "Moyano, cerca de volver a la protesta". La Nación, 20/02/2002, p. 9.

735 "Daer vaticinó que habrá estallidos si no cobran los estatales”. La Nación, 23/02/2002, p. 10.

736 “La CGT de Moyano, cerca de la protesta”. La Nación, 28/02/2002, p. 9.

737 “La CGT Daer visita mañana al presidente”. La Nación, 07/04/2002, p. 11.

738 "El Presidente pidió una tregua a los sindicalistas". La nación, 12/05/2002, p. 9.
} 
climáticas" ${ }^{, 739}$ e transferido para o dia 22. Por fim, decidiu-se uma interrupção das atividades por 12 horas em reivindicação de uma política salarial do Governo. ${ }^{740}$ Durante o ato, o discurso de Moyano enfatizou a relação do Governo com o FMI e a política salarial: "não podemos andar mendigando como cachorro uns dólares pelo mundo para conseguir um pedaço de pão duro que não vão nos dar, enquanto no país se aprofunda a crise social". O dirigente também deu a seguinte declaração: "Vamos seguir falando de um aumento de salários e brigar para consegui-lo". Por fim, Moyano questionou: "Como é possível que um Governo que se diz peronista evite falar disso? Que não nos venham dizer que primeiro deve ser colocada em marcha a economia". ${ }^{741}$ Durante o ato, o dirigente declarou que Duhalde "não têm coragem nem vontade para mudar as coisas". ${ }^{742}$ Quando em julho de 2002 dois militantes desempregados foram assassinados, a CGT-Moyano não convocou nenhum protesto, nem aderiu ao ato das organizações de desempregados. Durante o Governo de Duhalde, a central realizou uma greve geral, mas não participou das outras três convocadas pela CTA no ano de 2002.

Entre o final de 1999 e o final de 2001, durante o governo de De la Rúa, foram convocadas dez greves gerais, das quais a CGT-Moyano participou de oito. Somente não esteve presente na greve da CTA, de 8 de agosto de 2001. Durante o período, o setor permaneceu mobilizado, com uma forte oposição ao Governo de De la Rúa, especialmente a sua política de arrocho salarial. Nas greves que convocou, o setor apoiou a ação conjunta com os desempregados, que realizaram bloqueios de rodovias simultâneos às mobilizações sindicais. Porém, o setor seguiu sem uma política sistemática de sua organização para a luta, apesar de denunciar constantemente a situação de desemprego do país. ${ }^{743}$ Durante o primeiro ano da gestão de Duhalde, a CGT-Moyano, que a princípio o apoiava, passou a se opor ao mesmo porque considerava que o presidente, em boa medida, seguia a mesma orientação do Governo da Alianza. A partir de então, realizou ações de protesto e uma greve geral de doze horas, mas não aderiu às paralisações nacionais convocadas pela CTA.

\footnotetext{
739 "La CGT suspendió el paro por mal tiempo". La nación, 14/05/2002, p. 9.

740 “Moyano: 'Nos arrastramos como gusanos mendigando unos dólares"”. Crónica, 23/05/2002, p. 8.

741 “Moyano, ante poca gente y duro con Duhalde". La Nación, 23/05/2002, p. 10.

742 "En un acto deslucido, Moyano dijo que Duhalde no tiene coraje”. Clarín, 23/05/2002, p. 22.

${ }^{743}$ Como veremos mais adiante, houve uma tentativa por parte de Moyano de estabelecer um vínculo com o movimento de desempregados na assembléia do encontro nacional das organizações realizado em 2001. No entanto, sob vaias do público presente, o dirigente teve que se retirar.
} 


\section{A CTA}

No começo do período analisado, diante da repressão em Corrientes, em dezembro de 1999, a CTA decidiu convocar uma greve, assim justificada por De Gennaro: "Repudiamos o brutal ataque sofrido pelos trabalhadores estatais dessa província e exigimos o imediato fim da repressão, a retirada das forças da Gendarmería e a liberação dos detidos". ${ }^{744}$

Durante o governo da Alianza, a CTA rejeitou de maneira contundente a reforma trabalhista proposta pelo Governo de De la Rúa. Para De Gennaro, essa oposição se justificou "porque a classe trabalhadora já está flexibilizada faz tempo". ${ }^{745}$ Nesse momento, o dirigente afirmava: "Todos estamos de acordo que esta lei não gera emprego e que é necessário discutir a política econômica". ${ }^{746}$ Durante a convocação da greve de 24 de fevereiro de 2000, a CTA decidiu não participar do ato da CGT na Plaza de Mayo, e no lugar, marchou até a Plaza de los Dos Congresos, com a finalidade de demarcar sua diferença com a rival: "não discrepamos com a metodologia escolhida pelos sindicalistas da rua Azopardo, e apesar de coincidir no repúdio à flexibilização do trabalho que querem impor as autoridades, nossos projetos são antagônicos, e não podemos conjunturalmente nos unir nesta ocasião". ${ }^{747} \mathrm{O}$ argumento dado por De Gennaro para o protesto era de que o projeto de reforma trabalhista "não resolve o problema do desemprego que afeta a nossos trabalhadores, mas que atende às necessidades impostas pelo Fundo Monetário Internacional e os grupos econômicos". O dirigente discorreu sobre aspectos da reforma da seguinte maneira:

A queda da ultra-atividade dos Convênios Coletivos de Trabalho permitirão legalizar o rebaixamento de salários, a extensão de horário de trabalho, o fracionamento das férias e o pagamento escalonado do décimo terceiro. A redução das contribuições patronais novamente ataca nossos aposentados, golpeando o sistema de previdência social que continuará tendo seu financiamento reduzido. Aqui não há desemprego por falta de trabalho. ${ }^{748}$

Demarcando sua oposição à estratégia da $\mathrm{CGT}^{749}$ diante da reforma trabalhista, De Gennaro argumentava que esta central "tem se caracterizado por firmar durante anos acordos contra os direitos dos trabalhadores, e que hoje volte a fazer não soa estranho". ${ }^{750}$ Durante o ato, o dirigente afirmou: "Parece que na Argentina não se quer repartir o trabalho, querem que

\footnotetext{
744 "Primer paro para el nuevo gobierno. La CTA a huelga para el lunes en repudio a la represión”. Página/12, $18 / 12 / 1999$, p. 8.

745 "La CTA rechazó la iniciativa”. La Nación, 02/02/2000, p. 5.

746 "Permite pasar elefantes". La Nación, 22/02/2000, p. 4.

747 “La CTA no irá con la CGT a Plaza de Mayo”. La Razón, 16/02/2000, p. 3.

748 "Si hicimos trece paros, podemos hacer el doble". Crónica, 23/02/2000, p. 3.

${ }^{749} \mathrm{O}$ dirigente se refere especificamente à CGT-Daer.

750 "La CTA marcha sola”. La Nación, 24/02/2000, p. 8.
} 
todos sejamos explorados pela necessidade dos grupos econômicos". Nesse contexto, ganhou força na entidade a proposta de um seguro-desemprego de 500 pesos para todos os chefes de família. ${ }^{751}$ Sobre a limitação das horas extras o dirigente assinalou: "Se obrigassem esses grupos a cumprir com a jornada de trabalho legal, sobraria trabalho para centenas de milhares de desempregados". ${ }^{752}$ Fazendo referência ao que chamava de "sindicalismo empresário" da CGT, o dirigente sublinhou que estes o chamavam para "a unidade de ação para nos utilizar para defender seus privilégios". 753

Sobre a suspensão da greve de fevereiro convocada pela CGT, De Gennaro expressou: "Não nos equivocamos quando decidimos não seguir a CGT, porque intuíamos que iam suspender a medida de força". Nesse momento, o dirigente voltou a afirmar que "a verdadeira flexibilização são os dois milhões de pessoas desempregadas". Sobre o acordo entre a CGT e a greve, De Gennaro declarou: "Os sindicalistas empresários têm que sentir vergonha de tirar foto com os grupos econômicos responsáveis pela atual situação do país". ${ }^{754}$ Durante o protesto, o dirigente afirmou: "Não nos deixamos ser levados por esses sindicalistasempresários que nos queriam usar como grupo de pressão para defender seus interesses". ${ }^{755}$

Cerca de dois meses depois, a CTA, juntamente com a CCC, aderiu à greve convocada pela CGT Moyano para 5 de maio. ${ }^{756}$ No dia 9 de junho, a entidade participou da greve geral chamada pela CGT-Daer. Sobre o protesto, De Gennaro assim se expressou: “Agora o Governo quer convocar uma grande concertação social. Já anunciaram outra vez e não sucedeu nada. Não me oponho, mas será inútil se não se discutem medidas concretas", 757

Em 26 de julho de 2000 a CTA começou a "Marcha Grande por el Trabajo", que partiu de Rosario com chegada prevista ao Congresso no dia 9 de agosto. $O$ protesto tinha o objetivo de arrecadar um milhão de assinaturas em defesa da política de emprego proposta pela central (seguro-desemprego de 380 pesos aos desempregados e um salário familiar de 60 pesos por filho menor de idade). Ao justificar o ato, De Gennaro afirmou: "Vamos caminhar cidade por cidade para mostrar que existe uma proposta alternativa". ${ }^{758} \mathrm{E}$ acrescentou:

\footnotetext{
751 “De Gennaro criticó al Gobierno y a la CGT”. La Nación, 25/02/2000, p. 4.

752 “La CTA sacó a la calle su propuesta alternativa”. Página/12, 25/02/2000, p. 2.

753 "De Gennaro y la CTA hicieron su propio reclamo ante el Congreso". Crónica, 25/02/2000, p. 10.

754 "Moyano fustigó a la CGT pactista y al Gobierno". Diario Popular, 25/02/2000, p. 2.

755 “La CTA también marchó, pero al Congreso". Clarín, 25/02/2000, p. 9.

756 "Paro parcial, con alto impacto en el transporte". Clarín, 06/05/2000, p. 3.

757 "La CTA condicionó un acuerdo social". La Nación, 10/06/2000, p. 14".

758 "Peregrinación de la CTA desde Rosario". La Nación, 27/07/2000, p. 8.
} 
Apostamos em um shock de distribuição de renda e em reativar o mercado interno, as pequenas e médias e empresas. Na Argentina sobra riqueza, o que se tem que fazer é redistribuição. Na última década se demonstrou que é falso que o desemprego dependa de crescimento. Houve épocas de recessão e de crescimento e em ambas aumentou o desemprego. O desemprego é funcional a este modelo econômico perverso, onde se enriquecem muito poucos. [A respeito dos programas emergenciais, o dirigente afirmou:] É muito importante ajudar a sobreviver as pessoas em um momento de emergência, mas haveria que regularizar tudo o que se contribui em planos sociais. Que se unifiquem e se concentrem para resolver os problemas das pessoas. Não há que eliminar ajuda. Queremos um seguro de emprego aos chefes de família desempregados e não que os planos Trabajar se instrumentem de uma forma perversa pela atitude humilhante e punteril [referente ao punterismo]. ${ }^{759}$

Quando a Marcha Grande chegou ao Congresso, a CTA realizou um ato no qual De Gennaro assim expressou: "Estamos dispostos a discutir cara a cara com quem se anime. Este subsídio custa 9.000 milhões de pesos, que é 10 por cento do PIB. O Governo não pode se desentender". ${ }^{760}$ A proposta da CTA para o seguro-desemprego, segundo De Gennaro, também se referia ao modo de recebimento: "O dinheiro será recebido no banco para evitar o punterismo". De la Rúa recebeu o sindicalista no dia seguinte ao protesto. ${ }^{761}$ A Marcha Grande ainda continuou com outras marchas menores com o objetivo de chegar ao milhão de assinaturas previstas: "O faremos até que todo o país caminhe para expressar com toda claridade que o desemprego é o verdadeiro problema das pessoas e da Argentina", 762

No mês seguinte, a central participou da greve geral de 22 e 23 de novembro em conjunto com a CGT-Daer, a CGT-Moyano e a CCC. Segundo De Gennaro, durante o protesto, a CTA realizou "mais de 200" mobilizações, atos e bloqueios em todo o país. O dirigente declarou também que a medida se justificou "para que tenha trabalho para todos", já que no país "sobra trabalho", mas "não querem dá-lo". Ademais, afirmou que o protesto serviu para "repudiar o plano de ajuste que segue produzindo um genocídio planejado da desigualdade". O dirigente esclareceu que o protesto foi uma forma de “(...) repudiar o assassinato do companheiro Aníbal Verón, que foi morto em Salta por defender o mais elementar que é a sobrevivência e o trabalho". ${ }^{763}$ Sobre a unidade entre os trabalhadores empregados e desempregados construída nessa mobilização, De Gennaro afirmou que essa "resposta coletiva" começou com o piquete da rodovia 3 em La Matanza, no final de outubro,

\footnotetext{
759 "La CTA reclama que la gente opine sobre política de empleo”. La Nación, 26/07/2000, p. 9.

760 "La CTA terminó su marcha con más fervor que manifestantes". La Nación, 10/08/2000, p. 10.

761 "De la Rúa recibirá a la cúpula de la CTA”. La Nación, 18/09/2000, p. 8.

762 "La CTA vuelve a organizar caminatas". La Nación, 15/10/2000, p. 13.

763 “De Gennaro: 'Será un parazo”’. Crónica, 23/11/2000, pp. 10-11.
} 
conhecido entre os militantes como Matanzazo. ${ }^{764}$ Durante a greve, houve bloqueios de rodovias, entre os quais o ocorrido naquela mesma rodovia, convocado pela CCC e pela FTV. ${ }^{765}$

Em 2001, diante do aprofundamento da crise e o anúncio do um novo plano de ajuste do Governo, a CTA considerou a convocação de uma greve em conjunto com a CGT-Moyano para março. De Gennaro avaliou que esse ato seria parte do "aprofundamento do plano de luta": "Este é o ano que temos que resolver a pobreza. O Governo deve deixar de discutir ajustes que a única coisa que faz é beneficiar o mercado". ${ }^{766}$ Finalmente, no dia 21 de março, realizou-se a greve contra o modelo econômico do Governo, avaliada pelos diferentes setores como de alta adesão.

No dia 8 de junho, a CTA realizou outra greve geral, em conjunto com a CGT-Moyano, contra o modelo econômico. Diante do rebaixamento salarial dos aposentados e dos estatais, a central convocou uma greve geral para 19 de julho, em conjunto com as duas CGTs e a CCC. No dia 18, a Asociación de los Trabajadores del Estado (ATE) e a Frente de Gremios Estatales realizaram uma paralisação de atividades com mobilizações em repúdio às medidas econômicas anunciadas pelo Governo. Sobre o protesto, De Gennaro argumentou: "não é reduzindo os salários dos aposentados e dos estatais que se resolve o drama que hoje têm os milhões de argentinos". ${ }^{767}$ No dia 25 de julho se realizou uma paralisação da ATE contra essas mesmas medidas. Vale sublinhar a constante mobilização conjunta com os desempregados nesses protestos, o que confirma a relativa unidade construída especialmente pela CTA naquele momento. Segundo o titular do sindicato estatal, Pablo Micheli, "A todos os piqueteiros dizemos que na próxima terça vão ter os estatais bloqueando avenidas e rodovias em solidariedade a sua medida". ${ }^{768}$ Dia 8 de agosto, a CTA realizou mais uma greve geral contra a política econômica e o rebaixamento salarial dos estatais e aposentados, à qual não se somaram as outras centrais sindicais.

Em dezembro, a CTA ainda participou da greve do dia 13, convocada sob a consigna "Nem dolarização nem desvalorização. Sim a uma justa distribuição da riqueza". Como principal articuladora da Frente Nacional contra la Pobreza (Frenapo), a central iria começar

\footnotetext{
764 "De Gennaro satisfecho, pero sin dejarse ver". Clarín, 24/11/2000, p. 23.

765 "Barricadas contra trenes en La Matanza". La Nación, 24/11/2000, p. 11.

766 "La CTA quiere parar con la CGT de Moyano”. La Nación, 10/03/2001, p. 10.

767 "Estatales, de pie contra el recorte". Crónica, 19/07/2001, p. 10.

768 "Los estatales van a sumarse a los cortes. Acompañarán el plan de lucha piquetero”. La Nación, 26/07/2001, p. 7.
} 
nessa data uma consulta popular pelo seguro-desemprego de 380 pesos para chefes e chefas de família desempregados, o salário universal por filho de 60 pesos e o benefício de 150 pesos aos maiores de 65 anos. Porém, postergou a medida para o dia seguinte para se somar à greve geral da CGT. ${ }^{769}$ Sobre o plebiscito, quando ainda haviam contado $65 \%$ das urnas, a central já tinha conseguido 1.7 milhões de votos. ${ }^{770}$ No dia 18 de dezembro terminou a votação e a CTA entregou o resultado ao Governo. Porém, na noite seguinte se produziu a insurreição espontânea que levou à queda de De la Rúa. A greve geral convocada para 20 de dezembro pela em repúdio à declaração de estado de sítio pelo Governo não ganhou repercussão.

Quando assumiu Duhalde, a CTA e a FTV, por meio da Frenapo, se reuniram com o presidente para reivindicar os pontos presentes no plebiscito. ${ }^{771}$ Ao avaliar que suas demandas não estavam sendo contempladas e que o Governo não estava fazendo grandes transformações na política econômica em relação à gestão anterior, cresceu o descontentamento na central em relação ao presidente. Diante do anúncio da Lei de Orçamento Nacional, a entidade convocou uma marcha de protesto para o dia 20 de fevereiro juntamente com a CCC. ${ }^{772}$ Para Juan González, da ATE, a lei se tratava de uma "provocação irresponsável". ${ }^{773}$ A central decidiu convocar uma greve de 24 horas com mobilização para o dia 29 de maio. ${ }^{774} \mathrm{O}$ protesto foi realizado contra "a política de fome, desemprego e a entrega que leva adiante o Governo de Eduardo Duhalde ${ }^{775}$. O protesto foi considerado pela central como "multisetorial", pela participação de organizações de desempregados, como a FTV, a CCC e o Barrios de Pie, assim como pela utilização de bloqueios de ruas e rodovias. ${ }^{776} \mathrm{Na}$ avaliação de De Gennaro, a paralisação significou "uma atitude de unidade da classe operária", ${ }^{777}$ A central contabilizou em todo o país mais de 600 ações: "240 bloqueios de ruas e rodovias, 77 atos, 70 marchas, 49 assembléias de bairro, 29 ollas populares, 35 aulas públicas, 17 escrachos $^{778}, 8$ ocupações e

\footnotetext{
769 “La CTA se sumará a la huelga del jueves 13”. La Nación, 8/12/2001, p. 13.

770 "Masivo apoyo a un seguro de empleo". Clarín, 18/12/2001, p. 18.

771 "Pidieron al Gobierno un seguro de empleo". La Nación, 15/01/2002, p. 10.

772 "Diversos sectores confluyen hoy en una protesta nacional”. La Nación, 20/02/2002, p. 10.

773 “Daer vaticinó que habrá estallidos si no cobran los estatales". La Nación, 23/02/2002, p. 10.

774 "Entre as reivindicações da central durante o protesto, De Gennaro destacou: “(...) um aumento salarial de emergência para todos os trabalhadores, um seguro de emprego e formação de 450 pesos para chefas e chefes de família desocupados, um salário universal por filho de 70 pesos e uma asignación universal de 170 pesos para os maiores de 60 anos sem cobertura previdenciária" De Gennaro: el paro de la CTA será una rebelión nacional contra el Gobierno". La Nación, 25/05/2002, p. 10.

775 "Se realiza el paro con movilización de la CTA". Crónica, 29/05/2002, p. 3.

776 "La protesta de la CTA promete un día de caos para el tránsito”. Clarín, 29/05/2002, p. 8.

777 "Paro de la CTA fue a puro piquete". Crónica, 30/05/2002, p. 11.

${ }^{778}$ Manifestação pública de repúdio, realizada em um local público e dirigida a uma pessoa ou instituição que avaliada como responsável por alguma injustiça social.
} 
36 abraços a edifícios públicos". ${ }^{779}$ No protesto, De Gennaro propôs ao presidente Eduardo Duhalde que "no lugar de falar de adiantamento das eleições, anime-se a aceitar um plebiscito para que as pessoas digam se aceitam ou não os acordos previstos com o (...) FMI", 780

Poucos dias depois, dois militantes desempregados foram assassinados em Avellaneda. A CTA convocou uma greve geral "em repúdio à repressão e ao autoritarismo" para 27 de junho. $^{781}$ Também aderiu à "marcha de repúdio" convocada pelas organizações de desempregados e partidos de esquerda. ${ }^{782}$ Um setor da CTA e a FTV, de Luís D'Elía, não participaram do ato por desentendimento com o Bloque Piquetero Nacional ${ }^{783}$. D’Elía afirmou que havia advertido sobre a possibilidade de repressão: “A gente avisou". Essa declaração do dirigente gerou, por um lado, a imagem midiática de dirigente prudente em oposição aos outros, inconseqüentes e irresponsáveis, que não o haviam “escutado". Por outro lado, entre as organizações, a declaração foi interpretada como uma responsabilização dos reprimidos pela violência que haviam sofrido. ${ }^{784}$

Em um congresso em Santa Fe, a CTA e a FTV expressaram seu desejo de participação política, mas sem conformar um partido. Segundo De Gennaro: "a CTA não vai ser nunca um partido, mas sim pode formar parte de um movimento". O dirigente afirmou também que "Não só acredito que em algum momento governaremos a Argentina, mas considero imprescindível que o façamos". ${ }^{785}$ Em dezembro de 2002, essa estratégia foi aprovada no $6^{\circ}$ Congresso Nacional da central, realizado em Mar del Plata, no qual se consolidou na central o conceito de "movimento político, social e cultural". Segundo De Gennaro, "temos em nossas próprias mãos a possibilidade de construir uma força de unidade política que possa conduzir nossa pátria a partir de uma perspectiva diferente". Nesse momento, para a central, a eleição de Lula no Brasil foi um disparador para o fortalecimento dessa proposta: "Como não se sentir orgulhoso que um trabalhador e sindicalista como Lula seja o próximo governante do maior país da América do Sul [?]". ${ }^{786}$ Para recordar os eventos de dezembro de 2001, a CTA

\footnotetext{
779 "La jornada de protesta de la CTA se sintió en todo el país”. Clarín, 30/05/2002, p. 14.

780 "En un paro con adhesión dispar, la CTA reclamó un plebiscito". La Nación, 30/05/2002, p. 8.

781 "Repudio y paro de la CTA". Crónica, 27/06/2002, p. 8.

782 "La CTA llama a darle forma a una nueva movilización”. Clarín, 28/06/2002, p. 8. Ver también “Controversia en la CTA por la presencia en la Plaza”. Clarín, 28/06/2001, p. 9.

${ }^{783}$ Aliança de organizações político-sindicais de desempregados composta essencialmente por diversos grupos ligados a partidos de esquerda, tais como o PO e o MTL.

784 “Avisamos que iba a haber represión”. La Nación, 27/06/2002, p. 6.

785 “Avance en el armado político de los piqueteros”. La Nación, 25/11/2002, p. 7.

786 "De Gennaro llamó a convertir la CTA en una fuerza política”. La Nación, 14/12/2002, p. 11. Ver também "La CTA será un movimiento político". La Nación, 15/12/2002, p. 18.
} 
convocou um cacerolazo para a noite de 19 e uma greve geral para 20 de dezembro, medidas adotadas em conjunto com as organizações de desempregados, mas sem a participação de outros setores sindicais. ${ }^{787}$

Durante o período analisado neste item, a CTA se mobilizou em oposição à política econômica e social do Governo da Alianza. Participou das oito greves do período, ampliou sua política de organização dos desempregados e investiu constantemente em ações conjuntas com esse segmento, especialmente durante as paralisações gerais. A entidade realizou a Marcha Grande e foi uma das convocadoras do Matanzazo. Como principal articuladora da Frenapo, convocaou uma consulta popular para coletar assinaturas pela aprovação de uma proposta de seguro-desemprego. Em 2002, realizou três das quatro greves gerais convocadas durante o primeiro ano do Governo de Duhalde. Assim, durante o período tratado neste item, convocou treze greves gerais. Pode-se dizer que sua estratégia se diferenciou dos demais setores do sindicalismo argentino (com exceção da CCC, que não foi abordado nesta parte do trabalho) por propor a organização para a luta dos trabalhadores sem emprego. O que não quer dizer que tenha sido a única que buscou representar os interesses desse segmento ou contemplado propostas para o desemprego. E qualquer forma, é possível sublinhar que sua atuação foi chave para a constituição do relativo grau de unidade entre o ativo e a reserva verificado no período, que em muito contribuiu para o momento ascendente do ciclo de lutas tratado neste item.

\subsection{Representações dos quadros dirigentes sobre a organização dos desempregados}

Nesta parte, apresentarei uma descrição das representações feitas pelos dirigentes do movimento sindical e de desempregados sobre as políticas sindicais diante ao desemprego, levando em consideração as situações de demissão e de desemprego, os sujeitos (demitidos e desempregados) e suas organizações. Para facilitar a exposição, dividirei o texto em três itens, que correspondem a cada grupo de entrevistados: os líderes das organizações de desempregados, os dirigentes da CGT e os da CTA. As principais questões contempladas neste item serão as seguintes: como o conjunto das organizações avalia a política sindical

787 “La CTA llama a un paro general”. La Nación, 5/12/2001, p. 8. 
diante do desemprego? Como seus dirigentes explicam o surgimento do movimento de desempregados na formação social argentina?

\section{As organizações de desempregados}

Os dirigentes das organizações de desempregados entrevistados foram quase unânimes quanto à idéia de que, na década de 1990, a CGT não se ocupou dos desempregados e, ao contrário, a CTA teve uma política voltada para esse segmento. Para estes entrevistados, a CGT foi cúmplice do "modelo neoliberal" implantado na Argentina e co-responsável da eliminação de postos de trabalho, enquanto a CTA resistiu às políticas neoliberais e formulou propostas para resolver o problema do desemprego. Porém, alguns entrevistados fizeram a mesma caracterização das duas centrais, como cúmplices do modelo que se aplicou na Argentina.

O entrevistado do MTD-La Matanza argumentou que: “A CGT cumpriu um papel absolutamente cúmplice no processo de transformações estruturais na Argentina e não fez absolutamente nada". O militante sustentou que no período de maior eliminação de postos de trabalho, os desempregados "ficavam absolutamente indefesos" e que a resistência na base também não foi satisfatória: "em geral, não há uma só mobilização acompanhada pelos sindicatos para lutar pelas demissões especificamente". O entrevistado assim explicou a questão:

(...) a CGT tem em seu seio o que nós chamamos de burocracia sindical, onde agora nem sequer tem interesse de casta, onde os próprios sindicatos participaram na festa das privatizações dos [anos 90], tendo parte das ações das empresas privatizadas (...) o caso mais categórico é o dos ferroviários, onde o sindicato tem ações nas empresas ferroviárias (...). [Referindo-se a empresas do setor estatal]: em empresas como Somisa [Sociedad Mixta Siderurgia Argentina] e YPF se duplicavam as indenizações para seduzir os trabalhadores que saíam da empresa, e o sindicato era correia de transmissão dessas políticas. (...) tomavam como uma conquista lograr o dobro de indenização, para que você fosse embora (...) (E30).

Visão semelhante foi apresentada pelo entrevistado do MTD-Solano, segundo o qual a CGT "se desvirtuou" e seus dirigentes se converteram em "empresários" por "acordar nas costas dos trabalhadores as grandes entregas". O entrevistado destacou também que a burocratização nos sindicatos cegetistas "inibe ou não permite o desenvolvimento de alternativas". Esse militante argumentou que o sindicalismo argentino, durante os anos 90, esteve predominantemente "ligado ao poder" e que nos sindicatos oficiais "históricos", de 
"maior incidência", os dirigentes foram "comprados" e tiveram um "envolvimento muito forte" com as políticas implantadas no país. Por último, ressaltou que os dirigentes sindicais não tomaram iniciativa, "sobretudo nos momentos repressivos"; porém reconheceu que na base "houve resistências que foram esmagadas", apesar de haver sido "muito frágil perante o que foram as privatizações" (E32).

O dirigente do MTL afirmou que a CGT não se ocupou dos desempregados porque, "mais que a defesa dos trabalhadores", o sindicalismo cegetista é "um extraordinário negócio, onde os principais dirigentes sindicais se transformaram em importantes empresários". O entrevistado acrescentou que os sindicalistas "não têm nenhum interesse em se envolver com um setor que não é rentável. Falando em termos empresariais, não seria rentável para uma central investir tempo, recursos e esforço na briga dos mais necessitados deste país” (E8). Em seu entender, a CGT se baseia em um modelo que funciona do seguinte modo:

(...) enquanto você tem trabalho e paga a quota sindical, eu te defendo. O dia de maior debilidade, o dia que você mais necessita que te defendam, que é quando você fica sem trabalho, te abandonam, porque não paga a quota sindical. É um modelo sindical perverso (E32).

Esse dirigente advertiu que a política da CGT durante a década de 90 foi de "absoluta cumplicidade": "Aqui a instalação do modelo neoliberal teve dois pilares fundamentais: a burocracia sindical e o controle do território através dos punteros políticos. A partir daí puderam instalar o movimento neoliberal". Para justificar sua posição, também citou o exemplo dos ferroviários e de outros setores em que as privatizações foram apoiadas pelos sindicatos:

A falência e o desmantelamento das ferrovias na Argentina só se pôde realizar com a cumplicidade da Unión Ferroviaria. E por isso [José] Pedraza, seu titular, ficou com um dos ramais, um dos mais lucrativos, entregaram as obras sociales, um negócio que move 500 milhões de dólares anuais. Então tem havido uma cumplicidade absoluta. Não se poderia haver entregue o petróleo deste país, a energia deste país, as comunicações, as ferrovias, a água, sem a cumplicidade desse aparato sindical.” (E32).

O entrevistado da CCC também afirmou que a CGT não teve nenhuma política para os desempregados por seu caráter empresarial, mas também por sua ausência de perspectiva classista:

Porque a CGT nunca pensou nos operários. Não é que em algum momento tenham pensado como classe (...). Todos eles (...) são empresários, têm ações com o Estado, com algumas empresas, como o ferroviário (...), como no petróleo, na eletricidade. Os sindicalistas têm ações com o Estado também. Então, passam a ser empresários. E não vão pensar como classe, porque se pensassem como classe, defender ao operário como classe, como tal, o sindicato teria que (...) nos agrupar (...) em cada sindicato onde estivemos, para a 
partir daí brigar com o Estado que eu tenho que voltar à produção. [Sobre a resistência diante das demissões na base, declarou que] (...) foram dois ou três sindicatos que saíram a defender quando começaram a privatizar as empresas estatais, quando começaram as haver demissões [e as organizações sindicais] (...) nunca tomaram a decisão de defender a fonte de trabalho (E25).

Destaco também a fala do entrevistado do BP, segundo o qual a política da CGT se explica por sua "cumplicidade":

[A CGT] ao ser cúmplice da implementação desses modelos (...) [A] imensa maioria dos sindicatos da CGT; há exceções, mas (...) [a] imensa maioria - ao ser cúmplice da implementação do modelo de Menem ou do consenso de Washington, as políticas de diminuição do aparato produtivo, de privatizações; em definitivo, a expulsão de trabalhadores, foram cúmplices porque receberam muito. Por exemplo, o sindicato dos trabalhadores de Luz y Fuerza termina sendo empresário do setor [eletricitário]. O sindicato é acionista e empresário do setor em muitíssimos casos, como produto da política de privatizações, uma política que ia expulsando trabalhadores, e eles [os dirigentes] iam agarrando um pedaço da torta do que significava esse negócio (...). Esse é um elemento muito significativo. (...) [A CGT] em geral acompanhou o processo que levou adiante Menem, de redução do aparato produtivo, de estrangeirização da economia, privatizações e tudo mais. Portanto, esse movimento operário foi cúmplice da implementação da redução da economia e da geração dos desempregados na Argentina (E26).

O dirigente da FTV se referiu à CGT como "tradicional, amarela, traidora, entreguista" e afirmou que durante a década de 1990 os dirigentes da central "foram colaboradores do sistema político que promoveu a maior catástrofe social de toda nossa história”. O entrevistado argumentou também que os sindicalistas da CGT "foram o pilar necessário nos anos 90 para flexibilizar os direitos dos trabalhadores, para entregar o patrimônio nacional" e que essa central, "entre salvar os sindicatos e salvar os trabalhadores, preferiu salvar os sindicatos.” (E29). Com relação à política sindical para os desempregados e ao desemprego, o dirigente afirmou: "para a CGT não existimos. Porque isso é uma central de sindicatos, onde os trabalhadores delegam o poder no secretário geral, então vinte querem resolver em nome de milhões". Porém, reconheceu que parte da CGT, nucleada no MTA, impulsionou a resistência às políticas neoliberais: "Moyano, a CTA e a Corriente Clasista y Combativa fizemos as sete greves ao menemismo, a Marcha Federal, a Marcha Grande.” (E29).

Alguns entrevistados não fizeram distinção entre a CGT e a CTA ao se referirem à ausência de ações diante do desemprego. Para o entrevistado do PO, os sindicatos deveriam ter tido um papel fundamental na representação dos desempregados:

Mas não tiveram, por parte da burocracia formal, por parte das duas centrais que dirigem o movimento operário na República Argentina, nem vão ter. Nem vão ter porque são centrais burocratizadas, que estão restritas aos negócios da saúde sindical, às vantagens por ser assinantes de convênios, mas se adaptaram 
por completo a todos os motivos do desemprego e, portanto, estiveram alheios dos movimentos dos desempregados. Por parte dessa burocracia, os sindicatos não têm perspectivas. (...) [Em relação à política para esse segmento, sustentou que as duas centrais]: Estiveram de costas. Eles, ao compartilharem com a política de privatização, ao compartilhar com a política de flexibilidade trabalhista, ao compartilhar a entrega de todo o sistema previdenciário argentino, dos aposentados, ao regime privado das AFJP [Administradoras de Fondos de Jubilación y Pensión] que se fundou aqui, abandonaram por completo os trabalhadores. Quer dizer, que eles são co-responsáveis pelo desemprego (E31).

Porém, este mesmo entrevistado sublinhou que na base houve ações importantes contra a eliminação de postos de trabalho, ações essas que foram derrotadas em parte pela atitude dos sindicatos:

Houve grandes lutas contra as demissões nos anos 90, que foram derrotadas: no sindicato telefônico, no sindicato ferroviário, no sindicato dos petroleiros. Grandes lutas do movimento operário, mas todas foram entregues pelas direções sindicais. As direções sindicais peronistas se aliaram à privatização e ao governo de Menem. De modo que seu papel foi nefasto, absolutamente nefasto. E acredito que exista um grande repúdio nos dias de hoje, nas próprias filas operárias e no movimento popular em geral, por este papel de associação com Menem que tiveram nos anos noventa (E31).

$\mathrm{O}$ entrevistado do MIJD, referindo-se tanto à CGT como à CTA, afirmou: "Aqui a direção operária está subordinada ao governo" e "profundamente ligada e cooptada pelo governo e o Estado”. Esse militante argumentou que a ação sindical diante das demissões durante a década de 90 foi "vergonhosa, miserável, algo penoso de ver e repudiável". Sustentou também que os sindicatos "foram cúmplices da demissão de milhões de operários. Foram cúmplices os dirigentes da CGT, da CTA e dos sindicatos deste país”. E acrescentou:

A direção sindical está absolutamente corrompida, são donos... Nas privatizações dos anos 90, os sindicatos passaram a fazer parte dos que ficaram com as empresas que se privatizavam, se associavam a grandes grupos empresários. Igualmente ao que fez a máfia na Rússia com o desmantelamento da ex URSS (...) por exemplo nas ferrovias, o sindicato representa os operários ferroviários, mas alguns ramais são do sindicato ferroviário. Quer dizer, são patrões desses operários e, por sua vez, são os sindicatos desses operários. Com a empresa que administra a eletricidade são donos de empresas e, por sua vez, o sindicato desses operários. São patrões e sindicato simultaneamente. Isto talvez pareça muito estranho, mas essa é a realidade (...) dirigentes sindicais de operários que vivem com U\$S 300 por mês e os dirigentes sindicais passando as férias em Cancún, em Bahamas, etc. (E27).

Em resumo, para os dirigentes do movimento de desempregados a ausência de políticas da CGT diante do desemprego se explica por seu apoio às políticas neoliberais implantadas durante a década de 90. Assim, referem-se à "subordinação ao governo", "colaboracionismo", "associação com Menem”, "ligação com o poder”, “cumplicidade”, “política de regalias”, "traição à classe trabalhadora", "corrupção", "entreguismo" e adoção de um modelo de 
"sindicalismo empresário". Ademais, em algumas respostas se afirmou que a CGT se baseia em um modelo sindical "corporativista" e "burocrático", que não tem "interesse" em representar os desempregados. Por todos esses fatores, os militantes afirmaram que a central foi co-responsável do aumento do desemprego na Argentina. Sobre as ações sindicais diante das demissões, alguns assinalaram que houve "reações diversas". Outros reconheceram que houve "algumas resistências" na base, diante do desemprego e das privatizações, mas destacam que essas foram insuficientes. Por último, apareceu o argumento segundo o qual muitos desses protestos foram derrotados, em parte pela atuação da direção sindical. Nenhum entrevistado distinguiu entre a política da CGT durante a primeira e a segunda presidência de Menem. As diferenças políticas existentes entre as correntes internas da CGT nesse período foram destacadas somente por um entrevistado.

Vejamos agora as posições dos entrevistados sobre a CTA. O militante do MTD-Solano afirmou que, diferentemente da CGT, essa central "tomou como um eixo de trabalho o tema dos desempregados" (E32), e que isso se deve a sua posição frente às políticas neoliberais aplicadas pelo governo de Menem. Por sua vez, o entrevistado do BP sublinhou que na Argentina, durante a década de 1990, “o movimento operário está fraturado em dois: uma parte minoritária, que está agrupada na CTA, que resiste e combate a implementação desse modelo, e a parte majoritária que se transforma em cúmplice da implementação desse modelo". Sobre as ações sindicais diante das demissões, esse dirigente explicou as diferentes reações com base nessa fratura:

Havia sindicatos que, fundamentalmente empurrados pelos sindicatos estatais, vinham resistindo à implementação do modelo neoliberal, vinham resistindo às privatizações em uma quantidade de coisas. Portanto, esses sindicatos, que se agruparam centralmente na CTA, tiveram um combate frente a essa implementação (E26)

A maioria dos entrevistados explica a posição adotada pela CTA diante da política neoliberal a uma forma de concepção política e ao modelo de organização sindical dessa central. Referindo-se à representação baseada na afiliação individual, o entrevistado do MTL argumentou que "a CTA se propõe como uma central de novo tipo" e "entende a evolução do modelo capitalista" (E28). Os militantes também destacaram que a atuação da CTA foi de apoio à mobilização dos trabalhadores sem emprego. O BP sustentou que "a CTA albergou em seu seio organizações de desempregados" e que "teve um papel de acompanhamento e de apoio dos movimentos de desempregados, porque em alguma medida a CTA combateu o governo de Menem durante a década dos noventa". 
É importante ressaltar que o BP se constituiu vinculado a essa central: "No momento do surgimento do Barrios de Pie nós éramos parte da CTA. Na realidade, previamente a isso vínhamos desenvolvendo uma ferramenta dentro da CTA que se chamava CTA Barrios." (E26). A mesma observação deve ser feita para o entrevistado do MTL, que também se considera parte da CTA: "Nós somos parte da CTA (...), porque acreditamos que a CTA adverte a esse fenômeno [do desemprego]". Nesse sentido, o próprio entrevistado ressaltou: "Eu não pertenço a nenhum sindicato e eu sou parte da direção da Central aqui na Capital [Federal]". Seus argumentos também apontaram o modelo sindical adotado pela central:

Nós acreditamos que deve ser construído um novo tipo de sindicalismo (...), que identifique a situação da evolução do capitalismo e que incorpore os trabalhadores empregados, desempregados, flexibilizados, informal, aposentados, em igualdade de condições, [e] que estabeleça graus de democracia real, como na Central. (E28).

Este entrevistado declarou defender o conceito de "central de novo tipo" a partir do qual, segundo ele, seria possível desenvolver a "igualdade entre os trabalhadores e [a] predisposição a se constituir em uma ferramenta de caráter estratégico para a briga dos que menos têm". Porém, o dirigente afirmou não apoiar a sindicalização dos desempregados porque este setor "não é um ofício", embora tenha destacado a importância de uma luta conjunta com os trabalhadores empregados: "O que nós acreditamos é que os desempregados e os empregados devem estar organizados. O MTL não é um movimento de desempregados, é um movimento de companheiros que não têm trabalho e estão desempregados, mas se conseguem trabalho não o expulsamos do movimento" (E28).

Comparando a CTA com a CGT, o entrevistado da FTV também destacou as diferenças de modelo de organização: "nós acreditamos que a CTA é o melhor que aconteceu à classe trabalhadora operária argentina nos últimos quinze anos. Porque, ao contrário, o que temos é a CGT, que é uma central de sindicatos: nós somos uma central de trabalhadores". Esse dirigente acrescentou que "a CTA, o que se propõe, é uma organização distinta da classe operária, que excede o âmbito do trabalho" e "compreende também a organização no território": "Hoje, do milhão de afiliados da CTA, 250.000 são 'dos territórios"”. Esse entrevistado afirmou também que a central "tem uma história de honradez, de dignidade e de 
coerência muito grande" por não ter sido cúmplice da aplicação das políticas neoliberais (E29). ${ }^{788}$

Porém, alguns entrevistados apontaram contradições nas práticas da CTA. Alguns argumentaram que sua política para os desempregados foi "insuficiente" e "ineficiente", embora a central tenha resistido durante os anos 90. Também ressaltaram que atualmente é "cúmplice" do "modelo" econômico e social que se aplica na Argentina pela aliança com o kirchnerismo. O entrevistado do MTD-La Matanza está de acordo com a idéia que a CTA representou os desempregados e a CGT, não. Porém, afirmou que essa política não foi suficiente por sua proposta assistencialista:

A CTA cumpriu um papel, teve uma política, ainda que nos pareça insuficiente porque sempre fez desde uma lógica típica dos sindicatos que é pedir ao Estado que solucione, a um Estado que tem outra política de Estado, que não é gerar mais emprego, mas todo o contrário (...). E a CTA não investiu em desenvolver empreendimentos autogestionados e cooperativos, porque me parece que não está de acordo com sua política de acumulação de novos empregados. O processo de auto-organização, através dos empreendimentos produtivos, vai gerando um novo setor social, que são os dos empreendedores, que praticamente não têm enquadramento sindical. E então isso faz com que a CTA tenha políticas insuficientes (...) para solucionar o problema do emprego. Mas sem dúvida, entre a CGT e a CTA, a CTA cumpriu um papel, [ainda que] podemos dizer que insuficiente (E30).

$\mathrm{O}$ dirigente do $\mathrm{PO}$ argumentou que o vínculo entre a CTA e a FTV "é e não é uma exceção, porque a FTV hoje está integrada ao governo e está integrada ao Estado, e [portanto] deixou de desempenhar um papel na luta dos desempregados":

A FTV esteve ligada a uma experiência que pretendeu ser um novo sindicalismo na Argentina, que foi a CTA, e que terminou sendo um fracasso. Fracassou porque hoje são duas centrais cooptadas pelo poder político de Kirchner. Não temos na CTA uma central operária independente e de luta. Por isso mesmo a FTV é parte integral do clientelismo político do governo, e em particular de Kirchner. A FTV é a tropa clientelista das mobilizações de Kirchner. Deixou de cumprir um papel na luta dos que têm fome e na luta dos desempregados, de modo que se propôs como exceção no final dos 90 e fracassou completamente, pela orientação política de sua direção (E31).

O dirigente do MIJD apresentou essa mesma argumentação: “A CTA atualmente está em uma situação similar. Não foi assim nos anos 90 onde houve um grau de resistência significativo. Hoje, em 2007, isso também inclui os dirigentes da CTA" (E27). É necessário esclarecer que as entrevistas com esses dirigentes foram feitas em 2007, em um momento de

\footnotetext{
${ }^{788}$ É importante sublinhar que desde 2009, a FTV não faz mais parte da direção da CTA, ainda que siga se reconhecendo como parte dessa central. Desde então, seu líder, Luis D’Elía passsou a investir na Central de Movimientos Populares (CMP), que agrupa organizações aliadas ao governo nacional.
} 
conflito entre as organizações de desempregados e a CTA. O entrevistado da FTV reconheceu essa questão: "[a relação] não está passando por seu melhor momento" (E29). Ao se referir à construção da unidade na luta entre a central e a FTV, esse dirigente destacou a dificuldade de se conciliar o que sucede na fábrica e no bairro, em razão da concepção sindical de que as organizações sociais são suas “correias de transmissão": "É muito difícil conciliar o que sucede na fábrica e no bairro, muito difícil. (...) Porque os sindicatos sentem que as organizações sociais são como um apêndice do sindicato. E que existem para fazer o que o sindicato não pode fazer" (E29). Para esse militante, os dirigentes sindicais, "na hora de socializar o poder político na central, buscam a hegemonia de cargos institucionais e tudo mais. É muito difícil a relação". Por último, esse entrevistado argumentou que, ao contrário, os militantes desempregados participaram dos protestos sindicais da CTA: "quando eles necessitam, ou há algum conflito...”. Porém, sustentou que a recíproca não passa: "Não há consciência de classe nos trabalhadores sindicalizados. O trabalhador sindicalizado só se mobiliza por aumentos de salário ou por reformas estatutárias de seu setor. Mas depois não participa de nossas mobilizações". Sobre a questão da sindicalização dos desempregados, afirmou:

Nós acreditamos que há um novo tipo de organização, e nisso coincidimos com a CTA, uma organização de trabalhadores, cada trabalhador um voto, o voto não se delega a ninguém, como sucede nas centrais sindicais que o voto se delega ao secretário geral, a prática de assembléia, a contribuição de um peso, como cota de cada trabalhador. E nós estamos convencidos que, por exemplo, [assim como o] Canadá tem as uniões transitórias de emprego, nós acreditamos que hoje a FTV pode cumprir um papel similar (E29).

Ao se referir a outros momentos de maior entendimento entre a CTA e a FTV, o dirigente ressaltou que houve experiências articuladas significativas, como no chamado Matanzazo, em 2000, e em algumas marchas realizadas em conjunto com metalúrgicos e docentes:

[No Matanzazo] nós conseguimos que se armasse um plano de emprego a nível nacional, o Plan Trabajar, que se construíssem escolas, que atribuíssem diplomas aos estatais e aos docentes, tudo no mesmo convênio. Era o primeiro convênio coletivo de trabalho de "novo tipo". Ou seja, conseguimos melhoras para os trabalhadores ativos e melhoras para os desempregados. Maravilhoso esse convênio. (...) Nós fizemos a marcha do aço com os metalúrgicos, e os acompanhamos, milhares de desempregados. Fizemos a marcha da dignidade, de Tigre a La Plata, com 50.000 desempregados acompanhando os docentes, fizemos a marcha de Rosario a Buenos Aires... milhares de desempregados acompanhando os docentes (E29). 
A unidade na luta também foi destacada pelo BP, que comentou a respeito de uma experiência recente levada a cabo por esta organização:

Nós estamos impulsionando agrupamentos que os chamamos 'Trabajadores de Pie', que temos desenvolvido em vários sindicatos do país. Ou seja, companheiros do Barrios de Pie que vão recuperando seu lugar de emprego e ficam organizados no Barrios de Pie, mas já com uma experiência de trabalho sindical (...). Mas isso seria uma iniciativa nossa (E26).

O entrevistado do MTD-Solano recordou um evento importante de destacar. Trata-se da assembléia do Encontro Nacional das Organizações de Desempregados, realizado em La Matanza no dia 24 de julho de 2001, na qual, segundo o dirigente, a CGT quis se "aproveitar", mas seus dirigentes foram "repudiados":

Uma assembléia de três mil pessoas vaiando Moyano, expulsando deputados, precisamente pelo oportunismo, como nesse momento se dava uma grande assembléia, um encontro de gente de todo o país. Ainda quando D’Elía, que era dirigente da CTA, nesse momento, dos desempregados, da FTV, chamava a receber Moyano, à CGT ("não podemos ser sectários..."), suas próprias bases o repudiaram, e era a demonstração da deterioração dos sindicatos frente aos setores em luta. Quando havia câmaras de televisão, apareciam. Mas depois, na ação, brilharam por sua ausência. (E30).

Alguns entrevistados afirmaram que a CTA representou uma mudança no movimento sindical, por seu esforço de construção de unidade entre empregados e desempregados. Outros, porém, não fizeram distinção entre esta e a CGT, por seu caráter burocratizado, e pela cooptação do governo e subordinação ao kirchnerismo. Ao se referir às contradições na sua relação com a CTA, o dirigente da FTV destaca a ausência dos sindicatos nos protestos de desempregados e a visão sindical predominante de que a organização de desempregados deveria ser um "apêndice" do sindicalismo. Os entrevistados coincidem em assinalar a ausência de políticas por parte da CGT diante do desemprego, por sua "cumplicidade" com o governo de Menem e pelo modelo de "sindicalismo empresário" que apoiou seus projetos. Um entrevistado destacou a oposição do MTA, encabeçado por Hugo Moyano, às políticas neoliberais. Porém, outro dirigente recordou que, quando houve uma oportunidade de construção de unidade entre essa corrente e o conjunto do movimento de desempregados, a própria assembléia expulsou aquele dirigente.

Alguns entrevistados expuseram a existência de uma fratura na relação entre empregados e desempregados, que advém da prática sindical de defender somente melhorias no salário e nas condições de trabalho. Sustentaram, ademais, que os sindicalistas não se mostravam preocupados pela defesa dos interesses dos trabalhadores sem emprego, porque estes não contribuem financeiramente com o sindicato. Segundo alguns entrevistados, esse 
seria um dos motivos de porque as organizações de desempregados surgiram por fora do aparelho sindical oficial. Verificarei mais adiante se essa constatação procede.

Afinal, que papel o sindicalismo cumpriu no surgimento desse movimento? Analisarei essa relação levando em conta quatro aspectos: (a) a participação dos sindicatos na constituição das organizações; (b) a participação de ex-militantes sindicais na base e no núcleo originário; (c) a contribuição de determinadas correntes sindicais para a expansão e nacionalização do movimento; (d) a influência da ideologia político-sindical na tradição de luta e organização dos trabalhadores.

Alguns entrevistados ressaltaram a ausência de participação sindical no surgimento das organizações. O militante do MTD-La Matanza advertiu que essas "surgiram na absoluta defensiva e orfandade", embora tenha destacado que a CTA cumpriu um papel importante com relação ao tema:

Não havia partido político, não havia sindicato que tivesse uma política [para os desempregados]. Além do fato de que a CTA, por exemplo, tenha defendido a renda universal (...), não havia política para o problema do desemprego. Somente havia para ajudar, mas não para ingressar ao aparato produtivo ou gerar trabalhos distintos (E30).

O entrevistado do BP advertiu que "durante esse processo o sindicalismo em geral esteve ausente" (E26). O representante do MTD-Solano afirmou que os primeiros protestos "se realizam precisamente por fora dos sindicatos, ou do movimento operário organizado, que tinha que ter encabeçado as lutas". Sendo assim, o dirigente ressaltou que, ao contrário, não o fizeram pela "cumplicidade" com governo e empresários (E32).

Pelo que ficou demonstrado até aqui, é possível concluir que as centrais sindicais não tiveram uma participação direta e decisiva na constituição dos movimentos de desempregados na Argentina. Ao investigar sobre as experiências de luta prévias da base, esse argumento foi reforçado. De modo geral, os entrevistados apontaram as seguintes características em suas organizações: (i) as experiências prévias eram muito variáveis; (ii) foi pequeno o peso relativo das experiências prévias de militância político-partidária ou sindical; (iii) a maioria dos integrantes era composta por "novos contingentes", sem experiência prévia de militância; (iv) os grupos sociais mais representativos eram as mulheres donas de casa e os jovens.

Porém, ao questionar a respeito da trajetória política do núcleo originário, diferenciando-o, portanto, do processo de engajamento individual na constituição do movimento, o sindicalismo passa a ter um lugar central nos argumentos. Nas explicações dadas pelos entrevistados, apareceram os seguintes elementos: (i) o caso particular da FTV, 
que já existia previamente à CTA e não contou com militantes de origem sindical em seu núcleo fundador, apesar de ter sido a partir do vínculo com a central que esse movimento adquiriu caráter massivo e nacional; (ii) o caso específico da CCC, que antes de organizar os desempregados já atuava como corrente político-partidária e sindical, tendo contado com militantes advindos do sindicalismo em seu núcleo fundador; (iii) os casos do MTL, do PO e do $\mathrm{BP}$, que apesar de terem origem político-partidária, ressaltam a luta sindical como constitutiva do movimento $^{789}$; (iv) o caso do MIJD, que não reconhece a origem sindical em seu núcleo fundador, apesar de que o próprio entrevistado tenha sido delegado sindical; (iv) o MTD-La Matanza e o MTD-Solano, que apesar de serem movimentos organizados a partir de um trabalho de base no bairro, sem participação de militantes sindicais, reconhecem a importância das experiências prévias no interior do sindicalismo no núcleo fundador das organizações de desempregados de maneira geral.

A que fatores os entrevistados atribuem a emergência do movimento de desempregados no país? De maneira geral apareceram os seguintes argumentos: (i) a construção dessas organizações se deu por fora e em oposição aos "sindicatos" como resposta à ausência de política dos mesmos ao problema do desemprego; (ii) a atuação por parte de algumas "correntes sindicais" foi fundamental para que alguns movimentos adquirissem caráter massivo e nacional; (iii) de maneira geral, foram importantes entre o núcleo originário as experiências prévias de luta político-partidária, sindical ou no bairro; (iv) e, por último a tradição de luta e organização da classe operária argentina foi acionada na mobilização dos desempregados.

Valem alguns esclarecimentos sobre as respostas obtidas. Os relatos que apontam a ausência dos "sindicatos" na constituição do movimento não excluem os demais argumentos. Também é necessário ressaltar que quando os entrevistados apontam essa questão, na realidade se referem aos grandes sindicatos, ligados à CGT, e não à participação das entidades sindicais de maneira geral. Por isso os militantes reconhecem que algumas correntes sindicais, como a CCC e a CTA, foram importantes para o surgimento ou expansão de seus respectivos movimentos (como a CCC e a FTV, as maiores do país em número de participantes). Ademais, a maioria dos entrevistados ressaltou que as experiências prévias de militância

\footnotetext{
${ }^{789}$ O MTL, que advém do Partido Comunista argentino, reconhece a existência de militantes com experiência sindical na composição do núcleo fundador; o PO, que surgiu do Partido Obrero, de origem trotskysta, afirma ter sido a partir dos militantes sindicais que a organização passou a atuar nos bairros; o BP, que tem sua origem vinculada ao Patria Libre, de origem nacionalista de esquerda, afirma que houve uma estreita ligação com a CTA na origem e expansão do movimento.
} 
sindical de base desempenharam um papel fundamental no núcleo originário das organizações. Alguns argumentaram que os desempregados que organizaram os primeiros cortes de ruta eram ex-trabalhadores empregados que transferiram seus conhecimentos de organização para as novas formas e instrumentos de luta. Esses argumentos já seriam suficientes para concluir que a ausência de participação dos sindicatos na constituição de ditas organizações não significa a ausência total da participação sindical, se consideramos o sindicalismo em seu conjunto (correntes, comissões internas, corpo de delegados, militância de base e participação cotidiana dos trabalhadores na vida sindical).

Para desenvolver esta tese, ressaltarei a seguir o aspecto mais citado pelos entrevistados, o qual considero central para a análise: o vínculo entre a emergência das organizações de desempregados e a tradição do movimento operário e sindical argentino. Essa relação não se restringiu aos instrumentos de luta empregados e à estrutura organizativa do sindicalismo, mas suas as tradições deste último funcionaram como uma "ideologia inerente" na formação deste "protesto popular" levado a cabo pelos desempregados (Rudé, 1982). Vale destacar que o marco teórico adotado no primeiro capítulo para definir a categoria de tradições de luta começou a ser construído a partir do contato com as questões às quais me referirei a seguir.

Para o entrevistado do MIJD, os trabalhadores "retomaram a longa tradição operária e a influência socialista, comunista e anarquista do início do século passado [XX] e o transferiram para os movimentos de desempregados" (E27). O dirigente do PO explicitou que os desempregados "empregaram sua tradição de organização operária" e "transferiram essa experiência coletiva de trabalhador organizado a sua nova situação de desempregados":

[a origem do movimento se deve] à grande tradição de organização da classe operária, porque muitos dos líderes do movimento piqueteiro foram trabalhadores que de repente se viram desempregados e que empregaram a tradição de organização operária no contexto de desempregados (...). Realmente o mais importante veio dos próprios operários que tinham a experiência dentro dos sindicatos quando eram empregados e transferiram essa experiência coletiva de trabalhador organizado a sua nova situação de desempregados (E31).

O informante do MTL ressaltou a "herança dos companheiros que escaparam da Europa" e faz referência aos grandes marcos do movimento operário argentino para concluir que "isso está fortemente gravado na memória do nosso povo":

Nós viemos da herança de todos os companheiros que vinham escapando da Europa. Não é casualidade que nós adotamos a bandeira anarquista, a bandeira histórica, como bandeira. Bom, neste bairro, no Parque Patricios, a alguns quarteirões, estava a oficina Vasena. Nessas ruas se combateu o que foi a Semana Trágica. Depois veio a Patagônia Rebelde, o Cordobazo, o Mendozazo. Quantos marcos, não? 
Todos os marcos que se pode encontrar de lutas operárias. E isso está fortemente gravado na memória de nosso povo. E todos nós, e a maioria dos dirigentes do movimento piqueteiro, dos movimentos de desempregados, são trabalhadores, trabalhadores que vêm de uma prática política sindical (E28).

Destaco, a seguir, três outros relatos que apontam nessa mesma direção, respectivamente, dos entrevistados do MTD-La Matanza, da CCC e da FTV, que fazem referência tanto ao papel da memória histórica como do emprego de instrumentos de luta e do método de sindicalismo:

(...) nosso país teve uma grande organização sindical, que deixou na cabeça daqueles que depois ficaram desempregados que, por exemplo, para conseguir o que necessitava era necessário se associar com outros, com outros semelhantes. (...) Isso de se juntar com os pares é um registro na memória histórica que ajudou muitíssimo quando ficamos desempregados (E30).

$\mathrm{O}$ entrevistado da CCC acrescentou que "a metodologia do piquete foi trazida pela rica história (...) do movimento operário na Argentina" que, segundo o mesmo, vem dos anarquistas. Ressalta ainda que sua organização se considera "parte do movimento operário", por meio do qual "aprendeu (...), inclusive, como negociar":

[...] na Argentina, aqui, nós temos uma tradição... (...) Já tínhamos uma prática de fazer piquetes. E como ao ficar (...) sem trabalho, não temos uma fábrica onde fazer piquete, então o piquete o transferimos para a rodovia [...] A metodologia do piquete foi trazida da rica história (...) do movimento operário na

Argentina. Quer dizer, inclusive no início do século, quando começaram a se organizar os trabalhadores, essas metodologias foram trazidas pelos anarquistas. [...] Então, isso foi introduzido à organização como tal, porque nós nos consideramos parte do movimento operário. [...] Então por isso, fomos aprendendo, aprendemos do movimento operário todas essas coisas que foram muito ricas (...) inclusive [de como] negociar. (E25).

Por último, destaco a fala de um dirigente da FTV, que também relaciona a emergência da luta dos desempregados como uma forma de adaptação da organização sindical:

Houve um deslocamento organizacional da classe operária, que antes se organizava nas fábricas. Agora não há mais fábricas, então começamos a encontrar no território o lugar da organização social... com um tipo de organização similar ao do sindicato: uma organização por bairro, com delegados, por quarteirão, e subdelegados com comissões específicas de trabalho (E29).

\section{A CGT}

Para o conjunto dos entrevistados da CGT, é certa a idéia de que a central não representou os desempregados. Como afirmou um dirigente da AOT, "não fizemos muito". A ausência de iniciativas cegetistas foi justificada por este dirigente pelo desconhecimento da dimensão real do problema do desemprego, visto como passageiro: "Nunca se pensou que se ia chegar aos valores de desemprego que tínhamos". E acrescentou: 
O desacerto de todas as políticas de estado fez que também tivéssemos desacertos na política [sindical]... porque em momentos de tanta desprolixidade, tanta dissídia e tanta preocupação (...) cada um [de nós] nos preocupamos com nossa casa sem olhar o bairro. Essa é a realidade. Vivíamos aqui dentro, fechados. Havia dias que [eu] passava 20 horas aqui dentro e dizia 'para que estive 20 horas aqui dentro?'. Porque realmente não dava para ficar tranqüilo. Mas foi a briga constante de cada um com seu sindicato, de qual alternativa era mais preocupante ou melhor (E38).

O entrevistado da $\mathrm{AB}$ afirmou que, entre as ações que poderiam ter sido adotadas, "cada sindicato deveria ter tido uma seção especializada nos trabalhadores desempregados do setor" ou “(...) uma área específica para atender as problemáticas respondendo aos princípios de unidade e solidariedade dos trabalhadores". Sobre os motivos pelos quais não foi possível esse tipo de ação na CGT, o dirigente destacou que "o trabalhador argentino e a direção sindical argentina não tinham consciência do que era o desemprego como fenômeno". Por último, assinalou que não se tratava somente de um problema de "traição" à classe trabalhadora, mas que era um problema mais complexo, de falta de compreensão dos efeitos das políticas de governo que se estavam implementando:

Não é um problema de 'pelegos' e corruptos somente... é de ignorância. Porque todo o processo neoliberal termina destruindo o poder sindical, o poder do sindicato; então, não é que alguns dirigentes se enriqueceram (...) somente por não confrontar com as políticas do menemismo. É muito mais profundo. (E33).

Um dirigente comerciário do SEC de Buenos Aires afirmou que na década de 1990 os sindicatos cegetistas tiveram uma "reação muito morna", que se explica por uma "questão de convivência política" e pelo "descrédito que se tinha nas organizações sindicais". Esse entrevistado ressaltou que a CGT teve "movimentos espasmódicos", pois "de repente reagia por algo", apesar de que este não tenha sido seu "fio condutor" (E39).

Por sua vez, um dirigente da UOM-La Matanza declarou que foi um erro das conduções sindicas não ter buscado estratégias de ação conjuntas com os trabalhadores desempregados, e que isso explica porque as organizações desses últimos tenham surgido por fora da estrutura sindical oficial:

O movimento operário em geral, e incluindo-nos, tivemos um equívoco nesse momento, em seguir olhando os trabalhadores empregados e não tanto os desempregados. Por isso tiveram que cumprir um papel próprio de amparo e, ademais, de sobrevivência. Os sindicatos, quando reagiram, era muito tarde, foram muito poucos os que rapidamente levantaram a bandeira de se ocupar também dos desempregados. (E36).

Esse entrevistado argumenta que a base desse "equívoco" esteve no apoio sindical ao governo de Menem: 
(...) todos, e nós como parte da sociedade, também acreditamos nesse homem (que não o nomeamos porque tocamos madeira...), nesse iluminado riojano [referente a La Rioja, a província de origem de Menem] que veio, acreditamos nele, e todos tínhamos muita esperança, porque o via como o homem do interior, um homem humilde; todo mundo acreditou nele, e a verdade é que nos destruiu (E36).

Segundo este dirigente, houve uma quota importante de cumplicidade de uma parte do sindicalismo, que aderiu às principais políticas levadas a cabo pelo menemismo: "dentro desse processo também houve dirigentes sindicais que se aliaram e aceitaram as privatizações, que terminaram sendo mais empresários que dirigentes sindicais". Nesse sentido, citou o exemplo de alguns sindicalistas do setor estatal: "eles foram cúmplices dessas privatizações (...). E isso ajudou a destruir a Argentina” (E36).

Alguns dirigentes argumentaram que a ausência de políticas para os desempregados foi comum a todos os sindicatos, inclusive os da CTA. Um diretor da AB afirmou que durante os anos 90, com algumas exceções, todos os sindicatos "negaram aos trabalhadores desempregados formas de organização". Para esse entrevistado, a inexistência de uma política para esse segmento se justificou pelo corporativismo que caracteriza a instituição sindical: "Na realidade, na maioria dos casos, o movimento sindical, o trabalhador empregado, sempre se ocupa de sua própria realidade". No entanto, reconheceu que foi um "erro" dos dirigentes sindicais “não assumir a representação dos desempregados de seu setor" (E33).

A respeito dos motivos que levaram a CGT a não assumir uma postura de organizar os desempregados, um sindicalista do SEC assinalou que a própria conjuntura política não favorecia a resistência: "na década de 90 se arbitraram todas as ferramentas para que os sindicatos não pudessem fazer nada. Para além da vontade que [o sindicalista] tivesse, havia leis até para poder despedir as pessoas, a flexibilização do trabalho, o topo indenizatório". O dirigente argumentou que essas leis "saíam do Congresso Nacional" e os sindicatos nada podiam fazer para evitar sua aplicação: "Uma vez que tinha a lei, tchau. Poderia ter sido feitas marchas antes, discussões antes, eu creio que sim, que poderia haver modificado, mas...”. Esse dirigente acrescentou ainda que nesse período "há uma conivência que não é somente sindical”, mas do conjunto da sociedade (...).” Por último, destacou que a falta de trabalho "amedronta as pessoas" que, "diante da perda de trabalho não reage, ficam quietas" (E39).

O entrevistado da Faecys afirmou que não existiram experiências de representação dos desempregados por parte da federação porque não houve um "desemprego massivo no setor". Sobre a questão se o sindicato deve se ocupar dos desempregados, o dirigente declarou: "Sim, o que não sei é como". Por último, explicitou: 
Há alguns movimentos sindicais que têm dado resposta a isso criando sindicatos de desempregados; em outros casos há sindicatos que recorreram à afiliação direta do trabalhador desempregado, não tem que passar pelo circuito de pertencer a uma empresa para poder se afiliar a um sindicato; e há outros sindicatos que vêem o problema do desemprego como um problema mais conjuntural e tratam por todos os meios de dar resposta do ponto de vista político para lograr aumentar a ocupação e reduzir o desemprego e voltar a ter uma mais alta taxa de sindicalização (E35). ${ }^{790}$

Com uma explicação semelhante, um dirigente da central sustentou:

A CGT sempre confiou que o modelo poderia ser mudado... e nisso não nos equivocamos... Nossa política visou garantir o trabalho, e garantir um modelo de Argentina que tivesse trabalho para todos. Nesse sentido, por uma correta estratégia, teve um erro tático de [não levar em conta] que isso não ia ser imediato... que tinha que ter dado uma resposta [aos] desempregados (E41).

No entanto, este mesmo entrevistado argumentou que a representação sindical dos desempregados não pode ser considerada um fim em si mesmo, pois sua organização seria legitimar a condição de desempregado e "excluído:

(...) a CTA no início cria o Sindicato dos Desempregados, que nós dizíamos "não pode haver um Sindicato dos Desempregados porque o sindicato tem um fim, e nenhum sindicato pode ter como fim sua desaparição”. Porque qual é o objetivo? Que sigam desempregados? Vamos aceitar a exclusão estrutural, que na Argentina nunca existiu? Pelo menos desde o peronismo, nunca existiu. Nós nos opúnhamos. Então, o Sindicato [dos Desempregados], qual é o objetivo? Que eles tenham trabalho e, se cumprem esse objetivo, desaparece o Sindicato (E41).

O entrevistado do SEC argumentou que, apesar da falta de iniciativa da direção da CGT e seus principais sindicatos para representar os desempregados, a central não deixou de dar respostas cotidianas aos trabalhadores diante das demissões com os dirigentes de base:

Nós, como CGT, ou integrantes da CGT, damos respostas claras, evidentes, ao trabalhador todos os dias e aos dirigentes de base, que (...), diria a CTA, "isso não faz a CGT", e eu creio que sim faz, mas não em suas cúpulas, mas nos dirigentes de base, sindicatos pequenos, e é assim (E39). ${ }^{791}$

Ademais, o dirigente entrevistado da AB argumentou que um setor da CGT (o MTA) opôs-se constantemente às políticas neoliberais:

\footnotetext{
${ }^{790}$ Para esse militante, a CGT se enquadra nesse último grupo, já que apesar de não ter representado os desempregados, preocupou-se com o desemprego, tratando o tema nas negociações com o governo: "No movimento sindical argentino você tem duas centrais: há uma que é a CTA, que tenta representar os trabalhadores desempregados (...), tem um sistema de afiliação direta à central; e tem a CGT, que é a central majoritária, que é mais da segunda idéia, quer dizer, de estar permanentemente metida na questão mais política para tratar de que os governos elaborem planos econômicos que gerem emprego, e dessa forma sair do desemprego" (E35).

${ }^{791}$ Este entrevistado citou exemplos de ações concretas nos anos 90 das quais participou, como em uma empresa na qual "tomamos a planta, a mantivemos uma semana, fomos ao Ministerio, fizemos audiência [e] logrou-se retomar a maior quantidade de trabalhadores" (E39).
} 
(...) a CTA teve um discurso que envolvia claramente o tema dos desempregados, mas há uma corrente da CGT que se caracterizou por desempenhar as ações sindicais mais fortes contra as políticas neoliberais que é o MTA (...) que também teve iniciativas claras em relação ao tema dos desempregados (E33).

Com o mesmo argumento, o entrevistado da UOM-La Matanza destacou a participação do sindicato que representa e do MTA nos protestos mais importantes do período:

Em 2000 fizemos uma marcha que rotulamos Marcha por la Producción Nacional y el Trabajo e saímos desde Villa Constitución, San Nicolás, Zárate, Campana, La Matanza, Congreso, Plaza de Mayo, durante um par de dias. (...) Essa marcha, que a conformamos em todo o cordão de siderúrgicos e muitos metalúrgicos, foi acompanhada pela CTA e pelos grupos de companheiros desempregados, que os chamavam "piqueteiros" (nessa época estavam D’Elía, Alderete e todos esses setores, [que] nos acompanharam nesta marcha) que (...) terminamos com um ato central no Congresso, com aproximadamente 20.000 companheiros." (E36).

O entrevistado da AOT afirmou que "nos últimos anos" a CGT começou a se "preocupar com os desempregados", com as "bolsas de trabalho" e a política de "capacitação para novas tarefas". Segundo este entrevistado, "é uma coisa que aprendemos na marra depois da última parte da década [de 1990]. Quase todos os sindicatos estão em sua plenitude de capacitação". (E38).

A respeito do vínculo da CGT com as organizações de desempregados, destaco também a fala de um dirigente do SEC, segundo o qual a central não se ocupou de maneira institucional, mas que houve ações pontuais de alguns militantes:

Não houve uma relação direta, pelo menos institucionalmente, de nenhuma maneira. A CGT, o que tem, são sindicatos muito grandes, e às vezes não é necessário nem que as coisas as façam os secretários gerais (...) mas não somos de fazer propaganda disso institucionalmente. Sim há uma relação estreita entre movimentos sociais com trabalhadores e delegados que são da CGT, mas que por aí não têm institucionalmente a representação (E39).

Esse mesmo dirigente comerciário destacou o caráter "progressista" da CTA por fazer uma leitura mais abarcadora da situação do trabalho vivida no país e buscar alternativas de representação dos setores não contemplados pela organização sindical oficial:

Eu creio que ideologicamente o que tem a CTA é uma evolução; a CTA teve uma evolução e necessitou gerar espaços diferentes diante do enrijecimento do movimento sindical argentino. Há uma diferença: (...) a visão de futuro, a visão de entender o mercado de trabalho novo. A CTA soube acomodar esses mercados laborais novos, ver uma transição diferente no mundo do trabalho que a CGT não viu, ou ficcou no que estava acostumada, a governos paternalistas que tinham laços sindicais atrás deles e recebiam as regalias do governo. A CTA soube ver isso, percebeu; é uma central sindical muito mais progressista do ponto de vista teórico, pelo menos, que a CGT. O que não se dá na realidade é que todos os representantes 
ou todos os que militam na CGT com sindicatos pequenos e de base sejam exatamente igual às cúpulas, não é $\operatorname{assim}(\ldots)$ (E39). ${ }^{792}$

Porém, esse dirigente relaciona o tipo de ação sindical da CTA com a base que representa, predominantemente de sindicatos estatais, apesar de reconhecer que esse elemento não é definitivo:

Mas também não esqueçamos que a CTA é uma central sindical que tem muitos sindicatos do Estado, que não é a mesma coisa brigar com o sindicato do Estado que com o sindicato privado, é muito difícil, totalmente diferente... (...) Mas sim teve uma política inteligente a CTA com relação aos desempregados, isso vai além do Estado; eu creio que aponta uma questão de conceito ideológico... (E39).

Para o entrevistado da UOM La-Matanza, ao contrário, a representação dos desempregados pela CTA "foi especulação política e estratégica" da central porque "em algum momento lhes serviu a incorporação de um setor de companheiros desempregados" (E36). O entrevistado da Faecys ressaltou a "diferença na concepção político sindical”. O dirigente argumentou que "a CTA tem uma característica um pouco mais ideológica que a CGT" e que estaria "mais voltada para a esquerda". O sindicalista reconheceu que o vínculo da CGT com o PJ também é "ideológico", mas afirmou que este é mais "complicado de explicar", já que: "No movimento nacional justicialista teve gente de direita ortodoxa e teve guerrilha e esquerda (...) há direita, centro direita, centro, centro esquerda e esquerda". Ao contrário, afirmou o entrevistado: "na CTA há uma identificação maior com o peronismo de esquerda". O dirigente também sublinhou a necessidade de buscar base por parte da CTA para sua consolidação como central, já que a mesma não possui muitos sindicatos formais:

Nós representamos a imensa maioria dos trabalhadores formais, e por ação indireta a uma enorme maioria também de trabalhadores informais. A CTA tem uma representação de trabalho formal menor, muitíssimo menor que a CGT, e me parece que esse é um elemento para que os companheiros da CTA se preocupem por ter representações além do trabalho formal, além dos trabalhadores formais nas empresas (E35).

O entrevistado da AOT argumentou que "a CTA representou tanto os desempregados como a CGT". Para esse dirigente, os "desempregados foram à CTA pelos líderes":

[as organizações de desempregados] estão mais perto da CTA por uma [questão de] ideologia política, [que] aos da CGT, que somos "burgueses", etc., etc. Mas os da CTA e os líderes dos grupos desempregados vivem como vivemos os líderes da CGT. (...) Mas (...) há muitos grupos de

\footnotetext{
${ }^{792}$ Sobre a CTA esse militante afirmou que é "uma central muito mais moderna, mais progressista, que viu muito mais a mudança das questões laborais que a CGT. Hoje a CGT é totalmente diferente, mudou, está avançando a outras coisas (...). Eu creio que à CTA chegou a mudança muito mais rápido que para nós... [...] eu creio que a CTA tem tido maior aproximação aos desocupados que teve a CGT e teve uma atitude diferente diante das demissões" (E39).
} 
desempregados que estão com a CGT, tem relação. Muitíssimos. Mas o grosso, como os famosos, esses de La Matanza, estão na CTA. Isso é verdade também” (E38).

Para o entrevistado da $\mathrm{AB}$, "houve organizações de desempregados que lograram um espaço durante um [tempo] relativamente curto [na história] da CTA; mas por causas políticas o nível de integração dessas organizações de desempregados nunca foi total". Segundo esse dirigente, "não se pode dizer que os sindicatos da CTA se ocuparam dos desempregados e os da CGT não, porque a conduta foi muito similar na realidade dos fatos em todos os sindicatos, de se desentenderem do problema dos desempregados". Ao diferenciar a política da central e de seus sindicatos, o entrevistado acrescentou:

(...) o principal sindicato da CTA, que é a Ctera, praticamente não teve expulsão de trabalhadores, não teve despedidos. Sim teve ATE, (...) e o Estado tem com o ajuste grande quantidade de demitidos de seus postos de trabalho, mas esse sindicato não foi capaz de organizar seus desempregados dentro do movimento sindical. O que aconteceu? E o mesmo acontece na maioria dos sindicatos da CGT, ou seja, a conduta dos sindicatos integrantes das confederações é sindical; o que sim é distinto é que, avançado o processo, em meados da década de 90, a CTA incorpora a sua organização setores de desempregados representados por uma corrente, que é a FTV, representada pelo dirigente D'Elía, mas essa organização de desempregados (...) sempre viveu e vive ainda em tensão permanente com a condução da central sindical e isso é perfeitamente visível hoje. [A CGT] não incorpora nenhuma organização de desempregados a suas filas; mas o tratamento que é dado aos desempregados nos distintos sindicatos é muito similar nos sindicatos da CTA, que são estes dois, e nos sindicatos da CGT” (E33).

Segundo este dirigente bancário, a CTA aglutinou parte das organizações por uma questão de identificação ideológica:

A preocupação da CTA pelos desempregados provém [da] decisão política de alguns dos organizadores dos movimentos de desempregados, que elegeram essa central por considerá-la mais adequada, digamos, a sua posição político-ideológica, mas hoje a CTA não tem tido interesse neles, [e] os sindicatos a compõe não lograram conformar e integrar os trabalhadores desempregados (...) A dívida com os trabalhadores desempregados é de todo o movimento sindical argentino; e salvo algumas raras exceções, tem sido um erro grave não ter sabido integrar em cada um dos sindicatos, não às centrais sindicais, em cada um dos sindicatos, aos trabalhadores desempregados de sua base (E33).

Com um argumento crítico ao tipo de organização da CTA, o entrevistado da CGT argumentou: "A CTA se apresenta como uma alternativa ao êxito desse modelo destruidor". Para este dirigente, se "o modelo neoliberal tivesse triunfado na Argentina e tivessem desaparecido as organizações sindicais, esse modelo armado pela CTA, nucleando os feridos, seria o único que teria ficado para começar a construir a partir daí, mas começando do zero" (E41). 
Sobre a participação sindical na conformação do movimento de desempregados, o dirigente da Faecys reconheceu que a CTA teve um papel importante: "Na CTA, sim. A CTA tinha um movimento piqueteiro, o de Luis D’Elía (...), e depois a maioria dos movimentos piqueteiros era movimentos piqueteiros e de desempregados da ultra-esquerda ou de setores independentes" (E35). O entrevistado do SEC também ressaltou que a CTA foi uma das organizações que impulsionaram os movimentos de desempregados:

[...] a formação desses movimentos, creio que vem mais do lado político que do sindical, salvo alguns grupos que foram criados pela CTA. Da CGT (...) eu creio que a participação é de companheiros de base, mas não institucionalmente, o que é feito pela CTA. A CTA, institucionalmente, se dedica a formar um movimento social sobre tal ou qual tema, a CGT não (E39).

Vejamos a seguir como os dirigentes cegetistas explicaram o surgimento das organizações de desempregados. Entre os dirigentes da CGT foi comum o argumento segundo o qual o chamado movimento "piqueteiro" se originou do punterismo praticado pelos partidos de esquerda. O entrevistado da AOT, por exemplo, destacou a existência de uma "utilização política", em "termos eleitorais", por parte das organizações dos desempregados: "A prova é que todos os que começaram com os movimentos, esses vão todos a cargos eleitorais. (...) alguém pode dizer que é uma necessidade que essa parte da população tenha um representante (...). Como somos velhos conhecidos aqui, temos certa desconfiança” (E38).

Um dirigente nacional da central afirmou que, apesar da existência de duas ou três grandes organizações, essas "não nasciam com uma identidade de desempregados como tal, mas em função de punteros políticos, em geral de esquerda". Segundo este entrevistado, para levar a cabo essa política, os agrupamentos contaram com o mecanismo da administração direta dos programas sociais: "Eram as organizações que repartiam os planos [e] para repartir os planos você tinha que ir [às mobilizações] (...) "bom, você veio tantas vezes ao piquete, segue com o plano, você faltou três vezes, cancelamos seu plano". ${ }^{793}$ No entanto, este mesmo entrevistado ressaltou que as primeiras ações do movimento de desempregados foram "autênticas" do "povo" e que depois, com a implementação dos planos, os agrupamentos se configuraram a partir de organizações partidárias (E41).

O entrevistado da SEC também destacou que "houve um interesse político" por parte dos partidos na administração dos planos sociais: "foi a primeira vez (...) que as organizações

\footnotetext{
${ }^{793}$ Esse dirigente relacionou a presença da esquerda com a "fragmentação" do movimento de desempregados na Argentina: "como a esquerda está tão fragmentada ideologicamente cada um armava seu grupinho em determinado bairro e depois já não se unia um com o outro (...) [Sendo assim,] a atomização histórica da esquerda argentina (...) se expressa na quantidade de grupos de desempregados" (E41).
} 
de ultra-esquerda estavam subsidiadas por um governo peronista". Na visão desse dirigente, o crescimento das organizações esteve condicionado à concessão dos planos: "essas organizações receberam subsídios e através dessas organizações as pessoas puderam pelo menos comer" (E39). Assim, em sua visão, a militância prévia de partidos de esquerda e a existência dos planos fora os motores do movimento:

Eu acho que se explica por uma questão política. A espontaneidade é muito difícil (...) eu não creio na espontaneidade. Não é que um dia todos os pobres ou desempregados se levantam e dizem 'hoje todos nós nos juntamos', não, não, não! Isso tem que ter um fio condutor, alguém que conduza, alguém que tem a idéia (...). Os pobres nesse país demonstraram [que] se juntaram, [que] se organizaram sempre por trás de certas linhas. Hoje se você vê uma marcha de organizações de piqueteiros, que são os desempregados, (...) Por que têm um nome? Por que têm líderes? Justamente porque os juntam. Não é que as pessoas naturalmente o fazem, quando os juntam, sabem que [...] pode solicitar subsídios (E39).

Sobre a relação entre os desempregados e a esquerda partidária, o entrevistado da Faecys argumentou que esse vínculo esteve presente apenas no momento de eclosão do movimento, mas que logo em seguida, ao recuperarem os postos de trabalho, os trabalhadores voltaram para a militância sindical e abandonaram esses partidos:

Quando as taxas de desemprego começaram a cair, os trabalhadores voltaram aos sindicatos e se esqueceram dos partidos de esquerda. Hoje temos uma taxa de desemprego de 10, 9\%. Essa margem, esses $13 \%$ que faltavam para chegar aos $23 \%$ que tínhamos em 2001, esses $13 \%$ voltaram todos aos sindicatos [e não ficaram nos partidos] (E35).

Este dirigente aludiu, ademais, à situação anterior de pleno emprego e à tradição de organização e luta da classe trabalhadora argentina, argumento que foi amplamente destacado pelas organizações de desempregados:

Há uma tradição na Argentina de que esses mesmos desempregados eram, eles, seus pais e seus avós, trabalhadores formais, e são pessoas que se organizaram para não ver desaparecer a sociedade do trabalho que primou na Argentina até a década de 90 (...) são ex-trabalhadores reais que passaram a pedir trabalho, voltar a trabalhar, que não é o mesmo que o desempregado conjuntural ou estrutural que havia em outros países, como vocês [referindo-se ao Brasil], que tem cerca de 60, 70 milhões de pobres estruturais, que nunca trabalharam [formalmente] (...). A maioria dos movimentos de desempregados e piqueteiros até quinze anos atrás eram trabalhadores formais sindicalizados com seguridade social pública e convênio coletivo de trabalho (E35).

Quando perguntado sobre as origens dessa tradição de organização, o entrevistado respondeu categoricamente: "isso tem duas palavras: o peronismo, e a história da classe trabalhadora argentina, que tem uma parte institucional e fundante, (...) a etapa pré-peronista e uma etapa institucional e de repotencialização, que é a etapa peronista". A respeito da etapa 
anterior ao peronismo, o entrevistado fez referência "às duas grandes correntes imigratórias que surgiram na Argentina no final do século XIX e no começo do século XX, que duplicaram a população do país, ou seja, que encheu o território, basicamente de italianos, espanhóis e alemães" (E35).

O dirigente da $\mathrm{AB}$ também afirmou que o elemento central para explicar a "epopéia" do movimento de desempregados, segundo ele, "desassistidos por seus sindicatos", é que o núcleo originário das organizações vem de "quadros com experiência sindical" que foram "formados dentro do movimento sindical argentino". Esse dirigente explicitou ainda que foram dirigentes com esse perfil os que primeiramente organizaram os bloqueios de rodovias, nas províncias de Salta e Neuquén (E33).

$$
* * *
$$

Parte dos dirigentes da CGT esteve de acordo com a idéia de que a central não levou adiante nenhuma política para os desempregados. Entre as explicações dos entrevistados para essa ausência, encontra-se: o sentimento de impotência diante da profundidade do desemprego vivido no país; a falta de consciência ou de compreensão do tema por parte dos sindicalistas; a conivência, não só sindical, mas de toda a sociedade, com o neoliberalismo; as ferramentas institucionais criadas pelo governo para desmobilizar os sindicatos; e o medo do desemprego, que diminuiu a capacidade de resistência dos trabalhadores.

Em geral, os entrevistados se puseram na defensiva ao se abordar o tema, e poucos buscaram explicações na estrutura sindical. Alguns explicitaram a questão do apoio ao governo de Menem por parte dos dirigentes da CGT, assim como no "sindicalismo empresário" praticado por um setor da central. Porém, outros assinalaram que, apesar da falta de iniciativa ou desinteresse da condução da CGT, alguns sindicatos levaram a cabo importantes movimentos de resistência contra as demissões. Os dirigentes também argumentaram que a prioridade da CGT não foi a representação política dos desempregados, mas a luta contra o desemprego nas negociações com o governo.

Ao ressaltar as diferenças entre as duas centrais em relação à organização dos desempregados, os entrevistados da CGT afirmaram que a política desenvolvida pela CTA se explica por sua "concepção político sindical” ou por seu componente ideológico "mais voltada para a esquerda". Nesse sentido, afirmaram que a CTA teve uma "evolução" por "entender o novo mercado de trabalho". 
Os entrevistados levaram em conta em suas explicações que a CTA tem uma base sindical de representação composta em sua maioria por empregados estatais. Porém, enfatizaram mais explicitamente sua pequena representatividade, o que lhe garantiria melhores condições para a luta. Ao contrário, ressaltam que a CGT representa majoritariamente empregados privados, com a quase totalidade dos sindicatos da produção, inclusive as empresas de capital concentrado e com grande quantidade de operários, o que dificulta sua mobilização.

É importante destacar a ênfase de alguns entrevistados na afirmação de que a CTA organizou os desempregados como central, mas não em seus sindicatos de base. Sobre o tema, os dirigentes citaram o caso da ATE, que apesar das demissões massivas, não teve uma política de representação de seus demitidos. Nesse sentido, diferenciaram a central dos sindicatos que representa, e interpretaram que a dívida com os desempregados foi comum a todo o movimento operário organizado sindicalmente. Os sindicalistas também destacaram o papel da experiência prévia de militância sindical dos quadros que orientaram as organizações de desempregados, especialmente nas províncias de Salta e Neuquén. Ao tentar explicar porque os líderes de organizações de desempregados buscaram se integrar à CTA, os entrevistados marcaram a comum afinidade entre esses no que se refere à "ideologia política". Porém, destacaram as tensões existentes entre esta e a FTV. Chamou-me a atenção o fato de que os dirigentes da CGT não tenham destacado os protestos levados a cabo pela central durante os anos 90 e seus momentos de confrontação com algumas políticas implementadas pelo governo de Menem, especialmente em seu segundo mandato, tal como foi descrito neste capítulo.

\section{A CTA}

Entre os dirigentes da CTA predominou a idéia de que essa central se ocupou dos desempregados e a CGT não teve uma política para esse segmento. Um membro da diretoria destacou que a defesa dos trabalhadores sem emprego foi, inclusive, "a bandeira de luta que caracterizou sua diferença com a CGT" (E48). Outro membro da Executiva Nacional destacou que as distintas políticas das duas centrais se devem a que "caminho tomou frente às políticas neoliberais uma organização sindical e outra" (E45); no caso da CTA, marcada por sua constante oposição às políticas de governo durante a década de 90. 
Entre os argumentos utilizados para explicar a presença de políticas da CTA aos desempregados, esteve o "conceito amplo de trabalhador". Nesse sentido, como afirmou um diretor da entidade: "O trabalhador é todo aquele que vive de seu trabalho, viveu de seu trabalho ou quer viver de seu trabalho"; e que, portanto, "os desempregados, os precários, os privados, os estatais, os convencionados, os autônomos, são trabalhadores". Este entrevistado acrescentou: "não aceitamos isso de que só se pode afiliar o trabalhador permanente, formal, convencionado, que é, lamentavelmente, uma minoria”. O entrevistado argumentou, ademais, que na CTA "o trabalhador vale por aquilo que ele é":

(...) "não, mas eu sou desempregado", "e o que isso tem a ver?; quem determina, você ou o patrão?", "mas eu sou precário, trabalho informalmente", "e o que isso tem a ver? Isso quem determina é o patrão". Quer dizer que nós vamos reconhecer os direitos somente daqueles que os patrões reconhecem? "Não, não é nossa classe...". Nós mudamos o estatuto, essa é a grande diferença com a CGT (...)” (E43).

Dessa forma, pode-se afirmar que a busca de representação dos desempregados por parte da CTA se fundamentou em um discurso de ruptura com o corporativismo sindical. Como explicitou um dirigente nacional da central:

Quando se diz "sindical", que quer dizer? Que o sindicato não são os desempregados, que o sindicato não são os do bairro (...) [sobre a participação dos sindicatos na conformação do movimento de desempregados] diz-se como participou ATE, como participou os Judiciários. (...) esse é um conceito sindical do sistema. Para os companheiros anarquistas, na greve das vassouras, dos inquilinos, eram todos trabalhadores, as crianças que estavam proibidas de trabalhar eram parte da classe trabalhadora. (...) Então, o que quer dizer "sindical"? Não são um sindicato? De qual sistema? Deles, porque sindicato é sindicato, partido é partido e o que conduz é o partido que chega ao Estado, e se acabou. Isso se acabou, não é mais assim. O campo socialista caiu (E43). ${ }^{794}$

Sobre as tentativas de organização sindical dos desempregados, este dirigente expôs um elemento semelhante a um argumento que apareceu com mais freqüência no Brasil: "a gente se deu conta de que o desempregado não quer ser desempregado. Não quer [formar] um Sindicato de Desempregados, quer trabalhar. Então, [que o desemprego seja] o mais transitório possível”. No entanto, logo em seguida ressaltou que a CTA buscou uma saída para superar essa barreira: "nós passamos a entender que o sindicato é qualquer organização de trabalhadores que se reúne para se organizar (...) e transformar a sociedade, este é o sindicato" (E43).

\footnotetext{
794 O dirigente também argumentou que não se pode resumir o sindical à "estrutura orgânica de um sindicato reconhecido pelo governo": "há mais de 200 organizações 'simplesmente inscritas' e mais de 300 em vias de organização; [que] não são reconhecidas pelo governo, ou seja, não são sindicatos” (E43)
} 
A partir dessas premissas, a central promoveu a afiliação direta de seus membros e que permitiu incluir os trabalhadores sem emprego em sua base de representação. Com base nesses princípios, explicou um dirigente, “(...) surge a CTA, como uma tentativa de descolarmos dessas políticas estatais e como uma tentativa de incorporar dentro de sua estrutura orgânica os movimentos sociais", entre os quais se encontram as organizações de desempregados (E48). ${ }^{795}$

Para o presidente da central, a incorporação de uma parte das organizações de desempregados à estrutura organizativa da central se baseia nas seguintes características:

(...) os desempregados estão organizados em movimentos que têm vida autônoma dentro da central e que elegem sua condução, através do voto direto. Os desempregados formam parte da lista da Central; se elege através do voto direto; tem seus delegados ao Congresso da CTA, quer dizer, são uma mais das organizações. (E48).

Outro dirigente da central se referiu à necessidade de se construir uma ferramenta política, alternativa ao "modelo" neoliberal, para explicar a articulação entre a central e as organizações de desempregados:

Aqueles dirigentes que não estavam dispostos a claudicar, que sabiam como vinha a coisa com este modelo, resistiram e por isso constituíram outra ferramenta. Por isso o conceito amplo de trabalhador que toma em seu estatuto fundacional a central; por isso a afiliação direta, sabendo que ao se destruir o tecido social, os trabalhadores ficavam sozinhos, soltos em qualquer lado, e a central tem a afiliação direta para voltar a reconstruir uma ferramenta (...) a legislação não permite a permanência do trabalhador, quando perde o emprego, na estrutura sindical. Diferente ao que faz a CTA. A CTA diz: "um trabalhador da atividade é dessa atividade sempre"; mesmo sendo passivo, aposentado, pensionista, poderia ser membro da condução dessa central (E45).

A política de incorporação das organizações de desempregados à estrutura organizativa da central é considerada pela CTA como uma experiência de luta nova, tal como explicitou este mesmo dirigente:

A CTA nesse sentido consolidou uma experiência inédita. Há muito poucas centrais no mundo que incorporem, como parte de sua estrutura orgânica, movimentos de desempregados. Nós iniciamos esse caminho a partir de uma análise da situação que tínhamos na Argentina no princípio dos [anos] 90. Se a CTA somente tivesse se dedicado a representar os trabalhadores em relação de dependência, que são os que têm sindicato e são os que têm convênio coletivo, essa força de trabalho chegou a representar na Argentina, a meados dos noventa ou a fins dos noventa, menos de um terço da força de trabalho (E45).

\footnotetext{
795 Esse entrevistado explicou ainda como é feita essa política: "Nós incorporamos os movimentos de desocupados, por exemplo por meio do pagamento de uma quota simbólica; hoje seria um peso" (E48).
} 
A CTA também reivindicou políticas universais para enfrentar o desemprego e mecanismos mais amplos de negociação que envolvessem os setores não representados pelos sindicatos oficiais. Um membro da diretoria assim se referiu ao tema:

[Nós] já não falamos de paritária em termos sindicais, mas defendemos um conceito mais amplo, abarcador, que é a paritária social. A paritária social inclui o salário dos que têm trabalho, mas também inclui a demanda de um subsídio universal por filho, a demanda de seguro de emprego e formação, a incorporação dos movimentos de desempregados para discutir as políticas para o setor (E48).

Este entrevistado definiu o "seguro de emprego e formação", como "salário cidadão" "garantido pelo Estado para aqueles que estavam fora do aparato produtivo." Também explicitou que outra bandeira de combate ao desemprego defendida pela central foi a de redução da jornada de trabalho, que segundo o entrevistado, "tem sido uma bandeira que na realidade, nas condições de nosso país, ainda não tomou força, porque o neoliberalismo introduziu formas de exploração e de flexibilização do trabalho muito intensas" (E48). Por último; o dirigente assinalou que o surgimento da central se deu por oposição ao "modelo sindical" cegetista:

[A CGT] (...) já não dava resposta às demandas reais da classe operária que continha dentro de si um setor importantíssimo de desempregados. Então, a partir dos sindicatos que compõem a CTA, houve um papel ativo e houve iniciativa política, porque a Central converteu o tema dos desempregados em uma bandeira de luta, uma das bandeiras de luta que caracterizou a CTA. (...) Como contrapartida, os que estiveram nos sindicatos da CGT, que são grandes organizações, vinculadas sobretudo à atividade produtiva, mantiveram apatia e distância desse tema. Inclusive hoje ainda o vêem como algo que não lhes compete (E48).

Sobre o trabalho de representação e organização dos desempregados por parte da CTA, outro diretor da central destacou seu caráter pioneiro: "abrimos a central praticamente desde o começo como uma das bases das primeiras organizações; a primeira, a UTD [de Rosario]" (E47).

Para outro entrevistado, a FTV foi uma das impulsoras do movimento de desempregados quando este "se instala no cenário urbano". Sobre o tema, o dirigente declarou: "Os pioneiros disso foram a Federación de Tierra y Vivienda, que é uma organização da CTA, que começou com um piquete histórico que durou praticamente um mês, (...) um bloqueio de uma rodovia do setor mais populoso do conurbano". Em relação ao começo desse vínculo, o dirigente explicitou:

(...) se inicia a partir da prática de luta, na qual a CTA participa e apóia, sobretudo (...) os primeiros piquetes do conurbano, de La Matanza. E aí surge uma iniciativa (...) de constituir dentro da Central uma 
federação desses movimentos. (...) E surge então a iniciativa de lhes dar uma projeção organizativa e unitária em termos de construir uma federação que agrupasse os distintos movimentos locais da província de Buenos Aires e de outras províncias e se realiza na CTA um congresso constitutivo da Federación de Tierra y Vivienda, se discute com o departamento jurídico da CTA um estatuto para que essa organização tivesse forma estatutária, funcione organicamente e se garanta o apoio material também para que essa federação pudesse dar os primeiros passos para se consolidar organizativamente. Quer dizer, a federação surgiu na luta dos piquetes, na rua, mas organizativamente surgiu das entranhas da CTA (E48).

Como exemplos de experiências de luta articuladas entre os trabalhadores empregados e desempregados representados pela central, esse entrevistado destacou a Frente Nacional contra la Pobreza, definida como "uma espécie de frente de organizações sociais, na qual estavam a CTA, a FTV e outros movimentos de desempregados, grupos da pequena e média empresa, a Federación Agraria, que agrupa pequenos produtores agrícolas". O dirigente também citou uma marcha "da Capital Federal a Rosario" e outra, que se fez com quatro colunas que partiram da Patagônia, do norte, na fronteira com Bolívia, "do oeste, na Cordilheira e que confluíram na Capital Federal”. Também se referiu à Marcha Grande pelo Trabalho, sobre a qual destacou:

[A Marcha Grande surgiu] reivindicando um seguro de emprego e formação, reivindicando políticas para os desempregados (...), impulsionou em 2001 uma consulta popular para lograr mostrar ao governo que uma maioria importante de cidadãos reivindicava políticas ativas do Estado para garantir a renda cidadã; e que conseguiu fazer no país (...) uma consulta popular autônoma convocada por essa Frente Nacional contra la Pobreza, e que na Argentina logrou contabilizar nessa consulta popular três milhões e meio de votos, que para o número de habitantes que temos é uma cifra importante (E48).

Para outro membro da diretoria, o momento que expressou o ponto máximo de unidade entre os empregados e os desempregados foi o "Matanzazo", em 2000: "durante 17 dias, desempregados organizados na FTV e na CCC, junto a trabalhadores da saúde, estatais e docentes, cortaram a rodovia 3 em La Matanza, ação acompanhada por uma greve dos estatais". O resultado da luta, segundo o dirigente, foi a assinatura do primeiro "convênio coletivo social" (E43).

Entre os entrevistados, só um dirigente destacou algumas "contradições" na prática da CTA. Um dirigente da Foetra ressaltou que a CTA cumpriu um papel no surgimento do movimento de desempregados, mas representou esse segmento “(...) como central, como CTA, mas não como sindicatos que conformam a CTA. Os sindicatos que conformam a CTA nunca se ocuparam disso, sim se ocupou a central como aparelho político, não como aparelho de organização sindical; são duas coisas distintas". O relato desse entrevistado coincide com o 
que foi dito por alguns dirigentes cegetistas, em relação ao generalizado desinteresse das organizações sindicais por ramo de atividade em organizar os desempregados:

A CTA, com muito boa orientação política, deu toda uma batalha de organização dos desempregados e foi correta, mas em algum momento havia que dar um salto, e talvez houve uma inércia nessa política de organizar os desempregados onde cada um se apaixona por sua criação. Houve uma demora talvez em ir com esses desempregados aos sindicatos para exigir resposta. (E46).

Este mesmo entrevistado destacou que a organização sindical dos desempregados deve se constituir como um movimento que tenha por finalidade o desaparecimento dessa categoria, e não como um "fim em si mesmo":

Em um momento os desempregados passaram ao estatuto de sujeito histórico (...) a organização dos desempregados passava a ser um fim em si mesmo, quando organizar os desempregados significa, ou deveria significar, sua própria desaparição como desempregados. Às vezes, e durante muitos anos, os desempregados passaram a ser um fim em si mesmos, como se fosse sujeito histórico, como se tivesse um papel para cumprir em uma transformação histórica, e isso não é assim porque se supõe, na medida em que os desempregados se organizam, o fim é sua desaparição como tal, e isso não se deu assim (E46).

Segundo os dirigentes da CTA, a CGT não representou os desempregados. Ao contar sua experiência de militância de base em um sindicato cegetista, um dirigente da CTA argumentou que aquela entidade dava aval à flexibilização, "permitindo jornadas extensíssimas" e até "demissão grátis, sem pagamento de indenização" (E45).

Esse dirigente acrescentou que a CGT optou por ser "cúmplice, ou "aliada" às políticas neoliberais e que, por isso, "evidentemente, não lhe importou a classe trabalhadora". O entrevistado argumentou também que: "O que fizeram essas organizações sindicais e esses dirigentes foi (...) fortalecer sua estrutura sindical ou garantir melhor seus poderes ou bemestar para eles e nenhum para a classe trabalhadora". Sobre essa questão, o dirigente explicitou:

[os sindicatos da CGT] (...) não só não se ocuparam, mas ademais montou negócios para obter lucros com a classe trabalhadora, como faziam com as AFJP e as ART [Administradoras de Riesgos del Trabajo]. Muitas dessas AFJP eram instrumentalizadas nas próprias organizações sindicais e muitos deles [dirigentes sindicais] foram empresários: por isso a central [a CTA] diz que esse é um sindicalismo empresário, [que] tomou o trabalhador somente como cliente, somente para que contribua. (E45).

Os entrevistados da CTA não fizeram referência às diferentes correntes políticas que atuaram na CGT nesse período. Porém, alguns destacaram a existência de ações contra as demissões na base, tal como se pode observar na fala de um membro da direção da central: "Houve resistências setoriais, dos que foram afetados por um processo de privatização ou a quem tocava um processo de reconversão industrial" (E47). O dirigente da Foetra argumentou 
que a ausência de política para os desempregados por parte da CGT se explica do seguinte modo: "A maioria dos dirigentes se aliaram com o processo dos 90, com o processo neoliberal, muitos foram sócios disso; ou seja, muitos montaram empresas, se fizeram empresários, muitos se fizeram milionários com esse processo". (E46). Na mesma linha estão os argumentos de outro diretor, segundo o qual na década de 1990 prevaleceu na CGT "a corrupção, a subordinação a Menem" e que a central "foi cúmplice e partícipe efetivo na época menemista". Ademais, o entrevistado afirmou que seus sindicalistas "foram sócios das privatizações" e que a CGT se converteu em um "projeto de sindicalismo empresarial". Porém, este entrevistado afirmou que é "injusto" dizer que a CGT não se ocupou dos desempregados: "se brigavam por um seguro de desemprego, se ocupavam; se davam a obra social aos desempregados, se ocupavam; se brigavam para não estar desempregados, se ocupavam. Se ocupavam mal, pouco ou regular, isso é outra coisa. Porque não alcança, é um modelo velho" (E43).

As diferenças políticas entre as duas centrais diante do desemprego e das demissões foram explicadas por um diretor da CTA pela prática corporativa da CGT: "na Argentina, (...) a CGT é uma estrutura sindical corporativa, que se ocupa da defesa dos direitos dos trabalhadores sindicalizados, dos trabalhadores que estão sob um convênio coletivo". Esse mesmo entrevistado argumentou, ademais, que a CGT se constituiu "com a chegada do peronismo"; um vínculo perdurável no qual a central funciona como "o partido da classe do governo" e o sindicato como "correia de transmissão das políticas do Estado". Por fim, o dirigente concluiu:

(...) essa estrutura da CGT foi funcional para fazer passar as políticas neoliberais (...) É impensável que um governo que não tivesse sido um governo peronista pudesse ter levado, sem resistência do movimento sindical, as políticas neoliberais. (...) A CGT é estruturalmente constitutiva do movimiento justicialista, do peronismo (...) e os [anos] 90, além do processo neoliberal, foi um governo peronista quando houve essa transição. Termina o peronismo, vem um governo da Alianza; assim como o menemismo durou 10 anos, o governo da Alianza durou, nas mesmas condições sociais, um ano e meio. Quer dizer, que quando a força da resistência somou outros setores, entre eles a própria CGT, a experiência desemboca rapidamente na crise, na queda do governo radical (...) quando quebram a CGT única e a direção é cooptada pelo menemismo, os trabalhadores ficam praticamente desprotegidos (E47).

Vejamos como os sindicalistas da CTA elaboram resposta para o tema do surgimento das organizações de desempregados. Quando perguntado sobre a questão, um dirigente nacional da central sugeriu que a organização dos desempregados se deu for fora dos 
sindicatos e não fez qualquer relação com a militância sindical, apesar de reconhecer o papel da própria CTA nesse processo:

(...) o movimento sindical estava preparado, em termos históricos, para a luta salarial, a luta distributiva, não estava preparado para um cenário onde o desemprego aparecia como um elemento massivo e, ademais, estrutural. (...) a década de 90 inaugurou uma etapa de lutas defensivas do movimento sindical. (...) a articulação de políticas se deu mais dos sindicatos para fora. Ou seja, não houve políticas dos sindicatos da porta para dentro que resultaram válidas para enfrentar o tema do desemprego. O que houve foi uma politização de algumas lutas, de alguns sindicatos, que articularam socialmente estratégias com os piqueteiros, com os movimentos piqueteiros, com os movimentos sociais, mas lutas que (...) não podiam ser definidas como estritamente sindicais (E48).

Na CTA também está presente o argumento de que o movimento de desempregados se consolidou após a expansão dos programas sociais. O entrevistado da Foetra recordou que essa política remonta ao Plan Alimentario Nacional, criado durante o governo de Alfonsín. Nos anos 90, quando os planos, como o Plan Jefas y Jefes de Hogar Desocupados, passaram a ser administradas pelas organizações, essas tiveram um grande impulso:

(...) o problema é que esse seguro social se distribuía por meio dos líderes das (...) organizações de desempregados. Então, cada um, cada partido, cada setor organizava seus desempregados e tinham a regalia que era receber o subsídio, cumprindo o papel de intermediário (...). Em determinado momento isso se fez com uma retenção, ou seja cada uma dessas organizações retinha dinheiro dos desempregados e lhes dava uma parte e a outra a retinham (...) cobravam uma cota obrigatória, se você vai a algumas mobilizações (...) vai encontrar muitas crianças com as mães, os carrinhos de bebê, os velhos, os nenéns. Não há uma participação legítima, eles vêm se não, não lhes pagam o subsídio. Isso é terrível, mas é assim, um clientelismo da pior orientação de direita, conservadora (E46).

Para este entrevistado, esse foi o elemento fundamental para a expansão das organizações, já que o motor principal das mobilizações era a ampliação do acesso e o aumento de seu valor: "[Os agrupamentos] se organizavam e pediam aumentos (...), não pediam trabalho, pediam aumento do subsídio". Este dirigente também criticou o protagonismo que se procurou dar para os desempregados no auge do movimento: “(...) em um momento, junto com essa coisa do fim da história e o fim do trabalho, [o desempregado] apareceu como um setor com um fim histórico, como se fosse classe operária...” (E46).

O entrevistado da Foetra também atribuiu o surgimento das organizações de desempregados à "magnitude do processo neoliberal", que não teria tido "equiparação" com relação a outros países: "Como fizeram aqui, não se fez em nenhum lado. Aqui se vendeu tudo". Em seguida, relacionou a eclosão do movimento com o neoliberalismo: "o movimento de desempregados seguiu esse processo [neoliberal] como a sombra segue o corpo". Ademais, 
o entrevistado declarou que a mobilização é fruto da "hecatombe" social vivida na grande Buenos Aires. Ressaltou que muitos trabalhadores quando ficaram desempregados se dedicaram a pequenos empreendimentos, mas depois, "quando esse dinheiro acabou, quando nem todos podiam montar uma videolocadora, é onde muitos ativistas começaram a organizar, porque já conheciam a organização (...)”. Este dirigente não excluiu a participação de ex-militantes do sindicalismo na origem das organizações: "ademais, demitiu-se ativistas sindicais que ficaram desempregados (...) que vinham com uma experiência organizativa prévia. (...) Não se esqueça que a classe operária argentina é uma das mais organizadas, tem uma experiência muito forte de organização sindical" (E46). Praticamente todos os entrevistados da CTA fizeram referência a essa questão. Um dirigente nacional da central argumentou que a mobilização dos desempregados esteve fortemente conectada à tradição de luta do país:

A classe trabalhadora em nosso país era uma classe trabalhadora organizada e muito forte, com forte consciência de classe. Então, mesmo desempregada, mesmo no bairro, mesmo excluída, não havia dúvida de que ia se organizar (...), reagir como classe. Esteja empregado ou desempregado, mas sempre vai se se organizar, ainda que seja na defensiva, mas sempre vai se organizar (E45).

Quando perguntado sobre os elementos que comprovam essa tese, o entrevistado fez referência à utilização do piquete como instrumento de luta e às experiências prévias do núcleo originário:

(...) o que encontramos depois dos piquetes nas organizações sociais era que os grandes líderes desses movimentos eram delegados de fábrica, eram dirigentes sindicais que tinham ficado excluídos e desempregados (...) nesses dirigentes havia muita experiência como classe trabalhadora organizada, ainda que estivessem sem trabalho (...) tinham essa formação cultural de sempre se organizar como classe na fábrica, e agora que estavam excluídos, no território. Por isso, Víctor De Gennaro dizia "hoje a fábrica está no bairro", e isso é o que temos que organizar, para recuperar a luta contra o capital e voltar a conquistar a redistribuição da riqueza (E45).

Para explicar o surgimento do movimento de desempregados, este dirigente explicitou a situação anterior da Argentina, que até a década de 90 lograva um amplo acesso ao emprego formal, e novamente fez referência à história de organização da classe trabalhadora, dessa vez relacionando-a ao peronismo:

Eu acho que são duas razões. A primeira, que a Argentina era um dos principais países industriais na região, e onde praticamente partíamos do pleno emprego. Então, havia uma forte consciência de classe trabalhadora e de organização de classe trabalhadora. Ao se produzirem os impactos das políticas neoliberais e o terrível desemprego que isso produziu, esses trabalhadores que já não estavam dentro da fábrica, dentro dos locais [de trabalho], iam seguir se organizando da mesma maneira, e a partir daí 
surgem as organizações de desempregados em nosso país (...) creio que o governo de 45 do general Perón dá ferramentas (...), lhes dá [à classe trabalhadora] um marco de legalidade para avançar na organização. Isso foi se consolidando mais, depois através da legislação, e então, culturalmente, [resultou em] uma classe trabalhadora muito forte. Então, na Argentina se deu um coquetel, a distribuição da economia argentina, portanto, um dos mais altos índices de desemprego, mas com uma forte consciência de classe trabalhadora, por isso já sem emprego, organizaram-se como desempregados (E45).

Um dirigente da central explicitou a diferença entre as organizações de desempregados surgidas "territorialmente" daquelas que se consolidaram com a prática clientelista de distribuição dos planos sociais a partir de organizações de esquerda, nas quais os líderes não eram, estritamente, desempregados:

Não há um dirigente desempregado, de todos os dirigentes dos organismos supostamente desempregados.

Veja bem, Pitrola [líder do Polo Obrero], era gráfico. Então, não são movimentos de desempregados, são movimentos de trabalhadores de "determinado tipo"... O que há, depois de 2002, com o plano de Jefas y Jefes, é uma estruturação de organização daqueles que recebiam esse plano de uma maneira direta e com alto grau de participação. Isso já é outro processo, mas o movimento de trabalhadores territoriais, do bairro, inclusive de desempregados, vinha de muito antes, e foi estrutural. Agora, outra coisa é a explicitação partidária disso, a tal ponto que do Partido Obrero se chamou Polo Obrero (...), Movimiento de los Sin Trabajo [MST, referindo-se ao partido do qual surgiu, o Movimiento Socialista de los Trabajadores]. Ou seja, buscavam as mesmas siglas... (E43).

Este entrevistado também criticou a noção de que o movimento de desempregados teria surgido espontaneamente. Ao contrário, ressaltou o papel da organização prévia em diversos contextos. Citou, como exemplo, o caso de Cutral-Có, em Neuquén, onde ocorreu um dos primeiros bloqueios de rodovia de desempregados:

(...) ocorre o piquete em Cutral-Có e quando se investiga, atrás dessa organização está o Movimiento de Demitidos de YPF, está a ATE, mas está [o Sindicato dos] Judiciários, está ATEN [Asociación de Trabajadores de la Educación del Neuquén], que são os docentes, estão as Comunidades Eclesiais de Base de Jaime de Nevares, está a Assembléia de Direitos Humanos está todo um movimento estrutural ${ }^{[796]}$, está a CTA aí em Cutral-Có, que foi a que organizou todos esses setores. Não há nenhuma luta sem organização, espontânea. É uma erupção em algum momento, por alguma causa, mas não há nenhuma espontaneidade, a luta é sempre organizada, sempre há fatores que contribuem (...), a luta não se dá magicamente (E43).

Outro diretor da central também explicou o surgimento do movimento de desempregados pela tradição de luta da classe trabalhadora do país:

\footnotetext{
${ }^{796}$ Tal como apontam alguns estudos, processos semelhantes foram vividos nas províncias de Chaco (Carrera e Cotarelo, 2009) e Salta (Benclowicz, 2009), no norte do país.
} 
Em primeiro lugar, seu passado de trabalhadores convencionados, trabalhadores sindicalizados, foi muito importante nas primeiras marchas com os desempregados. Era incrível ver a quantidade de extrabalhadores. Não se esqueça que o desemprego foi compulsivo e se produziu em um curto período de tempo, pelas privatizações e pela "reconversão" [referindo-se ao plano de convertibilidade]. Exferroviários, ex-trabalhadores de energia, ex-trabalhadores do Estado, ex-trabalhadores de fábricas que fecharam, quer dizer, em geral tinham uma experiência de luta. Creio que isso foi o que facilitou a organização dos desempregados: a consciência sindical” (E47).

Este dirigente também não concorda com a idéia de que a organização dos desempregados tenha surgido por fora do sindicalismo, e para sustentar sua explicação, reforçou os argumentos apresentados na passagem anterior, diferenciando dois "momentos" do movimento:

Eu não compartilho [com essa idéia] pela experiência que vi, que pude verificar e pelos lugares onde se desenvolveu. Há dois momentos do movimento piqueteiro. [Referindo-se ao primeiro momento:] Os primeiros piquetes importantes, que foram em Tartagal, Cutral-Có e Cruz del Eje, são lugares onde havia uma grande população de trabalhadores do petróleo, por exemplo, ou ferroviários. É verdade que no mundo dos piquetes, no mundo das organizações houve uma grande presença da juventude, mas em geral quem organizou e implementou isso foram ex-trabalhadores que caíram no desemprego. É provável que não tenham vínculo com a estrutura sindical porque na Argentina, notavelmente a CGT, é uma estrutura sindical corporativa, que se ocupa da defesa dos direitos dos trabalhadores sindicalizados, dos trabalhadores que estão sob um convênio coletivo (E47).

Em segundo lugar, este entrevistado destacou o papel dos planos sociais, fundamentados na lógica de "proteção do Estado para os desempregados": "nos anos 90 não havia absolutamente nada. A única coisa que existia era um seguro-desemprego que durava seis meses e depois vinha a indigência”. Para ele, este foi o motor da expansão das organizações de desempregados:

[Referindo-se ao segundo momento:] Depois, houve uma eclosão dos movimentos em 2000, 2001, quando começam a se efetivar os primeiros planos. Houve em um dado momento cerca de dois milhões de planos do Estado (Plan Jefas y Jefes), que é uma miséria, 150 pesos, mas aí houve uma expansão maior. Mas em suas origens estavam profundamente ligados a desempregados que tinham trabalho formal. É verdade que muitas vezes contra as próprias organizações sindicais que não os defendiam, mas até mesmo em oposição às organizações sindicais estava a consciência sindical (E47).

Os dirigentes da CTA são unânimes em afirmar que a central levou a cabo iniciativas de representação dos desempregados. Segundo os entrevistados, os eixos da política diante do desemprego por parte da entidade foram: a afiliação direta dos desempregados, justificada a partir do "conceito amplo de trabalhador"; o apoio à organização dos desempregados (da experiência pioneira da UTD de Rosario aos primeiros bloqueios de estrada do conurbano, 
em La Matanza); a defesa de políticas universais para os desempregados (como a renda cidadã e o seguro de emprego e formação); a proposta de redução da jornada de trabalho e a oposição às políticas neoliberais que geravam desemprego. Como momentos de articulação na luta entre empregados e desempregados foram citadas a Marcha Federal, a Marcha Grande, a Frenapo e a paritária social firmada a partir do Matanzazo.

Por outro lado, a ausência de iniciativas por parte da CGT em relação aos desempregados foi explicada pelos dirigentes da CTA pela cumplicidade daquela central com o governo e as políticas neoliberais, por exemplo, em seu apoio à flexibilização. Um entrevistado enfatizou a relação orgânica entre a CGT e o peronismo, o que explicaria o alinhamento dos dirigentes dessa organização com os governos. Outro entrevistado destacou o "corporativismo" predominante nessa central e muitos ressaltaram a prática empresarial levada a cabo por seus sindicalistas. Houve quem assinalasse a existência de sindicatos cegetistas que montaram negócios a partir das privatizações e do desmantelamento das políticas públicas, como nos casos das AFJP e das ART. Nesse sentido, afirmaram que a prática da central se sustentou no apego à estrutura sindical e à política de regalias individuais.

$* * *$

Com base no material apresentado neste item, farei algumas considerações com o objetivo de avançar na compreensão da relação entre o ativo e a reserva na sociedade argentina, com base no registro e análise das representações dos quadros de organizações sindicais e de desempregados. Um primeiro aspecto que considero importante de se sublinhar é a necessidade de se distinguir as políticas desenvolvidas pelos sindicatos daquelas levadas a cabo pelas centrais sindicais, assim como suas implicações nas situações de demissão e de desemprego. Essa questão permite interpretar como foram construídos alguns discursos citados. Por exemplo, os dirigentes da CTA destacam que esta central representou os desempregados, e a CGT não. Por sua vez, os dirigentes cegetistas argumentam que os sindicatos das duas centrais não tiveram uma política efetiva diante das demissões. No âmbito das representações, essa demarcação contribui para a formulação algumas hipóteses sobre o porquê de não haver diferenças significativas entre os quadros da CTA e da CGT no que se refere à interpretação das causas e possíveis soluções para o desemprego, e em reconhecer os desempregados como parte da classe operária, mas sim há divergências de interpretação acerca das políticas sindicais desenvolvidas para esse segmento. 
De modo geral, os entrevistados na Argentina não fizeram referência aos limites da organização dos desempregados, justamente porque nesse país houve um importante movimento dessa fração da classe trabalhadora. No entanto, as explicações sobre a ausência de uma política sindical para os desempregados se focaram especialmente na ideologia político-sindical defendida pelos diferentes setores. Também não apareceram muitas declarações que fizessem referência à estrutura sindical, em boa medida porque uma das centrais (a CTA) buscou superar a acomodação ao corporativismo. Sobre esse tema, o entrevistado da Foetra explicitou:

A 23.141, que é Ley de Asociación Sindical, é uma lei que deveria ser modificada, que tem muitos elementos nos quais se refugia a burocracia sindical, haveria que fazer uma ampla modificação da lei que regulamenta a vida interna dos sindicatos, mas não é esse o problema essencial. Não é um problema legislativo, em definitivo, cedo ou tarde as leis refletem as relações que há embaixo (E43).

De acordo com a análise apresentada, a meta da CGT foi garantir a reprodução da força de trabalho assumindo a defesa e promoção do emprego, e reservando ao governo do Estado a regulação da atividade econômica com políticas industriais. A CTA, por sua vez, além disso, buscou promover a organização político-sindical da reserva e defendeu políticas assistenciais para essa fração operária, como sintetiza sua proposta de renda cidadã universal.

Pode-se concluir, então, que embora tenha formulado propostas para o desemprego, a CGT não representou os desempregados em seus interesses imediatos, nem os organizou para a luta. Além disso, jamais se propôs a fazê-lo, ainda que seus dirigentes reconheçam que tal política teria sido importante. A CTA buscou representar o conjunto da classe operária como grupo social, ao incorporar parte das organizações de desempregados a sua estrutura organizativa, oferecendo-lhes suporte para se mobilizarem para a luta. Dito de outra forma, a CGT atuou como uma central de sindicatos que organizam o grupo profissional, ou seja, o ativo de seu respectivo setor, privilegiando em suas ações o interesse de seus representados como "assalariados". A CTA também incluiu sindicatos que agrupam o ativo de seu setor, mas também se propõe a organizar a reserva tendo como meta a mobilização da classe trabalhadora como grupo social. ${ }^{797}$

Essa diferença entre a CGT e a CTA se explica, parcialmente, pelo maior distanciamento das organizações de desempregados em relação ao ativo representado pela CGT. A base social desta central é, exclusivamente, o grupo profissional de setores de médio

\footnotetext{
${ }^{797}$ Essa caracterização, baseada nas categorias de grupo social e grupo profissional, no marco mais amplo das relações de forças políticas, advém da leitura da obra de Gramsci (1976).
} 
e grande capital. Por isso, diante do desemprego, sua meta principal foi evitar, propor a implementação de políticas de geração de postos de trabalho, e não organizar os desempregados para a luta. Como a CTA pretendeu organizar o ativo e a reserva, reivindicando do governo políticas assistenciais, seus objetivos coincidiram com os interesses materiais imediatos de parte das organizações de desempregados, que por sua vez possibilitavam que a central ampliasse sua base de representação. Aprofundarei essa questão no capítulo seguinte.

Ideologicamente, poder-se-ia afirmar que há mais proximidade entre a CTA e algumas organizações em direção ao peronismo de esquerda. Os setores mais críticos a esta central são justamente os que mais se distanciam dessa perspectiva, embora em alguns momentos tenham atuado em conjunto. Por isso, os quadros das organizações político-sindicais da esquerda socialista e das correntes autonomistas tendem a considerar que a CTA, na realidade, tem uma prática muito similar à da CGT.

Vale uma última observação. A representação dos dirigentes acerca das políticas sindicais não está diretamente relacionada à concepção das organizações sobre as causas e possíveis soluções para o desemprego, e o pertencimento dos desempregados à classe trabalhadora. Corresponde, muito mais, ao alinhamento político do momento, que, em última instância, tem seu lastro nos interesses materiais e nas representações ideológicas das organizações, e é o que define as relações de enfretamento e a construção de unidade e fratura da classe trabalhadora entre o ativo e a reserva.

$* * *$

Antes de passar aos comentários finais deste capítulo, farei um breve relato sobre a visita à sede da CGT, que muito me ajudou a tentar compreender o significado do peronismo na Argentina. O edifício histórico, localizado na rua Azopardo, n. 802, e construído com recursos da Fundação Evita Perón, foi concluído em 1950. Na entrada do prédio, encontramse as esculturas do casal Eva Duarte e Juan Domingo Perón, do sindicalista Rucci ${ }^{798}$ e da Virgem de Luján, padroeira nacional. Essas três imagens atestam as principais fontes ideológicas constitutivas da central: o justicialismo, o cristianismo e o sindicalismo negociador.

\footnotetext{
${ }^{798}$ Dirigente sindical, um dos principais defensores da volta de Perón ao país durante seu exílio “ aliado de Vandor, com quem defendia uma política sindical negociadora. Foi presidente da CGT no período de 1970 a 1973, quando foi assassinado pelos montoneros, grupo armado que se opunha à política praticada pela central.
} 
Nessa sede funciona o Memorial Evita Perón, na qual se pode ter acesso à sala onde a ex-primeira dama permaneceu embalsamada desde sua morte, em 1952, até o ano de 1955, quando seu corpo foi seqüestrado pelos militares responsáveis pelo golpe que destituiu Perón. Além de objetos pessoais de Evita, é possível ver reproduções de fotos de diversos momentos de sua carreira política, especialmente das obras assistencialistas promovidas por sua fundação, e de seu velório, que durou mais de seis dias e atraiu uma multidão que fez fila durante horas pelas ruas de Buenos Aires para se despedir de sua "líder".

Esses fatos são emblemáticos de um dos aspectos centrais do peronismo: seu caráter "mítico e ritualístico". Mais do que um regime político, a doutrina peronista é uma "visão de mundo" "799, no sentido weberiano de "sistema de valores que organiza as ações dos indivíduos" (Weber, 1991). Ademais de seu caráter de classe, como política populista baseada na aliança entre capital e trabalho, exerceu-se a partir de uma dominação carismática, pois explorou os atributos pessoais e o culto à imagem dos líderes, o messianismo, presente na legitimidade dada pelo povo às decisões do "general", visto como um "redentor", a caridade em torno da fundação da primeira-dama, que se auto-definia como "líder dos descamisados" e "protetora das crianças", a histeria coletiva através dos comícios de massa, o dogmatismo na interpretação dos discursos de Perón e sua esposa, o fanatismo em relação ao presidente ${ }^{800}$ e a devoção a "Evita", que levou muitos a considerá-la uma "santa", inclusive com uma proposta de beatificação registrada no Vaticano após sua morte. Voltemos à análise.

\subsection{Movimento sindical e de desempregados na Argentina}

Para realizar a análise, dividi o período estudado em quatro momentos, cujas características sintetizo a seguir. (i) Na primeira medição de 1995, o desemprego alcançou o nível mais alto da história argentina até esse momento. As demissões em massa produziram diversas ações de protesto. Em uma delas, levada a cabo pela UOM de Tierra del Fuego, o operário da construção Víctor Choque foi assassinado. A CTA e o MTA convocaram uma greve geral, da qual não participou a CGT. Dirigida pelo menemista Antonio Cassia, ainda que tenha havido resistências em seu interior, a posição oficial dessa entidade nesse período

\footnotetext{
${ }^{799}$ Não é por acaso que o atual presidente da CGT, Hugo Moyano, tenha afirmado: "O peronismo é uma realidade que ninguém pode desconhecer. O peronismo está nas pessoas, não está no partido, nos dirigentes. Tem muita gente que é peronista e não se dá conta". ("No tenemos ni piso ni techo", entrevista a Hugo Moyano, secretario general de la CGT. Debate, Jueves 22, febrero 2007, Año 4, n. 206, p. 21).

${ }^{800}$ Nas palavras da própria Eva Perón: "Os opositores dizem que isto é fanatismo, que sou fanática de Perón e do povo, que eu sou perigosa porque sou muito sectária e muito fanática do General Perón: o fanatismo é a sabedoria do espírito. Que importa ser fanático na companhia dos mártires e dos heróis?” (CGT, 2005).
} 
foi apoiar as posições do Governo, especialmente em sua proposta de flexibilização para combater o desemprego. Por sua vez, o MTA, como corrente interna opositora, assumiu uma posição contrária à política econômica do Governo e ao projeto de reforma trabalhista. A CTA defendeu uma postura semelhante, convergindo com o setor dissidente da CGT em diversos protestos. Apesar do desemprego crescente no período, Menem conseguiu a reeleição e, diante da expectativa frustrada de lograr cargos indicados pelo Governo, realizouse uma mudança na direção da CGT.

(ii) O período que se estende de setembro de 1995 a dezembro de 1996 abarca a totalidade da condução de Gerardo Martínez e o começo da gestão de Rodolfo Daer na CGT. Apesar de não haver abandonado a estratégia negociadora e a política de aliança com o Governo, nesse período se produziram os protestos mais significativos da central durante a era menemista, com a convocação de quatro greves gerais. Permaneceu a divisão interna na entidade, mas nesse momento o conjunto do movimento operário organizado sindicalmente logrou protestar por objetivos comuns. O MTA seguiu sua linha crítica às políticas do Governo. A CTA continuou atuando na mesma linha e iniciou uma política de construção de unidade com os desempregados. Por sua vez, os sindicatos nucleados por Cassia no MOP seguiram defendendo as propostas flexibilizadoras de Menem e se opondo a todas as ações de protesto convocadas pelos demais setores.

(iii) No período seguinte, entre 1997 e 1999, com a permanência de altos índices de desemprego, realizaram-se os primeiros bloqueios de estrada e os desempregados começaram a se constituir como um dos principais sujeitos da rebelião. O efeito "caipirinha" produzido no país a partir da desvalorização do real em 1998 provocou um crescente descontentamento com a política econômica, industrial, cambial e comercial do governo entre os diferentes setores do sindicalismo. A política da CGT se caracterizou pela concertação, com a aprovação da Acta de Coincidencias, apoiada pelo MOP, mas com críticas das 62OP e da UOM que, juntamente com a CTA, o MTA e a CCC, convocaram uma greve geral em julho de 1997. A situação social do país se agravou, mas somente a CTA convocou uma greve geral.

(iv) A partir de dezembro de 1999, até 2002, o desemprego alcançou os níveis mais altos já registrados na história argentina. Com a expansão das organizações de desempregados, aumentaram os piquetes e o movimento se consolidou no conurbano bonaerense. A CTA investiu na estratégia de construir uma unidade na luta entre empregados e desempregados, incentivando a ação conjunta entre os dois setores nos diferentes atos que 
convocou. A CGT-Daer e a CGT-Moyano não se ocuparam diretamente da representação política dos trabalhadores sem emprego, mas tampouco se opuseram a sua mobilização. Nas greves ocorridas a partir do segundo semestre de 2000 a unidade entre o movimento operário organizado sindicalmente, por meio das três centrais, alcançou seu ponto máximo. Em 2001, a rebelião chegou ao auge com a insurreição espontânea de 19 e 20 de dezembro que levou à queda de De la Rúa. O movimento sindical teve presença importante no processo de formação do descontentamento popular. Os três setores haviam realizado uma greve geral para o dia 13 de dezembro e a CTA, entre os dias 14 e 18, havia organizado uma consulta popular pela aprovação de um seguro de emprego e formação. Durante o governo de Duhalde, essa central seguiu investindo na oposição sistemática às políticas anti-populares de seu governo convocando três greves gerais, uma delas em repúdio ao assassinato de dois militantes de esquerda em Avellaneda. A CGT-Moyano também realizou ações de protesto e manifestou sua insatisfação. A CGT-Daer pressionou o Governo, mas prevaleceu nesse setor a busca de concertação por aumentos salariais. Cumpre notar também que esse período correspondeu ao pico da unidade entre o movimento operário organizado sindicalmente e as organizações de desempregados. Durante as catorze greves gerais convocadas nesses três anos, essa tendência ficou evidente com a consolidação da utilização dos bloqueios de rodovias simultâneas às mobilizações sindicais (Ver Quadro II). A greve geral, como instrumento mais expressivo da mobilização do ativo, foi reconhecida pela reserva como um momento de acúmulo de forças na luta e, por isso, parte de suas organizações se somaram a esses protestos. Por um lado, é notável que, entre as três organizações analisadas, somente a CTA investiu em uma política de organização dos desempregados para a luta. Também é perceptível que o poder de convocação dos sindicatos representados pela CGT tenha sido sempre decisivo para o alto nível de adesão dos protestos e que, por isso, os demais setores sempre tenham aderido a suas mobilizações. As fontes consultadas não informaram sobre as alianças entre as organizações de desempregados e as entidades sindicais convocadoras das greves gerais. Porém, a presença constante da CCC e da FTV, esta última integrada à CTA, confirmou que esta central teve uma importante participação na construção dessa unidade.

A posição das centrais diante da flexibilização, das causas do desemprego e da política para os desempregados é reveladora do mapa sindical argentino desse momento, composto pelas quatro tendências descritas. No período considerado, entre os setores analisados (CGT, MOP, MTA/CGT-Moyano e CTA), é mais difícil demarcar a posição da primeira que das 
outras três, que apresentaram uma leitura mais constante da situação vivida pelo país: a CTA e o MTA, por sua constante oposição aos governos de Menem e De la Rúa; o MOP, por seu apoio incondicional a Menem. Na CTA e no MTA, o centro do debate sobre as causas do desemprego foi a política econômica do Governo. Por sua vez, o MOP culpava os empresários e propunha a radicalização das propostas do Governo, especialmente a flexibilização das leis trabalhistas. Quanto à CGT, como Direção Nacional, sua posição durante o período de Menem, De la Rúa e Duhalde oscilou entre a estratégia de diálogo e a confrontação. Entretanto, quando esgotavam as vias de negociação, a central convocava ações de protesto.

Nessas mobilizações, entre seus objetivos estava a busca da concertação, suficiente para suspender três greves gerais (em 1996, 2000 e 2001). Por seu poder de convocação e grau de legitimação nos espaços institucionais de negociação, pode-se dizer que a CGT sempre esteve presente nas grandes decisões. Em diferentes momentos apoiou ou negociou parcialmente as propostas dos governos. Em outros, convocou ações quando considerou que seus interesses estavam sendo ameaçados, como a administração sindical das obras sociales e a representação dos sindicatos nacionais nos convênios coletivos. Apesar de terem sido mais freqüentes ações pela defesa dos interesses da organização, não estiveram ausentes mobilizações pela defesa dos trabalhadores. De qualquer forma, a interpretação do período selecionado possibilitou questionar a idéia muito comum, inclusive entre alguns dirigentes, de que a CGT não se mobiliza quando os justicialistas estão no poder. Embora durante a gestão de De la Rúa os protestos sindicais tenham sido mais intensos, na segunda gestão de Menem também tiveram um peso importante.

As propostas cegetistas diante do desemprego a partir da gestão de Martínez foram se consolidando não só em políticas ativas (geração de postos de trabalho) e passivas (segurodesemprego). A central reivindicou um conjunto de medidas macroeconômicas, comerciais, industriais e cambiais para resolver o problema, tais como uma maior proteção às importações, incentivo às pequenas e médias empresas, uma política financeira voltada à produção, e não à especulação, e o fim da sobrevalorização do peso por meio da política de convertibilidade.

Por seu caráter pragmático e pelo grau de dependência dos acordos políticos com o Governo, é possível observar momentos em que a CGT se aproximou mais da ala menemista e em outros, do sindicalismo opositor. Durante os momentos em que prevaleceu a estratégia 
de diálogo, a central aceitou parcialmente as propostas de flexibilização e a leitura das causas do desemprego se deu em torno de fatores exógenos às políticas do Governo. Assim, sob a acusação de "politização" do tema, a central atribuía a culpa da falta de emprego aos estrangeiros, à atitude empresária e ao contexto mundial. Nos momentos de enfrentamento, a política econômica era uma das responsáveis pelo crescimento do desemprego e o Governo era culpado por não se levar adiante políticas para os desempregados. Porém, se a posição oficial da CGT durante a presidência Menem esteve muito marcada pelas diferenças ideológicas com relação aos demais setores, e pelas alterações constantes em suas alianças, no Governo de De la Rúa a oposição da central às políticas econômicas se configurou de maneira mais clara. Isto não significou o abandono da estratégia do diálogo e da busca da concertação por meio do pacto social tripartite. Porém, o agravamento da situação social do país, o fato de ter deixado de participar majoritariamente na aliança do Governo e a ameaça constante de que o poder sindical de negociar coletivamente fosse afetado, levaram a CGT a adotar uma postura mais confrontacionista, convocando três greves gerais no segundo semestre de 2001 .

Durante o Governo de De la Rúa também se verificou o momento de maior grau de unidade entre o ativo e a reserva. O material consultado permitiu constatar, primeiramente, que não houve hostilidade sindical ao movimento de desempregados, já que sua organização encontrava apoio de todas as centrais, ainda que em distintos graus. Quando o discurso do Governo era de criminalizar o protesto, a CGT legitimava os piquetes, o MTA considerava importante a estratégia de ação conjunta com esse segmento e a CTA permitia sua filiação e incorporava a sua estrutura parte das organizações de trabalhadores desempregados.

Entre 2000 e 2002, ocorreu a maior quantidade de eventos em que participaram desempregados e demitidos, tanto isoladamente como em conjunto com os empregados. Esse fato evidencia, por um lado, o considerável grau de unidade desse segmento com sindicalismo, ainda que somente no caso da CTA essa unidade tenha se concretizado parcialmente em uma organização conjunta. Por outro, revela o reconhecimento, de ambas as partes, da greve geral como uma ferramenta de luta que possibilita a confluência do conjunto do movimento operário organizado. Essa ação conjunta foi fundamental para o acúmulo de forças existente na insurreição espontânea de dezembro de 2001. Esse aspecto tem sido negado por alguns autores, especialmente entre os adeptos do fim do protagonismo operário, ainda que todas as evidências empíricas apontem sua persistência. Ao desconsiderarem esses fatos, muitas dessas interpretações se baseiam em afirmações descontextualizadas de aspectos 
parciais da temática sindical dos anos 90. Sendo assim, restringem-se à acusação de corrupção do sindicalismo empresário, ou à aliança da CGT com o Governo de Menem, e não levam em consideração que: (i) que durante todo o período analisado os trabalhadores "assalariados" foram os principais sujeitos da rebelião; (ii) que a greve foi um dos instrumentos de luta mais adotados; (iii) o papel desenvolvido pela CTA e pelo MTA como setores que se opuseram constantemente às políticas menemistas; (iv) a importância da CTA como um setor sindical que investiu na organização dos desempregados e na construção da unidade na luta entre o ativo e a reserva; (v) as divergências presentes no interior da cúpulas dirigentes; (vi) a oposição da Direção Nacional da CGT a certos aspectos da política econômica; (vii) os momentos de confrontação dessa central, que levou a cinco greves gerais durante o Governo de Menem (incluindo a de 1992, não considerada na análise) e outras quatro durante o Governo de De la Rúa; (viii) o conjunto dos protestos, e especialmente as paralisações nacionais, que totalizaram nove eventos no Governo de Menem, dez no de De la Rúa e quatro no primeiro ano de Duhalde; (ix) o papel desenvolvido pelo sindicalismo no conjunto do ciclo de lutas que culminou na insurreição espontânea de 19 e 20 de dezembro de 2001; (x) e por último, ainda que não tenha sido tema deste trabalho, o nível de conflitividade da base, que não pode ser medido pelas declarações das cúpulas, mas pelos protestos de resistência no local de trabalho.

Como se depreende da análise realizada, não se pode desvincular a emergência das organizações de desempregados na Argentina do sindicalismo a partir da simples constatação sobre a "ausência dos sindicatos" ou a predominância numérica de "novos contingentes" na base das organizações. A partir das entrevistas com líderes do movimento sindical e de desempregados, foi possível concluir que, ao contrário do que alguns autores expõem, existiram fortes vínculos entre ambos. Vários entrevistados apontaram a presença de trabalhadores despedidos, entre os quais muitos ex-militantes sindicais, no núcleo originário das organizações, que utilizaram suas experiências e tradições de luta nas novas experiências. Ademais, alguns ressaltaram o papel desenvolvido por determinadas correntes sindicais para a expansão e nacionalização do movimento. Esses elementos já seriam suficientes para distanciar da hipótese de construção totalmente "por fora do sindicalismo". Esses elementos vão de encontro ao postulado por Klachko (2007, p. 231), segundo a qual as organizações de desempregados, especialmente as que se concentraram na Grande Buenos Aires, consolidaram-se por iniciativa de organizações ou militantes político-sindicais de esquerda e 
centro-esquerda de diversas origens (nacionalista, peronista, trotskista, comunista), ou de militantes ou ex-militantes com experiência política de outras conjunturas. No entanto, o dado que mais me chamou a atenção foi que a tradição de luta da classe trabalhadora argentina tenha sido citada como o principal fator de mobilização dos desempregados. Isso revela o alto grau de influência do movimento operário e sindical no surgimento dessas organizações, ao contrário do que a maioria dos analistas aponta.

Este trabalho se contrapõe teoricamente às análises que se pautam nas teses do "fim do proletariado", "desaparecimento da classe trabalhadora" e protagonismo dos "novos movimentos sociais". A relação entre o sindicalismo e os protestos de desempregados na Argentina se desenvolveu não só por meio das alianças entre algumas de suas organizações. $\mathrm{O}$ esforço de descrição desse vínculo aqui empreendido teve como objetivo mostrar, por um lado, os traços de continuidade entre os protestos de empregados e desempregados e, por outro, a persistência do sindicalismo como principal sujeito da rebelião na Argentina, fruto da reprodução de elementos da ideologia "inerente" e da tradição de luta de sua classe trabalhadora. Como parte do movimento operário, a mobilização dos desempregados, a parte mais visível da "reserva", está sujeita às múltiplas determinações que compõem a ideologia de protesto popular, entre as quais o diálogo histórico com as experiências concretas do ativo cumpre um papel fundamental. No caso argentino, é possível concluir que a eclosão de ditos movimentos é devedora da organização sindical no país. 


\section{CAPÍTULO 5 - UNIDADE E FRATURA ENTRE O ATIVO E A RESERVA NO BRASIL E NA ARGENTINA}

Este capítulo tem o objetivo de comparar a relação entre o exército de operários ativo e de reserva no Brasil e na Argentina, tomando como eixo da análise as ações e representações do movimento sindical diante dos desempregados no período estudado. Não se trata propriamente de uma conclusão. Este é o único momento da exposição em que as questões analisadas são articuladas sob parâmetros comparativos. Ademais, a retomada do marco teórico e dos argumentos desenvolvidos ao longo do texto que este exercício exigiu me absteve da necessidade de dedicar uma parte específica para tecer as considerações finais.

Para realizar a análise, será acionado o repertório conceitual exposto no primeiro capítulo, com destaque para a tese da superpopulação relativa marxiana e engelsiana, e a noção de construção social do desemprego advinda da sociologia francesa. Ressaltarei também alguns dos elementos que conformam as experiências e tradições de luta do movimento operário e sindical brasileiro e argentino, desenvolvidos no segundo capítulo, a fim de mencionar seus principais traços de continuidade e descontinuidade na correlação de forças analisada. Por último, procurarei retomar os resultados da pesquisa descritos no terceiro e quarto capítulos, buscando articulá-los sob uma perspectiva comparativa.

É importante destacar que o presente capítulo não pretende abarcar todas as mediações possíveis de serem feitas com base no material de análise utilizado. Deixarei algumas das temáticas abordadas para futuros trabalhos e me concentrarei em três questões específicas. Para facilitar a exposição, apresentarei essas discussões por itens. No primeiro, farei um exercício de compreensão da relação entre o sindicalismo e os desempregados no Brasil e na Argentina. No segundo, enumerarei alguns fatores explicativos da relativa ausência de organização dos desempregados, no caso brasileiro, e de sua existência, no caso argentino. No terceiro, apresentarei um quadro das formas de organização da reserva e sua relação de unidade e fratura com o ativo nas duas formações. ${ }^{801}$

\subsection{Sindicalismo e desempregados}

No período analisado, a relação do movimento sindical com os desempregados foi muito diferente nos dois países. No Brasil, as ações da CUT e da FS se basearam

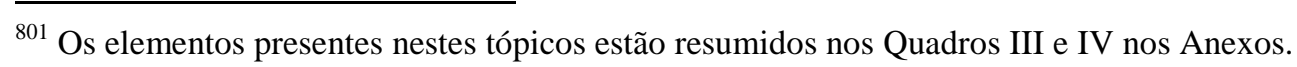


especialmente na lógica do oferecimento de serviços, embora essa política tenha sido sustentada a partir de diferentes discursos e propostas para a geração de empregos. As duas centrais investiram em políticas de requalificação profissional e intermediação da força de trabalho. No caso cutista, foram construídas estratégias no campo da chamada "economia solidária" e uma aliança com as organizações populares que tinham desempregados em sua base social. Na Argentina, a CGT (e no interior desta, o MTA) apresentou propostas de políticas ativas e passivas para combater o desemprego, mas somente a CTA se propôs a organizar os desempregados para a luta. Esta última, a partir do conceito de "central de trabalhadores", incorporou parte das organizações de desempregados a sua estrutura organizativa.

Como compreender a relação entre o movimento sindical e os desempregados construída nos dois países no período estudado e de que maneira esse vínculo expressou a unidade e fratura entre o ativo e a reserva? O método analítico adotado neste trabalho partiu da estrutura social, da correlação de forças, das experiências e tradições de luta das formações estudadas. Nas páginas seguintes me concentrarei em alguns dos tópicos mencionados ao longo do terceiro e quarto capítulos, escolhidos por contarem com maior fundamentação a partir do material de pesquisa. São eles: (i) a ideologia político-sindical predominante nas centrais analisadas e o modelo de relação do sindicalismo com o Estado e a classe capitalista; (ii) a posição adotada pelas entidades diante do neoliberalismo; (iii) suas práticas diante da estrutura sindical; (iv) os interesses imediatos de sua base; (v) e os interesses organizacionais de sua cúpula.

(i) Em parte, pode-se explicar as práticas das centrais por sua ideologia políticosindical, esta entendida em seu vínculo com a correlação de forças, as experiências históricas e as tradições do movimento operário e sindical de cada formação. Como vimos, no Brasil, o tipo de política desenvolvida pelas centrais foi o resultado e um dos principais motores das transformações político-ideológicas mais gerais em direção a um sindicalismo "propositivo", "de serviços" e "cidadão", posição que se tornou hegemônica ao longo do período estudado. As propostas de representação dos desempregados levadas a cabo pelas entidades foram condizentes com essa perspectiva. No caso cutista, essa orientação conviveu com a tradição classista e combativa mantida parcialmente por algumas correntes minoritárias. ${ }^{802}$ Mas o

\footnotetext{
${ }^{802}$ Sobre a prática de sindicatos ligados a correntes cutistas minoritárias nos anos 1990 e 2000, ver Figueiredo (2007) e Souza (2005b).
} 
sindicalismo propositivo possui uma matriz histórica no "democratismo", presente desde a formação da CUT, especialmente no setor "sindicalista" que deu origem à Articulação Sindical, setor majoritário da central. Essa ideologia se baseia, entre outros aspectos, na política institucionalista de "atuar por dentro" do Estado para transformá-lo. No caso da FS, o propositivismo tem sua raiz na tradição assistencialista e no governismo participacionista da central, tendência já expressiva em seus sindicatos mais importantes, como os metalúrgicos de São Paulo, antes da fundação da central. Por último, é necessário levar em conta que, embora tenha negado aspectos do trabalhismo populista, adaptando-o a sua adesão ao neoliberalismo, a FS preservou seu elemento básico: a busca da aliança capital-trabalho mediada pelo Estado como condição necessária para desenvolver e modernizar as relações capitalistas. Nesse contexto, é possível afirmar que os recursos do FAT e as Câmaras Setoriais expressaram as aspirações mais gerais das correntes hegemônicas do sindicalismo brasileiro. No caso cutista, foram, ademais, um exercício para a participação de seus quadros no aparelho estatal, o que se concretizou no nível federal após a eleição de Lula, em 2002.

$\mathrm{Na}$ Argentina, o tipo de política levada a cabo pelas centrais também possui uma relativa correspondência com as divisões político-ideológicas presentes no sindicalismo do país, ainda que, em seu conjunto, as entidades e os setores internos analisados se enquadrem em diferentes correntes do peronismo. A ala majoritária da CGT se fundamenta no participacionismo-propositivo, matriz ideológica que caracteriza a ala hegemônica do movimento sindical no país desde a conformação dessa central. Esse setor se pauta, fundamentalmente, na política de "concertação", noção historicamente mais difundida no sindicalismo argentino do que no brasileiro, por ser constitutivo da doutrina justicialista. A partir dessa prática, os sindicatos são considerados legítimos interlocutores de um "pacto social”, construído em torno de uma aliança entre os trabalhadores e os capitalistas, com a intermediação do Estado, que por sua vez deve incorporar quadros de dirigentes em seu aparelho adminstrativo. Destaco a seguir dois relatos que sintetizam como o movimento sindical no país concebe a ideologia política peronista. $\mathrm{O}$ primeiro, de um dirigente da Foetra, ligada à CTA, e o segundo, de um dirigente da Asociación Bancaria, vinculada à CGT:

(...) o movimento peronista [representa] a maioria do sindicalismo na Argentina, e essa ideologia do peronismo [é uma] ideologia de conciliação de classes, porque é a participação na combatividade. Ou seja, de onde surge essa participação, essa combatividade do movimento operário argentino se na realidade está sustentada por uma ideologia de conciliação de classes? Não se esqueça que o Estado 
argentino é um Estado, do ponto de vista do funcionamento democrático burguês, absolutamente débil e precário (...). De fato, nossa história está repleta de muitos golpes militares (E46).

A Argentina teve acesso, a partir da segunda metade da década de 40 com o peronismo, a políticas de pleno emprego. E isso fortaleceu o movimento sindical, que teve um importante grau de participação na direção do Estado (...). Esse primeiro governo peronista [referindo-se ao período de 1946 a 1955] marcou a consciência do trabalhador argentino e determinou o nível de confrontação que teve o movimento sindical argentino com todas as ditaduras de 1955 em diante (E33).

O MTA e a CTA correspondem às frações sindicais mais ligadas a um sindicalismo confrontacionista, sem referência a estratégias classistas, já que seu horizonte político não é a superação do capitalismo. Nesse sentido, pode-se dizer que a organização para a luta dos desempregados levada a cabo pela CTA foi a concretização de sua ideologia combativa, pautada na noção de que os trabalhadores devem se mobilizar para obter mais conquistas. Esse argumento não vale para o caso do MTA, o que poderia ser explicado pelo fato de que o modelo de relação com o Estado nessa corrente também se expresse na fórmula peronista de busca de aliança dos trabalhadores com o poder político e econômico. Entretanto, como esta também é uma característica presente na CTA, a questão não se esgora nesse elemento. $\mathrm{O}$ sindicalismo de negócios e empresário praticado pela CGT foi a consubstanciação de sua tendência concertacionista, sustentado pela busca de participação institucional no aparelho estatal e na aliança com o partido político no governo, o que é levado ao paroxismo quando o PJ está no poder e.

A análise da ideologia político-sindical das centrais conduz a discussão de dois problemas nos casos analisados. No Brasil, as correntes classistas e combativas da CUT também não levaram a cabo uma prática de organização dos desempregados para uma luta de um caráter massivo e nacional, ainda que se pautem, ideologicamente, em uma referência de mobilização do conjunto da classe trabalhadora. Na Argentina, o MTA, setor confrontacionista da CGT que conformou uma dissidência interna na central, embora tenham atuado conjuntamente com a CTA, também não organizou esse segmento para a luta.

(ii) No caso brasileiro, a CUT, a maior central do país, opôs-se ao neliberalismo. No caso argentino, a ala majoritária da CGT se constituiu como a principal base de apoio sindical do governo de Menem quando este aplicou a plataforma neoliberal. Logo no início do período analisado, surgiram setores sindicais opositores nos dois países. No Brasil, apareceu a FS para se contrapor à CUT e apoiar a política de Collor. Na Argentina, de dentro da CGT apareceram dissidências internas (CGT-Azopardo, MTA, CGT-Moyano) e uma fratura que levou à 
formação da CTA. Esses setores se caracterizaram pela oposição ao neoliberalismo e às políticas de Menem e de De la Rúa. Pode-se dizer que a aliança dos governos com setores expressivos do sindicalismo foi uma condição indispensável para a implantação das políticas neoliberais nesses países. Porém, o apoio da ala majoritária do sindicalismo na Argentina não significa que houve menos resistência ao neoliberalismo nesse país do que no Brasil. A FS e a CGT não defenderam as políticas neoliberais sem restrições. Nos dois casos, quando os interesses da base e da cúpula foram ameaçados, as entidades assumiram posturas mais combativas.

No caso do Brasil, a política da FS para os desempregados se inseriu na lógica do discurso neoliberal de "empregabilidade", o que se explica parcialmente por seu apoio ao neoliberalismo, ainda que essa defesa não tenha sido feita sem conflitos internos e momentos de descontinuidade. A CUT, embora no nível do discurso não tenha defendido abertamente a ideologia da "empregabilidade", na prática se fundamentou em seus argumentos para justificar a construção de políticas para os desempregados. A central apresentou bandeiras de combate ao desemprego alternativas às propostas pelas políticas neoliberais, denunciou os planos econômicos dos governos, mas não se propôs a organizar os trabalhadores sem emprego para a luta. Conservou, parcialmente, no nível do discurso, uma referência a um "horizonte" socialista, embora as práticas do sindicalismo "cidadão" tenham sido desenvolvidas mais como "terceira via" entre a social-democracia e o capitalismo neoliberal do que como superação deste último. Nesse sentido, as ações cutistas nesse campo atestaram o relativo abandono da bandeira socialista e o recuo da central diante da ofensiva do neoliberalismo, já que a entidade aceitou, em certa medida, o modelo de "assistência" aos desempregados propugnado pela plataforma neoliberal. As experiências de economia solidária expressaram essas transformações, ainda que estrategicamente tenham se justificado na central como forma de combinar as lutas históricas com as lutas imediatas da classe trabalhadora.

No caso argentino, o setor majoritário da CGT aderiu aos aspectos centrais do neoliberalismo, especialmente às privatizações e à bandeira da "revolução produtiva", que fundamentava a aplicação de políticas econômicas como a sobrevalorização cambial e a diminuição das alíquotas às importações. O MTA e a CTA fizeram oposição a essas medidas, combatendo a venda das estatais, as propostas de flexibilização, a abertura comercial e a "convertibilidade". Para se contrapor ao modelo, o MTA defendeu políticas de geração de 
emprego e políticas sociais como o seguro-desemprego, embora essas bandeiras também estivessem presentes na CGT, especialmente nos momentos em que a central rejeitou aspectos das reformas propostas por Menem e De la Rúa. A CTA apresentou, ademais, a reivindicação de uma "renda cidadã" universal. As diferentes correntes sindicais não se diferenciaram, porém, no objetivo de levar a cabo uma política nacionalista de desenvolvimento do capitalismo argentino. Pelo que foi exposto, é possível afirmar que assim como a ideologia político-sindical e sua matriz ideológica mais geral, a maior ou menor adesão ao neoliberalismo não explica totalmente a ausência ou presença de organização dos desempregados por parte das entidades analisadas.

(iii) No caso brasileiro, pode-se dizer que a política das centrais em relação aos desempregados possui uma correspondência direta com sua acomodação à estrutura sindical. A FS critica alguns de seus aspectos, mas defende abertamente o tripé do sindicalismo de Estado. A CUT faz o discurso sobre a necessidade de seu desmonte, mas prevalece nessa central a prática sindical dentro da estrutura. Esse aspecto contribui para compreender porque o conjunto do sindicalismo cutista, incluindo os setores minoritários, não levou a cabo uma política de organização dos desempregados, ainda que tenha feito discurso sobre sua importância. Ora, as chamadas correntes de esquerda também não estiveram imunes ao acomodamento à estrutura sindical, e por isso o corporativismo também se reproduz em seu interior como ideologia e prática hegemônica. Em minha dissertação de mestrado, verifiquei que uma importante entidade cutista vinculada predominantemente à ASS (o Sindicato dos Metalúrgicos de Campinas e Região, atualmente na Intersindical) não avançou no rompimento das amarras da estrutura sindical, entre elas, o modelo de representação corporativista (Souza, 2005b). Ao comparar a CTA com a CUT, um dirigente da central brasileira destacou que se trata de "organizações diferentes", de um "jeito diferente de se organizar”. Em seguida, concluiu: “(...) eu acho que aqui na CUT dificilmente nós teríamos (...) na nossa central sindical a possibilidade de abrir os estatutos (...) e aceitar a afiliação individualizada dos desempregados [como o faz a CTA]" (E4).

No caso argentino, a CGT e o MTA defendem o atual modelo de organização sindical por ramo de atividade baseado na afiliação de trabalhadores empregados formalmente, assim como o conjunto do aparelho jurídico do sindicato oficial corporativo. A CTA não se opõe à estrutura sindical em sua totalidade, mas reivindica seu reconhecimento como central sindical sob a bandeira do pluralismo no nível da cúpula e da organização de base. Também defende, 
na prática, a ruptura com o modelo de representação, na medida em que incorpora a prática de filiação direta e individual, que possibilita a associação de qualquer trabalhador, independentemente de seu vínculo de trabalho, e a incorporação de organizações populares em suas federações. Desse modo, ainda que a entidade não tenha buscado romper com o edifício corporativista estatal como um todo, sua concepção de sindicalização se constituiu, parcialmente, na superação da ideologia jurídica da forma legal do sindicato, um dos principais obstáculos para a construção da unidade entre o ativo e a reserva.

(iv) Qual a relação entre a política sindical para os desempregados e os interesses materiais imediatos de seus representados? Em última instância, os interesses da base são os do ativo, para o qual, em última instância, a luta sindical é um meio para a manutenção de seu emprego e a conquista de melhores salários e condições de trabalho. A realização desses objetivos não depende do incremento do número de trabalhadores ou da redução dos níveis de desemprego, que são reivindicações econômico-corporativas da reserva. É importante indagar, entretanto, se o perfil da base influencia a superação dessa fratura. No Brasil, a CUT representa trabalhadores dos diferentes setores (agrário, comércio e serviços, indústria, etc.) de pequeno, médio e grande capital privado e estatal. A FS atua predominantemente em sindicatos do setor privado, sendo inexpressivo em seu interior o sindicalismo do setor rural e do funcionalismo público. Na Argentina, a base social da CGT é diversa, mas essa central reune os sindicatos de trabalhadores em empresas de capital mais concentrado, especialmente do setor industrial. No período em que atuou como setor cegetista dissidente, o MTA possuía sindicatos vinculados a setores de empresas de médio capital, embora não tenha sido inexistente em seu interior entidades vinculadas ao grande capital. A CTA representa dois sindicatos importantes do funcionalismo público e tem uma pequena inserção no sindicalismo privado. Não realizei uma pesquisa entre os representados das centrais analisadas. No entanto, a partir do material investigado, não foi possível estabelecer um vínculo direto e mecânico entre o perfil dos representados e a política sindical para os desempregados. A pequena representatividade e a predominância de sindicatos do funcionalismo público no interior da CTA foram apontados por alguns entrevistados da CGT como elementos que facilitaram sua política de mobilização dos desempregados. Porém, no caso cutista, apesar de que o sindicalismo do setor público tenha sido identificado como um dos que teve maior resistência ao neoliberalismo, suas entidades não propuseram uma alternativa de política sindical para 
esse segmento. Valeria investigar mais detidamente, em futuras pesquisas, as implicações da relação entre o perfil das centrais e suas práticas em relação à questão estudada.

(v) Se as ações e representações para os desempregados não está diretamente relacionada aos interesses específicos do grupo sócio-profissional, ou seja, da base sindical de representados, qual a relação entre as medidas levadas a cabo pelas centrais e os interesses organizacionais da cúpula? Essa política corresponde a suas estratégias de expansão e manutenção do poder no sindicalismo de Estado e, mais amplamente, no próprio aparelho estatal? Por que a direção de algumas entidades decidem organizar os desempregados para a luta e outras, não?

Não busco fazer uma leitura "voluntarista" das práticas da direção sindical, como se esta fosse formada por um conjunto de atores que expressam vontades individuais, embora no plano microssocial, esse fator esteja presente. Pode-se entender os dirigentes como burocratas, na medida em que atuam como funcionários de um órgão da administração do Estado que exerce um tipo de dominação legal (H. Martins, 1978), no sentido empregado pela análise clássica de Weber (1991) como ação racional com relação a fins. Ademais, as cúpulas, ou quadros de dirigentes, são portadores de relações sociais de classe. Como a inserção política desses sujeitos se dá no nível do Aparelho Ideológico de Estado, em última instância estes são agentes da reprodução da ideologia do Estado burguês (Saes, 1998). Esta ideologia se pauta essencialmente no fetiche do Estado-protetor, visto como representante de todas as classes sociais. Este fetiche, por sua vez, evidencia-se, em relação ao objeto estudado, na leitura das causas e na apresentação de propostas de solução para o desemprego, que em todas as centrais analisadas são canalizadas para políticas de Estado ativas (geração de empregos) e passivas (assistência aos desempregados).

No Brasil, a política para os desempregados se deu por meio do interesse dos dirigentes pela gestão de verbas públicas com base na lógica do oferecimento de serviços. Essa prática esteve subordinada ao interesse político-partidário dos quadros pela conquista de espaços institucionais. Para F. Oliveira (2003), a partir dos anos 90 os sindicalistas teriam se convertido em operadores de fundos públicos, ao manipular verbas de previdência complementar, ativos das estatais privatizadas e recursos do FAT. ${ }^{803}$ Para Boito Jr. (2002a), esse processo seria uma das evidências da ascensão de um neocorporativismo societal no

${ }^{803}$ Sobre o tema ver também A. M. Cardoso (2003). 
sindicalismo brasileiro. ${ }^{804}$ Ademais, ainda em relação a este tema, há uma questão relacionada ao acomodamento dos dirigentes à estrutura sindical, pois o sindicalismo de Estado, ao garantir o monopólio de representação e da arrecadação financeira, não necessita dos desempregados para se manter, pois estes não contribuem nem votam nas eleições sindicais.

Essa última observação vale também para o sindicalismo argentino e para toda forma legal do sindicato, ou seja, a sua expressão histórica como Aparelho Ideológico de Estado. Tanto a CGT como o MTA não se interessaram pela representação direta dos desempregados, o que foi justificado por essas entidades com o argumento da prioridade da defesa de políticas de emprego, idéia que também aparece nas centrais brasileiras. Por isso, as diferenças político-ideológicas entre os dois setores não se estenderam à postura diante da estrutura sindical. O objetivo maior da cúpula cegetista no período estudado foi a manutenção de seu poder institucional nas negociações coletivas e na administração do sistema de saúde sindical através das obras sociales, meios principais para a reprodução de seus interesses como organização. O MTA teve como estratégia principal assumir a direção da entidade (o que, de fato, ocorreu durante o Governo de Néstor Kirchner) para retomar o que, em sua avaliação, eram os autênticos ideais peronistas. Como explicitou um entrevistado da atual Direção Nacional da CGT, pertencente a essa corrente nos anos 90:

Nós defendemos o modelo sindical argentino. Nós sempre dizemos que os melhores momentos dos trabalhadores foram quando o sindicalismo estava unido. Mas o objetivo [do MTA] nesse momento era se opor ao modelo econômico e recuperar a condução da Confederação [a CGT] para colocá-la a serviço de todos os trabalhadores. [Ademais,] jamais quisemos formar uma central. O objetivo era, Moyano sempre dizia: "primeiro, recuperamos o movimento sindical, depois recuperamos a CGT, depois recuperamos o peronismo" (E41)

Diante dos interesses organizacionais mais imediatos dessas entidades, os desempregados possuíam um papel secundário. No entanto, apesar da relação de fratura entre os desempregados e a CGT e o MTA, a construção de uma unidade com esse segmento foi parte da estratégia de representação de base levada a cabo pela CTA, embora nem todas as organizações de desempregados tenham sido mobilizadas por esta central. É importante destacar, ademais, que o vínculo partidário ou sindical esteve presente na constituição e expansão da maioria das organizações. Aqui torna-se relevante fazer duas observações. Primeiro, que isso explica porque é mais adequado chamar os agrupamentos de organizações

\footnotetext{
${ }^{804}$ Com o acesso a volumosos recursos não tardaram a aparecer denúncias de desvio das verbas, o que levou o governo de Lula a promover um corte significativo em sua concessão.
} 
político-sindicais de desempregados, e não de "movimentos piqueteiros", já que este conceito remete ao instrumento de luta empregado em detrimento da base social. Segundo, que o objetivo imediato da CTA também se aplica aos partidos de esquerda que organizaram esse segmento, pautado especialmente pela estratégia de expansão de suas entidades.

A CTA buscou representar os desempregados, aglutinando parte das organizações e contribuindo para dar impulso e atuação em nível nacional, especialmente à FTV, embora já existisse uma mobilização prévia desse agrupamento anterior à proposta pela central. Como entidade que representa setores minoritários do sindicalismo argentino, essa foi a estratégia da CTA para se consolidar como organização com poder de convocação e mobilização massiva, condição necessária para pressionar o Estado pelo seu reconhecimento legal como central sindical. Essa mesma tendência se verifica atualmente em setores minoritários do movimento sindical brasileiro dissidentes da CUT, como a Conlutas e a Intersindical, que a partir da proposta de criarem uma nova entidade, começaram a debater, a partir de 2007, se seu caráter seria de central "do mundo do trabalho", "sindical e popular" ou "de trabalhadores". No caso da CUT e da FS, a mobilização dos desempregados não se constituiu como estratégia de seu aumento de poder sindical, já que este estava relativamente garantido pela estrutura oficial. Por isso, a disputa entre ambas, durante os anos 90, restringiu-se ao âmbito sindical. No caso da CTA, teve um papel crucial sua estratégia para enfrentar o poder da CGT, garantida pela representatividade nacional de suas entidades.

\subsection{A mobilização dos desempregados}

Ao longo do trabalho, evitei sugerir que "os desempregados" no Brasil e na Argentina estiveram reunidos em algum lugar esperando serem mobilizados pelas entidades sindicais. É necessário, pois, avaliar alguns elementos próprios desse segmento que incidem sobre seu potencial organizativo nas duas formações para compreender porque no caso argentino surgiu um movimento de desempregados e o mesmo não se concretizou no caso brasileiro. Assim como no item anterior, para refletir sobre essa questão desenvolverei os argumentos em tópicos. Os fatores escolhidos foram os seguintes: (i) o processo de construção da cidadania, e mais especificamente, a categorização social do emprego; (ii) as transformações na estrutura social e sua repercussão sobre as formas de manifestação da superpopulação relativa; (iii) e as experiências e tradições de luta do movimento operário e sindical. 
(i) Um primeiro aspecto a ser notado para refletir sobre a relação entre a eclosão dos protestos sociais protagonizados por desempregados e as diferentes formas de manifestação do desemprego é considerar seus fatores "normativo-institucionais" e "biográfico-subjetivos" (Demazière, 2006c; Guimarães, 2002). Esse elemento é relevante para refletir sobre as possibilidades de construção da identidade política dos trabalhadores sem emprego.

No período estudado, os desempregados brasileiros não se organizaram massivamente como desempregados. Parte se mobilizou como sem-terra ou sem-teto. Outros se organizaram para a atividade econômica ou usufruíram dos serviços oferecidos pelos sindicatos. Sem organização de luta prévia no local de trabalho ou no bairro, e em uma situação de "frustação relativa" (Gurr, 1970) menor do que no caso argentino, aqueles que puderam, tiveram acesso a um seguro-desemprego. Os que não o tiveram, buscaram estratégias individuais para sua sobrevivência. As entidades sindicais brasileiras não organizaram os desempregados para a luta. Mas, como concretizar a organização desse segmento se a vivência cotidiana do desemprego no Brasil, especialmente entre os estratos mais pauperizados, está atravessada pela necessidade de buscar alternativas para a subsistência? Vale indagar também: a formação política e a organização (em uma palavra, o trabalho de militância) poderia ter sido o ponto de partida para superar a fratura entre o movimento sindical e os desempregados? Como é possível organizar um segmento cujo maior objetivo é o seu próprio desaparecimento?

O estatuto do emprego formal é relativamente débil no Brasil. As taxas de desemprego e subemprego, historicamente altas, a ausência de políticas de Estado para esses segmentos e as formas de sobrevivência baseadas no assalariamento encoberto formaram, culturalmente, um modo muito particular de vivência cotidiana do problema: fazer bicos ou ir para a rua trabalhar como ambulante. Por isso, o significativo sedimento condenado ao pauperismo e o baixo processo de constituição da cidadania ${ }^{805}$ no país resultaram na formação de uma tradição de organização popular de "movimento de pobres" (Fox Piven, Cloward, 1979). Isso se deve ao fato de que a expansão capitalista no país não foi acompanhada pela extensão de direitos sociais ao conjunto da população, tal como se deu na Argentina. Ao contrário, este processo acentuou a concentração do contingente de pobres nas periferias das grandes cidades. Esses elementos explicam, parcialmente, porque no período estudado a

\footnotetext{
${ }^{805}$ Emprego o conceito de cidadania aqui para designar o conjunto de direitos civis, sociais e políticos garantidos pelo Estado burguês. Não busco, com sua aplicação, dar conta da polissemia que envolve sua categorização, já que não se trata de uma noção universal, mas construído historicamente e passível de particularidades segundo o nível de desenvolvimento do capitalismo e a posição nas relações de forças internacionais de uma dada formação social.
} 
superpopulação relativa do país se mobilizou através de organizações sociais de sem-teto e, principalmente, de sem-terra, o que afirma sua tradição de luta no campo, mas também do movimento operário e popular organizado por melhores condições de vida nos bairros. $\mathrm{Na}$ Argentina, foi mais forte o processo de categorização social do emprego formal, o que contribuiu para a constituição de uma identidade política de desempregados. Também cumpriram um papel importante para a a construção social do estatuto de desempregado no país, no período estudado específico, as políticas assistencialistas dos governos para esse segmento, que funcionaram como um dos principais motores da mobilização, especialmente após a criação de mecanismos que permitiram a administração dos planos sociais por parte das organizações.

(ii) No Brasil, o crescimento do desemprego se deu a partir de uma situação prévia de alto índice de subemprego e informalidade. O surgimento e expansão de organizações de semterra e sem-teto estão relacionados ao crescimento da superpopulação relativa consolidada no país e encontra seu lastro na pobreza crônica e no desemprego endêmico historicamente constitutivo da estrutura social brasileira. No caso argentino, o desemprego massivo e o subemprego tiveram um crescimento explosivo em curto prazo. Nesse sentido, pode-se afirmar que o movimento de desempregados foi fruto do "choque" da expansão da superpopulação relativa do país. Ademais, as experiências prévias de luta sindical no núcleo originário e a política de auxílio do Estado criaram um contexto favorável para a mobilização desse segmento.

Para compreender as mudanças na composição da classe trabalhadora das duas formações sociais, é necessário levar em conta o contexto específico em que se constituiu, em cada uma, a hegemonia do capital financeiro. No período estudado, as políticas neoliberais dos governos de Fernando Collor de Melo (1990-1992), Itamar Franco (1992-1994) e Fernando Henrique Cardoso (1995-1998; 1999-2002), no caso brasileiro, e de Carlos Menem (1989-1999) e Fernando De la Rúa (1999-2001), no caso argentino, tiveram algumas tendências comuns: regulamentação mais flexível das leis trabalhistas, redução dos gastos sociais, privatizações, sobrevalorização cambial, altas taxas de juros e abertura comercial e financeira. Essas políticas estiveram sustentadas, materialmente, pela mundialização do capital em larga escala e pelo processo de introdução de novas tecnologias no processo produtivo e renovação dos métodos de gestão, especialmente nas grandes empresas de capital concentrado instaladas nos dois países. Essas medidas tiveram o desemprego como um de 
seus pilares de sustentação (Duménil e Lévy, 2003). Em decorrência dessas transformações, os dois países passaram nas últimas décadas por um crescente processo de proletarização, pauperização e aumento do peso relativo da população sobrante para as necessidades imediatas do capital.

É necessário levar em conta que o neoliberalismo brasileiro foi menos radical que o argentino em vários aspectos. O maior exemplo desse elemento esteve na política de sobrevalorização cambial, mais "flexível” no Brasil após a crise de 1998 se comparada à "rigidez" da "convertibilidade" na Argentina e sua insistência em manter a paridade do peso com o dólar até o colapso de 2001. Ademais, o processo de privatizações nesse país foi muito mais intenso, tendo atingido alguns setores estratégicos que não chegaram a ser vendidos no Brasil, como a exploração petrolífera. A YPF, principal empresa estatal do país, foi privatizada. A Petrobrás passou a ser uma corporação mista após a quebra do monopólio estatal, mas seguiu sendo majoritariamente estatal. No caso brasileiro, ademais, a implantação do câmbio flutuante a partir de 1999 permitiu uma maior sobrevida à indústria nacional, menos suscetível ao crescimento das importações. ${ }^{806}$

Cumpre um papel significativo na análise mencionar a relação entre as frações de classe hegemônicas da burguesia presente nos dois países nas últimas décadas. Na Argentina, o capital financeiro internacional passou a ter um papel importante pelo menos desde a ditadura militar iniciada em 1976, quando a produção industrial já se encontrava relativamente estancada. No Brasil, seguiu sendo importante a presença das oligarquias regionais ligadas à atividade agrícola, mas o peso do setor industrial paulista era hegemônico pelo menos desde a década de 1950. Fazendo um exercício de análise a longo prazo, pode-se dizer que na Argentina se formou uma burguesia associada com baixa capacidade de expansão em larga escala (especialmente para além de sua fronteira, dado que seus limites internos se encontram relativamente esgotados). No Brasil, a grande burguesia logrou manter o domínio de algumas atividades econômicas de capital concentrado, o que lhe vem dando maiores condições para a expansão extensiva e intensiva no cone-sul americano.

As características da economia capitalista nos dois países têm uma íntima relação com a política levada a cabo por suas respectivas ditaduras militares. A repressão ao movimento operário e sindical iniciada em 1964 cumpriu o objetivo de amortecer os constrangimentos ao desenvolvimento do capitalismo no país; na Argentina, a política de Estado de genocídio de

\footnotetext{
${ }^{806}$ Alguns aspectos dessa comparação estão fundamentados por Devoto e Fausto (2004).
} 
militantes políticos e sindicais a partir de 1976 teve a finalidade de dificultar a resistência à implantação da plataforma neoliberal que começava a ser ditada pelo imperialismo estadunidense.

Os dados apresentados por Tarditi (2000, p. 49) sobre a produção automobilística nos dois países mostram que a partir de 1964 o Brasil conheceu um grande crescimento no setor. Observa-se também que a curva ascendente se estendeu até 1980, entre os chamados "anos de chumbo" e o "milagre" brasileiro. A partir dos anos 1980, a produção de automóveis teve um período de estagnação, com pequenos intervalos em que oscilou, voltando a se recuperar em 1992, a partir da implantação das Câmaras Setoriais Automotivas. Na Argentina, a indústria automobilística praticamente se estancou de 1973 a 1992. Na década de 1990, a fabricação de carros voltou a crescer, quando o país ganhou o mercado de outros países sul-americanos, como a Colômbia e a Venezuela. Cumpriram papel importante também nesse período os acordos que o país firmou a partir da fundação do Mercosul, em 1995. O caráter subimperialista do capitalismo brasileiro tem se tornado cada vez mais evidente a partir do governo de Lula. A liderança regional do país e a ação de seus empresários em solo argentino, tanto em relação à balança comercial como na aquisição de empresas deste país, comprovam esta tendência. ${ }^{807}$

É importante destacar ainda que, no período estudado, durante a implantação do projeto neoliberal na Argentina, houve pelo menos três momentos de "crise econômica": 1989-1990; 1995-1995; 1998-2003, sendo que foi ao longo desta última, mais duradoura e com efeitos mais profundos sobre a classe trabalhadora, que se verificou a constituição de um movimento de desempregados massivo e nacional. No caso brasileiro não se viveu uma crise tão prolongada e intensa. Ademais, ao analisar a estrutura social dos dois países, é notável uma diferença fundamental em relação à taxa de superpopulação relativa, consolidada

\footnotetext{
${ }^{807}$ A partir de Gramsci, em Americanismo e Fordismo (Gramsci, 1976), parece plausível considerar que a posição subimperialista brasileira se deve às condições de aprofundamento do processo de americanização presentes no país, com maiores possibilidades de desenvolvimento interno e externo. Com a diferença, em relação aos EUA, de que o fator decisivo para o desenvolvimento em larga escala do capitalismo brasileiro não foi a estrutura demográfica "racionalizada", mas um estoque de força de trabalho disponível quase-inesgotável que barateia o valor pago pelo emprego da força de trabalho. A burguesia brasileira se associou ao capital imperialista estadunidense desde a Segunda Grande Guerra, processo que se efetivou durante o Governo de JK (Ianni, 1994). Na Argentina, além de uma superpopulação relativa consolidada historicamente menor, há uma referência histórica mais marcante de uma política nacionalista, fruto do processo de constituição da cidadania no país, cujo ápice se encontra no peronismo, além de uma forte tradição de luta sindical e negociação coletiva, fatores que pressionam a classe capitalista e constrangem a expansão do capital no país. A maior fragilidade desses elementos no Brasil possibilita melhores condições para a superexploração do trabalho e a apropriação de maiores taxas de extração de mais-valia por parte da classe capitalista.
} 
historicamente de forma crônica no Brasil e expressa de forma epidêmica na Argentina no início do período estudado. Essas características podem ser sintetizadas a partir dos seguintes elementos: (i) maior peso da população rural pobre sem emprego registrado e com ocupações irregulares (superpopulação relativa latente), no caso brasileiro; (ii) maiores taxas de rotatividade, desemprego oculto pelo trabalho "precário" e "informal" (superpopulação relativa flutuante e estagnada), no Brasil; (iii) maior nível de assalariamento formal do proletariado urbano (ativo empregado formalmente), com alto nível de cobertura de direitos e benefícios, no caso argentino; (iv) maior incidência histórica da pobreza crônica (camada pauperizada), no caso brasileiro. Ademais, enquanto a Argentina passou por um amplo processo de construção da cidadania, especialmente a partir do governo de Perón, o Brasil se caracterizou por uma "cidadania regulada" (Santos, 1979), dual e restrita. A situação mais desfavorável no Brasil se acentua pelas desigualdades internas no país, que fazem com que a força de trabalho das regiões menos industrializadas sirva constantemente como população sobrante para as necessidades de expansão do capital dos grandes centros urbanos com maior nível de desenvolvimento capitalista, especialmente no eixo Rio-São Paulo.

(iii) Sobre a inexistência de um movimento de desempregados tal como na Argentina, um sindicalista cutista explicitou que se trata de uma "questão histórica" de "diferença de construção e de organização", apesar de ressaltar que a política da CTA e da CUT é "muito similar". Esse entrevistado também se referiu à "forma como os trabalhadores brasileiros e os trabalhadores argentinos fizeram o enfrentamento da ditadura" e as "políticas sociais que cada país teve ao longo destes últimos 30 anos" (E6), reportando-se aos programas assistenciais para os desempregados na Argentina. Ao comparar as experiências de luta brasileiras com as argentinas, um entrevistado da direção da central ressaltou a importância do apoio da Igreja na constituição da mobilização no Brasil e destacou o papel do movimento popular para a organização dos desempregados, ainda que o tenha feito sob outras bandeiras:

(...) a Argentina não tem uma Igreja [Católica] atuante, como é aqui no Brasil, que estimula, organiza a resistência dos desempregados, as Pastorais Sociais da Igreja, o MST também que organiza uma parcela dos desempregados (...). São formas de organização diferentes e de representação diferentes que canalizam a luta dos desempregados. Por isso que aqui no Brasil os movimentos sociais são muito mais fortes do que os movimentos sociais da Argentina. Lá, como os movimentos sociais são extremamente frágeis e a Igreja Católica argentina nunca foi uma Igreja progressista como a brasileira, eu acredito que uma parcela significativa desses desempregados, etc., foram canalizados para se organizarem dentro de 
uma central sindical. No caso do Brasil, não. No Brasil, há uma militância muito grande dos desempregados, autônomos, etc., [mas estes] foram canalizados para outros movimentos sociais (...) (E4). Em seguida, este dirigente justificou a política cutista de priorizar a articulação com as organizações populares:

(...) o que nós temos que fazer, e é isso que a CUT faz, é estimular (...) que o sindicato tenha comitês de desempregados, que nós façamos articulações políticas com os movimentos sociais, e isso nós fazemos. A CUT é a principal organizadora do Fórum Social Mundial, que organiza (...) um conjunto de movimentos sociais, e muitos desses movimentos sociais tem militância muito forte (...) [com os] desempregados, seja através das Pastorais Sociais da Igreja, seja através de outros movimentos sociais (...) (E4).

Nos anos 90, no Brasil, parte dos trabalhadores repelidos da indústria, ou em busca do primeiro emprego, realizou cursos de requalificação profissional oferecidos pelos sindicatos. Essa estratégia assistencialista foi prioritária em relação à falta de uma política de mobilização desse segmento. Porém, é interessante notar também que a economia solidária, como organização dos trabalhadores para a produção e o consumo através do assalariamento encoberto, ressignificou a tradição da superpopulação relativa brasileira de se organizar individualmente para a atividade econômica, imprimindo-lhe um caráter coletivo por meio do cooperativismo. Esses elementos estiveram ausentes no caso argentino, onde a construção social do emprego formal, pelos baixos índices históricos de desemprego e subemprego, era muito mais sólida.

É importante analisar também as relações de classe nos dois países, considerando a correlação de forças que possibilitou aos trabalhadores desempregados argentinos a construção de organizações com tamanho peso político no conjunto dos protestos sociais. Nesse sentido, tal como foi explicitado no quarto capítulo, as tradições e experiências prévias de luta do movimento operário e sindical foram os elementos fundamentais.

Quando iniciei esta pesquisa, esperava encontrar muito mais semelhanças entre o sindicalismo brasileiro e argentino. No entanto, no decorrer da investigação, observei que apesar da presença comum dos aspectos centrais da estrutura sindical corporativa oficial nos dois países (investidura, unicidade e imposto sindical) e alguns de seus efeitos mais recorrentes (burocratização, cupulismo, assistencialismo, entre outros), há também diferenças institucionais, legislativas e organizativas marcantes. Esses elementos explicam, parcialmente, as diferentes experiências de luta que se conformaram nas duas formações sociais, construídas em torno de distintos modelos de relação das entidades sindicais com os 
trabalhadores, com os empresários e com o Estado, que forjaram tradições de luta muito particulares.

Ao formular esses argumentos, não busquei explicar a inexistência de um movimento de desempregados no Brasil pela falta de "elementos argentinos" em sua história. Tal procedimento analítico seria um erro teórico e metodológico. Ora, se a comparação fosse feita com outro país, provavelmente as ausências seriam outras. Os fatores desencadeantes da eclosão de um movimento e os elementos explicativos de sua inexistência no Brasil provavelmente são mais amplos que os explicitados neste trabalho. É menos complexo explicar a presença do que a ausência, pois esta última é mais suscetível a especulações. Por isso, o exercício que farei a seguir se restringe aos parâmetros comparativos decorrentes da análise de caso da Argentina, mas não se trata de invalidar os argumentos construídos ao longo desta tese.

É possível afirmar que a tradição de luta e organização do movimento operário argentino desenvolveu, como principal ideologia inerente (Rudé, 1982), um "sentimento" (Willians, 1997) reivindicativo, cuja maior manifestação está em sua "tradição de mobilização de rua", que se reproduz historicamente no país por meio de suas "experiências" (Thompson, 1997), da "tradição oral" e da "memória folclórica" da classe trabalhadora. A expressão sindical desse elemento é a recorrência de greves gerais como ferramenta de protesto utilizada há mais de um século, mas se concretiza também em outras formas e instrumentos de luta adotados desde o começo do século XX. O sindicalismo argentino desempenha um papel fundamental na reprodução desses fatores. Destaco dois deles. Primeiramente, a doutrina justicialista, que constitui a ideologia derivada hegemônica no terreno sindical no país. Muitos estudos apontam o sindicalismo como elemento constitutivo das "origens do peronismo", assim como o "vínculo perdurável" da relação entre ambos (Doyon, 2006; Murmis e Portantiero, 2004, Del Campo, 2005). Este é um aspecto explicativo crucial, pois a reprodução dessa ideologia funciona como um dos principais impulsionadores da organização e mobilização sindical do país. Em segundo lugar, cumpre um papel fundamental o modelo sindical argentino, que se mantém praticamente intacto em seus elementos essenciais desde o surgimento da CGT, em 1930. Vale ressaltar duas de suas particularidades, que se evidenciam ainda mais na comparação com o Brasil. O sindicalismo argentino possui mecanismos de representação no local de trabalho, por meio de comissões internas e corpo de delegados com estabilidade de seus membros garantida por lei. Ademais, está presente no país a garantia de 
existência de sindicatos e centrais nacionais com poder de negociação coletiva centralizada, e capacidade de mobilização e convocação de greves gerais com alta adesão e repercussão política, o que contribui para o surgimento de experiências de luta mais unificadas no país. A conexão entre esses fatores tradicionais e os eventos presentes é uma questão históricosociológica complexa e, tal como argumenta Hobsbawn (2000), afeta mais o estilo de um movimento do que sua natureza, devendo ficar restrita, em última instância, ao terreno da especulação. No caso argentino, foi justamente isso que ficou demonstrado, pois os fatores mais destacados foram os instrumentos de luta e o método de organização dos desempregados, que possuem uma forte conexão histórica com as experiências de luta do movimento operário e sindical do país.

Ao contrário, as experiências e tradições de luta do sindicalismo brasileiro não constituíram no interior dos setores urbanos de seu exército de reserva a acumulação prévia necessária para uma mobilização nacional e massiva que tivesse como eixo a construção identitária em torno da condição de trabalhador desempregado. No caso do Brasil, foi outra parcela da população sobrante que se organizou politicamente, construindo um peso político central no conjunto das lutas sociais do país: os camponeses sem-terra representados principalmente pelo MST.

$$
* * *
$$

No Brasil, a vivência dos desempregados se aproximou mais, no caso brasileiro, da lógica de ir para a rua fazer um "bico" ${ }^{808}$; na Argentina, sustentou-se mais pela noção de "protesto de rua". Embora em ambos estivessem presentes o assistencialismo, a caridade e outras formas de auxílio que, no Brasil este tem sido papel da Igreja, de ONGs e, de certa forma, a partir da década de 90, dos sindicatos, no caso argentino foi, ademais, papel do Partido Justicialista.

Com base nos fatores apresentados, foi possível formular uma explicação para a mobilização dos desempregados na Argentina e sua inexistência no Brasil. As tradições e as experiências de luta do movimento operário e sindical, a organização popular dos pobres, a participação da superpopulação relativa na estrutura social, a categorização social do

\footnotetext{
${ }^{808}$ Em Americanismo e Fordismo, Gramsci (1976) destaca alguns elementos tradicionais, presentes no sul da Itália, muito semelhantes a estes aspectos brasileiros aos quais chamo a atenção. $\mathrm{O}$ autor cita o caso de Nápoles, onde existia uma "vadiagem orgânica", dada a maneira como a cidade organiza sua "vida prática", com "suas indústrias artesanais, seu comércio ambulante, e com a incrível pulverização da venda de mercadorias e serviços entre os desempregados que circulam pelas ruas". Em outra passagem, o autor faz referência à composição da população italiana, e destaca a existência de uma "desocupação endêmica" em algumas regiões agrícolas do país.
} 
emprego, o grau de constituição da cidadania e a ideologia inerente no processo de formação do protesto popular foram os elementos centrais destacados pela análise realizada neste capítulo.

No caso argentino, o exército de operários ativo possui a experiência e a tradição sindical de mais de um século de organização e militância no local de trabalho, além de mecanismos de representação, poder de negociação e mobilização no nível nacional, que se expressam por meio dos sindicatos nacionais e da existência estável de uma central sindical única. Vale destacar, a respeito dessa questão, o papel das convenções coletivas centralizadas e da greve geral como instrumento de luta recorrente ao longo da história do país. No período estudado, foram convocados nove eventos desse tipo durante a presidência de Menem, dez durante a gestão de De la Rúa e quatro no primeiro ano de Duhalde, algumas com alto grau de adesão e formação de unidade no conjunto do movimento sindical. A reserva na Argentina era relativamente pequena, mas cresceu expressivamente ao longo do período estudado. A combinação desses elementos (forte tradição de lutas sindicais, amplo processo de construção da cidadania e "frustração relativa" diante situação anterior de baixo índice de superpopulação relativa) foi o ponto de partida para a organização de sua reserva como desempregados.

No Brasil, a situação foi diferente. $\mathrm{O}$ ativo possui, historicamente, menor tradição de organização sindical, a qual foi marcada pelo desenvolvimento "tardio" do capitalismo no país, pela descontinuidade de sua ascensão como fenômeno de massa, pela repressão de governos autoritários, pela tutela estatal e pela dificuldade de organização nacional. Ademais, a representação no local de trabalho é uma prática pouco difundida no país, em parte por conta da arbitrariedade patronal e da inexistência de estabilidade garantida por lei, mas também pela acomodação das entidades à estrutura sindical. No início do período estudado, as centrais sindicais estavam se consolidando novamente como sujeito dos protestos sociais após vinte anos de ditadura militar, mas jamais havia tido uma presença institucional estável. Porém, passados quase trinta anos do processo de formação da CUT, os sindicatos seguem pulverizados e as negociações e mobilizações, relativamente fragmentadas. $\mathrm{O}$ instrumento de luta da greve geral, menos freqüente no país, ganhou expressão nacional em poucos momentos. Foram convocadas apenas três paralisações nacionais no período estudado, sendo que apenas uma foi realizada pelo conjunto das centrais. A reserva, que já era expressiva no país no início dos anos 90, cresceu substancialmente em sua parcela estagnada e em sua camada pauperizada. A combinação desses elementos (frágil tradição de organização e luta 
sindical, processo de construção de uma cidadania dual e restrita, superpopulação relativa consolidada em sua forma crônica) explica parcialmente a ausência de organização da reserva como desempregados e a eclosão de organizações populares como os sem-terra e os sem-teto. Essa forma de luta pode ser explicada pela tradição de séculos do movimento camponês e de pobres no país, que se remete, por sua vez, à estrutura social e às experiências históricas de mobilização desses setores.

A "tradição de manifestação de rua" na Argentina, como principal ideologia inerente do processo de formação do protesto popular explica parcialmente a eclosão do movimento de desempregados no país. No Brasil, esse papel foi cumprido por sua "tradição de luta pela terra", que também funcionando como ideologia inerente, explica porque o MST foi o maior aglutinador da reserva urbana e rural do país. Na correlação de forças estudada, as respostas sindicais para os desempregados nas duas formações ressignificaram esses elementos tradicionais.

\subsection{Formas de organização da reserva e relação de unidade e fratura com o ativo}

O quadro explicativo destacado nos itens anteriores ajuda a compreender não só a relação entre o movimento sindical e os desempregados, mas a relação de unidade e fratura entre o ativo e a reserva no Brasil e na Argentina. Para concluir este trabalho, farei uma breve apresentação da composição da superpopulação relativa e das formas de representação e organização de suas diferentes parcelas e camadas nas duas formações.

\section{A parcela latente}

Como já ressaltei, no caso brasileiro a parcela latente da superpopulação relativa é historicamente mais representativa, até mesmo por conta de sua estrutura social, que possui uma população camponesa mais significativa. A partir dos anos 80, o processo de expansão capitalista no campo através da mecanização (expresso, atualmente, pelo crescimento do chamado "agronegócio") fez com que um contingente significativo de trabalhadores repelidos da produção agrícola migrasse para a cidade ou se pauperizasse no campo. Essa parcela é composta ainda por expropriados pelo processo de concentração fundiária (como as vítimas de grileiros), pela população indígena pauperizada, por pequenos proprietários de produção familiar proletarizados, por camponeses parcialmente empregados (peões e bóias-frias) e por trabalhadores em regime de escravidão. Uma parte desses trabalhadores se organiza no 
sindicalismo rural, no movimento de resistência indígena, nas comunidades quilombolas, ribeirinhas e em organizações de camponeses, cuja maior expressão é o MST. Ao longo da década de 90, a CUT teve uma política constante de aliança com este último, apresentando a bandeira da reforma agrária como uma de suas principais propostas de combate ao desemprego. Por sua vez, como parte de sua política desde os anos 90, o MST organizou trabalhadores urbanos desempregados para voltar ao campo e, fruto dessa mobilização, surgiram os assentamentos "rururbanos" do Movimento dos Trabalhadores Desempregados (MTD). Este último foi fundado em 2000 e a partir de 2003, passou a compor, juntamente com a CUT e o MST, a Coordenação de Movimentos Sociais (CMS). Além disso, parte dos trabalhadores do campo é representada pela Contag, que congrega os sindicatos rurais de todo o país. Esta Confederação esteve filiada à CUT de 1991 a 2009, quando se desligou da central. Na Argentina, a parcela latente da superpopulação relativa é historicamente menos expressiva. Os setores mais significativos da população do campo estão organizados em sindicatos rurais. Ainda assim, nos anos 90, surgiu o Movimento Campesino de Santiago del Estero (Mocase), que representa pequenos proprietários em processo de proletarização em uma das províncias mais pobres do país.

\section{A parcela estagnada}

A superpopulação relativa estagnada é a que mais cresceu ao longo do período estudado, tanto no Brasil como na Argentina, com a diferença de que se trata de uma parcela historicamente maior no caso brasileiro, que representa a maior parte da reserva urbana no país. Está composta, em ambos, por trabalhadores parcialmente empregados, com ocupações "irregulares" e temporárias, pequenos proprietários urbanos, ambulantes e trabalhadores sem registro. No caso brasileiro, também é mais expressiva a "classe dos serviçais” (Marx, 1982, p. 512), estudada por Pochmann (2003) a partir da categoria de "agregados sociais". Dessa parcela, surgiram no Brasil sindicatos de ambulantes (ou da economia informal) e um expressivo movimento pela moradia (sem-teto). Atualmente, o Movimento dos Trabalhadores Sem-Teto (MTST) faz parte da estrutura organizativa da Conlutas e o Movimento Terra, Trabalho e Liberdade (MTL) está filiado à Intersindical. Durante o período estudado e especialmente nos anos 2000, cresceu o cooperativismo no país. A CUT organizou parte desse movimento por meio da economia solidária. Na Argentina, a parcela estagnada foi uma das principais bases para a expansão das organizações de desempregados no país. Parte desses 
agrupamentos vinha de uma experiência de organização de bairro que desde a década de 80 lutava por melhores condições de vida em um contexto marcado pelo crescimento da pobreza nas periferias. No caso brasileiro, o núcleo originário do movimento popular que tem essa parcela como base social esteve composto significativamente por militantes católicos progressistas inspirados pela Teologia da Libertação (Löwy, 2007). No caso argentino, a Igreja Católica esteve presente, mas com menor peso. O fator fundamental para compreender a formação do movimento de desempregados nesse país foi a tradição de organização e luta de seu movimento operário, além dos demais destacados no item anterior.

\section{A parcela flutuante}

A superpopulação relativa flutuante cresceu nas duas formações sociais, por conta das políticas neoliberais e do processo de reestruturação produtiva. Sua maior evidência foi a eliminação de postos de trabalho e o crescimento do desemprego aberto. Essa parcela protagonizou processos de resistência às demissões por intermédio das organizações sindicais. No entanto, com a permanência na situação de desemprego, um segmento expressivo migrou para o "assalariamento encoberto", como ambulante, pequeno comerciante ou "agregado social". Sua trajetória de trabalho foi marcada, a partir de então, pela alternância entre o emprego temporário, a ocupação irregular e o desemprego, processo verificado tanto no Brasil (Guimarães, 2004) quanto na Argentina (Castillo et alli, 2006). A situação anterior de predominância do emprego, com contrato formal por tempo indeterminado e baixos índices de desemprego, rotatividade e assalariamento encoberto, contribuem para explicar o aparecimento na Argentina de organizações de desempregados massivas e nacionais, bem como um significativo movimento de recuperação de fábricas que chegou a reunir cerca de 170 unidades produtivas (Fajn, 2003). A organização territorial prévia, por meio de associações de bairro e do movimento pela moradia, foi fundamental para a formação dessas experiências. No entanto, foi na organização sindical, principal mobilizadora de experiências e tradições de luta do país, que o núcleo originário encontrou seu potencial organizativo. No Brasil, embora tenha aparecido o MTD e o cooperativismo autogestionário, inclusive em algumas empresas de grande porte como a Flaskô (Raslan, 2007), esse tipo de experiência esteve menos presente. O movimento de recuperação de empresas foi aglutinado, de certa forma, pelo sindicalismo, especialmente pela CUT (cuja experiência mais notória é a da Conforja). Ademais, pode-se dizer que a superpopulação relativa flutuante no Brasil foi 
organizada pelas centrais por meio dos cursos de requalificação profissional e da intermediação do emprego da força de trabalho.

\section{O lumpemproletariado e o pauperismo}

Uma parcela expressiva da reserva ainda é composta pelo lumpemproletariado e pelo pauperismo. No Brasil, ambas são mais expressivas historicamente. Ainda que esteja presente na Argentina, no caso brasileiro é considerável a parcela da população que consegue sua sobrevivência por meio do "delito" (Engels, 1986), especialmente pelo tráfico de drogas. Nos grandes centros urbanos, o controle de seu comércio se dá por meio de um confronto entre facções inimigas, e destas com o aparelho estatal repressor. Entre os setores pauperizados, encontram-se moradores de rua e favelados que vivem de esmola, coleta de lixo para o consumo ou a venda para a reciclagem, caridade de igrejas e ONGs, furtos, ou ainda, do "benefício" do pauperismo oficial através de políticas focalistas do Estado como o BolsaFamília. O movimento sindical dificilmente aglutina essa camada.

Ao longo do período estudado, cresceu o pauperismo e o lúmpem na Argentina, mas estes são menos expressivos que no Brasil. De qualquer forma, o movimento de desempregados do país recrutou camadas da classe trabalhadora em processo de pauperização, tendo sido um dos motores mais importantes do movimento a obtenção de auxílios do Estado, como o Plan de Jefas y Jefes de Hogar Desocupados. Ademais, nessas organizações, estiveram muito presentes a organização coletiva para a produção e o consumo (com refeitórios e hortas comunitárias), e pequenos empreendimentos autogestionários (como padarias, confecção de roupas e artesanato). A partir dessas experiências, constituiu-se, inclusive, a prática de trueques, feiras em que não se circula dinheiro, e as organizações realizam trocas dos produtos entre si.

$$
* * *
$$

Nesta tese, apresentei uma proposta de quadro explicativo que teve como maior aspiração contribuir para a compreensão de um tema que, a despeito de sua importância para o debate contemporâneo do movimento operário e sindical, ainda possui poucos estudos nas Ciências Sociais. De acordo com a perspectiva teórica adotada, as ações e representações do movimento sindical diante dos desempregados foram compreendidas como uma síntese de múltiplas determinações. Neste capítulo procurei articular apenas alguns elementos trabalhados ao longo do texto para compreender como essa questão se manifestou no Brasil e 
na Argentina. O ponto de partida da pesquisa foi pautado na noção de que da formação de uma ação conjunta entre o sindicalismo e os trabalhadores sem emprego é parte de formação histórico-social das classes e da luta de classes. Nessa construção, a relação entre o movimento operário organizado sindicalmente (forma de manifestação orgânica do exército de operários ativo no capitalismo) e os desempregados (segmento mais expressivo do exército de operários de reserva), pode se expressar em uma relação de unidade ou de fratura. Marx apontou a importância da ação conjunta entre empregados e desempregados como ponto de partida para perturbar o funcionamento puro do movimento de oferta e demanda da força de trabalho. No entanto, têm sido freqüentes na História os momentos em que, tal como aponta Engels, os desempregados se encarregam de "decidir seu destino com suas próprias forças". 


\section{BIBLIOGRAFIA}

ABÓS, Alvaro. La columna vertebral: sindicatos y peronismo. Buenos Aires: Hyspamérica Ediciones, 1986.

AGUITON, Christophe. Le mouvements des chômeurs en France. Les Temps Modernes. Juillet-Août-Septembre, n. 600, 1998.

ALMEIDA, Maria Hermínia Tavares de. Sindicatos em tempos de reforma. São Paulo em Perspectiva, São Paulo, v. 12, n. 1, p. 3-9, jan.-mar. 1998.

ALTHUSSER, Louis. "Práctica teórica y lucha ideológica". La filosofía como arma de la revolución. Córdoba: Cuadernos pasado y presente, 1986.

ALTHUSSER, Louis. Sobre a reprodução. Petrópolis, RJ: Vozes, 1999.

ALVES, Giovanni. Limites do sindicalismo: Marx, Engels e a crítica da economia política. São Paulo: Editora Práxis, 2003.

ALVES, Giovanni. O novo (e precário) mundo do trabalho: reestruturação produtiva e crise do sindicalismo. São Paulo: Boitempo, 2000.

ANDERSON, Perry. Alcances y limitaciones de la acción sindical. In: PIZZORNO et alii. Economía y política en la acción sindical. (Cuadernos de Pasado y Presente, 44). Buenos Aires: Siglo XXI, 1973.

ANTUNES, Ricardo. Adeus ao Trabalho? São Paulo: Cortez; Campinas: Editora da Unicamp, 1995.

ANTUNES, Ricardo. 2005. O caracol e sua concha: ensaios sobre a nova morfologia do trabalho. São Paulo: Boitempo, 2005.

ANTUNES, Ricardo. Trabalho, reestruturação produtiva e algumas repercussões no sindicalismo brasileiro. In: ANTUNES, Ricardo. Neoliberalismo, trabalho e sindicatos: reestruturação produtiva na Inglaterra e Brasil. 2 ed. São Paulo: Boitempo Editorial, 2002, p. 71-84.

ARBIX, Glauco A. T. Uma aposta no futuro: os primeiros anos da câmara setorial automobilística. São Paulo: Scritta, 1996.

ARBIX, Glauco, RODRIGUES, Iram Jácome. Novas estratégias sindicais diante do desemprego. São Paulo em Perspectiva, v. 10, n. 1, jan.-mar., p. 77-86, 1996. 
BARRETO, Eleonora Frenkel. Desemprego e (des) mobilização política: a luta do Sindicato dos Bancários de Campinas e Região. Dissertação (Mestrado). Instituto de Filosofia e Ciências Humanas, Universidade Estadual de Campinas, Campinas, 2004.

BARRETO, Eleonora Frenkel. Desemprego e (des) mobilização política no capitalismo contemporâneo. Campinas: Cemarx/ IFCH/ Unicamp. Cadernos do Cemarx, v. 1, n. 2, 2005.

BENCLOWICZ, J. D. Piqueteros en Tartagal y Mosconi: ¿nuevo movimiento social o lucha sociosindical? Las luchas entre 1999 y 2001. Buenos Aires, Primer Congreso Nacional sobre Protesta Social, Acción Colectiva y Movimientos Sociales en Argentina, 2009.

BENJAMIN, C; SADER, E.; STÉDILE, J. P. et alli. A opção brasileira. Rio de Janeiro: Contraponto, 1998.

BÉROUD, Sophie, MOURIAUX, René, VAKALOULIS, Michel. Le mouvement social en France: essai de sociologie politique. Paris: La Dispute/Snédit, 1998.

BÉROUD, Sophie. La mobilisation des chômeurs en Espagne : la difficile émergence d'un mouvement autonome (1988-2002). In : CHABANET, Didier, FANIEL, Jean. (dir.) L'Europe du chômage. Paris: L’Harmattan, Politique européenne, n. 21, hiver 2007, pp. 133-156.

BILSKY, Edgardo, COGGIOLA, Osvaldo. História do movimento operário argentino. São Paulo: Xamã Editora, 1999.

BLASS, Leila Maria da Silva. Alcance e limites da reestruturação negociada. São Paulo em Perspectiva. v. 12, n. 1, jan.-mar. 1998.

BOITO JR., Armando. A crise do sindicalismo. (p. 319-333). in: RAMALHO, José Ricardo \& SANTANA, Marco Aurélio. Além da Fábrica: trabalhadores, sindicatos e a nova questão social. São Paulo: Boitempo Editorial, 2003.

BOITO JR., Armando. As relações de classe na nova fase do neoliberalismo no Brasil. (pp. 271-296). In: CAETANO, Gerardo (Org.). Sujetos y nuevas formas de protesta en la historia reciente de América Latina. Buenos Aires: Clacso, 2006.

BOITO JR., Armando. Neoliberalismo e corporativismo de estado no Brasil (p. 59-87). In: ARAÚJO, Ângela Maria Carneiro (Org.). Do corporativismo ao neoliberalismo. São Paulo: Boitempo Editorial, 2002a.

BOITO JR, Armando. Neoliberalismo e relações de classe no Brasil. In: Idéias (Neoliberalismo e lutas sociais no Brasil), ano 9, n. 1, pp. 13-48, $2002 \mathrm{~b}$.

BOITO JR., Armando. O sindicalismo de Estado no Brasil: uma análise crítica da estrutura sindical. Campinas-SP: Editora da Unicamp; São Paulo: Hucitec, 1991a. 
BOITO JR., Armando. Política Neoliberal e Sindicalismo no Brasil. São Paulo: Xamã Editora, 1999.

BOITO JR., Armando. "Reforma e persistência da estrutura sindical". (p. 43-91). In: (Org.). O sindicalismo brasileiro nos anos 80. Rio de Janeiro: Paz e Terra, 1991b.

BORÓN, Atilio. Imperio: dos tesis equivocadas. Crítica Marxista, n. 16, pp. 143-166, 2003.

BOSOER, Fabián, GONZÁLEZ, Santiago Senén. El sindicalismo en tiempos de Menem. Buenos Aires: Corregidor, 1999.

BOURNEAU, F., MARTIN, V. Organiser les sans-emploi? L'experience de l'APEIS dans le Val-de-Marne. In: FILLEULE, O. (org.). Sociologie de la protestation. Les formes de l'action collective dans la France contemporaine. Paris: L'Harmattan, 1993, pp. 157-180.

BOURDIEU, P. Esquisse d'une théorie de la practique. (1 ${ }^{\mathrm{a}}$ ed. 1972). Paris: Éditions du Seuil, 2000.

BOURDIEU, P. Meditações pascalianas. (1ª ed. 1997). Rio de Janeiro: Bertrand Brasil, 2001. BOURDIEU, Pierre, WACQUANT, Loïc. An invitation to reflexive sociology. Chicago: The University of Chicago Press, 1992.

BRESCIANI, Luís Paulo. Reestruturação industrial e negociação coletiva: o sindicalismo brasileiro vai à luta? (p. 194-207). In: MARTINS, H. H. T. de S.; RAMALHO, J. R. Terceirização: diversidade e negociação no mundo do trabalho. São Paulo: Hucitec; CEDI/NETS, 1994.

CAHUC, Pierre, ZYLBERBERG, André. Chômage, fatalité ou nécessité? Paris: Flammarion, 2005.

CARDOSO, Adalberto Moreira. A década neoliberal e a crise dos sindicatos no Brasil. São Paulo: Boitempo Editoriral, 2003a.

CARDOSO, Ana C. M. Emprego: estratégias e ação sindical nos anos 90: o caso dos metalúrgicos do Estado de São Paulo. Dissertação (mestrado). FFLCH/USP, 1998.

CARDOSO, F. H., FALETTO, E. Dependência e desenvolvimento na América Latina: ensaio de interpretação sociológica. Rio de Janeiro: Zahar Editores, 1970.

CARDOSO, Adalberto Moreira; RODRIGUES, Leôncio M. Força Sindical: uma análise sócio-política. Rio de Janeiro: Paz e Terra, 1993.

CARRERA, N. I. A century of general strikes. Strikes in Argentina. (pp. 61-85). In: Sjaak Van der Velden; Heiner Dribbusch, Dave Lyddon, Kurt Vandaele (Orgs.). Strikes around the world, 1968-2005. Case studies of 15 countries. Amsterdam, Aksant, 2007a. 
CARRERA, N. I. Algunos instrumentos para el análisis de las luchas populares en la llamada Historia Reciente. (pp. 77-94). In: CALVEIRO, P.; CARRERA, N. I.; LOPEZ MAYA, M. (Orgs.). Luchas contrahegemómicas y cambios políticos recientes de América Latina. Buenos Aires, Clacso, 2008.

CARRERA, N. I.. "El desarrollo del capitalismo argentino y la clase obrera: 1975-2005". Buenos Aires: Cuadernos de cultura, n. 2, pp. 70-85, 2006.

CARRERA, N. I. "La lucha de los obreros y de los pobres en la Argentina del capital financiero". In: VILLANUEVA, E.; MASSETTI, A (orgs.). Movimientos sociales y acción colectiva en la Argentina de hoy. Buenos Aires: Prometeo Libros, 2007b.

CARRERA, Nicolás Iñigo. La estrategia de la clase obrera - 1936. Buenos Aires: Ediciones Madres de Plaza de Mayo, 2004.

CARRERA, N. I. "Las huelgas generales, Argentina 1983-2001: un ejercicio de periodización". Pimsa, Documento de Trabajo n. 33, 2001.

CARRERA, N. I. ¿Reserva o excluídos? El caso de la población aborigen y criolla en una localidad del impenetrable chaqueño (1970-1998). Tandil-Buenos Aires: Anuario del Instituto de Estudios Histórico-Sociales (IEHS)/Universidad Nacional del Centro, n. 14, 1999.

CARRERA, N. I.; COTARELO, M. C. “Algunos rasgos de la rebelión en Argentina: 19932001”. Pimsa, Documento de Trabajo n. 49, 2004.

CARRERA, N. I., COTARELO, M. C. El movimiento obrero organizado sindicalmente y los desocupados: un estudio de caso, Chaco 1994 - 2004. Buenos Aires, Primer Congreso Nacional sobre Protesta Social, Acción Colectiva y Movimientos Sociales en Argentina, 2009. CARRERA, Nicolás Iñigo; DONAIRE, Ricardo. ¿Qué interés se manifiesta en las centrales sindicales argentinas? Pimsa, Documento de Trabajo n. 38. Buenos Aires, 2002.

CARRERA, N. I.; FERNÁNDEZ, F. El movimiento obrero ante la organización y formas de rebelión de los desocupados: 1930-1935. mimeo. Buenos Aires, 2007.

CARRERA, Nicolás Iñigo; GRAU, María Isabel; MARTÍ, Analía. Augustín Tosco: la clase revolucionaria. (2 ${ }^{\mathrm{a}}$. Ed.) Buenos Aires: Ediciones Madres de Plaza de Mayo, 2006.

CARRERA, N. I.; PODESTÁ, J. “Análisis de una relación de fuerzas sociales objetiva: caracterización de los grupos sociales fundamentales en la Argentina actual". Cuadernos de Cicso, Serie Estudios n. 46, 1989.

CASTEL, Robert. Les métamorphoses de la question sociale: une chronique du salariat. Paris: Fayard, 1995. 
CASTILLO, Victoria; NOVICK, Marta; ROJO, Sofía; YOGUEL, Gabriel. La movilidad laboral en Argentina desde mediados del decenio de 1990: el difícil camino de regreso al empleo formal. Revista de la Cepal, n. 89, pp. 157-177, agosto de 2006.

CHESNAIS, F. La mondialisation de l'armée industrielle de réserve. Disponível em: http://www.alencontre.org/Economie/ChesnaisMondialisation01_07.htm. À l'Encontre, 05/01/2007.

CHIAVENATO, Júlio José. As lutas do povo brasileiro: do "descobrimento" a Canudos. São Paulo: Moderna, 1988.

CHÔMEURS HEUREUX. Rapport d'inactivité $n^{\circ}$ 1. Berlin : Le chien rouge, 1996.

CINGOLANI, Patrick. La précarité. Paris: PUF, 2005.

COHEN, V. Chômage et mobilisation collective: processus de formation et tentatives d'affirmation d'une force protestataire. Thèse de doctorat de Sociologie, Université de Paris$\mathrm{X}, 2003,427 \mathrm{p}$.

COLETTI, Claudinei. A trajetória do MST: da crise da ditadura ao período neoliberal. Tese (doutorado). Instituto de Filosofia, Letras e Ciências Humanas, Universidade Estadual de Campinas, 2005.

COSTA, Hélio. Em busca da memória: comissão de fábrica, partido e sindicato no pósguerra. São Paulo: Scritta, 1995.

COTARELO, María Celia. Aproximación al análisis de los sujetos emergentes en la crisis de 2001-2002 en Argentina. (pp. 198-217). Pimsa, Documentos y Comunicaciones, 2005.

CROSS, C.; LENGUITA, P.; WILKIS, A. "Sindicalismo y piqueteros: ¿dos formas políticas del trabajo?". In: FERNÁNDEZ, A. Sindicatos, crisis y después. Buenos Aires: Ediciones Biebel, 2002.

D'ARAÚJO, Maria Celina; GOMES, Ângela de Castro. Getulismo e trabalhismo. São Paulo: Editora Ática, 1989

DEL CAMPO, Hugo. Sindicalismo y peronismo: los comienzos de un vínculo perdurable. Buenos Aires: Siglo veintiuno Editores Argentina, 2005.

DEL FRADE, Carlos. Nosotros los trabajadores: historia de la Central de los Trabajadores Argentinos (1991-1997). Buenos Aires: Cooperativa de Trabajo Cultural, 2004.

DEMAZIÈRE, Didier. Des chômeurs sans représentation collective : une fatalité ? , Esprit, n. 226, novembre 1996, pp. 12-32. 
DEMAZIÈRE, Didier. Introdução: uma abordagem sociológica sobre a categoria do desemprego. In: GUIMARÃES, Nadya A.; HIRATA, Helena (orgs.). Desemprego: trajetórias, identidades, mobilizações. (Série Trabalho e Sociedade). São Paulo: Editora Senac São Paulo, 2006a.

DEMAZIÈRE, Didier. Le Chômage du longue durée. Paris: Presses Universitaires de France, 1995a.

DEMAZIÈRE, Didier. Precarités d'emploi, precarités de condition: entre formes et normes. Colóquio Internacional Novas Formas do Trabalho e do Desemprego: Brasil, Japão e França numa perspectiva comparada, realizado na FFLCH/USP nos dias 11 e 12 de setembro, $2006 b$.

DEMAZIÈRE, Didier. Sociologie des chômeurs. Paris: Éditions La Découverte, 2006c.

DEMAZIÈRE, Didier e PIGNONI, Maria-Teresa. Chômeurs: du silence a la révolte. Sociologie d'une action collective. Paris : Hachette Littératures (Forum), 2003.

DEVOTO, Fernando J., FAUSTO, Boris. Brasil e Argentina: um ensaio de história comparada (1850-2002). São Paulo, Ed. 34, 2004.

DI TELLA, Torcuato S. Tendencias recientes en el sindicalismo argentino y brasileño. In: DI TELLA, T. S; LUCHINNI, C. (Orgs.). Elementos de Sociología. Buenos Aires: Editorial Biblos, 1997.

DOYON, Louise M. Perón y los trabajadores: los orígenes del sindicalismo peronista, 19431955. Buenos Aires: Siglo XXI Editora Iberoamericana, 2006.

DUMÉNIL, G. LÉVY, D. Superação da crise, ameaças de crises e novo capitalismo. (pp. 1541). In: CHESNAIS, F., DUMÉNIL, G. LÉVY, D. WALLERSTEIN. Uma nova fase do capitalismo? São Paulo: Xamã, 2003.

ELIAS JR., Jorge; GEBRIM, Vera; NORONHA, Eduardo. Explicações para um ciclo excepcional de greves: o caso brasileiro. Latin American Studies Association - XXI International Congress, 1998.

ENGELS, Friedrich. A situação da classe trabalhadora na Inglaterra. São Paulo: Global, 1986.

ENGELS, Friedrich. “Os sindicatos”. In: ENGELS, F. \& MARX, K. Sobre o sindicalismo. Pontos de Vista: Lisboa, 1974. 
ENRÍQUEZ, Corina Rodríguez. Trabajo, empleo y políticas asistenciales de transferencias monetarias: uma mirada de género a partir del caso argentino. Comunicação apresentada no $V$ Congreso Latinoamericano de Sociología del Trabajo. Montevidéu, 2007.

FAJN, Gabriel. (org.) Fábricas y empresas recuperadas. Buenos Aires: Centro Cultural de la Cooperación, 2003.

FANIEL, J. Les syndicats, le chômage et les chômeurs. Raisons et évolution d'une relation complexe. Thèse de doctorat en sciences politiques ULB, 2006.

FERNANDES, Florestan. A revolução burguesa no Brasil. Rio de Janeiro: Zahar Editores, 1975.

FERNÁNDEZ, Arturo. Flexibilización laboral y crisis del sindicalismo. Buenos Aires: Espacio Editorial, 1997.

FERNÁNDEZ, Arturo. Modificaciones de la naturaleza sociopolítica de los actores sindicales: hallazgos y conjeturas (pp. 07-29). En: FERNÁNDEZ, Arturo (comp.). Sindicatos, crisis y después. Buenos Aires: Ediciones Biebel, 2002.

FIGUEIREDO, Mariana Leite. Uma alternativa sindical? A negação do "propositivismo" no sindicalismo metalúrgico paulista. Dissertação (mestrado). Campinas, Unicamp, 2007.

FILLIEULE, O. Conscience politique, persuasion et mobilisations des engagements: l'example du syndicat des chômeurs, 1983-1987. In : FILLEULE, O. (org.). Sociologie de la protestation. Les formes de l'action collective dans la France contemporaine. Paris: L'Harmattan, 1993, p. 137.

FOX PIVEN, F., CLOWARD, R. A. Poor people's movements: why they succeed, how they fail. New York : Vintage Books, 1979.

FREYSSINET, Jacques. Le chômage. 11a. ed. Paris: La Découverte, 2004.

FURTADO, Celso. Formação Econômica do Brasil. São Paulo: Publifolha, 2000.

FURTADO, Celso. O mito do desenvolvimento econômico. Rio de Janeiro: Paz e Terra, 1974.

GALLAND, O., LOUIS, M-V. Chômage et action collective. Sociologie du travail, $\mathrm{n}^{\circ} 2$, pp. 173-191, 1981.

GALVÃO, Andréia. A CUT na encruzilhada: impactos do neoliberalismo sobre o movimento sindical, Idéias (Neoliberalismo e lutas sociais no Brasil), ano 9, n. 1, p. 105-154, 2002.

GALVÃO, Andréia. Neoliberalismo e reforma trabalhista no Brasil. Rio de Janeiro: Revan; Fapesp, 2007. 
GALVÃO, Andréia. O movimento sindical frente ao governo Lula. Outubro, n. 14, pp. 131$150,2006$.

GALVÃO, Andréia. Participação e fragmentação: a prática sindical dos metalúrgicos do $\mathrm{ABC}$ nos anos 90. Dissertação (Mestrado). Instituto de Filosofia e Ciências Humanas, Universidade Estadual de Campinas, Campinas, 1996.

GANZ LÚCIO, Clemente. Balanço das negociações coletivas e das greves no Brasil no período 1998-2007. Dieese: Mimeo, 2008.

GAUTIÉ, Jérôme. "De l'invention du chômage à sa déconstruction". Dossier Genèses, 46, mars 2000, pp. 60-76.

GIANOTTI, Vito. Força Sindical a central neoliberal - de Medeiros a Paulinho. Rio de Janeiro: Mauad, 2002.

GIANOTTI, Vito; LOPES NETO, Sebastião. CUT Ontem e Hoje, Petrópolis, Vozes, 1991.

GIRARD, Claude. "Le mouvement action-chômage de Montréal: 20 ans de pratique sociale". Nouvelles pratiques sociales, vol. 2, n. 2, pp. 37-48, 1989.

GRAMSCI, A. "Espontaneidad y dirección consciente” (pp. 327-330). In: Escritos políticos. México-DF: Siglo XXI Editores, 1977.

GRAMSCI, A. Maquiavel, a política e o Estado moderno. $2^{\text {a }}$ ed. Rio de Janeiro: Civilização Brasileira, 1976.

GRIMSON, Alejandro (Comp.); NUN, José (supervisión). Pasiones nacionales: política y cultura en Brasil y Argentina. Buenos Aires: EDHASA/UNPD, 2007.

GUIMARÃES, Nadya A. Caminhos cruzados: estratégias de empresas e trajetórias de trabalhadores. São Paulo: USP, Curso de Pós-Graduação em Sociologia, Ed. 34, 2004.

GUIMARÃES, Nadya A. Por uma Sociologia do Desemprego. Revista Brasileira de Ciências Sociais, v. 17, n. 50, out. 2002.

GURR, T. Why men rebel? Princeton: Princeton University Press, 1970

HOAREAU, Charles. Marseille 97-98. Entrevista. Les temps modernes, $\mathrm{n}^{\circ} 600$, juilletseptembre, 1998.

HOBSBAWN, E. J. Os trabalhadores: estudos sobre a história do operariado. (orig. 1964). São Paulo: Paz e Terra, 2000.

HOLLOWAY, John. Cambiar el mundo sin tomar el poder. Buenos Aires: Herramienta, 2002. 
HYMAN, Richard. Industrial Relations: a marxist introduction. London: Macmillan Press, 1975.

HYMAN, Richard. "Trade Unions and the Disaggregation of the Working Class". In: REGINI, Marino (Ed.). The Future of Labour Movements. London: Sage, 1994.

IANNI, Octavio. O colapso do populismo no Brasil. Rio de Janeiro: Civilização Brasileira, $5^{\text {a }}$ ed., 1994.

ITURBE, Alejandro. Desemprego: traço estrutural do capitalismo. Marxismo vivo, out.-jan., 2001.

JARDIM, Fabiana A. A. Entre o desalento e a invenção: experiências de desemprego em São Paulo. Dissertação (Mestrado) - Faculdade de Filosofia, Letras e Ciências Humanas, Universidade de São Paulo, São Paulo, 2004.

KLACHKO, P. La forma de organización emergente del ciclo de la rebelión popular de los '90 en la Argentina. Tese (doutorado). Facultad de Humanidades y Ciencias de la Educación, Universidad Nacional de La Plata. La Plata, Argentina, 2007.

KOROL, Claudia. Memorias piqueteras. (p. 7-14). In: UNIVERSIDAD DE LAS MADRES DE PLAZA DE MAYO (Cuadernos de Educación Popular). Cortando las rutas del petróleo (Memórias Piqueteras). Buenos Aires: UPMPM, 2003.

KOWARICK, Lucio. Capitalismo e marginalidade na América Latina. Rio de Janeiro: Paz e Terra, 1975.

LARANJEIRA, Sônia. Há lugar para o sindicalismo na sociedade pós-industrial? São Paulo em Perspectiva, v. 12, n. 1, jan.-mar., p. 174-183, 1998.

LAZARSFELD, Paul; YAHODA, Marie; ZEIZEL, Hans. Les Chômeurs de Marienthal. Paris: E. de Minuit, 1981.

LECERF, E. La famine des temps modernes: essai sur le chômeur. Paris: L'Harmattan, 1992.

LEDRUT, Raymond. Sociologie du chômage. Paris: PUF, 1966.

LEITE, Marcia. O que é greve. São Paulo: Brasiliense, $2^{\text {a }}$ ed., 1992.

LENIN, V. I. Caracterización del romanticismo económico. In: Obras completas, tomo II. Buenos Aires: Editorial Cartago, 1958.

LENIN, V. I. El régimen capitalista de la agricultura contemporánea. In: Obras completas, tomo XVI. Buenos Aires: Editorial Cartago, 1960.

LENIN, V. I. Sobre os sindicatos. São Paulo: Editora Polis, 1979. 
LEVITSKY, Steven. La transformación del justicialismo. Del partido sindical al partido clientelista,1983-1999, Siglo XXI, Buenos Aires, 2005.

LOISON, Laurence. L'expérience vécue du chômage au Portugal. Paris : L'Harmattan, 2006. LÓPEZ, Alfredo. Historia del movimiento social y la clase obrera argentina. Buenos Aires: Editorial Programa, 1971.

LÖWY, Michel. Cristianismo da Libertação e marxismo. (pp. 411-437). In: REIS, D. A., RIDENTI, M. História do marxismo no Brasil. Campinas-SP: Editora da Unicamp, 2007.

MAESTRI, Mário. O Escravismo no Brasil. São Paulo: Atual Editora, 1994.

MAESTRI, Mário. Terra do Brasil: a conquista lusitana e o genocício tupinambá. São Paulo: Moderna, 1993.

MANGUEIRA, Sérgio Muniz. Ocupações e assentamentos rururbanos: um estudo a partir da ação política do Movimento dos Trabalhadores Desempregados no Brasil. V Congreso Latinoamericano de Sociología del Trabajo. Montevidéu, 2007.

MARANHÃO, Ricardo. Sindicatos e democratização (Brasil 1945/1950). São Paulo: Editora Brasiliense, 1979.

MARÍN, Juan Carlos. Los hechos armados. Buenos Aires: La Rosa Blindada; Pi.Ca.So, 2003. MARINI, Ruy Mauro. La acumulación capitalista mundial y el subimperialismo. Cuadernos Políticos, México, n. 12, abril-junio, 1977.

MARSHAL, Adriana. Efectos de las regulaciones del trabajo sobre la afiliación sindical: estudio comparativo de Argentina, Chile y México. Buenos Aires: Cuadernos del IDES (Instituto de Desarrollo Económico y Social), n. 8, abr. 2006.

MARTINS, Heloisa H. T. de Souza. O Estado e a burocratização do sindicato no Brasil. São Paulo: Hucitec, 1978.

MARTINS, José de Souza. Exclusão social e a nova desigualdade. $3^{\mathrm{a}}$ ed. São Paulo: Paulus, 2007

MARTINS, Heloisa H. T. de Souza; RODRIGUES, Iram Jácome. O sindicalismo brasileiro na segunda metade dos anos 90. Tempo Social, Revista de Sociologia da USP, 11(2), pp. 155182, out. 1999.

MARUANI, Margaret. Les mécomptes du chômage. Paris: Bayard, 2002.

MARX, K. Contribuição para a crítica da economia política. Lisboa: Editorial Estampa, 1974a. 
MARX, K. O papel econômico imediato dos sindicatos. In: ENGELS, F. \& MARX, K. Sobre o sindicalismo. Pontos de Vista: Lisboa, 1974b.

MARX, K. Preâmbulo aos estatutos da $1^{\text {a }}$. Internacional. In: ENGELS, F. \& MARX, K. Sobre o sindicalismo. Pontos de Vista: Lisboa, 1974c.

MARX, K. Resolução da Associação Internacional dos Trabalhadores sobre os sindicatos. In:

ENGELS, F., MARX, K. Sobre o sindicalismo. Pontos de Vista: Lisboa, 1974d.

MARX, K. O Capital. São Paulo: Abril Cultural, 1982.

MARX, K. Dezoito Brumário de Luis Bonaparte. Lisboa: Edições Avante, 1984.

MARX, K. Les luttes de classes en France. Paris: Éditions Gallimard, 1994.

MATOS, Marcelo Badaró. As greves na trajetória da classe trabalhadora brasileira. Anais Anpuh, GT Mundos do Trabalho, pp. 422-439, Pelotas, 2007.

MATOS, Marcelo Badaró. Trabalhadores e sindicatos no Brasil. São Paulo: Expressão Popular, 2009.

MATTOSO, J. A desordem do trabalho. São Paulo: Scritta, 1995.

MATTOSO, J. O Brasil desempregado. São Paulo: Ed. Fundação Perseu Abramo, 1999.

MAURER, S. Les chômeurs en action (décembre 1997-mars 1998). Paris: L'Harmattan, 2003.

MELENDEZ, Raquel; MONTEAGUDO, Néstor. Historia del movimiento obrero. Buenos Aires: Centro Editor de América Latina, 1971.

MENELAU NETO, J. Desemprego e luta de classes: as novas determinidades do conceito marxista de exército industrial de reserva. In: TEIXEIRA, F., OLIVEIRA, M. (Orgs.). Neoliberalismo e Reestruturação Produtiva. Fortaleza: UECE; São Paulo: Cortez, 1996.

MÉSZÁROS, István. “Desemprego e precarização: um grande desario para a esquerda”. In: ANTUNES, R. (org.). Riqueza e miséria do trabalho no Brasil. São Paulo: Boitempo, 2006.

MORAES FILHO, Evaristo de. O problema do sindicato único no Brasil. 2. ed. São Paulo: Alfa-Omega, 1978.

MOUCHARD, Daniel. Les mobilisations des "sans" dans la France contemporaine: l'émergence d'un radicalisme autolimité? Revue française de sciences politiques, v. 52, n. 4, pp. 425-447, aôut 2002.

MOURIAX, René. A esquerda e a reanimação das lutas sociais na Europa. In: Crítica Marxista, n. 14, pp. 150-170. São Paulo: Boitempo Editorial, 2002. 
MURILLO, M. Victoria. La adaptación del sindicalismo argentino a las reformas de mercado en la primera presidencia de Menem. In: Desarrollo Económico (Revista de Ciencias Sociales), n. 147, vol. 37, oct-dic, 1997.

MURMIS, Miguel; PORTANTIERO, Juan Carlos. Estudios sobre los orígenes del peronismo. Buenos Aires: Siglo XXI Editores Argentina, 2004.

NEGRI, Antonio. Contrapoder. In: NEGRI, Antonio e alli. Contrapoder: una introducción. Buenos Aires: Ediciones de Mano en Mano, 2001.

NEVEU, Erik. Sociologie des mouvements sociaux. Paris: La Découverte, 1996.

NORONHA, Eduardo. A explosão das greves na década de 80. (p. 93-135). In: BOITO JR., Armando (Org.). O sindicalismo brasileiro nos anos 80. Rio de Janeiro: Paz e Terra, 1991.

NUN, J. Marginalidad y Exclusión Social. Buenos Aires: Fondo de Cultura Económica, 2001.

OLIVEIRA, Francisco. Crítica à razão dualista/ O ornitorrinco. São Paulo: Boitempo, 2003.

OLIVEIRA, Marco Antonio. Avanço e limites do sindicalismo brasileiro recente (p. 497518). In: $O$ mundo do trabalho: crise e mudança no final do século. São Paulo, Scritta, 1994.

OLSON, M. Logique de l'action collective. Paris: PUF, 1978.

PAGAT, Maurice. Entrevista. Temps Modernes, n496-497, pp. 284-285, 1987.

PAUGAM, Serge. Les formes élementaires de la pauvreté. Paris: PUF, 2005.

PEREIRA, Vera Maria Cândido. Quem são os “desempregados” para a Sociologia. In: Natureza, História e Cultura. (pp. 27-37). Cadernos de Sociologia, Programa de PósGraduação em Sociologia, v. 04, número especial. Porto Alegre: PPGS/UFRGS, 1993.

PEREYRA, Sebastián; SVAMPA, Maristela. Entre la ruta y el barrio: la experiencia de las organizaciones piqueteras. Buenos Aires: Editorial Biblos, 2003.

PERRIN, Evelyne. Chômeurs et précaires au cœur de la question sociale. Paris: La dispute, Snédit, 2004.

PIERRU, Emmanuel. Guerre aux chômeurs ou guerre au chômage. Paris : Editions du Croquant, 2005.

PIGNONI, Maria-Teresa. Desemprego e mobilização de desempregados na França e na Itália. In: GUIMARÃES, N. A., HIRATA, H. (orgs.). Desemprego: trajetórias, identidades, mobilizações. (Série Trabalho e Sociedade). São Paulo: Editora Senac São Paulo, 2006.

PIGNONI. Maria-Teresa. Silence, on chôme! Informations sociales, n³7, 1994. 
POCHMANN, Marcio. Mudança e continuidade na organização sindical brasileira no período recente (p. 269-301). In: MATTOSO, J. E. L. \& OLIVEIRA, C. A. B. (Orgs.). Crise e Trabalho no Brasil: modernidade ou volta ao passado? São Paulo: Scritta, 1996. POCHMANN, Marcio. O Trabalho sob Fogo Cruzado. São Paulo: Contexto, 1999a. POCHMANN, Marcio. Respostas sindicais à globalização: o caso brasileiro. Campinas: mimeo, $1999 \mathrm{~b}$.

POCHMANN, Marcio. "Sobre a nova condição de agregado social no Brasil: algumas considerações". Revista Paranaense de Desenvolvimento, n. 105, pp. 5-23, jul./dez. 2003.

PODESTÁ, J. La “crisis” de desocupación en la Argentina (1993-1998). Pimsa, DT n. 17, pp. 7-35, 1999.

POULANTZAS, Nicos. Poder Político y Clases Sociales en el Estado Capitalista. México, Argentina, Espanha: Siglo Veintiuno Editores, 1971.

POUSADELA, Inés M. "Las políticas públicas y las matrices nacionales de cultura política”. En: GRIMSON, Alejandro (Comp.); NUN, José (supervisión). Pasiones nacionales: política y cultura en Brasil y Argentina. Buenos Aires: EDHASA/UNPD, 2007.

PRADO JR. Caio. Formação do Brasil contemporâneo. São Paulo: Publifolha/Brasiliense, 2000.

PREOBRAZHENKSII, Nikolai. A Hidden Story of the 1905-7 Russian Revolution: The Unemployed Soviet. Mimeo, 2005.

QUIJANO, Aníbal. Redefinición de la dependencia y marginalización en América Latina. Santiago: Centro de Estudios Socio-Económicos, Univ. Chile, 1970.

RAMALHO, José Ricardo. Precarização do trabalho e impasses da organização coletiva no Brasil. In: ANTUNES, Ricardo. Neoliberalismo, trabalho e sindicatos: reestruturação produtiva na Inglaterra e Brasil. 2 ${ }^{\text {a }}$. ed. São Paulo: Boitempo Editorial, 1998, p. 85-113.

RAMALHO, José Ricardo, SANTANA, Marco Aurélio. Trabalhadores, sindicatos e a nova questão social (p. 11-43). In: RAMALHO, José Ricardo, SANTANA, Marco Aurélio. Além da Fábrica: trabalhadores, sindicatos e a nova questão social. São Paulo: Boitempo, 2003.

RAMALHO, José Ricardo, RODRIGUES, Iram Jácome. Sindicalismo na Inglaterra e no Brasil: estratégias diante das novas formas de gestão da produção. São Paulo em Perspectiva, v. 12, n. 1, jan.-mar., 1998, p. 142-153.

RAPOPORT, Mario. Historia económica, política y social de la Argentina. Buenos Aires: Ediciones Macchi, 2003. 
RASLAN, Filipe. Resistindo com classe: o caso da ocupação da Flaskô. Dissertação (mestrado). Campinas: Unicamp, 2007.

RODRIGUES, I. Jácome. “A trajetória do novo sindicalismo” (p. 73-94). In: $O$

Novo Sindicalismo: vinte anos depois. São Paulo; Petrópolis: Educ/Unitrabalho; Editora Vozes, 1999.

RODRIGUES, Iram Jácome. Sindicalismo, emprego e relações de trabalho na indústria automobilística. (p. 115-129). In: ANTUNES, Ricardo. Neoliberalismo, trabalho e sindicatos: reestruturação produtiva na Inglaterra e Brasil. 2 ed. São Paulo: Boitempo Editorial, 1998.

RODRIGUES, Iram Jácome. Sindicalismo e política: a trajetória da CUT. São Paulo: Scritta, 1997.

RODRIGUES, José A. Sindicato e Desenvolvimento no Brasil. São Paulo, Difel, 1968.

RODRIGUES, Leôncio M. As tendências políticas na formação das centrais sindicais. (p. 1142). In: BOITO JR., Armando (Org.). O sindicalismo brasileiro nos anos 80. Rio de Janeiro: Paz e Terra, 1991.

RODRIGUES, Leôncio. M. Conflito industrial e sindicalismo no Brasil. São Paulo: Difusão Européia do Livro, 1966.

RODRIGUES, Leôncio M. CUT: os militantes e a ideologia. Rio de Janeiro: Paz e Terra, 1990a.

RODRIGUES, Leôncio M. O sindicalismo corporativo no Brasil. In: Partidos e Sindicatos. São Paulo: Ática, 1990 b.

RODRIGUES, Leôncio M. Sindicalismo e Classe Operária (1930-1964). (pg. 528-555), In: (Org.) Brasil Republicano (tomo III: O Brasil Republicano). São Paulo: Difel, 1981.

ROSANVALLON, Pierre. La nouvelle question sociale : repenser l'Etat-providence. Essais, Paris: Editions du Seuil, 1995.

ROYALL F. Mobilisations de chômeurs en Irlande (1985-1995). Paris : L'Harmattan, 2005.

RUDÉ, G. Ideologia e Protesto Popular. Rio de Janeiro: Zahar Editores, 1982.

SADER, Eder. Quando novos personagens entram em cena. Rio de Janeiro: Paz e Terra, 1988.

SAES, Décio. "O conceito de Estado burguês" (pp. 15-50). In: Ensaio e democracia: ensaios teóricos. Coleção Trajetória 1, 2a ed. Campinas: Unicamp, 1998.

SALAIS, R., BAVAREZ, N., REYNAUD, B.: L'invention du chômage. Paris: PUF, 1999. 
SALLUM JR., Brasílio (Org.). Brasil e Argentina hoje: política e economia. Bauru-SP: Edusc, 2004.

SANTANA, Marco Aurélio. Homens partidos: comunistas e sindicatos no Brasil. São Paulo: Boitempo Editorial, 2001.

SANTELLA, Agustín. Trabajadores, sindicato y conflictos en la industria automotriz argentina: un estudio de caso (1989-2006). Tese (doutorado). Facultad de Ciencias Sociales, Universidad de Buenos Aires, 2008.

SANTELLA, Augustín. Conflictos obreros en el sector automotriz en 1994-2006. Mimeo. Buenos Aires, 2007.

SANTOS, Wanderley Guilherme dos. Cidadania e justiça: a política social na ordem brasileira. Rio de Janeiro: Campus, 1979.

SCHMITTER, Philippe. Still the century of corporatism? In: Pike \& Strich (Orgs.). The new corporatism. Notre Dame, University of Notre Dame Press, 1974.

SCHNAPPER, D. L'épreuve du chômage. Paris: Editions Gallimard, 1994 (1 ${ }^{\mathrm{er}}$. ed. 1981).

SEOANE, José. Crisis de régimen y protesta social en Argentina. (pp. 99-110). México: Instituto de Investigaciones Económicas/ Universidad Nacional Autónoma de México, Chiapas, n. 13, 2002.

SILVA, Marineide M. O mosaico do desemprego. Tese (doutorado). Campinas: Unicamp, 2009.

SIMÃO, Azis. Sindicato e Estado. São Paulo, Dominus Editora, 1981.

SINGER, Paul. Globalização e desemprego: diagnóstico e alternativas. São Paulo: Contexto, 2003.

SINGER, Paul. Economia solidária: um modo de produção e distribuição. (pp. p. 11 - 28). In:

SINGER, Paul; SOUZA, André Ricardo. (Org.). A economia solidária no Brasil: a autogestão como resposta ao desemprego. São Paulo: Editora Contexto, 2000.

SOUZA, Davisson C. C. de. A atualidade dos conceitos de superpopulação relativa, exército industrial de reserva e massa marginal. Cadernos do Cemarx, Campinas: Cemarx/ IFCH/ Unicamp. v. 1, n. 2, 2005a.

SOUZA, Davisson C. C. de. Movimento operário e mobilização política dos desempregados. In: XXXII Encontro Anual da ANPOCS, GT Marxismo e Ciências Sociais, 2008, CaxambuMG. Anais do XXXII Encontro Anual da ANPOCS, Caxambu-MG, 2008a. 
SOUZA, Davisson C. C. de. Mobilisation politique des chômeurs: en débat avec la bibliographie française. Passages de Paris, Revue Scientifique de l'Association des Chercheurs et Etudiants Brésiliens en France. Numéro Spécial, 2008b.

SOUZA, Davisson C. C. de. Mobilisation politique des chômeurs: le cas argentin. In: XVIII Congrès de l'Association International des Sociologues de Langue Française (AISLF), Istambul, Turquia. Anais do GT-19 (Sociologie de l'Action Sociale), XVIII Congrès de l'Association International des Sociologues de Langue Française, 2008c.

SOUZA, Davisson C. C. de. Sindicalismo y desempleo: bosquejo de un cuadro comparativo entre Brasil y Argentina. In: VIII Congreso Nacional de Estudios del Trabajo, CD-ROM, 2007, Buenos Aires - Argentina. Anais do VIII Congreso Nacional de Estudios del Trabajo, 2007.

SOUZA, Davisson C. C. de. Sindicalismo y movimientos de desocupados en Argentina. Buenos Aires, Primer Congreso Nacional sobre Protesta Social, Acción Colectiva y Movimientos Sociales en Argentina, 2009a.

SOUZA, Davisson C. C. de. Sindicato dos Metalúrgicos de Campinas e Região diante do desemprego no período de 1990 a 2002. Dissertação (Mestrado) - Faculdade de Filosofia, Letras e Ciências Humanas, Universidade de São Paulo, São Paulo, 2005b.

SOUZA, Davisson C. C. de. Unidade e fratura entre o ativo e a reserva: notas sobre a relação entre sindicatos e desempregados. In: Anais. $6^{\circ}$ Colóquio Marx Engels, Cemarx/Unicamp, Campinas-SP, 3 a 6 de novembro de 2009b.

STEPAN, Alfred. Estado, corporativismo e autoritarismo. São Paulo, Paz e Terra, 1980.

STROH, Paula. Vai trabalhar vagabundo. A exclusão social e o protesto político dos desempregados em São Paulo. Dissertação (Mestrado) - Pontifícia Universidade Católica, São Paulo, 1989.

SVAMPA, Maristella. La Argentina: movimientos sociales e izquierdas. Quito, Entre Voces, Revista del grupo Democracia y Desarrollo Local, número 5, enero 2006.

TARDITI, Roberto. La crisis mundial de los '70 y los '80 observada a partir de la evolución de la producción automotriz. (pp. 25-57). Pimsa: Documentos y Comunicaciones, 2000.

TELLES, Vera. Pobreza e cidadania: precariedade e condições de vida (pp. 85-111). In: MARTINS, Heloisa Helena Teixeira de Souza, RAMALHO, José Ricardo. Terceirização: diversidade e negociação no mundo do trabalho. São Paulo: Hucitec; CEDI/NETS, 1994. 
THOMPSON, E. P. A formação da classe operária inglesa (tomos I, II e III). $3^{\mathrm{a}}$. Ed. Rio de Janeiro: Paz e Terra, 1997.

TOLEDO, Caio Navarro de. O governo Goulart e o golpe de 64. São Paulo: Editora Brasiliense, 2004.

TOPALOV, C. "Invention du chômage et politiques sociales au début du siècle". Les temps modernes, $\mathrm{n}^{\circ}$ 496-497, novembre-décembre, 1987.

TOPALOV, Christian. Naissance du Chômeur: 1880-1910. Paris: Albin-Michel, 1994.

TORRE, Juan Carlos. El gigante invertebrado. Los sindicatos en el gobierno, Argentina 1973-1976, Siglo XXI, Buenos Aires, 2006.

TRÓPIA, Patrícia. Força Sindical: política e ideologia no sindicalismo brasileiro. São Paulo: Expressão Popular, 2009.

TRÓPIA, Patrícia. “A adesão da Força Sindical ao neoliberalismo”. Idéias, vol. 9, n 1. Instituto de Filosofia e Ciências Humanas/Unicamp, 2002.

TUMOLO, Paulo Sérgio. Da contestação à conformação: a formação sindical da CUT e a reestruturação capitalista. Campinas: Editora da Unicamp, 2002.

VÉRAS, Roberto. Sindicalismo e democracia no Brasil: atualizações do novo sindicalismo ao sindicato cidadão. Tese (doutorado). São Paulo, USP, 2002

VIANNA, Luiz Werneck. Liberalismo e Sindicato no Brasil. Rio de Janeiro, Paz e Terra, 1976.

WEBER, Max . “Os Tipos de Dominação”. In: Economia e Sociedade. Brasília-DF: Ed. da Unb, 1991.

WUHL, Simon. Les exclus face à l'emploi. Paris : Syros/Alternatives, 1992.

WILLIANS, Raymond. Marxismo y literatura. (1ª ed. 1977). Barcelona: Ediciones Península, 1997.

ZARPELON, Sandra R. “ONGs, movimento sindical e o novo socialismo utópico”. Idéias, vol. 9, n 1. Campinas: IFCH/Unicamp, 2002, p. 203-244.

ZIBECHI, Raul. Genealogía de la revuelta. Argentina: la sociedad en movimiento. La Plata, Argentina: Letra Libre; Montevideo, Uruguay: Nordan Comunidad, 2003.

ZIEGLER, Albert. Chômage: la crise des années trente. Revue française des affaires sociales, janvier-mars, 1980, pp. 177-208; avril-juin, 1980, pp. 171-207.

ZORRILLA, Rubén H. El liderazgo sindical argentino: desde sus orígenes hasta 1975. Buenos Aires: Hyspamérica Ediciones, 1988. 


\section{DOCUMENTOS SINDICAIS}

\section{Central Única dos Trabalhadores:}

CUT. Resoluções da $3^{a}$ Plenária Nacional da CUT. São Bernardo do Campo, 1989.

CUT. Resoluções da $4^{a}$ Plenária Nacional da CUT. Belo Horizonte, 1990.

CUT. Resoluções da $5^{a}$ Plenária Nacional da CUT. São Paulo, 1992.

CUT. Resoluções da $6^{a}$ Plenária Nacional da CUT. São Paulo, 1993.

CUT. Resoluções da $7^{a}$ Plenária Nacional da CUT. São Paulo, 1995.

CUT. Resoluções da $8^{a}$ Plenária Nacional da CUT. São Paulo, 1996.

CUT. Resoluções da $9^{a}$ Plenária Nacional da CUT. São Paulo, 1999.

CUT. Resoluções da 10ª Plenária Nacional da CUT. São Paulo, 2002.

CUT. Resoluções do $3^{\circ}$ Congresso Nacional da CUT (Concut). Belo Horizonte, 1988.

CUT. Resoluções do $4^{o}$ Congresso Nacional da CUT (Concut). São Paulo, 1991.

CUT. Resoluções do $5^{\circ}$ Congresso Nacional da CUT (Concut). São Paulo, 1994.

CUT. Resoluções do $6^{\circ}$ Congresso Nacional da CUT (Concut). São Paulo, 1997.

CUT. Resoluções do $7^{\circ}$ Congresso Nacional da CUT (Concut). Serra Negra, 2000.

DE FATO. Revista da CUT, Ano 2, n. 4, jul-set 1994.

INFORMACUT. Revista da CUT, vários anos.

\section{Força Sindical}

FORÇA SINDICAL. Um projeto para o Brasil: a proposta da Força Sindical. São Paulo: Geração Editorial, 1993.

JORNAL DA FORÇA, vários anos.

REVISTA DA FORÇA SINDICAL, vários anos.

\section{Central de los Trabajadores de la Argentina:}

CTA. 1991a. Debate para la organización de los trabajadores. Encuentro de organizaciones y dirigentes sindicales. Burzaco, Província de Buenos Aires, 17 de dezembro de 1991. . 1992a. Encuentro Sindical: hacia el Congreso de los Trabajadores Argentinos (CTA) para volver a creer que es posible una sociedad más justa, para que nuestra dignidad se ponga en marcha. Rosario, 4 de abril de 1992. 
. 1992b. Reconversión salvaje y ajuste sobre los trabajadores. Grupo Coordinador del

Encuentro de Dirigentes Sindicales reunidos en Burzaco. 30 de janeiro de 1992.

. 1995. Anuario 1995. CTA, 1995.

. 1996a. El congreso nacional de delegados y los pre-congresos regionales. Buenos Aires.

. 1996b. Estatuto de la Central de los Trabajadores Argentinos. . 1996c. Primer Congreso Nacional Delegados: Documentos. 4 e 5 de novembro.

. 1996d. Primer Congreso Nacional de Delegados: Materiales de Trabajo n. 1. . 1996e. Primer Congreso Nacional de Delegados: Materiales de Trabajo n. 2.

. 1996f. Primer Congreso Nacional de Delegados: Materiales de Trabajo n. 3.

. 1999a. Anuario 1999. CTA, 1999.

. 1999b. II Congreso Nacional de Delegados. Mar del Plata, 28 e 29 de mayo.

. 2002. Documento para el Debate n. 1: apuntes sobre nuestra estrategia.

. 2006a. Historia en imágenes de la Central de los Trabajadores Argentinos - (1991-

2005): nuestra organización. CTA, 2006.

. 2006b. Historia en imágenes de la Central de los Trabajadores Argentinos - (1991-

2005): nuestras acciones. CTA, 2006.

. 2006c. Resoluciones VII Congreso Nacional de Delegados de la CTA. Mar del Plata, 30

y 31 de marzo de 2006.

. 2008. Dilemas y conflictos en torno a la representación directa en el lugar de trabajo.

Observatorio del Derecho Social. CTA, 2008.

\section{CGT:}

CGT. 2000. Contribución de los trabajadores a una solución socioeconómica. Mimeo. CGT.

_.2002. El debate actual sobre la seguridad social. Instituto Arturo Jauretche, CGT.

_. 1950. Estatuto de la Confederación General del Trabajo de la República Argentina. 2005. Evita 1919-1952. Secretaria de Cultura, Ciencia y Tecnología, Confederación Nacional del Trabajo.

\section{Outros documentos:}

ARQUIDIOCESE de São Paulo. Brasil Nunca Mais: um relato para a história. Petrópolis: Vozes, 1985. 
CONADEP. Nunca Más: informe de la Comisión Nacional sobre la Desaparición de Personas. Buenos Aires: Editorial Universitária de Buenos Aires, 1985.

IBGE. Sindicato: indicadores sociais 2001. Instituto Brasileiro de Geografia e Estatística, 2001.

MTEySS. Ministerio de Trabajo, Empleo y Seguridad Social. Trabajo, ocupación y empleo : dimensiones del trabajo en el nuevo modelo económico y social. Serie Estudios 6, Argentina, febrero de 2007a.

MTEySS. Ministerio de Trabajo, Empleo y Seguridad Social. Trabajo, ocupación y empleo : los retos laborales en un proceso de crecimiento sostenido. Serie Estudios 7, Argentina, noviembre de $2007 b$. 


\section{ANEXOS}

\section{Mapa da Argentina}

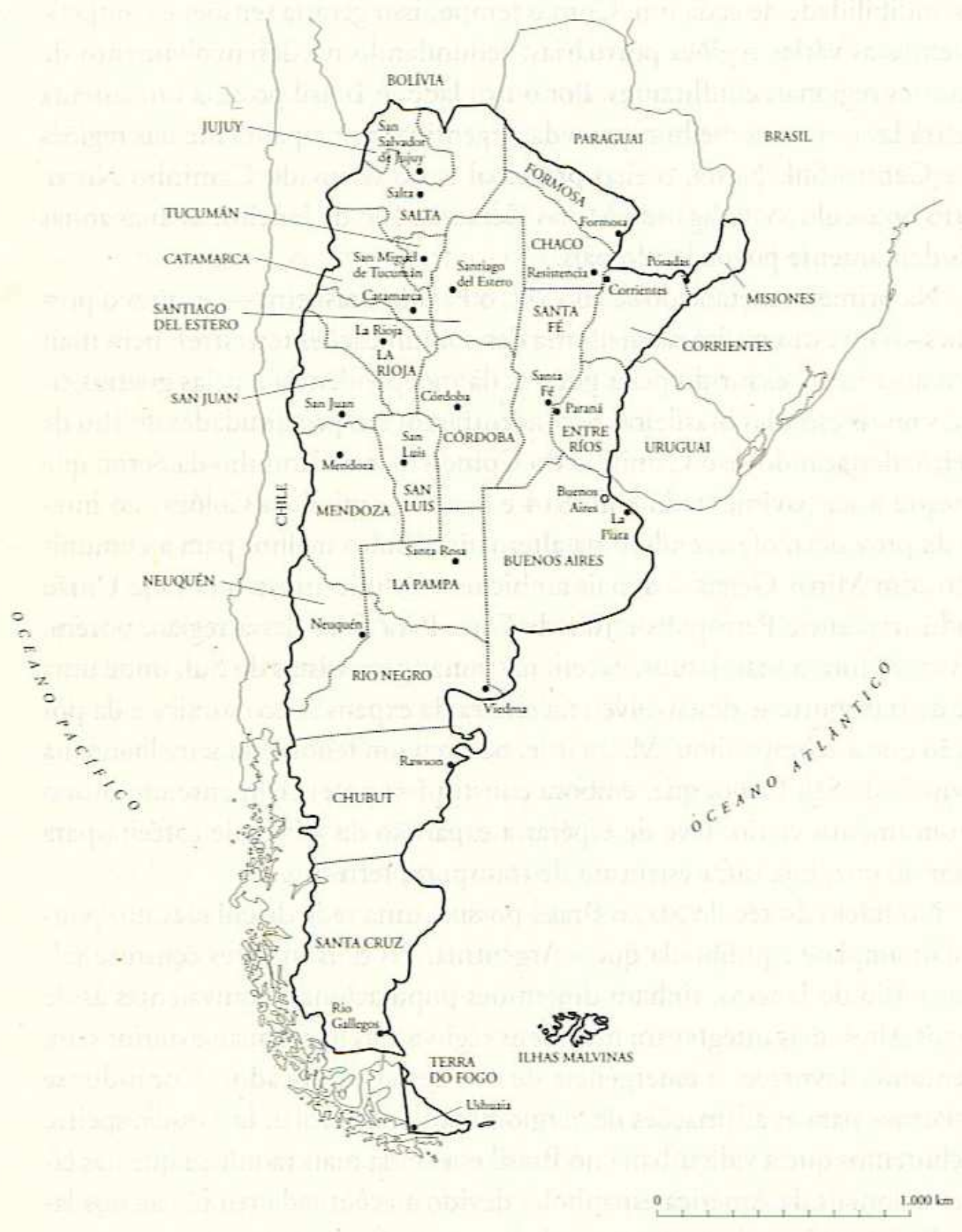

Fonte: Devoto e Fausto (2004, p. 38). 


\section{Roteiro de Entrevista}

\section{Introdução:}

1) Apresentação, data e local da entrevista

1) O senhor possui algum incoveniente de que o conteúdo dessa entrevista seja utilizado para a publicação de trabalhos acadêmicos?

\section{Dados biográficos:}

1) Qual o seu nome completo?

2) Resuma brevemente sua trajetória profissional e política.

\section{Questões gerais}

1) Quais são as causas do desemprego?

2) Há solução para o desemprego? (Se "sim”, qual? Se "não”, por quê?).

\section{Questões gerais para os dirigentes sindicais:}

1) Qual deve ser o procedimento de um sindicato diante do anúncio de demissões em massa? E depois de efetuadas, que ações devem ser adotadas?

2) Que ações o movimento sindical deve adotar diante do desemprego?

3) O movimento sindical deve desenvolver políticas para representar os desempregados?

4) O movimento sindical deve organizar os desempregados para a luta?

5) É possível uma ação conjunta entre sindicatos e desempregados?

6) Quais são as maiores dificuldades para concretizar essa unidade? Quais são as maiores dificuldades para a construção de uma organização política de desempregados no Brasil? Por que não há experiências de movimentos duradouros e com força política desse setor no país?

\section{Questões específicas para os dirigentes sindicais:}

1) Qual a sua avaliação sobre as ações do(a) (nome entidade sindical) diante do desemprego?

2) Qual a sua avaliação sobre as ações do(a) (nome entidade sindical) diante das demissões?

3) Qual a sua avaliação sobre as ações do(a) (․ㅡome entidade sindical) dos desempregados?

4) Houve experiências de ação conjunta entre o(a) (nome entidade sindical) e os desempregados?

5) Em sua opinião o(a) (nome entidade sindical) poderia ter desenvolvido outras ações em relação a essas temáticas? Por que essas medidas não foram adotadas?

6) Quais foram as principais dificuldades para concretizar essas ações?

7) Que comparação pode ser feita entre a política da (nome central sindical que representa) e da ( $\underline{\text { nome central }}$ sindical opositora) em relação a essas temáticas? 
8) No caso argentino: Quais foram os fatores que possibitaram o surgimento das organizações de desempregados no país? No caso brasileiro: Quais foram os fatores que impossibilitaram o surgimento de organizações de desempregados no país?

\section{Questões específicas para as organizações de desempregados argentinas:}

1) Em sua opinião, como se explica o surgimento do movimentos de desempregado no país?

2) Que papel teve o movimento sindical nesse processo?

3) Existe a imagem de que a maior parte das organizações de desempregados se consolidou por meio de uma rede clientelar de distribuição dos planos sociais. Qual a sua avaliação a respeito do tema?

4) Quando e como surgiu o(a) (nome da organização)?

5) Quantos membros representa o(a) (nome da organização) no país? E na Grande Buenos Aires?

6) Os militantes (a) (ำme da organização) possuem experiências prévias de luta? Se sim: a) quais são as experiêncais mais representativas?; b) é representativa a parcela de militantes que vêm do movimento sindcal? c) quais são as principais contribuições dessas experiências?

7) Quais são as experiências prévias predominantes do núcleo fundador do movimento?

8) Como é a atividade cotidiana de um militante do(a) (nome da organização)?

9) Quais são os principais instrumentos de luta do(a) (nome da organização)?

10)O movimento recebe planos sociais do governo? Se a resposta for "não”, por quê? Se a resposta for sim: a) quantos membros do movimento recebem o benefício atualmente? b) como são administrados: os beneficiários recebem individualmente ou são administrados de maneira comunitária?; c) onde se realiza a contraprestação?; d) o fato de que o movimento receba planos não é uma forma de dependência com relação ao governo?; e) e se o Estado retirasse os planos, de que maneira isso afetaria o movimento?

11) $\mathrm{O}(\mathrm{a})$ (nome da organização) recebe apoio de outras organizações? Que organizações? Que tipo de apoio?

12) $\mathrm{O}$ (a) (․ㅡome da organização) mantém relações com organizações sindicais? Se "sim", que tipo de relações? Se for "não", por quê?

13) Que experiências de luta articulada existiram entre os sindicatos e o movimento? Opcional (em caso de resposta não satisfatória): Os desempregados participam das ações dos sindicatos? E os sindicatos, participam das ações do movimento?

14) Qual a sua avaliação a respeito da política do(a) (nome da organização) em relação ao conjunto do movimento de desempregados do país? O movimento tem (ou já teve) alianças com outras organizações de desempregados?

15)Qual a sua avaliação da trajetória do(a) (nome da organização)?

16)Qual a sua avaliação a respeito das ações sindicais diante das demissões e do desemprego?

17) Qual a sua avaliação a respeito da política sindical para os desempregados?

18)Houve diferenças entre a CGT e a CTA em relação a essas temáticas? 


\begin{tabular}{|c|c|c|c|c|c|c|c|c|c|c|c|c|}
\hline & 1872 & 1890 & 1900 & 1920 & 1940 & 1950 & 1960 & 1970 & 1980 & 1991 & 2000 & Est 2008 \\
\hline Brasil & 9.930 .478 & 14.333 .434 & 17.438 .434 & 30.635 .605 & 41.236 .315 & 51.944 .397 & 70.191 .370 & 93.139 .037 & 119.002 .706 & 146.825 .475 & 169.799 .170 & 189.985 .135 \\
\hline & 1869 & 1895 & \multicolumn{2}{|c|}{1914} & \multicolumn{2}{|c|}{1947} & 1960 & 1970 & 1980 & 1991 & 2001 & Est. 2008 \\
\hline Argentina & 1.800 .000 & 4044911 & \multicolumn{2}{|c|}{7903662} & \multicolumn{2}{|c|}{15893811} & 20013793 & 23364431 & 27949480 & 32615528 & 36260130 & 39.745 .613 \\
\hline
\end{tabular}

Fontes: IBGE (Brasil) e Indec (Argentina).

\begin{tabular}{|c|c|c|c|c|c|c|c|c|c|c|}
\hline & Anos & 1895 & 1914 & \multicolumn{2}{|c|}{1947} & 1960 & 1970 & 1980 & 1991 & 2001 \\
\hline \multirow{3}{*}{ Argentina } & População urbana & 37,4 & 52,7 & \multicolumn{2}{|c|}{62,5} & 73,7 & 79,0 & 83,0 & 87,2 & 89,5 \\
\hline & População rural & 62,6 & 47,3 & \multicolumn{2}{|c|}{37,5} & 26,3 & 21,0 & 17,0 & 12,8 & 10,5 \\
\hline & Anos & - & - & 1940 & 1950 & 1960 & 1970 & 1980 & 1991 & 2000 \\
\hline \multirow[t]{2}{*}{ Brasil } & População urbana & - & - & 30,24 & 36,16 & 45,08 & 55,94 & 67,59 & 75,59 & 81,23 \\
\hline & População rural & - & - & 69,76 & 63,84 & 54,92 & 44,06 & 32.41 & 24,41 & 18,77 \\
\hline
\end{tabular}

- Argentina (1895-1980): (1) Anuario Estadísticos de la República Argentina 1981-82 y (2) Censos Nacionales de Población (1895, 1914, 1947, 1960, 1970, 1980) apud Carrera y Podestá (1987); 1991 y 2001:

Elaboração própria a partir de Indec, Censos Nacionales de Población 1991 y 2001.

- Brasil (1940-2000): IBGE, Censo Demográfico de 1940, 1950, 1960, 1970, 1980, 1991, 2000.

${ }^{809}$ Segundo dados citados por Rapoport (2003, p. 29-30) a população na Argentina entre 1880 e 1914 era de 2.492.866, em 1880, 3.377.780, em 1890, 4.607.341, em 1900, 6.586.022, em 1910 e 7.784.644, em 1914. 
Tabela 3: População urbana e rural no Brasil e na Argentina (1991-2000)

\begin{tabular}{|c|c|c|c|}
\hline & & $\mathbf{1 9 9 1}$ & $\mathbf{2 0 0 0 / 2 0 0 1}$ \\
\hline Brasil & Pop. Urbana & 110.990 .990 & 137.925 .238 \\
\hline Argentina & Pop. Rural & 35.834 .485 & 31.947 .618 \\
\hline & Pop. Urbana & 28.436 .110 & 32.431 .950 \\
\hline Diferença & Pop. Rural & 4.179 .418 & 3.828 .180 \\
\hline & Pop. Rural & 3,90 & 4,25 \\
\hline
\end{tabular}

Fontes: IBGE (Brasil) e Indec (Argentina).

Tabela 4: Imigrantes no Brasil e na Argentina (1861-1920)

\begin{tabular}{|c|c|c|c|c|c|c|c|}
\hline & $\mathbf{1 8 6 1 -}$ & $\mathbf{1 8 6 1 -}$ & $\mathbf{1 8 7 1 -}$ & $\mathbf{1 8 8 1 -}$ & $\mathbf{1 8 9 1 -}$ & $\mathbf{1 9 0 1 -}$ & $\mathbf{1 9 1 1 -}$ \\
& $\mathbf{1 9 2 0}$ & $\mathbf{1 8 7 0}$ & $\mathbf{1 8 8 0}$ & $\mathbf{1 8 9 0}$ & $\mathbf{1 9 0 0}$ & $\mathbf{1 9 1 0}$ & $\mathbf{1 9 2 0}$ \\
\hline Argentina & 4.879 & 160 & 261 & 841 & 648 & 1.764 & 1.205 \\
\hline Brasil & 3.481 & 98 & 219 & 531 & 1.144 & 691 & 798 \\
\hline
\end{tabular}

Fonte: Rapoport (2003, p. 43). 
Tabela 5: População total, de estrangeiros, rural e urbana na Argentina (1869-1914)

\begin{tabular}{|c|c|c|c|c|c|c|c|c|c|}
\hline Censo & Argentinos & $\%$ & Estrangeiros & $\%$ & $\begin{array}{c}\text { Pop. } \\
\text { rural }\end{array}$ & $\%$ & $\begin{array}{c}\text { Pop. } \\
\text { urbana }\end{array}$ & $\%$ & Total \\
\hline 1869 & 1.526 .734 & 87,9 & 210.292 & 12,1 & 1.164 .026 & 67,0 & 573.000 & 33,0 & 1.737 .026 \\
\hline 1895 & 2.950 .384 & 74,6 & 1.004 .527 & 25,4 & 2.294 .000 & 58,0 & 1.661 .000 & 42,0 & 3.954 .911 \\
\hline 1914 & 5.527 .285 & 70,2 & 2.357 .952 & 29,8 & 3.312 .000 & 42,0 & 4.573 .000 & 58,0 & 7.885 .237 \\
\hline
\end{tabular}

Fonte: Rapoport (2003, p. 45).

Tabela 6: População total e estrangeira em São Paulo e Buenos Aires (1886-1936)

\begin{tabular}{|c|c|c|c|c|}
\hline \multicolumn{5}{|c|}{ São Paulo } \\
\hline & 1886 & 1890 & 1920 & 1934 \\
\hline Total & 47.697 & 64.934 & 579.033 & 1.033 .202 \\
\hline Estrangeiros & $12.990(26 \%)$ & $35.454(55 \%)$ & $205.245(35 \%)$ & $289.058(28 \%)$ \\
\hline \multicolumn{5}{|c|}{ Buenos Aires } \\
\hline & 1887 & 1895 & 1914 & 1936 \\
\hline Total & 432.661 & 663.854 & 1.560 .986 & 2.145 .142 \\
\hline Estrangeiros & $128.167(30 \%)$ & $345.493(52 \%)$ & $766.156(49 \%)$ & $869.451(36 \%)$ \\
\hline
\end{tabular}

Fonte: Devoto e Fausto (2004, p. 179). 
Tabela 7: PIB do Brasil e da Argentina (1900-1935)

(em milhões de dólares)

\begin{tabular}{|c|c|c|c|c|}
\hline & $\mathbf{1 9 0 0}$ & $\mathbf{1 9 1 0}$ & $\mathbf{1 9 2 5}$ & $\mathbf{1 9 3 5}$ \\
\hline Argentina & 12.932 & 26.125 & 40.597 & 51.524 \\
\hline Brasil & 12.668 & 17.672 & 29.724 & 43.226 \\
\hline
\end{tabular}

Fonte: (Devoto e Fausto, 2004, p. 151).

Tabela 8: PIB do Brasil e da Argentina (1960-2008)

(em milhões de dólares)

\begin{tabular}{|c|c|c|c|c|}
\hline & $\mathbf{1 9 6 0}$ & $\mathbf{1 9 8 3}$ & $\begin{array}{c}\mathbf{2 0 0 8} \\
\text { (estimativa) }\end{array}$ & $\begin{array}{c}\mathbf{2 0 0 7} \\
\text { (estimativa) }\end{array}$ \\
\hline Argentina & 35.000 & 63.000 & - & 523.700 \\
\hline Brasil & 59.000 & 230.000 & 1.981 .000 & - \\
\hline
\end{tabular}

Fonte: 1960 e 1983: Rapoport (2002, p. 1057); Brasil (2008): IBGE; Argentina (2008): Indec.

Tabela 9: PIB per capita no Brasil e na Argentina (1965-1985)

(em milhões de dólares de 1985)

\begin{tabular}{|c|c|c|c|c|}
\hline & PBI p/c 1965 & PBI p/c 1985 & $\begin{array}{c}\text { 2008 } \\
\text { (estimativa) }\end{array}$ & $\begin{array}{c}\mathbf{2 0 0 7} \\
\text { (estimativa) }\end{array}$ \\
\hline Argentina & 2.144 & 2.145 & - & 13.308 \\
\hline Brasil & 724 & 1.755 & 10.326 & - \\
\hline
\end{tabular}

Fonte: 1965 e 1985: Rapoport, 2003, p. 610; Brasil (2007): IBGE; Argentina (2008): Indec.

Tabela 10: Afiliados sindicais na Argentina, segundo a tendência (1936-1940)

\begin{tabular}{|c|c|c|c|c|}
\hline & $\mathbf{1 9 3 6}$ & $\mathbf{1 9 3 7}$ & $\mathbf{1 9 3 9}$ & $\mathbf{1 9 4 0}$ \\
\hline CGT & 262.630 & 289.393 & 270.320 & 311.075 \\
\hline USA & 25.095 & 32.111 & 26.980 & 32.039 \\
\hline $\begin{array}{c}\text { Fed. Asoc. De } \\
\text { Empleados }\end{array}$ & 8.012 & 8.079 & 18.500 & 18.965 \\
\hline Autônomos & 72.834 & 68.105 & 120.809 & 120.188 \\
\hline Indefinidos & 1.398 & 21.114 & - & - \\
\hline TOTAL & 369.969 & 418.902 & 436.609 & 472.828 \\
\hline
\end{tabular}

Fonte: (Meléndez e Monteagudo, 1971, p. 78). 
Tabela 11: Greves no Brasil (1888-2007)

Tab. 11a: Média anual de greves no Brasil por períodos político-econômicos

\begin{tabular}{|c|c|c|}
\hline $1888-1900$ & Abolição - fim do século (a) & 2 \\
\hline $1901-1914$ & Pré-guerra (a) & 9 \\
\hline $1915-1929$ & Da guerra a crise de 29 (a) & 8 \\
\hline $1930-1936$ & Vargas -- Primeira fase (a) & 12 \\
\hline $1937-1944$ & Estado Novo (a) & 43 \\
\hline $1945-1964$ & Democracia (populismo) (b) & 13 \\
\hline $1965-1968$ & Militares (Castelo - Costa e Silva) (b) & 0 \\
\hline $1969-1977$ & Militares ('duros') (c) & 259 \\
\hline $1978-1984$ & Militares (abertura) (d) & 2203 \\
\hline $1985-1990$ & Sarney/ Collor (d) & 978 \\
\hline $1991-1992$ & Collor (d) (e) & 926 \\
\hline $1992-1997$ & Itamar/FHC (f) & (f) \\
\hline
\end{tabular}

(a) (Simão 1981) Sindicato e Estado. Dados referem-se apenas ao Estado de São Paulo; (b) (Sandoval 1993) Social Changes and Labour Unrest in Brasil since 1945; (c) Não há informações coletadas para esse período; (d) NEPP/UNICAMP. Pesquisa: Acompanhamento de Greves no Brasil; (e) Desep; (f) Dieese. Banco de Dados Sindicais. Fonte: Noronha, Elias Jr. e Gebrin (1998, p. 7).

Tab. 11b: Médial anual de greves no Brasil por períodos

\begin{tabular}{|c|c|c|}
\hline $1988-1997$ & Sarney/Collor/Itamar/FHC1 & 1084 \\
\hline $1998-2007$ & FHC2-Lula & 385 \\
\hline $2003-2007$ & Lula & 300 \\
\hline
\end{tabular}

Fonte: Ganz Lúcio (2008).

Tab. 11c: Greves no Rio de Janeiro (1890-1930)

\begin{tabular}{|c|c|c|c|c|c|}
\hline Ano & Número & Ano & Número & Ano & Número \\
\hline 1890 & 6 & 1904 & 5 & 1918 & 29 \\
\hline 1891 & 7 & 1905 & 8 & 1919 & 22 \\
\hline 1892 & 3 & 1906 & 3 & 1920 & 26 \\
\hline 1893 & 1 & 1907 & 8 & 1921 & 4 \\
\hline 1894 & - & 1908 & 6 & 1922 & 2 \\
\hline 1895 & - & 1909 & 14 & 1923 & 1 \\
\hline 1896 & 2 & 1910 & 3 & 1924 & 3 \\
\hline 1897 & - & 1911 & 8 & 1925 & 3 \\
\hline 1898 & 5 & 1912 & 14 & 1926 & 3 \\
\hline 1899 & 8 & 1913 & 5 & 1927 & 9 \\
\hline 1900 & 10 & 1914 & 2 & 1928 & 24 \\
\hline 1901 & 5 & 1915 & 7 & 1929 & 20 \\
\hline 1902 & 4 & 1916 & 3 & 1930 & 11 \\
\hline 1903 & 30 & 1917 & 13 & TOTAL & 346 \\
\hline
\end{tabular}

Fonte: Matos (2004) apud Matos (2007). 
Tabela 12: Greves, grevistas e dias parados na Argentina (1906-1918)

\begin{tabular}{|c|c|c|}
\hline Ano & Greves & Grevistas (dias parados) \\
\hline 1906 & 170 & 70.743 \\
\hline 1907 & 231 & 160.017 \\
\hline 1908 & 118 & 11.561 \\
\hline 1909 & 139 & 4.762 \\
\hline 1910 & 298 & 18.806 \\
\hline 1910 & 296 & $18.803(357.996)$ \\
\hline 1911 & 102 & $27.992(1.431 .457)$ \\
\hline 1912 & 99 & $8.992(88.613)$ \\
\hline 1913 & 95 & $23.698(147.651)$ \\
\hline 1914 & 64 & $14.137(83.041)$ \\
\hline 1915 & 64 & $12.077(49.183)$ \\
\hline 1916 & 80 & $24.321(233.878)$ \\
\hline 1917 & 138 & $135.062(2.100 .269)$ \\
\hline 1918 & 196 & $133.042(2.191 .773)$ \\
\hline
\end{tabular}

Fonte: López (1971, p. 177, 197, 223). 
Tabela 13: Greves na Argentina (1955-2006)

\begin{tabular}{|c|c|c|c|}
\hline Ano & $\begin{array}{l}\text { No. de } \\
\text { greves }\end{array}$ & Grevistas & $\begin{array}{c}\text { Dias não } \\
\text { trabalhados }\end{array}$ \\
\hline 1955 & 21 & 11.990 & 144.120 \\
\hline 1956 & 50 & 853.994 & 5.167 .294 \\
\hline 1957 & 56 & 304.209 & 3.390 .529 \\
\hline 1958 & 84 & 277.381 & 6.245 .286 \\
\hline 1959 & 45 & 1.411 .062 & 10.078 .138 \\
\hline 1960 & 26 & 130.044 & 1.661 .520 \\
\hline 1961 & 43 & 236.462 & 1.755 .170 \\
\hline 1962 & 15 & 42.386 & 268.749 \\
\hline 1963 & 20 & 207.216 & 812.396 \\
\hline 1964 & 27 & 114.230 & 636.302 \\
\hline 1965 & 32 & 203.596 & 590.511 \\
\hline 1966 & 27 & 235.913 & 1.003 .710 \\
\hline 1967 & 6 & 547 & 2.702 \\
\hline 1968 & 7 & 1.609 & 15.502 \\
\hline 1969 & 8 & 6.697 & 150.256 \\
\hline 1970 & 5 & 2.912 & 32.849 \\
\hline 1971 & 16 & 68.632 & 159.277 \\
\hline 1972 & 12 & 61,259 & 153,047 \\
\hline
\end{tabular}

\begin{tabular}{|c|c|c|c|}
\hline 1973 & - & - & - \\
\hline 1974 & 543 & 271.697 & 651.555 \\
\hline 1975 & 1266 & - & - \\
\hline 1976 & 43 & 80.120 & - \\
\hline 1977 & 54 & 156.022 & - \\
\hline 1978 & 19 & 145.480 & - \\
\hline 1979 & 113 & 244.744 & - \\
\hline 1980 & 132 & 194.218 & - \\
\hline 1981 & - & - & - \\
\hline 1982 & - & - & - \\
\hline 1983 & - & - & - \\
\hline 1984 & 495 & 8.459 .192 & 16.521 .182 \\
\hline 1985 & 333 & 4.248 .248 & 8.296 .518 \\
\hline 1986 & 582 & 11.236 .940 & 23.170 .963 \\
\hline 1987 & 470 & 5.980 .507 & 13.372 .628 \\
\hline 1988 & 443 & 7.443 .344 & 33.593 .112 \\
\hline 1989 & 418 & 7.720 .985 & 24.359 .522 \\
\hline 1990 & 326 & 9.970 .886 & 32.844 .016 \\
\hline 1991 & 119 & 3.468 .930 & 10.201 .821 \\
\hline 1992 & 99 & 4.656 .536 & 7.208 .282 \\
\hline
\end{tabular}

\begin{tabular}{|c|c|c|c|}
\hline 1993 & 116 & 1.642 .512 & 6.033 .246 \\
\hline 1994 & 44 & - & - \\
\hline 1995 & 77 & - & - \\
\hline 1996 & 19 & - & - \\
\hline 1997 & 55 & - & - \\
\hline 1998 & 61 & - & - \\
\hline 1999 & 92 & - & - \\
\hline 2000 & 178 & - & - \\
\hline 2001 & 264 & - & - \\
\hline 2002 & 160 & - & - \\
\hline $2003 *$ & 129 & - & - \\
\hline 2004 & 376 & - & - \\
\hline 2005 & 537 & - & - \\
\hline 2006 & 293 & - & \\
\hline
\end{tabular}

Fonte: 1955-1972: ILO, Yearbook of Labour Statistics, 1965 and 1975; 1974-1975: Ministerio de Trabajo, Departamento de Estadisticas, quoted by Wurtele (1977); Pegoraro, J., 'Lo conflictos laborales, 1973-1976', Cuadernos de Marcha, segunda época, num. 2, Julio-Agosto 1979, p. 96 Mexico; 1976-1980: Fernández, A. 1985, Las prácticas sociales del sindicalismo. 1976-1982, Buenos Aires 1985, Cedal, p. 140141; fonte jornalística; 1984-1993: McGuire J., Peronism without Peron: unions, parties and democracy in Argentina Stanford, Stanford University Press 1997, p. 239, based on data from Consejo Técnico de Inversiones, La economía argentina (Yearbooks for 1984-1993). 1994-2006: Base de dados do Pimsa. Apud Carrera, 2007. 
Tabela 14: Greves gerais na Argentina (1901-2002)

Tab. 14a: Greves gerais na Argentina en quatro períodos segundo a escala

\begin{tabular}{|c|c|c|c|}
\hline Período & No. greves & Locais & Nacionais \\
\hline $1901-1927$ & 19 & 15 & sd \\
\hline $1930-1943$ & 104 & $\mathrm{Sd}$ & 28 \\
\hline $1955-1976$ & 41 & 44 & 33 \\
\hline $1979-2002$ & 77 & 13 & \\
\hline
\end{tabular}

Fonte: Santella (2008)

Tab. 14b: Greves gerais na Argentina por escala e período (1979-2002)

\begin{tabular}{|c|c|c|c|}
\hline Período & Locais & Nacionais & Total \\
\hline 1979 & 1 & s/d & 20 \\
\hline $1983-1989$ & 13 & 7 & 56 \\
\hline $1989-2002$ & 19 & 44 & 77 \\
\hline Total & 33 & 44 & \\
\hline
\end{tabular}

Fonte: Santella (2008)

Tab. 14c: Greves Gerais nacionais na Argentina convocada por centrais (1979-2002)

\begin{tabular}{|c|c|c|}
\hline $1979-1982$ & Ditadura militar & 5 \\
\hline $1983-1989$ & Governo Alfonsín & 13 \\
\hline $1989-1999$ & Governo Menem & 9 \\
\hline $1999-2001$ & Governo De la Rua & 3 \\
\hline 2002 & Governo Duhalde & 39 \\
\hline
\end{tabular}

Fonte: Carrera, 2007 
Tabela 15: Desemprego no Brasil (1980-2007)

\begin{tabular}{|c|c|c|c|}
\hline & IBGE & Dieese aberto & Dieese total \\
\hline 1980 & 6,5 & - & - \\
\hline 1981 & 7,9 & _- & - \\
\hline 1982 & 6,27 & - & - \\
\hline 1983 & 6,7 & - & - \\
\hline 1984 & 7,12 & - & - \\
\hline 1985 & 5,25 & 7,8 & - \\
\hline 1986 & 3,59 & 6,1 & - \\
\hline 1987 & 3,73 & 6,1 & - \\
\hline 1988 & 3,85 & 7,0 & - \\
\hline 1989 & 3,35 & 6,6 & - \\
\hline 1990 & 4,28 & 7,2 & \\
\hline 1991 & 4,83 & 7,9 & - \\
\hline 1992 & 5,97 & 9,1 & - \\
\hline 1993 & 5,32 & 8,7 & - \\
\hline 1994 & 5,06 & 8,9 & - \\
\hline 1995 & 4,64 & 9,0 & _- \\
\hline 1996 & 5,47 & 9,9 & - \\
\hline 1997 & 5,66 & 10,2 & - \\
\hline 1998 & 7,6 & 11,91 & 19,35 \\
\hline 1999 & 7,64 & 12,96 & 21,35 \\
\hline 2000 & 7,14 & 12,1 & 19,91 \\
\hline 2001 & 6,24 & 12,3 & 19,98 \\
\hline 2002 & 7,14 & 12,3 & 20,11 \\
\hline 2003 & 12,31 & 13,65 & 21,78 \\
\hline 2004 & 11,47 & 12,85 & 20,56 \\
\hline 2005 & 9,82 & 12,01 & 18,96 \\
\hline 2006 & 9,97 & 11,6 & 17,93 \\
\hline 2007 & 9,39 & 11,03 & 16,5 \\
\hline
\end{tabular}

Fonte: IBGE e Dieese. 
Tabela 16: Desemprego na Argentina (1974-2002)

\begin{tabular}{|c|c|c|c|c|c|c|c|c|}
\hline & anual & Maio & outubro & agosto & $\begin{array}{c}\text { subocupação } \\
\text { horária }^{810}\end{array}$ & $\begin{array}{l}\text { desempregados } \\
\text { e subocupados. }\end{array}$ & $\begin{array}{c}\text { subocupados. } \\
\text { demandantes }^{811}\end{array}$ & $\begin{array}{c}\text { subocupados } \\
\text { não } \\
\text { demandantes }\end{array}$ \\
\hline 1974 & - & 5,0 & 3,4 & - & - & - & - & - \\
\hline 1975 & - & 3,5 & 3,8 & - & - & - & - & - \\
\hline 1976 & - & 5,2 & 4,4 & - & - & - & - & - \\
\hline 1977 & - & 3,9 & 2,7 & - & - & - & - & - \\
\hline 1978 & - & 4,2 & 2,3 & - & - & - & - & - \\
\hline 1979 & - & 2,6 & 2,4 & - & - & - & - & - \\
\hline 1980 & 2,5 & 2,6 & 2,5 & - & - & - & - & - \\
\hline 1981 & 4,7 & 4,2 & 5,3 & - & - & - & - & - \\
\hline 1982 & 5,3 & 6,0 & 4,6 & - & - & - & - & - \\
\hline 1983 & 4,7 & 5,5 & 3,9 & - & - & - & - & - \\
\hline 1984 & 4,5 & 4,7 & 4,4 & - & - & - & - & - \\
\hline 1985 & 5,9 & - & 5,9 & - & - & - & - & - \\
\hline 1986 & 5,5 & 5,9 & 5,2 & - & - & - & - & - \\
\hline 1987 & 5,8 & 6,0 & 5,7 & - & - & - & - & - \\
\hline 1988 & 6,3 & 6,5 & 6,1 & - & - & - & - & - \\
\hline
\end{tabular}

${ }^{810}$ A taxa de subocupação horária na Argentina é composta pelo total de trabalhadores que exercem alguma ocupação por uma quantidade de horas abaixo da jornada de trabalho legal (40 horas semanais).

${ }^{811}$ Os subocupados demandantes são todos aqueles que buscam um emprego formal de acordo com a jornada estabelecida em lei. 


\begin{tabular}{|c|c|c|c|c|c|c|c|c|}
\hline 1989 & 7,6 & 8,1 & 7,1 & - & 8,6 & 16,2 & - & - \\
\hline 1990 & 7,4 & 8,6 & 6,3 & - & 9,1 & 16,5 & - & _- \\
\hline 1991 & 6,4 & 6,9 & 6,0 & - & 8,2 & 14,6 & - & - \\
\hline 1992 & 6,9 & 6,9 & 7,0 & - & 8,2 & 15,1 & - & - \\
\hline 1993 & 9,6 & 9,9 & 9,3 & - & 9,0 & 18,6 & - & - \\
\hline 1994 & 11,4 & 10,7 & 12,1 & - & 10,3 & 21,7 & 5,1 & 5,3 \\
\hline 1995 & 17,5 & 18,4 & 16,6 & - & 11,9 & 29,4 & 7,35 & 4,55 \\
\hline 1996 & 17,2 & 17,1 & 17,3 & - & 13,1 & 30,3 & 8,3 & 4,8 \\
\hline 1997 & 14,9 & 16,1 & 13,7 & - & 13,1 & 28,0 & 8,25 & 4,9 \\
\hline 1998 & 12,9 & 13,2 & 13,2 & 12,4 & 13,5 & 26,4 & 8,3 & 5,2 \\
\hline 1999 & 14,2 & 14,5 & 14,5 & 13,8 & 14,3 & 28,5 & 9,6 & 5,25 \\
\hline 2000 & 15,0 & 15,4 & 14,7 & - & 14,5 & 29,5 & 9,4 & 5,2 \\
\hline 2001 & 17,3 & 16,4 & 18,3 & - & 15,6 & 32,9 & 10,1 & 5,3 \\
\hline 2002 & 19,6 & 21,5 & 17,8 & - & 19,2 & 38,8 & 13,2 & 6,0 \\
\hline
\end{tabular}

Fonte: Indec

Tabela 17: Protestos de empregados e desempregados na Argentina (1993-2006)

\begin{tabular}{|c|c|c|c|c|c|c|c|c|c|c|c|c|c|c|c|}
\hline & $1993^{812}$ & 1994 & 1995 & 1996 & 1997 & 1998 & 1999 & 2000 & 2001 & 2002 & 2003 & 2004 & 2005 & 2006 & total \\
\hline Empregados & 26 & 105 & 242 & 96 & 120 & 165 & 298 & 755 & 1067 & 705 & 423 & 786 & 1189 & 834 & 6811 \\
\hline Desempregados & 0 & 0 & 3 & 4 & 42 & 16 & 17 & 225 & 458 & 806 & 462 & 571 & 366 & 164 & 3134 \\
\hline
\end{tabular}

Fonte: Pimsa

${ }^{812}$ Os dados de 1993 correspondem ao mês de dezembro, quando se iniciou a coleta de dados. 
Tabela 18: Protestos de assalariados segundo o segmento (1993-2007)

\begin{tabular}{|c|c|c|c|c|c|c|c|c|c|c|c|c|c|c|c|c|}
\hline & 1993 & 1994 & 1995 & 1996 & 1997 & 1998 & 1999 & 2000 & 2001 & 2002 & 2003 & 2004 & 2005 & 2006 & 2007 & Total \\
\hline Sem dado & 0 & 1 & 4 & 6 & 2 & 0 & 4 & 75 & 169 & 60 & 22 & 4 & 1 & 3 & 4 & 355 \\
\hline Empregados & 26 & 106 & 243 & 96 & 121 & 165 & 302 & 759 & 1065 & 700 & 503 & 786 & 1182 & 831 & 1162 & 8047 \\
\hline Demitidos & 1 & 2 & 3 & 15 & 7 & 15 & 6 & 23 & 35 & 56 & 22 & 35 & 31 & 20 & 3 & 274 \\
\hline Desempregados & 0 & 0 & 3 & 4 & 41 & 16 & 12 & 189 & 410 & 745 & 448 & 522 & 188 & 112 & 18 & 2708 \\
\hline $\begin{array}{c}\text { Empregados e } \\
\text { desempregados }\end{array}$ & 1 & 0 & 1 & 2 & 6 & 0 & 2 & 27 & 107 & 172 & 20 & 39 & 14 & 2 & 6 & 399 \\
\hline Empregados e demitidos & 0 & 2 & 27 & 4 & 7 & 10 & 5 & 16 & 29 & 3 & 2 & 17 & 0 & 1 & 3 & 126 \\
\hline Dirigentes sindicais & 0 & 0 & 0 & 1 & 1 & 0 & 0 & 1 & 0 & 0 & 1 & 0 & 6 & 2 & 0 & 12 \\
\hline $\begin{array}{c}\text { Desempregados com } \\
\text { Planes Trabajar ou } \\
\text { semelhantes }\end{array}$ & 0 & 0 & 0 & 0 & 1 & 0 & 5 & 37 & 50 & 61 & 142 & 49 & 177 & 52 & 5 & 579 \\
\hline $\begin{array}{c}\text { Demitidos e } \\
\text { desempregados }\end{array}$ & 0 & 0 & 0 & 0 & 0 & 0 & 1 & 1 & 0 & 0 & 0 & 6 & 0 & 0 & 0 & 8 \\
\hline $\begin{array}{l}\text { Desempregados e de } \\
\text { fábrica recuperada }\end{array}$ & 0 & 0 & 0 & 0 & 0 & 0 & 0 & 0 & 0 & 1 & 1 & 0 & 0 & 0 & 0 & 2 \\
\hline Total & 28 & 111 & 281 & 128 & 186 & 206 & 337 & 1128 & 1865 & 1798 & 1161 & 1458 & 1599 & 1023 & 1201 & 12510 \\
\hline
\end{tabular}

Fonte: Base de Dados do Pimsa. ${ }^{81}$

${ }^{813}$ Agradeço a Germán Rosati e María Celia Cotarelo pela concessão dos dados. 
Tabela 19: Protestos de desempregados e demitidos, em conjunto ou não com empregados (1993-2007)

\begin{tabular}{|c|c|c|c|c|c|c|c|c|c|c|c|c|c|c|c|c|}
\hline & 1993 & 1994 & 1995 & 1996 & 1997 & 1998 & 1999 & 2000 & 2001 & 2002 & 2003 & 2004 & 2005 & 2006 & 2007 & Total \\
\hline Demitidos & 1 & 2 & 3 & 15 & 7 & 15 & 6 & 23 & 35 & 56 & 22 & 35 & 31 & 20 & 3 & 274 \\
\hline Desempregados & 0 & 0 & 3 & 4 & 41 & 16 & 12 & 189 & 410 & 745 & 448 & 522 & 188 & 112 & 18 & 2708 \\
\hline $\begin{array}{l}\text { Empregados e } \\
\text { desempregados }\end{array}$ & 1 & 0 & 1 & 2 & 6 & 0 & 2 & 27 & 107 & 172 & 20 & 39 & 14 & 2 & 6 & 399 \\
\hline Empregados e demitidos & 0 & 2 & 27 & 4 & 7 & 10 & 5 & 16 & 29 & 3 & 2 & 17 & 0 & 1 & 3 & 126 \\
\hline Total & 2 & 4 & 34 & 25 & 62 & 41 & 25 & 255 & 581 & 976 & 492 & 613 & 233 & 135 & 30 & 3507 \\
\hline
\end{tabular}

Fonte: Base de Dados do Pimsa. 
Quadro I: Perfil das organizações de desempregados da Argentina

\begin{tabular}{|c|c|c|c|c|c|c|c|c|}
\hline & FTV & $\mathrm{CCC}$ & Polo Obrero & MIJD & MTD-Solano & MTL & Barrios de Pie & $\begin{array}{l}\text { MTD-La } \\
\text { Matanza }\end{array}$ \\
\hline Surgimento & $\begin{array}{c}\text { Fundado em } 7 \text { de } \\
\text { novembro de } 1997 \\
\text { como organização } \\
\text { nacional, com } \\
\text { cerca de } 2000 \\
\text { delegados em todo } \\
\text { o país, que } \\
\text { representavam } \\
\text { principalmente } \\
\text { camponeses e } \\
\text { habitantes de } \\
\text { favelas. Tem seus } \\
\text { antecedentes nas } \\
\text { lutas pela moradia } \\
\text { nas periferias, com } \\
\text { ocupação de } \\
\text { terrenos nos } \\
\text { grandes centros } \\
\text { urbanos, } \\
\text { especialmente da } \\
\text { Grande Buenos } \\
\text { Aires (GBA). } \\
\text { Nasce com o } \\
\text { objetivo de lutar } \\
\text { por terra, moradia } \\
\text { e condições de } \\
\text { habitação e dois } \\
\text { anos depois, dado } \\
\text { aprofundamento } \\
\text { da crise, assume o } \\
\text { desemprego como } \\
\text { tema principal e } \\
\text { passa a representar } \\
\text { os desempregados. }\end{array}$ & $\begin{array}{c}\text { Fundado em } 1994 \\
\text { como corrente } \\
\text { político-sindical } \\
\text { ligada ao Partido } \\
\text { Comunista } \\
\text { Revolucionário } \\
\text { (PCR), de } \\
\text { tendência maoísta. } \\
\text { Almeja organizar } \\
\text { três afluentes do } \\
\text { movimento } \\
\text { operário } \\
\text { (ocupados, } \\
\text { desempregados e } \\
\text { aposentados). Não } \\
\text { se propõe a criar } \\
\text { uma central, pois } \\
\text { considera que isso } \\
\text { significaria “" } \\
\text { dividir” a classe } \\
\text { trabalhadora. } \\
\text { Considera que o } \\
\text { desemprego } \\
\text { assumiu um } \\
\text { caráter estrutural e } \\
\text { por isso é } \\
\text { necessário } \\
\text { organizar os } \\
\text { desempregados } \\
\text { nos bairros. } \\
\text { Defende a } \\
\text { incorporação dos } \\
\text { desempregads à } \\
\text { produção e a }\end{array}$ & $\begin{array}{c}\text { Fundado em } 16 \text { de } \\
\text { dezembro de } 2000 \\
\text { em um congresso } \\
\text { do Partido Obrero } \\
\text { (PO), de tendência } \\
\text { trotskysta. } \\
\text { Assumiu o } \\
\text { objetivo de } \\
\text { constituir uma } \\
\text { organização de } \\
\text { desempregados } \\
\text { sobre "bases } \\
\text { socialistas" e de } \\
\text { "unidade de } \\
\text { classe", tendo a } \\
\text { luta contra o } \\
\text { desemprego como } \\
\text { parte dessa } \\
\text { estratégia mais } \\
\text { geral. }\end{array}$ & $\begin{array}{c}\text { Fundado em } 1993 \\
\text { por cinco } \\
\text { militantes } \\
\text { socialistas. Iniciou } \\
\text { suas atividades na } \\
\text { periferia da } \\
\text { Grande Buenos } \\
\text { Aires, mas cresceu } \\
\text { também na Capital } \\
\text { Federal. É co- } \\
\text { fundador da CCC, } \\
\text { a quem integrou } \\
\text { entre } 1996 \text { e 2001, } \\
\text { da qual se retirou } \\
\text { por divergências } \\
\text { partidárias com o } \\
\text { PCR. Seu líder } \\
\text { nacional, Raúl } \\
\text { Castells, foi } \\
\text { candidato a } \\
\text { Presidente da } \\
\text { República nas } \\
\text { últimas eleições. }\end{array}$ & $\begin{array}{l}\text { Fundado em } 1997 \\
\text { em Solano, na } \\
\text { periferia da } \\
\text { Grande Buenos } \\
\text { Aires, a partir de } \\
\text { um trabalho } \\
\text { eclesial de base } \\
\text { coordenado por } \\
\text { um padre que se } \\
\text { identificava com a } \\
\text { Teologia da } \\
\text { Libertação. Surgiu } \\
\text { como uma } \\
\text { resposta às } \\
\text { "inquietudes" das } \\
\text { pessoas, que } \\
\text { enfrentavam } \\
\text { dificuldades } \\
\text { econômicas e } \\
\text { questionavam as } \\
\text { políticas } \\
\text { institucionais e as } \\
\text { práticas } \\
\text { tradicionais de } \\
\text { clientelismo e } \\
\text { punterismo } \\
\text { político. } \\
\text { Identifica-se como } \\
\text { um movimento } \\
\text { autônomo e não } \\
\text { mantém relações } \\
\text { com partidos ou } \\
\text { correntes sindicais. }\end{array}$ & $\begin{array}{c}\text { Fundado no dia } 23 \\
\text { de julho de } 2001, \text { a } \\
\text { partir da reunião } \\
\text { de cerca de trinta } \\
\text { militantes que } \\
\text { tinham } \\
\text { experiencias } \\
\text { similares e que } \\
\text { estavam dispersos } \\
\text { no país, em um } \\
\text { congresso de mais } \\
\text { de } 500 \text { pessoas. } \\
\text { Adota a bandeira } \\
\text { anarquista. } \\
\text { Segundo a } \\
\text { organização, a } \\
\text { Argentina iniciou } \\
\text { um processo de } \\
\text { "liberação" ainda } \\
\text { inconcluso e isso } \\
\text { justifica a sigla. } \\
\text { Parte da idéia de } \\
\text { que a luta pelo } \\
\text { poder assumiu a } \\
\text { forma "territorial". } \\
\text { Segundo o } \\
\text { entrevistado, } \\
\text { "quem controla o } \\
\text { poder, controla o } \\
\text { território". }\end{array}$ & $\begin{array}{c}\text { Fundado em } 2000 \\
\text { com o nome CTA } \\
\text { de los Barrios } \\
\text { (“CTA dos } \\
\text { Bairros"), por seu } \\
\text { vínculo com a } \\
\text { central. Associa-se } \\
\text { ao movimento } \\
\text { Patria Libre, } \\
\text { corrente do } \\
\text { peronismo de } \\
\text { esquerda. Por } \\
\text { discordâncias em } \\
\text { relação às posições } \\
\text { diante do governo } \\
\text { de De la Rúa, } \\
\text { separa-se da } \\
\text { central no final de } \\
\text { 2001 e adota o } \\
\text { nome Barrios de } \\
\text { Pie. Juntamente } \\
\text { com a FTV, é uma } \\
\text { das organizações } \\
\text { que participa da } \\
\text { administração do } \\
\text { Governo de } \\
\text { Kirchner. }\end{array}$ & $\begin{array}{l}\text { Fundado em 1996, } \\
\text { com o nome de } \\
\text { MTD-La Juanita. } \\
\text { Foi a primeira } \\
\text { organização que } \\
\text { surgiu no } \\
\text { conurbano } \\
\text { bonaerense, como } \\
\text { um dos } \\
\text { convocadores da } \\
\text { "Primeira Marcha } \\
\text { Contra a Fome" e } \\
\text { o Desemprego, } \\
\text { que em seguida } \\
\text { deu origem a } \\
\text { diversos outros } \\
\text { MTDs. Foi uma } \\
\text { das organizadoras } \\
\text { das primeiras } \\
\text { Assembléias } \\
\text { Nacionais } \\
\text { Piqueteiras, onde } \\
\text { após discordâncias } \\
\text { em relação às } \\
\text { políticas de planos } \\
\text { assistenciais, } \\
\text { resolvem se } \\
\text { separar e investir } \\
\text { em trabalhos } \\
\text { autogestionários. }\end{array}$ \\
\hline
\end{tabular}




\begin{tabular}{|c|c|c|c|c|c|c|c|c|}
\hline & & $\begin{array}{l}\text { continuidade da } \\
\text { luta político- } \\
\text { sindical no local } \\
\text { de trabalho. }\end{array}$ & & & & & & \\
\hline $\begin{array}{c}\text { Quantidade de } \\
\text { membros }\end{array}$ & $\begin{array}{c}120.000 \text { em todo o } \\
\text { país e } 60.000 \text { na } \\
\text { GBA. }\end{array}$ & $\begin{array}{c}\text { Entre } 50.000 \text { e } \\
60.000 \text { em todo o } \\
\text { país e } 10.000 \text { na } \\
\text { GBA. }\end{array}$ & $\begin{array}{c}25.000 \text { em todo o } \\
\text { país e } 10.000 \text { na } \\
\text { GBA. }\end{array}$ & $\begin{array}{l}40.000 \text { em todo o } \\
\text { país e } 10.000 \\
\text { somente na GBAs. }\end{array}$ & $\begin{array}{c}\text { Em } 2007, \text { cerca de } \\
100 \text { famílias, mas } \\
\text { chegaram a } \\
\text { representar } 800 \\
\text { militates e suas } \\
\text { famílias, em } \\
\text { Solano e Florencio } \\
\text { Varela, com dois } \\
\text { "assentamentos" } \\
\text { em cada um dos } \\
\text { municípios. }\end{array}$ & $\begin{array}{l}30.000 \text { em todo o } \\
\text { país e } 2.500 \text { na } \\
\text { capital. (não } \\
\text { possui dados para } \\
\text { a GBA). }\end{array}$ & $\begin{array}{l}\text { Entre } 14.000 \text { e } \\
15.000 \text { no país, e } \\
7.000 \text { na GBA. }\end{array}$ & $\begin{array}{c}\text { Cerca de } 50 \\
\text { militantes. }\end{array}$ \\
\hline $\begin{array}{c}\text { Causas do } \\
\text { desemprego }\end{array}$ & $\begin{array}{c}\text { Segundo o } \\
\text { entrevistado, a } \\
\text { pobreza e o } \\
\text { desemprego estão } \\
\text { planificados como } \\
\text { parte do modelo } \\
\text { neoliberal. Na } \\
\text { Argentina, a } \\
\text { abertura } \\
\text { indiscriminada } \\
\text { durante os anos } \\
\text { 1990 resultou na } \\
\text { falência de } 400 \\
\text { mil indústrias e } \\
\text { três milhões de } \\
\text { postos de trabalho, } \\
\text { em um país que } \\
\text { havia passado por } \\
\text { um processo de } \\
\text { inclusão e }\end{array}$ & $\begin{array}{c}\text { O sistema } \\
\text { capitalista } \\
\text { necessita da } \\
\text { formação de um } \\
\text { exército de reserva } \\
\text { para "pressionar" } \\
\text { os trabalhadores } \\
\text { ocupados e } \\
\text { rebaixar os } \\
\text { salários. No caso } \\
\text { específico da } \\
\text { conjuntura } \\
\text { estudada, foi } \\
\text { necessário para } \\
\text { poder aplicar as } \\
\text { leis de } \\
\text { flexibilização } \\
\text { trabalhista } \\
\text { (contratos por } \\
\text { tempo } \\
\text { determinado, }\end{array}$ & $\begin{array}{l}\text { O desemprego é } \\
\text { "orgânico" na } \\
\text { sociedade } \\
\text { capitalista. No } \\
\text { entanto, no caso da } \\
\text { explosão do } \\
\text { desemprego na } \\
\text { Argentina nos } \\
\text { anos 1990, foi } \\
\text { provocado pelas } \\
\text { privatizações, pela } \\
\text { flexibilidade } \\
\text { trabalhista e pela } \\
\text { reforma } \\
\text { previdenciária. }\end{array}$ & O capitalismo. & $\begin{array}{l}\text { O desemprego é } \\
\text { inerente ao modo } \\
\text { de produção } \\
\text { capitalista, } \\
\text { podendo se tornar } \\
\text { mais agudo em } \\
\text { determinadas } \\
\text { conjunturas. }\end{array}$ & $\begin{array}{l}\text { O desemprego é } \\
\text { funcional ao } \\
\text { sistema capitalista } \\
\text { e é necessário para } \\
\text { garantir as taxas } \\
\text { de lucro. O } \\
\text { capitalismo não } \\
\text { pode funcionar } \\
\text { com pleno } \\
\text { emprego, pois } \\
\text { entraria em crise. } \\
\text { Diferencia o } \\
\text { desemprego do } \\
\text { keynesiano do } \\
\text { desemprego do } \\
\text { neoliberalismo, o } \\
\text { qual promove o } \\
\text { desemprego } \\
\text { estrutural e a } \\
\text { "exclusão em } \\
\text { massa" como parte }\end{array}$ & $\begin{array}{c}\text { As políticas } \\
\text { econômicas } \\
\text { neoliberais } \\
\text { adotadas na } \\
\text { Argentina desde a } \\
\text { ditadura militar } \\
\text { (1976-1983) e } \\
\text { aprofundada nos } \\
\text { anos anos 1990, } \\
\text { com base na } \\
\text { abertura da } \\
\text { economia ao } \\
\text { mercado } \\
\text { internacional e na } \\
\text { diminuição do } \\
\text { aparato produtivo } \\
\text { nacional. }\end{array}$ & $\begin{array}{l}\text { As transformações } \\
\text { no "capitalismo } \\
\text { tradicional" com } \\
\text { base em novas } \\
\text { tecnologias e as } \\
\text { políticas } \\
\text { econômicas } \\
\text { adotadas pelos } \\
\text { governos } \\
\text { neoliberais na } \\
\text { Argentina. Para o } \\
\text { entrevistado, os } \\
\text { desempregados já } \\
\text { não podem nem } \\
\text { mesmo ser } \\
\text { considerados uma } \\
\text { "reserva", por } \\
\text { terem se tornado } \\
\text { desnecessários } \\
\text { para o capitalismo. }\end{array}$ \\
\hline
\end{tabular}




\begin{tabular}{|c|c|c|c|c|c|c|c|c|}
\hline & eqüidade social. & $\begin{array}{l}\text { flexibilidade da } \\
\text { jornada, não } \\
\text { pagamento de } \\
\text { horas extras). }\end{array}$ & & & & do modelo e. & & \\
\hline $\begin{array}{c}\text { Solução para o } \\
\text { desemprego }\end{array}$ & $\begin{array}{c}\text { Na Argentina há } \\
\text { solução para o } \\
\text { desemprego desde } \\
\text { que se mantenha } \\
\text { as atuais taxas de } \\
\text { câmbio (de 2007), } \\
\text { priorize-se o } \\
\text { mercado interno e } \\
\text { se invista em uma } \\
\text { estratégia de } \\
\text { reindustrialização } \\
\text { do país. Para o } \\
\text { entrevistado, o } \\
\text { governo Kirchner } \\
\text { criou } 3 \text { milhões de } \\
\text { empregos nos } \\
\text { últimos } 4 \text { anos } \\
\text { (desde 2003), } \\
\text { mesmo } \\
\text { reconhecendo que } \\
\text { estes foram } \\
\text { majoritariamente } \\
\text { "precários, } \\
\text { temporários e mal } \\
\text { pagos". }\end{array}$ & $\begin{array}{c}\text { Na Argentina há } \\
\text { solução para o } \\
\text { desemprego, desde } \\
\text { que se "defenda a } \\
\text { produção } \\
\text { nacional" e se } \\
\text { utilize superávit } \\
\text { fiscal do país para } \\
\text { a criação de } \\
\text { créditos acessíveis } \\
\text { a pequenas e } \\
\text { médias empresas, } \\
\text { principalmente, no } \\
\text { campo. Para o } \\
\text { entrevistado, "sem } \\
\text { reforma agrária } \\
\text { não há solução } \\
\text { para o } \\
\text { desemprego" no } \\
\text { país. }\end{array}$ & $\begin{array}{c}\text { Para o } \\
\text { entrevistado, "não } \\
\text { há solução } \\
\text { capitalista" para o } \\
\text { desemprego. Na } \\
\text { Argentina, poderia } \\
\text { diminuir desde que } \\
\text { se rompa com as } \\
\text { "cadeias de } \\
\text { subordinação ao } \\
\text { capital financeiro } \\
\text { internacional"e às } \\
\text { multinacionais, e } \\
\text { se acabasse com a } \\
\text { dívida externa. O } \\
\text { entrevistado } \\
\text { defende medidas } \\
\text { emergenciais para } \\
\text { colocar um "freio" } \\
\text { ao desemprego } \\
\text { (construção de } \\
\text { casas populares, } \\
\text { fim da } \\
\text { flexibilidade } \\
\text { trabalhista e do } \\
\text { trabalho não } \\
\text { registrado, redução } \\
\text { da jornada para } 6 \\
\text { horas). }\end{array}$ & $\begin{array}{l}\text { Não há solução } \\
\text { nos marcos desse } \\
\text { "sistema social" } \\
\text { (capitalista). No } \\
\text { entanto, o Estado } \\
\text { pode diminuir o } \\
\text { desemprego, } \\
\text { embora não se } \\
\text { proponha a fazê-lo } \\
\text { porque "usa a } \\
\text { massa de } \\
\text { desempregados } \\
\text { para pressionar os } \\
\text { trabalhadores } \\
\text { empregados e } \\
\text { reduzir os salários, } \\
\text { ameaçando-os } \\
\text { com os milhões } \\
\text { que querem } \\
\text { trabalhar". }\end{array}$ & $\begin{array}{l}\text { No capitalismo, } \\
\text { não há solução. O } \\
\text { Estado não é } \\
\text { neutro, mas } \\
\text { funcional ao poder } \\
\text { da burguesia. Por } \\
\text { isso, não pode } \\
\text { resolver o } \\
\text { problema do } \\
\text { desemprego. }\end{array}$ & $\begin{array}{c}\text { Nos marcos do } \\
\text { neoliberalismo, } \\
\text { não há solução. No } \\
\text { entanto, fora desse } \\
\text { modelo e com } \\
\text { "vontade política", } \\
\text { o que, mesmo } \\
\text { assim, } \\
\text { "demandaria trinta } \\
\text { ou quarenta anos". }\end{array}$ & $\begin{array}{l}\text { Há solução, tal } \\
\text { como tem feito o } \\
\text { governo atual (de } \\
\text { Kirchner), } \\
\text { aproundando as } \\
\text { políticas de } \\
\text { distribuição de } \\
\text { renda e de } \\
\text { desenvolvimento } \\
\text { econômico } \\
\text { baseado no } \\
\text { mercado interno. }\end{array}$ & $\begin{array}{l}\text { Há solução, desde } \\
\text { que se formule } \\
\text { "novos objetivos" } \\
\text { para a produção } \\
\text { baseado em } \\
\text { "empresas sociais, } \\
\text { em "não tenham } \\
\text { apenas o afã do } \\
\text { lucro, mas de } \\
\text { satisfazer as } \\
\text { necessidades da } \\
\text { população" (as } \\
\text { "empresas } \\
\text { sociais"). }\end{array}$ \\
\hline $\begin{array}{l}\text { Principais } \\
\text { bandeiras }\end{array}$ & $\begin{array}{l}\text { Depende do } \\
\text { momento político. } \\
\text { Atualmente, a }\end{array}$ & $\begin{array}{l}\text { Luta pela } \\
\text { "liberação" e a } \\
\text { integração da }\end{array}$ & $\begin{array}{l}\text { O governo dos } \\
\text { trabalhadores e a } \\
\text { unidade socialista }\end{array}$ & $\begin{array}{l}\text { Suspensão do } \\
\text { pagamento da } \\
\text { dívida externa, }\end{array}$ & $\begin{array}{l}\text { A constituição de } \\
\text { uma "outra forma } \\
\text { de vida" e uma }\end{array}$ & O socialismo. & $\begin{array}{l}\text { A consciência e } \\
\text { participação } \\
\text { popular, a }\end{array}$ & $\begin{array}{c}\text { Reconstituição dos } \\
\text { laços sociais com } \\
\text { a educação do }\end{array}$ \\
\hline
\end{tabular}




\begin{tabular}{|c|c|c|c|c|c|c|c|c|}
\hline & $\begin{array}{l}\text { renovação da } \\
\text { política e a } \\
\text { distribuição de } \\
\text { renda. }\end{array}$ & $\begin{array}{l}\text { militância política } \\
\text { e sindical. }\end{array}$ & $\begin{array}{l}\text { da América } \\
\text { Latina. }\end{array}$ & $\begin{array}{l}\text { reforma agrária, } \\
\text { nacionalização dos } \\
\text { recursos naturais, } \\
\text { o governo dos } \\
\text { trabalhadores e do } \\
\text { povo, e o } \\
\text { socialismo. }\end{array}$ & "sociedade nova". & & $\begin{array}{l}\text { autodeterminação } \\
\text { dos povos e a } \\
\text { emancipação dos } \\
\text { trabalhadores. }\end{array}$ & $\begin{array}{l}\text { trabalho } \\
\text { autogestionário, } \\
\text { cooperativo e } \\
\text { solidário, que } \\
\text { satisfaça as } \\
\text { necessidades da } \\
\text { comunidade. }\end{array}$ \\
\hline $\begin{array}{c}\text { Principais } \\
\text { instrumentos de } \\
\text { luta }\end{array}$ & $\begin{array}{c}\text { Piquete, } \\
\text { assembléia, } \\
\text { mobilização, etc., } \\
\text { desde que sejam } \\
\text { utilizados "com } \\
\text { responsabilidade". } \\
\text { Segundo o } \\
\text { entrevistado, "aqui } \\
\text { há alguns } \\
\text { movimentos que } \\
\text { primeiro fazem o } \\
\text { bloqueio e depois } \\
\text { dialogam". }\end{array}$ & $\begin{array}{c}\text { Além dos } \\
\text { restaurantes } \\
\text { comunitário e a } \\
\text { organização dos } \\
\text { jovens, considera } \\
\text { o piquete uma das } \\
\text { principais } \\
\text { ferramentas, desde } \\
\text { que seja feito em } \\
\text { "território" próprio } \\
\text { para se colocar "na } \\
\text { ofensiva" em } \\
\text { momentos de } \\
\text { repressão. }\end{array}$ & $\begin{array}{c}\text { Segundo o } \\
\text { entrevistado, são } \\
\text { muito variáveis. } \\
\text { Considera o } \\
\text { piquete uma } \\
\text { "grande criação } \\
\text { popular, que vem } \\
\text { das greves } \\
\text { operárias". } \\
\text { Também ressalta o } \\
\text { papel da } \\
\text { assembléia e do } \\
\text { delegado. }\end{array}$ & $\begin{array}{c}\text { Para o } \\
\text { entrevistado, "a } \\
\text { mobilização, a } \\
\text { greve, a ocupação } \\
\text { de edifícios } \\
\text { públicos, os } \\
\text { piquetes e o que o } \\
\text { povo vá indicando } \\
\text { em cada } \\
\text { circunstância". }\end{array}$ & $\begin{array}{l}\text { O entrevistado } \\
\text { afirma que o } \\
\text { movimento } \\
\text { começou com } \\
\text { ações diretas } \\
\text { "contundentes", } \\
\text { como saques, } \\
\text { ocupação de } \\
\text { edifícios públicos } \\
\text { e piquetes. No } \\
\text { entanto, considera } \\
\text { que o } \\
\text { cooperativismo e } \\
\text { os } \\
\text { empreendimentos } \\
\text { produtivos } \\
\text { autogestionários se } \\
\text { constituem hoje } \\
\text { nas maiores } \\
\text { ferramentas do } \\
\text { movimento. }\end{array}$ & $\begin{array}{c}\text { A contracultura } \\
\text { e a confrontação } \\
\text { "direta", tais } \\
\text { como os } \\
\text { bloqueios de } \\
\text { ruas, e a } \\
\text { "mobilização } \\
\text { permanente". }\end{array}$ & $\begin{array}{c}\text { A mobilização. A } \\
\text { partir do governo } \\
\text { Kirchner, adotou a } \\
\text { participação } \\
\text { política. Admite o } \\
\text { piquete como uma } \\
\text { "ferramenta } \\
\text { válida". No } \\
\text { entanto, afirma } \\
\text { que no contexto } \\
\text { atual de } \\
\text { crescimento do } \\
\text { emprego é } \\
\text { "contraproducente, } \\
\text { pois "impede" o } \\
\text { que vai trabalhar } \\
\text { de chegar a seu } \\
\text { trabalho. }\end{array}$ & $\begin{array}{c}\text { A contracultura, os } \\
\text { empreendimentos } \\
\text { autogestionários e } \\
\text { o cooperativismo. } \\
\text { No começo, } \\
\text { defendia o piquete, } \\
\text { mas afirma que } \\
\text { essa ferramenta } \\
\text { "foi se } \\
\text { desvirtuando". } \\
\text { Também defende a } \\
\text { educação como } \\
\text { instrumento de } \\
\text { luta. Possui uma } \\
\text { escola infantil e } \\
\text { um programa de } \\
\text { alfabetização de } \\
\text { adultos. }\end{array}$ \\
\hline
\end{tabular}

Fonte: Entrevistas com militantes das organizações realizadas pelo autor em 2007. 
Quadro II: Fisionomia das greves gerais na Argentina (1989-2002)

\begin{tabular}{|c|c|c|c|c|c|}
\hline Período & Greve & Participantes & Nível de adesão & Objetivos & $\begin{array}{l}\text { Unidade entre empregados e } \\
\text { desempregados }\end{array}$ \\
\hline \multirow{2}{*}{$\begin{array}{c}\text { 1989-1994: governo de } \\
\text { Menem anteriormente ao } \\
\text { primeiro pico de desocupação }\end{array}$} & $9 / 11 / 1992$ & CGT, CTA & Entre $50 \%$ e $75 \%$ & $\begin{array}{l}\text { Em defesa das convenções coletivas de } \\
\text { trabalho e dos aposentados }\end{array}$ & N.I. $^{814}$ \\
\hline & 2/08/1994 & CTA, MTA & $\begin{array}{l}\text { Parcial, com } \\
\text { maior adesão no } \\
\text { interior do país }\end{array}$ & $\begin{array}{c}\text { Contra a política econômica e social do } \\
\text { Governo }\end{array}$ & N.I. \\
\hline $\begin{array}{l}\text { janeiro a agosto de 1995: pico } \\
\text { de desemprego e protestos } \\
\text { contra as demissões }\end{array}$ & 21/04/1995 & CTA, MTA & $\begin{array}{l}\text { Parcial. A UOM } \\
\text { realizou uma } \\
\text { greve no mesmo } \\
\text { dia pelo mesmo } \\
\text { motivo }\end{array}$ & $\begin{array}{l}\text { Contra a política econômica e social do } \\
\text { Governo e em repúdio à morte do operário } \\
\text { Víctor Choque em Ushuaia }\end{array}$ & N.I. \\
\hline \multirow[t]{3}{*}{$\begin{array}{c}\text { setembro de } 1995 \text { a dezembro } \\
\text { de 1996: greves gerais e } \\
\text { unidade do movimento } \\
\text { operário }\end{array}$} & $6 / 09 / 1995$ & CGT, CTA, MTA & $\begin{array}{l}\text { Parcial em Buenos } \\
\text { Aires, quase total } \\
\text { em Córdoba, San } \\
\text { Juan e Santa Fe, } \\
\text { importante em } \\
\text { outras províncias }\end{array}$ & $\begin{array}{l}\text { Pelo pleno emprego, contra a política } \\
\text { econômica, o desemprego e para garantir o } \\
\text { funcionamento das obras sociales }\end{array}$ & N.I. \\
\hline & $8 / 08 / 1996$ & CGT, CTA, MTA & Alto & $\begin{array}{l}\text { Contra a redução das asignaciones familiares } \\
\text { e a política impositiva em relação com o } \\
\text { pagamento do salário de tickets }\end{array}$ & N.I. \\
\hline & $26,27 / 09 / 1996$ & CGT, MTA, CTA & $\begin{array}{c}\text { Alto, com } \\
\text { mobilização } \\
\text { massiva em Plaza } \\
\text { de Mayo (mais de } \\
70.000 \\
\text { manifestantes) }\end{array}$ & $\begin{array}{c}\text { Contra a política econômica e a flexibilização } \\
\text { das leis trabalhistas }\end{array}$ & N.I. \\
\hline
\end{tabular}

\footnotetext{
${ }^{814}$ N.I. = não informado pelas fontes consultadas.
} 


\begin{tabular}{|c|c|c|c|c|c|}
\hline & 26/12/1996 & CGT, CTA, MTA & $\begin{array}{c}\text { Parcial, } \\
\text { importante na } \\
\text { zona industrial de } \\
\text { Buenos Aires e } \\
\text { Santa Fe, } \\
\text { Córdoba, } \\
\text { Tucumán e Mar } \\
\text { del Plata }\end{array}$ & $\begin{array}{l}\text { Contra os decretos de flexibilização das leis } \\
\text { trabalhistas }\end{array}$ & N.I. \\
\hline \multirow{2}{*}{$\begin{array}{l}\text { 1997-1999: os bloqueios de } \\
\text { rodovias, o "efeito caipirinha" } \\
\text { e o surgimento das } \\
\text { organizações de } \\
\text { desempregados }\end{array}$} & $14 / 08 / 1997$ & $\begin{array}{l}\text { CTA, MTA, CCC, } \\
\text { UOM, } 62 \mathrm{OP}\end{array}$ & $\begin{array}{c}\text { Alto, com } \\
\text { mobilização } \\
\text { massiva }\end{array}$ & $\begin{array}{l}\text { Contra o modelo econômico e os projetos de } \\
\text { flexibilização }\end{array}$ & $\begin{array}{l}\text { Durante o protesto houve mobilizações, atos, } \\
30 \text { ollas populares e } 20 \text { bloqueios de ruas e } \\
\text { rodovias, de empregados e desempregados }\end{array}$ \\
\hline & $06 / 07 / 1999$ & CTA & Parcial & $\begin{array}{l}\text { Contra a política econômica, reivindicando } \\
\text { "trabalho para todos", pela redução da } \\
\text { jornada de trabalho e por um subsídio aos } \\
\text { desempregados }\end{array}$ & $\begin{array}{c}\text { Houve bloqueios de rodovias, de empregados } \\
\text { e desempregados, e manifestações na capital } \\
\text { e muitas cidades do interior }\end{array}$ \\
\hline \multirow{4}{*}{$\begin{array}{c}\text { 2000-2002: pico de } \\
\text { desemprego, crescimento das } \\
\text { organizações e a insurreição } \\
\text { espontânea de } 19 \text { e } 20 \text { de } \\
\text { dezembro }\end{array}$} & 20/12/1999 & CTA & Parcial & $\begin{array}{l}\text { Contra a repressão ao protesto dos } \\
\text { funcionário públicos de Corrientes }\end{array}$ & N.I. \\
\hline & $05 / 05 / 2000$ & $\begin{array}{l}\text { CGT-Moyano, } \\
\text { CTA, CCC }\end{array}$ & $\begin{array}{c}\text { As cifras são } \\
\text { díspares, } \\
\text { oscilando entre } \\
33.31 \% \text { segundo o } \\
\text { Governo e } 85 \% \\
\text { segundo a CGT }\end{array}$ & $\begin{array}{l}\text { Reivindicam a convocação do Consejo del } \\
\text { Salario para fixar um aumento do salário } \\
\text { mínimo, vital e móbil, a recomposição dos } \\
\text { salários básicos dos convênios coletivos, a } \\
\text { eliminação do IVA aos bens que integram a } \\
\text { canasta básica, a imediata outorga } \\
\text { (aprovação) de um subsídio para um milhão } \\
\text { de chefes de família e o aumento das } \\
\text { aposentadorias mínimas. }\end{array}$ & $\begin{array}{c}\text { Houve bloqueios de desempregados } \\
\text { tentativas de saques a supermercados e ollas } \\
\text { populares }\end{array}$ \\
\hline & $09 / 06 / 2000$ & $\begin{array}{l}\text { CGT-Daer, CGT- } \\
\text { Moyano, CTA, } \\
\text { CCC }\end{array}$ & $\begin{array}{l}\text { Para o Governo, } \\
\text { de } 60 \% \text {; para as } \\
\text { centrais, entre } \\
85 \% \text { e } 90 \%\end{array}$ & $\begin{array}{c}\text { Contra o rebaixamento salarial dos estatais e } \\
\text { dos aposentados, contra a política econômica, } \\
\text { o ajuste e a desregulamentação das obras } \\
\text { sociales }\end{array}$ & $\begin{array}{l}\text { Houve cortes no interior, piquetes, queima de } \\
\text { pneus, quebra de vidraças e bloqueios nas } \\
\text { rodovias de acesso à Capital }\end{array}$ \\
\hline & 23 e $24 / 11 / 2000$ & $\begin{array}{l}\text { CGT-Daer, CGT- } \\
\text { Moyano, CTA, } \\
\text { CCC }\end{array}$ & Muito grande & $\begin{array}{l}\text { Em repúdio à presença do FMI, contra o } \\
\text { modelo econômico e por maior incentivo à } \\
\text { produção }\end{array}$ & $\begin{array}{l}\text { Durante o protesto se realizaram } \\
\text { mobilizações, cacerolazos e ollas populares, } \\
\text { assim como piquetes, cortes de ruas e } \\
\text { rodovias pelos desempregados, medidas }\end{array}$ \\
\hline
\end{tabular}




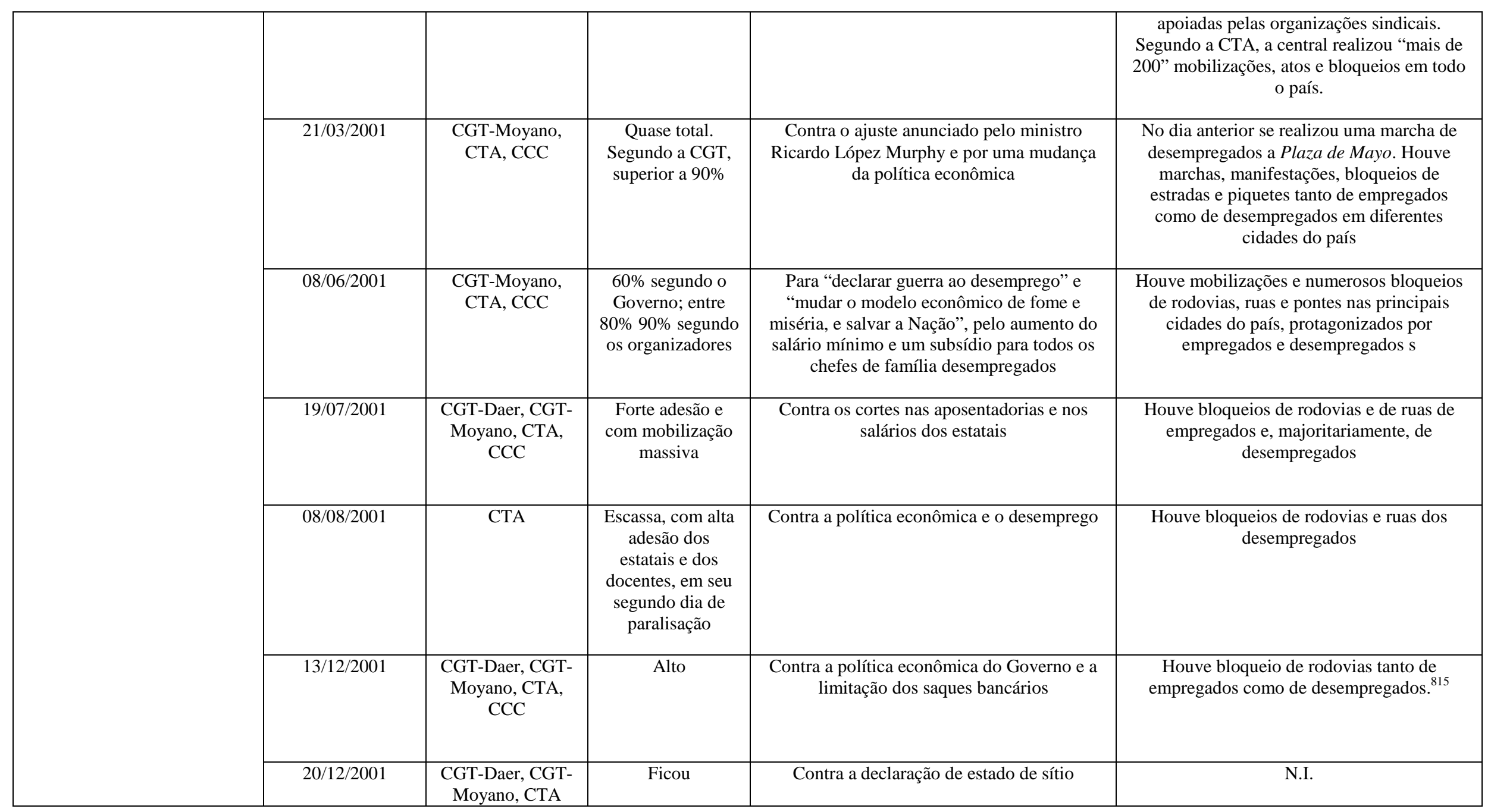

${ }^{815}$ Segundo Carrera (2001), aparecem nessa greve elementos de revolta de fome (“saques”), motim (Pergamino), tomada e defesa de posição e luta de rua (Neuquén). 


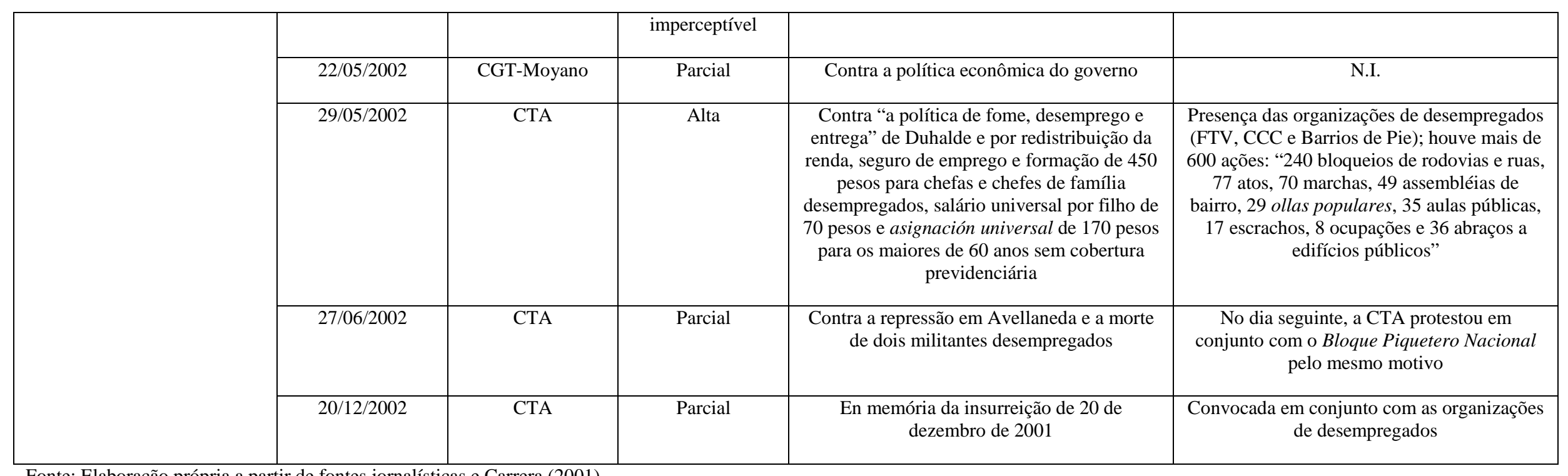

Fonte: Elaboração própria a partir de fontes jornalísticas e Carrera (2001) 


\section{Quadro III: Sindicalismo desempregados no Brasil e na Argentina}

\begin{tabular}{|c|c|c|c|c|}
\hline $\begin{array}{l}\text { Central ou corrente } \\
\text { interna }\end{array}$ & Ideologia político-sindical & Matriz político-ideológica & $\begin{array}{c}\text { Posição diante do } \\
\text { neoliberalismo }\end{array}$ & Posição diante da estrutura sindical \\
\hline $\begin{array}{c}\text { CGT (Direção } \\
\text { Nacional)/ MOP }\end{array}$ & $\begin{array}{c}\text { Propositiva/ } \\
\text { participacionista }\end{array}$ & $\begin{array}{l}\text { Aliança capital e trabalho/desenvolvimento do } \\
\text { capitalismo (populismo peronista) }\end{array}$ & Apoio com restrições & Apoio \\
\hline MTA & Combativa/ confrontacionista & $\begin{array}{l}\text { Aliança capital e trabalho/desenvolvimento do } \\
\text { capitalismo (populismo peronista) }\end{array}$ & Oposição & Apoio \\
\hline CTA & $\begin{array}{l}\text { Combativa/ } \\
\text { classista }\end{array}$ & $\begin{array}{l}\text { Aliança capital e trabalho/desenvolvimento do } \\
\text { capitalismo (populismo peronista, ainda que } \\
\text { tenha rompido com o vínculo com o PJ) }\end{array}$ & Oposição & $\begin{array}{c}\text { Crítica a aspectos parciais, com luta por seu } \\
\text { reconhecimento legal; abertura do seu } \\
\text { estatuto para representação dos } \\
\text { desempregados }\end{array}$ \\
\hline CUT (ala majoritária) & Propositiva/ cidadã & $\begin{array}{l}\text { Aliança capital e trabalho/desenvolvimento do } \\
\text { capitalismo (democratismo social) }\end{array}$ & $\begin{array}{l}\text { Oposição com } \\
\text { incorporação }\end{array}$ & Oposição com acomodação \\
\hline $\begin{array}{l}\text { CUT (setor } \\
\text { minoritário) }\end{array}$ & Combativo/ classista & Superação do capitalismo (socialismo) & Oposição & Oposição com acomodação \\
\hline Força Sindical & $\begin{array}{c}\text { Propositiva/ } \\
\text { participacionista }\end{array}$ & $\begin{array}{l}\text { Aliança capital e trabalho/desenvolvimento do } \\
\text { capitalismo (liberalismo, trabalhismo) }\end{array}$ & Apoio com restrições & Apoio \\
\hline
\end{tabular}

\begin{tabular}{|c|c|c|c|c|c|}
\hline $\begin{array}{l}\text { Central ou corrente } \\
\text { interna }\end{array}$ & Interesses da base & Interesses da cúpula & Política diante dos desempregados & $\begin{array}{c}\text { Unidade e fratura } \\
\text { movimento sindical e de } \\
\text { desempregados }\end{array}$ & $\begin{array}{c}\text { Relação com as } \\
\text { organizações da } \\
\text { reserva }\end{array}$ \\
\hline $\begin{array}{l}\text { CGT (Direção } \\
\text { Nacional)/ MOP }\end{array}$ & $\begin{array}{l}\text { Capital concentrado de } \\
\text { diferentes setores }\end{array}$ & Manter o poder sindical & Não organizou os desempregados & $\begin{array}{l}\text { Não se opôs, mas não se } \\
\text { aliou às organizações }\end{array}$ & Não houve \\
\hline MTA & $\begin{array}{l}\text { Capital médio } \\
\text { predominante }\end{array}$ & $\begin{array}{l}\text { Assumir a direção da } \\
\text { CGT }\end{array}$ & Não organizou os desempregados & $\begin{array}{l}\text { Não representou, mas } \\
\text { buscou se aliar }\end{array}$ & Não houve \\
\hline CTA & $\begin{array}{c}\text { Setor público, } \\
\text { superpopulação, relativa }\end{array}$ & $\begin{array}{c}\text { Fortalecimento e } \\
\text { reconhecimento da central }\end{array}$ & $\begin{array}{c}\text { Buscou organizar os desempregados para a } \\
\text { luta }\end{array}$ & $\begin{array}{c}\text { Representou parte das } \\
\text { organizações }\end{array}$ & $\begin{array}{c}\text { Representou parte das } \\
\text { organizações }\end{array}$ \\
\hline CUT (ala majoritária) & $\begin{array}{l}\text { Setor privado, público e } \\
\text { agrário de diferentes } \\
\text { níveis de concentração }\end{array}$ & $\begin{array}{c}\text { Ampliação da } \\
\text { participação em espaços } \\
\text { institucionais e no } \\
\text { aparelho do Estado }\end{array}$ & $\begin{array}{l}\text { Requalificação profissional, intermediação do } \\
\text { emprego da força de trabalho, cooperativismo }\end{array}$ & $\begin{array}{l}\text { Não houve; a partir de } 2000 \\
\text { passou a compor a CMS } \\
\text { juntamente com o MTD }\end{array}$ & $\begin{array}{c}\text { Não representou, mas se } \\
\text { aliou ao MST }\end{array}$ \\
\hline $\begin{array}{l}\text { CUT - setores } \\
\text { minoritários }\end{array}$ & Setor público e privado & $\begin{array}{l}\text { Ampliação de espaços na } \\
\text { direção da CUT }\end{array}$ & $\begin{array}{l}\text { Possui algumas experiências de recuperação } \\
\text { de empresas }\end{array}$ & Não houve & $\begin{array}{l}\text { Não representou, mas se } \\
\text { aliou ao MST }\end{array}$ \\
\hline Força Sindical & $\begin{array}{l}\text { Setor privado do } \\
\text { comércio, serviços e } \\
\text { indústria (pouca } \\
\text { presença de estatais) }\end{array}$ & $\begin{array}{c}\text { Ampliação da } \\
\text { participação em espaços } \\
\text { institucionais e no } \\
\text { aparelho do Estado }\end{array}$ & $\begin{array}{l}\text { Requalificação profissional e intermediação } \\
\text { do emprego da força de trabalho }\end{array}$ & Não houve & Não houve \\
\hline
\end{tabular}




\section{Quadro IV: A mobilização dos desempregados no Brasil e na Argentina}

\begin{tabular}{|c|c|c|}
\hline & Brasil & Argentina \\
\hline $\begin{array}{c}\text { Presença da } \\
\text { superpopulação relativa na } \\
\text { estrutura social }\end{array}$ & $\begin{array}{l}\text { Alto índice histórico de superpopulação relativa (desemprego } \\
\text { endêmico e ocupações irregulares como traço crônico)/ crescimento } \\
\text { epidêmico do desemprego nos anos } 90\end{array}$ & $\begin{array}{l}\text { Baixo índice histórico de superpopulação relativa (desemprego } \\
\text { epidêmico e alto índice de formalização do mercado de trabalho), } \\
\text { crescimento explosivo do desemprego nos anos } 90\end{array}$ \\
\hline $\begin{array}{l}\text { Construção da cidadania e } \\
\text { categorização social do } \\
\text { emprego }\end{array}$ & $\begin{array}{c}\text { Baixo processo de construção da cidadania (corporativismo } \\
\text { excludente), com piores indicadores sociais, frágil categorização } \\
\text { social do emprego }\end{array}$ & $\begin{array}{c}\text { Alto processo de construção da cidadania (corporativismo } \\
\text { includente), com melhores indicadores sociais, forte } \\
\text { categorização social do emprego }\end{array}$ \\
\hline $\begin{array}{l}\text { Tradição do movimento } \\
\text { operário e sindical }\end{array}$ & $\begin{array}{l}\text { Negociação coletiva descentralizada, baixa incidência de greves } \\
\text { gerais, frágil organização no local de trabalho, presença recente de } \\
\text { centrais sindicais }\end{array}$ & $\begin{array}{c}\text { Negociação coletiva centralizada, greve geral como instrumento } \\
\text { de luta recorrente, forte organização no local de trabalho, } \\
\text { presença secular de centrais e sindicais nacionais }\end{array}$ \\
\hline $\begin{array}{l}\text { Tradição do movimento } \\
\text { camponês e de pobres }\end{array}$ & $\begin{array}{l}\text { Forte (convivência história entre o movimento operário e camponês } \\
\text { organizado por reivindicações como o acesso à terra e por melhores } \\
\text { condições de vida }\end{array}$ & $\begin{array}{c}\text { Predomínio do movimento operário e sindical nos protestos da } \\
\text { classe trabalhadora, com aparecimento esporádico e pouco } \\
\text { significativo ao longo da história de organizações populares e de } \\
\text { pobres }\end{array}$ \\
\hline $\begin{array}{l}\text { Ideologia inerente no } \\
\text { processo de formação } \\
\text { protestos populares }\end{array}$ & $\begin{array}{l}\text { Tradição de luta pela terra e organização individual para a atividade } \\
\text { econômica }\end{array}$ & $\begin{array}{c}\text { Tradição de manifestação de rua, sentimento reivindicativo para a } \\
\text { luta coletiva }\end{array}$ \\
\hline
\end{tabular}

